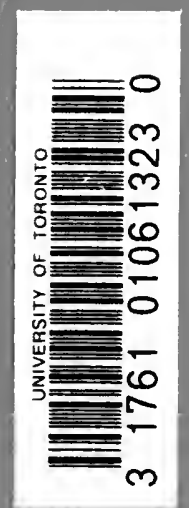




(19) 


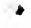


.

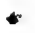

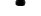

- 


\section{CYNEWULF}

Across the centuries we spell thy name, Wrought deep within thy verse by runic sign, For though thy soul was rapt with things divine, Thou yet couldst not forego the dream of fame. The virgin martyr's faith thou dost acclaim; Dost sing the cross revealed by Heaven's design; The Advent's hope, the Ascent of Christ benign, The trump of Judgment, and its hurtling flame. 


\title{
THE OLD ENGLISH
}

\section{ELENE, PHCENIX, AND PHYSIOLOGUS}

\author{
EDITED BY \\ ALBERT STANBURROUGH COOK
}

PROFESSOR OF THE ENGLISH LANGUAGE AND LITERATURE IN YALE UNIVERSITY
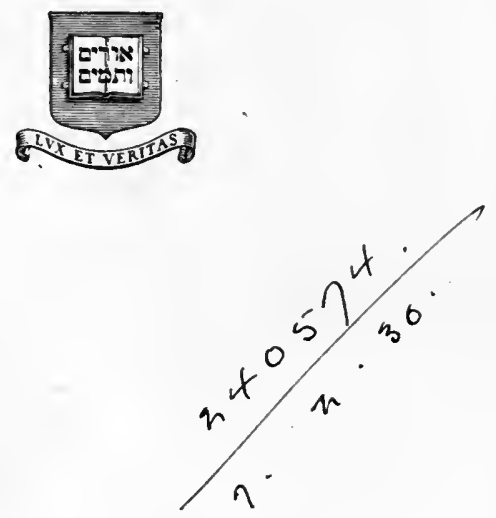

NEW HAVEN: YALE UNIVERSITY PRESS LONDON: HUMPHREY MILFORD OXFORD UNIVERSITY PRESS MDCCCCXIX 
CopyrtGht, IgIg
By YALE UNIVERSTry PRESS

$P R$

1505

cop. 2 


\section{CONTENTS}

Introduction $\ldots \ldots \ldots \ldots \ldots \ldots \ldots \ldots \ldots \ldots \ldots$, vii

Elene $\ldots \ldots \ldots \ldots \ldots \ldots \ldots \ldots \ldots \ldots \ldots \ldots \ldots$ vii

Manuscript $\ldots \ldots \ldots \ldots \ldots \ldots \ldots \ldots \ldots \ldots \ldots \ldots$ vii

Author and Date ....................... xiii

Sources of the Legend...$\ldots \ldots \ldots \ldots \ldots \ldots$ xiv

Constantine and the Vision of the Cross ....... xxii

Phœnix ............................ $\mathrm{xxv}$

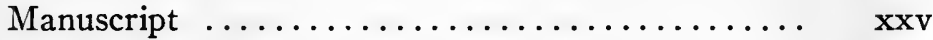

Author and Date $\ldots \ldots \ldots \ldots \ldots \ldots \ldots \ldots \ldots$ xxvi

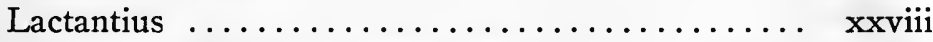

Lactantius and the De Ave Phønice ........... xxxiii

The Phœnix as a Symbol ................. xxxviii

Heliopolis .......................... xlv

The Earthly Paradise .................. lii

Physiologus $\ldots . \ldots \ldots \ldots \ldots \ldots \ldots \ldots \ldots$. lvii

The Physiologus in General ............... lvii

The Old English Physiologus ............. $\quad$ lx

Manuscript ....................... $\quad \mathrm{lx}$

Coherence of the Poems ............... $1 \mathrm{~lx}$

Author and Date .................... lxi

The Panther...$\ldots \ldots \ldots \ldots \ldots \ldots \ldots \ldots$. Ixii

The Whale (Asp-Turtle) .............. 1xiii

The Growth of the Legend .............. Ixiii

The Name of the Monster .............. lxxiii

The Partridge..$\ldots \ldots \ldots \ldots \ldots \ldots \ldots \ldots$ lxxxv

The Text of the Poems $\ldots \ldots \ldots \ldots \ldots \ldots \ldots \ldots$ I

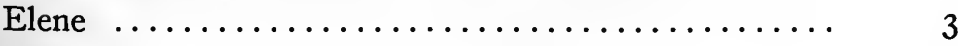

Phœnix $\ldots \ldots \ldots \ldots \ldots \ldots \ldots \ldots \ldots \ldots \ldots, 47$ 


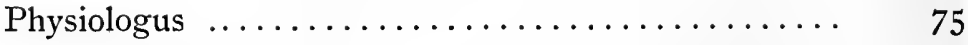

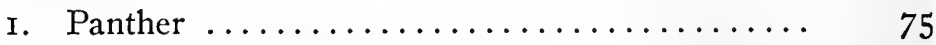

2. The Whale (Asp-Turtle) ............ 77

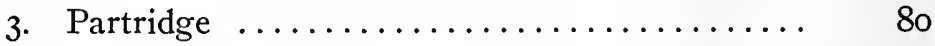

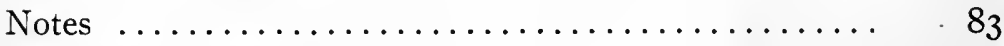

Notes on Elene ...................... 85

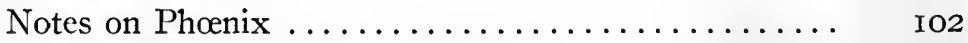

Supplement to Notes on Phœenix ........... I24

Translation of Lactantius, De Ave Phonice..... $\quad 124$

The Late Old English Version of the Phœnix ... I 28

Notes on Physiologus ................. I 33

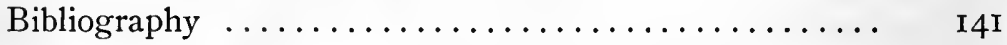

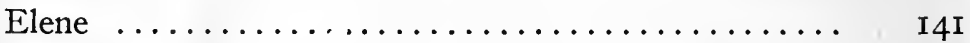

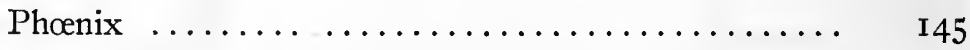

Physiologus ........................... I49

Glossary $\ldots \ldots \ldots \ldots \ldots \ldots \ldots \ldots \ldots \ldots \ldots \ldots \ldots \ldots \ldots \ldots \ldots \ldots \ldots \ldots$ I I 


\section{INTRODUCTION}

\section{ELENE}

\section{MANUSCRIPT}

The manuscript in which the Elene is found is No. cxvir of the library of the Cathedral of Vercelli, in Northern Italy, midway between Turin and Milan, and is hence known as the Codex Vercellensis, or Vercelli Book. It was discovered in 1822 by a German jurist, Friedrich Blume, who then and there copied out the poetical pieces; the result of his investigations in this and other Italian libraries was made known in his book Iter Italicum, ${ }^{1}$ the first volume of which was published in 1824 .

The manuscript belongs to the later decades of the tenth century. ${ }^{2}$ It contains 135 written leaves, and the average size of the written page is $9^{1 / 2}$ by 6 inches, while that of the complete page approximates $12 \frac{1}{4}$ by $8 .^{3}$ It comprises twenty-three homilies and six interspersed poems, the arrangement of the latter being as follows: Andreas (fol. $29^{\mathrm{b}}-52^{\mathrm{b}}$ ) and Fates of the Apostles $\left(52^{\mathrm{b}}-54^{\mathrm{a}}\right)$, after the fifth homily; Address of the Soul to the Body ( $\left.\mathrm{IOI}^{\mathrm{b}}-\mathrm{IO}^{\mathrm{b}}\right)$, Falsehood of $\mathrm{Men}\left(\mathrm{IO}^{\mathrm{a}}-\mathrm{IO}^{\mathrm{b}}\right)$, Dream of the Rood ( $\left.104^{\mathrm{b}}-106^{\mathrm{a}}\right)$, after the eighteenth; and Elene $\left(\mathrm{I} 2 \mathrm{I}^{\mathrm{a}}-\mathrm{I} 33^{\mathrm{b}}\right)$, after the twenty-second. The language is Late West Saxon, interspersed with occasional Early West Saxon

${ }^{1}$ 1. 99. It seems to be mentioned by G. F. Leone in an inventory of the Cathedral Library compiled in 1602 (cf. Förster, Il Codice Vercellese, p. 40 ), and is certainly mentioned in a letter written by Giuseppe Bianchini (printed by Förster, p. 4I), who suspected that it was German ('lingua Theotisca'), and reproduced a portion of one of the homilies, with many errors. Cf. Festschrift für Lorenz Morsbach, pp. 54-5.

${ }^{2}$ Brandl, in Paul, Grundriss der Germ. Phil., 2d ed., 2. 1110; Förster, p. 14 (Festschrift, p. 26). Wülker and others have said the early part of the eleventh century; cf. Förster, p. I2.

${ }^{3}$ Förster, p. 7 ; Festschrift, p. 21 . 
and many Anglian forms, and a few traces of Kentish. The poems were probably Anglian, and have been changed by passing through West Saxon hands, but it is not necessary to suppose that the West Saxon elements were introduced by the latest scribe. The manuscript perhaps originated at Worcester, and in any case resembles the language as written at Worcester in that period. ${ }^{1}$

Nothing is known as to the manner in which the manuscript reached Vercelli, but various theories have been proposed. That of Wülker may thus be translated from his own words ${ }^{2}$ :

As I was informed in Vercelli, there sprang up there in early times a hospice for Anglo-Saxon pilgrims on their journeys to and from Rome. This is intelligible enough if one considers that Vercelli lies directly on the road to Rome by Mont. Cenis or the Little or Great St. Bernard, and that these were the passes over which English pilgrims in the Middle Ages journeyed toward Rome. At this hospice a library of edifying books may gradually have been formed, to which our manuscript may have belonged.

This theory has but little to recommend it. The existence of the Anglo-Saxon hospice reposes upon modern hearsay, so far as appears; the library is purely hypothetical; and the presence of this volume in the hypothetical library is at least equally hypothetical. Is it likely that so large and precious a volume would have been contributed to the library of a mere hospice? And is it likely that pilgrims on their way to Rome would have had time to pore over any edifying books but their breviaries?

The other theory was first broached by an unnamed writer in the Quarterly Review for December, I844, and March, I845; it is to the effect that the book was presented to the church of St. Andrew in Vercelli by Cardinal Guala Bicchieri, not long after I2I9. This theory I revived, and supported with new considerations, in Library Bulletin No. Io of the University of California (I888). I thus briefly summarized the earlier arguments:

${ }^{1}$ Förster, pp. 19-21 ; Festschrift, pp. 33-5. A facsimile of the poetical texts was published by Wülker in 1894 , and of the whole manuscript by Förster in 1913.

${ }^{2}$ Codex Vercellensis, pp. vi, vII. 
I. Cardinal Guala was in England from I216 to 1218.

2. While in England he had in his possession a priory of St. Andrew. ${ }^{1}$

3. After his return to Italy he founded the collegiate church of St. Andrew at Vercelli, and bestowed upon it relics of English saints.

4. The income from his English benefices perhaps enabled him to establish and endow the church at Vercelli.

5. The plan and many of the details of the church are Early English.

6. One of the chief poems of the Vercelli book is St. Andrew.

To the foregoing I added:

The facts not hitherto adduced in support of the hypothesis, and which seem to be as conclusive as circumstantial evidence can well be, are: Guala was a learned man, zealous for learning and religion, and the owner of perhaps the finest private library possessed at that time in Western Europe. The funds for the establishment of the monastery and the purchase of his books must have come largely from England-and why not certain books also? He must have been openminded, and appreciative of the good he found in foreign parts, and especially anxious to testify his appreciation of English art; then why not of English letters? His spirit of good-will toward England was to some extent reciprocated there, and he sought to perpetuate it by selecting as abbot an ecclesiastic who, though French, should have English connections and sympathies, and a stake in English prosperity. The wisdom of his course is attested by the renown of the monastery school, and the fact that it immediately attracted one of the greatest Englishmen of the Middle Ages, who remained a firm friend after his departure, and perhaps gained other friends for its head. Guala must have thought oftenest of St. Martin and St. Andrew, patrons of France and North Britain respectively, especially revered by the two foreign nations in which his lot was cast, and which he afterwards honored on his return to his native country and his native town. Several circumstances must have conspired to deepen the impression thus made, particularly with reference to St. Andrew. We need not be surprised, then, at his immediate commemoration of that saint (by founding the monastery of St. Andrew in 1219), nor should we be surprised if a book once belonging to him commemorated both St. Martin and St. Andrew. By evincing a special interest in the Vercelli Book, he would have been honoring another saint (St. Helena) pecu-

${ }^{1}$ Of Chesterton, near Ely. Cf. Förster, p. 25; Festschrift, p. 39. 
liarly dear to the English heart. Finally, his library did contain one or more books in English chirography, was bequeathed to this monastery, and, with whatever augmentations it had received, was a notable one at the beginning of the fifteenth century.

In replying to the above arguments, Wülker admits (Codex Vercellensis, p. vI) the possibility of this mode of transmission, but urges that Guala probably understood no English, let alone Anglo-Saxon, and that if he be supposed to have presented this book to his foundation because it contained a poem on St. Andrew, that implies a good knowledge of Old English on his part. Besides, asks Wülker, who among his countrymen was to read the manuscript? To this it may be answered: Collectors of rare and precious volumes are not always familiar with the languages in which they are written, and yet are frequently aware of the notable matters they contain. In the case of a fine book like the Vercelli manuscript, we may either assume that there were Englishmen living who could read it, or that its contents were known in a general way by tradition. If it were venerated by the English, that would be a reason why a collector might be anxious to acquire it, whether he could read it or not; but we have seen, besides, that his monastery school at Vercelli attracted into residence a great Englishman (Adam de Marisco), so that his book may not have lacked readers on Italian soil, though we should grant that Italians found it unreadable.

The matter has recently been reopened by Förster, ${ }^{1}$ who adduces the following facts as bearing upon the problem:

I. Guala's church, or rather monastery, was erected on the site of a former church of St. Andrew.

2. The monastery was erected by, and for the use of, Augustinians whom Guala brought from St. Victor, near Paris, and a well-known French archæologist has declared the architecture to be Gothic of Northern France.

3. The catalogue of the books which Guala left to his monastery contains no mention of our manuscript.

4. In 1748 , and perhaps in 1602 , the manuscript belonged to

${ }^{1}$ Op. cit., pp. 23 ff.; Festschrift, pp. 35 ff. 
the cathedral library, and we are not sure that it was ever in the possession of the monastery.

5. No member of the higher clergy at the time of Guala's residence in England would probably have cared for an Old English manuscript, or have been able to read it, or even have been able to spell out the characters in which it was written. ${ }^{1}$ Even the English themselves could hardly understand Old English perfectly at the end of the I2th century. Hence the 'Andrea(s)' of the manuscript (occurring 32 times, by the way) would not have been likely to attract their attention, especially as it is nowhere conspicuous on the page.

Förster then suggests that, as Blume found in 1822 in the cathedral library a Gregorian sacramentary which had been lent by Erkanbald, Abbot of Fulda, to Henry, Bishop of Würzburg between 997 and IoI I, either Fulda or Würzburg, both centres of British learning, might perhaps have been the means of transmitting the Vercelli Book to Italy in the IIth or I 2 th century. Other monasteries which might be thought of are Luxeuil and Fleury.

The objections raised by Förster under (I) and (2) seem valid. To (3) it might be replied, as Förster himself admits, that Guala might already have presented the manuscript to his monastery; to (4) that the books of the monastery may have been turned over, at least in part, to the cathedral library, since no one seems to know what became of them. ${ }^{2}$ With respect to (5), I will quote from Earle $^{3}$ (pp. cviii-cxix) a few sentences already used in my brief paper, 'Archaic English in the Twelfth Century'4: 'Priority of attention to Latin, with a growing neglect of the mother tongue, was the prevailing tendency in the first half of the twelfth century; but then came a reaction, perhaps only

${ }^{1}$ Förster explicitly says (p. 33) that the period between I000 and II75 is the only one in which the writing and the language could have been read, and that, in fact, at any time after II25, the dominant French theology would have rendered a knowledge of Old English manuscripts the possession of only the occasional amateur. Cf. Festschrift, p. 47.

${ }^{2}$ So Förster, pp. 28-9; Festschrift, pp. 42-3.

${ }^{3}$ Hand-book to the Land Charters, and other Saxon Documents.

'Scottish Historical Review 12. 213-5. 
partial and local, of which our best specimens are in a book from Winchester. . . . Consequently we observe all the tokens of a Renaissance of the mother tongue. . . The study has manifestly engendered a real taste for the royal style of the old language, and a sincere passion to master the charm of it.' Earle then speaks of 'the genuine early forms that here and there peep out through the scholastic text' [of the charters that he cites], and adds: 'This brings us to the end of the twelfth or the beginning of the thirteenth century.' Again he speaks (p. 348) of the 'scholastic attention to the ancient forms of the language,' and of 'an Anglosaxon Renaissance at the close of the twelfth century,' and remarks of one of the charters in question ${ }^{1}$ that it is 'a work of the thirteenth century.', Evidently, then, there were ecclesiastics, higher or lower, who could read Old English at this time, and who would strive to communicate their enthusiasm to others. ${ }^{3}$

As to the transmission of English manuscripts to Vercelli by way of French or German monasteries, is it not more likely that any such should have come direct from England by the passes that Wülker designates? As late as the fourteenth century, at least, parties descending the Alps by the Mont Cenis passed through Vercelli on their way to larger and more important towns. ${ }^{4}$

${ }^{1}$ Cott. Claud. C. ix of the British Museum.

${ }^{2}$ For examples of the influence of a dominating foreign culture in stimulating the spirit of nationality, and reviving a vernacular literature, see Gaston Paris, La Poésie du Moyen Age 2. 35, 72, 74; Ker, English Literature: Medieval, pp. 65, 75 ff., 80; Morley, English Writers 3. 206; Wells, Manual of the Writings in Middle English, p. I95; Taylor, The Mediceval Mind 2. 164, 223; Zielinski, Cicero im Wandel der Jahrhunderte, 2d ed., pp. $235,397-8$.

${ }^{3}$ Since Layamon's 'English book that St. Bede made' is held to refer to Alfred's translation of the Ecclesiastical History, we must agree with Skeat that he 'could read the old version of Bede intelligently' (Encyc. Brit., IIth ed., I6. 3rr). Of his language Sir James Murray has said (ibid. 9. 59r): "The language, though forty years later than the specimen from the Chronicle [II40], is much more archaic in structure, and can scarely be considered even as Early Middle English.' Cf. Morley, English Writers 3. 2I I-2.

' See my paper, The Last Months of Chaucer's Earliest Patron (Trans. Conn. Acad. of Arts and Sciences 21. 43). 
We are evidently reduced to hypotheses; and, of all that have been proposed, that concerning Guala still seems to me the most plausible.

\section{AUTHOR AND DATE}

On the evidence of the interpersed runes near the end of the poèm, the Elene, like the Juliana, the Christ, and the Fates of the Apostles, was written by Cynewulf. The Juliana and the Elene spell the name Cynewulf, while the Christ, and probably the Fates of the Apostles, have Cynwulf. Cyne- in such words is the earlier spelling, and obtains from about 750 A. D. ; $C y n$-belongs almost wholly to the ninth century, but does not altogether crowd out the earlier Cyne-, which in turn had succeeded a still earlier Cyni-, again without completely displacing it. ${ }^{2}$ The prevailing view among scholars is that Cynewulf was a Northumbrian, or at least an Anglian, ecclesiastic, who wrote in the second half of the eighth century, ${ }^{2}$ or possibly as late as the very beginning of the ninth. ${ }^{3}$ Greater precision than this does not at present seem

${ }^{1}$ Christ, ed. Cook, p. 1xviii; Tupper, in Pub. Mod. Lang. Assoc. 26 (I9II). 240-244.

${ }^{2}$ See Carleton F. Brown, in Eng. Stud. 33 (1907). 225; Brandl, Gesch. der Altengl. Lit. (1908), p. 100; cf. Christ, ed. Cook, p. 1xxi.

${ }^{3}$ So Henry Bradley, in Encyc: Brit., IIth ed., 7. 691. Certain reasons which I advanced in 1892 (Angl. I 5. 9-20; cf. Christ, pp. lxix-1xx) in favor of this view were proved untenable by Carleton F. Brown (following Trautmann in Anglia Beiblatt II. 325) in 1903 (Pub. Mod. Lang. Assoc. 18. 308-334). The date could be established more exactly if the poet could be identified with the Bishop of Lindisfarne who died in 783 , as conjectured by Bouterwek (I857), and accepted by Dietrich (I865), Grein (I880), Trautmann (1898), and Brown (I907); cf. Christ, ed. Cook, pp. 1xx-1xxiii ; Brown, in Eng. Stud. 38. 225-233. The latter says (p. 226) : 'Bishop Cynewulf was appointed to the see of Lindisfarne in 740. After forty years' service, he resigned his office in 780 , and died in 783 . The date of his birth may by reasonable inference be fixed between 705 and 7 I0.' After traversing my objections, he concludes (pp. 232-3) : 'The poet was certainly an ecclesiastic; he was in all probability a Northumbrian; his poems were written during the second half of the eighth century. All these conditions are satisfied by Bishop Cynewulf. Outside of York, there is no place in Northumbria more likely to have been the poet's home than Lindisfarnefrom the time of Aidan a distinguished seat of Christian learning. In the library of this ancient monastery Cynewulf would certainly have found 
possible. A terminus a quo for the composition of the Elene may be assumed, if my conjecture regarding $1206^{\mathrm{b}}-12^{\mathrm{a}}$ is accepted. According to this, he would have written after 73I.

\section{SOURCES OF THE LEGEND}

The Elene is based upon a Latin version of a legend which, in its fully developed form, seems to be Syriac in origin, ${ }^{1}$ and which probably, though not certainly, entered Latin through the medium of Greek. This elaborated legend must have arisen about the beginning of the fifth century, though its larger outlines may have established themselves about 375 A. D. ${ }^{2}$ It became pretty well diffused over Latin Christendom from about the middle of the fifth century. ${ }^{3}$ Cynewulf's direct source, as Carleton F.

the writings of the Fathers, which he used so extensively, and the "books" to which he refers in the epilogue of Elene. Everything, in a word, which we know of Lindisfarne and of the bishop accords well with what we infer concerning Cynewulf from a study of the poems to which he has signed his name. Further than this, present evidence will not carry us.'

${ }^{1}$ Probably at Edessa, the seat of Syrian learning and literature in that period. Cf. Tixeront, Les Origines de l'Église d'Édesse, pp. 7-8: 'Édesse a été la première fondée de ces chrétientés [de Mésopotamie]; c'est de son sein que sont partis les missionnaires qui les ont évangélisées; elle est restée le centre des églises de langue.syriaque. Admirablement située entre le monde grec et le monde oriental, communiquant, d'une part, avec Antioche, dont elle relevait, et de l'autre, avec la Perse, la grande Arménie, et même avec l'Inde, la capitale d'Osrhoène était bien placée pour profiter à la fois et de la culture hellénique et de la puissante originalité des pays barbares. Elle était comme le confluent où les idées de deux mondes venaient se mêler et se confondre.' See also Holthausen's second edition of the Elene, p. xi.

The foundation of the developed story is not Syrian, as the various extracts quoted below will show.

${ }^{2}$ Tixeront, pp. I89-19I ; Lipsius, Die Edessenische Abgar-Sage; pp. 91-2; Ryssel, in Herrig's Archiv 93. 2; Byz. Zs. 4. 342 ff.; Holder, Inventio Sancte Crucis, pp. X-xI; Lejay, in Revue Critique, I89o, p. 40; Wotke, in Wiener Studien I3. 300-2.

${ }^{3}$ For bibliographies of the various versions, see Nestle, in Byz. Zs. 4 (1895). 319-345; Holthausen, in Zs. für Deutsche Phil. 37 (1905). 2-4. Holthausen lists, besides a prose version in Old English (Morris, Legends of the Holy Rood), others in Icelandic, Old Swedish, Middle English, and Middle High German, not to speak of those in Syriac, Greek, and Latin. 
Brown has shown, may well have been derived from Ireland, and he even inclines to suppose that 'the legend made its way to Ireland in a Greek text, and was there translated into Latin. ${ }^{{ }_{1}}$

If one undertakes to trace the growth of the legend, he finds it extremely difficult to determine where authentic history ends, and embellishment and invention begin. In what follows, the principal documents are quoted or summarized in order, beginning in the later years of Constantine's reign, and continuing down to about 500 A. D. ${ }^{2}$

Our earliest authority is Eusebius of Cæsarea (ca. 260-ca. 340 ), the most learned man of his age, highly esteemed by Constantine, and favored with access to many original sources of information which are now lost.

\section{(ABOUT 335 A. D.)}

Eusebius, Life of Constantine, Book 3, chaps. 26-30.

[The heathen had endeavored to obliterate from memory the sepulchre of Christ by covering it with earth, and laying over this a stone pavement. Eusebius continues:] They prepare on this foundation a truly dreadful sepulchre of souls, by building a gloomy shrine of lifeless idols to the impure spirit whom they call Venus. ${ }^{3}$. . . He [Constantine] . . gave orders that the place should be thoroughly purified. ... He gave further orders that the materials of what was thus destroyed, both stone and timber, should be removed and thrown as far from the spot as possible. ... Once more, ... he directed that the ground itself should be dug up to a considerable depth.... This also was accomplished without delay. But as soon as the original surface of the ground, beneath the covering of earth, appeared, immedi-

${ }^{1}$ Engl. Stud. 40. 14-29. Cf. Schirmer, Die Kreuzeslegenden im Leabhar Breac (St. Gall, $\mathrm{x} 886$ ).

${ }^{2}$ See Lipsius, pp. 7x ff.; Tixeront, pp. 163-170. For the original texts see Holder, pp. 45 ff.; Nestle, De Sancta Cruce, pp. Ioo, Ior, II4.

${ }^{3}$ This is also asserted by Rufinus, Eccl. Hist. ro. 7; Paulinus of Nola, Epistle to Severus 3I (II). 3; Jerome, Epistle to Paulinus 58. 3 (Migne, Patr. Lat. 22. 581) : 'For about 180 years, from the time of Hadrian to the reign of Constantine, an image of Jupiter was worshiped on the site of the resurrection, and a statue of Venus, erected by the heathen, on the site of the cross; the authors of the persecution imagining that if they polluted the holy places with idols, they would rob us of our faith in the resurrection and the cross.' Cf. Schürer, Hist. Jewish People $\mathrm{x}^{2}$. 314-320. 
ately, and contrary to all expectation, the venerable and hallowed monument of our Saviour's resurrection was discovered. ${ }^{1}$. . . Immediately after the transactions which I have recorded, the emperor sent forth instructions, . . . commanding that a house of prayer worthy of the worship of God should be erected near the Saviour's tomb, on a scale of rich and royal greatness. ... He also dispatched the following letter to the bishop who at that time presided over the church at Jerusalem :

Victor Constantinus Maximus Augustus, to Macarius:

... That the monument of his most holy passion, so long ago buried beneath the ground, should have remained unknown for so long a series of years, until its reappearance to his servants, is a fact which truly surpasses all admiration. ... With regard to the erection and decoration of the walls, this is to inform you that our friend Dracilianus, ${ }^{2}$ the deputy of the prætorian prefects, and the governor of the province, have received in charge from us.

Independent contemporary testimony to the discovery of the tomb and the erection of the church is furnished by the following :

\section{(332 A. D.)}

Itinerary from Bordeaux to Jerusalem (Palestine Pilgrims' Text Society), pp. 23-4.

About a stone's throw from thence [Golgotha] is a vault wherein his body was laid, and rose again on the third day. There, at present, by the command of the Emperor Constantine, has been built a basilica, that is to say a church, of wondrous beauty.

Thus far, there has been no mention of the discovery of the cross, but only of the tomb. The first author to speak of the former is Bishop Cyril of Jerusalem (d. 386):

$$
\text { (347 A. D.) }
$$

Cyril of Jerusalem, Catech. 4. Io (Migne, Patr. Gr. 33. 468-9).

${ }^{1}$ A. D. 326 (Ryssel, p. 3).

${ }^{2}$ The existence of this Dracilianus as deputy of the prætorian prefects is otherwise attested by instructions sent to him by Constantine in the years 325 and 326 (Lipsius, p. 72). 
He was indeed crucified for our sins; shouldst thou be disposed to deny it, the very place which all can see refutes thee, even this blessed Golgotha, in which, on account of him who was crucified on it, we are now assembled; and further, the whole world is filled with the fragments of the wood of the cross.

\section{Ibid. I0. I9 (ibid. 685, 688).}

The holy wood of the cross is his witness, which is seen among us to this day, and, through the agency of those who have in faith received it, has already from this place almost filled the whole world.

\section{Ibid. 13. 4 (ibid. 776-7).}

For though I should now deny it, this Golgotha confutes me, near which we are now assembled; the wood of the cross confutes me, which has from hence been distributed piecemeal to all the world. ${ }^{1}$

One of the most important testimonies is contained in an inscription from the Roman province of Africa:

\section{(359 A. D.) \\ Inscription at Tixter}

Three or four miles south of the railway station of Tixter, which is about sixteen miles from Sétif, on the railway leading to Algiers, there was found in October or November, I889. an inscribed stone some $5 \mathrm{I}$ inches square, which, according to the date near the end, was erected in the year 320 of the province of Mauretania, that is, 359 of our era. ${ }^{2}$ This stone originally marked the place of a basilica which, according to the inscription, possessed a portion of the wood

${ }^{1}$ Still more specific is an Epistle to Constantius of May 7, 35I, attributed to Cyril, but of somewhat doubtful authenticity (cf. Lipsius, pp. 73-4; Ryssel, p. 3, note I; Migne, Patr. Gr. 33. II53 ff.). The passage runs (Patr. Gr. 33. 1168): 'In the days of thy father Constantine, dear to God and of blessed memory, the saving wood of the cross was found in Jerusalem, divine grace granting the discovery of the hidden sacred places to him who sought piety aright.'

${ }^{2}$ Mélanges d'Archéologie et d'Histoire (École Française de Rome) 10. 440-468; Comptes-Rendus de l'Acad. des Inscriptions (M. Duchesne) I7. 4I7; I8. 233; Analecta Bollandiana 10. 366-7. The report in the Mélanges, by $\mathrm{M}$. Audollent, contains an excellent study of the inscription, and on p. $44 \mathrm{I}$ a photographic reproduction. The text of the inscription follows (ligno is actually lignu):

P Memoria sa(n)cta.-Victorinus Miggin, septimu(m) idus sept(e) $m(b) r(e s)$, bdv et dabulail, de lign(o) crucis, de ter(ra) promis- 
of the cross, as well as some of the soil of the Holy Land. This date is extremely important, since it is only 33 years, or less, after the reputed discovery by Helena, and only 25 years after the death of Constantine. The stone is now in the Christian Museum of the Louvre.

(BEFORE 363 A. D.)

Julian the Apostate, quoted by Cyril of Alexandria, Cont. Jul., Bk. 6 (Migne, Patr. Gr. 76. 796-7).

You worship the wood of the cross; you outline figures on your foreheads, and paint them in front of your houses.

\section{(ABOUT 385 A. D.)}

Pilgrimage of St. Sylvia (Palestine Pilgrims' Text Society), pp. 63-4.

A chair is placed for the bishop in Golgotha, behind the cross which stands there now; the bishop sits down in the chair; there is placed before him a table covered with a linen cloth, the deacons standing round the table. Then is brought a silver-gilt casket, in which is the holy wood of the cross; it is opened, and, the contents being taken out, the wood of the cross and also its inscription are placed on the table. When they have been put there, the bishop, as he sits, takes hold of the extremities of the holy wood with his hands, and the deacons, standing round, guard it. It is thus guarded because the custom is that every one of the people, faithful and catechumens alike, leaning forward, bend over the table, kiss the holy wood, and pass on. And as it is said that one time a person fixed his teeth in it, and so stole a piece of the holy wood, it is now guarded by the deacons standing round, so that no one who comes may dare to do such a thing again. And so all the people pass on one by one, bowing their bodies down, first with their forehead, then with their eyes, touching the cross and the inscription, and so kissing the cross they pass by, but no one puts forth his hand to touch it.

$$
\text { Ibid., p. } 76 .
$$

The dedication-festival of these holy churches [at Golgotha and the site of the Resurrection] is observed with the greatest honor, since the cross of the Lord was found on that day [Sept. I3].

(si)onis ub(i) natus est $C(h)$ ristus, apostoli Petri et Pauli, nomina m(a)rt(y)rum Datiani Donatiani C(y)priani Nemes(i)ani (C)itini et Victo(ri)as. An(n)o prov(inciae) (tr)ecentivi(g)es(imo)-Posuit Benenatus et Pequarla. 
Letter of Paula and Eustochium (Palestine Pilgrims' Text Society), p. I4.

When will the day come when we shall be able ... to weep with our sister and with our mother in the sepulchre of the Lord? Afterwards, to kiss the wood of the cross?

(BEFORE 387 A. D.)

Chrysostom, That Christ is God (Migne, Patr. Gr. 48. 826).

How is this very wood, on which the holy body was stretched and impaled, struggled for by all? For many, both men and women, taking a small portion of it, and setting it in gold, suspend it from their necks as an ornament.

Helena is first introduced by Eusebius, in connection with the churches of the Nativity and the Ascension:

\section{(ABOUT 335 А. D.)}

Eusebius, Life of Constantine, Book 3, chaps. 4I-43 (Migne, Patr. Gr. 20. I IOI, I IO4).

In the same country he discovered two other places, venerable as being the localities of two sacred caves, and these also he adorned with lavish magnificence.... And while he thus nobly testified his reverence for those places, he at the same time eternized the memory of his mother, who had been the instrument of conferring so valuable a benefit on mankind. For this empress, having resolved to discharge the duties of pious devotion to the supreme God, ... had hastened to survey this venerable land.... As soon, then, as she had rendered due reverence to the ground which the Saviour's feet had trodden,... she immediately bequeathed the fruit of her piety to future generations, for without delay she dedicated two churches ${ }^{1}$ to the God whom she adored. . . . Thus did Helena Augusta, the pious mother of a pious emperor, erect these two noble and beautiful monuments of devotion,.... and thus did she receive from her son the countenance and aid of his imperial power.

${ }^{1}$ The church of the Nativity is thus referred to in the Pilgrimage of St. Sylvia, about 385 A. D. (Palestine Pilgrims' Text Society), p. 50: 'And what shall I say of the decoration of that structure which Constantine, with the assistance of his mother, adorned, as far as the resources of his kingdom would go, with gold, mosaic, and precious. marbles?' 


\section{(395 A. D.)}

Ambrose, Oration on the Death of Theodosius, chaps. 43, 45-48 (Migne, Patr. Lat. I6. 1400-2).

Helena, wishing to revisit the holy places, went thither. Now the Spirit put it into her head to demand the wood of the cross. So, approaching Golgotha,.... she opens the ground, and removes the dust; there she finds three indistinguishable crosses, which ruin had covered, and the enemy had concealed, though unable to obliterate the triumph of Christ. She remains undecided, ... but the Holy Spirit suggests a clue in the fact that two thieves were crucified with the Lord. She therefore casts about to find the middle cross. Yet it might have happened that the crosses had become shifted in the ruins. Returning to the text of the Gospel, she finds that the inscription on the middle cross ran: 'Jesus of Nazareth, the King of the Jews.' From this the truth was determined: the cross of salvation was made known by its title. ... She therefore found the inscription, and adored the King, not the wood-for this is the error of the heathen, and the vanity of the wicked; him she adored who hung upon the wood. ... Then she sought the nails with which the Lord was crucified, and found them. Of one she commanded a bridle to be made, of another a crown to be fashioned. . . . She sent to her son Constantine the crown adorned with gems, ... and also the bridle. Constantine made use of both, and transmitted the faith to the kings who followed.

(ABOUT 400 A. D.)

\section{Rufinus, Eccl. Hist. Io. 7, 8 (Migne, Patr. Lat. 21. 475 ff.).}

[This in the main is like the account by Ambrose, up to the identification of the Saviour's cross. The inscription was found, but could not be assigned to any one of the crosses in particular.] Now it happened that there lay grievously i.".$n$ that city a woman of rank. At that time Macarius was bishop of that church. When he saw that the queen and those with her lingered, he said: 'Bring hither all the crosses which have been found, and God will show us which one bore the Lord.' Then, proceeding with the queen and the people to the house of her who was lying ill, he kneeled down and prayed thus: 'O Lord, thou who hast vouchsafed to bestow salvation on mankind by the passion of thy only begotten Son on the cross, and in these latter times hast inspired in the heart of thy handmaid to seek the blessed wood on which our salvation hung, show plainly which of these three was for the glory of the Lord, and which for slavish punishment, by causing this woman, who lies half dead, to return to life from the gates of death, so soon as she shall touch the saving 
wood.' When he had said this, he brought one of the three, but it had no effect. He brought the second, but nothing occurred. But when he had brought the third, the woman suddenly opened her eyes and sat up; having recovered her strength, she began to go about the house much more blithely than before she had been taken ill, and to magnify the power of the Lord. . . Part of the saving wood Helena sent to her son, and part she deposited in a silver case and left on the spot, where it is still preserved as a memorial.

\section{(ABOUT 403 A. D.)}

Paulinus of Nola, Epistle to Severus 3I (II). $73 \mathrm{ff}$. (Migne, Patr. Lat. 61. 326 ff.).

[Paulinus relates that Hadrian, thinking to injure the Christian religion, had erected a temple of Jupiter on the site of the passion. At the request of Helena, Constantine gives her authority to destroy all temples and idols which had profaned the holy places, and to erect churches in their stead. Arrived at Jerusalem, she knows not how to find the cross. Eventually she seeks out and consults, not only Christian men full of learning and sanctity, but also the cleverest of the Jews. She commands to dig at the spot designated. Citizens and soldiers join in the work. The crosses are found. God inspires her to make trial with the corpse of one newly dead. This is done, but the two crosses produce no effect. The Lord's cross raises the dead. A church is erected, which preserves the cross in a secret shrine.]

$$
\text { (ABOUT } 450 \text { A. D.) }
$$

Sozomen, Eccl. Hist. 2. I.

[Sozomen reproduces, in general, earlier accounts, but, after mentioning the temple of Venus, adds a significant statement:] At length, however, the secret was discovered, and the fraud detected. Some say that the facts were first disclosed by a Hebrew who dwelt in the East, and who derived his information from some documents which had come to him by paternal inheritance.

(ABOUT 496 A. D. ${ }^{1}$ )

(Pseudo-) Gelasius, Conciliar Decree on Canonical and Apocryphal Books (Mansi, Concil. 8. $163^{2}$ ).

${ }^{1}$ According to Duchesne, early 6th century.

${ }^{2}$ Cf. Hefele, Conciliengesch. $2^{2}$. 618 ff.; Liber Pontificalis, ed. Duchesne, I. cvir ; Epistole Romanorum Pontificum, ed. Thiel, I. 460. 
Likewise the writing concerning the invention of our Lord's cross, and the other writing concerning the invention of the head of the blessed John the Baptist, are new stories (novella quidem relationes sunt). Some Catholics read them; but when they come into the hands of Catholics, let it be with the prefatory text from St. Paul [I Thess. 5. 21] : Prove all things; hold fast that which is good.

According to another form of the legend, the cross was found in the reign of Tiberius (I4-37 A. D.), while St. James the Greater was Bishop of Jerusalem, by. Protonike, wife of the Emperor Claudius (4I-54 A. D.). This form has by some scholars been regarded as earlier than the story of Helena, but is now considered by the most competent authorities to be merely an adaptation of the latter. ${ }^{1}$

\section{CONSTANTINE AND THE VISION OF THE CROSS}

Eusebius, Life of Constantine I. 28-3I (Migne, Patr. Gr. 20. 944-5, 948).

Accordingly, he called on him with earnest prayer and supplications that he would reveal to him who he was, and stretch forth his right hand to help him in his present difficulties. And while he was thus praying with fervent entreaty, a most marvelous sign appeared to him from heaven, the account of which it might have been difficult to receive with credit, had it been related by any other person. But since the victorious emperor himself long afterwards declared it to the writer of this history, when he was honored with his acquaintance and society, and confirmed his. statement by an oath, who could hesitate to accredit the relation, especially since the testimony of after-times has established its truth? He said that about midday, when the sun was beginning to decline, he saw with his own eyes the trophy of a cross of light in the heavens, above the sun, and bearing the inscription, 'Conquer by this.' At this sight, he himself was struck with amazement, and his whole army also, which happened to be following him on some expedition, and witnessed the miracle.

He said, moreover, that he doubted within himself what the import of this apparition could be. And while he continued to ponder and reason on its meaning, night imperceptibly drew on; and in his sleep

${ }^{1}$ See Nestle, De Sancta Cruce, pp. I ff., 65 ff.; Lipsius, pp. 88-92; Tixeront, pp. I84-I9I; Ryssel, pp. I-3. The IIth edition of the Encyclopadia Britannica $(7.506)$ is wrong, then, in calling the legend of Protonike the older. 
the Christ of God appeared to him with the same sign which he had seen in the heavens, and commanded him to procure a standard made in the likeness of that sign, and to use it as a safeguard in all engagements with his enemies. At dawn of day he arose, and communicated the secret to his friends; and then, calling together the workers in gold and precious stones, he sat in the midst of them, and described to them the figure of the sign he had seen, bidding them represent it in gold and precious stones. And this representation I myself have had an opportunity of seeing.

Now it was made in the following manner. A long spear, overlaid with gold, formed the figure of the cross by means of a piece transversely laid over it. On the top of the whole was fixed a crown, formed by the intertexture of gold and precious stones; and on this, two letters indicating the name of Christ symbolized the Saviour's title by means of its first characters-the letter $\mathrm{P}$ being intersected by $\mathrm{X}$ exactly in its centre; and these letters the emperor was in the habit of wearing on his helmet at a later period. From the transverse piece which crossed the spear was suspended a kind of streamer of purple cloth, covered with a profuse embroidery of most brilliant precious stones; and which, being also richly interlaced with gold, presented an indescribable degree of beauty to the beholder. This banner was of a square form; and the upright staff, which, in its full extent, was of great length, bore a golden half-length portrait of the pious emperor and his children on its upper part, beneath the trophy of the cross, and immediately above the embroidered streamer. The emperor constantly made use of this salutary sign as a safeguard against every adverse and hostile power, and commanded that others similar to it should be carried at the head of all his armies.

Lactantius, Of the Manner in which the Persecutors died, chap. 44 (Migne, Patr. Lat. 7. 260-2).

And now a civil war broke out between Constantine and Maxentius. . . They fought, and the troops of Maxentius prevailed. At length Constantine, with steady courage and a mind prepared for every event, led his whole forces to the neighborhood of Rome, and encamped them opposite to the Milvian bridge. . . . Constantine was directed in a dream to cause the heavenly sign to be delineated on the shields of his soldiers, and so to proceed to battle. He did as he had been commanded, and he marked on their shields the letter $\mathrm{X}$, with a perpendicular line drawn through it and turned round at the top, thus, $\mathbb{X}$, being the cipher of Christ. Having this sign, his troops stood to arms. The enemy advanced, but without their emperor, and they crossed the bridge. The armies met, and fought 
with the utmost exertions of valor, and firmly maintained their ground. . . : [At length Maxentius went to the field.] The bridge in his rear was broken down. At sight of that the battle grew hotter. The hand of the Lord prevailed, and the forces of Maxentius were routed. He fled towards the broken bridge; but the multitude pressing on him, he was driven headlong into the Tiber. The destructive war being ended, Constantine was acknowledged as emperor, with great rejoicings, by the senate and people of Rome. 


\section{PHENIX}

\section{MANUSCRIPT}

The Phonix is contained on leaves $55^{\mathrm{b}}-65^{\mathrm{b}}$ of the Codex Exoniensis, or Exeter Book, which has been in possession of Exeter Cathedral since about the middle of the eleventh century, having been presented to it, among other valuable gifts, by Leofric, Bishop of Devon and Cornwall from about 1046, who was enthroned at Exeter in 1050, and died in ro72.

The manuscript is 14 centimetres in height by $18 \mathrm{r} / 2$ in breadth-approximately $5^{\mathrm{T} / 2}$ by $7 \mathrm{~T} / 2$ inches. It is written on vellum, apparently by a single hand of the early eleventh century. Thorpe calls the writing 'fair and rather fine,' and Conybeare speaks of 'the clearness and beauty of its characters.' At present the volume proper consists of I23 leaves, or 246 pages, from $8^{a}$ to $130^{b}$. Only one leaf is wanting in the interior of the volume, that between fol. 37 and fol. 38 . On the other hand, several leaves are missing at the beginning and end. Only the commonest abbreviations are found. The whole manuscript must have been corrected by another hand after writing, the corrections being in a paler ink.

Among the other poems of the Exeter Book are the Christ, Guthlac, Azarias, Juliana, Wanderer, Seafarer, Harrowing of Hell, and Ruin. With the exception of a few fragments at the end of the manuscript, then thought undecipherable, the poems were all published by Thorpe in 1842 , under the title Codex Exoniensis. Opposite p. 293 of that volume is a facsimile of part of page $77^{2}$ of the manuscript, the beginning of the Gifts of Men. The first volume of a republication of the Exeter Book, containing the Christ, Guthlac, Azarias, Phonix, Juliana, Wanderer, Gifts of Men, and A Father's Instruction, was issued by Gollancz (E. E. T. S. 104) in I895. A careful collation by Schipper was published in 1874 (Germania 19. 327-338), and another was made by Assmann for the Grein-Wülker Bibliothek der Angelsächsischen Pocsie. 
For further particulars concerning the manuscript and its donor, see my edition of The Christ of Cynezulf, pp. xiii-xvi.

\section{AUTHOR AND DATE}

Beginning with Kemble, in 1840 , many scholars, including such as Klipstein (1849), Dietrich (1859), Sweet (I871), Ten Brink (I877), Gaebler (I880), Grein (I880), Sarrazin (I886), Brooke (1892), have believed that Cynewulf was, or may have been, the author of the Phonix. Holtbuer (I884) was the first to reject this view, and such scholars as Sievers (I885), Ebert (I887), Bülbring (I89I), Wülker (I896), Trautmann (1907), Brandl (1908), and Strunk (1904) have come to a similar negative conclusion.

As the Phonix contains no runic passage embodying the name of the author, the ascription of it to Cynewulf rests upon identities or similarities of diction, subject, or general treatment with the undoubted works of Cynewulf, or with such as are ascribed to him by practically universal consent.

Dietrich $^{1}$ adduces, besides certain correspondences with the Elene (and with Guthlac and Andreas, which he ascribes to Cynewulf), such as these between the Phonix and the Christ: Ph. 420: Chr. 142, 250-253, 367, 587; Ph. 50-70, 589, 61 1-617: Chr. 1634-1664; Ph. 56, 613: Chr. 1660-1661; Ph. 329, 493: Chr. 1228; Ph. 516: Chr. 1079; Ph. 525: Chr. 811; Ph. 584: Chr. 820; Ph. 604: Chr. 505; Ph. 628: Chr. 726.

Dr. Arthur W. Colton, in an unpublished investigation, discovered (about 1892) that the verbal and phrasal correspondence between the Christ and the Phonix was even greater than between the Christ and either the Elene or the Juliana, undoubted poems of Cynewulf. Words and phrases were listed separately, and these were divided into four main categories, according as the expression occurred in one, two, three, or four poems besides the Christ, the plan being that formulated in my first edition of the Judith. The ratio of correspondence between the Christ and the Elene was .085 , this ratio being the result of dividing the

${ }^{1}$ Commentatio, pp. 9, I0. 
total number of correspondences by the number of lines in the poem. In the case of the Juliana it was .084; in that of the Phonix, .o9. This result would accordingly create a presumption that the Phœnix was the work of Cynewulf.

The chief arguments against such a presumption lie (as Strunk has said ${ }^{1}$ ) in 'the absence of the runic signature, and the metrical necessity of admitting quantities and inflectional forms (as glōdum, glādum, Ph. 92, 303; fōtas, Ph. 3II) not found in the acknowledged poems. Further, it must be admitted that the resemblances of word, phrase, and idea extend in varying degree through practically the whole body of Old English religious poetry.'

Brandl $^{2}$ (I908) would place the author of the Phœnix among the contemporaries or immediate successors of Cynewulf ${ }^{3}$ : in style and syntax they resemble each other; both acknowledge indebtedness to books ( $P h$. 424; cf. my edition of The Christ of Cynewulf, p. lxxxiii) ; and both make use of rhyme; on the other hand, the author of the Phœnix employs sharp antitheses, and ends his poem with macaronic verses.

I can not better express my own opinion than by quoting a paragraph already in print": 'The theme of the Phonix would have been congenial to Cynewulf, and his reading may well have included Lactantius. ${ }^{5}$ The verbal parallels and similarities of thought are striking, and the percentage of correspondences in Dr. Colton's table agrees remarkably with that of the Juliana and the Elene. In respect to the prominence of color, flowers, fragrance, and music, of brooks, trees, groves, and plains, the Phonix excels the undoubted poems; but against this must be set Cynewulf's impressibility-the fact that his vocabulary and imagery change to some extent with his mood and with the

${ }^{1} J u l i a n a$, p. xxii.

${ }^{2}$ Gesch. der Alteng. Lit., p. 106.

${ }^{3}$ Schlotterose, in his edition of the Phonix (p. 92), holds a somewhat similar opinion: the Phonix is later than Cynewulf, but was strongly influenced by him. Barnouw (I902) is in doubt, but is sure that, if Cynewulf wrote it, the Phanix was his latest work.

${ }^{4}$ The Christ of Cynewulf, pp. 1xiv-1xv.

${ }^{5}$ Lactantius was among the authors included in the York Library, according to Alcuin. 
original upon which he is working. From no three of his undoubted poems could one, on stylistic grounds, and in the absence of the runic testimony, have ascertained his fourth. When he is paraphrasing long, didactic speeches he is another man than when he is telling a stirring tale, or reproducing the spirit of a poem full of sublime sentiment and magnificent appeals to the imagination. There is therefore no a priori ground for assuming that the Phonix cannot be by Cynewulf. Much of the sentiment is demonstrably his; the correspondences in phraseology indicate the hand of a master, so inwoven are they into the tissue of the style; and a doxology like that of lines 6I 5-629 would of itself almost persuade the critic to believe in Cynewulf's authorship, so similar is it in tone and setting to those of the Elene and the Christ. ${ }^{2}$ It cannot be said that the question is decided; but I believe that scholars will end by assigning the Phonix, like the Andreas, to Cynewulf.'3

On the supposition that the Phœnix is by Cynewulf, reference may be made to the Introduction to the Elene (pp. xiii-xiv), where his date and personality are discussed. If it is not by Cynewulf, we can hardly say more than that the writer must have been a monk or ecclesiastic, apparently under the influence of the Cynewulfian poetry, and likely to have lived either within the period of Cynewulf's poetic activity (about $750-800),{ }^{4}$ or soon after.

\section{LACTANTIUS}

It has long been recognized that the Phœnix was largely derived from the $D e$ Ave Phœnice ${ }^{5}$ attributed to Lactantius. We shall therefore first give a brief account of Lactantius, and then review the evidence in favor of his authorship of the $D e A v e$ Phonice.

744-754.

$385-415$.

${ }^{3}$ For the history of opinion on this subject, see Jansen, Die CynererulfForschung von ihren Anfängen bis zur Gegenwart, Bonn, I908, pp. 105-8; Schlotterose, op. cit., pp. 88-92.

"This is the period assigned by Carl Richter (Chronologische Studien zur Ags. Literatur, I9Io) to both Cynewulf and the Phanix.

First by Conybeare, Arch. 17 (1814). 193 
The name of Lactantius was Lucius Cælius (or perhaps Cæcilius) Firmianus Lactantius. ${ }^{1}$ Born in Africa, not far from the year 260, he became a pupil of Arnobius, who taught rhetoric with brilliant success at Sicca Veneris ${ }^{2}$ in Proconsular Africa, near the borders of Numidia. At this time both Lactantius and his master were heathen. Here he must have applied himself with much diligence to the study of Latin literature. He modeled his style so closely on Cicero that he far surpassed Arnobius as a writer, and already Jerome characterized him as 'a river of Ciceronian eloquence. ${ }^{3}$ In consequence of this devotion, his diction shows comparatively few traces of Africanisms, such as were not infrequent in the writings of others who lived in that province of the Roman Empire. His philosophical training must have been largely in the doctrines of the Stoics, and to the end he seems more deeply imbued with their philosophy than with the teachings of Scripture.

About four or five years after Diocletian's accession to the throne, or in the neighborhood of A. D. 288, he was called by that

${ }^{1}$ This sketch reposes chiefly upon Brandt, Ueber das Leben des Lactantius (Sitzungsber. der Wiener Akad., Vol. 120), who has criticized in several points the statements of Jerome, our chief ancient authority for the biography of Lactantius, and is in turn criticized by Seeck, Gesch. des Untergangs der Antiken Welt I. 456-460. The longest statement of Jerome's is the following (On Illustrious Men, chap. 80) : 'Firmianus, also known as Lactantius, a pupil of Arnobius, received a call in the reign of the emperor Diocletian, along with the grammarian Flavius, whose book in verse, On Things Medical, is still extant. He taught rhetoric at Nicomedia, but on account of the lack of pupils-for the city was a Greek one-betook himself to authorship. We have from him the Banquet, which he wrote as a young man in Africa; an Itinerary (Hodoporicon) from Africa to Nicomedia, written in hexameters; another book entitled The Philologist (Grammaticus); the fine treatise, On the Anger of God; seven books of Divine Institutions, directed against the heathen; an Epitome of the last-named work; one book $\dot{\alpha} \kappa \dot{\epsilon} \phi a \lambda o \nu$; two books $T \dot{o}$ Asclepiades; one book On Persecution; four books of letters To Probus; two books of letters To Severus; two books of letters To Demetrianus, an attendant on his lectures; one book to the same On the Work of God in the Formation of Man. In extreme old age he was the tutor in Gaul of Crispus Cæasar, the son of Constantine, who was afterward put to death by his father.'

${ }^{2}$ Now Kef, east of Constantine.

${ }^{3}$ Epist. 58. 10. 
emperor to the chair of rhetoric, or oratory, in his new capital of Nicomedia, which he was then adorning with public buildings, little imagining that it was so soon to be superseded by Constantinople as the seat of the Eastern Empire. This call indicates what celebrity Lactantius had already achieved.

Arrived in Nicomedia, he must have devoted himself to his professional work for fifteen or eighteen years, without endeavoring to engage in the practice of forensic oratory. In his Christian zeal, he afterwards came to disprize the teaching of oratory, almost in the spirit of Plato. ${ }^{1}$

It was probably while in Nicomedia that Lactantius became a Christian, though he would undoubtedly have had opportunities of coming in contact with Christians while still in Africa. There were several communities of Jews in North Africa, ${ }^{2}$ and in these the first conversions to Christianity would be almost certain to occur.

His profession of Christianity may well have been the cause of his degradation from the professorial rank, since Diocletian's edict of Feb. 24, 303 expressly commanded that Christians should be deprived of their honors and dignities. ${ }^{3}$ That he had reason to shrink from too great publicity with regard to his Christian belief is shown by his tractate, On the Work of God, written about this time. In the first place, the doctrines which he here professes are virtually Stoic-those of monotheism and Providence. In the second place, he is extremely guarded in his allusions to the faith professed in common by himself and his correspondent, while at the same time he shows that he had given up other pursuits, and was devoting himself to authorship. ${ }^{4}$

Lactantius must have remained in Bithynia for two years after the persecuting decree of Diocletian. ${ }^{5}$ The fifth book of his Divine Institutes shows, by its allusions, that he was not at that time in Nicomedia. Now scholars are practically agreed that the Institutes were completed not later than $3 \mathrm{IO}$, or $3 \mathrm{II}$ at latest.

${ }^{1}$ Inst. I. I. 8.

${ }^{2}$ See Hastings, Dict. Bible, Extra Vol., p. 97; Monceaux, in Revue des Études Juives 44. I-28.

${ }^{3}$ Eusebius, Eccl. Hist. 8. 2; Lactantius, Deaths of the Persecutors 13.

${ }^{4}$ Cf. De Opif. I. I. I-4, 9; 20. I.

Inst. 5. II. I5. 
Hence it becomes natural to think of 308 , or thereabouts, as the year when he accepted Constantine's invitation to Gaul as the tutor of his son Crispus. ${ }^{1}$

If we may attach full weight to Jerome's words, extrema senectute, he may have died about 340, and possibly in Trier, but this date, like that of his birth, is merely inferential, and at best approximate.

We have no certain knowledge that Lactantius ever visited Egypt, but since he presents in his poem on the Phœnix an epitome of extant knowledge on the subject, in this respect, and in his reflections on the theme, much surpassing his predecessors, it would not be surprising if his deep interest in it had been either occasioned or strengthened by a sojourn in that country. Certain of the ancient authorities on the Phœnix were themselves Egyptians (such as Nonnus and Horapollo), or had resided in Egypt (Hecatæus, Herodotus' informant, and Claudian, ${ }^{2}$ for example). The worship of Isis flourished at Rome during this period, and for that reason, and because the Egyptians had tenaciously maintained their ancient religion in the face of innovation, their institutions may well have attracted the curiosity of a young and highly educated traveler, already a celebrity. Then, too, Lactantius manifests some knowledge of Egyptian history in his undoubted works-especially the Divine Institutes ${ }^{3}$ though this, it is true, might have been derived from books.

If he did visit Egypt, it might have been in the train of Diocletian, on the occasion of the latter's military expedition thither in 295 or 296 . Since we must infer that Constantine the Great spent some time in Egypt, ${ }^{4}$ either with Diocletian, ${ }^{5}$ or later in

${ }^{1}$ Authorities are not at one concerning this date, however. Cf. Brandt, op. cit., p. 33; Seeck, Gesch. des Untergangs der Antiken Welt, 2d ed., I. 458,475 .

${ }^{2}$ Jeep (Claudii Claudiani Carmina $\mathrm{I}, \mathrm{xxx}$ ) assumes that his poems on the Nile and the Phœenix were written while he was living in Egypt.

${ }^{3}$ Cf. Inst. I. 20. 36 ; 2. I3. I0, II ; 2. 5. 35, 36 (here he calls this worship endurable); 5. 20. 12; Epit. 50 (55). 3. For other references see the index to Brandt's Lactantius (Corp. Script. Eccl. Lat. 27. 280) under Acgyptii, Aegyptus.

${ }^{4} \mathrm{Cf}$. his Oration to the Saints 16. 2.

'Schiller, Gesch. der Röm. Kaiserzeit 2. I38-I40. 
$302,{ }^{1}$ it might have been in his company. This supposition is strengthened by the consideration that Constantine stood in peculiar relations to two scholars-Eusebius, who wrote his biography, and Lactantius. Eusebius was in Egypt, according to his own testimony (Eccl. Hist. 8. 9), and Lactantius, whose doctrines furnished the basis for Constantine's oration mentioned above, may likewise have been there. ${ }^{2}$

A man of warm friendships, ${ }^{3}$ the best Latin prose writer of his time, and with the instinct of a born teacher, Lactantius was a mediator between ancient culture and the new faith, recommending the latter by his suavity and moderation, and the charms of his style, to educated and courtly circles who otherwise would have remained contentedly ignorant of it, or have cherished toward it an invincible aversion. He dwelt upon what was common to Christianity with the austerest moral creed of antiquity, and thus conciliated the most virtuous element in the society of his time. Born in Africa, passing his middle life in Asia, and dying (as is probable) in Europe, he served in this sense, too, as a mediator between the Orient and the Occident, between the old and the new. Called to teach ancient literature by a heathen emperor and persecutor, he so far gained the favor of the first Christian emperor as to be entrusted by him with the education of the heir to his throne. Graced with a learning which enabled him to associate on terms of intimacy with the great, he seems to have known the pangs of poverty and disgrace, yet to have preserved his equanimity, and illustrated his enforced leisure. If we do not feel justified in calling him a time-server, we can but admire the dexterity with which, without sacrificing any conviction which

${ }^{1}$ Seeck, op. cit. I. $479-480$.

${ }^{2}$ It is worthy of note that Eusebius (Vita Const. 4. 72) is the only ancient author who calls the Phœnix Egyptian. Constantine paid peculiar attention to the symbol of the Phœnix, no doubt because he was especially addicted to the worship of the sun. The Phønix is found on his coins and those of his sons, with such legends as Felix Reparatio Temporum, and Perpetuitas (see Schöll, Vom Vogel Phönix, p. 12); and John of Salisbury (Policr. I. I3; see Schöll, p. 46) reports that Constantinople was founded on the occasion of the appearance of a Phœnix, which is interesting as showing how later ages associated the two.

${ }^{3}$ Brandt, in Sitzungsberichte, p. $4 \mathrm{I}$. 
seemed to him vital, he yet contrived to escape martyrdom while urging the claims of truth and virtue, and to win the favor of a Christian emperor while not falling under the worst displeasure of his heathen predecessor.

Such a character as we have seen Lactantius to be would be sure to attract the men of the Renaissance, and accordingly we find that he appealed strongly to its protagonists, men like Petrarch and Pico della Mirandola. Petrarch' speaks of him as 'rolling forth in a milky torrent,' with an obvious allusion to the name Lactantius. Perhaps with Jerome's estimate ${ }^{2}$ in mind, Pico della Mirandola calls him the Christian Cicero, and even suggests that he may be Cicero's superior in eloquence. ${ }^{3}$ The estimation in which he has since been held is attested by the fact that, up to 1905, there are said to have been I 12 editions of his works, a number greater than that of any other church-writer, the earliest being dated in 1465 , at Subiaco, and being the first book printed in Italy. ${ }^{4}$

\section{LACTANTIUS AND THE DE AVE PHCENICE.}

The question of Lactantius' authorship of the De Ave Phonice has been much debated. ${ }^{5}$ Those who answer it in the affirmative rely upon four arguments, urged by various scholars with various force. These are: (I) the testimony of the manuscripts; (2) the attribution of the poem to Lactantius by mediæval writers; (3) the similarity of its sentiments and diction to those of Lactantius' undoubted prose works; (4) the Christian character of the poem. Of these it is the last which has been most vigorously contested by the opponents.

${ }^{1}$ De Otio Religiosorum, Bk. 2 (Opera, Basel, 1554, p. 363; 1581, p. 322).

${ }^{2}$ See above, p. xxix.

${ }^{3}$ De Studio Divina atque Humane Philosophic, Bk. I, chap. 7 (Opera, Basel, 1573, p. 21).

- Schanz, in Müller, Handbuch, 2d ed., $8^{3} .474$.

- Bibliographies may be found in Brandt, Corpus Script. Eccl. Lat. 27. xxi; Manitius, Gesch. der Christl.-Lat. Poesie, p. 44; Teuffel, Gesch. der Lat. Litt., § 397, note 8; Schanz, op. cit., pp. 468-70; cf. also Löbe, Jahrbb. für Prot. Theol. 18. 37. 
As to the first argument, the best manuscript, the Parisinus of the eighth century, assigns no title to the poem; the next, the Veronensis of the ninth century, after giving Claudian's Phonix, subjoins: Item Lactatii de eadem Ave; the third, the Vossianus (Leiden University), of the nineteenth century, has: Versus Lactantii de Ave Frnice. ${ }^{1}$

Secondly, Gregory of Tours ${ }^{2}$ (before 582), treating of the wonders of the world, and coming to the third one, begins: Tertium [miraculum] est quod de Phœnice Lactantius refert. He then passes on to an abstract of the poem, partly in the original words, but with some difference of detail, as if Gregory might have been quoting from memory. ${ }^{3}$ Again, a grammarian of the seventh century ${ }^{4}$ ascribes the poem to Lactantius, and quotes it eight times. Finally, Alcuin, ${ }^{5}$ in a lișt of books in the York Library, names, among Christian poets,

Quid Fortunatus vel quid Lactantius edunt,

which would seem to refer to the Phœnix.

Thirdly, various correspondences have been traced between the Phonix and Lactantius' undoubted works. ${ }^{7}$ A few of these may be here noted:

I. The description of Paradise accords in general with that of Inst. 2. 12. I5; Epit. 27. 2.

${ }^{-1}$ Löbe, p. 40; Baehrens, Poet. Lat. Min. 3 (I88I). 247-8; Manitius, p. 45 .

${ }^{2}$ De Cursu Stellarum, chap. 12.

${ }^{3}$ The passage of Gregory is quoted, and the differences emphasized, by Baehrens, pp. 250-252; cf. below, p. xxxviii.

'De Dubiis Nominibus, in Keil, Gram. Lat. 5. 577. 14-593. 26.

${ }^{5}$ De Sanctis Eccl. Ebor. 1552.

- Manitius, p. 45; Brandt, Corpus 27. 135.

'Thus by Dechent (Rhein. Mus. 35 (1880). 50 ff.), but especially by Löbe.

${ }^{8}$ If, as Pichon asserts (see p. xxxy), Constantine's Oration to the Saints reposes on Lactantian doctrine, it is significant that the oration contains this passage (2. 5): 'And immediately he transferred our newly created parents (ignorant at first, according to his will, of good and evil) to a happy. region, abounding in flowers and fruits of every kind. At length, however, he appointed them a seat on earth, befitting creatures endued with reason.' 
2. Lines 64 and 109 indicate a dualistic doctrine, which is also reflected in Epit. 27. 4; Inst. 2. 12. I9; 2. 9.5 ff.; cf. 2. 9. I9, 21 with $P h .22,24$.

3. Lines 57,58 , which make the Phœnix a priest in the sun's temple, find a parallel in De Ira I4. $\mathbf{r}$.

4. Line 164 , in praise of chastity, may be illustrated by Epit. 66; De Ira 23. 22, 27 ; De Opif. I9. ro, but especially 6. 23 ff.; 7. 27 .

5. Line 58 , with its mention of 1000 years, may correspond to Inst. 7.22 .7 ff.; Epit. 27. $5 ; 72.3 \mathrm{ff}$.

6. In various respects the use of words, the constructions, and the figures of speech employed by Lactantius are like those of the Phonix. ${ }^{1}$

7. The extent and minuteness of knowledge displayed by the author of the Phonix is such as one would expect in the work of a student, one may say a philologist, ${ }^{2}$ like Lactantius. ${ }^{3}$

8. Jerome tells us that Lactantius wrote poetry; there is therefore no intrinsic improbability of his writing such a poem as the Phonix.

To these we may add three others:

9. Lines II-r4, referring to the destruction of the earth by fire and water, refer to Phaethon and Deucalion; but so also does Inst. 2. I0. 23, and in the same order: 'All may perish, . . . either . . . by the conflagration of the world, as is said to have happened in the case of Phaethon, or by a deluge, as is reported in the time of Deucalion.'

Io. Pichon, ${ }^{4}$ in a literary appreciation of Lactantius as a prose writer, says: 'He possesses all the serious classical qualitiesregularity, equilibrium, moderation, clearness, precision, noble gravity, simple and sober eloquence, ingenious and patient industry; in one word, intellectual probity. On the other hand, we find in him the defects, or rather the gaps and limits of classicism: he is neither very deep, very impassioned, very clever, nor very

${ }^{1}$ Löbe, pp. 53 ff.

${ }^{2}$ We must remember that Lactantius wrote a Grammaticus.

${ }^{8}$ Löbe, pp. 38-9, 43, 64-5.

Lactance, p. 455. 
original.' Would not much of this serve to characterize the Phœnix?

I I. Lactantius himself says (Inst. 5. I. 9-I I) : 'Many waver, and especially those who have any acquaintance with literature. For in this respect philosophers, orators, and poets are pernicious, because they are easily able to ensnare unwary souls by the sweetness of their discourse, and of their poems flowing with delightful modulation. These are sweets which conceal poison. And on this account I wished to connect wisdom with religion, that that vain system may not at all injure the studious; so that now the knowledge of literature may not only be of no injury to religion and righteousness, but may even be of the greatest profit.' Is there anything in the Phœnix.which militates against this conception?

Fourthly, as to the Scriptural character of the poem:

I. Lines 25-30 describe a spring-living, transparent, in the midst of the grove, which it waters every month, and which bears fruit. This corresponds to Rev. 22. I-2; Ezek. 47. 7, I2; Gen. 2. 9, Io (cf. Ps. I..3; 46. 4; Jer. 2. I3; I7. 8, I3; Ezek. 19. Iо ; John 4. IO, I4). ${ }^{1}$ It is evident that 'tree of life,' Rev. 22. 2, is a collective, and stands for a number (cf. Ezek. 47. 7, 12).

A slight difficulty is occasioned by the word fons, which, however, reposes on Gen. 2. 6, a verse followed by other Christian writers of the first centuries. Thus the poem Ad Flavium Felicem (Vienna Corpus Script. Eccl. Lat. $3^{3} \cdot 3$ I8) has (238-9):

Fons illic placido perfundit agmine campos;

Quattuor inde rigant partitam flumina terram. ${ }^{2}$

The other difficulty is with respect to the monthly irrigation, but this is merely an inference, it would seem, from the fact of the monthly bearing of fruit (see esp. Ezek. 47. 12). ${ }^{3}$

${ }^{1} \mathrm{Cf}$. below, pp. lii-liii.

${ }^{2}$ So also Pseudo-Cyprian, De Laude Mart. 2I (ibid., p. 44) ; Alcimus Avitus, Poem. I. 252, 259, 260 (Migne, Patr. Lat. 59. 329); Isidore of Seville, Etymol. I4. 3. 3 (Patr. Lat. 82. 496) ; cf. Milton, P. L. 4. 229.

${ }^{3}$ The use of the number 12 in line 8 may also be due to a Biblical reminiscence, e. g. Ezek. 43. 16. 
2. Line $6_{4}$ speaks of the reign of death. This must refer to such conceptions as those conveyed by Rom. 5. 12, I4, I7 (cf. Gen. 2. I7; 3. 19, 23).

3. Line 93, 'commends his spirit,' is apparently due to Lk. 23. 46 (cf. Inst. 4. 26. 32).

4. More remote and doubtful are such. parallels as 78: Lk. 24. 26; II6: Jn. I4. 2 ; I55: Mk. I. $45 \cdot{ }^{1}$

Ebert (Gesch. der Christl.-Lat. Lit., 2 d ed., I. IOO) points to the praise of chastity (lines I64-5), the reference to the earth as the abode of death (line 64), and the emphasis on voluntary death (line 93-4), as evidences of Christian influence.

The apparent introduction of chiliastic doctrine (cf. above, p. $\mathbf{x x x v}$ ) is perhaps sufficiently accounted for by the belief in a phœnix-cycle of a thousand years entertained by Martial, Pliny (29. I. 29), Claudian, and certain Jewish Rabbis (see Bochart, Hierozoicon, ed. I796, 3. 8Io). Most of the earlier Christian authorities prefer the term of 500 years, while that of 1000 years is preferred bý Ambrose, Gregory Nazianzen, Ausonius, and Nonnus. ${ }^{2}$

Those who do not distinctly favor the attribution of the Phœnix to Lactantius fall into two classes: (I) those who have no decided opinion, who, in discussing Lactantius, fail to mention this poem, or who assign no reasons for their rejection of it (Heumann, Fritzsche, Bernhardy, Kotze, Nirschl, Alzog, Ritschl); and (2) those who adduce reasons, of whom Bachrens may be regarded as the type. These reasons, so far as they deserve our attention, reduce themselves to $\operatorname{six}^{3}$ :

I. No ancient author assigns the poem to Lactaritius.

2. It exhibits no traces of Christian influence.

3. The argument from chiliastic doctrine is weak.

4. A Christian author would have 'improved' much further the opportunities which the poem afforded him.

5. Lines $33 \mathrm{ff}$., 58 seem to point to sun-worship.

${ }^{1}$ Adduced by Löbe, pp. 50, 51 .

${ }^{2}$ See note on $P h$. I5I.

${ }^{3}$ See especially Löbe, p. 37 ; Poet. Lat. Min., ed. Baehrens, 3. $248 \mathrm{ff}$. 
6. The passage from Gregory of Tours, ${ }^{1}$ attributing the poem to Lactantius, exhibits some divergences from the $D e A v e$ Phonice, so that Gregory's rendering may repose upon a portion of Lactantius' Hodoporicon in which he might have incorporated the Phonix of an earlier heathen author, that is, our very poem.

(I), (2), and (3) demand no further comment than is given above; (4) is sufficiently met by the consideration that Lactantius may have become a Christian by slow degrees, and certainly, as we have seen ( $\mathrm{p} . \mathbf{x x x}$ ), hesitated at times to avow the Christian faith in an explicit manner; under (5), as Löbe points out, ${ }^{2}$ the reference may as easily be to Christ; and (6) is too involved a hypothesis, when the difficulties may be met as well by supposing Gregory to have quoted from memory. ${ }^{3}$

The arguments in favor of Lactantius' authorship are, then, convincing, if not overwhelming; and in the light of all the considerations, I am inclined to think he published it after his conversion to Christianity, after he arrived in Nicomedia, and perhaps during the Diocletian persecution, or at least before Constantine had manifested his intention of favoring the Christians. The ambiguity which has so perplexed scholars is no doubt incident to the syncretism which the poem manifests, and which at precisely this time was so much in vogue.

\section{THE PHENIX AS A SYMBOL.}

The Phœnix, as represented upon Egyptian monuments, is a bird of the heron family, with the two characteristic long feathers streaming from the back of the head, and a tuft on the breast.

${ }^{1}$ Cf. p. xxxiv, above.

${ }^{2}$ Pp. 49, 5 I.

${ }^{8}$ Cf. Manitius, p. 45 , note 3 .

"According to Lepsius, followed by Wiedemann, it is the Ardea cinerea or purpurea (Aclteste Texte des Todtenbuches, p. 51; Zs. für Ägypt. Spr. r6. 104) ; according to Brugsch (Geog. Inschr. I. 258), the Ardea garzetta, according to Renouf (Book of the Dead, p. 45), the common heron of heronshaw; according to Rawlinson (Hist. Anc. Egypt, r881, I. 82), the Ardea bubulcus. Singularly enough, the peasants of French Guiana cal the Ardea helias the 'bird of the sun' (Littré, Dict. s. v. Oiseau, 7) Gruppe (Griech. Myth. $2^{2}$. 795) thinks that Ovid, in describing the heror 
The Egyptian name of the Phœnix is bennu, ${ }^{1}$ from a root meaning 'to turn,' so that the bennu signifies, as it were, the returning traveler. ${ }^{2}$ This is an appropriate name for the heron, since he is a bird of passage, spending the summer in the north, and the winter in the south. ${ }^{3}$

The bennu, or heron, was evidently a symbol among the Egyptians-but of what? Some have said, of the planet Mercury (thus Seyffarth), others of Venus (Brugsch, Lauth), ${ }^{4}$ but the generally accepted theory is that the Phœnix is a symbol of the rising sun. In a secondary sense, no doubt, it stands for other things, but the legend is constructed around this conception as its core. To become convinced of this, it will be necessary to examine the evidence of the texts.

\section{Classical Texts}

I. The goal of the Phœnix's solemn flight to Egypt is generally Heliopolis, ${ }^{5}$ or the city of the sun (Tacitus, Ovid, Pliny (who adds, 'near Panchaia'), Clement of Rome, Aelian, Epiphanius, Pseudo-Epiphanius, Horapollo, the Greek Physiologus, Lactantius (if we emend ortus to urbem, as was first done by Gryphiander, $\mathbf{1 6} 18$ ), Claudian, Achilles Tatius). Others add or substitute 'temple of the sun' (Herodotus, Ovid, Pseudo-Epi-

which flew away from the burning city of Ardea (Met. I4. $573 \mathrm{ff}$.), has in mind this identification. Other writers have thought of the hawk (Maspero), of the golden pheasant (Cuvier, Lenz, Benecke), of the lapwing (Keller), or of the flamingo (Fundgruben des Orients I. 202). Ebers (Egypt. Princess, chap. 20) suggests a resemblance to the bird of paradise.

${ }^{1}$ The identification first made by Seyffarth (ZDMG. 3 (I849). ${ }^{\circ} 3$ ), and confirmed from monumental evidence-by Brugsch (Nouvelles Recherches, etc., Berlin, 1856; Geog. Inschr. I. 258; ZDMG. Io. 649 ff.; cf. Wiedemann, Aegypt. Gesch., p. 45, note; Schö11, Vom Vogel Phönix, p. 42, note 4).

${ }^{2}$ Cf. Horapollo I. 35 ; 2. 57 .

${ }^{8}$ Wiedemann, 'Die Phönix-Sage im Alten Äegypten' (Zs. fïr Agypt. Sprache 16. 104.

"For a discussion of some of the various theories see Lauth, 'Die Phonixperiode,' in Abh. d. Phil.-Phil. Classe der Bayer. Akad. 52 (I88I). $348 \mathrm{ff}$.

${ }^{5}$ See below, pp: xlv-li. 
phanius); 'altar of the sun' (Tacitus, Pliny, Clement of Rome, Apostolical Constitutions, Pseudo-Epiphanius, the Greek Physio$\log u s$, Nonnus).

2. Its pyre is lighted from the sun's rays (Dionysius, PseudoEustathius, De Aucupio, Lactantius, Claudian, Pseudo-Jerome).

3. It dies at sunrise (Horapollo), or faces the sunrise (Horapollo, Pseudo-Jerome), or turns to the sun's ray (Isidore of Seville>Rabanus Maurus), or prays to the sun (Claudian), or stands toward the East and prays to the sun (Apost. Const.).

4. It is sacred to the sun (Tacitus, Pliny).

5. It is a symbol of the sun (Horapollo, Johannes Gazæus).

6. It rejoices more than other birds in the sun (Horapollo).

7. It is the sun's bird (Claudian).

8. It is the friend of the sun (Dracontius).

9. It is descended from the sun (Achilles Tatius).

ro. It resembles the sun (Pseudo-Eustathius).

II. It is the priest of the sun (Lactantius).

I2. Its head is crowned by a splendid circle, the very image of the sun (Achilles Tatius; cf. Claudian, Ph. I7-20).

\section{Egyptian Texts ${ }^{1}$}

I. 'The temple of obelisks' of the Pankhy-inscription (below, p. xlviii), in which, as we shall see, Rā, the Sun-god, was adored, is in Egyptian $h a-[t]$-benben- $[t]$. Now on a hypocephalus in Paris a deceased person is represented as saying: ' $\mathrm{I}$ am in the form of the Phœnix, which issues from ha-t-benben in Heliopolis.'

2. The obelisk of the Porta del Popolo at Rome, which represents near the top an adoration of Rā by one of the kings who erected it, bears in the left line of the northern face the words, 'Rameses II, son of Rā, who filled the temple of the Phœnix [ha-t-benmu] with his splendors.'"

3. In the Book of the Dead, chap. 17, we read' : 'I am that

${ }^{1}$ What here follows reposes chiefly upon Wiedemann, op. cit.

${ }^{2}$ Marucchi, Gli Obelischi Egiziani di Roma, pp. 58, i46; cf. Ammianus Marcellinus 17. 4; Wiedemann, op. cit., p. 92.

${ }^{3}$ Wiedemann's translation; somewhat different in Budge, Book of the Dead. 
great Phœnix which is in Heliopolis; I unite everything which is there.' What is the meaning of this? The Phœnix signifies the Osiris which is in Heliopolis; the union of everything which is there signifies his body, or, in other words, eternity and everlastingness, eternity signifying the day, and everlastingness the night.'

The Phœnix, then, signifies the union of day and night, or, one might say, of life and death; now as, according to Egyptian religious conceptions, Osiris represents the deceased, or, we might here say, death, and as the union of day and night, the point where the two come together, is represented by the Phœnix, the Phœenix must be the rising sun, with the emphasis not on the night from which he emerges, but on the attributes of the sun as it issues from darkness or death. ${ }^{1}$

4. The Book of the Dead, chap. I3, has, in Budge's translation: 'I go in like the Hawk, and I come forth like the Bennu bird [the Phœnix], the morning star (?) of $\mathrm{Ra}^{-2}$-where, for 'morning star,' Wiedemann prefers to read 'morning divinity,' i. e., morning sun. ${ }^{3}$

5. On the wooden coffin of Hetepher-t-s in the Vatican we have, on each side of a central picture, a hawk and a Phœnix respectively. On the right, seated on a standard planted on the mountain of the sun, which is painted in red, is the hawk, with the legend, 'Glory be to Rā in the underworld!' On a similar standard on the left is the Phœnix, with the legend, 'Glory be to Rā when he rises!'

So, too, on the door of a tomb figured by Lepsius, ${ }^{4}$ the middle is occupied by a picture of the bark of the sun; on the right is a Phœnix, with the legend, 'He rises each day in the morning; he traverses the heaven as ...'; while on the left is a hawk, with the words, 'He enters into the underworld; he shines.'

${ }^{1}$ So I understand Wiedemann, pp. 93-4.

${ }^{2}$ Similarly in chap. 122 (Budge, p. 185).

'Those who identify the Phœnix with Venus rely on the words 'morning star,' but Wiedemann shows (p. Io0) that elsewhere Venus is called 'the star of the bark of Bennu-Osiris.' Now Bennu-Osiris, as we have seen under 3 , means the rising sun, and hence Venus is here called, with all propriety, the star of the rising sun's bark.

${ }^{4}$ Denkmäler aus Aegypten 3. $272^{\mathrm{a}}$. 
6. In the Book of the Dead, chap. 24, we have': 'I am Cheperā [the rising sun], who brings himself into being . . . in order to traverse the heaven like the Phœnix among the great gods.'

7. In the Book of the Dead, chap. 64, we read (Wiedemann): 'He [Osiris] comes from Sekhem to Heliopolis to make known to the Phœnix the things of the underworld. "Hail, . . . thou creator of forms, like the god Chepera [the rising sun], issuing as sun-disk above the auta-incense.",

8. In a Louvre papyrus, No. I. 2, the Phœnix appears with the red sun-disk on his head.

9. On the coffin of Suti-mes in the Louvre, and similarly on the coffin of Tent-Amon in Berlin, 'the great god Phœnix' says: 'I am the Phœnix who begets himself, who gives incense to the Osiris.'

Io. In a Louvre papyrus, No I. I, we read: 'Glory to thee, O Rā,... thou who comest into being above Heliopolis, O Phœenix, great god!' Beside this are two pictures, one of Rā, and one of the Phœnix.

I I. On a monument at Leiden he is called 'the Phœnix, the soul of Rā,' a scarab calls him 'the heart of the renewed Rā,' and a papyrus 'the Phœnix of Rā.'

To the foregoing may be added a few passages from the Book of the Dead (tr. Budge). Chap. 29 B (p. 77): ' I am the Benmu [Phœnix], the soul of Rā.' Chap. 77 (p. I32): 'Those who were dwelling in their companies have been brought unto me, and they bowed low in paying homage unto me, and in saluting me with cries of joy. I have risen, and I have gathered myself together like the beautiful hawk of gold, which hath the head of a Benmu bird, and Rā entereth in day by day to hearken untc my words.' Chap. I25 (p. I89) : 'He hath caused me to come forth like a Bennu bird, and to utter words.'

The ancient Egyptians conceived of the sun as describing : circle round the earth, and hence they gave it the name of bennu the returning traveler. Now it happened that benmu was alsc

${ }^{1}$ So Wiedemann; Budge differs.

'Some other texts, cited by Wiedemann, are here omitted, as thei bearing is less readily understood. 
the name of a bird of passage which regularly disappeared and returned, and so this was declared holy to the sun, and one of its manifestations. The return of the sun took place in the morning, and so the bennu became the symbol of the rising sun. From this idea was evolved the further one that the sun engendered itself anew, and so likewise the bennu. He combined night and day into one whole, fashioned and guided time in a mystical and holy manner, and each morning rose to a spheral music, while the songs of gods and men resounded in joyful chorus to his praise. At his birth the heaven flamed in splendor, the new sun was born in fire, and from the dying flames of dawn he flew new-born up the sky. To him may be applied the words of the Boulak hymn to Rāi : 'Glory is his in the temple when he arises from the house of flames; all the gods love his perfume when he approaches from Arabia; he is the lord of dew when he comes from Matáu; he draws nigh in beauty from Phœnicia, encompassed by the gods.'

Since the Phœenix in this, his central mythological aspect, may thus be identified with the deified sun at his rising, the hymns to Rà (or Kheperā) will yield other passages applicable to the Phœnix of our poem. Thus the birds which follow and salute him are paralleled by the gods who follow Rā: 'Rā riseth in his horizon, and his company of the gods follow after him.'s 'All the gods rejoice when they behold thee, the King of heaven.' $R \bar{a}$ is self-begotten:

Thou self-begatten one, $\mathrm{O}$ thou who didst give thyself birth. ${ }^{5}$

$O$ thou beautiful being, thou dost renew thyself in thy season in the form of the disk. ... O Rā,... the divine man-child, the heir of eternity, self-begotten and self-born, king of earth. ${ }^{\circ}$

Thou art crowned with the majesty of thy beauties; thou mouldest thy limbs as thou dost advanice, and thou bringest them forth without birth-pangs in the form of Rā, as thou dost rise up unto the upper air. ${ }^{7}$

${ }^{1}$ Also translated in Records of the Past 2. 127-136.

${ }^{2}$ This paragraph closely follows Wiedemann.

'Book of the Dead, tr. Budge, chap. I33, p. 214.

'Ibid., p. 37 ; similarly pp. 4, 7, 9 .

'Ibid., p. 9.

'Ibid., p. I0.

'Ibid., p. 38. 
As rising with fragance:

The land of Punt is stablished [to give] the perfumes which thou smellest with thy nostrils. ${ }^{2}$

Let me snuff the air which cometh forth from thy nostrils.

With reference to the egg associated with the Phœnix :

O thou who art in thine egg (i.e., Rā), who shinest from thy disk and risest in thy horizon. ${ }^{*}$

With reference to one of the colors attributed to the Phœnix:

Thou illuminest the two lands with rays of turquoise light.s

Thou hast made heaven and earth bright with thy rays of pure emerald light. ${ }^{\circ}$

The Phœnix, as the symbol of the rising sun, is at the same time, among a people so keen for immortality as were the Egyptians, a natural symbol of the resurrection. ${ }^{7}$ In this sense it is taken by the Christians of the first centuries, who drew for illustration of the renewed life, now upon the cycles of vegetation (cf. $P h .243$, note), and now upon the phases of the heavenly bodies (sun, moon, stars; day and night; winter and spring). ${ }^{8}$ Among the patristic writers who employ the Phœnix in this sense may be named Clemens Romanus, the author or authors of the Apostolical Constitutions, Tertullian, Eusebius, Zeno, Cyril of Jerusalem, Ambrose, and Epiphanius. ${ }^{9}$ Other writers who employ the same figure are Commodian, Nonnus, Sidonius, Ennodius, Dracontius, and the Englishman, Elfric.

As both the Old and the New Testament associate God and Christ with light ${ }^{10}$; as Jehovah is explicitly called a sun in Ps.

${ }^{1}$ S. W. Arabia. ,

${ }^{2}$ Ibid., p. 8.

${ }^{8}$ Ibid., p. 34.

${ }^{4}$ Ibid., p. 54.

'Ibid., p. 10.

'Ibid., p. 8.

${ }^{7}$ Cf. Froude, Short Studies in Great Subjects, pp. 24-5.

${ }^{8}$ See the citations in Thalhofer, Bibliothek der Kirchenväter 405. 77.

${ }^{9}$ Thalhofer, op. cit. 415. 286.

${ }^{10}$ So Ps. 42. 3; Isa. 9. 2; Wisd. 5. 6; 7. 29, 30 ; Ecclus. 42. 2-5, 16; Matt. 4. 5-6; Lk. I. $78-9 ;$ Jn. I. $4-5,9 ; 9.5 ;$ 12. $46 ;$ I Tim. 6. I6; 
84. I I ; and as the early Fathers identify the sun of righteousness ${ }^{1}$ (Mal. 4. 2 ; cf. Lk. I. 78) with Christ, ${ }^{2}$ it is not surprising that the Phœenix should come to be employed as a figure of the Saviour.

\section{HELIOPOLIS}

The name of the Phœnix is indissolubly associated with that of Heliopolis, to which reference is made by Lactantius, $P h$. I2r, Solis ad urbem (rendered in our poem by sunbeorht gesetu, 278). About 586 B. c., in the reign of Apries, or Uahabra, Jeremiah, being then in Tahpanhes, the modern Defneh, wrote thus of Nebuchadrezzar, King of Babylon: 'He shall also break the pillars [obelisks?] of Bethshemesh, that is in the land of Egypt; and the houses of the gods of Egypt shall he burn with fire'; and in 568 в. c. Nebuchadrezzar actually invaded Egypt. Bethshemesh, a translation into Hebrew of the Egyptian Per-Ră, 'house or city of the.sun,' was the city known to the Greeks as Heliopolis, of which nothing now remains but the ruins shown at Matarieh, some five miles northwest of Cairo. In Jeremiah's time it must have already been about 3400 years old, if we may

I Jn. I. 5 ; especially Mal. 4. 2 ; Jn. 8. 12. Cf. Usener, Götternamen, pp. 183-5, Dict. Christ. Antiqq. I. 357-8, and my note on Chr. 104-129. A whole series of modern poets continue the tradition. Thus Dante (Purg. 7. 26; Par. 9. 8; 10. 53 ; 18. 105; 25. 54 ; 30. 126; Conv. 3. 12. 51-6); and, to instance a poet five hundred years later, and of quite different character, Byron (Sardanapalus 2. 1. 14-7):

Oh! thou true sun!

The burning oracle of all that live,

As fountain of all life, and symbol of

Him who bestows it.

${ }^{1}$ The motto of Rutgers College is: Sol justitic, et Occidentem illustra.

${ }^{2}$ As early as 242-3 A. D. (Cumont, Textes et Monuments Figurés Relatifs aux Mystères de Mithra I. 355). This led some of the Christians of the first centuries to identify the physical sun with Christ, an error which was combated by Augustine, among others. The 'Deo soli' of Exod. 22. 20 was even sometimes interpreted as 'to God, the sun' (Civ. Dei 19. 23); and there were pagans who appear honestly to have believed that the sun was the god of the Christians (Tertullian, Apol. 16, etc.). As late as the fifth century, Pope Leo the Great complained that the faithful still persisted in adoring the sun at the instant of his rising. On the whole subject, see Cumont, op. cit., pp. 355-6. 
trust the assignment of it to the time of King Menes, ${ }^{1}$ or Mena, the founder of the First Dynasty. In the Second Dynasty (ca. 3100 B. C.), the worship of Mnevis, the sacred bull, was established there, according to Manetho. ${ }^{2}$ Inscriptions of the Fourth Dynasty (ca. 2900-2750) mention it. ${ }^{3}$ The Fifth Dynasty (ca. 2750-2625), according to one tradition, starts from a high priest of Heliopolis, and claims divine descent from Rā, the sun-god." In the Twelfth Dynasty, Sesostris I (I980-I935 B. c.) is said to have built in Heliopolis a temple to the sun; and a leathern roll, dating from the time of Amenhotep $\mathrm{IV}^{5}$ (I375-I358 в. c.), professes to contain a record of this founding. ${ }^{6}$ The hymn sung or recited on this occasion included the sentence, 'the works will last' (or, as the German translation has it, 'Das Gemachte sei bleibend') ; but all that has lasted is one obelisk, '7 the most beautiful now in Egypt.

Somewhere about I640 в. c., 8 in the Seventeenth Dynasty, may perhaps be placed the period of Joseph's residence in Egypt. Joseph's wife was of Heliopolis, for we are told in Gen. 4 I. $45^{\circ}$ that 'Pharaoh gave him to wife Asenath the daughter of Potiphera $^{10}$ priest of On, ${ }^{11}$ that is, high priest (probably) of Heliopolis. ${ }^{12}$

${ }^{1}$ Lepsius, Chron. I. 326; cf. Petrie, Hist. Egypt I. 20; Breasted, Hist. Egypt, p. 44. Ebers, Durch Gosen zum Sinai, p. 493, says it is as old as the oldest inscribed monuments.

${ }^{2}$ Petrie I. 22.

${ }^{8}$ Hastings, Dict. Bible 3. 622.

Breasted, op. cit., pp. I22-3.

${ }^{-} \mathrm{He}$ also erected a temple to Rā in Heliopolis (Petrie 2. 22I).

${ }^{6}$ Petrie I. I57; Zs. für Agypt. Spr. I2 (1874). 85-96; Records of the Past 12. 5I-5; Breasted, op. cit., pp. 196-7, and Fig. 87.

${ }^{7}$ Ephraem the Syrian has an account of the obelisks in his Commentary on Jeremiah, chap. 33 (Oper. Syr. 2. I44-5; Pinkerton's Voyages 15. 827). Various Arabic writers of the Middle Ages mention them (cf. Pinkerton I5. 807,827 ff.).

${ }^{8}$ See Hastings, Dict. Bible 2. 77I ; cf. Petrie 3. II 5.

${ }^{\circ}$ Cf. 4 I. $50 ; 46.20$.

${ }^{10}$ 'He whom Ră (the Sun-god) gave'; see Hastings, Dict. Bible 4. 23.

"In hieroglyphics Anu, Annu, On, Un.

12 The Septuagint version of Jer. 43 (Sept. 50). I3 identifies On with Heliopolis, and so in Exod. I. II, in an addition to the text of the passage, 
According to an account preserved by Eusebius, ${ }^{1}$ the Jews whom Joseph brought into Egypt were assigned to Heliopolis and Sais, and afterwards built a temple in Heliopolis (cf. 9. 27). ${ }^{2}$

It was at Heliopolis that human sacrifices were abolished, if we may believe Manetho, ${ }^{3}$ by King Aahmose, or Amasis (I 580-I 557

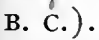

Heliopolis ${ }^{4}$ was, in the Eighteenth Dynasty, the centre of one of the greatest religious reforms known to history, a reform associated with, the name of Amenhotep IV (see p. xlvi), later known as Akhenaten or Ikhnaton ('the splendor of the sun's disk'). The nature of this reform, which, as an exotic, was destined to expire with its promoter, may be described in the words of Petrie ${ }^{5}$ :

Other ages had worshiped the human-figured sun-god $\mathrm{Ra}$, or a hawk as his emblem; and when the sun itself was represented, it was as a concrete solid ball. But a more refined and really philosophical worship was substituted for this by Akhenaten, that of the radiant energy of the sun, of the sun as sustaining all life by his beams. No one-sun-worshiper or philosopher-seems to have realized until within this [Igth] century the truth which was the basis of Akhenaten's worship, that the rays of the sun are the means of the sun's action, the source of all life, power, and force in the universe. ... If this were a new religion, invented to satisfy our modern scientific conceptions, we could not find a flaw in the correctness of this view of the energy of the solar system. . . Not a rag of superstition or of falsity can be found clinging to this new

Epiphanius (Ancor. 84) says of the name Heliopolis that it is 'a translation from the Egyptian and Hebrew On' (cf. Sayce, Rel. of Anc. Egypt and Bab., pp. 86-7). See also Ephraem the Syrian, Comm. on Jeremiah, chap. 33. The Aven of Ezek. 30. 17 is the same word (Hastings 3. 621).

${ }^{1}$ Prap. Evang. 9. 23.

${ }^{2}$ Eusebius also preserves a statement (9. I8; cf. Josephus, Ant. I. 7. 2) according to which 'Abraham dwelt with the Egyptian priests in Heliopolis, and taught them many things; and it was he who introduced astronomy and the other sciences to them, saying that the Babylonians and himself had found these things out.' We of course know that Abraham, according to the Biblical account, was in Egypt (Gen. I2. Io ff.).

'Quoted from Porphyry, On Abstinence 2. 55, by Eusebius, Prap. Evang. 4. 16; Praise of Constantine 13. See also Ebers, Durch Gosen zum Sinai, pp. 495-6.

"Wiedemann, Ägypt. Gesch. I. 46-47, 397.

${ }^{8}$ Hist. Egypt 2. 213 ff. 
worship evolved out of the old Aten of Heliopolis, the sole lord or Adon of the universe.

Petrie then quotes the great hymn to the Aten, which he thinks may have been composed by the King. One stanza runs :

How many are the things which thou hast made!

Thou createst the land by thy will, thou alone,

With peoples, herds, and flocks,

Everything on the face of the earth that walketh on its feet,

Everything in the air that flieth with its wings.

He then adds:

In this hymn all trace of polytheism, and of anthropomorphism, or theriomorphism, has entirely disappeared.... It would tax any one in our days to recount better than this the power and action of the rays of the sun.... In ethics a great change also marks this age. The customary glorying in war has almost disappeared; only once, and that in a private tomb, is there any indication of war during the reign. The motto 'Living in Truth' is constantly put forward as the keynote to the king's character, and to his changes in various lines. And domestic affection is held up as his ideal of life, the queen and children being shown with him on every occasion. In art the aim was the direct study of nature, with as little influence as possible from convention; animals in rapid motion, and natural grouping of plants, were specially studied, and treated in a manner more natural than in any other Oriental art. ${ }^{1}$

Rameses III (II98-67 B. C.) gave to Heliopolis, among other things, I2,963 serfs, 45,544 cattle, and Io3 Egyptian towns ${ }^{2}$; and in the great Harris papyrus he tells of the gardens, lakes, sculptures, jewels, and scrolls which he there made for $R \bar{a} .^{3}$ The temple he built is at Tell el Yehudeh, north of Heliopolis. ${ }^{4}$

One of the most interesting mentions of Heliopolis belongs to the period of the Twenty-third Dynasty, under what is called the Ethiopian Dominion. A stele recording the events of an expedition undertaken by Pankhy, or Piankhi I, describes the

${ }^{1}$ Cf. Erman, Aegypten, pp. 73 ff.; Brugsch, Hist. Egypt I. 44I ff.; Sayce, Rel. of Anc. Egypt, pp. II, 35, 92 ff., I95; Steindorff, in Hilprecht's Explorations in Bible Lands, p. 674; Breasted, op. cit., pp. 36i ff.

${ }^{2}$ Petrie, Hist. Egypt 3. I54; Records of the Past 6. $59 \mathrm{ff}$.

${ }^{3}$ Records of the Past 6. 52-70.

${ }^{4}$ Erman, Life in Ancient Egypt, p. 285. 
elaborate ceremonies and solemn devotion attending this monarch's visit to Heliopolis. Here we have several things of interest in relation to our poem-the lake or fountain in which the sun-god bathes his face, adoration to the rising sun, ${ }^{1}$ the offering of incense, and the temple of the sun entered by the king with solemn priestly ceremonial. ${ }^{2}$

Strabo (ca. 60 B. c.-ca. 25 A. D.) says ${ }^{3}$ :

There, too, is Heliopolis, situated upon a large mound. It contains a temple of the sun. ... In front of the mound are lakes, into which the neighboring canal discharges itself. At present the city is entirely deserted.... At Heliopolis we saw large buildings, in which the priests lived. For it is said that anciently this was the principal residence of the priests, who studied philosophy and astronomy; but there are no longer either such a body of persons or such pursuits. ... The residences of Plato and of Eudoxus were shown to us. Eudoxus came here with Plato, ${ }^{4}$ and, according to some writers, lived thirteen years in the society of the priests. For the latter were distinguished for their knowledge of the heavenly bodies, but were mysterious and uncommunicative, yet after a time were prevailed upon by courtesy to acquaint them with some of the principles of their science, but the barbarians concealed the greater part of them.

In the period of Plato and Eudoxus, Egypt had been groaning for more than a century under Persian rule; Nebuchadrezzar and Cambyses ${ }^{5}$ had laid waste the noble edifices of Heliopolis, and burned them with fire; Egypt, as Petrie says, 'was a carcase' $^{\mathbf{6}}$; yet Heliopolis still remained the university of Egypt, the home of philosophy, and astronomy, and medicine.

${ }^{1}$ Apion reported that Moses offered all his prayers toward the sunrising, and in the open air, while at Heliopolis (Josephus, Contra Apion 2. 2).

${ }^{2}$ For a full account of this, see note on $\mathrm{Ph} .107 \mathrm{ff}$.

17. $27-9$.

"To these Plutarch (Is. and Osir. I0) adds Pythagoras, his teacher being Oinuphis; and Solon (Solon 26), his teacher being Psenophis. The teacher of Plato was Sechnuphis (Clement of Alexandria, Strom. I. I5. 69); that of Eudoxus, Chonuphis (Diog. Laert. 8. 8. 6). For full references on the visits of famous Greeks to Egypt, see Parthey's edition of Plutarch's Isis and Osiris, pp. 162, $183 \mathrm{ff}$.

"Strabo, as above.

${ }^{6}$ Hist. Egypt 3. 387. 
It had brooded over the whole course of Egyptian history; but its end was not yet. Influential from at least the period of the Fifth Dynasty (2750-2625 в. c.) in laying down religious law for Egypt, ${ }^{1}$ its spirit, when now its vigor was almost spent, may have imbued the philosophy and science of Greece, and so eventually have tinged the barbarism of Western Europe.

Nearly all the longer accounts of the Phœnix either mention the city by name or refer to it in an unmistakable manner; and to this circumstance, more than any other, was Heliopolis indebted for its European reputation in ancient times.

It is singular that Heliopolis often emerges into prominence when a foreign influence, especially a Mesopotamian or Syrian, manifests itself. It would seem that the purest and most vital conceptions associated with it might have been of foreign birth, or have been most keenly appreciated by foreigners.

The obelisks of London and New York were originally from Heliopolis (Petrie 2. I27), and of the seven genuine obelisks of the older period now in Rome, five are from Heliopolisthose of the Porta del Popolo, Pantheon, Villa Mattei, Monte Citorio, and Dogali. ${ }^{2}$ The obelisk now standing at Matarieh (68 feet high) is the oldest Europe temple-obelisk still in position. This was erected in the reign of Sesostris (Senwosri I), of the Twelfth Dynasty (ca. 1980-1935 B. c.). ${ }^{3}$

There are two objects associated with Heliopolis which are of peculiar interest in relation to our poem. These are a tree and a fountain. On the Metternich stele we read: 'Thou art the great Phœnix, which comes into being on the tip of the trees in the

${ }^{1}$ Maspero, Études de Mythologie 2. 372 ff. The first historical recension of the Book of the Dead (see Budge's trans., p. Lxxiv) was made by the priests of Heliopolis, and, with reference to these texts, 'the general testimony of their contents indicates an Asiatic home for their birthplace' (ibid., p. XLVI). The oldest copies belong to the Fifth and Sixth Dynasties (ibid., p. Lxxiv).

${ }^{2}$ Marucchi, Gli Obelischi Egiziani di Roma, p. 155.

${ }^{8}$ Encyc. Brit., IIth ed., 9. 79, 82 ; 19. 945. This authority says (19. 945): 'The pyramidions were sheathed in bright metal, catching and reflecting the sun's rays as if they were thrones of the sunlight. They were dedicated to solar deities, and were especially numerous at Heliopolis.' 
great hall in Heliopolis.' Cleopatra's needle, now in London, speaks of the venerable tree in the interior of the temple of the Phœnix. This was properly the Persea tree, which afterwards becomes a palm, an acacia, or a sycamore. In the Louvre papyrus No. 3092, there is an adoration of a yellow tree with green leaves, above which the red disk of the sun is rising. In Wilkinson's Manners and Customs of the Ancient Egyptians ${ }^{1}$ we find a picture of a tomb, near which is a tree surmounted by a Phœnix, with the legend, 'The soul of Osiris.'2

The Phœnix poised on one of the upper branches of a palm is represented at Rome in the mosaics of Saints Cosmas and Damian, St. Praxed, the Lateran, Santa Maria Maggiore, and St. Cecilia in Trastevere. In that of the apse of SS. Cosmas and Damian, which is the oldest, the bird is evidently a heron, with head, breast, and wings of red, feet and legs of gold, and the rest of the body light blue.

For the fountain of the sun at Heliopolis, see note on $P h$. 107 ff. ; cf. Hastings, Dict. Bible 5. I89; Wiedemann, Religion of the Ancient Egyptians, pp. 20-I, 92 ; Ephraem Syrus, Opera Syr. (Rome, I740) 2. 50, 5I.

For the palm-tree in the desert which, during the Flight into Egypt, bent over at the command of the infant Jesus, and refreshed the Holy Family with its fruit, and which afterwards opened a spring of water from its roots, see the Apocryphal Gospel of Matthew, chap. 20. According to the Arabic Gospel of the Infancy, this was a sycamore at Matarieh, while Sozomen ${ }^{3}$ attaches a similar story to a Persea tree at Hermopolis. Travelers are still shown a sycamore and a spring at Matarieh. ${ }^{4}$

${ }^{1}$ Ed. Birch, 3. 349.

2 This is regarded by Erman, Aegypten, p. 368, as the tree described by Plutarch, Isis and Osiris 20. On the general subject, cf. Brugsch, Geog. Inschr. I. 258-9; Hastings, Dict. Bible 3. 622; 5. I90; Erman, Life, pp. 272, 348.

${ }^{8}$ Eccl. Hist. 5. 2 I.

"See Wilkinson, Handbook for Travellers in Egypt (London, 1847), p. 168; Sandys, Travailes, 6th ed. (London, 1658), p. 99; E. D. Clarke, Travels (London, 1814) 3. 99; John Evesham, in Hakluyt, Principal Navigations (Glasgow, 1904) 6. 38, and cf. Hakluyt 5. 338. 


\section{THE EARTHLY PARADISE}

What may be called the central tradition concerning the Earthly Paradise, the tradition which is reflected in the Phonix, is Oriental and very ancient. Whether originally Semitic or not, it is not without representative in Aryan texts as well. According to this central tradition, the elements of the Earthly Paradise are:

I. An extremely high mountain.

2. Noble trees, often forming a grove.

3. A fountain of living water, or one or more rivers.

4. Absence of the ugly, irksome, and noxious, and abundance of what is delightful and invigorating.

To these are sometimes added:

5. A tree distinguished above the rest.

6. A bird which sits upon the tree, or stands in a peculiar relation to it.

The Semitic tradition, with which we are more immediately concerned, is perhaps most familiar to us from the account in Genesis (2. 8-10) :

And the Lord God planted a garden eastward in Eden; and there he put the man whom he had formed. And out of the ground made the Lord God to grow every tree that is pleasant to the sight, and good for food; the tree of life also in the midst of the garden, and the tree of knowledge of good and evil. And a river went out of Eden to water the garden; and from thence it was parted, and became into four heads.

Here we are explicitly told of the trees, the river, and the pleasure afforded by the trees. The height of the garden is only to be inferred from the fact that the river, parting into fourthe Pison, Gihon, Hiddekel, and Euphrates-through these four irrigates vast tracts, including no doubt the whole inhabited earth, as the writer conceived it.

Parts of the conception are developed in Ezek. 47. 7-9, 12:

Behold, at the bank of the river were very many trees on the one side and on the other. Then said he unto me, These waters issue out toward the east country, and go down into the desert, and go into the sea: which being brought forth into the sea, the waters shall be healed. And it shall come to pass, that everything that 
liveth, which moveth, whithersoever the rivers shall come, shall live: and there shall be a very great multitude of fish, because these waters shall come thither: for they shall be healed; and everything shall live whither the river cometh. ... And by the river upon the bank thereof, on this side and on that side, shall grow all trees for meat, whose leaf shall not fade, neither shall the fruit thereof be consumed: it shall bring forth new fruit according to his months, because their waters they issued out of the sanctuary: and the fruit thereof shall be for meat, and the leaf thereof for medicine.

Here the water has an active principle of life and healing, as have the fruit and foliage of the trees. This thought is resumed in Rev. 22. I-2:

And he shewed me a pure river of water of life, clear as crystal, proceeding out of the throne of God and of the Lamb. In the midst of the street of it, and on either side of the river, was there the tree of life, which bare twelve manner of fruits, and yielded her fruit every month: and the leaves of the tree were for the healing of the nations.

Akin to the river of the water of life is the fountain, though the Bible does not expressly place it in Paradise. Thus Ps. 36. 9: 'For with thee is the fountain of life'; Jer. 2. I3 (cf. I7. I3): 'They have forsaken me, the fountain of living waters'; Jn. 4. I4: 'The water that I shall give him shall be in him a well of water springing up into everlasting life'; Rev. 21. 6 (cf. 22. I7) : 'I will give unto him that is athirst of the fountain of the water of life freely.' ${ }^{\prime}$ In all these instances, the terms are used figuratively; but so also they are in the passages from Ezekiel and the Apocalypse referring to the river.

As to the absence of what is hurtful and unpleasing, and the positive delights, in that New Jerusalem which is the Apocalyptist's substitute for Paradise, ${ }^{2}$ reference may be made to Rev. 2I. I-4, IO, I I, 23 ff. ; 22. 3-5.

${ }^{1}$ Cf. Professor E. W. Hopkins' learned article. 'The Fountain of Youth,' in JAOS. 26 (I905). I-67, 4II-5. There is a spring at the foot of the tree Yggdrasill of Scandinavian mythology, which is a tree of life (cf. Havamal). For such trees and waters in Egyptian mythology, see above, pp. 1-li.

${ }^{2}$ Yet there is mention of Paradise in Rev. 2. 7: 'To him that overcometh will I give to eat of the tree of life, which is in the midst of the paradise of God.' 
Hindu mythology tells of the mountain Meru, somewhat over 500,000 miles high, upon whose summit the Ganges first flows from heaven, and then divides into four rivers, which water the world. The trees are always covered with fruits and flowers. Among them are the Kālamra(-ba) tree and the Jamvu(-bu) tree, some 6600 miles in height, whose fruit makes one ever youthful. ${ }^{1}$ This has been identified in a general way with the Pamirs in Central Asia, the so-called Roof of the World, which Parsis consider as the original seat of the Aryan race, and the Mohammedans of the region regard as having been the terrestrial paradise.

In the Avesta and the Bundahish, the mountain is Albûrz, or the Hara Berezaiti, the rivers are twenty in number, there are the 'tree opposed to harm' and the Gôkard tree, and the bird is the griffon, the Kamrôs, or the Sin or Simurgh. ${ }^{2}$

Akin to these Aryan legends, if not derived from them, is the view $^{3}$ advanced by Ephraem the Syrian in the 4th century. $\mathrm{He}$ says of Paradise ${ }^{4}$ :

It is situated on a very high spot, and looks down on all the highest mountains. For this reason the waters of the deluge, that were spread over all the world, did not touch even its root with the tops of their billows, and, as it were, kissing its feet, worshiped the approaich to it.

He then goes on to speak of Paradise as being very far from our world, and as surrounding the sea and the earth.

Among those who held similar opinions ${ }^{5}$ were (Pseudo-)Basil, Theophilus of Antioch, Gregory of Nazianzen, Gregory of Nyssa, Tertullian, and Cosmas Indicopleustes. To take a single example, (Pseudo-)Basil thus describes Paradise ${ }^{6}$ :

${ }^{1}$ Cf. Mahabharata 6. 7; 3. 163; Vishnu Purana, tr. Wilson, 2.' 2.

${ }^{2}$ Sacred Books of the East 5. 22-23, 29, 31, 35, 42-3, 47, 65-7, 89-9I, 99-100, 176-7; 23. 131-2, 173.

${ }^{3}$ Cf. Uhlemann, 'Ephräm des Syrers Ansichten von Paradies' ( $Z$ s. für Hist. Theol. I (1832). 155 ff.).

${ }^{4}$ Hom. I on Paradise (Opera, 1743, 3. 563).

${ }^{5}$ The works of Ephraem were early translated into both Greek and Latin (they were known to both Chrysostom and Jerome). In the Eastern Church, and perhaps in the Western, lessons from them were read after those from the Bible (cf. Migne, Patr. Lat. 23. 708).

${ }^{\circ}$ Hom. de Paradiso (Migne, Patr. Gr. 30.64). 
A place superior by nature to all created spots, over which, by reason of its height, there was no shadow, of wonderful beauty. . . Here, then God planted Paradise, where there was neither violence of winds, nor inclemency of the seasons, nor hail, etc.

One of the most important utterances in its bearing upon the Phonix is that by Bede, Hexameron (Migne, Patr. Lat. 91. 43) :

Nonnulli volunt quod in orientali parte orbis terrarum sit locus paradisi, quamvis longissimo interjacente spatio vel oceani vel terrarum a cunctis regionibus quas nunc humanum genus incolit secretum. Unde nec aquæ diluvii, quæ totam nostri orbis superficiem altissime cooperuerunt, ad eum pervenire potuerunt. Verum seu ibi seu alibi Deus noverit; nos tantum locum hunc fuisse et esse terrenum dubitare non licet: . . . locum scilicet amœnissimum, fructuosis nemoribus opacatum, eundemque magnum et magna fonte fecundum. ${ }^{1}$

Bede says that it is far removed from the knowledge of men. ${ }^{2}$ This phrase is literally derived from Augustine. ${ }^{3}$

Dante's conception of the Earthly Paradise has much in common with those of the Fathers mentioned, situated, as it was, far from the world of men, upon a lofty mountain, and embracing a forest, a fountain from which issued limpid waters, and one tree which 'would be marveled at for its height by Indians in their woods.'

${ }^{1}$ Cf. 91. 206.

'Thus Patr. Lat. 91. 43-44, 207.

In Gen. 8. 7. For the patristic and mediæval views of Paradise, see the Bible dictionaries under Paradise and Eden; McClintock and Strong, Encyclopadia of Bibl., Theol., and Eccl. Lit. 7. 652-9; Schenkel, BibelLexikon 2. 49-50; Schaff-Herzog, Encyc. of Religious Knozeledge, ed. Jackson, 8. 348-9; Zöckler, Gesch. der Beziehungen zwischen Theologie und Naturwissenschaft 1. 127-9, 173, 287, 349; Renan, Hist. Gén. des Langues Sém., 2d ed., pp. 466-479. A brief popular account is given by Baring-Gould, Curious Myths of the Middle Ages, pp. 250-265. Cf. also Patch, 'Some Elements in Mediæval Descriptions of the Otherworld' (Pub. Mod. Lang. Assoc. 33 (1918). 601-643).

"Purg. 28 ; 32.38 ff. For analogies with Dante's Terrestrial Paradise, see the notes of Scartazzini, Plumptre, and Longfellow, on Purg. 28. I ff.; Kraus, Dante, p. 4I7; Coli, Il Paradiso Terrestre Dantesco. With his doctrine of the dissemination of seeds or germs might be compared several of the passages cited above from the Avesta and the Bundahish. 
A synopsis of the views of Ephraem, Bede, and others who hold kindred opinions, may be found in Raleigh's History of the World (1. 3).

From the Middle Ages on, and particularly during the Renaissance, poets like Chaucer (Parl. Fowls 172-210), Boccaccio (Teseide, Bk. 7), Tasso (Gerusalemme Liberata, Bk. I5), and Milton (Par. Lost, Bk. 4), have been in part indebted for their Paradises and enchanted gardens to classical writers, in such passages as the following from the Odyssey (tr. Cotterill):

Here comes never the snow, nor a violent tempest and rain-storm; Here incessantly breatheth the breeze of the soft-voiced Zephyr.

Which winds ne'er shake nor ever a rain-storm

Wetteth, and never a snowflake falleth, but cloudless the æther Spreadeth above, and over it floateth a radiant whiteness."

The descriptions of the Golden Age are likewise drawn upon for this purpose. ${ }^{3}$

1. 566-7.

6. 43-5.

${ }^{3}$ For references to such classical writers, see Rohde, Der Griechische Roman, pp. 172 ff., 512 ff.; 2 d ed., pp. 183 ff., 545 ff. 


\section{PHYSIOLOGUS}

\section{THE PHYSIOLOGUS IN GENERAL}

The Physiologus-also known as the Bestiary-is a book of popular theology and morality, illustrating some of the chief doctrines of the Christian religion by means of the real or supposed characteristics of actual or fabulous animals, or employing these same characteristics as alluring or warning examples. ${ }^{1}$ It is not unlikely that this Christian Physiologus reposes upon earlier pagan books of natural history, setting forth the qualities of animals, and incidentally of plants and stones. Heliodorus, writing his Greek romance of Theagenes and Chariclea in the second half of the third century, ${ }^{2}$ has one of his characters, an Egyptian, exclaim (3.8): 'If you wish an example from natural history, here is one taken out of our sacred books. The bird Charadrius cures those who are afflicted with the jaundice. If it perceives at a distance any one coming towards it who labors under this distemper, it immediately runs away and shuts its eyes-not out of an envious refusal of its assistance, as some suppose, but because it knows by instinct that, on the view of the afflicted person, the disorder will pass from him to itself, and therefore it is solicitous to avoid encountering his eyes." ${ }^{3}$ Now as a similar trait is ascribed to the Charadrius in the Physiologus, it has been thought that these Egyptian sacred books contained much of the matter appropriated by the Physiologus, and that probably the original collection which was to constitute the basis of the later Physiologus may have been formed under such a ruler as Ptolemy Euergetes II (I76-II7 B. C.). ${ }^{4}$

Whenever such earlier compilations may have been made, the book that we understand by the term Physiologus (the word

\footnotetext{
${ }^{1}$ Lauchert, Geschichte des Physiologus, p. 46.

${ }^{2}$ Croiset, Hist. Litt. Gr. 5. 796.
}

${ }^{8}$ Similarly Aelian (ca. A. D. 225) Nat. An. 17. 13; Plutarch (ca. 100), Sympos. 5. 7. 2. 8; cf. Pliny 30. II. 94.

'Cf. Hommel, Die Aethiopische Uebersetzung des Physiologus, p. xii. 
means Naturalist) seems clearly to have been put together in Alexandria, ${ }^{1}$ before I40 B. C. ${ }^{2}$

The earliest texts of it must have been in Greek, though the Greek manuscripts of it at present known are late. About the beginning or middle of the fifth century it was translated into Ethiopic $^{3}$ and Syriac, ${ }^{4}$ and somewhat later into Armenian ${ }^{5}$ and Arabic. ${ }^{6}$ The Latin translation must have been made before 431. ${ }^{7}$ There are also complete or partial translations into Old High German, Flemish, Dutch, Provençal, Old French (4), Middle English, Italian, Waldensian, Roumanian, Icelandic, Mediæval Greek, Servian, and Russian, besides Old English. ${ }^{8}$ One writer has said: 'With the exception of the Bible, there is perhaps no other book in all literature that has been more widely current in every cultivated tongue and among every class of

${ }^{1}$ That it is of Egyptian, and specifically of Alexandrian origin is shown by various considerations: (I) the mention of the ibis, ichneumon, crocodile, and Phœnix; (2) the occurrence of fifteen of the stories in the work of the Egyptian priest, Horapollo; (3) the mention of the Nitrian desert, northwest of Cairo; (4) the mention of Indian products, and references to Indian fables, which would naturally find their way to Alexandria; (5) the Alexandrian origin of the symbolism by which the animal stories were adapted to Christian uses; etc.

${ }^{2}$ It seems to be referred to by Justin Martyr (d. I68 A. D.), by Clement of Alexandria, Origen, and other early Fathers (Lauchert, pp. 65, 68 ff.; Hommel, p. xxxi; Land, Anec. Syr. 4. I26-7).

${ }^{3}$ Translation into German by Hommel, pp. $45 \mathrm{ff}$; also Rom. Forschungen 5. 13-36.

"Translation into Latin by Tychsen in Physiologus Syrus, Rostock, 1795. A later Syriac version in Land, Anec. Syr., Vol. 4.

'Translated into French by Cahier, Nouveaux Mélanges d'Archéologie I. II7-I38.

- Translated into Latin by Land, op. cit. 4. $137 \mathrm{ff}$. For all four translations, see Lauchert, pp. 79 ff., and cf. Mann, Anglia Beiblatt Io. 278-9.

${ }^{7}$ Lauchert, p. 89. Texts in Mai, Class. Auct. 7 (1835). 589-596; Cahier and Martin, Mélanges d'Archéologie, Vols. 2, 3, and 4. Cf. Mann, as above, pp. 279-280.

${ }^{8}$ Lauchert, pp. I10-155, 300-2 ; Mann, as above, pp. 280-5; Reinsch, Das Thierbuch des Normannischen Dichters Guillaume Le Clerc, pp. 46-56. Concerning the sea-monster, Holbrook (Dante and the Animal Kingdom, p. 204) says: 'From my friend Sàndor L. Landeau I learn that he heard the tale in his childhood from the lips of peasants in Hungary.' 
people.' ${ }^{1}$ Certain it is that current notions of the pelican, the Phœnix, the unicorn, and the salamander are due to the former popularity of the Physiologus.

The mention of the Bible suggests how often, in parable, allegory, or metaphor, natural objects are employed to enforce spiritual lessons, or human beings are characterized by comparison with animals or plants:

Go to the ant, thou sluggard (Prov. 6. 6).

But ask now the beasts, and they shall teach thee; and the fowls of the air, and they shall tell thee; or speak to the earth, and it shall teach thee; and the fishes of the sea shall declare unto thee (Job. 12. 7, 8.).

The kingdom of heaven is like to a grain of mustard seed (Matt. I3. 3I).

The field is the world; the good seed are the children of the kingdom; but the tares are the children of the wicked one (Matt. 13. 38). I am the true vine, and my Father is the husbandman (John 15. I). $\mathrm{Be}$ ye therefore wise as serpents, and harmless as doves (Matt. I0. 16).

Their wine is the poison of dragons, and the cruel venom of asps (Deut. 32. 33).

Go ye, and tell that fox, Behold, I cast out devils (Lk. 13. 32).

Ye are the salt of the earth (Matt. 5. 13).

Inwardly they are ravening wolves (Matt. 7. 15).

They are greedy dogs that can nevẹr have enough (Isa. 56. II).

The sense of the spiritual meaning within the material fact is what makes poets, and all supreme artists. It is what led Mrs. Browning ${ }^{3}$ to say:

Earth's crammed with heaven, And every common bush afire with God.

${ }^{1}$ Sokoll, Zum Angelsächsischen Physiologus, p. 3.

${ }^{2}$ The Ethiopic text of the Physiologus ends: "The Holy Scriptures have said nothing at random concerning animals and birds'; the Armenian says they 'do not mention animals without some mystery.' Cf. Cahier, Mélanges 3. 239 (MS. C) : 'Nihil Scripturæ sine similitudine nobis dixerunt' (with manifest allusion to Matt. 13. 34).

'Aurora Leigh, Bk. 7. 
If a man could feel,

Not one day, in the artist's ecstasy,

But every day, feast, fast, or working-day,

The spiritual significance burn through

The hieroglyphic of material shows,

Henceforward he would paint the globe with wings,

And reverence fish and fowl, the bull, the tree,

And even his very body as a man.

Hence, however severely we may condemn the abuses of the allegoric method in its application to Scripture, there is at the root of symbolism something natural and necessary. We all take the sign for the thing signified. We all understand what is meant when a person is called a bear, a serpent, a cur, or a cat. ${ }^{1}$ We all, to refer specifically to the Physiologus, attribute human virtues and vices to animals, and find pleasure and instruction in Aesop's fables, Reynard the Fox, and the Uncle Remus stories.

\section{THE OLD ENGLISH PHYSIOLOGUS}

\section{MANUSCRIPT}

These three poems, like the Phonix, are contained in the Exeter Book $\left(95^{b}-98^{a}\right)$, for which see p. xxv.

\section{Coherence of the Poems}

The standard form of the Physiologus has 49 chapters, corresponding to as many topics, though the various translations differ with respect to the number. Of the whole, Old English poetry has made use of only three-the Panther, the Whale (AspTurtle), and the Partridge-or, if we add the Phonix, four.

Do these three short poems which follow the Phonix in the Exeter Book form a brief Physiologus? Do they constitute a portion of a longer Old English poetical Physiologus, the rest of which has been lost? Or are they unrelated-merely versions of three unconnected chapters which happened to strike the translator's eye, or his fancy?

The third hypothesis is easily disproved, at least on the assump-

${ }^{1}$ For echoes of the Physiologus in certain Elizabethan writers see Lauchert, Englische Studien I4. I88-210. 
tion (see p. 1xxxviii) that the third poem is the Partridge: for ( $x$ ) the order found here is that of Pitra's Greek MS. A, of MS. Royal 2. C. XII, of Cahier's B, of the fragment found in Jerome's writings, of the Arabic, the Ethiopic, the archetype of the Syriac version at Leiden, and of Cahier's MS. C, so far as the first two animals are concerned (the third is missing); (2) the second and third have a backward reference in the word gen ('further') ; (3) the first poem, the Panther, has a general introduction, referring to the variety of birds and animals upon the earth, under the second of which classes the author proceeds to speak of the Panther; (4) the first poem has 'We heard tell' (8-9), while the third poem begins, 'I heard tell'; (5) the third poem ends in the same hortatory manner as the second, with a sentence beginning with Uton (see p. Ixxxviii); (6) the third poem ends with Finit, which, under the circumstances, is more likely to mark the end of a series than of a single short poem. Hence the three poems are not versions of unconnected chapters, nor did the Old English poet treat them as unconnected.

Do they, then, constitute a portion of a larger poetic cycle? The answer to this depends upon the reply to the question raised by the gap in the third poem. If this gap represents only a part of this single poem, the cycle, upon the basis of the facts adduced above, must have consisted, so far as we can see, of only these three members ${ }^{1}$; and the evidence adduced under the head of the Partridge (pp. 1xxxvi ff.) points to this conclusion. ${ }^{2}$

\section{Author and Date}

Dietrich $^{3}$ believed the Physiologus to have the same author as the Phœnix, Guthlac, and Juliana, that is, Cynewulf. This he argues from similarity of diction, and from general likenesses in conception and treatment. However, the scant page which he devotes to the subject does not afford him scope for detailed

${ }^{1}$ Dietrich (Commentatio, p. II) suggested that three orders of animals were represented by the three poems-quadrupeds, fishes, and birds; Ebert (Anglia 6. 24I) modified this to animals of the land, of the sea, and of the air.

${ }^{2}$ Cf. Tupper, Jour. Eng. and Germ. Phil. II. 10.

${ }^{8}$ Commentatio, pp. Io-II. 
proof. Sokoll goes into the subject much more fully. He says ${ }^{1}$ that almost the whole vocabulary of the Physiologus belongs also to the Phonix, and likewise affirms a close relationship between the diction of the Physiologus and that of the Christ. Several pages $^{2}$ of his monograph are devoted to an examination of the vocabulary, metre, style, etc., of the Physiologus, in order to prove that it must be ascribed to Cynewulf.

On the other hand, Lefèvre, Wülker, Körting, Brandl, Mann, and Schwarz oppose this view. ${ }^{3}$ Trautmann thinks that the Physiologus may be ascribed to Cynewulf with some probability. Barnouw ${ }^{5}$ will go no further than to assert that, if the Physio$\log u s$ is by Cynewulf, it is later than the Elene.

If I did not hesitate before assigning to Cynewulf so many Old English poems, ${ }^{6}$ I should associate myself on this point with Dietrich and Sokoll. If the Physiologus is not by Cynewulf, it must be by some disciple or close imitator; if by him, it is probably one of his later productions. As for the date, it is in general that of Cynewulf's period, the second half of the eighth century. ${ }^{7}$

\section{The Panther}

The account of the panther in the Physiologus may be typically represented by the Greek text published by Lauchert. ${ }^{8}$ In the Biblical passage which serves as a foundation, 'panther' is due to the Septuagint, the 'young lion' of the Authorized Version representing the Hebrew. The sentence from Hosea, however, serves as a mere pretext for this chapter.

The prophet prophesied and said: 'I am become as a panther to Ephraim' [Hos. 5. 14]. The Naturalist said concerning the panther

${ }^{1}$ Op. cit., p. $2 \mathrm{I}$.

${ }^{2}$ Pp. II 1 -21.

${ }^{8}$ Jansen, Die Cynerwulf-Forschung, pp. II5-6.

${ }^{4}$ Kynerwulf, pp. 42, 122.

${ }^{-}$Textkritische Untersuchungen, p. 206.

- $\mathrm{Cf}$. my edition of the Christ, p. lxv.

'Brand1, Gesch. der Altengl. Lit. (Paul, Grundriss, 2d ed., 2. I034, 1044, 1047); Trautmann, Kynewulf, p. I22 (A. D. 740-780); Richter, Chronologische Studien, p. IоI.

${ }^{8}$ Pp. 248-9. 
that he has this natural property: $\mathrm{He}$ is beloved by all the animals, but a foe of the dragon. $\mathrm{He}$ is as variegated as Joseph's coat. $\mathrm{He}$ is exceeding quiet and meek. When he has eaten and is filled, he sleeps in his den. And the third day he arises from sleep, crying out with a loud voice. And the animals that are nigh and that are afar off hear his voice. From his voice there streams all the fragrance of spices. And the animals follow the fragrance of the panther's smell, running up to it.

Thus when Christ was roused on the third day and rose from the dead, all fragrance came to us, both the peaceable ones that are nigh and those that are afar off [Eph. 2. I7; cf. Ps. 57. 19]. Manifold is the intellectual wisdom of God, as the Psalmist said [Ps. 45. 9, 13]: 'Upon thy right hand did stand the queen, clothed in vesture wrought with gold, and arrayed in divers colors.' She is the Church. Manifold is Christ, since he is virginity, temperance, compassionateness, faith, virtue, patience, concord, peace. Well, therefore, did the Naturalist speak concerning the panther.

\section{The Whale (Asp-Turtle) \\ THE GROWTH OF THE LEGEND}

There can be no doubt that the germ of that chapter of the Physiologus which is concerned with the sea-monster (or so-called whale) is to be found in a story related by Nearchus, who was admiral of Alexander's fleet during the voyage from the mouth of the Indus to the coast of Persia. In late October or November of 325 B. C., he sailed past the island of Ashtóla (Astóla) or Sungadeep (Sangadip), ${ }^{1}$ off the coast of Baluchistan, in Lat. $25^{\circ} 7^{\prime}$, Long. $63^{\circ} 40^{\prime}$, and between Ras Ormárah (Hormárah, Urmárah, Aruba, Arabah) and Ras Jaddi (Cape Passeenoe, Passenoe, Pessaní, Pasni). ${ }^{2}$ From the Ichthyophagi of the opposite coast of Mekrán (Makrán) he heard the tale preserved by Arrian ( $\dagger$ ca. I80 A. D.) and Strabo (†ca. 25 A. D.). The fuller form of the legend is thus reported by Arrian $^{3}$ :

${ }^{1}$ The island was and is known by a great variety of names (PaulyWissowa, Real-Encyclopädie der Classischen Wissenschaften, s. v. Ashtola; Cyclopadia of India, s. v. Ashtola; Geographi Graci Minores, ed. Müller, I. 344). Among these are Karnina, Seléra, Satáluh, Island of the Sun.

${ }^{2}$ Among the writers who mention it are Ptolemy (6. 8, 20, 21), Pliny (6. 26), Solinus (54), Mela (3. 7), Curtius (Io. I).

${ }^{3}$ Indica, chap. 31 (cf. chap. 26). 
(BEFORE 300 B. C.)

While Nearchus was passing the coast of the Ichthyophagi, he heard tell of an island about a hundred stadia distant from the mainland, where no one dwelt. The natives said that it was consecrated to the Sun, and bore the name of Nosala, and that no one was willing to land there, but that if any one did so through ignorance, he was never seen again. Nearchus goes on to relate that one of his cutters, manned by Egyptians, disappeared not far from this island, whereupon the leaders of the expedition affirmed that they had landed on the island without being aware of the danger, and so had vanished. Nearchus then sent a thirty-oared vessel to circumnavigate the island, warning the crew not to land, but rather to sail close to the shore, and call out to the steersman by name, or to any others whose names they knew. Since no one answered, Nearchus himself rowed to the island, and forced his sailors, against their will, to land. He then went ashore, and this proved that the talk about the island was an idle tale.

Another story that he heard about it was to the effect that one of the Nereids dwelt there, though her name is not mentioned; she, it was said, would take her fill of love with any man who came, but afterward would turn him into a fish, and cast him into the sea. On this account, the Sun grew angry with the Nereid, and at length commanded her to depart. This she promised to do, but at the same time solicited his love, which the Sun granted; but, having compassion upon the men whom she had turned into fishes, he restored them to their former state. From these had descended the race of the Ichthyophagi, which had come down to Alexander's time.

${ }^{1}$ According to Philostratus (Life of Apollonius of Tyana 3. 56), this Nereid was 'a dreadful female demon, which would snatch away many mariners, and would not even allow them to fasten a cable to the rock.' He calls the 'sacred island' Seléra. Cf. below, p. 1xviii, note 3 .

The Nereid may be related to the Siren which Boiardo, Berni, and Ariosto represent as lying further out to sea than the whale which is two miles long, and rises eleven paces above the water, and which Alcina accordingly persuades Astolfo is an island (Orl. Innam. 2. 13. 58, 62, 64; 2. 14. 6; (Berni) 42. 60, 64-68; Orl. Fur. 6. 37, 40-42. Shakespeare's ( $M . N . D .2$ I. 150-2)

\section{mermaid on a dolphin's back}

Uttering such dulcet and harmonious breath

That the rude sea grew civil at her song

is the siren of Ariosto (6. 40),

Che col suo dolce canto accheta il mare,

but the position upon the dolphin's back carries us directly back to classical mythology and art (see, for example, Pliny 36. 5. 4). 


\section{A shorter form is found in Strabo' ${ }^{1}$ :}

Nearchos says that he proved the falsehood of a story which was firmly believed in by the sailors in his fleet-that there was an island situated in the passage which proved fatal to those who anchored on its shores, since a bark disappeared when it came to this island and was never seen again, and some men who were sent in search did not dare to land upon the island, but before sailing away from it shouted and called to the crew, when, as no one returned an answer, they took their departure. But as all blamed the island for the loss of the men, Nearchos tells us that he himself sailed to it, and having anchored, disembarked with a part of his crew, and made a circuit of the island. But as he could find no trace of the men of whom he was in search, he gave up the task and returned.

Various theories have been proposed to account for the legend:

I. Mela seems to imply that the heat in the island was unendurable. $\mathrm{He}$ is somewhat confused regarding the geography, though he appears to be speaking of our island (3. 7) : 'Opposite the mouths of the Indus lie the regions of the sun, so called. These are so uninhabitable that the power of the surrounding air causes instant death; and between those mouths is the district of Patalene, which in some parts is without any one to till the soil, on account of the intolerable heat.'

2. Müller suggests ${ }^{2}$ that the island was a rendezvous for pirates, who might be interested to keep their haunts to themselves. Pliny tells us (6. 26) that companies of archers were carried on board the vessels plying between Arabia and the west coast of India, because the Indian seas were infested by pirates. Curzon (Persia 2. 448) remarks of certain Arab tribes skirting the southern littoral of the Persian Gulf that 'they have been addicted from time immemorial to piratical escapades.' ${ }^{3}$ Near this same coast, Lingah, on the Persian side, is the chief town

${ }^{1}$ 15. 2. 13, p. 726, translated by McCrindle, Ancient India, pp. 9I-2.

${ }^{2}$ Geogr. Gr. Min. 1. 352.

${ }^{3}$ Marco Polo (3. 24, 25) tells of the pirate vessels, more than a hundred in number, that went on summer cruises from the coast below Goa, twenty or thirty vessels together. For those at Socotra, cf. Marco Polo 3. 32 . 
of the piratical Joasmees ${ }^{1}$ (Jowasmis, Jewasimis, Jowasimees), who, at least previous to 1820 , frequented Ashtola: 'This island was once famous as the rendezvous of the Jowásimee pirates; and here they committed many horrid and savage murders on the crews of the vessels which they captured.' ${ }^{2}$ The vessels they burnt, after massacring the crew.

3. The air of the island may have been unhealthful in antiquity, if no longer so. Thus Lord Curzon says of Gwadur, only about a hundred miles away (Persia 2. 43I) : 'Gwadur was once one of the most popular stations of the Telegraph Line, and was regarded as the sanitarium of the Gulf ports, the temperature being very equable, and existence quite endurable even in the summer months. From some unknown cause, however, attributed by some to the sea-water, which is here so strongly impregnated with sulphuretted hydrogen that the fish are often killed in great numbers, a malarial fever has developed itself, which attacks every new-comer; and the place is now as much shunned as it was once sought.'

4. As large numbers of turtles are caught upon the island for the sake of their shells, it may be that the legend was invented by those who were engaged in this pursuit, in order to keep possible intruders at a distance; or the air may have been so infected ${ }^{3}$ by the abandoned carcases of the turtles which were caught only for the sake of their shells as to be, or seem, poisonous to those who attempted to land, especially as there appears to be but one good landing-place. To do justice to this theory, and to gain a tolerable idea of the character of the island, it is desirable to consider two comparatively modern accounts. Lieutenant G. B. Kempthorne, ${ }^{4}$ describing in 1835 a survey made in 1828 , thus writes :

${ }^{1}$ Cycl. of India.

${ }^{2}$ Lieut. G. B. Kempthorne, Jour. Royal Geog. Soc. 5 (1835). 268.

${ }^{8}$ Pliny says that in the island 'every animal instantly dies'; Mela that it is 'so uninhabitable that the power of the ambient air instantly kills those who land.' Kempthorne found no living animal there excep1 rats (see opposite page). Holdich (Gates of India, p. 160) says that 'sea-urchins and sea-snakes abounded in such numbers as to make the process of exploration quite sufficiently exciting.'

Jour. Royal Geog. Soc. 5. 266-8. 
Ashtola is a small desolate island, about four or five miles in circumference, situated twelve miles from the coast of Mekrán. Its cliffs rise rather abruptly from the sea to the height of about three hundred feet; and it is inaccessible except in one place, which is a sandy beach, about one mile in extent, on the northern side. Great quantities of turtle frequent this island for the purpose of depositing their eggs. . . . Not a vestige of any habitation now remains.

A party went on shore one night for the purpose of catching turtle, a description of which may not be uninteresting. We left the ship at sunset, and reached the shore about dark, then hauled the boat up on the beach; and when this was done formed ourselves into two distinct parties, and dispersed to different parts along the beach. Having reached the place where we thought it likely that the turtle would land, we lay down, keeping a sharp look out and making as little noise as possible. . . . We were thus all in anxious expectation of the appearance of the turtle; and six bells had just gone on board-that is, it was eleven o'clock, P. M.-when we saw the first, to our great delight, coming on shore just opposite us. It looked like a black rock moving slowly and steadily out of the water. We did not interrupt its progress until it had got some distance upon the beach, when a rush was made towards it, and it was immediately turned over on its back, without giving it time either to defend itself or blind its assailants by throwing the sand with its flippers or fins, which they do with such force that it is almost dangerous to come near them. It took six stout men thus to turn the largest that was caught. . . . We caught seven turtle that night, and six more the night after.

The Arabs come to this island and kill immense numbers of these turtle, not for the purpose of food, for they never partake of it, considering it as an unclean animal; but they traffic with the shell to China, where it is made into a kind of paste, and then into combs, ornaments, \&c., in imitation of tortoiseshell. The carcases of the poor animals are thus strewed about the beach in all directions, causing a stench so great that it was scarcely bearable; in fact, we could smell it some distance off the shore. The only land-animals we could see on the island were rats, and they were swarming; they feed chiefly on the dead turtle.

And earlier, according to Vincent, ${ }^{1}$ Captain Blair had written :

We were warned by the natives of Passenoe that it would be dangerous to approach the island of Ashtola, as it was enchanted ${ }^{3}$;

${ }^{1}$ The Commerce and Navigation of the Ancients in the Indian Occan I. 299.

${ }^{2} \mathrm{McC}$ rindle (Ancient India, p. 92, note I) says: 'It is still regarded with superstitious fear by the natives of the neighbouring coast.' 
and that a ship had been turned into a rock. This superstitious story did not deter us; we visited the island, found plenty of excellent turtle, and saw the rock alluded to, which at a distance had the appearance of a ship under sail. ${ }^{1}$ The story was probably told to prevent our disturbing the turtle; it has, however, some affinity to the tale of Nearchus's transport.

According to Charles Masson, ${ }^{2}$ Ashtóla is now a goal of Buddhist pilgrimage:

Many votaries and pilgrims proceed no farther than Hinglátz, but it is deemed to be especially praiseworthy and beneficial to extend the pious tour to Satadip, an island off the coast of Mekrân, and between Hormára and Pessaní. I was surprised at discovering that this celebrated island was no other than the Ashtola of our maps, the Asthílâl of Arabs and Baloches, the Carnina and Enchanted Isle of Nearchus, and the Asthæ[a] of Ptolemy.

Holdich (Gates of India, p. I60) remarks: 'I have been to that island, the island of Astola, and the tales that were told to Nearkhos are told of it still. There, off the southern face of it, is the "sail rock," the legendary relic of a lost ship.'

${ }^{1}$ Cf. Odyssey i3. 154 ff.

${ }^{2}$ Narrative of Various Journeys in Belochistan, etc., $4.39 \mathrm{I}-3$; cf. 4. 295, and, for Masson himself, Holdich's Gates of India, p. 345.

${ }^{3}$ 'Sacred to the goddess Nana (now identified with Siva by Hindus). ... The Assyrian or Persian goddess Nana ... was a well-established deity in Mesopotamia 2280 years B. c.' According to Holdich, this shrine, 'next possibly to Juggernath, draws the largest crowds of pilgrims (Hindu and Mussulman alike) of any in India.' The character of Nana is outlined by Jastrow (Hastings, Dict. Bible, Extra Vol., p. 54I): 'At Erech, in the extreme south, there flourished the cult of a goddess known as Nanâ, who appears to have been conceived as a deity of a violent character, punishing severely those who disobey her-a wargoddess rather than a mother of life-but who in later texts is identified with Ishtar.' Elsewhere Jastrow says (Encyc. Brit., IIth ed. 14. 870-I): 'She [Ishtar] appears under various names, among which are Nanā, etc. ... Ishtar is celebrated and invoked as the great mother, as the mistress of lands, as clothed in splendor and power-one might almost say as the personification of life itself. But there are two aspects to this goddess of life. She brings forth, she fertilizes the fields, she clothes nature in joy and gladness, but she also withdraws her favors, and when she does so the fields wither, and men and animals cease to reproduce. In place of life, barrenness and death ensue. She is thus also a grim goddess, at once cruel and destrúctive. We can, therefore, 
The germ of the later legend is thus seen to be as follows:

An enchanted island, or the being that inhabits it, causes the disappearance or transformation of men who touch upon its shores. As a historical fact, the island in question was and is the resort of large turtles in great numbers; and it is possible that there may be some connection between the capture of these turtles and the reputation of the island.

The story enters upon a new phase with the romance of PseudoCallisthenes, or rather with the apocryphal letter of Alexander to Aristotle, which must have been already extant when the romance was compiled. ${ }^{1}$ As the romance was composed at Alexandria about 200 A. D., ${ }^{2}$ and as the outlines of the work are to be ascribed to the age of the Ptolemies (323-247 в. c.), it is apparent that no great interval is likely to have elapsed between the story related by Nearchus and that of the Pseudo-Callisthenes.

The kernel of the new story is to this effect: A reputed island, being approached by a boat, proves to be an animal, suddenly sinks, and causes the occupants of the boat to be engulfed. The tale runs, translated from the $\mathrm{Greek}^{3}$ :

understand that she was also invoked as a goddess of war and battles and of the chase.'

May not the Nereid (p. 1xiv, above), then, so seductive and so ruthless, represent this Naná-Ishtar-worshiped at Hinglátz, and might not the antiquity of the legend thus bear some relation to Babylonian mythology? Erech is hardly more than 200 miles in a straight line from the Persian Gulf, and Susa, where, according to Holdich (p. 163), Nana dwelt for 1635 years (to 645 B. C., when she was reinstated at Erech), not so far. As to the sea-route in ancient times through the Persian Gulf, along the coast of Baluchistan, to India, see Holdich, pp. $54-57$.

${ }^{1}$ Rohde, Der Griechische Roman, 2d ed., p. 200.

${ }^{2}$ So Zacher, Pseudocallisthenes, p. 102. Rohde is disposed to think that the earliest form of the romance was actually written down in the Ptolemaic era (op. cit., p. 197, note I). See also C. Müller, PseudoCallisthenes, p. xx (in Arriani Anabasis et Indica, Paris, 1846).

${ }^{3}$ Ed. Müller, 3. 17. The Latin version by Julius Valerius, composed between 270 and $330 \mathrm{~A}$. D. (so Kuebler in the Teubner edition of Valerius, p. vir), will be found at the foot of the page in Müller's edition, as well as in the Teubner volume. The Latin, while making certain points of the Greek clearer, misses the essential thing for us by failing to identify the island with an animal. 
When we had come to the city of Prasiaka, which seemed to be the metropolis of India, we discovered a fertile promontory. When I had set out with a few of my men for this promontory, we ascertained that the inhabitants subsisted on fish, and had the form of women. On questioning some of them, I found that they were of barbarous speech. When I made .inquiry about the region, they pointed away to an island, which was visible off at sea. This, they said, was the sepulchre of a very ancient king, and contained much consecrated gold. Hereupon the barbarians disappeared, leaving their boats, to the number of twelve, behind.

My kinsman and friend, Philo, together with Hephæstion and Craterus, were unwilling that I should cross over. Philo's words were: 'Let me go in your stead, so that, should it turn out badly, I may run the risk, and not you; while if all goes well, I will send a boat back for you. Even should Philo perish, you would never want for other friends ${ }^{1}$; but if anything should happen to you, Alexander, all the world would suffer.' Thereupon I allowed myself to be dissuaded. He then set off for the island, but, when an hour had elapsed, all at once the animal sank to the bottom of the sea. Thus, while we were looking on, ${ }^{2}$ the animal disappeared, and the whole boat's crew perished miserably, to our great sorrow. But when I searched for the barbarians, they were nowhere to be found.

We remained on that promontory for eight days, and there we saw the Hebdomadarion, an animal with elephants on its back."

This story is pieced together from several earlier ones. The promontory is probably Ras Ormárah, ${ }^{4}$ since, after passing it, Nearchus came to the fishermen who fled at the sight of his vessels. The island containing the sepulchre of the ancient king, however, was not Ashtóla, but was situated at the entrance to the Persian Gulf, the ancient name being Ogyris ${ }^{5}$ (Organa), or Oarakta, ${ }^{6}$ the former probably representing Ormuz, and the latter, Kishm. Curtius relates (IO. I) that those who were attracted by the rumors of gold to seek the island that contained the monument of this king, Erythras, were never seen again. The rest of the tale in Pseudo-Callisthenes seems to be an echo of the story related by Nearchus of Ashtóla.

A play on the word Philo.

${ }^{2} \delta \rho a \xi \operatorname{san}_{\nu} \omega \nu$. The translation is guesswork.

${ }^{3} \mathrm{Cf}$. the later Hindu stories of the earth supported by an elephant on the back of a tortoise.

'Cf. Arrian, Indica, chap. 26, with Holdich, Gates of India, p. I58.

'Strabo 16. 766-7; Mela 3. 8; Pliny 6. 28.

"Arrian, Indica, chap. 37. 
There is an important parallel in Pseudo-Callisthenes 2. $38{ }^{1}$ where we are told that Alexander, having encamped on the seashore, embarked his soldiers, and sailed to an island not far away, where they heard, but did not see, men speaking Greek. Some of the soldiers, persuaded by a diver, leaped overboard and swam ashore, in order to explore the island; but no sooner had they landed than crabs issued from it, and dragged them back into the water. This frightened Alexander, so that he ordered the sailors to return to land.

The legends of Pseudo-Callisthenes are thus reducible to this: An island, or a sea-beast (crab) representing in some sort an island or its destructive power, plunges the seafarer who would land upon it into the deep.

The tale is next related in Hebrew by Rabbah bar bar Hana, a Babylonian rabbi who lived between A. D. 257 and 320 . One of the journeys he undertook was through the desert in which the children of Israel wandered for forty years, and where his Arab guide pointed out to him Mount Sinai, and the place where Korah had been swallowed up by the earth. From this guide or other Arabs he may have heard the fantastic tales which he afterwards recounted, and which caused his colleagues to remark, "All Rabbahs are asses, and all bar bar Hanas fools." ' Since the Arabs were the active carriers or intermediaries in the commercial intercourse between Egypt and India in those times, ${ }^{3}$ nothing is more natural that that they should pick up such a legend in passing and repassing Ashtóla. ${ }^{4}$ Rabbah's version is in the Babylonian Talmud (Baba Bathra 73b):

${ }^{1}$ Müller's ed., p. 89; cf. Zacher, p. I39.

${ }^{2}$ Jewish Encyclopadia 10. 291.

- Schoff, Periplus of the Erythraan Sea, pp. 3 ff.; Vincent, Periplus, pp. $37,59,60$.

'It was while sailing to the East Indies by way of the Persian Gulf that Sindbad, on his first voyage, came to the island like one of the gardens of Paradise.' While the passengers were disporting themselves on the shore, and some had lighted the fires in their fire-pots, the master of the ship called upon them to embark speedily, 'for this apparent island upon which ye are is not really an island, but it is a great fish that hath become stationary in the midst of the sea, and the sand hath accumulated upon it, so that it hath become like an island, and trees have 
Once, while on a ship, we came to a gigantic fish at rest, which we supposed to be an island, since there was sand ${ }^{1}$ on its back, in which grass ${ }^{2}$ was growing. We therefore landed, made a fire, and cooked our meal. But when the fish felt the heat, he rolled over, and we should have drowned had not the ship been near.

grown upon it since times of old.' He spoke, but too late for some, although they abandoned their goods, including the fire-pots. "The island had moved, and descended to the bottom of the sea, with all that were upon it, and the roaring sea, agitated with waves, closed over it' (Lane's translation of the Arabian Nights). Cf. Rohde, Der Griechische Roman, 2 d ed., pp. 19I-6; 'De Reizen von Sindebad,' De Gids (1889) 3. 278-312.

${ }^{1}$ So in the Latin texts of Mai (Class. Auct. 7. 590) and Cahier (Mélanges d'Archéologie 3. 253, MS. B): "habens super corium suum tamquam sabulones qui sunt (B, sicut) iuxta litora (B, littore) maris.' So likewise in the Sindbad story, in Kazwini, Philipp de Thaon ("Le sablon de mer prent, sur sun dos l'estent. . . . Les graveles sunt les richeises del mund'), Guillaume le Clerc (ed. Reinsch, 11. 2259-60; also 2272-3, 'Font granz pels el sablon ficher, Qui semble terre a lor avis'; ed. Cahier, Mélanges 3. 255, 'Altretel est come sablon L'eskerdes de son dos en som'), Olaus Magnus, Brunetto Latini (Tresor, ed. Chabaille, p. 186, ' $\mathrm{Li}$ vent aporte sablon et ajostent sor lui, et $\mathbf{i}$ naist herbes et petiz arbrissiaus'), etc. There is no mention of sand in the Ethiopic or the two Syriac versions; the Armenian has (Cahier, Nouv. Mél. I. 129), 'He keeps to sandy places,' with which compare R. F. Burton's statement (Zanzibar I. 200): 'When fewer ships visited the port, the sandspit projecting from "Frenchman's Island" was covered with bay-turtle [green turtle].'

${ }^{2}$ Perhaps this trait may owe something to the islands of shrubbery which float away from estuaries into tropical seas (Dana, Manual of Geology, 4th ed., p. 156). Floating islets of matted trees are sometimes seen fifty or a hundred miles off the mouth of the Ganges (and perhaps the Indus as well; cf. Curtius 9. 8), and among the Moluccas or the Philippines (Lyell, Principles of Geology, I Ith ed., 2. 364-6). According to Lyell, ships have sometimes been in imminent peril, as these islands have often been mistaken for terra. firma, when in fact they were in rapid motion. Less pertinent are the ancient stories concerning the islands of Rhodes, Anaphe, Thera, and Delos (for volcanic islands like Thera (Santorin), see Lyell 2. $58 \mathrm{ff} ., 67 \mathrm{ff}$.). On the disappearance of islands along the Baluchistan coast, see Jour. Royal Soc. Arts 49. 419, 424. Under date of Sept. I2, 1913, a report came from San Francisco: 'Falcon and Hope Islands, of the Friendly or Tonga group, in the South Pacific, have disappeared from view. With them several hundred natives and a few white men also have disappeared.' 
Here, at length, are the particulars which belong to the mediæval form of the story.

In the Arabic Book of Indian Marvels, edited and translated by Van der Lith and Devic (Leyden, I883-6), consisting of stories collected by the captains of trading vessels between 900 and $95^{\circ}$ (Préface, p. vi), we have the following version:

I have also heard very curious stories about turtles, which the mind has difficulty in crediting. Here is one that I have from Abu Mohammed-al-Haçan, son of Amr. He had heard a respectable sailor relate that a ship, sailing from India for some country or other, was driven from its course by the violence of the wind, notwithstanding the efforts of the captain, and sustained some damage. They finally reached a little island, entirely destitute of wood and water, where they were forced to stop. The cargo was unloaded, and they remained there long enough to repair the damage, after which the bales were put back on board, in order that they might continue their journey. While this was in progress, the New Year festival arrived, and, in order to celebrate it, the passengers carried ashore to the island such pieces of wood, palm-leaves, and rags as they could find aboard ship, and set them on fire. Suddenly the island shook beneath their feet. Being near the water, they threw themselves in, and made for the small boats. At that instant the island sank into the waves, producing such a swirl that they all narrowly escaped drowning, and only saved themselves with the greatest difficulty, being terrified beyond measure. Now the island was nothing but a turtle asleep on the water, which, a wakened by the heat of the fire, sought to escape. I asked my informant how that happened. 'Every year,' he replied, 'there is a number of days when the turtle rises to the surface of the water to rest from his long sojourn in the caverns of the submarine mountains; for at these depths there grow frightful trees and prodigious plants, much more wonderful than our terrestrial trees and plants. It comes, then, to the surface of the water, and passes whole days there deprived of sensation, like a drunken man. When it has regained its senses, and becomes tired of its position, it dives.'

THE NAME OF THE MONSTER

The Physiologus differs from a mere account of animal-traits in that it tags the characterization of each animal with a moral called an interpretation, which is sometimes formally labeled as such, and sometimes not. This will be apparent from the Greek chapter which deals with our incident, which will also show that 
another peculiarity of our sea-monster, or some other fabulous sea-monster, is combined with it. The Greek chapter is found in two forms, a shorter and longer. The first is printed by Pitra $^{1}$ :

There is a sea-beast in the ocean, called asp-turtle, which has two natural properties.

(I) Its first nature is this. When it is hungry, it opens its mouth, and from its mouth there streams all fragrance. The little fishes, attracted by the odor, swarm into its mouth, and the monster drinks them down. But you will not find the big and perfect fishes coming near the beast.

Such a perfect fish was Job, Moses, Isaiah, Jeremiah, and the whole company of the prophets. In this manner did Judith escape from Holofernes, and Esther from Artaxerxes.

(2) The second natural property of the sea-monster: it is very large, like an island. Not being aware of this, the seamen fasten their boats to it as to an island, and attach the anchors and the stakes. They build a fire on the back of the sea-monster, in order to boil somewhat for themselves. When he is scorched, he plunges to the bottom, and wrecks the boats.

Interpretation. Well then did Solomon say in the Proverbs: 'Give no heed to a worthless woman; for honey drops from the lips of a harlot; but afterwards thou wilt find her more bitter than gall.' So if thou shalt depend upon the hope of the devil, he will plunge thee with himself down to the hell of fire.

\section{The other is edited by Lauchert ${ }^{2}$ :}

Solomon teaches in the Proverbs, [in the Septuagint 5. 3-5], saying: 'Give no heed to a worthless woman; for honey drops from the lips of a harlot, who for a season pleases the palate: but afterwards thou wilt find her more bitter than gall, and sharper than a twoedged sword. For the feet of folly lead those who deal with her down to the grave with death.'

There is a monster in the sea, called asp-turtle, which has two natural properties. Its first is this. When it is hungry, it opens its mouth, and all fragrance issues from its mouth. And the little fishes crowd into its mouth, and he swallows them, but the large and perfect it does not find approaching it. Thus the devil and the heretics by their fair speeches and the guile of their supposed fragrance entice the simple and unschooled in understanding, but are unable to lay hold of those who are perfect in mind. Such a perfect fish was Job, Moses, Jeremiah, Isaiah, and the whole com-

${ }^{1}$ Spicilegium Solesmense 3. 352.

'Op. cit., pp. 249-251. 
pany of the prophets. In this manner did Judith escape from Holofernes, Esther from Artaxerxes, Susanna from the elders, and Thecla from Thamyris.

Its other natural property is as follows. The monster is very large, like an island. Not being aware of this, the seamen fasten their boats to it as to an island, and also their anchors and their stakes. So they disembark as on an island, and build a fire to boil them food. And the whale, being burned, plunges to the bottom, and wrecks the boat and all that belongs to it. And if thou, O man, dost hang upon the false hopes of the devil, he will plunge thee with himself down to the hell of fire. Well, therefore, did the Naturalist speak concerning the asp-turtle.

Ignoring, for the moment, the new 'nature,' or trait, introduced, let us consider what manner of sea-beast is intended by this version of the legend. The word here translated 'sea-beast' is in the original $\kappa \tilde{\eta}$ ros (Lat. cetus), the same that in Gen. I. 2 I is, in the plural, translated 'whales' in the Authorized Version, while the Revised Version more accurately renders 'sea-monsters.' The word itself, then, does not demand to be translated 'whale' in this place, any more than in the great majority of other occurrences in Greek and Latin. The exacter term is a $\sigma \pi \delta \delta_{\chi} \chi \lambda \omega \prime \eta$, and this must be translated either by 'shield-turtle'

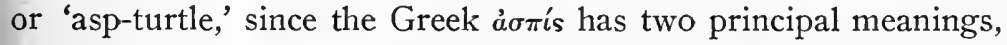
'round shield,' and 'asp.' In any case, the second element, $\chi \in \lambda \omega \dot{\eta} \eta$, must mean 'turtle.' This designation of the fabulous beast by 'turtle' is supported by various considerations :

I. Kazwini, an Arab writer of the latter half of the thirteenth century, begins his story thus, ${ }^{2}$ in his account of water-animals: 'The tortoise is a sea- and land-animal. As to the sea-turtle, it is very enormous, so that the people of the ship imagine that it is an island.'

2. When the $\chi \epsilon \lambda \omega^{\prime} \eta$ of this chapter is translated into Latin, it is always as testudo.

3. The folk-tales of widely separated peoples, who cannot have borrowed from one another, unite in giving a similar account of the tortoise. Thus Catlin heard among the Mandan Indians ${ }^{3}$

${ }^{1}$ Cf. pp. Ixxxi ff.

${ }^{2}$ Quoted by Lane in his translation of the Arabian Nights, on Sindbad's First Voyage.

${ }^{8}$ North American Indians, 6th ed., I. 181. 
that 'the earth was a large tortoise, that it carried the dirt on its back-that a tribe of people, who are now dead, and whose faces were white, used to dig down very deep in this ground to catch badgers; and that one day they stuck a knife through the tortoise-shell, and it sank down so that the water ran over its back, and drowned all but one man.' And Callaway ${ }^{1}$ has the following Zulu story:

It happened that some boys went to play on the banks of the river Umtshezi; on their arrival they said, 'There is a beautiful rock. . . But it was a tortoise. . . . A little boy said, 'This rock has eyes.' The others said, 'No; you are telling lies.' He said, 'It has eyes.' $\mathrm{He}$ was silent; and took his stick, and thrust it into the tortoise's eye, saying, 'What is this eye? See, the eye stares.' They said, 'There is no eye, child.' The little boy came home, and said, 'There is a rock which has eyes.' His father answered, 'What kind of eyes are in the rock?' He said, 'Indeed, there are eyes.' It happened on another day the tortoise turned over with them; one little boy crossed the river at a great distance; he went crying home; they asked, 'What is the matter?' He said, 'The rock has turned over with the other boys; it went with them into the pool.' They were all lost; there escaped that one only, who went home crying.

4. The roughness and hardness of its body are sometimes mentioned. Thus in Pseudo-Eustathius of Antioch' : 'Its body resembles rough stones,' reminding us that Pacuvius ${ }^{3}$ had already characterized the tortoise as 'aspera.' In the Voyage of St. Brandan ${ }^{4}$ we are told: 'Erat autem illa insula petrosa sine herba.' In the fragment of Pseudo-Jerome (Vallarsi's ed. of Jerome, Venice, I77 r, II. 219) we have:' 'Ostendit se in ipso mari tamquam petram.' Finally, the turtle in Kempthorne's description (p. lxvii) looks like a 'black rock.'

5. The back of a whale is not well adapted for the comfortable sojourn of several people. Bullen says ${ }^{5}$ : 'By dint of hard work I pulled myself right up the sloping, slippery bank of

${ }^{1}$ Nursery Tales, Traditions, and Histories of the Zulus, pp. 341-2.

${ }^{2}$ Migne, Patr. Gr. I8. 724.

${ }^{8}$ Cicero, De Div. 2. 64. I33. Similarly Oppian, Hal. 5. 396, 404.

'Brendans Meerfahrt, ed. Wahlund, Upsala, 1900, p. 24; cf. pp. 239-243.

${ }^{5}$ Cruise of the Cachalot, chap. 15. 
blubber.' ${ }^{1}$ Nor would the Greenland whale, at least, remain passive under such a sojourn, the lighting of fires, etc. 'It is indeed an extremely timid beașt. It has been remarked that a bird alighting upon its back sometimes sets it off in great agitation and terror.'2

6. The size of the turtle at its largest affords some color of plausibility to the story. According to the ancients, their shells were used as barks by the Chelonophagi, ${ }^{3}$ or served as roofs over their heads. ${ }^{4}$ We are told of green turtles so large that they will crawl about on land with as many as fourteen men upon their back. ${ }^{5}$ In the Voyage of François Leguat ${ }^{6}$ there is a picture, reproduced from De Bry's India Orientalis, of a tortoise-shell with ten men seated upon it. From the same work of De Bry is quoted a statement concerning the tortoises of Mauritius at the end of the sixteenth century that readily carried two men. El Bekri, an Arabian geographer (A. D. I067-8), relates a story ${ }^{7}$ told him by a jurisconsult whom he names, to the effect that a company of travelers bound for Tirca, near Timbuctoo, stopped for the night at a place infested with white ants, which are very destructive. Nothing is safe from them which is not deposited on heaps of stones or on poles stuck in the ground. One of the travelers, espying what he took for a rock, deposited on it two camel-loads of luggage (perhaps 2000 or 3000 pounds; certainly

${ }^{1}$ Cf. Camb. Nat. Hist. ro. 34I. Arngrim Jonas, The True State of Iceland, 1582 (Hakluyt, Principal Navigations, Glasgow, 1904, 4. I38), thus mocks: 'O silly Mariners, that in digging cannot discern Whales flesh from lumps of earth, nor know the slippery skin of a Whale from the upper part of the ground.' Even Milton's 'scaly rind' in the well-known passage (P. L. I. 200-208) would suit the turtle rather better than the whale; the direct allusion is of course to the crocodile (Job 41. 15).

${ }^{2}$ Camb. Nat. Hist. 1o. 359.

'Diodorus Siculus 3. 20; Pliny 9. I0; Aelian, Nat. Animal. 16. I4; El Bekri, in Jour. Asiat. 5. 13. 500.

'Pliny 6. 28. 24; 9. 10; cf. Aelian 16. 17; Diodorus Siculus 3. 20; Tennant, Ceylon, 4th ed., I. 90 ; Camb. Nat. Hist. 10. 384; Bullen, Denizens of the Deep, pp. 122-3.

'Brehms, Thierleben 7. 80.

'Hakluyt Soc. 2. 375.

'Jour. Asiatique 5. 13. 517-9. 
not less than I000). In the morning the goods and the rock were missing, but he found them several miles away by following the track of the tortoise. ${ }^{1}$ Whatever we may think of this, there is no difficulty in accepting the statements of Darwin ${ }^{2}$ and Bullen ${ }^{3}$ concerning their rides on the backs of tortoises. 4 In the Fourth Voyage to Virginia, $1587,{ }^{5}$ mention is made of tortoises 'of such bignes, that sixteene of our strongest men were tired with carying one of them but from the sea side to our cabbins'; and Darwin $^{6}$ was told by the vice-governor of the Galapagos of several tortoises so large that it required six or eight men to lift them from the ground. Of existing species of (sea-) turtles, some are known that are seven feet or more in length, ${ }^{7}$ and that weigh at least $\mathrm{r} 800$ pounds. ${ }^{8}$

Of fossil or extinct species, the shell of the Colossochelys Atlas of the Siwalik Hills, in India, was estimated by Hugh Falconer, its discoverer, to have been 12 feet 3 inches long ( 15 feet 9 inches, measured along the curve of the back), 8 feet in diameter, and 6 feet high. ${ }^{9}$

${ }^{1}$ Later writers garble this story. Thus Leo Africanus, Bk. 9 (Hakluyt Soc. 3. 950), turns 'Bekri' into 'Bikri,' has the traveler go to sleep on the rock for fear of serpents and venomous beasts, and wake up three miles from the point of departure. He is followed by Konrad Gessner, Icones Animalium Quadrupedium, p. II8.

${ }^{2}$ Voyage of the Beagle, chap. 17.

${ }^{3}$ Cruise of the Cachalot, chap. Io.

${ }^{4}$ One with a shell-length of 40 inches can carry two full-grown men (Camb. Nat. Hist. Io. 377).

'Hakluyt's Voyages, Glasgow ed., 8. 387.

'Voyage of the Beagle, chap. I7.

${ }^{7}$ Cycl. of India, 3d ed., 3. 960 ; cf. ז. 672.

${ }^{8}$ Bullen, Idylls of the Sea, p. I62. Agassiz is reported to have seen some weighing over a ton (Camb. Nat. Hist. 10. 333).

- Palcontological Memoirs I. 363; cf. 1. 374. This is accepted by Bronn, Klassen und Ordnungen des Thier-Reichs $6^{3} .408$, and Brehms 7. 4I, but the Camb. Nat. Hist. (40. 372) thinks it can not have been more than 6 feet long.

The Peabody Museum of Yale University has the skeleton of the largest known marine turtle (Archelon Schyros), from South Dakota, which is 1o feet io inches long, must have measured nearly i2 feet across the front flippers, and have weighed not far from $3^{\mathrm{T} / 2}$ tons. Lieutenant Nelson, in Trans. Geol. Soc. of London, 2d Ser., 5. III, tells 
7. Pseudo-Eustathius ${ }^{1}$ speaks of the monster as sinking when it is heated by the sun. Various writers, following Agatharchides, ${ }^{2}$ refer to the pleasure of turtles in sleeping about midday in the sunshine on the surface of the Indian Ocean, with their backs entirely out of water, while at night they feed at the bottom of the sea; but Aristotle ${ }^{3}$ and Pliny ${ }^{4}$ report in addition that, under these circumstances, their shells dry up, so that they are unable to dive easily, and thus become a prey to fishermen. Thus, though the effect of the sun is described as different in the two cases, the susceptibility of the turtle to its heat is emphasized.

8. The method of catching green turtles, in the Indian Ocean and elsewhere, has some features which remind us of our tale. The pursuer approaches noiselessly from behind, jumps upon the animal's back, catches it with both hands by the shell of the neck, and attempts to turn it over, and secure it with a rope. ${ }^{5}$ In the process, ${ }^{6}$ as well as when he first catches sight of the pursuers, ${ }^{7}$ the turtle seeks to dive. The fact that they are sometimes shot by arrows ${ }^{8}$ might also suggest a relation to the insertion of anchor-flukes or stakes.

9.. The first 'nature' of the animal (see p. lxxiv) may also possibly point to the turtle. On the one hand, it is true, the manof skeletons of turtles in the Bermuda Islands measuring 9 feet by 7 . Aelian knows of Indian ocean-turtles 15 cubits long (16. 17), and of river-turtles whose shells would hold 205 gallons ( 16.14 ); but this is surpassed by Sindbad's estimate (Third Voyage) of one 20 cubits in each direction!

${ }^{1}$ As above.

${ }^{2}$ Geogr. Gr. Min., ed. Müller, I. 138-9; Diod. Sic. 3. 20; Pliny 9. 10; cf. Cycl. of India, 3d ed., 3. 960.

${ }^{3}$ Hist. An. 8. 4.

9. 10.

${ }^{3}$ Cycl. of India, 3d ed., 3. 960; Darwin, Voyage of the Beagle, chap. 20. Francis Beaumont, Karamania, 2d ed., London, 1818, pp. 299-300, relates: 'Some of the large turtles were so powerful as to escape with two heavy fellows lying on their backs, who in vain strove to turn them before they got into deep water.'

'Bullen, Idylls of the Sea, pp. 169-170.

'Darwin, chap. 20.

${ }^{8}$ Oppian, Hal. 5. 40I ; cf. Bates, The Naturalist on the River Amazon, 3d ed., pp. 292-4. 
ner in which it swallows its prey belongs to the whale rather than the turtle, though the green turtle, and perhaps some other kinds, eat fish readily. ${ }^{1}$ But when we are told that all fragrance issues from the animal's mouth, we are at a loss for an explanation. Can this imputed trait be an adaptation of that attributed to the panther? If not, there may conceivably be a reference to the 'strong, odoriferous oil' secreted, according to Agassiz, ${ }^{2}$ from glands in the lower jaw of certain species of turtle, or to the musky odor emitted by other turtles and tortoises. ${ }^{3}$

The foregoing considerations render it practically certain that, in the Physiologus-account of the second 'nature,' the author is chiefly indebted to legends which involve the turtle, and that, even in the first 'nature,' where there seems to be a clear reference to the whale, one trait may at least be derived from the chelonian race.

The confusion between the monster tortoise and the whale may have been facilitated by the exaggerated classical accounts ${ }^{4}$ of the latter's size, or by Basil's (and subsequently Ambrose's) comparison $^{5}$ of them to mountains or islands. Tychsen ${ }^{6}$ thinks that

${ }^{1}$ Brehms 7. 8I.

${ }^{2}$ Cont. to the Nat. Hist. of the U. S. I. 289-290.

${ }^{3}$ Cf. Camb. Nat. Hist. Io. 339; Bullen, Denizens of the Deep, p. 123; Brehms 7. 29.

"Pliny (9. 2) knows of whales four jugera (about $2 \frac{1}{2}$ acres) in extent, and others 100 yards long; cf. 32. 4. Io. Nearchus, followed by Strabo and Arrian, tells of whales I40 or I50 feet long. Hercules leaped into a whale, according to Homer (Il. 20. 147). The whale that swallowed Lucian (True Hist. I. 30; cf. 2. 2) was 200 miles long. The longest whale known, Sibbald's Rorqual, actually measures 85 feet, or a little more (Camb. Nat. Hist. Io. 340).

5 "They equal the greatest mountains in size. . . . They often create the impression (davrafiav, fantasy) of islands, when they rise to the surface of the water' (Hex. 7. 6: Migne, Patr. Gr. 29. I6I; cf. 7. 4: 29. 156). Ambrose says (Hex. 5. II. 32 : Patr. Lat. I4. 220-I; cf. 5. 10. 28: I4. 218) that when they float on the waves you would think them islands, or lofty mountains lifting their peaks to the sky. Both writers say they are only to be found well off shore in the Atlantic Ocean.

${ }^{-}$Phys. Syr. p. 163; cf. Pontoppidan, Nat. Hist. of Norway 2. 121 (2. 5. 8) ; Lacépède, Hist. Nat. des Cétacées, p. 65.

Pontoppidan blends the physical traits of the giant squid, or octopus, with those of our fabulous animal, and thus obtains his kraken. In 
the shellfish, etc., which collect on the back of an old whale, is responsible for the description of the sea-beast as stony.

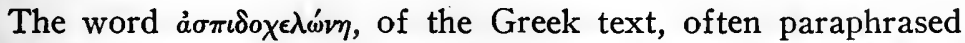
by 'whale,'1 occasions some difficulty, because of the twofold meaning of the Greek árnis-'shield' and 'asp.'

Oppian (ca. I80 A. D.) is the first datable author to conjoin the two words which may be translated 'asp' and 'turtle' ( $\mathrm{Hal}$.

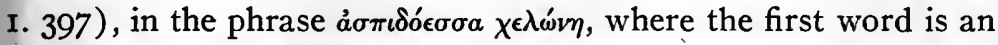
adjective. Shall we translate 'shielded turtle' ('shield-turtle') or 'aspine turtle' ('asp-turtle')? The scholiast on the passage gives us but little help: the adjective either refers to the circularity of the turtle's shell, or to the turtle's having the head (lit. face) of an asp. The sixteenth-century Latin translation has scutata testudo (similarly Salvini's Italian translation of I728). This must be wrong, if the first of the scholiast's alternatives is right, since scutata could not-refer to a circular shield, which would rather require clipeata; but then, this emendation being granted, it remains that the shell of the turtle is not circular. Ger. Schildkröte might seem to afford some ground for a compound like 'shield-turtle,' and indeed Ebert says,' 'Der rücken des tieres ragte wie ein gleich einem schild gewölbter felsblock aus dem meere hervor'; but, while it is true that Ger. Schild represents 'shield,' Kröte does not mean 'turtle,' but 'toad.' Schildkröte, 'shield-toad,' might thus signify 'turtle'; but since the Greek $\chi \in \lambda \omega \dot{\omega} \eta$ already has this meaning, no real parallel to the German compound would result from the addition of a word or element signifying 'shield.'

Lowell's allusion (Ode to France) we find ourselves on familiar ground:

$\mathrm{Ye}$ are mad, ye have taken

A slumbering kraken

For firm land of the Past.

Cf. Tennyson's early poem, The Kraken.

${ }^{1}$ Cf. p. lxxv, above. Basil (Hex. 7. 3: Patr. Gr. 29. 150) apparently regards turtles and whales as of the same general class, and, so late as the sixteenth century, Rondelet (De Piscibus Marinis, Universe Aquatilium Historia) classed turtles as medium-sized whales, while Gessner (Nomenclator Aquatilium Animalium, p. 183) would go no further than to call them cetacean.

${ }^{2}$ Anglia 6. 244; cf. Mod. Lang. Notes 9. 65. 
In favor of the rendering 'aspine,' there are these considerations:

I. The scholiast, as we have seen, admits it as a possibility.

2. In the line of Oppian cited above, the turtle is reported to couple with the eel, the two being thus treated as akin, just as both are classed among 'cruel sea-beasts' (1. 394). ${ }^{1}$ This kinship seems to be confirmed by the common belief in antiquity that the moray (murcena), a species of eel, couples with serpents. ${ }^{2}$

3. Pacuvius, as quoted by Cicero, ${ }^{3}$ attributes to the turtle a serpent's neck and a ferocious aspect (cervice anguina, aspectu truci).

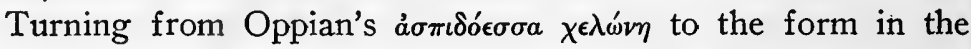

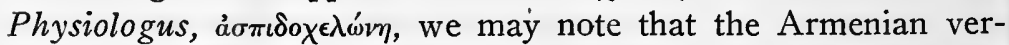
sion renders it by 'shield-turtle," ${ }^{, 4}$ though it immediately adds, 'similar to the dragon or the whale,' on which Cahier remarks: 'Cette fois, le mot aotıs aura conduit en outre à l'idée d'un serpent aquatique, ou dragon de mer.'

Against this may be set the following considerations:

I. The compound is rendered by 'asp-turtle' in Sophocles' Lexicon of Byzantine Greek.

2. Bearing in mind that Lat. aspis never means 'shield,' but always 'asp,' it is significant that the first element is left untranslated in Latin. Thus : 'Aspis Chelone belua est immanis, quæ a Latinis aspis testudo nominari potest.' Cahier's text B begins, ${ }^{\circ}$ 'De Aspedocalone,' and proceeds, 'Est belua in mari quæ dicitur

${ }^{1}$ Antiquity believed in many hybrid animals, such as the leopard (Pliny 8. I7; Rabanus Maurus 8. I), the camelopard (Horace, Ep. 2. I. 195; Diodorus Siculus 2. 5I), the progeny of the partridge and the domestic cock (Aristotle, De Gen. 2. 738 b). Add the griffin (Pausanias I. 24. 6), the chimæra (Homer, Il. 6. I8I), the Triton (Pausanias 9. 2I. I), the centaur, the harpy, the medixval basilisk, the popular notions of the mermaid (cf. Horace, Art of Poetry 4), etc.

${ }^{2}$ Oppian, Hal. I. 554 ff.; Aelian, Hist. An. I. 50; 9. 66; Athenæus, 7. 90; Pliny 9. 39; 32. 2; Nicander, Ther. 826-7; Basil, Hex. 7.5 (cf. 7. 2); Ambrose, Hex. 5. 7.

${ }^{3}$ De Div. 2. 64. 133 .

"Cahier, Nouv. Mélanges I. 129.

${ }^{5}$ Mai, Class. Auct. 7. 590.

${ }^{-}$Mélanges 3. 253. 
aspido testudo'; his text $\mathrm{C}$ begins, 'De Ceto Magno Aspidohelunes,' and proceeds, 'Est cætus in mare, aspido helune.' The first element is found in a corrupt form in a Latin manuscript at Leipzig as fastilon ${ }^{1}$ (cf. the OE. fastitocalon). In like manner the Icelandic has aspedo ${ }^{2}$; the Syrian version published by Land, ${ }^{3}$ aschelone; the Syrian version published by Tychsen, espes ${ }^{4}$; the Ethiopic version, Aspadaklôn $\hat{\imath}^{5}$.

3. In a tract entitled, On Female Companions, ${ }^{6}$ by Basil the Great ( $\dagger$ 379), there is an important occurrence of the word

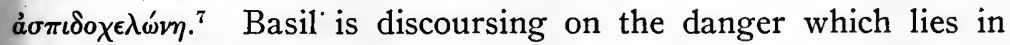
the association of unmarried religious, vowed to virginity, with unrelated women. He describes in eloquent terms the temptations incident to such association, and the blandishments to which the unfortunate monk would be exposed. While he does not quote Prov. 5. 3-5, as the Physiologus does, ${ }^{8}$ he more than once alludes to verses 3 and 4 : 'Whose words are eloquent, and her voice sweet" ; "Her sweet words shall at last be more bitter to thee than gall. ${ }^{10}$ Accordingly, we may suppose that he had the

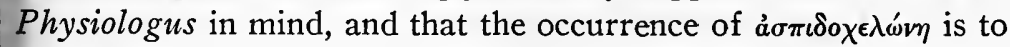
be accounted for by this fact. On that supposition, it is significant that the women in question are frequently referred to as being venomous, or resembling serpents. Thus:

All the prophets compare women to venomous beasts $\left(8 \mathrm{I}_{5} \mathrm{D}\right)$. Her mind that of dragons, and her purposes those of serpents (817 A).

If the dragon is not harmed by living with the asp, neither will you be harmed (820 C).

Tell me, $\mathrm{O}$ wily beast, who . . . dost cherish in thy bosom the mind of the asp (820 D-821 A).

${ }^{1}$ Carus, Gesch. der Zoologie, p. 127, note.

${ }^{2}$ Hommel, p. 100.

Anec. Syr. 4. 86.

'Physiologus Syrus, p. 16r.

Hommel, p. 63.

- Migne, Patr. Gr. 30. 812-828; cf. Mod. Lang. Notes 9 (1894). 67.

${ }^{7} 824 \mathrm{C}$.

See above, p. lxxiv.

'8I7 A.

${ }^{10} 824$ B. 
To whom do I speak this? To a rational being who pursues the policy of a crawling dragon (82I C).

Finally, we come to the passage particularly in question:

Her sweet words shall at last be more bitter to thee than gall; her delicate aspect shall drag thee down to the gates of hell, whereas the love of a brother would purchase for thee the kingdom of heaven. Why dost thou prefer the feigned love of this asp-turtle to the genuine love of thy brother $(824 \mathrm{~B}, \mathrm{C})$ ?

In the light of the earlier references to the serpent, and to the asp in particular, would it be natural to translate here by 'shieldturtle'?

4. In this same tract, Basil, addressing the monks, exclaims, with reference to Ps. 58. 4, 'You have shut your ears like the deaf asp.' This is developed in the Latin Physiologus published by $\mathrm{Mai}^{3}$ : 'Illæ ne audiant vocem incantantis, ponunt capita sua ad terram, et unam quidem aurem suam premunt in terram, aliam vero aurem de cauda sua obturant.'4 The French of Guillaume le Clerc is (ed. Reinsch, 11. 2555-6) :

Qui ses oreilles clot e serre

Od sa cue encontre la terre.

Now in the passage of the Voyage of Brandan which deals with our subject, Brandan explains to his followers ${ }^{5}$ : 'Insula non est ubi fuimus, sed piscis, prior omnium natantium in oceano, et querit semper ut suam caudam jungat capiti suo, et non potest

${ }^{1}$ There is an explicit reference to the Physiologus-story by Peter of Sicily (Patr. Gr. 104. I28I A, B), writing between 868 and 87I, in which our word occurs.

${ }^{2} 817$ A. The word in the Septuagint is 'asp' (AV. 'adder').

${ }^{B}$ Class. Auct. 7. 59r.

"For a sculptured representation of the adder pressing one ear against the ground, and stopping her other with her tail, see the picture of 'le beau Dieu' of Amiens Cathedral treading upon the lion and the adder (Ps. 91. I3) in Mâle, L'Art Religieux du XIII Siècle en France, p. 6I. For a miniature of the same subject, see Cahier, Mélanges 2. I47 (also Nouv. Mélanges I. I34), with accompanying Latin text (2. 149-150). For the asp as the type of the devil, see Pitra, Spicilegium Solesmense 3. 92.

${ }^{8}$ Ed. Wahlund, p. 24. 
pre longitudine.' ${ }^{1}$ It seems evident, then, that at this stage there is a relation between the sea-beast and the asp.

5. A miniature described by Strzygowski ${ }^{2}$ depicts the seamonster, not as a whale, but with a serpent's body and a fish's tail-brown, with a golden head.

6. In the Avesta ${ }^{3}$ the sea-monster is a green horny dragon, swallowing men and horses, poisonous. When Keresâspa once undertook to cook his meat at noonday in an iron cauldron on the monster's back, the latter started up, sprang away, and dashed out the boiling water, while Keresâspa fled in fear."

7. In the Ethiopic version the Aspadaklônî is the 'chief of snakes.'5

8. In Tychsen's Syriac version, the heading, translated into Latin, is, 'De Aspide s[eu] Testudine,'6 and the story goes on concerning 'illa testudo.'

From the evidence, then, there would seem to be no doubt that the monster is conceived as possessing the qualities of a serpent-which the turtle of course is-often designated as an 'asp';

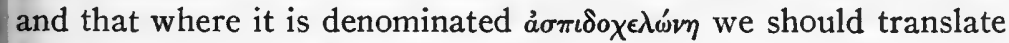
'asp-turtle,' and not 'shield-turtle.'

The Partridge

As in the case of the Panther, the Greek text of Lauchert ( $p$. 25I) may be taken as typical:

Jeremiah the prophet says [17. II]: 'The partridge gathers what she did not lay; so is a man gaining his wealth unjustly; in the midst of his days his riches shall leave him, and at his latter end he will be a fool.' The Naturalist said concerning the partridge that it broods and hatches the eggs of others. And when they are grown, each sort flies away and goes to its own, leaving the partridge alone.

${ }^{1}$ See the French text on p. 27. The Middle English thinks of him as trying to put his tail in his mouth (Percy Soc. Pub. 16. 8, 39).

${ }^{2}$ Byz. Arch. 2. 25.

- Sacred Books of the East 3I. 234.

"In op. cit. 23. 295, the snake, called Srvara, is yellow, and Keresâspa is cooking his food in a brazen vessel. At the time of noon the fiend felt the heat, and stood upon his feet-at once a snake and, we may suppose, a turtle.

${ }^{5}$ Hommel, p. 63.

${ }^{\circ} \mathrm{P} . \mathrm{I} 6 \mathrm{I}$. 
In like manner does the devil ${ }^{1}$ get possession of the foolish in heart. But when they have come to full age, they begin to recognize their heavenly parents, our Lord Jesus Christ and the Church, the apostles and the prophets, and betake themselves to them. Well, therefore, did the Naturalist speak concerning the partridge.

Thorpe was the first to recognize that there was a gap after $3^{\mathrm{a}}$. $\mathrm{He}$ said" : Here the want of connexion, both in sense and grammatical construction, clearly shows that a leaf or more is wanting; the latter part being merely the religious application of what has been related of the bird, if not the end of some other poem.' Grein $^{3}$ thought that one leaf of the manuscript was wanting. If one leaf were missing, it would follow that about 65 lines of the poetry had been lost. But it is not necessary to accept this hypothesis, for (I) there is no sign of such a missing leaf, and (2) the loss may have been in an earlier manuscript, and the pages of that manuscript may easily have been smaller. To the latter alternative Sokoll ${ }^{4}$ objects that it would be odd if the gap in another manuscript should exactly coincide with the end of a page in this one. Suppose, then, for the sake of argument, we assume the loss of one leaf of the Exeter Book, ${ }^{5}$ this would mean, supposing that both of the existing fragments belong to the Partridge, that the latter poem was about 80 lines long (Panther, 74; Whale, 89). Sokoll ${ }^{6}$ argues that the second fragment can hardly belong, then, to the Partridge, since the corresponding chapter of the Physiologus is shorter than those devoted to the Panther and the Whale; but his argument is vitiated by the fact that, according to him, these two poems occupy only about a page each in the MS., and that therefore the Partridge would be over twice as long as either, the truth being that the Panther and the Whale each occupy more than a leaf-not page. The Partridge, then, on the above supposition, would be longer than the Panther, and shorter than the Whale; but, as we have seen, the gap may

${ }^{1}$ So Rabanus Maurus (Migne, Patr. Lat. III. 249, 949), and similarly Eustathius (ibid. 53. 949) and Isidore (ibid. 82. 467).

${ }^{2}$ Codex Exoniensis, p. 365 .

B Bibliothek I. 237.

${ }^{4}$ Zum Angelsächsischen Physiologus, p. 8.

${ }^{5}$ Cf. Tupper, Jour. Eng. and Germ. Phil. rr. 9, note 39.

${ }^{\circ}$ Op. cit., p. 7. 
have been due to a defect in an earlier manuscript, and therefore not be so great as Sokoll supposes. ${ }^{1}$

Sokoll's argument from this point on is of a piece with his mistaking a leaf for a page. Since there is no sign of a missing leaf, he assumes a missing quire-eight leaves-sufficient to contain about seven versified chapters ${ }^{2}$ of the Physiologus. He next assumes that the fragmentary end of the Partridge is the close of the Charadrius. Now the Charadrius is a bird-No. 3 of the Greek Physiologus, No. 5 of Cahier's Latin MS. B. (supposed to stand nearest to the Old English)-which, brought to the bedside of a sick man, shows whether he is to recover or not. If the bird turns from him, he dies; if to him, the bird takes over his sickness. So Christ turned from the Jews, and to the Gentiles. ${ }^{3}$ To substantiate his view, Sokoll quotes Jn. I. II, to which there is no reference in the Greek Charadrius, as illustrating lines 5-I I. Then, because in certain Latin manuscripts-not, be it observed, in Cahier's B and C-the Charadrius is followed by only one chapter, the Phonix, Sokoll will have it that the author of the Old English Physiologus closed his version with the Charadrius, perhaps because he had already covered the Phœnix in our longer poem. Hence he would have dealt in succession with the partridge, weasel, ostrich, turtle-dove, hart, salamander, and ape ${ }^{4}-$ following the order of MS. B-and would have ended with the charadrius, which in MS. B stands fifth in the total Physiologus. Moreover, since the author is not likely to have been ignorant of important parts of the Physiologus, and as there is no reason why he should have suppressed them, he must, according to Sokoll, have translated all the chapters which preceded the Panther; in other words, only three chapters out of a complete Old English Physiologus have come down to us. ${ }^{5}$

All these 'men in buckram' grow out of Sokoll's assumption that the Biblical passage versified toward the end of the Partridge

${ }^{2} \mathrm{Cf}$. the gap in the Whale, lines $82^{\mathrm{b}} \mathrm{ff}$.

${ }^{2}$ Cf. Angl. 6. 247.

Lauchert, p. 7.

'Lauchert, p. 109; Peebles, Mod. Phil. 8. 577; but cf. Ebert, Angl. 6. 247.

Sokoll, pp. 6-7. 
belongs more naturally to the Charadrius. Let us see. Sokoll assumes that the passage in question is Jn. I. II : 'But as many as received him, to them gave he power to become the sons of God'-a historical statement, while the poem requires direct address. Such direct address we find in 2 Cor. 6. 17, 18: 'Come out from among them (cf. II. 5-6a), . . and touch not the unclean thing $\left(6^{b}-7^{a}\right)$; and I will receive you $\left(7^{b}-9^{a}\right)$, and will be a Father unto you, and ye shall be my sons and daughters' $\left(9^{\mathrm{b}}-\mathbf{I} \mathbf{I}\right)$. This, too, is by St. Paul, as is Panther 70-74. Christ here represents 'the Lord Almighty,' in the character of father. In the Greek (p. lxxxvi), Christ and the Church are the parents; the Ethiopic version says that they 'hear the name of their Father Christ'1 ; and the Latin B has the following important passage $^{2}$ : 'Ubi vox Christi a parvulis fuerit audita, . . . evolant et se Christo commendant; qui statim eos potissimum paterno quodam munere et amore sub umbra alarum suarum ipse suscipit, et matri dat Ecclesiæ nutriendos.' ${ }^{3}$ In the poem, it is true, the author, remembering that Christ frequently calls his disciples brethren (see note on $\mathrm{II}^{\mathrm{a}}$ ), reconciles this fact with the general tenor of the passage.

Since this quotation, then, is in perfect keeping with the 'improvement' of the Partridge, and since the poem concludes with a Uton-passage, similar to that which forms the close of the Whale, there seems no reason to doubt that the fragments we have are the beginning and end of the Partridge, immediately following the Whale. Hence it follows that the figment of a lost quire, and consequently of a series of lost chapters, is baseless.

The traits here ascribed to the partridge do not seem to have been known to Aristotle, though he calls it $^{4}$ a bird of an evil and cunning disposition. Aelian goes only so far as to say ${ }^{5}$ that they

${ }^{1}$ Cf. Tennyson's 'And so thou lean on our fair father Christ' (Guinevere).

${ }^{2}$ Cahier, Mélanges 3. 248.

'Apparently from Ambrose, Hex. 6. 3 (Patr. Lat. 14. 246-7); cf. Epist. 32 (16. 1071).

${ }^{4}$ Hist. An. 9. 8.

3. 16. 
do not lay their eggs in the place where they brood them, fearing other birds and flowers. Origen, however, cites ${ }^{\mathbf{1}}$ as an

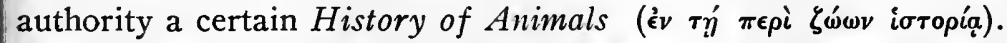
Rabanus Maurus makes this statement, ${ }^{2}$ apropos of the partridge:

Aiunt scriptores naturalis historix, tam bestiarum et volucrum quam arborum herbarumque, quorum principes sunt apud Græcos Aristoteles et Theophrastus; apud nos, Plinius Secundus: hanc perdicis esse naturam, ut ova alterius perdicis, id est, aliena, furetur, et eis incubet foveatque; cumque fetus adoleverint avolare ab eo, et alienum parentem relinquere. ${ }^{3}$

It is natural to suppose that the traits of the partridge may have been confused with those of the cuckoo, about which antiquity was tolerably well informed. ${ }^{4}$ According to a recent authority, ${ }^{5}$ the cuckoo waits till the bird she has chosen as fostermother begins sitting, and then carries one of her own eggs in her claws, and deposits it in the selected nest, pushing out for the purpose one or two of the eggs already there. The fledgling stranger, as soon as it is strong enough, ousts the other eggs or nestlings. Meanwhile, its own parents watch near by-but not to feed it - until it is ready to fly away.

${ }^{1}$ Patr. Gr. 13. 565.

${ }^{2}$ Migne, Patr. Lat. III. 948.

${ }^{8}$ For references to patristic authorities in general, see note in Patr. Gr. 13. 455. Add Ephraem Syrus, Opp. Syr. 2. I30; Bochart, Hierozoicon 2. I. I2; Horapollo, ed. Leemans, p. 380 .

"Aristotle, H. A. 6. 7; 9. 20, 29; Pliny 10. 9; Aelian 3. 30; Oppian(?), Ixeut. I. II ; etc.

${ }^{5}$ Oliver G. Pike, Farther Afield in Bird Life. 



\section{THE TEXT OF THE POEMS}

For the readings of the Elene, I have relied upon the collation of Wülker (properly Assmann), checked by the facsimiles of the Vercelli Book; for those of the Phonix, upon Gollancz, Wülker, and Schlotterose ; for the Physiologus, upon Wülker. Emendations are enclosed in square brackets, those by the present editor being. also italicized; common contractions are expanded without notice. Punctuation and the use of capitals are my own, as are the divisions of poems into sections, with their headings. The manuscript-divisions of the Elene are indicated in the variants; those of the Phonix would seem to be (I) I-84, (II) 85-18I, (III) I82-264, (IV) 265-349, (V) 350-423, (VI) 424-5I7, (VII) 5I8-588, (VIII) 589-677; and so Gollancz divides. The text of Lactantius is from Brandt (Corpus Script. Eccl. Lat., Vol. 27), with consonantal $i$ and $u$ printed as $j$ and $v$ respectively.

The authors quoted in the variants are as follows (see the Bibliography):

Barn. = Barnouw.

$\mathrm{BB} .=$ Bonner Beiträge.

B1. = Blackburn.

$\mathrm{Br} .=$ Bright.

Con. = agreement of two following.

Con. ${ }^{1}=$ Conybeare, 1814.

Con. $^{2}=$ Conybeare, 1826.

Cos. $^{1}=$ Cosijn, $\mathbf{1} 896$.

Cos. $^{2}=$ Cosijn, 1898 .

Ett. = Ettmüller.

Först. $=$ Förster.

$\mathrm{Gm} .=\mathrm{Grimm}$.

Go. = Gollancz.

$\mathrm{Gr}^{1}=$ Grein, $1857-8$.

$\mathrm{Gr}^{2}=$ Grein, 1865 .

Grdt. = Grundtvig.

Hart $=$ Hart.

$\mathrm{H}^{1}{ }^{1}=$ Holthausen, $\mathbf{1 9 0 5}$.

$\mathrm{H}^{2}{ }^{2}=$ Holthausen, 1910 .

Holt. $^{1}=$ Holthausen, 1899.

Holt. $^{2}=$ Holthausen, I904.

$\mathrm{K} .=$ Kemble.

Kal. = Kaluza. 
Klaeb. ${ }^{1}=$ Klaeber, 1904 (Archiv).

Klaeb. ${ }^{2}=$ Klaeber, 1906.

Klip. = Klipstein.

Kö. = Körner.

$\mathrm{PBB} .=$ Paul and Braune's Beiträge.

Schl. = Schlotterose.

Siev. $=$ Sievers.

Sw. $=$ Sweet.

Th. $=$ Thorpe.

$\operatorname{Tr}^{1}=$ Trautmann, 1898 .

$\mathrm{Tr}^{2}{ }^{2}=$ Trautmann in Schlotterose's ed., 1908.

$\mathrm{Tr}^{3}{ }^{3}=$ Trautmann, 1907.

Wa. $=$ Warth.

Wan. $=$ Wanley.

Wü. $=$ Wülker.

$Z^{1}{ }^{1}=$ Zupitza, 1877 .

$\mathrm{Z}^{2}=$ Zupitza, 1899 . 


\section{ELENE}

I. CONSTANTINE AND HIS FOE PREPARE FOR WAR

Pā wæs āgangen gēara hwyrftum tū hund ond prēo geteled rīmes, swylce oritig èac, pinggemearces, wintra for worulde, pæs be Wealdend God

5 ācenned wearơ, cyninga Wuldor, in middangeard purh mennisc hēo, sōofæstra Lēoht; pā wæs syxte gēar Constantīnes cāserdōmes, pæt hē Rōmwara in rīce wearð .

Io āhæfen, hildfruma, tō heretēman.

Wæs se 1 [of]hwata 1 [ēo] dgeb[y]rga eorlum ārfæst; æðel[i] nges wēox rice under roderum; hē wæs riht cyning, gūơwear [d] gumena. Hine God trymede

I5 mǣrðum ond mihtum, pæt hē manegum wearð geond middangeard mannum tō hrōðer, werpēodum tō wræce, syððan wǣpen āhōf wi⿱ het $[t]$ endum.

Him wæs hild boden, wiges wōma. Werod samnodan

20 Hūna lēode ond Hrēðgotan; fōron fyrdhwate Francan ond $\mathrm{H} \bar{u}[\mathrm{~g}] \mathrm{as}$. Wæron hwate weras,

3 MS. $\mathrm{xxx}$; Gm. prittig.- $\mathrm{II}^{\mathrm{a}} M S$. leod-; $G r^{2}$ lind-; $H_{.}^{2}$ lof-.- $\mathrm{II}^{\mathrm{b}}$ $M S$. lind-; $G r_{.}^{2}$ leod-; $M S$. -geborga; $Z .^{2}$-gebyrga. - I2 $M S$. æठеlnges; em. Th. - I4 MS. -wearð; em. Th. - I6 MS. -g ; em. Th.; Gm. hroðre. - I8 MS. hetendum; em. Rieger (Zeitschrift f. D. Phil. 7. 52).-2I MS. Hunas; em. $Z .^{1}-22$ No break in MS., but one assumed by Th., Gm., $K ., Z .^{1}-22^{\mathrm{a}} M S$. hwate; $H_{.^{2}}$ hearde; $W a$. hwate weras wæron; $T r .^{3}$ wæron hwate hæleðas; Klaeb. (Angl. 29. 27I) swylce Hetware(-an).$22^{\mathrm{b}}$ Ett. hildemecgas; Gr. ${ }^{1}$ on herebyrnan; Kö. herebreatas; Siev. (Gött. Gel. Anz. I882, p. 997) hilde gefysde; $T r^{3}$ heaठurofe weras; Klaeb. wæron hwate weras; $H^{2}$ hearde for hwate. 
gearwe tō gūoxe. Gāras lixtan, wriðene wælhlencan; wordum ond bordum

25 hōfon he $[0] \mathrm{r}[u] \mathrm{c}[\mathrm{u}] \mathrm{mbol}$. Đā wæ̈ron heardingas sweotole gesamnod ond eal [syb] geador; fōr folca gedryht. Fyrdlēơ āgōl wulf on wealde, wælrūne ne māor; ūrigfeðera earn sang āhöf

30 lāoum on lāste. Lungre scynde ofer burg[locan] beaduprēata mǣst hergum tō hilde, swylce Hūna cyning ymbsittendra āwer meahte ābannan tō beadwe $\mathrm{b}$ [yrn] wigendra.

35 För fyrda mǣst - fēðan trymedon ēoredcestum - pæt on ælfylce deareðlācende • on Dānūbie stærcedfyrhðe stæðe wīcedon ymb pæs wæteres wylm, werodes breahtme;

40 woldon Rōmwara rīce gepringan, hergum āhȳðan.

¡ǣr wearð Hūna cyme cūo ceasterwarum. $\quad \mathrm{P} \vec{a}$ se cāsere heht ongēan gramum gūogelǣcan under earhfære ofstum myclum

45 bannan tō beadwe, beran $\bar{u} t$ præce rincas under roderum. Wǣron Rōmware, secgas sigerōfe, sōna gegearwod wǣpnum tō wīgge, pēah hīe werod lǣsse hæfdon tō hilde pon [n]e Hūna cining 50 ridon ymb rōfne. Ponne rand dynede, campwudu clynede; cyning prēate fōr, herge, tō hilde. Hrefen úppe gōl, wan ond wælfel. Werod wæs on tyhte; hlēopon hornboran, hrēopan friccan;

25 MS. herecombol; $Z .^{2}$-cumbol; $H_{0^{2}}$-woman. - $26 \mathrm{Gm}$. eal sweot geador; Gr. ${ }^{2}$ eal siömægen geador; Siev. (Gött. Gel. Anz.) eal sib geador; $K \ddot{o}$. siðwerod eal geador. - 3I MS. -enta; $H_{.}{ }^{1}$-locan. - $34 M S$. burg-; $G r{ }^{2}$ byrn-?; $H$. byrn-. - $35 M S$. for ::::: fyrda. - $49 M S$. bone; em. Th. $-54^{\mathrm{a}}$ Th. hleowon; Ett. bleowon, $-54^{\mathrm{b}} \mathrm{Th}$. hreowan. 
55 mearh moldan træd. Mægen samnode, cāfe, tō cēase.

Cyning wæs āfyrhted, egsan geāclad, siððan elpēodige, Hūna ond Hrēđa here, scēawed[e], ðæt hē on Rōmwara rices ende

60 ymb pæs wæteres stæð werod samnode, mægen unrīme. Mōdsorge wæg Rōmwara cyning; rīces ne wënde for werodlēste: hæfde wigena tō lȳt, eaxlgestealna, wio of ermægene

65 hrōr[r]a tō hilde.

\section{THE VISION OF THE CROSS}

Here wicode, eorlas ymb̄ æð̌eling ēgstrēame nēah on nēaweste nihtlangne fyrst, pæs pe $h[\bar{i}]$ e fëonda gefær fyrmest gesǣgon.

Pā wearð on sl̄̄pe syl̨fum ætȳwed

70 pām cāsere, pǣr hē on corơre swæf, sigerōfum gesegen swefnes wōma. Pühte him wlitescȳne on weres hāde hwìt ond hïwbeorht hæleða nāthwylc geȳwed, ǣnlicra ponne hē ǣr oððe sìð

75 gesēge under swegle. Hê of slǣpe onbrægd, eofurcumble bepeaht. Him se ār hraðe, wlitig wuldres boda, wið pingode, ond be naman nemde - nihthelm tōglād - : 'Constantīnus, heht pē Cyning engla,

80 wyrda Wealdend, wäre bēodan, dugư⿱ Dryhten. Ne ondrǣ pū $\gamma \bar{e}$, rēah pē elpēodige egesan hwōpan, heardre hilde. $\quad \overline{\mathbf{p}} \overline{\mathbf{u}}$ tō heofenum beseoh on wuldres Weard; $\bar{p} \bar{x} r \bar{\gamma} \bar{u}$ wrað̌e findest,

58 MS. sceawedon; em. Ten Brink (Zs. f. D. Alt., Anz. 5. 58).- 59 MS. he; Gr. be; Ten Brink hie.-6o Ett. samnodon?; Ten Brink samnodon. - 65 MS. hrora; Gr. hrorra?; em. $Z{ }^{1}{ }^{1}-68 M S$. he; em. Th. 
85 sigores tācen.'

\section{Hē wæs sōna gearu}

purh pæs hālgan hǣs, hreðerlocan onspēon, ūp lōcade, swā him se ār ābēad, fäle friðowebba. Geseah hē frætwum beorht wliti $[g]$ wuldres trēo ofer wolcna hrōf

90 golde ge $[g]$ lenged; gimmas lixtan.

Wæs se blāca bēam bōcstafum āwriten beorhte ond lēohte: 'Mid bȳs bēacne $\delta \bar{u}$ on pām frēcnan fære fēond oferswīðesð, geletest lāor werod.'

Pā pæt lēoht gewāt,

95 ūp sīrode, ond se ār somed,

on clǣnra gemang. Cyning wæs pȳ blïðra ond pē sorglēasra, secga aldor, on fyrhð̌sefan purh pā fǣgeran gesyhð.

\section{THE HOLY STANDARD IS VICTORIOUS}

Heht pā onlīce æð̌elinga hlēo,

IoO beorna bēanggifa, swā hē pæt bēacen geseah, heria hildfruma, pæt him on heofonum $\bar{æ}$ geiewed wearð, ofstum myclum, Constantīnus, Crīstes rōde, tỉrēadig cyning, tācen gewyrcan.

I05 Heht pã on ūhtan mid ǣrdæge wigend wreccan ond [tō] wēpenpræce hebban heorucumbul, ond pæt hālige trēo him beforan ferian, on fēonda gemang, beran bēacen Godes. Bȳman sungon

IIO hlüde for hergum. Hrefn weorces gefeah; ūrigferra earn sīo behēold, wælhrēowra wìg; wulf sang āhōf, holtes gehlēða. Hildegesa stōd.

†ǣr wæs borda gebrec ond beorna geprec,

II 5 heard handgeswing ond herga [c] ring,

$89 M S$. wliti ; em. Gm. $-90 M S$. gelenged; em. Th. -99 Before this line MS. has II. - $106 M S$. ond ; Wa. ond to? - I07 Th. om. hebban. - II5 $M S$. gring; em. Ett. 
syððan hēo earhfære ǣrest mētton.

On pæt fæ̈ge folc flāna scūras, gāras ofer geolorand on gramra gemang, het $[\mathrm{t}]$ end heor $[\mathrm{u}]$ grimme, hildenǣdran,

I20 purh fingra geweald for onsendan. Stōpon stiðhīdige, stundum wrǣcon, brǣcon bordhrē[o]ðan, bil in dufan, prungon præchearde. $\mathbf{p} \bar{a}$ wæs pūf hafen, segn for swēot $[u] m$, sigelēoð galen.

I25 Gylden grīma, gāras lixxtan on her[e]felda. Hæððene [c]rungon, fēollon friðelēase. Flugon instæes Hūna lēode, swā pæt hālige trēo āräran heht Rōmwara cyning

I30 heaðofremmende. Wurdon heardingas wide tōwrecene. Sume wig fornam; sume unsōfte aldor generedon on pām heresīoe; sume healfcwice flugon on fæsten ond feore burgon

I35 æfter stānclifum, stede weardedon ymb Dānūbie; sume drenc fornam on lagostrēame lifes æt ende. Đā wæs mōdigra mægen on luste, ëhton elpēoda oð pæt ǣfen forð

I 40 fram dæges orde; daroð[as] flugon, hildenæ̈dran. Hēap wæs gescyrded, lāorra lindwered; lȳthwōn becwōm Hūna herges hām eft panon. Đā wæs gesȳne pæt sige forgeaf

I45 Constantino Cyning ælmihtig æt pām dægweorce, dōmweorðunga, rīce under roderum, purh his rōde trēo.

II9 MS. hetend; em. Kluge (Litbltt. I884, p. I39); MS. heora-; Th. heoru-?; em. Gr. - I22 MS. -hreðan; em. Gm. - I24 MS. sweotolum; em. Th. - I26 MS. herafelda; em. Gm.; MS. grungon; em. Ett. - I40 $M S$. daroð æsc; em. $Z .^{1}-\mathbf{I} 4 \mathrm{r} M S$. gescyrded; Gm. gescyrted; $Z$. gescynded. 
4. THE MIRACLE BEING EXPLAINED, CONSTANTINE IS CONVERTED

Gewāt pā heriga helm hām eft panon hūðe hrēmig — hild wæs gescēaden -

I 50 wīgge geweorðod. Cōm pā wigena hlēo pegna prēate prȳobo[1]d sē[c]an, beadurōf cyning burga nēosan.

Heht pā wigena weard pā wīsestan snūde tō sionoðe, pā pe snyttro cræft

I 55 purh fyrngewrito gefrigen hæfdon; hēoldon higepancum hæleða rǣdas. Đā pæs fricggan ongan folces aldor, sigerōf cyning, ofer sīd weorod, wæ̈re pǣr ǣnig yldra oððe gingra I6o pe him tō sōðe secggan meahte, galdrum cȳðan, hwæt se God wǣre, $\mathrm{b}[1 \overline{\mathrm{C}}] \mathrm{des}$ Brytta, 'pe pis his bēacen wæs pe mē swā lēoht ơȳwde, ond mine lēode generede, tācna torhtost, ond mē tīr forgeaf,

I65 wīgspēd wið wräðum, purh pæt wlitige trēo.' Hio him andsware ǣnige ne meahton āgifan tōgēnes, nē ful geare cūðon sweotole gesecggan be pām sigebēacne.

pā pā wīsestan wordum cwǣon

I70 for pām heremægene pæt hit Heofoncyninges tācen wǣre, ond pæs twēo nǣre.

Pā pæt gefrugnon pā purh fulwihte 1ærde wæ̈ron, him wæs leoht sefa, ferhð gefēonde - pēah hira fēa wǣron -

I75 đæxt hịe for pām cāsere cȳðan mōston godspelles gife, hū se gāsta Helm in prȳnesse prymme geweorðad ācenned wearo, cyninga Wuldor;

I5I MS. -bord; em. Sarrazin (Zs. f. D. Phil. 32. 548); MS. stenan; $\mathrm{Gm}$. scenan; $K \ddot{o}$. stun(i)an? stendan?; Sarrazin secan. - $156 \mathrm{Gm}$. hæleðas. - I59 MS. oðరе; $T r$. (Kynezulf, p. 24) ठe? - I62 MS. boldes; $K \ddot{o}$. goldes; $Z{ }^{1}$ blædes; $H .{ }^{2}$ bledes. 
ond hū on galgan wear $\gamma$ Godes āgen Bearn

I80 āhangen for hergum heardum witum, àlȳsde lēoda bearn of locan dēofla, gēomre gãstas, ond him gife sealde purh pā ilcan gesceaft pe him geȳwed wearo sylfum on gesyhðe, sigores [tō] tācne

I85 wið pēoda præce; ond hū $\gamma \bar{y}$ priddan dæge of byrgenne beorna Wuldor, of dēaðe, ārās, Dryhten ealra hæleða cynnes, ond tō heofonum āstāh. Đus glēawlīce gāstgerȳnum

I90 sægdon sigerōfum swā fram Silvestre lǣrde wǣron. Ėt pām se lēodfruma fulwihte onfēng, ond pæt forð gehēold on his dagana tīd, Dryhtne tō willan.

Đā wæs on sǣlum sinces brytta,

I95 nïðheard cyning: wæs him nīwe gefēa befolen in fyrhðe; wæs him frōfra mǣst ond hyht[a] [h]ïhst heofonrīces Weard. Ongan pä Dryhtnes $\bar{æ}$ dæges ond nihtes purh Gāstes gife georne cȳoran, 200 ond hine, sōxlīce, sylfne getengde goldwine gumena in Godes pēowdōm, æscrōf, unslāw. .

5. CONSTANTINE ORDERS THE SEARCH FOR THE ROOD

Pā se æð̌eling fand, lēodgebyrga, purh lārsmið̌as, gūoheard, gārprīst, on Godes bōcum

205 hwǣ āhangen wæs heriges beorhtme on rōde trēo rodora Waldend æfstum purh inwit, swā [hīe] se ealda fēond forlæ̈rde ligesearwum, lēode fortyhte, Iūdēa cyn, pæt hīe God sylfne

$184 M S$. tacne; $Z .^{1}$ tacen; $T r .^{3}$ to tacne. - I94 Before this line MS. has III. - I97 MS. hyht nihst; $Z .^{1}$ hyhta hihst; $K \ddot{o}$. hyhta nihst; Wii. hyhta nihst. - $207 M S$. swa; Siev. (Angl. I. 579) swa hie. 
2ro āhēngon, herga Fruman;- pæs hie in hȳnðum sculon

tō wīdan feore wergðu drēogan.

Pā wæs Crīstes lof pām cāsere

on firhðsefan; [he wæs] for gemyndig

ymb pat mære trēo; ond pā his mōdor hēt

215 fēran $\mathrm{f}[$ lō]dwege folca prēate

tō Iūdēum, georne sēcan

wigena prēate hwǣr se wuldres bēam

hālig under hrūsan hȳded wāre,

Eðxelcyninges röd.

\section{THE VOYAGE AND THE LANDING}

\section{Elene ne wolde}

220 pæs sīðfates sǣne weorðan, nē ðæs wilgifan word gehyrwan, hiere sylfre suna, ac wæs sōna gearu wîf on willsī̄, swā hire weoruda helm, byrnwiggendra, beboden hæfde.

225 Ongan pā ofstlīce eorla mengu tō flote fȳsan. Fearơhengestas ymb geofenes stæð gearwe stōdon, sǣlde sǣmearas, sunde getenge. Đā wæs orcnǣwe idese sīofæt,

230 siððan wǣges [w] elm werode gesōhte.

Pǣr wlanc manig æet Wendelsǣ on stæðe stōdon. Stundum wrǣcon ofer mearcpaðu, mægen æfter ōorum; ond pā gehlōdon hildesercum,

235 bordum ond ordum, byrnwigendum, werum ond wifum wǣghengestas.

Lēton pā ofer fīfelwǣg fāmige scrīðan

213 Before for $Z^{2} .^{2}$ assumes the loss of two hemistichs, such as fæste bewunden, folces aldor (hyrde, ræswa, etc., but not fruma); Pogatscher (Angl. 23. 289) he wæs fort. - 215 MS. fold-; em. Gr. ${ }^{2}-217 M S$. preate; Ten Brink werode?-229 Th. on cnawen; Gm. ( $p$. II5) oncnawe?; $K$. oncnæwe. $-230 M S$. helm; $G m$. holm; $Z .^{1}$ welm. -233 $M S$. -paðu; Th. -waðu. $-237 M S$. fifel-; $H^{2}$ fifl-. 
bronte brimpis[s]an; bord oft onfēng ofer earhgeblond $\bar{y}$ ða swengas;

240 s̄̄ swinsade. Ne hȳrde ic sīo nē ǣr on ègstrēame idese lǣdan, on merestrǣte, mægen fāg[e]rre. P̄̄r [gesīon meahte], se ðone sīð behēold, brecan ofer bæðweg brimwudu snyrgan

245 under $\mathrm{s}[\mathrm{w}]$ ellingum, sǣmearh plegean, wadan wǣgflotan. Wigan wǣron blīðe, collenferhð̌; cwēn sīðes gefeah.

Syppan tō hȳore hringedstefnan ofer lagofæsten geliden hæfdon

250 on Crēca land, cēolas lēton æt $s \bar{x}[w]$ aroðe $s[u]$ nde bewrecene, ald $\bar{y} \gamma[\mathrm{h}]$ ofu, oncrum fæste on brime bidan beorna gepinges, hwon[n]e hēo sīo gūơcwēn gumena prēate

255 ofer èastwegas eft gesōhte.

Đǣr wæs on eorle ēðgesȳne brogden byrne ond bill gecost, geatolīc gūðscrūd, grīmhelm manig, ǣnlī eoforcumbul. Wǣron æscwigan,

260 secggas ymb sigecwēn, sīðes gefȳsde:

fyrdrincas frome föron on luste on Crēca land, cāseres bodan, hilderincas hyrstum gewerede; pār wæs gesȳne sincgim locen 265 on pām hereprēate, hlāfordes gifu.

Wæs sēo ēadhrēðige Elene gemyndig, priste on gepance, pēodnes willan, georn on mōde pæet hio Iūdē [a] ofer herefeldas heape gecoste

270 lindwigendra land gesōhte,

$238 M S$. -pisan; em. $Z{ }^{2}-242 M S$. fægrre; em. Th. - $243 M S$. meahte jesion; em. Wa.-245 MS. spell-; em. Th.-25I MS. fearoðe; Krapp (Mod. Phil. 2. 407) -wearoðe; MS. sande; Gr. ${ }^{1}$ sunde?; $Z .^{1}$ sunde. $252 \mathrm{MS}$. -liofu; em. Th. $-254 \mathrm{MS}$. hwone; em. Gr. ${ }^{1}-268 \mathrm{MS}$. Iudeas; 2.. Iudea?; $Z .^{2}$ Iudea. 
secga prēate; swā hit siððan gelamp

ymb lȳtel fæc pæt ðæt lēodmægen,

gūðrōfe hælep, tō Hierusālem

cwōmon in pā ceastre corơra mǣste,

275 eorlas æscrōfe, mid pā æð̌lan cwēn.

\section{HELENA'S FIRST EXHORTATION}

Heht $\gamma \bar{a}$ gebēodan burgsittendum

pām snoterestum sīde ond wìde

geond Iūdēas, gumena gehwylcum, meðelh [e]gende, on gemōt cuman,

280 pā бe dēoplīcost Dryhtnes gerȳno

purh rihte $\bar{æ}$ reccan cūoon.

Đā wæs gesamnod of sīdwegum

mægen unlȳtel pā ô Moyses $\bar{x}$

reccan cūðon; pǣr on rīme wæs

285 prēo [pūsendu] pǣra lēoda

ālesen tō lāre.

Ongan pā lēoflic wĩf

weras Ebrēa wordum nēgan:

'Ic pæt gearolice ongiten hæbbe,

purg witgena wordgerȳno

290 on Godes bōcum, pæt gē gēardagum

wyrðe wǣron Wuldorcyninge,

Dryhtne dȳre ond dǣdhwæete.

Hwæt, gē [ealle] snyttro unwīslīce,

wrāðe, wiðw $[u]$ rpon, pā gē wergdon pane

295 pe ēow of wergðe purh his wuldre[s] miht, fram ligcwale, lȳsan pöhte,

of hæftnēde. Gē mid horu spēowdon

276 Before this line MS. has IIII. - 279 MS. -hengende; Gm. -hegende -285 MS. $\overline{\mathrm{m}}$;. Gm. pusend; Siev. (PBB. Io. $5^{I 8}$ ) pusendu. $-293^{\mathrm{a}} M S$ snyttro; $K$. swicon snyttro; Ten Brink (Zs. f. D. Alt., Anz. 5. 59) ealr snyttro; $H_{.}^{2}$ ealle. $-293^{\mathrm{b}} M S$. unwislice; $G m$. unwislice swicon?; $G r$. soð unwislice; Gr. ${ }^{2}$ swiðe unwislice; Siev. (Angl. I. 579) swicol unwislice?; Cos. (Tijdschrift I. I44) samwislice; $Z^{2}{ }^{2}$. . . unwislice.$294^{\mathrm{a}} M S$. -weorpon; Gm. -wurpon?; . $^{1}$-wurpon. - $295 M S$. wuldre em. Th. 
on pæs andwlitan pe ēow èagena lēoht, fram blindnesse bōte, gefremede

300 edniowunga purh pæt æðele spāld, ond fram unclænum oft generede dēofla gāstum. Gē [tō] dēape pone dēman ongunnon se $\gamma e$ of dēaðe sylf wor [n] āwehte on wera corpre

305 in pæe ǣrre lif ēowres cynnes. Swā gē mōdblinde mengan ongunnon lige wið sōðe, lēoht wið pȳstrum, æfst wið āre, inwitpancum wrōht webbedan. Ēow sēo wergðu forðan

310 sceðpeð scyldfullum; gē pā scīran miht dēman ongunnon, [in] gedw[o]lan lifdon, pēostrum gepancum, ơ pysne dæg. Gangap nū snūde, snyttro gepencap weras wisfæste, wordes [glēawe],

3I5 pā ðe ēowre $\bar{x}$, æðelum cræftige, on ferhðsefan fyrmest hæbben, pā mē sōolice secgan cunnon, andsware cȳðan for ēow[ic] forð tācna gehwylces pe ic him tō sēce.'

\section{HELENA'S SECOND EXHORTATION}

320 Ēodan pā on gerūm[an] rēonigmōde eorlas $\bar{x}[g] l e ̄ a w e, \quad$ egesan geprēade, gehðum gēomre; [g]eorne sōhton

$302 M S$. deape; $Z .^{1}$ to deape. - $304 M S$. woruld; $Z .^{1}$ worn. - 3 II $M S$. ond gedweolan; Gm. ond gedwolan; Siev. (Angl. 1 . 579) in gedwolan; Klaeb. (Angl. 29. 27I) opposes Siev., citing Jul. 410; Beow. 99, 2144; Jen. 73. - 313 $M S$. gangab; $H^{2}{ }^{2}$ secab?; $M S$. -pencab; Wa. -secab. After this line $H^{1}$ inserts ond findap gen ferhðgleawe men; cf. Jud. $4 I ; E l$. 327, 373. - 314 ${ }^{\mathrm{b}} M S$., Edd. cræftige. - 315 MS. cræftige; $Z .^{1}$. . . cræftige; Z.' gode?; H.1 gode; for the inst. with cræftig, see Crafts 98.-318 MS. sow; em. Siev. (PBB. I0. 5I8).-320 MS. gerū; Gr. gerun; other early Edd. gerum; Frucht (Metrisches, etc., p. 74) geruman; Schwarz (Cyneverlfs Anteil am Christ, p. 67) geryne, gerune; H. (Anglia Beibl. I7. I77, but not $\left.H .{ }^{1}, H_{.}{ }^{2}\right), W a$. ba on gerum eodan. - 32I MS. -cleawe; em. Th. $322 \mathrm{MS}$. eorne; em. Th. 


\section{pā wīsestan wordgerȳno}

pæt hio pǣre cwēne oncweðan meahton,

325 swā tiles, swā trāges, swā hīo him tō sōhte.

Hīo pā on prēate [pūsend] manna

fundon ferhðglēawra, pā pe fyrngemynd

mid Iüdēum gearwast cūơn.

Prungon pā on prēate pǣr on prymme bād

330 in cynestōle cāseres mǣg,

geatolīc gūorcwēn golde gehyrsted. .

Elene mapelode, ond for eorlum spræc:

'Gehȳrað, higeglēawe, hālige rūne, word ond wisdōm. Hwæt, gē wìtgena

335 lāre onfēngon, hū se Liffruma in cildes hād cenned wurde, mihta Wealdend. Be pām Moyses sang, ond pæt [word] gecwæX, weard Israhela: "Ēow ācenned bið Cniht on dēgle,

340 mihtum mǣre, swä pæs mōdor ne bið wæstmum geëacnod purh weres frige." Be ðām Dāvid cyning dryhtlēơ āgōl, frōd fyrnweota, fæder Salomōnes, ond pæt word gecwæp, wigona baldor:

345 "Ic fr[y]mpa God forescēawode, sigora Dryhten; hē on gesyhðe wæs, mægena Wealdend, mīn on pā swīoran, prymmes Hyrde. Panon ic ne wen[de] æfre tō aldre onsion mine."

$35^{\circ}$ Swā hit eft be ēow Essāias, witga for weorodum, wordum mǣlde, dēophycggende purh Dryhtnes Gāst: "Ic ūp āhōf eaforan ging[e], ond bearn cende, pām ic blǣd forgeaf, 355 hālige higefrōfre; ac hīe hyrwdon $[\mathrm{m}] \overline{\mathrm{e}}$,

323 MS. -geryno; $H_{0}^{2}$-geryna.-326 MS. $\overline{\mathrm{m}} ; \mathrm{Gm}$. pusenda; Gr pusend. $-338 M S$. pæt; $G r .{ }^{1}$ bæt word. - $345 M S$. frumpa ; $G r^{1}{ }^{\text {frymठta? }}$ $Z .{ }^{1}$ frymøa. $-348 M S$. weno; $T h$. wende?; $G m$. wende. $-353 M s$ gingne; em. $Z .^{1}-355 M S$. pe; em. $Z{ }^{1}$ 
fēodon purh fēondscipe, nāhton forepanc[a]s, wīsdōmes gewitt; ond pā wēregan nēat, pe man daga gehwām drifer ond pirsceð, ongitap hira gōddēnd, nales gnyrnwrǣecum

360 fēoga $\gamma$ frȳnd hiera pe him födder gif[a] $\gamma$; ond mē Israhela ǣfre ne woldon folc oncnāwan, pēah ic feala for him æfter woruldstundum wundra gefremede."

Hwæt, wē pæt gehȳrdon purh hālige bēc 365 pæt ēow Dryhten geaf dōm unscyndne, Meotod, mihta spēd, Moyse sægde hū gē Heofoncyninge hȳran sceoldon, lāre lǣstan. E E ond gē pām ryhte wiðroten hæfdon,

370 onscunedon pone sciran Scippend eallra, [dryhtna] Dryhten, ond gedwolan fylgdon ofer riht Godes. Nī gē rape gangap, ond findap gēn pā pe fyrngewritu purh snyttro cræft sēlest cunnen, 375 ǣriht ēower, pæt mē andsware purh sidne sefan secgan cunnen.'

\section{HELENA'S THIRD EXHORTATION}

Eodan đā mid mengo mōd[e] cwānige, collenferhðe, swā him sĩo cwēn [be]bèad; fund [o]n pā [fïf hund] forpsnotter [r]a

380 ālesen [ra] lēodmǣga, pā ðe leornungcræft purh mōdgemynd mǣste hæfdon, on sefan snyttro. Hēo tō salore eft

356 MS. -pances; Siev. (Angl. I. 580) -bancas?; $Z .^{2}$-pancas. - 360 IS. gifeð; em. Z. ${ }^{1}-364$ Before this line MS. has V. - $369 M S$. ryhte riorroten; $H_{.}{ }^{1}$ soðe ond ryhte wiðsecen; $H^{2}$ soðe wiðsecen? - 370 Edd. efore Gr. end line with scippend; $M S$. eallra ; $Z .^{1}$ (but not $Z .^{2}$ ) eowerne,\| alra dryhten. - 37 I MS. dryhten; Gr. ${ }^{1}$ dryhtna dryhten. - $377 M S$. rodcwanige; Tr. (Kynewulf, p. 82) mode(s) cwange; H. (Angl. 3. 516) modcwange guman. $-378 \mathrm{MS}$. bead; em. Siev. (PBB. 10. 5I8). - 379 MS. funden; em. Gm.; MS.d; Th. fifhund; MS.-snottera; em. Gm. - 380 MS., Edd. alesen; for the metrical type (D) see Chr. 978, tobrocene urgweallas, and Frucht, p. 63 . 
ymb lȳtel fæc laðode wǣron, ceastre weardas.

Hīo sīo cwēn ongan

$3^{85}$ wordum genēgan — wlāt ofer ealle - :

'Oft gē dyslīce dǣed gefremedon, wērge wræcmæcggas, ond gewritu herwdon, fædera lāre; nǣefre furður ponne nū ðā gē blindnesse bōte forsēgon,

390 ond gē wiðsōcon sōðe ond rihte pæt in Bethleme Bearn Wealdendes, Cyning ānboren, cenned wǣre, æXelinga Ord. Sēah gē pā æ cūðon, wìtgena word, gē ne woldon pā, 395 synwyrcende, sōð oncnāwan.'

Hìe pā ānmōde andswer[edon] : 'Hwæt, wē Ebreisce $\bar{x}$ leornedon, pā on fyrndagum fæderas cūðon æt Godes earce, nē wē [g] eare cunnon 400 purh hwæt $\delta \bar{u}$ ous hearde, hlǣfdige, ùs eorre wurde. Wē ðæt ǣbylgð nyton pe wē gefremedon on pysse folcscere, pēodenbealwa [sum] wið pec ǣfre.'

Elene maðelade, ond for eorlum spræc 405 undearninga; ides reordode hlūde for herigum: 'Gē nū hraðe gangað, sundor àsēcap pā ðe snyttro mid ēow, mægn ond mōdcræft, mǣste hæbben, pæt mē pinga gehwylc prīste gecȳðan 4ro untrāglìce, pe ic him tō sēce.'

ro. THE DISCLOSURE OF JUDAS

Ẽodon pā fram rūne, swā him sīo rīce cwēn bald in burgum beboden hæfde; gēomormōde georne smēadon,

392 MS. wære wære. - 396 MS. -swēr; em. Th. - 399 MS. eare; em Th. - $403 M S$. peodenbealwa; $H .{ }^{1}$ beodbealwa ænig; $W a$. beodenbealwi sum (or an); $H_{.}^{2}$ beodenbealwa sum. 
sōhton searopancum, hwæt sīo syn wǣe

4I5 pe hie on pām folce gefremed hæfdon wið pām cāsere, pe him sīo cwēn wite.

$\mathrm{Pā} p \bar{x} r$ for eorlum ān reordode gidda gearosnot $[t]$ or — Øām wæs Iūdas nama wordes cræftig: 'Ic wāt geare

420 pæet hīo wile sēcan be đām sigebēame on ðām prōwode pēoda Waldend eallra gnyr[n]a lēas, Godes āgen Bearn, pone [or]scyld[ne] eofota gehwylces purh hete hēngon on hēanne bēam

425 in fyrndagum fæderas ùsse pæt wæs prēalic gepōht! Nū is pearf mycel pæt wē fæstlice ferh $\gamma$ staðelien, pæt wē ðæs morðres meldan ne weorðen, hwār pæt hālige trīo beheled wurde

430 æfter wīgpræce, pȳ-lǣs tōworpen sīen frōd fyrngewritu, ond pā fæderlīcan lāre forlēt[e]n. Ne bið lang ofer $\delta æ t$ pæt Israhela æXelu mōten ofer middangeard mā rīcsian,

435 æcræft eorla, gif ðis yppe bið; swā pā pæt ilce gīo mīn yldra fæder sigerōf sægde - - pām wæs Sachius nama frōd fyrnwiota, fæder[e] minum, [pe wæs Sȳmon hāten, swǣsum] eaferan 440 - wende hine of worulde - ond pæt word gecwær :

"Gif pē pæet gelimpe on lifdagum pæt $\gamma \bar{u}$ gehȳre ymb pæt hälige trēo frōde frignan, ond geflitu ræaran be đām sigebēame on pām Sōocyning

$418 M S$. -snotor; Wa. -snottor. - 422 MS. gnyrnra; Bouterwek (Cadmon, p. 136) gnyrna. - 423 MS. scyldü; $T h$. unscyldigne?; $Z$. $^{2}$ orhlytne?; Tr. orscyldne. -432 MS. -leton; em. K. 438 MS. fæder; em. Siev. (PBB. Io. 483).-439 MS. eaferan; em. $H^{1}{ }^{1} ; \mathrm{Gr}^{1}$ be hit siððan cyðde sylfa his eaferan. 
445 āhangen wæs, heofonrīces Weard, eallre sybbe Bearn, ponne pū snūde gecȳo, mīn swǣs sunu, $\overline{æ r}$ pec swylt nime. Ne mæg ǣfre ofer pæt Ebrēa pēod, rǣdpeahtende, rīce healdan,

450 dugưum wealdan; ac pāra dōm leofar, ond hira dryhtscipe

in woruld w[o]rulda willum gefylled, ðe pone āhangnan Cyning . heriap ond lofiað."

'Pā ic fromlice fæder[e] minum,

455 ealdum $\bar{x} w i t a n$, āgeaf andsware: "H̄̄ wolde pæt geweorðan on woruldrice pæt on pone Hālgan handa sendan tō feorhlege fæderas ūsse purh wrāo gewitt, gif hìe wiston ǣr 460 pæt hē Crīst wǣre, Cyning on roderum, sōo Sunu Meotudes, sāwla Nergend?"

'Đā mē ylldra mìn āgeaf andsware, frōd on fyrhðe fæder reordode: "Ongit, guma ginga, Godes hēahmægen, 465 Nergendes naman. Sē is nið[ð] gehwām unāsecgendlíc; ' pone sylf ne mæg on moldwege man āspyrigean.

Nǣfre ic pā gepeahte pe pēos pēod ongan sēcan wolde, ac ic symle mec

470 āscēd pāra scylda, nales sceame worhte gāste minum. Ic him georne oft pæs unrihtes andsæc fremede, ponne $\bar{u} \gamma w e o t a n$ æht bisǣton, on sefan sōhton hū hie Sunu Meotudes

475 āhēngon, Helm wera, Hlāford eallra engla ond elda, æðelust bearna.

"Ne meahton hi[m] swā disige dēar oðfæran

$451^{\text {b }} G m$. mid yldrum deah; $G r^{1}{ }^{1}$ bið gedyrsod $æ f r e ; G r .^{2}$ dreames bruceঠ ; $H .^{1}$ deorlice bið (comparing El. II59). - $452 M S$., Edd. weorulda. - 454 Before this line MS. has VI; MS. fæder; em. Siev. (PBB. 10.483) $-465^{\mathrm{b}} M S$. niða ; $Z .^{2}$ niðరa. - $476 \mathrm{MS}$. bearna; $\mathrm{Gm}$. beorna. $-477 \mathrm{MS}$. hie ; $Z{ }^{1}$ him. 
weras wonsǣlige swā hīe wēndon $\bar{x}$, sārum settan, pēah hē sume hwīle 480 on galgan his gāst onsende, Sigebearn Godes. Pā siððan wæs of rōde āhæfen rodera Wealdend, eallra prymma Prym; prēo niht siððan in byrgenne bīdende wæs

485 under pēosterlocan; ond pā pȳ priddan dæg ealles lēohtes Lēoht lifgende ārās, Đēoden engla, ond his pegnum [hine], sōð sigora Frēa, seolfne geȳwde, beorht on blæ̈de.

Ponne brōoror pīn

490 onfēng æfter fyrste fulwihtes bæð, lēohtne gelēafan. §ā for lufan Dryhtnes Stēphānus wæs stānum worpod; ne geald hē yfel yfele, ac his ealdfēondum pingode prohthe[a]rd, bæd Prymcyning

495 pæt hē him pā wēadǣ tō wræce ne sette pæt $h[\bar{i}]$ e for æfstum unscyldigne, synna lēasne, $\mathrm{Sa}[\mathrm{u}]$ les lārum feore berǣddon, swā hē purh fēondscipe tō cwale monige Crīstes folces

500 dēmde, tō dēapè. Swā-pēah him Dryhten eft miltse gefremede, pæet hē manegum [wearð] folca tō frōfre. Syððan him frymða God, nið[ซ] a Nergend, naman oncyrde, ond hē syððan wæs Sanctus Paulus

505 be naman häten; ond him nǣnig wæs ǣlærendra ōðer betera under swegles hlēo syðpan ǣfre, pāra pe wīf oððe wer on woruld cendan, pēah hē Stēphanus stānum hehte

5 IO ābrēotan on beorge, brōpor pinne.

487 MS. pegnum; Gr. ${ }^{1}$ begnum hine. $-494 M S$. -herd; em. Gm. -496 $M S$. he; em. K.; $H^{2}$ hine. $-497 M S$. sawles; em. K. 50 or MS. manegum ; K. manegum wearð. - $503 M S$. niða ; em. $Z .^{2}$ 
"Nū ðū meaht gehȳran, hæleð min se lēofa, hū ārfæst is ealles Wealdend, pēah wē æabylgð wið hine oft gewyrcen, synna wunde, gif wē sōna eft

5I5 pāra bealudǣda bōte gefremmap, ond pæs unrihtes eft geswicap.

Forðan ic, sōðlice, ond min swās fæder syðban gelȳfdon [pissum lēofspelle,] pæt geprōwade eallra prymma God,

520 līfes Lāttiow, lāolìc wìte for oferpearfe ilda cynnes.

Forðan ic pē lǣre purh lēo[ð] rūne, hyse lêofesta, pæt $\chi_{\bar{u}}$ hospcwide, æfst nē eofulsæc $\bar{x} f$ re ne fremme,

525 grimne geagncwide, wir Godes Bearne; ponne $\gamma \bar{u}$ geearnast pæt pē bið èce líf, sēlust sigelēana, seald in heofonum."

"Đus mec fæder min on fyrndagum unweaxenne wordum lērde,

530 septe sōðcwidum - pām wæs Sȳmon nama -, guma g[id]dum frōd. Nū gē geare cunn[iað] hwæt èow pæs on sefan sēlest pince tō gecȳðanne, gif ðēos cwēn ūsic frigneð ymb ðet [frēo] trēo, nū gē fyrhð̌sefan

535 ond mōdgepanc minne cunnon.'

Him pā tōgēnes pā glēawestan on wera prēate wordum mǣldon: 'Nǣfre wē hȳrdon hæleð ǣnigne on pysse pēode būtan pec nūða,

540 pegn öðerne, pyslīc cy̆ð̌an ymb swā dȳgle wyrd. Dō swā pē pynce,

$5^{18^{\mathrm{a}}}$ Th. assumes gap before syobpan. $-518^{\mathrm{b}} G r^{1}$ in lifes fruman; $H .^{1}$ leohtum geboncum; $W a$. bissum leofspelle ( $c f . E l$. IOI7). - $522 M S$. leoða-; em. Siev. (PBB. IO. 504). - 530 MS. septe; Th. sewde. $-531^{\mathrm{a}}$ $M S$. gehdum; Th. gehðum; $Z .^{1}$ giddum; $H_{0}^{1}$ gidda (but $H^{2}$ gehðum).$53^{\mathrm{b}} M S$. ge; $H_{.}^{2}$ ge eal; $M S$., Edd. cunnon. $-532 M S$. on sefan selest; $H_{.}^{2}$ selest on sefan; $M S$. pince ; $H_{.}^{2}$ binceð. - $534 M S$. treo; $Z .^{2}$ ठa rode?; $H$. (Angl. 23. 516) fyrntreo; $H^{1}{ }^{1}$ foldgræf ; $H_{.}^{2}$ freotreo. 
fyrngidda frōd, gif $\bar{x} \bar{u}$ frugnen sie on wera corðre. Wīsdōmes beðearf, worda wærlīcra ond witan snyttro,

545 sē $ð \bar{æ}$ re æelan sceal andwyrde āgifan for pyslicne prēat on meple.'

II. HELENA'S THREAT, AND THE SURRENDER OF JUDAS

Wēoxan word cwidum; weras peahtedon on healfa gehwæ[ne], sume hyder, sume pyder, prydedon ond pōhton. $\mathrm{Pa}$ cwōm pegna hẽap

550 tō pām heremeð̌le. Hrēopon friccan, cāseres bodan: 'Ēow pēos cwēn lapap, secgas, tō salore, pæt gē seonoðdōmas rihte reccen. Is ēow ræ̈des pearf on mexelstede, mōdes snyttro.'

555 Hēo wǣron gearwe, gēomormōde lēodgebyrgean, pā hīe laðod wǣron purh heard gebann; tō hofe ēodon cÿð[a]n cræftes miht.

Pā sīo cwēn ongan weras Ebresce wordum nēgan, 560 fricggan fyrhðwērige ymb fyrngewritu, hū on worulde $\bar{x} r$ witga [n] sungon, gāsthālige guman, be Godes Bearne, hwǣr se Pēoden geprōwade, sōo Sunu Meotudes, for sāwla lufan.

565 Hēo wǣron stearce, stāne heardran, noldon pæet gerȳne rihte cȳðan nē hire andsware ǣnige secgan, torngenìllan, .pæs hīo him tō sōhte, ac hīo worda gehwæs wiðersæc fremedon

570 fæste on fyrhðe pæt hēo frignan ongan, cwǣdon pæt hīo on aldre ōwiht swylces

547 Before this line MS. has VII. MS. weoxan; Cos. (Tijdschrift I. I44) wrixledan; Th. joins word and cwidum. - $548 \mathrm{MS}$. gehwær; em. $Z .^{1}-558 M S$. cyðdon; em. $Z^{1}{ }^{1}-56$ I $M S$. witga; em. Th. 


\section{nē ǣr nē sì ǣ fre hȳrdon.}

Elene mapelade, ond him yrre oncwæð: 'Ic ēow tō sōðe secgan wille, 575 ond pæs in life lige ne wyrồ, gif gē pissum lēase leng gefylgað mid fǣcne gefice, pe mē fore standap, pæt ēow in beorge bǣl fornimeð, hāttost heaðowelma, ond ēower hrā bryttað, 580 lācende līg, pæt ēow [sēo] lēas[ung sceal] $\bar{a}[w e] n d[e] d$ weorðan tō woruldgedale; ne magon gē ðā word gesēðan pe gē hwile nū on unriht

wrigon under womma scēatum; ne magon gē pā wyrd bemiðon, bedyrnan pā dēopan mihte.'

Đā wurdon hīe dēaðes on wēnan, 585 ādes ond endelífes ; ond pǣr pā ænne betǣhton giddum gearusnottorne - pām wæs Iūdas nama cenned for cnēomāgum; pone hīe pǣre cwēne āgēfon,

sægdon hine sundorwīsne: 'Hē pē mæg sōð gecȳòan,

onwrēon wyrda gerȳno, swā $\delta \bar{u}$ hine wordum frignest,

590 æriht from ord[e] ờ ende for $\delta$;

hē is for eorðan æðeles cynnes, wordcræftes wis ond witgan sunu, bald on meðle; him gebyrde is pæt hē gëncwidas glēawe hæbbe,

$578 M S$. bæl fornimeð; Frucht bælfyr nimeð. $-580 M S$. sceal pæt leas; $G m$. sceal bæs leas; $G r^{1}$ sceal bæt leasspell; $G r .^{1}$ bæt leas sceal?; $Z .^{2}$ seo leasung sceal; $H_{.}^{1}$ bæt lease spel; $H_{0^{2}}$ retains $M S$. reading, but transfers apundrad to end of line.-58I MS. apundrad; Th. awundrad; Gm. awended?; Z. ${ }^{1}$ awended; Strunk (M. L. N. I7. I87) asundrad; H. reads $582^{\mathrm{a}}$ as the second hemistich of this line. $-582^{\mathrm{a}} Z .^{1}$ conjectures the loss of two hemistichs after this, and $H^{1}{ }^{1}$ so prints; $H^{2}$ assumes a gap for this hemistich, but conjectures ( $p .90$ ) hydan ba halgan geryno (cf. 589). $590 \mathrm{MS}$. ord ; em. Th. 
595 cræft in brēostum; hē gecȳðeð pè for wera mengo wisdōmes gife purh pā myclan miht, swā pin mōd lufap.'

12. CONFERENCE BETWEEN HELENA AND JUDAS

Hīo on sybbe forlèt sēcan gehwylcne āgenne eard, ond pone ænne genam

600 Iūdas tō gīsle, ond pā georne bæd

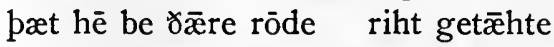
pē $\bar{x} r$ in legere wæs lange bedyrned, ond hine seolfne sundor ācīgde. Elene mapelode tō pām ānhagan,

605 tìrēadig cwēn: 'Pē synt tù gearuswā lîf, swā dēar, swā pē lēofre biơ tō gecēosanne. Cȳð ricene nū hwæt $\delta \bar{u} \mathrm{p} \bar{x}[r a]$ ping[a] pafian wille.'

Iūdas hire ongēn pingode - ne meahte hē pā gehðu bebūgan,

6Io oncyrran [cwealm] genīßlan; hē wæs on pāre cwēne gewealdum - :

'Hū mæg pǣm geweorðan pe on wëstenne mēðe ond metelēas mörland trydeð, hungre gehæfted, ond him hlāf ond stān on gesihðe bū. [samod] geweorðað,

6I5 st[ear]c ond hnesce, pæt hē pone stān nime wiơ hungres hlèo, hlāfes ne gìme, gewende tō wādle, ond pā wiste wiřsæce, beteran wiðhyccge, ponne hē bēga beneah?' Him pā sēo éadige andwyrde āgeaf

620 Elene for eorlum undearnunga:

'Gif $\delta \bar{u}$ in heofonrice habban wille

$608 M S$., Edd. hwæt; $M S$. pæs to pinge; $H_{.}^{1}$ bissa pinga; $H_{.}^{2}$ bæs to bance.-6ro MS. rex; Siev. (Angl. 1. 580) cyninges; Cos. (Tijdschrift I. 145) cyningan (=quecn) ; $H^{1}{ }^{1}$ cræfte; $\operatorname{Tr} .(B B .23 .102)$ carena; $H_{.}{ }^{2}$ cyning-. The emendation in the text posits nex for rex.-614 MS. on gesihðe bu; $G m$. on gesihðe beorne bu ; $G r^{1}$ gebroht on gesihðe bu; $Z$. $^{1}$ on gesihðe bu samod; Ten Brink ( Zs. f. D. Alt., Anz. 5. 60) on gesihðe bu gesette. -615 MS. streac; $H^{1}{ }^{1}$ stearc. -619 Before this line $M S$. has VIII. 
eard mid englum ond on eorðan lif, sigorlēan in swegle, saga ricene mē hwǣr sēo rōd wunige, Radorcyninges [bēam],

625 hālig under hrūsan, pe gē hwīle nū purh morðres mān mannum dyrndun.'

Iūdas maðelade - him wæs gēomor sefa, hāt æt heortan, ond gehwæơres wã : ge hē heofonrices [hyht] swā $\mathrm{m}[\overline{\mathfrak{e}} r n e]$

630 ond pis andwearde ānforlēte rīce under roderum, $\quad g[$ if ] hē đā rōde ne tǣhte - : 'Hū mæg ic pæt findan pæt swā fyrn gewearo wintra gangum? Is nū worn sceacen, [tū hund] oððe mā geteled rīme;

635 ic ne mæg āreccan, nū ic pæt rīm ne can. Is nū feal[a] siðpan forogewitenra frōdra ond gōdra pe ūs fore wǣron, glēawra gumena; ic on geogoðe wearð on sīddagum syðð

640 cnihtgeong hæleð ; ic ne can pæt ic năt findan on fyrhðe pæet swā fyrn gewearð.'

Elene mað̀elade him on andsware: 'Hū is pæt geworden on pysse werpëode pæt gē swā monigfeald on gemynd witon, 645 alra tācna gehwylc swā Trōiāna [s] purh gefeoht fremedon? Pæt wæs $\mathrm{f}[\mathrm{yr}]$ myc[le], open ealdgewin, ponne pēos æð̌le gewyrd, gēara gongum. Gē pæt geare cunnon

$624 M S$. radorcyninges; $W a$. radorcyninges beam. $-629^{2} M S$. he; $Z{ }^{1}$

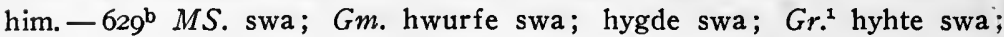
Z. ${ }^{1}$ hyht?; Z. ${ }^{2}$ hyht; Wii. hogde; Klaeb. (Angl. 29. 272) hyhtwynne; Wa. hyht wynne; $M S$. mode; $G r^{2}$ niode; $Z .^{1}$ swamode? (uniting the two words); H. ${ }^{1}$ meðe; Cos. (Tijdschrift I. I45), Klaeb. (Angl. 29. 272) samod (for two words); Wa. micelne?-630 MS. ond; Tr. (BB. 23. I02) ge. - 63I MS. ge; $T r$. gif; $M S$. ne tæhte; $Z .^{1}$ tæhte. $634 M S$. cc; $G m$. twa hund. $-636 M S$. feale; $G r^{1}$ feala; $H^{1}{ }^{1}$ fealo.$645 M S$. Troiana; em. $H_{.}^{2}-646 M S$. fær mycel; $G m$. fyr micle; Klaeb. (Angl. 29. 272) fir (fier) mycle; $H_{.}{ }^{2}$ fior mycle. $-647 \mathrm{MS}$. open; $H_{.}{ }^{2}$ opene; after ealdgewin $H^{1}{ }^{1}$ inserts ær geworden $\|$ Israhela folce, and $W a$. pæt be ær cuð wearð || eowrum ægleawum. 
ēdre gereccan, hwæt pǣr eallra wæs

650 on manrīme morðorslehtes,

dareðlācendra dēadra gefeallen

under bordhagan. Gē pä byrgenna

under stānhleoðum, ond pā stōwe swā some,

ond pā wintergerīm on gewritu setton.'

655 Iūdas maðelade - gnornsorge wæg - :

'Wē pæs hereweorces, hlææfdige mīn,

for nȳdpearfe nēan myndgiap,

ond pā wīggpræce on gewritu.setton, pēoda gebæru; ond pis nǣfre

660 purh ǣniges mannes mūo gehȳrdon hæleðu[m] cȳðan, būtan hēr nū̄a.'

Him sēo æðele cwēn āgeaf andsware:

'Wiðsæcest '̌̀ tō swīðe sōðe ond rihte ymb pæt lifes treow; ond nū lỳtle $\bar{x} r$

665 sægdest sōolīce be pām sigebēame lēodum pīnum, ond nū on lige cyrrest.'

Iūdas hire ongēn pingode, cwæð pæt hē pæt on gehðu gespræ̈ce

ond [on] twēon swīðost, wēnde him trāge hnāgre.

Him oncwæð̌ hraðe cāseres m̄̄g:

670 'Hwæt, wē ðæt hȳrdon purh hālige bēc hæleðum cȳðan pæt āhangen wæs on Calvārie Cyninges Frēobearn, Godes Gāstsunu. $\quad$ Pū scealt geagninga wīsdōm onwrēon, swā gewritu secgap,

675 æfter stedewange hwǣr sēo stōw sie [on] Calvār[i]è, $\overline{æ r}$ pec cwealm nime, swilt, for synnum, pæt ic hie syððan mæge geclǣnsian Crīste tō willan, hæleð̛um tō helpe, pæt mē hālig God 680 gefylle, Frēa mihtig, feores ingepanc, weoruda Wuldorgeofa, willan mīnne, gāsta Gēocend.'

$657 M S$. nean; $K$. near; $Z^{ \pm}$neah. $-66 \mathrm{r} M S$. hæleðu; $T h$. hæleðas; Gm. hæleðum. - $668 \mathrm{MS}$. tweon; Gm. on tweon?, tweonde?; Siev. (Angl. I. 580 ) on tweon. $-676 M S$. calvare; $T h$. calvarie; $W a$. on calvarie. 
Hire Iūdas oncwæð

stīðhycgende: 'Ic pā stōwe ne can, nē pæs wanges wiht nē pā wīsan cann.'

685 Elene maðelode purh eorne hyge: 'Ic pæt geswerige purh Sunu Meotodes, pone āhangnan God, pæt $\delta_{\bar{u}}$ hungre scealt for cnēomāgum cwylmed weorðan būtan pū forlǣte pā lēasunga,

690 ond mē sweotollīce sōox gecȳðe.'

Heht pā swā cwicne corðre lǣdan, scūfan scyldigne - scealcas ne gǣldon in drȳgne sēað, pǣr hē dugữ lēas siomode in sorgum [seofon] nihta fyrst

695 under hearmlocan hungre geprēatod, clommum beclungen. Ond pā cleopigan ongan sārum besylced on pone seofeðan dæg, mēðe ond metelēas - mægen wæs geswiðrod - : 'Ic ēow healsie purh heofona God

700 pæt gē mē of ðyssum earfeðum ùp forlǣten, hēanne fram hungres geniðlan; ic pæt hālige trēo lustum cȳðe, nū ic hit leng ne mæg helan for hungre. Is pes hæft tō Xan strang, prēanȳd [tō] pæs pearl, ond pes proht tō ऊæs heard

705 dōgorrīmum; ic ādrēogan ne mæg, nē leng helan be ðām līfes trēo, pēah ic ǣr mid dysige purhdrifen wǣre, ond ðæt sōð tō late seolf gecnēowe.' Pā ðæt gehȳrde sīo pǣr hæleðum scēad,

710 beornes gebǣro, hīo bebēad hraðe pæt hine man of nearwe ond of nȳdcleofan, fram pām engan hofe, ūp forlēte.

Hìe ðæet ofstlīce efnedon sōna, ond hine mid ārum ūp gelǣddon

7I 5 of carcerne, swã him sēo cwēn bebēad.

683 MS. can; $H^{1}{ }^{1}$ wat. -694 MS. vii ; Gm. seofon. - 697 MS. besylced ; Th. besyled (reading MS. as besyleed). -709 Before this line MS. has VIII. $-709^{\mathrm{b}} M S$. scead; Gm. sceod; Ten Brink (Zs. f. D. Alt., Anz. 5. 60) scraf; $\operatorname{Tr}$. (BB. 3. II7) weold. 
13. THE PRAYER OF JUDAS, AND ITS RESULT

Stōpon pā tō pǣere stōwe stīohycgende on pā dūne ūp ঠe Dryhten ǣr āhangen wæs, heofonrīces Weard, Godbearn, on galgan, ond hwærre geare nyste

720 hungre gehȳned hwǣr sīo hālig[e] rōd 72I-2 purh [fēondes] searu foldan getȳned, lange legere fæst lēodum dyrne, wunode wælreste. Word stunde āhōf

725 elnes oncȳðig, ond on Ebrisc spræc: 'Dryhten Hǣlend, pū ঠe āhst dōma geweald, ond pū geworhtest purh pines wuldres miht heofon ond eorðan ond holmpræce, sǣs sīdne fæðm, samod ealle gesceaft;

730 ond pī āmǣte mundum pīnum ealne ymbhwyrft ond ūprador: ond pū sylf sitest, sigora Waldend, ofer pām æðelestan engelcynne, pe geond lyft farað lēohte bewundene,

735 mycle mægenprymme; ne mæg pær manna gecynd of eorðwegum ūp gefēran in lichoman mid pā lēohtan gedryht, wuldres àras. $\quad \overline{\mathrm{u}}$ geworhtest $\mathrm{p} \overline{\mathrm{a}}$, ond tō pegnunge pinre gesettest,

740 hālig ond heofonlīc. ' Pāra on häde sint in sindrēame syx genemned; pā ymbsealde synt mid syxum ēac firrum, gefrætwad, fæ̈gere scinap. Đāra si[n]t [fēower] pe on flihte à

745 pā pegnunge prymme beweotigap fore onsȳne èces Dèman, singallice singap in wuldre hǣdrum stefnum Heofoncininges lof, wōða wlitegaste, ond pās word cweðap

$716 M S$. pære stowe; $W a$. stowe. $-720 M S$. halig; em. $Z^{1}-72$ I $M S$. burh searu; Th. assumes a gap; Gr. ${ }^{1}$ conjectures burh searucræft besenced læg on fyrndagum foldan getyned; $G r^{2}$ burh feonda searu; $Z^{1}$ feondes for feonda. $-744 M S$. sit; em. Th.; MS. iiii ; Gm. feower. 
750 clǣnum stefnum - pãm is ceruphīn nama"Hālig is se hālga hēahengla God, weoroda Wealdend. Is ðæs wuldres ful. heofun ond eorðe ond eall hëahmægen, tīre getācnod." Syndon tū on pānı,

755 sigorcynn, on swegle, pe man sēraphīn be naman hāteð. Hē sceal neorxnawang ond lïfes trēo lēgene sweorde hālig healdan; heardecg cwacap, beofap brogdenmǣl, ond blēom wrixleð

760 grāpum gryrefæst. एæs $\delta \bar{u}$, God Dryhten, wealdest wīdan fyrh $\gamma$, ond pū womfulle scyldwyrcende sceaðan of radorum āwurpe wonhȳdige. Pā sīo wērge sceolu under heolstorhofu hrēosan sceolde 765 in wìta forwyrd; pǣr hie in wylme nū drēogap dēaðcwale in dracan fæðme, pēostrum forpylmed. Hē pīnum wiðsōc aldordōme; pæs hē in ermðum sceal, ealra fūla ful, fāh prōwian,

770 pēownēd polian. $\quad$ ¡ǣr hē pin ne mæg word āweorpan, is in witum fæst, ealre synne fruma, sūsle gebunden.

'Gif pīn willa sie, Wealdend engla, pæt rīcsie se ðe on rōde wæs,

775 ond purh Mārian in middangeard ācenned wearð in cildes hād, Pēoden engla — gif hē pīn nǣre Sunu synna lēas, nǣefre hē sōðra swā feala in woruldrīce wundra gefremede 780 dōgorgerīmum; nō ช̄ of dēaðe hine swā prymlīce, pēoda Wealdend, àweahte for weorodum, gif hē in wuldre pin

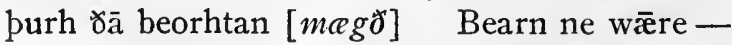

756 MS. he; Gr. ${ }^{1}$ be; $Z^{1}$ hie; $M S$. sceal; $Z_{.}{ }^{1}$ sceolon. -768 Siev. (Angl. I. 580) reads fūl as sb. -775 MS. middanğ ; em. Th. - 780 MS. no; $Z{ }^{1}$ ne? $-782 M S$. pin; Gm. binum. 
gedō nū, Fæder engla, forơ bēacen bīn.

785 Swā ờ gehȳrdest pone hālgan wer Moyses on meðle, pā ò̃u, mihta God, ge $[\bar{y}]$ wdest pām eorle on pã æờlan tīd under beorhhliðe bān Iōsephes, swā ic pē, weroda W[yn], gif hit sie willa pīn,

790 purg pæt beorhte gesceap biddan wille, pæt $[\delta \bar{u}]$ mē pæt goldhord, gāsta Scyppend, geopenie, pæt yldum wæs lange behȳded. Forlǣt nū, lifes Fruma, of đām wangstede wynsumne ūp

795 under radores ryne rēc āstigan lyftlācende. Ic gelȳfe pē sēl, ond pỹ fæstlīcor ferh $ð$ stað̌elige, hyht untwēondne, on pone āhangnan Crīst, pæet hē sie sōơlīce sāwla Nergend,

800 ēce, ælmihtig, Israhela Cining, walde wìdan ferh $\gamma$ wuldres on heofenum, à būtan ende ēcra gestealda.' Đā of đǣre stōwe stēam ūp ārās, [r]ēc under radorum. $\quad$ Đær ārǣed wearð

805 beornes brēostsefa; hē mid bǣm handum, ēadig ond ǣglēaw, ūpweard plegade. Iūdas mapelode, glēaw in gepance: ' $N \bar{u}$ ic purh sōơ hafu seolf gecnāwen on heardum hige pæt $\overline{\bar{u}} \mathrm{H}$ ælend eart 8ı middangeardes. Sīe ð̌ē, mægena God, prymsittendum panc būtan ende, pæs đ̀̃ mē swā mēơum ond swā mānweorcum purh pin wuldor [o]nwrige wyrda gerȳno. Nū ic pē, Bearn Godes, biddan wille, 8I5 weoroda Willgifa, nū ic wāt pæet ờ eart

$787 M S$. gehywdest; Gm. interprets as geywdest. - 789 MS. w; Th. weroda; Siev. (PBB. 10. 5I8) wen, but later (Angl. 13. 3) wyn; Z.' weard. - 791 MS., Edd. pæt me. - 803 Before this line MS. has X. - 804 MS. swylce rec; Schwarz (Cynewulfs Anteil am Christ, p. 59) om. swylce. $-813 . M S$. inwrige; $e m . T h$. 
gecȳðed ond ācenned allra cyninga Prym, pæe đ̛̀ mā ne sie minnra gylta, pāra pe ic gefremede nalles fēam sīoum, Metud, gemyndig. Lǣt mec, mihta God,

820 on rīmtale rīces pines mid hāligra hlÿte wunigan

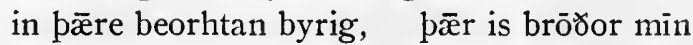
geweorðod in wuldre, pæs hē wæ̈re wið pec, Stēphanus, hēold, pēah hē stāngreopum

825 worpod wǣre; hē hafað wïgges lēan, blǣd būtan blinne. Sint in bōcum his wundor pā hē worhte, on gewritum, cyðed.'

I4 THE DISCOVERY AND IDENTIFICATION OF THE CROSS Ongan pā wilfægen æfter pām wuldres trēo, elnes ānhȳdig, eorðan delfan

830 under turfhagan, pæet hē on [twēntigum] fōtmǣlum feor funde behelede, under nēolum niðer næsse gehȳdde in pēostorcofan; hē $\gamma \bar{æ} r$ [prēo] mētte in pām rēoni $[\mathrm{g}]$ an hofe rōda ætsomne,

835 grēote begravene, swā hīo gēardagum ārlēasra sceolu eorðan bepeahton, Iūdēa [cynn] — hìe wið Godes Bearne nīo āhōfun, swā hīe nō sceoldon, pǣr hīe leahtra fruman lārum ne hȳrdon.

840 Pā wæs mōdgemynd myclum geblissod, hige onhyrded, purh pæt hālige trēo, inbryrded brēostsefa, syððan bēacen geseh hālig under hrūsan. Hē mid handum befēng wuldres wynbēam, ond mid weorode āhōf

845 of foldgræfe. Fēðegestas ēollon, æðelingas, in on pā ceastre. $\bar{A}$ setton pā on gesyhðe sigebēamas [prīe]

824. MS. -greopum; Gm. -greotum. -830 MS. xx; Gm. twentigum; $H^{2}{ }^{2}$ transposes the hemistichs. $-833 M S$. iii; em. Gm. $834 M S$. reonian; $Z_{.}{ }^{2}$ reongan. $-837 M S$. iudea ; em. Gr. ${ }^{1}-841$ I $M S$. -hyrded; Gm. -hyrted. -847 MS. iii ; Gm. pry. 
eorlas ānhȳdige fore Elenan cnēo, collenferhðe.

Cwën weorces gefeah

850 on ferhðsefan, ond pä frignan ongan on hwylcum pära bēama Bearn Wealdendes, hæleða Hyhtgifa, [ā] hangen wǣre: 'Hwæt, wē pæt hÿrdon purh hālige bēc tãcnum cy̆ðan · pæt twēgen mid him

855 geprōwedon, ond hē wæs pridda sylf on röde trëo - rodor eal geswearc on pā slï̀an tïd. Saga, gif đū cunne, on hwylcre pyssa prēora Pëoden engla geprōwode, prymmes Hyrde.'

860 Ne meahte hire Iūdas — ne ful ge[a]re wiste sweotole gecȳpan be đōm sigebēame, on hwylc [n]e se Hǣlend āhafen wǣre, Sigebearn Godes, [ac] hē āsettan heht on pone middel pǣre mǣran byrig

865 bēamas mid bearhtme, ond gebidan pǣr oððæt him gecÿðde Cyning ælmihtig wundor for weorodum be ðām wuldres trēo. Gesǣton sigerōfe, sang āhōfon, rǣdpeahtende, ymb pā röda prëo

870 ơ pā nigoðan tīd; hæefdon nēowne gefēan mǣrơum gemēted. $\overline{\mathrm{a}}$ pǣr menigo cwōm, folc unlȳtel, ond gefærenne man bröhton on bǣre beorna prëate on nēaweste - wæs pā nigoð̌ tīd -

875 gingne gāstlēasne. Dā ð̌ær Iūdas wæs on mōdsefan miclum geblissod; heht pā āsettan sāw [o]llēasne, life belidenes lic, on eorðan, unlifgendes, ond ūp āhöf

880 rihtes wēmend pāra rōda twā

$860 M S$. gere; em. Gr. ${ }^{1}-862 M S$. hwylcre; em. Gr. ${ }^{1}-863$ MS. ær; $Z^{2}$ ac?; $H_{.}^{2}$ ac. $-877^{\mathrm{b}} M S$., Edd. sawl-; $\mathrm{H}^{2}$ notes that the metre requires a disyllable. $-880 M S$. wemend; $T h$. reniend. 
fyrhðglēaw on fæòme ofer pæt f'̄ege hūs, dēophycgende. Hit wæs dēad swā ǣr, lic legere fæest; leomu cōlodon prēanēdum bepeaht. Pā sīo pridde wæs

885 āhafen hālig. Hrã wæs [o]n bīde oððæt him uppan झðelinges wæs rōd ārǣred, Rodorcyninges bēam, sigebēacen sōơ; hē sōna ārās gāste gegearwod, geador bū samod 890 līc ond sāw [o]1. ए̄̄r wæs lof hafen fǣger mid pȳ folce; Fæder weorðodon, ond pone sōxan Sunu Wealdendes wordum heredon. Sie him wuldor ond panc à būtan ende eallra gesceafta!

15. DEBATE OF THE DEVIL AND JUDAS 895 Đā wæs pām folce on ferhðsefan ingemynde, swā him ā scyle, wundor pā pe worhte weoroda Dryhten tō feorhnere fīra cynne, lîfes Lāttiow. $\quad$ Pā pǣr ligesynnig 900 on lyft āstāh lācende fēond; ongan pā hlēoơrian helledēofol, eatol $\bar{æ}[\mathrm{~g}] 1 \overline{æ c}$, y fela gemyndig: 'Hwæt is pis, lā, manna, pe minne eft purh fyrngeflit folgap wyrdeð, 905 īceð ealdne nīð, ̄hta strūdeð? Pis is singal sacu. Sāwla ne mōton mānfremmende in mīnum leng ǣhtum wunigan, nū cwōm Elpēodig pone ic $\bar{x} r$ on firenum fæstne talde, 9ro hafað mec berēafod rihta gehwylces, feohgestrēona; nis ðæt fæ̈ger sīð. Feala mē se Hæ̈lend hearma gefremede, niðða nearolicra, se ðe in Nazareð

885 MS. anbide; em. Frucht (p. 30). - $890^{\mathrm{a}}$. See $877^{\mathrm{b}} \cdot-890^{\mathrm{b}} M S$. hafen; $\operatorname{Tr} .(B B .23 .105)$ ahafen. $-902 \mathrm{MS}$. æclæca; em. Gr. 
āfēded wæs. Syððan furpum wēox

9I5 of cildhāde, symle cirde tō him

ǣhte mīne. Ne mōt ǣnige nū rihte spōwan. Is his rīce brād

ofer middangeard; mīn is geswirrod ræ̈d under roderum. Ic pā rōde ne pearf

920 hleahtre herigean. Hwæt, se Hǣlend mē in pām engan hām oft getȳnde, gēomrum tō sorge. Ic purh Iūdas ǣr hyhtful gewearð; ond nū gehȳned eom, gōda gēasne, purh Iūdas eft,

925 fāh ond frēondlēas. Gēn ic findan [c]an purh wrōhtstafas wiðercyr [s]iððan of ðām wearhtreafum: ic āwecce wið $\gamma \overline{\mathrm{e}}$ öðerne cyning se ēhteð pīn, ond hē forlǣteð lāre pīne

930 ond mānpēawum mīnum folgap, ond pec ponne sendeð in pā sweartestan ond pā wyrrestan wītebrögan, pæt $\delta \bar{u}$, sārum forsōht, wiðsæcest fæste pone āhangnan Cyning, pām đō hȳrdest ǣr.'

935 Him ðā glēawhȳdig Iūdas oncwæð, hæleð hildedēor — him wæs Hālig Gāst befolen fæste,' fȳrhāt lufu, weallende gewitt purh wī[t]gan snyttroond pæet word gecwæð wīsdōmes ful:

940 'Ne pearft đō̄ swā swìðe, synna gemyndig, sār nīwigan ond sæce rǣran, morðres mānfrēa; $\quad \mathrm{p}[\mathrm{ec}]$ se mihtiga Cyning in nēolnesse nyð̌er bescūfeð, synwyrcende, in sūsla grund, 945 dōmes lēasne, se đe dēadra feala

92I MS. oft; Gr. ${ }^{1}$ eft.-924 MS. geasne; Kluge (Litbl. for I884, p. I38) gæsne. - $925 M S$. ne can; em. Gr. ${ }^{2}-926 M S$. wiððan; Gr. ${ }^{1}$ siððan;

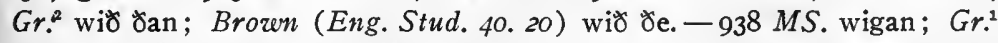
witan; Gr. ${ }^{2}$ witgan. - $942 M S$. pæt; $Z .^{1}$ pæt pē; Cos. (Aanteekeningen op den Beowulf, p. 32) bec. 
worde āwehte. Wite $\gamma \overline{\mathrm{u}}$ pē gearwor pæt $\delta \bar{u}$ unsnyttrum ānforlēte lēohta beorhtost ond lufan Dryhtnes, pone fǣgran gefēan, ond on fȳrbæðe

$95^{\circ}$ sūslum beprungen syððan wunodest, āde onǣled, ond p̄̄r āwa scealt, wiðerhycgende, wergð̌u drēogan, yrmơu būtan ende.'

Elene gehȳrde

hū se fēond ond se frēond geflitu rǣerdon,

955 tīrēadig ond trāg, on twā halfa, synnig ond gesælig. Sefa wæs pē glædra pæs pe hēo gehȳrde pone hellesceapan oferswiðe[dn]e, synna bryttan, ond pā wundrade ymb pæs weres snyttro,

960 hū hē swā gelēafful on swā lȳtlum fæceond swā [o]ncȳðig ǣefre wurdeglēawnesse purhgoten. Gode pancode, Wuldorcyninge, pæs hire se willa gelamp purh Bearn Godes bēga gehwæơres 965 ge æt pæ̈re gesyhðe pæs sigebēames, ge Xæs gelēafan pe hīo swā lēohte oncnēow, wuldorfæste gife in pæs weres brēostum.

I6. WORD IS BROUGHT TO CONSTANTINE, WHO COMMANDS TO BUILD A CHURCH

Đā wæs gefrēge in pǣre folcsceare, geond pā werpēode wīde lǣded,

970 mǣre morgenspel manigum on andan pāra pe Dryhtnes $\bar{x}$ dyrnan woldon, bod[e]n æfter burgum swā brimo fæơm[a]\%, in ceastra gehwæ $\bar{x}[\mathrm{~m}]$, pæt Crīstes [rōd], fyrn foldan begræfen, funden wæ̈re,

975 sēlest sigebēacna pāra pe sīð oððe $\bar{x} r$ hālig under heofenum āhafen wurde,

$958 M S$. -swiðende; em. Gr. ${ }^{1}-96 \mathrm{r} M S$. un-; Gr. onc-?; em. $H_{0}{ }^{1}-$ $972 M S$. bodan; $G m$. boden?, bodod?; $K$. boden; MS. fæðmeð; Gm. fæðmiað?; Z. ${ }^{1}$ fæðmað. - 973 MS. gehwære; em. Siev.; Th. suggests rod. 
ond wæs Iūdēum gnornsorga mǣst, werum wansǣligum, wyrda lāoost p̄̄e hie hit for worulde wendan meahton, 980 Crīstenra gefēan.

Đà sīo cwēn bebẻad ofer eorlmægen āras fȳsan ricene tō rāde; sceoldon Rōmwarena ofer hēanne holm hlāford sēcean, ond pām wīggende wilspella $\cdot \mathrm{m} \bar{e}$ st

985 seolfum gesecgan - $\quad \mathrm{p}[æ t]$ Xæt sigorbēacen purh Meotodes ēst mēted wǣre, funden in foldan, pæt ǣr feala mæla behȳded wæs hālgum tō tēonan,

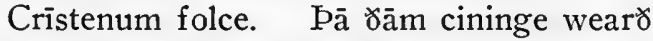

990 purh pā mǣran word mōd geblissod, ferhð gefēonde. Næs pā fricgendra under goldhoman gäd in burgum feorran gefered[ra]. Wæs him frōfra mǣst geworden in worlde æt $\delta a \bar{m}$ willspelle, 995 hlih[h]ende hyge, pe him hererǣswan ofer ēastwegas, āras, brōhton hū gesundne sīo ofer s[w]onrāde secgas mid sigecwēn āsete[d] hæfdon on Crēca land.

Hie se cāsere heht

IOOO ofstum myclum eft gearwian sylfe tō sīðe; secgas ne gǣldon syððan andsware ēdre gehȳrdon, æðelinges word. Heht hē Elenan hǣl ābēodan beadurōfre, gif hìe brim nes[a]n,

$979 M S$. bær; $G r^{1}{ }^{1}$ bæt; $M S$. meahton; $K$. ne meahton. $-985 M S$. be ; Siev. (Angl. I. 580) bæt?-993 MS. geferede; em. Siev. (Angl. r. 580). - 995 MS. hlihende; em. Ten Brink (Zs. f. D. Alt., Anz. 5. 54).- 997 $M S$. spon-; Th. reads swon-. $-998 \mathrm{MS}$. aseten; em. Dietrich.-1000 MS. gearwian; Ten Brink (Zs. f. D. Alt., Anz. 5. 60) gegearwian. 1004 MS. brim nesen; Th. brimnesen; Gm. ( $p p$. I09-IIO) brimnesen, -nēsen, -nesan; $Z .^{1}$ brim nesan; $Z .^{2}$ brim . . . nesen; Cos. (Tijdschrift I. 146$)$ brim nēsen; $H^{1}$ hæfden brim nesen; $\operatorname{Tr} .(B B .23$. IO6) brim nēsen ( $=$ nǣsen). 
1005 ond gesundne sīð settan mōsten, hæleð hwætmōde, tō pǣre hālgan byrig.

Heht hire pā āras ēac gebēodan

Constantinus pæt hīo cirican pǣr on pām beorhhliðe bēgra rǣdum

Ioro getimbrede, tempel Dryhtnes

on Calvarie Crīste tō willan,

hæleðum tō helpe, pǣr sīo hālige rōd

gemētèd wæs, mǣrost bēama

pāra pe gefrugnen foldbūende

IOI5 on eorðwege. Hīo geefnde swã, siððan winemāgas westan brōhton ofer lagufæsten lēofspell manig. Đā sēo cwēn bebēad cræftum getȳde sundor āsēcean, pā sēlestan,

I020 pā pe wrætlīcost wyrcan cūðon stāngefōgum, on pām stedewange girwan Godes tempel. Swā hire gāsta Weard reord of roderum, hēo pā rōde heht golde beweorcean ond gimcynnum,

ro25 mid pām æð̌elestum eorcnanstānum besett[a]n searocræftum, ond pā in seolfren fæt locum belūcan. Pǣr pæt līfes trēo, sēlest sigebēama, siððan wunode æổu[m] [u]nbrǣec; pǣr bið ā gearu

IO30 wraðu wannhālum wita gehwylces, sæce ond sorge; hie sōna pǣr purh pā hālgan gesceaft helpe findap, godcunde gife.

I7. JUDAS IS BAPTIZED, AND IS HALLOWED AS BISHOP CYRIACUS

Swylce Īùdas onfēng æfter fyrstmearce fulwihtes bæð, I035 ond geclǣnsod wearð Crīste getrȳwe, Lifwearde lēof. His gelēafa wearð

$1029 M S$. æðеlu; em. $Z .^{2} ; M S$. anbræce; $T h$. anbroce; $Z .^{2}$ unbræce. 
fæst on ferhðe, siððan frōfre Gāst wic gewunode in pæs weres brēostum, bylde tō bōte. Hē pæt betere gecēas,

ro40 wuldres wynne, ond pām wyrsan wiơsōc, dēofulgildum, ond gedwolan fylde,

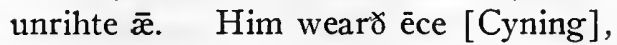
Meotud, milde, God, mihta Wealdend. Pā wæs gefulwad se ðe $\bar{æ}$ feala tīda I045 lēoht gearu inbryrded brēostsefa on pæet betere lif, gewended tō wuldre. Hūru, wyrd gescr [ā]f pæt hē swā gelēaffull ond swā lēof Godé in worldrice weorðan sceolde,

I050 Crīste gecwēme. ¡æt gecȳðed wearð, siððan Elene heht Eusēbium on rǣdgepeaht, Rōme bisceop,

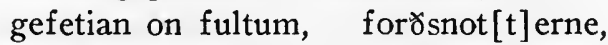
hæleða gerǣdum tō pǣre hälgan byrig,

I055 pæt hē gesette on sācerdhād in Ierusalēm Iūdas pām folce tō bisceope, burgum on innan, purh Gāstes gife tō Godes temple cræftum gecoren[n]e, ond hine Cyriācus

I060 purh snyttro gepeaht syððan nemde niwan stefne. Nama wæs gecyrred beornes in burgum on pæt betere for $ð$ $\bar{æ} \mathrm{H} \bar{æ}$ lendes.

\section{THE DISCOVERY OF THE NAILS}

\section{Pā gēn Elenan wæs}

mōd gemynde ymb pā mǣran wyrd

1065 geneahhe, for pām næglum pe $\gamma æ s$ Nergendes

$1042 M S$. rex; $H^{1}$ cyning. - I044 Before this line MS. has XIII. - 045 $M S$. gearu; $H^{1}$ gearolice; Edd. assume a gap at second hemistich; Gr. ${ }^{2}$ lange forhogode; $H^{1}{ }^{1}$ leahtre forhogode. - $1047 \mathrm{MS}$. gescreaf; em. Gm. - I050 $H_{.}^{1}$ (but not $H_{.}^{2}$ ) inserts after this line bæt bæs landes bisceop hrefde lif ofgifen. - $1053 \mathrm{MS}$. -snoterne; em. Z. ${ }^{2}$ - $1059 \mathrm{MS}$. -corene; em. Gm. 
fët purhwōdon ond his folme swā some, mid pām on rōde wæs rodera Wealdend gefæstnod, Frēa mihtig. Be đām frignan ongan Crīstenra cwēn; Cyriācus bæd

I070 pæt hire pā gīna Gāstes mihtum ymb wundorwyrd willan gefylde, onwrige wuldorgifum, ond bæt word ācwæð̌ tō pām bisceope, bald reordode:

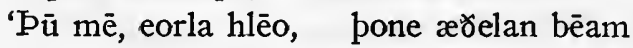

I075 [r]odera Cining[es] ryhte getǣhtes $\delta$, on $\mathrm{pa}[\mathrm{m}]$ āhangen wæs hǣðenum folmum gāsta Gēocend, Godes āgen Bearn, Nerigend fïra; mec pǣra nægla gēn on fyrhðsefan fyrwet myngap.

I080 Wolde ic pæt $\delta \bar{u}$ funde pā $\gamma e$ in foldan gēn dēope bedolfen dierne sindon, heolstre behȳded. $\overline{\mathrm{A}}$ min hige sorgað, rēonig rēoteð, ond gerested nō ǣrpan mē gefylle Fæder ælmihtig,

I085 wereda Wealdend, willan minne, nið[ð] a Nergend, purh pāra nægla cyme, Hālig of hīehða. Nū đō hrædlīce eallum ēaðmēdum, ār sēlesta, pīne bēne onsend in ð̄ā beorhtan gesceaft, Iogo on wuldres W[yn]: bide wigena Prym pæt pē geç̄ðe, Cyning ælmihtig, hord under hrūsan pæt gehȳded gēn, dugưum dyrne, dẽogol bīdeð.'

Pā se hālga ongan hyge staðolian, I095 brēostum onbryrded, bisceop pæs folces. Glæ̈dmöd ēode gumena prēate God hergendra; ond $\mathrm{p} \overline{\mathrm{a}}$ geornlīce

$1075 M S$. rode rodera; Siev. (PBB. 5. 518 ) rodera; $M S$. cining; Gr. cyninges?; $Z{ }^{1}$ cininges; $M S$. -tæhtes $\succsim ; T h$. -tæhtest. - 1076 MS. pa; em. $K$. - $1086 M S$. niða; em. $Z .^{2}$ - $1087 M S$. hiehða; Th. hiehðum?; Gm. hiehðo. - rogo MS. w; Th. wealdend; Gr. ${ }^{2}$ wenne (=wynne); Siev. (PBB. I. 518) wen, but later (Angl. 13. 3) wyn. 
Cỳriacus on Calvarie

hlēor onhylde, hygerūne ne māor,

I 100 Gāstes mihtum tō Gode cleopode

eallum èaðmēdum, bæd him engla Weard

geopenigean uncūðe wyrd,

niwan on nearwe, hwǣr hē pāra nægla swīost on pām wangstede wēnan porfte.

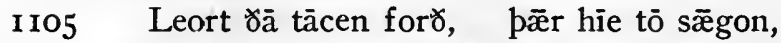
Fæder, frōfre Gāst, ðurh fȳres blēo ūp ēðigean pǣe pā æðelestan hæleða gerǣdum hȳdde wæ̈ron purh nearusearwe, næglas on eorðan.

I I Io Đā cwōm semninga sunnan beorhtra lācende līg. Lēode gesāwon hira Willgifan wundor cȳðan, б̄a $\delta \overline{æ r}$ of heolstre, swylce heofonsteorran oððe go[1]dgimmas, grunde getenge,

I I 5 næglas of nearwe neoðan scinende lēohte lixton.

Lēode gefǣgon, weorud willhrēðig, sægdon wuldor Gode ealle ānmōde, pēah hie ǣr wǣron purh dēofles spild in gedwolan lange,

I I20 ācyrred fram Criste. Hie cwǣdon pus :

'Nū wē seolfe gesēờ sigores tācen, sōðwundor Godes, pēah wē wiðsōcun ǣ̄r mid lēasingum; nū is in lēoht cymen, onwrigen, wyrda bigang. Wuldor pæs āge I 25 on hēannesse heofonrices God !' Đā wæs geblissod se đe tō bōte gehwearf purh Bearn Godes, bisceop pāra lēoda, nīwan stefne. Hē pā $[\mathrm{m}]$ nægl[um] onfēng egesan geāclod, ond pære ārwyrðan

I 107 MS. eðigean; Siev. (Angl. I. 578) siðigean; Cos. (Tijdschrift I. I47) ewigean. - III4 MS. god-; $Z^{1}{ }^{1}$ gold-; $H^{1}{ }^{1}$ gold ond. - II22 $M S$. peah; Z.' bæt. - II23 Gr. ${ }^{1}$ om. in. - II28 MS. ban næglan; em. Th. 
I 30 cwēne brōhte; hæfde Ciriācus eall gefylled, swā him sēo æðele bebēad, wīfes willan. $\quad$ ā wæs wōpes hring, hāt hēafodwylm, ofer hlēor goten, nalles for torne - tēaras fëollon

I 35 ofer wira gespon - wuldr [e] gefylled cwēne willa. Hēo [hīe] on cnēow sette lēohte gelēafan, lāc weorðode, blissum hrēmig, pe hire brungen wæs gnyrna tō gēoce; Gode pancode,

I 40 sigora Dryhtne, pæs pe hīo sōð gecnēow andweardlice pæt wæs oft bodod feor ær beforan fram fruman worulde, folcum tō frōfre. Hēo gefylled wæs wīsdōmes gife; ond pā wìc behēold

I 145 hālig heofonlīc Gāst, hreð̌er weardode, æð̌lne innoð̌; swā hīe ælmihtig Sigebearn Godes sioððan freoðode.

19. THE NAILS ARE FASHIONED INTO A BIT

Ongan pā geornlìce gāstgerȳnum on sefan sēcean sōðfæstnesse

I I5O weg tō wuldre. Hüru, we[ro] da God gefullæste, Fæder on roderum, Cining ælmihtig, pæt sēo cwēn begeat willan in worulde. Wæs se wītedōm purh fyrnwitan beforan sungen

I 55 eall æfter orde, swā hit eft gelamp ðinga gehwylces. Pēodcwēn ongan purh Gāstes gife georne sēcan nearwe geneahhe, tō hwan hīo pā næglas sēlost ond dēorlícost gedōn meahte,

I I60 dugoðum tō hrōðer, hwæt pæs wæ̈re Dryhtnes willa.

$1135 M S$. wuldres gefylled; $Z^{1}$ wuldre wæs gefylled; Cos. wuldre gefylled. - I136 MS. heo; $Z^{1}{ }^{1}$ heo hie. - II37 MS. leohte; Th. leohtne. - II48 Before this line MS. has XIII. - II50 MS. weorda; Th. weoruda; $Z^{1}$ weroda; $W$. weoroda. - I160 MS. hroðer; Gm. hroðre. 
Heht $\gamma \bar{a}$ gefetigean for $ð$ snotterne ricene tō rūne, pone pe rǣdgepeaht purh glēawe miht georne cūðe, frödne on ferhðe; ond hine frignan ongan

II65 hwæt him pæs on sefan sēlost pühte tō gelǣstenne; ond his lāre gecēas purh pēodscipe. Hē hire [prīste] oncwæơ : 'Pæt is gedafenlīc pæt $\delta \bar{u}$ Dryhtnes word on hyge healde, hālige rūne,

rryo cwēn sēlest[e], ond pæs Cininges bebod georne begange, nū pē God sealde sāwle sigespēd ond snyttro cræft, Nerigend fīra. $\quad \Phi \bar{u}$ ðās næglas hāt pām æðelestan eorðcyninga

II75 burgāgendra on his brïdels dōn, meare tō mìdlum. Pæt manigum sceall geond middangeard mǣre weorðan, ponne æt sæcce mid by oferswìðan mæge fēonda gehwylcne, ponne fyrdhwate

II80 on twā healfe tohtan sēcap, sweordgeniðlan, pǣr hie ymb [sigor] wi[nn]að, wrāð wið̀ wrāơum. Hē āh æt wịgge spēd, sigor æt sæcce, ond sybbe gehwæ̈r, æt gefeohte frið, se ðe fo[r] an læ̈deð

Ii 85 brīdels on blancan, ponne beadurōfe æt gārpræce guman gecoste berað bord ond ord; pis bið beorna gehwām wið ǣglǣee unoferswīðed wǣpen æt wīgge. Be ðām se wìtga sang I I90 snottor searupancum - sefa dēop gewōd, wisdōmes gewitt; hē pæt word gecwær : "Cūp pæt gewyrðeð pæt pæs cyninges sceal

I165 MS. on sefan selost; $H^{2}{ }^{2}$ selost on sefan.- II67 Gr. ${ }^{1}$ supplies priste. - II70 MS. selest; em. Siev. (PBB. IO. 5I8).- II8I MS. ymb willao; $G r .{ }^{1}$ ymbsacan willađ, later ymb sige (segen?) wigaơ?; $Z{ }^{1}$ ymb sige winnad; $Z .^{2}$ ymb sigor winnad. - II $84 M S$. fonan; em. Th. - II87 MS. pis; Th. bus? 
mearh under mödegum midlum geweor brīdelshringum; bið pæt bēacen Gode

I 95 hālig nemned, ond sē h[rēð]ēadig, wīgge [ge]weorðod, se pæt wicg byr[e]ð." , Pā bæt ofstlīce eall gelæste Elene for eorlum; æðelinges heht, beorna bēaggifan, bridels frætwan;

I200 hire selfre suna sende tō lāce ofer geofenes strēam gife unscynde.

20. HELENA EXHORTS THE CHRISTIANS, AND RETURNS HOME

Heht pā tōsomne pā hēo sēleste mid Iūdēum gumena wiste, hæleða cynnes, tō pǣre hālgan byrig,

1205 cuman in pā ceastre. Đā sēo cwēn ongan lǣran lēofra hēap pæt hìe lufan Dryhtnes, ond sybbe swā same sylfra betwēonum, frēondrǣ $[\mathrm{d}]$ enne, fæste gelǣston leahtorlēase in hira lífes tīd,

r210 ond pæs lāttēowes lārum hȳrdon, Crīstenum pēawum, pe him Cyriãcus bude, bōca glēaw. Wæs se bi[s] ceophād fǣgere befæsted; oft him feorran tō laman, limsēoce, lēfe cwōmon,

I2I5 healte, heorudrēorige, hrēofe, ond blinde, hẻane, hygegēomre; symle hǣlo pǣr æt pām bisceope, bōte, fundon èce tō aldre. Pā gēn him Elene forgeaf sincweorðunga pā hīo wæs sīðes fūs

1220 eft tō èßle, ond pā eallum bebēad on pām gumrīce God hergendum, werum ond wifum, pæt hie weor mōde ond mægene pone mǣran dæg, heortan gehigdum, in đām sīo hālige rōd

I195 MS. hwæt-; em. $H_{.}{ }^{1}-$ IIg6 MS. wigge weorðod; em. Cos.; $M S$. byrö; em. $Z .^{2}-1208 M S$. -ræddenne; em. Th. - I212 MS. bissceop-; em. Gm. 
1225 gemēted wæs, mǣrost bēama pāra pe of eorðan ūp āwēoxe geloden under lēafum. Wæs pā lencten āgān bütan [syx] nihtum $\bar{æ} r$ sumeres cyme on Maias k[a]1[end]. Sīe pāra manna gehwām

1230 behliden helle duru, heofones ontȳned, èce geopenad engla rīce, drēam unhwīlen, ond hira dǣl scīred mid Mārian, pe on gemynd nime pǣre dēorestan dægweorðunga

I235 rōde under roderum, pā se rices[t]a ealles Oferwealdend earme bepeahte.

Finit.

\section{I. THE RUNIC PASSAGE}

Pus ic, frōd ond fūs purh pæt $f \bar{x}[g] e$ hūs, wordcræft $[e]$ wæf ond wundrum læs, prāgum preodude ond gepanc [h] reodode

I240 nihtes nearwe. Nysse ic gearwe be $\Varangle \bar{æ} r e$ [rōde] riht $\bar{æ} r$ mē rūmran gepeaht purh $\gamma \bar{a}$ mæran miht on mōdes peaht Wīsdōm onwr[ā]h. Ic wæs weorcum fāh, synnum āsǣled, sorgum gewǣled, 1245 bitr[e] gebunden, bisgum beprungen, æer mē lāre onläg purh lēohtne hād gamelum tō gēoce, gife unscynde . Mægencyning āmæt, ond on gemynd begēat, torht ontȳnde, tīdum gerȳmde,

1250 bāncofan onband, brēostlocan onwand,

I228 MS. vi; Gm. six. - I229 MS. maias kl; Gm. maias kalendas; Imelmann (Angl. Beibl. 17. 226) maius kalend. - I235 MS. ricesða; K. ricesta. - 1237 Before this line MS. has XV; MS., Edd. fæcne; Rieger (Zs. f. D. Phil. I. 3I5) fæge. - I238 MS. -cræft; Siev. (PBB. I. 5I8) -cræftum. - $1239 M S$. reodode; $G m$. reordode; Leo hreodode; $H^{1}{ }^{1}$ freoðode. - $124 \mathrm{I}^{\mathrm{a}} M S$. riht; Ett. rihtæ; Gr. ${ }^{1}$ rode riht; Wü. riht . . .; Wï. note rihtan $æ ; H .{ }^{1}$ rode reht. - I24I $^{\mathrm{b}} M S$. ærme; Gm. earme; Ett. areaht; Leo ær me; Ms. -peaht; H. ${ }^{1}$-pæht. - $1242 M S$. miht ; H..$^{1}$ mæht ; $M S$. beaht; $H_{.}{ }^{1}$ xht. - I243 MS. -wreah; em. Gm. - I245 MS. bitrum; em. Siev. (Angl. I. 578).-1247 MS. -scynde; Ett. -seoce.-1248 MS. -geat ; $H .^{1}$-gæt. 
lēor [c]ræft onlēac, pæs ic lustum brēac, willum, in worlde. Ic pæs wuldres treowes oft, nales ǣne, hæfde ingemynd $\bar{\gtrless}$ ic pæt wundor onwrigen hæfde

I255 ymb pone beorhtan bēam, swā ic on bōcum fand wyrda gangum, on gewritum, cȳðan be ðām sigebēacne. $\overline{\mathrm{A}}$ wæs $\mathrm{s}[\mathrm{e}] \mathrm{c}[\mathrm{g}]$ oð ðæt cnyssed cearwelmum, $\mathbf{h}$ drūsende, pēah hē in medohealle māormas pēge,

I260 ap $[p]$ lede gold. A gnornode * gefēra, nearusorge drēah,

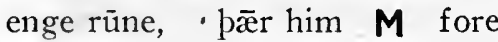
mîlpaðas mæt, mōdig prǣgde wirum gewlenced. $\triangleright$ is geswirrad,

I 265 gomen, æfter gēarum; geogo $\varnothing$ is gecyrred, ald onmēdla. n wæs gēara geogoðhādes glǣm. Nī synt gēardagạs æfter fyrstmearce for $\gamma$ gewitene, lifwynne geliden, swā $\boldsymbol{\wedge}$ tōglīdeð,

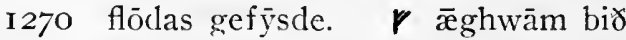
læne under lyfte; landes frætwe gewìtap under wolcnum winde gelī[c]ost - ponne hē for hæleðum hlūd āstīgeð,

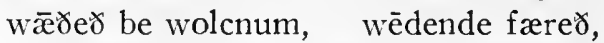

I275 ${ }^{\circ}$ ond eft semninga swige gewyrðeð in nēdcleofan nearwe geheaðrod, prēam forprycced.

22. THE LAST JUDGMENT, AND THE REWARD OF MEN'S DEEDS

Swā pēos wor $[u] l d$ eall gewìteð, ond ēac swā some pe hire on wurdon àtȳdrede tionlēg nimeð,

I 280 Xonne Dryhten sylf dōm gesēceð

I25I MS. leoðu-; H. ${ }^{2}$ leoð-?- I252 MS. willum; Riegsr (Zs. f. D. Phil. I. 3I7) hwilum. - I257 MS. -beacne; Ett. -beame; MS. sæcc; Leo secg. - I260 MS. æplede; Gm. æflede; MS. gnornode; Ett. geornode. $1262 \mathrm{Tr} .(B B .2 .120 ; 23.139)$ fōre. - I272 MS. -liccost; cm. Th. - $1277^{\mathrm{b}}$ $G r^{2}$ notes the metrical difficulty, and Siev. (PPB. IO. ${ }_{518}$ ) declares the 
engla weorude. Sceall ǣghwylc ðǣr reordberendra riht gehÿran

dǣda gehwylcra purh pæs Dēman mūo, ond worda swā same wed gesyllan,

I285 eallra unsnyttr[a] $\bar{\not} r$ gesprecenra, prīstra geponca. Ponne on prēo dǣleð in fȳres feng folc ānra gehwylc, pāra pe gewurdon on widan feore ofer sīdne grund. Sōðfæste bīơ

I290 yfemest in pām āde, èadigra gedryht, dugữ dōmgeorne, swā hìe ādrēogan magon ond būtan earfeðum ēað̌e gepolian, mōdigra mægen. Him gemetgap eall

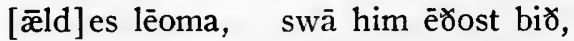

1295 sylfum gesēftost. Synfulle bēoð, māne gemengde, in ðām midle prēad, hæleð higegēomre, in hāt [um] wylm[e], prosme bepehte. Bið se pridda dǣl, āwyrgede womsceaðan, in pæs wylmes grund,

I300 lēase lēodhatan, lïge befæsted purh ǣrgewyrht, ārlēasra sceolu, in glēda gripe. Gode nō syððan of ðām morðorhofe in gemynd cumað, Wuldorcyninge; ac hie worpene bēor 1305 of ซām heaðuwylme in helle grund, torngenīolan. Bið̀ pām twām dǣlum ungelīce.

\section{Mōton engla Frēan}

gesēon, sigora Ğod, [p]e āsodene bēoð, asundrod fram synnum, swā smǣte gold

hemistich impossible; Frucht ( $p .30$ ) justifies it as an A-verse with double alliteration; $H$. (Angl. 13. 358) reads beod for swa beos world; $H_{.}^{1}$ substitutes in beosterlocan, reading as the next full line swa beos woruldgesceaft gewiteð eall, $H_{.}^{2}$ having swa peos æठ̀ ele world eall gewiteð; Wa. reads, as the second hemistich of 1277 , swa peos world eall ponan gewiteð. $1294 M S$. eðles; Leo æledes or eledes?; $Z .^{1}$ eldes; $Z .^{2}$ ëldes. - I296 $M S$., Edd. pread; Gm. dreogað? - $1297 M S$. in hatne wylm; Ett. in hatum wylme; $H^{2}$ hate wylme. - $1308 M S$., Edd. hie; for be $c f .1278$; pã be might be substituted for be (cf. 373), but would involve more change; be hie would also be possible (cf. Harr. Hcll 8). 
I3IO pæt in wylme bið womma gehwylces purh ofnes fȳr eall geclǣnsod, āmered ond gemylted: swã biơ pāra manna $\bar{x} l c$ āscyred and āsceāden scylda gehwylcre, dēopra firena, purh pæs dōmes fỹr ;

I3I5 mōton ponne siðpan sybbe brūcan, - èces ēadwelan. Him bið engla Weard milde ond blī̌e, pæs ðe hie māna gehwylc forsāwon, synna weorc, ond tō Suna Metudes wordum cleopodon; forðan hīe nū on wlite scīnap

I320 englum gelīe, yrfes brūcap Wuldorcyninges tō wīdan feore. Amen. 


\section{PHCENIX}

\section{THE PARADISE OF THE PHENIX}

Hæbbe ic gefrugnen pætte is feor heonan èastdǣlum on æpelast londa fïrum gefrāge. Nis sē foldan scēat ofer middangeard mongum gefëre

5 folcāgendra, ac hē āfyrred is purh Meotudes meaht mānfremmendum.

Wlitig is sē wong eall, wynnum geblissad, mid pām fāgrestum foldan stencum; ǣnlic is pæt iglond, æpele sē Wyrhta,

Io mōdig, meahtum spēdig, se pā moldan gesette. Đǣr bið oft open èadgum tōgēanes, onhliden hleopra wyn, heofonrices duru.

Pæt is wynsum wong, wealdas grēne, rūme under roderum. Ne mæg pǣr rēn nē snāw,

I5 nē forstes fnǣẹ $[s] t$, nē fȳres blēst, nē hægles hryre, nē hrimes dryre, nē sunnan hǣtu, nē sincaldu, nē wearm weder, nē winterscūr wihte gewyrdan, - ac sē wong seomað

20 eadig and onsund. Is pæt æpele lond blōstmum geblōwen. Beorgas p̄̄r nē muntas

5 MS., Con. folc agendra; Sw., Br. foldagendra; $T r^{2}$ feorhagendra; other Edd. folc(-)agendra. - Io $T r^{2}$ se be ba. - $12 ~ T r_{.}^{2}$ hleodora. - I5 $M S$. fnæft, $\mathrm{n}$ on erasure; Con. fræst (tr. 'gelu,' 'fetters'); Grdt. fnæst. - I7 Tr. ${ }^{2}$ sunhætu; Tr. ${ }^{2}$ om. ne?-2I Schl. om. bær.

Est locus in primo felix oriente remotus, Qua patet aterni maxima porta poli, Nec tamen astivos hiemisve propinquus ad ortus, Sed qua sol verno fundit ab axe diem. 
stēape ne stondað, nē stānclifu

hēah hlïfiað, swā hēr mid ūs,

nè dene nè dalu, nē dūnscrafu,

25 hlǣwas nē hlincas, nē p̄̄r hleonað oo

unsmēðes wiht; ac se æpela feld

wrīdað under wolcnum wynnum geblōwen.

Is pæt torhte lond twelfum hērr[e], folde fæơmrīmes, swā ūs gefreogum glēawe

30 witgan purh wisdōm on gewritum cȳpar, ponne ǣnig pāra beorga pe hēr beorhte mid ūs hēa hlïfia under heofontunglum.

Smylte is sē sigewong; sunbearo lixeð, wuduholt wynlic. Wæstmas ne drēosar,

35 beorhte blēde, ac pā bēamas à grēne stondað, swã him God bibēad; wintres and sumeres wudu bið gelice blëdum gehongen. Næ̈fre brosniað lēaf under lyfte, nē him līg scepeð

$40 \bar{æ}$ fre tō ealdre, $\bar{x}$ rpon edwenden worulde geweorðe. Swā iū wætres prym ealne middangeard, mereflōd peahte eorpan ymbhwyrft, pā sē æpela wong $\bar{æ}$ ghwæs onsund wið $\bar{y} \gamma$ fare

23 Ett. heah ne hlifiad. - 25 Con. hleonad. $\|$; Grdt. om. $\infty$; Klip. on for o); Cos. ${ }^{2}$ ower?, which Holt. ${ }^{1}$ rejects. $-28 \mathrm{MS}$. herra; Ett. hearre (=heahre)?; Schl. herre. - 29 Th. fealde?; Klip. fealdum; Grdt. gefrægum?; Th., Sw. gefreogum; Klip. gefrugnon; Ett. interprets as inst. - 3I Schl. bon. - $40 \mathrm{Th}$. æt ende for edwenden?; Klip. edwendung.

5 Illic planities tractus diffundit apertos,

Nec tumulus crescit nec cava vallis hiat, Sed nostros montes, quorum juga celsa putantur,

Per bis sex ulnas eminet ille locus.

Hic Solis nemus est et consitus arbore multa

Io Lucus, perpetuce frondis honore virens.

Cum Phaethonteis flagrasset, ab ignibus axis,

Ille locus flammis inviolatus erat,

Et cum diluvium mersisset fuctibus orbem,

Deucalioneas exsuperavit aquas. 
45 gehealden stōd hrēora wǣga, ēadig, unwemme, purh ēst Godes: bīdeð swā geblōwen ơ bǣles cyme, Dryhtnes dōmes, ponne dēaðræced, hælepa heolstorcofan, onhliden weorpað.

$5^{\circ}$ Nis pǣr on pām londe lāðgenīola, nẽ wōp nē wracu, wēatācen nān, yldu nē yrmðu, nē se enga dēað, nē lïfes lyre, nē lāpes cyme, nè synn nē sacu, nē sārwracu,

55 nē wǣđlle gewin, nē welan onsȳn, nē sorg nē slǣp, nē swār leger.

$\mathrm{Ne}$ wintergeweorp, nē wedra gebregd hrēoh under heofonum, nē se hearda forst caldum cylegicelum cnyseð ǣnigne.

60 Pǣr nē hægl nē hrīm hrēos[ $e] \delta$ tō foldan, nẽ windig wolcen, nē pǣr wæter feallep lyfte gebysgad; ac pǣr lagustrēamas, wundrum wræ̈tlice wyllan onspringað, fǣgrum f[lō]dwylmum foldan leccap,

65 wæter wynsumu of pæs wuda midle; pā mönpa gehwām of pǣre moldan tyrf brimcald brecað, bearo ealne geondfarað

48 Ett. dome?; Klip. -recedas. -54 Grdt., Th., Gr., ${ }^{1}$ Sw. sar wracu; Ett. sar ne wracu. - 55 Ett. wædla. - 56 Hart sorgende for sorg ne; Schl. ne sorglic slæp. $-57 \mathrm{Grdt}$. wedragebrec?; Klip. wedergebregd.-60 MS., Edd. hreosað. - $6 \mathrm{I}^{\mathrm{a}} T r^{2}$ winneb, or wind wedep; Schl. windeb? wæठ̈ep? $-64 M S$. fold-; em. Gr. ${ }^{1}$

I5 Non huc exsangues morbi, non agra senectus, Nec mors crudelis nec metus asper adest, Nec scelus infandum nec opum vesana cupido Aut ira aut ardens cadis amore furor:

Luctus acerbus abest et egestas obsita pannis Et curce insomnes et violenta fames.

Non ibi tempestas nec vis furit horrida venti

Nec gelido terram rore pruina tegit,

Nulla super campos tendit sua vellera nubes, $\mathrm{Nec}$ cadit ex alto turbidus umor aqua. 
prāgum prymlice: - is pæt Pēodnes gebod pætte twelf sipum pæt tīrfæste

70 lond geondlāce laguflōda wynn.

Sindon pā bearwas blēdum gehongene, wlitigum wæstmum; pǣr $\mathrm{n}[\mathrm{e}] \mathrm{w}[\mathrm{a}]$ niað ō, hālge under heofonum, holtes frætwe, nè feallað pǣr on foldan fealwe blōstman,

75 wudubēama wlite; ac pǣr wrǣtlice on päm treowum symle telgan gehladene ofet[e] edniwe in ealle tĩd.

On pām græswonge grēne stond[e]p, gehroden hyhtlice Hāliges meahtum,

80 beorhtast bearwa; nō gebrocen weorpeð holt on hīwe. P̄̄r se hālga stenc wunap geond wynlond; pæt onwended ne bir $\bar{æ}$ fre tō ealdre $\bar{x}$ rpon endige frōd fyrngeweorc se hit on frympe gescōp.

\section{THE ATTENDANT OF THE SUN} fugel feprum strong, sē is Fenix hāten; pǣr se ānhaga eard bihealdep, dēormōd drohtað̌; nǣfre him dēap scepeð

7o Sw. lond II. - 7I Siev. (PBB. Io. 459) gehongne. - $72 \mathrm{Grdt.,} \mathrm{Sw.} \mathrm{ne;}$ $M S$., other Edd. no; MS., Grdt. wuniad; em. Th.; Grdt. \| onhalge, \| unhale?; Klip. om. o. - $76 \mathrm{MS}$. symle; $T r^{2}{ }^{2}$ syndon. - $77 \mathrm{MS}$. of ett ; Cos. ${ }^{2}$ ofete. $-78 M S$. stondab; em. Schl. 79 Ett. gehrodne. - $80 \mathrm{Grdt}$. ne. -84 Half-line space between the sections.

25 Sed fons in medio [est], quem vivum nomine dicunt, Perspicuus, lenis, dulcibus uber aquis, Qui semel erumpens per singula tempora mensum Duodecies undis inrigat omne nemus. Hic genus arboreum procero stipite surgens

$30 \quad$ Non lapsura solo mitia poma gerit. Hoc nemus, hos lucos avis incolit unica Phonix, Unica, sed vivit morte refecta sua. 
on pām willwonge penden woruld stondep.

90 Sē sceal pǣre sunnan sīo bihealdan, and ongēan cuman Godes condelle, glǣdum gimme, georne bewitigan hwonne ūp cyme apelast tungla ofer ȳomere ē[a]stan lixxan,

95 Fæder fyrngeweorc frætwum blican, torht tācen Godes. Tungol bēop āhȳded, gewiten under wapeman westdǣlas on, bidēglad on dæegred, and sēo deorce niht won gewīteð; ponne wāpum strong

IoO fugel feprum wlonc on firgenstrēam under lyft ofer lagu lōcað georne hwonne ūp cyme ēastan glìdan ofer sī[d]ne sǣ swegles lēoma. Swā se æpela fugel æt pām ǣspringe

I05 wlitigfæst wunað wyllestrēamas. Pǣr se tīrēadga twelf sipum hine bibapað in pām burnan $\overline{æ r}$ pæs bēacnes cyme, sweglcondelle, and symle swā oft of pām wilsuman wyllgespryngum

I Io brimcald beorgeð æt baða gehwylcum.

Sippan hine sylfne æfter sundplegan hēahmōd hefer on hēanne bēam, ponan ȳpast mæg on ēastwegum sīo bihealdan, hwonne swegles tapur

94 MS. estan; em. Klip. - 96 Klip. ahydede; in the case of such past participles with a plural noun, Klip. frequently gives the plural form (so 97, 98, etc.) ; $T r .{ }^{1}$ hyded ( $\left.p .25\right) .-103 M S$. sione; em. Th. - 105 Klip. -streamum. - I Io Klip. -caldum; Tr. (p. 25) gehwam.

Paret et obsequitur Phobo memoranda satelles: Hoc natura parens munus habere dedit.

35 Lutea cum primum surgens Aurora rubescit, Cum primum rosea sidera luce fugat, Ter quater illa pias inmergit corpus in undas, Ter quater $e$ vivo gurgite libat aquam. Tollitur ac summo considit in arboris alte 40 Vertice, qua totum despicit una nemus, 
II5 ofer holm[p]ræce hǣdre blice, lēchtes lēoma. Lond bēoð gefrætwad, woruld gewlitegad, sippan wuldres gim ofer geofones gong grund gescinep geond middangeard, mǣrost tungla.

I20 Sōna swā sēo sunne sealte strēamas hēa oferhlifað, swā se haswa fugel beorht of pæs bearwes bēame gewiteð, fareð feprum snell flyhte on lyfte, swinsa $\gamma$ and singe $\gamma$ swegle tō[g]ēanes.

I25 Đonne bì̛ swā fǣger fugles gebǣru, onbryrded brēostsefa, blissum [h]rēmig; wrixleð wōðcræfte wundorlicor, beorhtan reorde, ponne ǣfre byre monnes hȳrde under heofonum, sippan Hēahcyning,

I30 wuldres Wyrhta, woruld stapelode, heofon and eorpan. Bip pæs hlēoðres swēg eallum songcræftum swētra and wlitigra and wynsumra wrenca gehwylcum. Ne magon pām breahtme bȳman nē hornas,

I35 nē hearpan hlyn, nē hælepa stefn ǣnges on eorpan,. nē organan swēg[h]lēopres geswin, nē swanes feðre,

II5 MS. -wræce; em. Th. - II6 Klip. by Grdt. - I26 MS. remig; em. Klip. - I28 Tr. beorhtran? - I34 Cos. ${ }^{1}$ be pam? - I36 MS. organan sweg; Th., Klip. organon-sweg \|; Ett. organonsweg\|; Gr. ${ }^{1}$ organon \|; Grdt., Br., Go. organan sweg \|; Wii. organan \|. 一 I37 MS. leopres; Grdt. hleoðres?; $G r^{1}$. swegleoðres; $B r$. ne hleoðres; Go. hleopres; Ett. geswins?; Gr., ${ }^{1} \mathrm{Br}$. geswins.

Et conversa novos Phabi nascentis ad ortus

Expectat radios et jubar exoriens.

Atque ubi Sol pepulit fulgentis limina porte

Et primi emicuit luminis aura levis,

45 Incipit illa sacri modulamina fundere cantus

Et mira lucem voce ciere novam,

Quam nec aedonia voces nec tibia possit

Musica Cirrhais adsimulare modis,

Sed neque olor moriens imitari posse putetur

50 Nec Cyllenea fila canora lyra. 
nē ǣnig pāra drēama pe Dryhten gescōp gumum tō glīwe in pās gēomran woruld.

I40 Singeð swā and swinsað sǣlum geblissad, oppæt sēo sunne on sūorodor s̄̄ged weorpeð; ponne swia hē and hlyst gefē[h] $\delta$, hēafde onbrygde $\gamma$ pri[wa] ponces glēaw, and priwa āscæceð

I45 fepre flyhthwate: fugol bið geswiged. Symle hē twelf sīpum tīda gemearcað dæges and nihtes.

\section{THE FLIGHT TO THE PALM-TREE}

Swā gedēmed is

bearwes bigenga $[n]$, pæt hē pǣr brūcan mōt wonges mid willum, and welan nēotan,

I50 lifes and lissa, londes frætwa, ơppæt hē pūsen[d] pisses lífes, wudubearwes weard, wintra gebidep. Đonne bið gehefgad haswigfeðra gomol, gēarum frōd. [G] rēne eorðan

I55 äfȳh $ð$ fugla [wyn], foldan geblōwene,

I42 Klip. sigen for sæged. - I43 MS. gefeð; em. Ett. - I44 MS. prist; Klip. bryste; Schl. priwa. - I5I $M S$. pusende; Klip., Bl. pusend ( $B l$. would be willing to regard busende as sing.); Ett. pusendo.-I54 MS. rene; Grdt. grene?; em. Th. - I55 Grdt. fugel?; Ett. fugla betst?; Gr.' fugla wynn.

Postquam Phobus equos in aperta effudit Olympi Atque orbem totum protulit usque means,

Illa ter alarum repetito verbere plaudit Igniferumque caput ter venerata silet.

Atque eadem celeres etiam discriminat horas Innarrabilibus nocte dieque sonis, Antistes luci nemorumque verenda sacerdos Et sola arcanis conscia, Phobe, tuis. Qua postquam vite jam mille peregerit annos

60 Ac se reddiderint tempora longa gravem, Ut reparet lapsum spatiis vergentibus avum, Adsuetum nemoris dulce cubile fugit.

Cumque renascendi studio loca sancta reliquit, Tunc petit hunc orbem, mors ubi regna tenet. 
and ponne gesēceð sīde rīce middangeardes, p̄̄r nō men būgað, eard and èpel. ए Pǣr hē ealdordōm onfëhr foremihtig ofer fugla cynn, I60 gepungen on pēode, and prāge mid him wèsten weardað. Bonne wäpum strong west gewiteð, wintrum gebysgad, flēogan feprum snel. Fuglas pringað ūtan ymbe æpelne; ' ǣghwylc wille

I65 wesan pegn and pēow pēodne mǣrum, oppæt $\mathrm{h}[\overline{\mathrm{e}}]$ gesēc $[\mathrm{e}] \gamma \quad$ Syrwara lond corðra mǣste. Him se clǣna pǣr ơscūfeð scearplice, pæt hē in sc[e]ade weardað on wudubearwe wēste stōwe

I7o biholene and bihȳdde hælepa monegum.

Đǣr hē hēanne bēam on holtwuda wuna $\gamma$ and weardað, wyrtum fæstne under heofu[n]hrōfe, pone hātað men fenix on foldan, of pæs fugles noman.

I75 Hafað pām treowe forgiefen tïrmeahtig Cyning Meotud moncynnes, mine gefrǣge, pæt [h] ē āna is ealra bēama on eorðwege ūplǣẹndra beorhtast geblöwen; ne mæg him bitres wiht I80 scyldum sceððan, ac gescylded ā wunar ungewyrded penden woruld stonder.

I56 MS. side from siðe; Th. sið火. - 164 Grdt., Th., Klip., Ett., Gr.' wesan \|l Siev., Br., Go., Wü., Schl. wille l. - 166 MS., Grdt., Go., Schl. hy gesecað; Th. he gesecað; other Edd. he geseceठั. - I67 Ett. corðre?; Br. clæne. - I73 MS. heofum-; Grdt. heofun-?; em. Th. - I77 Ett., Br. he; MS., other Edd. se. - I8I One-line space between the sections.

65 Dirigit in Syriam celeres longava volatus, Phenices nomen cui dedit ipsa vetus, Secretosque petit deserta per avia lucos, Sicubi per saltus silva remota latet. Tum legit aerio sublimem vertice palmam, 70 Quce Graium phanix ex ave nomen habet, In quam mulla nocens animans prorepere possit, Lubricus aut serpens aut avis ulla rapax. 


\section{THE BUILDING OF THE NEST}

Đonne wind ligeð̀, weder bið fǣger, hlūttor heofones gim hālig scīneð,, bēo $\delta$ wolcen tōwegen, wætra prȳpe

I85 stille stondar, bip storma gehwylc āswefed under swegle, sūpan blīcer wedercondel wearm, weorodum lȳhteð; ðonne on pām telgum timbran onginneð, nest gearwian. Bið him nēod micel

I90 pæt hē pā yldu ofestum möte purh gewittes wylm wendan tö lïfe, feor[h] geong onfōn. Ponne feor and nēah pā swētestan somnað and gædrað wyrta wynsume and wudublēda

I95 tō pām eardstede, æpelstenca gehwone, wyrta wynsumra pe Wuldorcyning, Fæder frymða gehwæs, ofer foldan gescōp tō indryhtum ælda cynne, swētes [t] under swegle.

200 in pæt treow innan torhte frætwe; pǣr se wilda fugel in pām wēstenne ofer hēanne bēam hūs getimbreð wlitig and wynsum, and gewicað pǣr sylf in pām solere, and ymbseteð ūtan

205 in pām lēafsceade līc and fepre on healfa gehwā $[\mathrm{m}]$ hālgum stencum, and pām æpelestum eorpan blēdum.

I9I $T r^{2}$ gewyrtes; Schl. gewices? - $192 \mathrm{MS}$. feorg; em. Ett. - I99 Go., Schl. swetest; MS., other Edd. swetes. - 206 MS. gehware; Grdt. gehwære; Siev. gehwam.

Tum ventos claudit pendentibus Aeolus antris,

$\mathrm{Ne}$ violent flabris aera purpureum

75 Neu concreta noto nubes per inania cali

Submoveat radios soiis et obsit avi.

Construit inde sibi seu nidum sive sepulchrum:

Nam perit, ut vivat, se tamen ipsa creat.

Colligit hinc sucos et odores divite silva, 


\section{THE DEATH BY FIRE}

Siteð sīpes fūs ponne swegles gim on sumeres tīd, sunne hātost,

2IO ofer sceadu scīneð, and gesceapu drēogeð, woruld geondwlïteð. एonne weorðeð his hūs onhǣted purh hādor swegl, wyrta wearmiað, willsele stȳmeð swētum swæccum, ponne on swole byrneð

2I 5 purh fỹres feng fugel mid neste. Bǣl bið onǣled; ponne brond peceð heor[o]drēorges hūs, hrēoh ōnetter, fealo lig feormar; and Fenix byrner fyrngēarum frōd ponne fȳr pigeð

220 lǣnne lichoman; lif bið on sīðe, fǣges, feorhhord, ponne flǣsc and bān ādlēg æleð.

217 MS. heore-; Th. heoro-?; Grdt. heoro-; $T r^{2}$ heabo-; Ett. -dreorig; $T r^{2}$-deores.

8o Quos legit Assyrius, quos opulentus Arabs, Quos aut Pygmea gentes aut India carpit Aut molli generat terra Sabaa simu.

Cinnamon hinc auramque procul spirantis amomi

Congerit et mixto balsama cum folio:

85 Non casice mitis nec olentis vimen acanthi

Nec turis lacrime guttaque pinguis abest.

$H$ is addit teneras nardi pubentis aristas

Et sociam myrra vim, panacea, tuam.

Protinus instructo corpus mutabile nido

90 Vitalique toro menbra vieta locat.

Ore dehinc sucos membris circumque supraque Inicit exsequiis inmoritura suis.

Tunc inter varios animam commendat odores, Depositi tanti nec timet illa fidem.

95 Interea corpus genitali morte peremptum Aestuat et flammam parturit ipse calor, Aetherioque procul de lumine concipit ignem: Flagrat et ambustum solvitur in cineres. 


\section{THE NEW BIRTH}

Hwæpre him eft cymeð

æfter fyrstmearce feorh ednīwe,

sippan pā ȳslan eft onginnað

225 æfter lïgpræce lūcan tōgædere, geclungne tō clēo[w]ne. Ponne clǣene bið̌ beorhtast nesta bǣle forgrunden, heaporōfes hof; hrā bì̛ ācōlad, bānfæt gebrocen, and se bryne sweprað.

230 Ponne of pām āde xples gelīenes on pǣre ascan bið eft gemēted; of pām weaxeð wyrm wundrum fǣger, swylce hē of $\bar{x} g[e]$ ūt ālǣde, scir of scylle. Ponne on sceade weaxeð,

235 pæt hē ̄̄rest bið swylce earnes brid, fǣger fugeltimber; 万onne furpor gin wrīdað on wynnum, pæt hē bið wæstmum gelīc ealdum earne; and, æfter pon, feprum gefrætwad, swylc hē æt frymðe wæs,

240 beorht geblōwen. Ponne brǣd weorpeð eal ednīwe eft ācenned, synnum āsundrad — sumes onlice

226 MS. cleowenne; Klip. cleofanne; Ett. cleowanne; Siev. cleo(w)ne; 3r. cleowne; Schl. cleowene. - $228 M S$. hof; Ett. hus. - 233 ${ }^{\mathrm{a}} M S$. egerum; Grdt. ægerum wæs?; Th. æge wære?, which Klip. accepts; 3r. æge. $-233^{\mathrm{b}} M S$. ut alæde; Th. utalæded?, which Klip. accepts; Ett. it alude (from aleodan, 'grow'). - $236 \mathrm{Tr}^{2}{ }^{2}$-umber. $-237 \mathrm{Br}$. wrideð; 1S., other Edd. wridað. - $240 \mathrm{Klip}$. brad. $-242 \mathrm{Th}$. sumeres on lice (tr. like as in summer')?

Quos velut in massam cineres natura coactos

IOO Conflat, et effectum seminis instar habet.

Hinc animal primum sine membris fertur oriri,

Sed fertur vermi lacteus esse color.

Crescit, at emenso sopitur tempore certo

Seque ovi teretis colligit in speciem.

105 Ac velut agrestes, cum filo ad saxa tenentur,

Mutari tinea papilione solent,

Inde reformatur qualis fuit ante figura,

Et Phonix ruptis pullulat exuviis. 
swā mon tō andleofne eorðan wæs[t]mas on hærfeste hām gelǣdeð,

245 wiste wynsume, $\overline{\mathrm{e}} \mathrm{r}$ wintres cyme, on rypes tīman, $\quad$ ȳ̄læs hī rēnes scūr

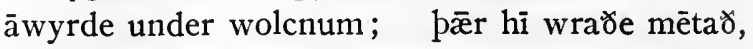
födorpege gefē[a]n, ponne forst and snāw mid ofermægne eorpan peccað

250 wintergewǣdum. Of pām wæstmum sceal eorla ēadwel[a] eft ālǣdan

purh cornes gecynd, pe ǣr clǣne bið sǣd onsāwen, ponne sunnan glǣm on lenctenne, lîfes tācen,

255 weceð woruldgestrēon, pæt pā wæstmas bēoð purh āgne gecynd eft ācende, foldan frætwe. Swā se fugel weorpeð,, gomel æfter gēarum, geong, edniwe flǣsce bifongen. Nō hē fōddor pigeð, 260 mete on moldan, nemne meledēawes dǣl gebyrge, se drẽoseð oft æt middre nih [t] ; bi pon se mōdga his feorh āfëdeð, oppæt fyrngesetu, āgenne eard, eft gesēcer.

265 Ponne bið āweaxen wyrtum in gemonge fugel feprum deal; feorh bið niwe, geong, geofona ful. Donne hē of grēote his lic leopucræftig, pæe ǣr līg fornōm,

243 MS. wæsmas; em. Th. -248 MS. gefeon; Grdt. gefean?; Gr. gefeot?; Klip. gefean. - 25I Th. eorl?; Klip. eorl; Schl. eorbe; MS other Edd. eorla; MS. eadwelan; em. Gr. ${ }^{1}-262$ Siev. (PBB. Io. 485) Schl. niht; $M S$, other Edd. nihte. -264 One-line space between thi sections. -267 Schl. om. he; Barn. (p. I98) om. his.

Non illi cibus est nostro concessus in orbe

IIO Nec cuiquam inplumem pascere cura subest. Ambrosios libat calesti nectare rores,

Stellifero tenues qui cecidere polo. Hos legit, his alitur mediis in odoribus ales,

Donec maturam proferat effigiem.

I15 Ast ubi primava copit florere juventa, 
somnað, swoles lāfe, searwum gegædrað

270 bān gebrosnad æfter bǣllpræce,

and ponne gebringe $\gamma$ bān and ȳslan,

ādes lāfe, eft ætsomne,

and ponne pæt wælrēaf wyrtum biteldeð,

fæ̈gre gefrætwed.

\section{THE RETURN}

Đonne āfÿsed bið

275 āgenne eard eft tō sēcan, ponne fōtum ymbfēhð fȳres lāfe, clām biclyppeð, and his cȳppu eft, sunbeorht gesetu, sēceð on wynnum, ēadig èpellond. Eall bið.genīwad

280 feorh and feperhoma swā hē æt frympe wæs, pā hine ǣrest God on pone æpelan wong sigorfæst sette. Hē his sylfes pǣr bān gebringeð, pā ǣr brondes wylm on beorhstede bāele forpylmde,

285 ascan tōēacan; ponne eal geador bebyrger beaducræftig bān and ȳslan on pām ēalonde. Bið him ednīwe pǣere sunnan pegn, ponne swegles lēoht, gimma glādost, ofer gārsecg ūp, 290 æepeltungla wyn, ēastan lïxeð.

272 Schl. gives ætbomne as $M S$. reading. $-274 T h$. gefrætwað?, which Ett. accepts. $-288 M S$. begn; Th. segn.

Evolat ad patrias jam reditura domus. Ante tamen proprio quidquid de corpore restat

Ossaque vel cineres exuviasque suas Unguine balsameo myrraque et ture soluto

I20 Condit et in formam conglobat ore pio. Quam pedibus gestans contendit Solis ad urbem Inque ara residens promit in ade sacra. Mirandam sese prastat prabetque verendam:

Tantus avi decor est, tantus abundat honor. 


\section{THE APPEARANCE OF THE PHCENIX}

Is sē fugel fǣger forweard hīwe, blēobrygdum fāg ymb pā brēost foran; is him pæet hēafod hindan grēne, wræ̈tlice wrixleð wurman geblonden;

295 ponne is se finta fǣgre gedǣled, sum brūn, sum basu, sum blācum splottum searolīce beseted. Sindon pā fipru hwit hindanweard, and se hals grēne niopoweard and ufeweard, and pæt nebb lixeð

300 swā glæs oppe gim, geaflas scȳne innan and ūtan. Is sēo èaggebyrd stearc, and hīwe stāne gelīcast, glādum gimme, ponne in goldfate smipa orponcum biseted weorpeð.

305 Is ymb pone swēoran, swylce sunnan hring, bēaga beorhtast br[o]gden feðrum. Wrätlīc is sēo womb neopan, wundrum fǣger, scīr and scȳne; is se scyld ufan frætwum gefēged ofer pæs fugles bæc;

$3^{\text {IO }}$ sindon pä scancan scyllum biweaxen, fealwe fōtas. Se fugel is on hiwe

$294 M S$. wrixleđ; Th. wrixled. $-300^{\mathrm{a}} T r^{2}$ be for oppe? - $30 \mathrm{~T} T \mathrm{r}^{2}$. -gebrygd. - $306 M S$. bregden; em. Ett. - 3II MS. se fugel; Barn. (p. I95) om. se.

I25 Principio color est, quali est sub sidere Cancri

Mitia quod corium punica grana tegit,

Qualis inest foliis qua fert agreste papaver,

Cum pandit vestes Flora rubente solo.

Hoc humeri pectusque decens velamine fulget,

I30 Hoc caput, hoc cervix summaque terga nitent.

Caudaque porrigitur fulvo distincta metallo,

In cuius maculis purpura mixta rubet.

Alarum pennas insignit desuper iris,

Pingere ceu nubem desuper acta solet.

I35 Albicat insignis mixto viridante zmaragdo

Et puro cornu gemmea cuspis hiat.

Ingentes oculi, credas geminos hyacinthos,

Quorum de medio lucida flamma micat.

Aptata est rutilo capiti radiata corona 
ǣghwæs ǣnlīc, onlīcost pēan

wynnum geweaxen, pæs gewritu secgar.

Nis hē hinderweard nē hygeḡ̄lsa,

3I5 swār nē swongor, swā sume fuglas

pā pe late purh lyft lācað fiprum;

ac hē is snel and swift and swipe leoht, wlitig and wynsum, wuldre gemearcad;

èce is se Epeling se pe him pæt ēad g[i]fer.

\section{THE RETINUE OF BIRDS}

320 Ponne hē gewīter wongas sēcan, his ealdne eard, of pisse ëpeltyrf.

Swā se fugel flēogeð, folcum oðēawe[d], mongum monna, geond middangeard, ponne somn[i]ar sūpan and norpan,

325 ēastan and westan, ēoredciestum; farað feorran and nēan folca prȳpum pǣr hī scēawiap Scyppendes giefe fǣgre on pām fugle, swā him æt fruman sette sigora Sōoxyning sellīcran gecynd, 330 frætwe fǣg[er] ran ofer fugla cyn. Đonne wundriað weras ofer eorpan

312 Th. æghwær?, which Ett. accepts. - 319 Schl. om. be; Gr. om. pæet; $M S$. gefeð; Grdt. gifeð?; Klip. gyfeð; Gr. ${ }^{1}$ gifeð̌.-324 MS. somnad; Klip., Gr. ${ }^{1}$ (Spr.) somniað. - $330 M S$. fægran; Th. fægerran?, which Ett. accepts.

I40 Phobei referens verticis alta decus.

Crura tegunt squame fulvo distincta metallo, Ast ungues roseo tinguit honore color.

Effigies inter pavonis mixta figuram

Cernitur et pictam Phasidis inter avem.

I45 Magnitiem terris Arabum qua gignitur ales

Vix aquare potest, seu fera seu sit avis.

Non tamen est tarda ut volucres qua corpore magno

Incessus pigros per grave pondus habent, Sed levis ac velox, regali plena decore:

I50 Talis in aspectu se tenet usque hominum. Huc venit Aegyptus tanti ad miracula visus

Et raram volucrem turba salutat ovans. 
wlite and wæstma, and gewritu[m] cȳpað, mundum mearciað̀ on marmstāne, hwonne sē dæg and sēo tīd dryhtum geēawe 335 frætwe flyhthwates.

Đonne fugla cynn on healfa gehwo[n]e hēapum pringar, siggað [of] sīdwegum, songe lofiað, mǣrað mōdigne meaglum reordum, and swā pone hālgan hringe beteldað,

340 flyhte on lyfte; Fenix bip on middum prēatum biprungen. Sēoda wlitað, wundrum w[ā]fiað hū sēo wilgedryht wildne weorpiað, worn æfter ōðrum, cræftum cȳpað and for cyning mǣrað

345 lēofne lēodfruman, læ̈dað mid wynnum æð̀elne tō earde, oppæt se ānhoga oðflēogeð feprum snel, pæt him gefylgan ne mæg drȳmendra gedryht, ponne dugừ wyn of pisse eorpan tyrf èpel sēcer.

350 Swā sē ges̄̄liga æfter swylthwīle his ealdcȳðpe eft genēosað, fǣgre foldan. Fugelas cyrrað from pām gūơfrecan gēomormōde eft tō earde, ponne sē æpeling bið 355 giong in geardum. God āna wāt,

332 MS. gewritu; Grdt. gewritum?; Th. gewritum; $\operatorname{Cos}^{2}$ on gewritum. - $334 \mathrm{Schl}$. om. se and seo. - $336 \mathrm{MS}$. gehwore; Grdt. gehware; Ett. gehwære; Th. gehwone; Br. gehwam (against Siev., PBB. I0. 485).342 MS. wefiad; em. Th. -354 Schl. om. se.

Protinus exculpunt sacrato in marmore formam Et titulo signant remque diemque novo.

I55 Contrahit in catum sese genus omne volantum Nec preda memor est ulla nec ulla metus. Alituum stipata choro volat illa per altum

Turbaque prosequitur munere lata pio. Sed postquam puri pervenit ad atheris auras, I60 Mox redit: illa suis conditur inde locis. 
Cyning ælmihtig, hā his gecyn[d] bið, wifhādes pe weres; pæt ne wāt ’enig monna cynnes, būtan Meotod āna, hū pā wìsan sind, wundorlice, 360 fæ̈ger fyrngesceap, ymb pæs fugles gebyrd.

Io. DEATH NOT DREADED

§ǣr sē ēadga mōt eardes nēotan, wyllestrēama, wuduholtum in, wunian in wonge, oppæt wintra bið pusend $[\bar{a}]$ urnen; ponne him weorpeð

365 ende lifes, hine ād peceð

purh æ̈ledfÿr; hwæpre eft cymeð, āweaht wrǣtlice wundrum tō life. Forpon hē drūsende dēað̀ ne bisorgað, sāre swyltcwale, pe him symle wāt

370 æfter ligpræce lif edniwe, feorh æfter fylle, ponne fromlice purh briddes hād gebr $[\bar{e}]$ dad weorðeð eft of ascan, edgeong weser under swegles hlēo.

Bið him self gehwæðer

375 sunu and swǣs fæder, and symle èac eft yrfeweard ' ealdre lāfe.

Forgeaf him se meaht[ig]a moncynnes Fruma

$356 M S$. gecynde; em. Klip. $-364 M S$. urnen; Cos. ${ }^{2}$ suggests aurnen, which Schl. adopts. - 372 MS. gebreadad; Klip. gebrædad. - 373 Grdt. wexeঠ? - $374 \mathrm{Tr}^{2}$ suggests hleowe. - $377 \mathrm{MS}$. meahta; Grdt. meahtiga?; Ett. meahtiga; Schl. meahtga.

At fortunate sortis finisque volucrem,

Cui de se nasci prestitit ipse deus!

Femina [seu sexu] seu mas est sive neïtrum, Felix, qua Veneris fadera nulla colit.

I65 Mors illi Venus est, sola est in morte voluptas:

$U t$ possit nasci, appetit ante mori.

Ipsa sibi proles, suus est pater et suus heres,

Nutrix ipsa sui, semper alumna sibi.

Ipsa quidem, sed non [eadem est,] eademque nec ipsa est,

I7o Aeternam vitam mortis adepta bono. 
pæt hē swā wrǣtlīce weorpan sceolde eft pæt ilce pæt hē ǣerpon wæs, 380 feprum bifongen, pēah hine fȳr nime.

Swā pæt ēce līf ēadigra gehwylc æfter särwræce sylf gecēoseð purh deorcne dēað, pæt hē Dryhtnes mōt æfter gēardagum geofona nēotan

385 on sindrēamum, and sippan à wunian in $w[u] l d[r] e$ weorca tō lēane. Pisses fugles gecynd fela gelīces bi pām gecor $[e]$ num Crīstes pegnum bēacnað in burgum - hū hì beorhtne gefēan 390 purh Fæder fultum on pās frēcnan tīd healdap under heofonum, and him hēanne blǣd in pām ūplìcan è̉le gestrȳnap.

\section{THE LOSS OF EDEN}

Habbap wē geāscad pæt se Ælmihtiga worhte wer and wif purh his wundra spēd,

395 and hì pā gesette on pone sēlestan foldan scēat[a], pone fīra bearn nemnað neorxnawong, pǣr him nǣnges wæs ēades onsȳn penden Eces word, Hālges hlēoporcwide, healdan woldan 400 on pām nīwan gefēan. ऍǣr him nīp gescōd, ealdfēondes æfest; sē him ǣt gebēad, bēames blēde, pæt hī bū pēgun æppel unrǣdum ofer ēst Godes, byrgdon forboden[n]e. $\mathrm{P} \overline{\mathfrak{x}}$ him bitter wearð 405 yrmpu æfter ǣte, and hyra eaferum swā sārlìc symbel, sunum and dohtrum;

$380 \mathrm{Grdt}$. has a space after this line. $-384 \mathrm{Grdt}$. heofona; Ett. geofene. - 386 MS. worulde; Klaeb. ${ }^{2}$ wuldre. -387 Th. gelic is?, which Klip. accepts. $-392 \mathrm{Grdt}$. has a space after this line. $-396 \mathrm{MS}$. sceates; Th. sceata?, which Ett. accepts. -400 Schl. gives cescod as MS. reading.404 MS. -bodene; em. Klip. 
† wurdon tēonlīce tōpas idge

āgeald æfter gylte; hæfdon Godes yrre,

bittre bealosorge; pæs pā byre sippan

4ro gyrne onguldon pe hì pæet gyfl pëgun

ofer Ẽces word. Forpon hī ēßles wyn

gēomormöde ofgiefan sceoldon

purh nǣdran nīp; pā hīo nearwe biswāc,

yldran ùsse, in ǣrdagum

4I5 purh fǣcne fer $[h] \gamma$, pæt hì feor ponan in pās dēaðdene drohtað sōhton,

sorgfulran gesetu. Him wearð sēlle lif heolstre bihȳded, and se hālga wong purh fēondes searo fæste bitỹned

420 wintra mengu, oppæt [hine] Wuldorcyning purh his hidercyme hālgum tō[g]ēanes, monncynnes Gefēa, mēpra Frēfrend, and se ānga Hyht, eft ontȳnde.

\section{THE SIGNIFICANCE OE THE NEST}

Is pon gelícast - pæs be ùs 1[ā]rē[ow]as

$425 \mathrm{w}[\mathrm{o}] \mathrm{rdum}$ secgað and [ge]writu[m] cȳpað pisses fugles gefær. Ponne frōd of gieieð eard and ēpel, and geealdad bið, gewiteð wērigmōd, wintrum gebysgad, pǣr hē holtes hlēo hēah gemēteð,

430 in pām hē getimbrè tānum and wyrtum pām æðelestum eardwìc niwe, nest on bearwe. Bið him nēod micel pæt hē feorh geong eft onfōn mōte purh līges blæsst, līf æfter dēape,

$407^{\text {a }} \mathrm{Grdt}$. to bas idge ageald \|; Th. to bas . . idge, note 'Apparently defective'; Klip. om. $407^{\mathrm{b}}$; Ett. to bas . . . idge; Gr. ${ }^{1}$ tobas idge; $B r$. (Reader, p. 228) grædige for idge, and quotes Hart idæge?; Tr. ${ }^{2}$ torne scyldge. $-408 \mathrm{Klip}$. agealde; $T r^{2}$ agæled. $-409 \mathrm{Ett}$. be. -420 Grdt. mengum?; Klip. mangum. - $42 \mathrm{I} M S$. to heanes; Grdt. togeanes?; $T h$. togeanes. - $424 M S$. leorneras; Th. lareowas?, which Klip. accepts. $425 M S$. weordum; em. Grdt.; MS. writu; $\operatorname{Cos}_{.}^{2}$ on gewritum?; Ett. writum; Schl. gewritum. 
435 edgeong wesan; and his ealdcȳðpu, sunbeorht gesetu, sēcan mōte æfter fȳrbaðe.

Swā ðā foregengan, yldran ūsse, ānforlēton pone wlitigan wong and wuldres setl

440 lēoflìc on läste, tugon longne sīo in hearmra hond, p $\bar{x}$ him hettende, earme āglæ̈can, oft gescōdan.

Wǣron hwæpre monge pā pe Meotude we[1] gehȳrdun under heofonum hälgum əēawum,

445 dǣdum dōmlīcum, pæt him Dryhten wearð, heofona Hēahcyning, hold on mōde. Đæt is se-hēa bēam in pām hālge nū wīc weardiað, pǣr him wihte ne mæg ealdfēonda nān ātre sceppan,

$45^{\circ}$ fācnes tācne, on pā [s] frēcnan tīd.

¡ǣr him nest wyrceð wì nīpa gehwām dǣdum dōmlīcum Dryhtnes cempa, ponne hē ælmessan earmum dǣleð, dugepa leasum, and him Dryhten gecȳgð,

455 Fæder, on fultum, forð ōnetteð, l̄̄nan lïfes leahtras dwǣscep, mirce māndǣde. Healdeð Meotudes $\bar{æ}$ beald in brēostum, and gebedu sēceð clǣnum gehygdum, and his cnēo bīgeð 460 æpele tō eorpan; flȳh ơ yfla gehwylc, grimme gieltas, for Godes egsan;

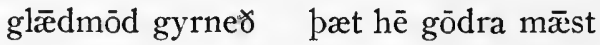
dǣđa gefremme; pām bip Dryhten scyld in sippa gehwane, sigora Waldend, 465 weoruda Wilgiefa. Pis pā wyrta sind,

$438 \mathrm{Schl}$. gives yldan as MS. reading. - 44I MS. hond; Grdt. lond?; Klip. hearma land; other Edd. hond. - 442 Schl. gescodon. - 443 MS. we; Grdt. wel?; Th. om.; Gr. ${ }^{1}$ wel. - $450 M S$. pa ; em. Barn. (p. 20I).$453 \mathrm{Schl}$. om. he. $-464-5 \mathrm{Th}$. sigora wilgiefa, weoruda waldend?, and is followed by Klip. and Ett. 
wæstma blēde, pā sē wilda fugel somnað under swegle side and wide tō his wīcstōwe, pǣr hē wundrum fæst wið nīpa gehwām nest gewyrceð.

470 Swā nū in pām wīcum willan fremmað mōde and mægne Meotudes cempan, mǣrða tilgað; pæs him meorde wile Ece, Almihtig, ēadge forgildan. Bēờ him of pām wyrtum wìc gestapelad

475 in wuldres byrig, weorca tō lēane, pæs pe hī gehēoldan hālge lāre häte æt [h]eortan, hige weallende dæges and nihtes Dryhten lufiar, lēohte gelēafan Lēofne cēosað

480 ofer woruldwelan; ne bip him wynne hyht pæt hy pis lǣne lif long [e] gewunien. Pus ēadig eorl ēcan drēames, heofona hāmes, mid Hēahcyning earnað on elne, oppæt ende cymeð 485 dōgorrīmes. Ponne dēað nimeð, wiga wælgīfre, wǣpnum geprȳped, ealdor ānra gehwæs, and in eorpan fær̀m

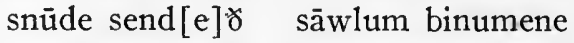
lǣne līchoman, 'p̄̄r hī longe bēor, 490 oð fy̆res cyme, foldan bipeahte.

\section{THE LAST JUDGMENT}

Đonne monge bēo $\gamma$ on gemōt lāed [ed] fȳra cynnes; wile Fæder engla, sigora Sōðcyning, seonop gehēgan, duguða Dryhten, dēman mid ryhte.

495 Ponne $\bar{x}$ riste ealle gefremmap men on moldan, swā se $\mathrm{m}[e a]$ htiga Cyning bëodeð, Brego engla, bȳman stefne

477 MS. eortan; Grdt. heortan?; Th. heortan. - 48r MS. long; Klip. lange. -483 Th. heofonlican? $-488 M S$. sendad; em. Klip. - 49I MS. lædap; Grdt. lædad; Th. læded?; Ett. læded; Klip. lædde. - 496 MS., Edd. mihtiga. 
ofer sīdne grund, sāwla Nergend;

bið se deorca dēað Dryhtnes meahtum

500 ēadgum geendad; æð̌le hweorfað̀, prëatum pringað, ponne pēos woruld, scyldwyrcende, in scome byrneð, āde onǣled. Weorpeð ānra gehwylc forht on fer[h]pe ponne fȳr briceð

505 lǣne londwelan, lìg eal pigéo eorðan ǣhtgestrēon, æpplede gold gïre forgripeð, grǣdig swelgeð londes frætwe. Ponne on lēoht cymeð ældum pisses, in pā openan tīd

5IO fǣger and gefēalīc fugles tācen, ponne Anwald [a] eal ūp āstell[e]ð̌ of byrgen[n] um, bān gegædrað̌ leomu lïc somod - and lī[f]es gǣest. fore Crīstes cnēo. Cyning prymlice

5I5 of his hēahsetle hālgum scineð̛, wlitig wuldres Gim. Wel bip pām pe mōt in pā gēomran tīd Gode līcian.

Đæ̈r pā līchoman leahtra clǣne gongað glǣdmōde, gǣstas hweorfað

520 in bānfatu, ponne bryne stīgeð hēah tō heofonum. Hāt bið monegum egeslīc ǣled ponne ānra gehwylc, sōofæest ge synnig, sāwel mid lice, from moldgrafum sēceð Meotudes dōm,

525 forht, āfæred. Fȳr bið on tihte, $\bar{x}$ leð uncyste.

Pǣr pā ēadgan bēoð

æfter wræchwile weorcum bifongen, àgnum dǣđum; pæt pā æpelan sind wyrta wynsume mid pām se wilda fugel

$498 \mathrm{Gr}^{1}{ }^{1}$ sidan. $-500^{\mathrm{a}} \mathrm{Tr}{ }^{2}$ eallum?; $\mathrm{Tr}$. ædre? - $5 \mathrm{Ir} \mathrm{MS}$. astellað; em. Klip. - 5I2 MS. of; Th. on; MS. byrgenum; em. Siev. - 513 MS. liges; Grdt. lifes?, which Br. accepts; Th. interprets gæst as 'guest.'-517 One-line space between the sections. $-523 \mathrm{Schl}$. be for ge? - $525 \mathrm{MS}$. ontihte; Th. on tihte?; Klip. ontiht; Ett. on tyhte; Gr. ${ }^{1}$ on tihte. $-5_{26}$ Grdt. æled; Klip. uncystan; Ett. uncysta. 
530 his sylfes nest biseteð ūtan, pæt hit fǣringa fȳre byrneð, forswēleð̛ under sunnan, and hē sylfa mid, and ponne æefter lige lïf eft onfēhð ednīwinga. Swā bið̌ ānra gehwylc

535 flǣsce bifongen fīra cynnes ǣnlīc and edgeong, se pe his āgnum hēr willum gewyrce $\gamma$ pæt him Wuldorcyning meahtig æet pām mæð̌le milde geweorðeð̌.

Ponne hlēopriað hālge gǣstas,

540 sāwla sōðfæste song āhebbað, clǣne and gecorene, hergað Cyninges prym stefn æfter stefne, stigar tō wuldre wlitige gewyrtad mid hyra weldǣedum. Bēoð ponne ämerede monna gǣestas,

545 beorhte ābȳwde, purh bryne fȳres.

\section{THE TESTIMONY OF JOB}

Ne wēne pæs ǣnig ælda cynnes, pæet ic lygewordum lēoð somnige, wrīte wōocræfte. Gehȳrað̌ wìtedōm, Iōbes gieddinga. Purh Gǣstes blǣd

550 brēostum onbryrded, beald reordade, wuldre geweorðad hē pæt word gecwæð :

'Ic pæt ne forhycge heortan geponcum, pæt ic in minum neste nēobed cēose, hæle hrāwērig, gewìte hēan ponan

555 on longne sì̛ lāme bitolden, gēomor gūdǣda in grēotes fæơm; and ponne æfter dēaðe, purh Dryhtnes giefe swā sē fugel Fenix - feorh ednīwe æfter æriste āgan mōte,

560 drēamas mid Dryhten, pæ̋r sēo dēore scolu Lēofne lofiað. Ic pæs lífes ne mæg $\bar{æ}$ fre tō ealdre ende gebīdan,

545 Th. abysde?, which Klip. accepts; Ett. ætywde. -553 Ett. on; Th. neabed?; Klip. neodbed; Ett. neabed. $-554 \mathrm{Th}$. hra werig; Gr. hrawerig: 
lēohtes and lissa. Đēah mīn līc sçyle on moldærne molsnad weorpan,

565 wyrmum tō willan, swā-pēah weoruda God æfter swylthwīle sāwle ālȳseð, and in wuldor āweceð; mē pæs wēn nǣfre forbirsteð in brēostum, $\chi \mathrm{e}$ ic in Brego engla forðweardne gefēan fæste hæbbe.'

570 Đus frōd guma on fyrndagum gieddade glēawmōd, Godes spelboda, ymb his ǣriste in èce līf, pæt wē pȳ geornor ongietan meahten tîrfæst tācen pæt sē torhta fugel

575 purh bryne bēacnað. Bāna lāfe, ascan and yslan, ealle gesomnað æfter lïgbryne, læ̈dep sippan fugel on fōtum tō frēan geardum, sunnan tōgēanes, $\quad \mathrm{p} \bar{æ} \mathrm{r} h[\overline{\mathrm{e}}]$ siððan for 580 wun[a] $\delta$ wintra fela - wæstmum geniwad, ealles edgiong, pǣr ǣnig ne mæg in pām lēodscipe l̄̄ppum hwōpan. Swā nū æfter dēaðe purh Dryhtnes miht somod sīpiap sāwla mid līce,

585 fǣgre gefrætwed, fugle gelīcast, in ēadwela[n] xpelum stencum, pǣr sēo sōpfæste Sunne līhteð wlitig ofer weoredum in wuldres byrig.

15. THE JOYS OF THE BLESSED

Đonne sōơfæstum sāwlum scīneð

590 hēah ofer hrōfas hǣlende Crịst, him folgia fuglas scȳne,

$568 \mathrm{Grdt}$. bæt ic. $-569 \mathrm{Ett}$. for $\delta$ wearde? $-570 \mathrm{MS}$. on; Th. in. -579 MS. hi; Grdt. him; Th. he?; Klip. he. $-580 M S$. wuniad; Th. wunað?, which Ett. accepts. -581 Cos. ${ }^{2}$ bær him ænig? $-582 \mathrm{Grdt}$. hwepan or wepan?; Th. assumes a gap after hwopan: 'Here some lines are evidently wanting, though the MS. has no hiatus'; Klip. indicates a hiatus; Ett. says that nothing is lost. $-585 \mathrm{Klip}$. gefræatwede; Klip. gelicaste. $-586 \mathrm{MS}$. -welam (Schl.) ; Grdt., Schl. -welan; other Edd. -welum. 588 One-line space between sections. - 59I Ett. fiörum for fuglas? 
beorhte gebrēdade, blissum hrēmige, in pām glādan hām, ḡ̄stas gecorene, èce tō ealdre. $\quad$ Pǣr him yfle ne mæg

595 fāh fēond gemāh, fācne, sceppan, ac pǣr lifgað ā lēohte werede swā se fugel Fenix - in freopu Dryhtnes, wlitige in wuldre. Weorc ānra gehwæs beorhte blīcero in pām blīpa[n] hām

600 fore onsȳne ēcan Dryhtnes, symle in sibbe sunnan gelīce.

Pǣr se beorhta bēag, brogden wundrum eorcnanstānum, ēadigra gehwām hlifað ofer hēafde; heafelan lixað, 605 prymme bipeahte; Đēodnes cynegold sōðfæstra gehwone sellīc glengeð lēohte in līfe p̄̄r sē longa gefēa, ēce and edgeong, $\bar{x}$ fre ne sweprað; ac hy in wlite wuniað, wuldre bitolden, 6ro fǣgrum frætwum, mid Fæder engla.

$\mathrm{Ne}$ bið him on pām wīcum wiht tō sorge wrōht nē wēpel nē gewindagas, hungor sē hāta nē sē heard[a] purst, yrmpu nē yldo: him se æpela Cyning

6I5 forgifeð göda gehwylc. एǣr gǣsta gedryht Hǣlend hergað and Heofoncyninges meahte mǣrsiað, singað Metude lof ; swinsað sibgedryht swēga mǣste, hǣedre ymb pæt hālge hēahseld Godes.

620 Blīpe blētsiað Bregu sēlestan, èadge mid englum, efenhlēopre pus: 'Sib sī pē, sōor God, and snyttrucræft, and pē ponc s[īe] prymsittendum geongra gyfena, gōda gehwylces,

592 Schl. queries gebredade; $T r^{2}{ }^{2}$ gewerede or besweðade?; Schl. gehrodene? -593 Ett. pone for pam? -599 Klip. blicad; MS. blipam; em. Th. $-600 \mathrm{Ett}$. eces. $-609 \mathrm{Klip}$. betoldne. $613 \mathrm{MS}$. hearde; em. Gr. -623 MS. sy ; Siev. sie. - 624 Klaeb. (Mod. Phil. 2. I4I) ginra; MS., other Edd. geongra. 
625 micel, unmāte, mægnes stren $[g] \gamma u$, hēah and hālig! Heofonas sindon fǣgre gefylled, Fæder ælmihtig, ealra prymma Prym, pines wuldres, uppe mid englum and on eorðan somod.

630 Gefreopa ūsic, frympa Scyppend. एū eart Fæder . ælmihtig

in hēannesse, heofuna Waldend.'

Đus reordiar ryhtfremmende,

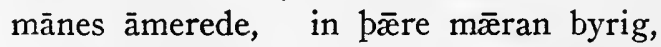
cyneprym cȳpað̌. Cāseres lof

635 singa[ð] on swegle sōðfæstra gedryht: 'Pām ānum is èce weorðmynd for $ð$ būtan ende. Næs his frymð ǣfre, èades ongyn. Pëah hē on eorðan hēr purh cildes hād cenned wæ̈re

640 in middangeard, hwæpre his meahta spēd hēah ofer heofonum hālig wunade, dōm unbryce. Bēah hē dēapes cwealm on rōde treow[e] ræfnan sceolde, pearlīc wìte, hē pȳ priddan dæge

645 æfter līces hryre liff eft onfēng purh Fæder fultum. Swā Fenix bēacnað, geong in geardum, Godbearnes meaht, ponne hè of ascan eft onwæcne[r] in lifes lif, leomum gepungen.

650 Swā se Hǣlend ùs [h] elpe gefremede purh his līces gedāl, líf būtan ende, swā sē fugel swètum his fipru tū and wynsumum wyrtum gefylleð, fǣgrum foldwæstmum, ponne āfỹsed bið.'

$625 M S$. strenðu; Grdt. strengðu?; Th. strengðu. - 635 MS. singad; $E d d$. singað. $-643 M S$. treow; Klip. -treowe. $-648 M S$. onwæened; Grdt. onwæcneð?, which other Edd. adopt. $-650 \mathrm{MS}$., Grdt. elpe; Grdt. helpe?, which other Edd. adopt. 


\section{I6. EPILOGUE}

655 Pæt sindon pā word, swā ūs gewritu secgað,, hlēopor hāligra pe him tō heofonum bið, tō pām mildan Gode, mōd āfȳsed in drēama drēam; $\quad$ pār hì Dryhtne tō giefe worda and weorca wynsumne stenc

660 in pā mǣr[an] gesceaft Meotude bringar, in pæet lēohte liff. Sȳ him lof symle purh woruld worulda, and wuldres blæ̈d, ār and onwald, in päm ūplìcan rodera rīce! Hē is on ryht Cyning

$66_{5}$ middangeardes and mægenprymmes, wuldre biwunden in pǣre wlitigan byrig.

Hafað ūs ālȳfed lucis Auctor pæt wē mōtun hēr mer [itare] gōddǣdum begietan gaudia in celo,

670 pǣr wē mōtu[n] maxima regna sēcan, and gesittan sedibus altis, lifgan in lisse lucis et pacis, āgan eardinga alm[e] letiti[e], brūcan blæ̈ddaga, bland $[\mathrm{u}] m$ et mi $[t] \mathrm{em}$

675 gesēon sigora Frēan sine fine, and him lof singan laude perenne ēadge mid englum. Alleluia.

$655 \mathrm{Schl}$. pæt ba word sindon. - $660 \mathrm{MS}$. mærum (Schl.); em. Grdt. 668 MS., Wan., Con. ${ }^{2}$, Grdt., Th., Klip., Ett., Siev., Br., Go. merueri ; Ett. meruisse?; Gr. ${ }^{1}, W u ̈$., Kal. mereri ; Holt. ${ }^{2}$ meri et veri ; $\mathrm{Tr}_{0}^{2}$ meritare. $670 \mathrm{Wan}$., Con. ${ }^{2}$ bæt; $M S$. motum; em. Con. -673 MS. alma; Ett. almæ; $M S$. letitię; Con. lætitiæ. - $674 M S$., Edd. blandem; MS. mittem; Grdt. mitem. -676 MS. perenne; Wan., Con. ${ }^{2}$, Klip., Ett. perenni.-677 Twoline space follows. 



\section{PHYSIOLOGUS}

\section{PANTHER}

Monge sindon geond middangeard unrīmu cynn, [pära] pe wē æpelu ne magon ryhte āreccan nē rīm witan; pæs wīde sind geond wor $[u] 1[d]$ innan

5 fugla and dēora foldhrērendra wornas widsceope, swā wæter bibūgeð pisne beorhtan bōsm, brim grymetende, sealtȳpa geswing.

Wè bi sumum hȳrdon wrǣtlic $[u m]$ gecynd $[e]$ wildra secgan,

Io fīrum frēamæ̈rne, feorlondum on, eard weardian, èjles nēotan, æfter dūnscrafum. Is pæt dēor Pandher bi noman hăten, pæs pe nippa bear[n], wīsfæste weras, on gewritum cȳpa [ð]

I5 bi pām ānstapan.

Sē is $\bar{x}[g]$ hwām frēond, duguða ēstig, būtan dracan ānum; pām hē in ealle tīd andwrāo leofap, purh yfla gehwylc pe hë geæfnan mæg.

Đæt is wrǣtlic dēor, wundrum scȳne,

20 hīwa gehwylces. Swā hæleð secgað, gǣsthālge guman, pætte Iōsēphes tunece wǣre telga gehwylces blēom bregdende, pāra beorhtra gehwylc, ǣghwæs ǣnlicra, ōprum lixte 25 dryhta bearnum, swā pæs dēores hīw,

$4 M S$. worl; $T h$. worlde?; $G r^{1}{ }^{1}$ world. $-6 T h$. widsceapene? $-7 T r$. (Kynewulf, p. 28) bearm (for bosm)? - 9 MS., Edd. wrætlice gecynd; Th. gecynde? - I3 MS. beard; em. Gr. ${ }^{1}-14 M S$. cypan; Gr. cyðað? ; ir..2 cyðdan. - I5 MS., Edd. æthwam. 
blæ̈c, brigda gehwæs, beorhtra and scȳnra wundrum lixeð, pætte wrætlicra ǣghwylc ōprum, ळ̄nlīcra gien and fǣgerra, frætwum bliceð, 30 symle sēllicra.

Hē hafað sundorgecynd, milde, gemetfæst. Hē is monpwæ̈re, lufsum and lēoftǣl: nele lāpes wiht $\bar{æ}[\mathrm{ng}]$ um geæfnan būtan pām āttorsceapan,

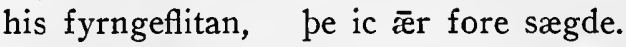

35 Symle, fylle fægen, ponne föddor pigeð, æfter pām gereordum ræste sēceð̌, dȳgle stōwe under dūnscrafum; ðær se pēo[d]wiga prēonihta fæi swife $\delta$ on swe[o] fote, slǣpe gebiesga [d].

40 Ponne ellenrōf ūp āstonder,, prymme gewelga [d], on pone priddan dæg, snēome of slǣpe. Swēghlēopor cymer,, wōpa wynsumast, purh pæs wildres mūð ; æfter pǣre stefne stenc ūt cymeð

45 of pām wongstede - wynsumra stēam, swēttra and swipra swæcca gehwylcum, wyrta blōstmum and wudublēdum, eallum æpelicra eorpan frætw [um]. Ponne of ceastrum and cynestōlum

$5^{\circ}$ and of burgsalum beornprēat monig farað foldwegum folca prȳpum; ēoredcystum, ofestum gefȳsde, dareơlācende — dēor [s]wā some æfter pāere stefne on pone stenc farað.

55 Swā is Dryhten God, drēama R̄̄end, eallum ēaðmēde ōprum gesceaftum, duguða gehwylcre, būtan dracan ānum,

33 MS. ægnum; em. Th. -38 MS. peoð-; em. Gr. ${ }^{1}-39 T h$. swefeঠt

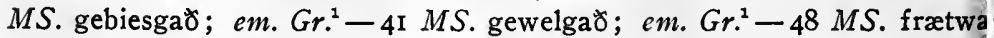
em. $G r^{1}-53 M S$., Edd. efne swa some. $-56 M S$. -mede corr. frol -medum; Th. -medum. 
āttres ordfruman - pæt is se ealda fēond pone hē gesālde in sūsla grund, 60 and gefetrade fȳrnum tēagum, bipeahte prēanȳdum; and pȳ priddan dæge of dīgle ārās, pæes pe hē dēar fore ùs prēo niht polade, Dēoden engla, sigora Sellend. Pæt wæs sweete stenc,

65 wlitig and wynsum, geond woruld ealle. Sippan tō pām swicce sōðfæste men, on healfa gehwone, hēapum prungon geond ealne ymbhwyrft eorpan scēat[a]. Swā se snottra gecwæð Sanctus Paulus:

70 'Monigfealde sind geond middangeard gōd ungnȳðe pe ūs tō giefe dǣleð and tō feorhnere Fæder ælmihtig, and se ānga Hyht ealra gesceafta uppe ge nipre.' Pæt is æpele stenc.

\section{WHALE (ASP-TURTLE)}

$N \bar{u}$ ic fitte gēn ymb fisca cynn wille wōðcræfte wordum cȳpan purh mōdgemynd, bi pām miclan hwale. Sē bið unwillum. oft gemēted,

5 frēcne and fer $[h]$ ชgrim, fareðlācendum, nippa gehwylcum; pām is noma cenned, fyr [ge]nstrēama geflotan, Fastitocalon.

Is pæs hīw gelīc hrēofum stāne, swylce wōrie bi wædes öfre,

Io sondbeorgum ymbseald, sǣrȳrica mǣst, swā pæt wēnap wǣglīpende pæt hỳ on eaalond sum èagum wliten; and ponne gehȳd $[i] \mathrm{a} \gamma$ hēahstefn scipu

66 Th. swæcce. -68 MS. sceatan; em. Gr. ${ }^{1}-7 \mathrm{I}^{\mathrm{a}}$ Th. -gneðе? -74 ine-space follows. - 7 MS. fyrn-; Th.?, Klip., Ett. firgen-; Bugge PBB. I2. 79) Fascitocalon. -8 Cos. $^{2}$ hreowum. -9 Ett. makes worie = uār (Dutch wier), 'seaweed'; Cos. sæwar? - 13 MS. gehydad; Th.?, Flip., Ett. gehyðað. 
tō pam unlonde oncyrrāpum,

I5 $\mathrm{s}[\bar{e}]$ lap sǣmearas sundes æt ende, and ponne in pæt èglond ùp gewita collenfer $[h]$ pe; cēolas stondar bi stape fæste strëame biwunden. Đonne gewīciar wērigfer $[h] \gamma \mathrm{e}$, 20 farờlācende, frēcnes ne wēnað.

On pām ēalonde হ̄eled weccað, hēah fȳr ǣlax. Hælep bēop on wynnum, rēonigmöde, ræste gel[y]ste.

Ponne gefēleð fācnes cræftig

25 pæt him pã fērend on fæste wuniap, wic weardiað, wedres on luste, ðonne semninga on sealtne wāg mid pā nōpe niper gewitep, gārsecges gæst, grund gesēceð,

30 and ponne in dēaðsele drence bifæsteð scipu mid scealcum.

Swā bið scinn $[e n]$ a pēaw, dēofla wìse, pært hī droht[i]ende purh dyrne meaht duguðe beswicað, and on teosu tyhtap tilra d̄eda,

35 wēma $\gamma$ on willan, pæt hỹ wrape sēcen, frōfre to fēondum, oppæt hȳ fæste $\bar{x} \bar{x}$ æt pām wǣrlogan wìc gecēosað.

Ponne pæt gecnāweð of cwicsūsle flāh fēond gemāh, pætte fīra gehwylc

40 hælepa cynnes on his hringe bip fæste gefēged, hē him feorgbona, purh slipen searo, sippan weorpeð, wloncum and hëanum pe his willan hër

15 MS., Edd. setlab. - I8 Klip. bewundne. - 22 MS. ælad; Edd. æle ; Cos. wealleठ? - 23 Klip. dreorig-; Gr. (Spr.) reomig-?, as An. 592 reads; but cf. Krapp on this latter line; MS. geliste; Ett. gelyste. -25 Klip. ferende. -28 Cos. nophlope? - 3I Th. scip? ; MS., Edd. scinna. - $32 M S$. Gr., Wü. drohtende;. Th.?, Klip., Ett. drohtiende. - 35 Gr. ${ }^{1}$ weniad. 39 Cos. hwylc. -40 Cos. hricge. 
firenum fremmað; mid pām hē fāæringa,

45 heolophelme bipeaht, helle sēceð, gōda gēasne, grundlēasne wylm

under mistglōme, swā se micla hwæl se pe bisenceð sæälīpende eorlas and ẏðmearas.

Hē hafað̌ öpre gecynd,

50 wæterpisa wlonc, wrætlīcran gien.

Ponne hine on holme hungor bysga $\gamma$, and pone āgl̄̄ean $\bar{x}$ tes lystep, ðonne se mereweard mūo ontȳneð, wide weleras; cymeð wynsum stenc

55 of his innope, pætte oppre purh pone, sǣfisca cynn, beswicen weorðap.

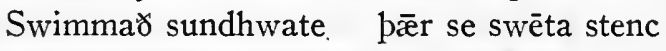
ùt gewīt[e]ช. Hī pār in farad, unware weorude, oppæet se wida ceafl

60 gefylled bið; ponne färinga ymbe pā herehūpe hlemmeð tōgædre grimme gōman.

se pe oftost his unwærlīce, on pās lǣnan tīd, līf biscēawað:

65 l̄̄teð hine beswican purh swētne stenc, lēasne willan, pæt hē bip leahtrum fāh wið Wuldorcyning. Him se āwyrgda ongēan æfter hinsīpe helle ontȳneð, pām pe lēaslīce līces wynne

70 ofer ferh[ð] gereaht fremedon on unr $\bar{x} d$. Ponne se fǣ̄cna in pām fæstenne gebrōht hafað, bealwes cræftig, æt pām $[\bar{a}]$ dwylme, pā pe him on cleofiað,

49 Klip. gecynde. $-50^{a}$ Klip. -wisa. -56 Klip. beswicne. $-58 M S$. rewitad; em. Ett. - 7o MS., Th., Gr., Wï. ferht(-)gereaht; Th.?, Ett. erhð-; Klip. ferhðgeriht; Klaeb. (Mod. Phil. 2. I42) ferhte reht?, 'conrary to just law; $M S$. fremedon; Ett. fremede. $-7 \mathrm{r}^{\mathrm{b}}$ Klip. bæt. $-73^{\mathrm{a}}$ US. ed-; Th.?, Klip., Ett., hæt-; Gr.2 ad-? 
gyltum gehrodene, and $\bar{x}$ georne his

75 in hira liffagum lārum hȳrdon,

ponne hē pā grimman gōman bihlemmeð,

æfter feorhcwale, fæste tōgædre,

helle hlinduru. Nägon hwyrft nē swice, ùtsīp ǣefre, pā [pe] pǣr in cumað,

80 pon mā pe pā fiscas, faraðlācende, of pæs hwæles fenge hweorfan mōtan.

Forpon is eallinga

dryhtna Dryhtne, and ā dēoflum wiðsace

85 wordum and weorcum, pæt wē Wuldorcyning gesēon mōton. Uton ā sibbe tō him, on pās hwīlnan tīd, hǣlu sēcan, pæt wē mid swā lēofne in lofe mōtan tō wīdan feore wuldres nēotan!

\section{PARTRIDGE}

Hȳrde ic secgan gèn bi sumum fugle wundorlícne

pæt word pe gecwæ⿱ wüldres Ealdor:

5 'In swā hwylce tiìd swā gē mid trēowe tō mē

on hyge hweorfað, and gē hellfirena

sweartra geswīcað, swã ic symle tō ēow

mid siblufan sōna gecyrre

purh milde mōd; gē bēơ më sippan

Io torhte, tīrēadge, talade and rīmde, beorhte gebrōpor on bearna stāl.'

79 Th. pa be bær?; Klip. pam-be bær. -82 Th. Here a line or more is wanting; Ett. us ofest selast \| bæt we gecweman [subj.] cyninga wuldrë? $G r$. ofost selast \| bæt we wuldorcyninge wel gecweman?-84 Ett wiðsacan. - 89 $M S$. has line-space following. - 2 Holt. wundorlicn [cwide be wæs wynlic and] fæger?; Tupper (Jour. Eng. and Germ. Phil Ix. 9) gewunan? 
Uton wē pȳ geornor Gode óliccan, firene fēogan, fripes earnian, duguð̌e tō Dryhtne, penden ūs dæg scine,

I5 pæet swā æpelne eardwīca cyst in wuldres wlite wunian mōtan. Finit. 

NOTES 



\section{NOTES ON ELENE}

I ff. The year designated is the 233 d after the cross was buried, according to the legend; see H., ${ }^{2}$ p. 82.

I. wæs. Note the singular.

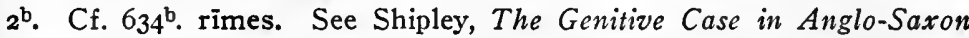
Poetry, pp. I12-3.

3. pinggemearces. So $A n$. I48.

4. wintra. 'Winters' $=$ 'years'; see 633,654 .

5. So 178 .

6. hēo. Ph. always hize.

7. Lèoht. So 486 ; cf. John 8. I.-syxte. This identifies the year as 3 I2 A. D., since Constantine had been acclaimed as emperor in 306 , when he was about 18 years old, by the army in Britain. The author has blended the events of three different years in these opening lines: (I) the war with the Franks (2I), which occurred in 306 ; (2) the original vision (cf. $69 \mathrm{ff}$.) of the flaming cross, with the legend, 'By this conquer,' in 312 ; (3) the war culminating in Constantine's victory (April 20, 322) over the Goths (or Scythians) in Dacia, the modern Rumania, on which occasion the standard of the cross was borne at the head of the army.

II. Holthausen justifies lofhwata, otherwise unknown, by citing ärhwat, dōmhwct, and lofgeorn.-lēodgebyrga. So 203,556 ; cf. Beow. 269.

I3. riht cyning. 'His claim to greatness rests mainly on the fact that he divined the future which lay before Christianity, and determined to enlist it in the service of his empire. . . . There is no reason to doubt the sincerity of Constantine's conversion to Christianity. . . . The moral precepts of the new religion were not without influence upon his life, and he caused his sons to receive a Christian education' (Encyc. Brit., IIth ed., 6. 989). Cf. Encyc. Brit. 23. 656-63: 'His reign of fourteen years was marked by two events of first-rate importance-the recognition of Christianity as the religion of the empire, and the building of the new capital at Byzantium.' And again (ib.23.510): 'The reign of Constantine the Great forms the most deep-reaching division in the history of Europe.'

I6. For hrōðer as dative, see (Sievers-Cook) Gram. 289.

I9b. Werod. The Middle Irish version goes into detail: 'All the barbarous, idolatrous, rude tribes from the north of Europe, namely from the Danube and Mœsia and the Riphæan mountains in the north, and over the river Don, and from the Mrotic marshes, and Alania, and Dacia, and Germany, and the land of the Goths, and over the river Danube in the north, and over the Rhine to the Elbe, even to the summits and verges of the Alps in the south' (Schirmer, Die Kreuzeslegenden im Leabhar Breac, pp. 31-2). 
20. Cf. $58^{\mathrm{a}}$. The names are coupled in Widsith 57 . The Huns do not appear in the history of Europe till nearly half a century later. About 374 they were fighting against the Goths (not with them) under Athanaric in the general region of this battle between Constantine and the Goths. Athanaric first retreated to the Danube, and then northward over the mountains into Transylvania, leaving the Huns in possession of Rumania. A little later they settled south of the Danube, and about this time professed Christianity (Encyc. Brit. IIth ed., I3. 933; I2. 273). - Hrëo= 'glorious.'

2I. The Hugas are coupled with the Franks and Frisians in Beow. 2502, 2914. The Quedlinburg Annals (Mon. Germ. Script. 3. 31) say that all the Franks bore this name from a certain leader, Hugo.

$23^{\mathrm{b}}$. So $125^{\mathrm{b}}$; cf. $90^{\mathrm{b}}$.

$24^{\mathrm{b}}$. Cf. $235^{\mathrm{a}}$, II $87^{\mathrm{a}}$.

$25^{\mathrm{a}}$. The emendation according to 107 , herecumbol not being found.

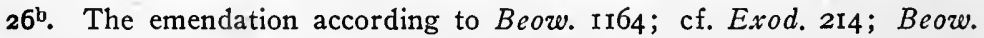
387,729 ; the vowel as elsewhere in Elene.

$27^{\mathrm{b}}$ ff. Cf. $110^{\mathrm{b}} \mathrm{ff}$.

29. Cf. $112^{\mathrm{b}}$.

31. burglocan. So Beow. I928; Gen. 2537, etc. Cf. Angl. 25. 386.

$34^{\mathrm{a}}$. Cf. $45^{\mathrm{a}}$.

$34^{\mathrm{b}}$. The emendation according to 224,$235 ; J u d$. I7.

$35^{\mathrm{b}}-6^{\mathrm{a}}$. Holt translates: 'Bands of picked horsemen strengthened the force [forces ?] of the foot-soldiers.' For a variety of translations, see $\mathrm{H}^{2}$ 's note on the passage. The subject of trymedon is implied; e ered is originally a compound-eoh-rād= 'horse-riding.' A cyst comprises a thousand men in Exod. 230-2, where the whole army of the Israelites (600,000 men, according to Exod. 12. 37) was divided into the 12 tribes (fédan), with 50 cysta to the tribe; but cyst in general is a more vague expression. Whether cyst is the same as the cyst which means 'the choicest' (cf. Pr. 15) is somewhat doubtful: Grimm translates éredcest here as 'electa legio,' and Körner as 'ausgewählte Reiterschar,' which H. ${ }^{2}$ inclines to accept; the poet seems to have the Roman legion in mind, in which the cavalry was normally not more than one-fifteenth of the whole.

36. pæet here = 'until.'

37. Dānübie. Rumania 'consists of a single inclined plane stretching upwards, with a north-westerly direction, from the left bank of the river to the summits of the Carpathians. It is divided into three zones-steppe, forest, and alpine. The first begins beyond the mud-flats and reed-beds which line the water's edge, and is a vast monotonous lowland

The surface is a yellow clay' (Encyc. Brit., IIth ed., 23. 826). 'For 290 miles, the Rumanian shore is a desolate fen-country. . . . East of Bucharest, a chain of lagoons and partially drained marshes stretches inland for 45 miles,' and is followed for IIo miles by a barren plain (ib., pp. 825-6). 
It is perhaps a testimony to the impression made by Constantine upon the peoples of that region that Rumanian literature still preserves his story. Cf. Encyc. Brit., IIth ed., 23. 848: 'Next [to the history of Alexander the Great] comes the legend of Constantine, of his tours and his exploits-a remarkable collection of purely Byzantine legends. In addition to these there is the history of St. Sylvester and the conversion of Constantine, \&c., all still in MS.'

$50^{\mathrm{b}}-\mathrm{I}^{\mathrm{a}}$. Note the rhyme.

50. rand. $\mathrm{H}^{2}$ notes this and other singulars for plurals: $55,125,245$, 256,264 , etc.

53. With -fel cf. Mod. Eng. felon in N.E. D. (H. $\left.{ }^{2}\right)$.

$5^{6} \mathrm{ff}$. The Latin has: 'Videns autem quia multitudo esset innumerabilis, contristatus est, et timuit vehementer.'

$5^{\mathrm{a}}$. Hrē̈ra. Cf. $20^{\mathrm{b}}$.

59 . 'Oæt $=$ 'so that.' - he $=$ Constantine; Pogatscher (Angl. 23, 289) assumes that it is the king of the Huns.

69-104. See Introduction, pp. xxii-xxiv.

72. Latin: 'vir splendidissimus.'

$74^{\mathrm{a}}$. geȳwed. Supply wesan.

$85^{\mathrm{a}}$. In allusion to in hoc signo vinces. Hence täcen, like bēacen, frequently $=$ 'cross.'

86 . Holt: 'he opened wide the secret places of his heart.' Körner interprets: 'he breathed free again.'

88b-go. Latin: 'vidit signum crucis ex lumine claro constitutum.' The poet had in mind the ecclesiastical crosses which he may have seen; cf. the beginning of the Dream of the Rood.

$93^{\mathrm{b}}$. oferswiòesơ. Cf. Gram. 20I. 6; 356, note I.

96. Cf. $108^{\mathrm{b}}, \mathrm{II}^{\mathrm{b}}$.

96b. bȳ. Cf. 796-7, 946, 956 .

$99^{\mathrm{a}}$. Heht bā. So 105, 153, 276, 691, 877, I161, 1202.

$99^{\mathrm{b}}$. Cf. $150^{\mathrm{b}}, 1074^{\mathrm{a}}$.

$100^{2}$. Cf. $1199^{2}$.

I03 ${ }^{\mathrm{b}}$-4. rōde . . . tăcen $=$ 'sign of the cross.'

I05-27 . The Latin basis is: 'Et surgens impetum fecit contra barbaros, et fecit antecedere sibi signum crucis; et veniens cum suo exercitu super barbaros cœpit cædere eos proxima luce.'

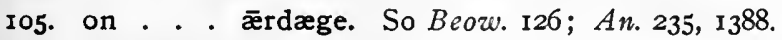

IIO ${ }^{2}$. So 406 ; cf. I80.

$110^{b}$ ff. Cf. Jud. 204 ff. ; Exod. I 60 ff.; Brun. 60 ff.; By. I 60 ff.; Beow. 3024 ff.; Gen. 1983-4.

IIob. weorces gefeah. So 849 .

II4-5. Note the rhymes.

121 ${ }^{\mathrm{b}}$. So $23^{\mathrm{b}}$.

123. pūf. Lat. tufa.

$125^{\mathrm{a}}$. For the singular, cf. $257 \mathrm{ff}$. 
127. Trautmann (BB. 23. 99) would read instēepes, for the sake of the metre.

I3I-6. Sume . . . sume. So Chr. 668-680; Jul. 473-490, etc.

134. So $B y$. 194 .

I35. Cf. Beow. 2540.

139 . So Jud. $237^{\mathrm{a}}$.

I $4^{\circ}$. So $A n$. $1535^{\mathrm{a}}$.

$140^{\mathrm{b}}$. For a defense of darod asc, the reading of the manuscript, see Klaeber, Archiv I12. 147-8.

I4 $\mathrm{I}^{\mathrm{a}}$. See $J u d$. $220^{\mathrm{b}}-223$.

I $42^{\mathrm{a}}$. Cf. $J u d .298^{\mathrm{a}}$.

$142^{\mathrm{b}}-3^{\mathrm{a}}$. Cf. $J u d \cdot 3 \mathrm{II}^{\mathrm{b}}-2^{\mathrm{a}}$.

$144^{\mathrm{a}}$. So $264^{\mathrm{a}}$.

146a. Cf. Jud. $266^{\mathrm{a}}$.

I $48 \mathrm{ff}$. The Latin has: 'Veniens autem Constantinus in suam civitatem'; the Middle Irish has $\left(\mathrm{H}^{2}{ }^{2}\right)$ : 'Thereupon the king came with great triumph to his own city.'

$149^{\mathrm{a}}$. So Beow. $124^{\mathrm{a}}$.

$15 \mathrm{I}^{\mathrm{a}}$. Cf. 215, 217, 254, 27I, 1096.

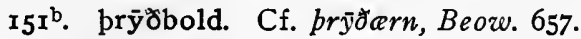

I54 ${ }^{\mathrm{a}}$. sionode. Lat. synodus.

160. Cf. 574 .

162 ${ }^{\text {. }}$ Cf. blëdgifa, An. 84, 656.

$162^{\mathrm{b}}$. 'whose beacon this was.'-bēacen. See note on $85^{\mathrm{a}}$.

166-7 ${ }^{\mathrm{a}}$. Cf. 536-7.

173. him wæs. So $18,627,936$; cf. was him, 195, 993.

$184^{\mathrm{b}}$. Cf. tīres tō tācne, Beow. I654.

I92 ${ }^{\mathrm{a}}$. Constantine was baptized in 337 , by Eusebius, the Arian bishop of Nicomedia. The Latin of the legend has $\left(\mathrm{H}^{2}\right)$ : 'Mittens autem rex . . ad . . . Silvestrum papam, fecit eum venire ad se, et . . . baptizavit eum.' Cf. McKilliam, Chronicle of the Popes, p. 29: 'Notwithstanding the fact that Constantine's baptism in Rome is well known to be legendary, the spot on which it is pretended to have taken place is marked in the church of St. John Lateran by an obelisk.'

I94. So Beow. 607.

I99 ${ }^{\mathrm{a}}$. So $105^{\mathrm{a}}$, II $57^{\mathrm{a}}$.

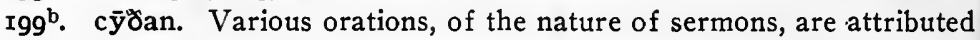
to Constantine.

$20 \mathrm{I}^{\mathrm{b}}$. One of the greatest services to the Church with which Constantine was credited in the Middle Ages was represented by the spurious Donation of Constantine, a document forged between 750 and 800 . In virtue of this, 'it was believed that the first Christian emperor, in withdrawing to Constantinople, had bestowed on the pope all the provinces of the Western Empire, and that in consequence all sovereignty in the West, even that of the emperor, was derived from pontifical concessions. 
From all points of view, both religious and political, the pope was thus the greatest man of the West, the ideal head of all Christendom' (Encyc. Brit., IIth ed., 20. 689). Dante believed in the fact of the Donation, but regarded it as a source of the greatest evils (Inf. 19. 115-7). His lines have thus been translated by Milton:

Ah Constantine! of how much ill was cause,

Not thy conversion, but those rich domains

That the first wealthy pope received of thee.

Petrarch goes so far as to imprecate the pains of hell upon Constantine for his gift. In his Sixth Eclogue (158-9), the apostle Peter (Pamphilus) speaking to Clement VI (Mitio), exclaims (ed. Avena, p. I24):

Eternum gemat ille miser, pastoribus aule Qui primus mala dona dedit!

On this the comment of Benvenuto da Imola is (Avena, p. 2ig) : 'Exclamat contra Constantinum, qui dedit primo dotem Ecclesie, ideo dicit: "Ille miser Constantinus ploret et crucietur perpetualiter in abisso inferni, quia primus Constantinus dedit mala dona prelatis Ecclesie."' See also the last two lines of Petrarch's sonnet, Fontana di dolore (tr. Cayley, p. I93).

Lorenzo Valla (ca. 1406-1457) was the first to assail (1440) the genuineness of this document, but its falsity was not universally admitted till the end of the I8th century (cf. Encyc. Brit. 8. 408-9; Voigt, Wiederbelebung des Classischen Alterthums, 3d ed., I. 469-470).

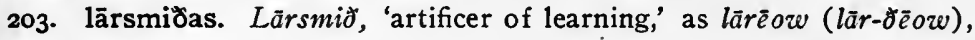
'servant of learning.'

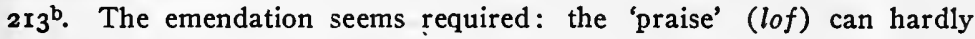
have been 'mindful' (gemyndig).

$24^{\mathrm{a}}$. Cf. $44^{2}, 664^{\mathrm{a}}$.

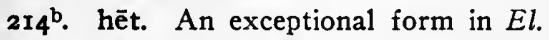

$214^{\mathrm{b}}-27 \mathrm{I}^{\mathrm{a}}$. The Latin basis is $\left(\mathrm{H}^{2}\right)$ : 'Misit suam matrem, Helenam, cum magno exercitu, ut exquireret sanctum lignum crucis Domini. . . . Helena . . . non est moras passa, donec victoriæ Christi invenit lignum.'

215 ${ }^{\text {a }}$ flōdwege. Foldweg also exists, but Elene went by sea; cf. $P h .64^{\mathrm{a}}$.

$218^{\mathrm{a}}$. So $625^{\mathrm{a}}, 843^{\mathrm{a}}$; cf. 1092.

$218^{\text {b }}$ hȳded. The Middle Irish text has $\left(\mathrm{H}^{2}{ }^{2}\right)$ 'that Christ was crucified and his cross hịden by the Jews.'

229 ${ }^{\text {a }}$ orcnæwe. $A n .770$ has orcnäze.

$230^{\mathrm{a}}$. So $J u l .680$; cf. $39^{\mathrm{a}}$.

232 $^{\mathrm{a}}$. stōdon. Note the subject.

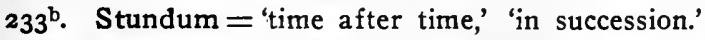

235. Rhyme. Cf. I18 $7^{\mathrm{a}} ; A n$. $1205^{\mathrm{b}}$. 
$237^{\mathrm{a}}$. The metre requires fifl-; cf. $P B B$. 10. $48 \mathrm{I}$.

238 . For -pissan cf. An. 257, 446.

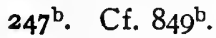

248. Cf. Beow. 32: 'P ̄̄r æt hȳðe stōd hringedstefna.'

250 $0^{\text {b } 253 . ~ C f . ~ B e o w . ~ 397-8 . ~}$

$25 \mathrm{I}^{\mathrm{a}}$. See Krapp's note on $A n .236$.

$\mathbf{2 5}^{\mathrm{I}}$. sunde. Cf. $A n .269$, where the corresponding word is ware, "by the ocean.'

252. Cf. Chr. 864 .

$255^{\mathrm{a}}$. So $996^{\mathrm{a}}$.

$256 \mathrm{ff}$. Cf. Beow. I I Io ff., I $243 \mathrm{ff}$.

274 $4^{\mathrm{b}}$. So $P h$. $167^{\mathrm{a}}$.

279. meðelhëgende would seem to be the direct object of Heht, 276.

284. wæs. But plural subject.

$289^{\mathrm{b}}$. So $323^{\mathrm{b}}$.

$295^{\mathrm{b}}$. Cf. $727^{\mathrm{b}}$.

$297^{\mathrm{b}}-8^{\mathrm{a}}$. Cf. Chr. $1126^{\mathrm{b}}-7^{\mathrm{a}}$. The Latin has: 'Eum qui per sputum oculos vestros illuminavit, immundis potius sputis injuriastis.'

$302^{\text {b. }}$ tō. So 500 .

$304^{\mathrm{b}}$. So $543^{\mathrm{a}}$.

314. glēawe. Cf. An. 1648, wisfastne and wordes glēazne. The poet is not likely to have ended 314 and 315 with the same word; but cf. 4 II.

$319^{\mathrm{b}}$. So $410^{\mathrm{b}}$; cf. $325^{\mathrm{b}}, 517^{\mathrm{b}}$.

$320^{a}$. H. ${ }^{2}$ cites Rid. I6. I6, and alleges the metrical necessity. Cf. Sievers, in $P B B$. 29. 312.

323. wordgerȳno. There is no necessity for Holthausen's emendation, as suggested by Shipley (The Genitive Case in Anglo-Saxon, p. 84), and thus making -gerȳno depend upon wisestan.

324. pæt. Introducing a final clause. One is tempted to emend to $b \bar{a}$, referring to wordgerȳno.

332. So 404 .

336. Cf. 776 .

337. Moyses. Rather Isaiah (7. 14).

$33^{\mathrm{a}}$. So $344^{\mathrm{a}}$.

$339 \mathrm{ff}$. The Latin has: 'Puer [vobis] nascetur [in secretis], et mater ejus virum non cognovit.'

345 ff. Ps. 16. 8 ; cf. Jer. 2. 27.

350. Essāias. The spelling with $s s$ is most naturally explained on the ground of Irish influence, according to Carleton F. Brown (Eng. Stud. 40. 10).

353 ff. Isa. I. $2-3$.

369. For his emendations, Holthausen compares 390 and 663.

$37 \mathrm{I}^{\mathrm{a}}$. So Chr. 405 ; Jul. 594, etc.

$372^{\mathrm{b}}$. Cf. $406^{\mathrm{b}}$.

375. Supply hie after $p a t$, and so $409\left(\mathrm{H}^{1}{ }^{1}\right)$.

378. bebēad. So 715, 980, IOI8, II3I, 1220. 
389. forsēgon. But forsäwon, I3I8; sēgon, I105. Cf. Gram. 39I. 2, and note 7 .

402 $^{\mathrm{a}}$. H. ${ }^{2}$ takes $b e$ as $b \bar{e}(=b \bar{y})$, but cf. 513-4, where $\overline{\mathscr{e}} b y l g \partial=$ synna wunde.

403 ${ }^{\mathrm{a}}$. bēodenbealwa. Perhaps better pēodbealwa, as in Chr. 1268; An. II 36 .

$$
418^{\mathrm{a}} \text {. Cf. } 586^{\mathrm{a}} \text {. }
$$

423. orscyldne. This word is not found, but there are half a dozen other compounds with or- (='destitute of'): thus mēte, 'small'; ormāte, 'immense.'

$$
\text { 426 bo } \text {. Shr. } 75^{\mathrm{b}} \text {, } 848^{\mathrm{b}} \text {; cf. Jul. } 695^{\mathrm{b}} \text {. }
$$

429. trio. No doubt miswritten for $\operatorname{trēo}$.

437. Sachius. Carleton F. Brown supposes that the $S$, for $Z$, is due to Irish influence (Engl. Stud. 40. 13).

439. Cf. $447^{\mathrm{a}}, 517^{\mathrm{b}}, 530^{\mathrm{b}}$.

44I. Here the Middle English poem has (1. I83): 'If it bifall, sun, in bi live.'

$$
447^{\mathrm{b}} \text {. Cf. } 676^{\mathrm{b}} \text {. }
$$

448-453. The Latin is: 'Jam enim amplius Hebræorum genus non regnabit, sed regnum [et gloria] eorum erit qui adorant Crucifixum; ipse autem regnabit in seculum seculi.'

457. sendan. Lat. injecerunt. Weorpan is similarly used: Mk. I4. 46 (injecerunt), Lk. 20. I9 (mittere); the Wycliffite version has 'sente into him hondis', Jn. 7. 30.

$$
46 \mathrm{I}^{\mathrm{a}} \text {. So } 564^{\mathrm{a}} \text {. }
$$

47. him. Not singular (H.), but the plural implied in gēod (468). The Latin has: 'multoties contradicebam illis.'

477. him. Not plural (H.), but singular (= Christ). Latin: 'putantes mortificare Immortalem.'

489. bröठor. Holthausen, after Schirmer and Nestle, comments on the fact that the martyr Stephen (Acts 7.59) is here made contemporary with Constantine, an anachronism of 300 years. The historic Judas (Cyriacus) suffered as a martyr in A. D. I34.

493. yfel yfele. Rom. 12. I7.

$495 \mathrm{ff}$. Acts 7.60 .

497. Saules. Acts 7. $58 ; 8$. I.

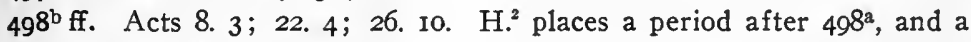
comma after $500^{\mathrm{a}}$.

$503^{\mathrm{a}}$. So $1086^{\mathrm{a}}$.

504-5a. Acts 13. 9.

$505^{\mathrm{a}}$. Cf. $75^{6}$.

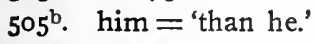

508 . odye. Here $=$ 'and.' Cf. Fates of Men 2: 'patte wer and wif in woruld cennad.'

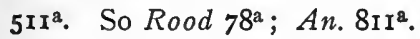

$5 \mathrm{II}^{\mathrm{b}}$. So $\operatorname{Rood} 78^{\mathrm{b}}, 95^{\mathrm{b}}$. 
514 $4^{\mathrm{a}}$. So Chr. 1314; Jul. 710.

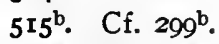

$5^{20^{\mathrm{a}}}$. So $899^{\mathrm{a}}$.

$5^{23^{\mathrm{a}}}$. So $A n$. $595^{\mathrm{b}}, 8 \mathrm{II}^{\mathrm{b}}$.

$\mathbf{5 2 3}^{\mathrm{b}}$-4. The Latin has: 'noli blasphemare eum.'

530. septe. See H. 's note, and Krapp's note on $A n .742$.

$53 \mathrm{I}^{\mathrm{a}}$. giddum. Cf. $4 \mathrm{I} 8,542,586 ;$ Wid. 139.

$53^{\mathrm{r}} \mathrm{b}^{\mathrm{b}} \cdot N \bar{u} . . . n \bar{u}=$ 'Now . . . since.' Cf. 814-5, and the other instances given by Grein, Sprachschatz 2. 30I.

$53^{\mathrm{I}}$. geare cunnon (cüðon) occurs $167^{\mathrm{b}}, 399^{\mathrm{b}}, 648^{\mathrm{b}} ; C h r .573^{\mathrm{b}}$; cf. Beow. 2070. However, the difficulties with this reading are here too great. $\mathrm{H}^{2}{ }^{2}$ ends $53 \mathrm{I}$ with a period, and 535 with a question-mark; while other editors end 53I with a comma, and 535 with a period. In both cases there is repetition $\left(531^{\mathrm{b}}, 535^{\mathrm{b}}\right)$, and Holthausen, besides, has a question $\left(532^{\mathrm{a}}-5^{\mathrm{b}}\right)$, which does not employ the inverted order, and ignores the parallelism of $N \bar{u}$. . . $n \bar{u}$. The emendation provides a verb equally fit to govern hwot, avoids the repetition, renders unnecessary the change of pince (cf. $54 \mathrm{I}^{\mathrm{b}}$, and the optatives in Gen. 2846, By. 215, Ps. 70. Io), and preserves the parallelism of $N \bar{u}$. . . $n \bar{u}$. For the phrase, $N \bar{u} g \bar{e}$... . imp. pl., see $372^{\mathrm{b}}$, and cf. $406^{\mathrm{b}}, 607^{\mathrm{b}}$.

$534^{\mathrm{a}}$. frēotrēo is not otherwise found, but cf. frēobearn, 672 .

538. Cf. 572.

$547^{\mathrm{a}}$. H. . $^{2}$ quotes from the old Saxon Heliand 5959-60: 'thuo bigunnun im quidi managa under thèm weron wahsan,' which would be in $\mathrm{OE}$.: ' $\gamma a \overline{~ b e g u n n o n ~ h i m ~ c w i d a s ~ m a n i g e ~ u n d e r ~ đ a ̄ m ~ w e r u m ~ w e a x a n . ' ~}$

575. wyröed. $P h$. has weorðeむ.

$57^{\mathrm{b}}$. Cf. $131^{\mathrm{b}}, 136^{\mathrm{b}}$, but also $1279^{\mathrm{b}}$.

$58 \mathrm{I}^{\mathrm{a}}$. Cf. $617^{\mathrm{a}}, 1047^{\mathrm{a}}$.

$583^{\text {a. }}$ Cf. Ps. 73. 6; 109. 18, 29.

$589^{\mathrm{a}}$. wyrda gerȳno. So $8 \mathrm{r} 3^{\mathrm{b}}$.

$59 \mathrm{I}^{\mathrm{a}}$. for eor'oan $=$ 'on earth.'

606-7 a. Cf. Chr. 596-7 .

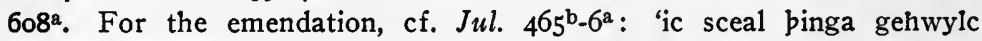
polian and bafian.'

609-10. Expanded lines, like 667-8, 701 .

6ro. The MS. rex is apparently miswritten for nex, which might naturally be translated by cwealm (cf. $676^{\mathrm{b}}$ ), and is so translated in the Wright-Wülker Vocabularies 456. 32. Cwealmgeniola would resemble sweordgeñ̄ola, El. I181; torngenīöla, El. 568, I306; An. І230; cf. māngeniðla, $A n$. 9I6. The latter designate persons, while cwealmgenidla must be abstract (= 'deadly enmity'), like hungres geñ̄dlan, El. 70r.

$612^{\mathrm{a}}$. So $698^{\mathrm{a}}$.

6r6a. Holt: 'to ward off his hunger.' Read wiơ hungre tō hlēo?

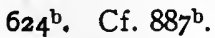

627 $7^{\text {b }}{ }^{\text {a }}$. Cf. Chr. 499-500; Gu. II8I-2; add Beow. 49, 24I9, 2632; Chr. 539; Gu. I310; An. I709. 
629 ff. ge . . . ond. See Gen. 752-3. The ge . . . ge of El. 965-6 must be taken into account in deciding on our interpretation; the passage is difficult, at best. For heofonrices hyht, see $A n$. 1052; for swā in this sense, Chr. 306; Jul. 170; W. 88;An. 922; Gen. 252 ff., etc. mǣrne. Cf. 990, 1064, 1223, 1242; Chr. 971; Jul. 731; Ph. 633, 660; An. 227, 815; Gu. 42; Gen. 950; Ap. 67, etc.

634. Cf. 2.

644. gemynd. Cf. Gram. 267. b.

$646^{\mathrm{b}}$. fyr. This form of the comparative in Beow. 143, 252; cf. El. II $42^{\mathrm{a}}$.

657. ond. Klaeber (Angl. 29. 271) would interpret almost as 'since.' 667. Cf. 609.

662. Cf. 6I9.

$676^{\mathrm{b}}-7^{\mathrm{a}}$. Cf. $447^{\mathrm{b}}$.

$697^{\mathrm{a}}$. The stem of besylced must be derived from the strong verb seolcan; cf. besolcen (= 'torpid,' 'inert'), Cura Past. 239. 3; 289. I5; āseolce (='grow weak, languid'), Cura Past. 275. 20; āsealcan (for äseolcan), Gen. 2167: 'ne lǣt bū bē bīn mōd āsealcan.'

709'. scēad. See Gram. 395. 2. b, note 4.

$72 \mathrm{I}^{\mathrm{a}}$. So $P h$. $4 \mathrm{I} 9$.

$724^{\mathrm{b}}$. So $A n$. $4 \mathrm{1}^{\mathrm{b}} \mathrm{b}, \mathrm{1} 497^{\mathrm{b}}$.

726 b. Cf. Chr. $228^{\mathrm{b}}$; Rood $107^{\mathrm{b}}$; Gifts of Men 27.

730. Ps. 95.5 ; 102. 25 ; Isa. 40.12.

731-2. Ps. 99. I.

734. The Latin has: 'sunt currentia in aera . . . luce immensa.'

$734^{\mathrm{b}}$. Cf. Chr. $164^{2}$; Rood $5^{\mathrm{b}} ; P h .596^{\mathrm{b}}$.

$740^{\mathrm{b}} \mathrm{ff}$. Cf. Chr. $385 \mathrm{ff}$; $A n .7 \mathrm{I} 7 \mathrm{ff}$.

$74^{\mathrm{b}}$. syx. The Latin has sex.

$743-4^{\mathrm{a}}$. Isa. 6. 2.

744. Ezek. I. 5.

745 -6. Ezek. I. 25-8.

747. Latin: 'incessabili voce clamant.'

747 ${ }^{\text {b-8. }}$ Cf. $P h .616-7,634-5$.

750. ceruphin. Isa. 6. 2. The spelling with $p h$, instead of $b$, is a definite mark of Irish orthography, according to Carleton F. Brown (Engl. Stud. 40. 6).

75I-4 . Isa. 6. 3. Cf. Chr. 403-5, $408-9 ; P h .626^{\mathrm{b}}-9$.

755. sēraphīn. But see Gen. 3. 24.

757. lëgene sweorde. Gen. 3. 24. Cf. fÿrene sweorde, Gen. 947, 1575. 759-771. See Abbetmeyer, pp. 9, 17.

763. āwurpe. Rev. 12. 9.

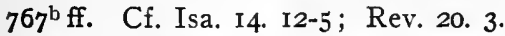

$769^{\mathrm{a}}$. Cf. Matt. 23. 27. For $f u l$ with the genitive, see $939^{\mathrm{b}}$.

776. Cf. $336 ; P h .639 ; G u .1335$.

$782^{\text {b. }}$ pin. Modifies Bearn, $783^{\text {b. }}$.

$783^{\mathrm{a}}$. mægo. For the emendation, see $775^{\mathrm{a}}, 790^{\mathrm{a}}, 1255^{\mathrm{a}} ; J u d .58,254$. 
787-8. Cf. Exod. 13. I9. For the Hebrew legend, see Emerson, Mod. Lang. Notes 14. 166, and the references in Holthausen's note.

$790^{a}$. purg. Unusual spelling. Cf. 289.-gesceap. Hardly 'universe,' as in Jul. 273. In 183, 1032, gesceaft $=$ 'cross.' Here possibly 'Mary'; cf. 783. See also $686,699$.

$793^{\mathrm{b}}-6^{\mathrm{a}}$. The Latin has: ' $\mathrm{Fac}$ ab eodem loco fumum ... suavitatis ascendere.'

796'. Ic gelyfe. 'I shall believe'; the Latin has: 'ut et ego credam.'

$801^{\mathrm{a}}$. walde $=$ 'that he rules'; in the same construction as sie, $799^{\mathrm{a}}$. The verb governs wuldres. Cf. wuldres $W(e)$ aldend, Beow. I7, 183, 1752; An. 193, 539; Dan. 13; add wuldres Cyning, Jul. 516; Wuldorcyning, Ph. I96, cf. El. 291. The idea is derived from Ps. 24. 7-10.

$802^{\mathrm{a}}$. So $894^{\mathrm{a}}$.

805 -6. Latin: 'Ita ut admiratus Judas, plauderet ambabus manibus suis.'

826' bōcum. Latin: 'qui [Stephanus] scriptus est in Actibus . . . apostolorum.'

$83^{\mathrm{b}}$-9. 'As they should [and would] not have done, had they not listened to the representations of the author of sins.' H. $^{2}$ takes fruman as nom. plur. = 'the Jews.'

839. bǣr. 'If'; cf. 979.-leahtra fruman. See $772^{\mathrm{a}}$; Jul. 347, 362.hȳrdon. Cf. 1210.

$85^{\mathrm{b}}$. āhangen. For the emendation cf. $445,67 \mathrm{r}, 862^{\mathrm{b}}$.

853-6a'. The Latin has: 'Scimus autem [de sanctis Evangeliis] quia ceteræ duæ latronum sunt qui cum eo crucifixi sunt.'

$85^{\mathrm{b}}-7^{\mathrm{a}}$. Matt. 27. 45.

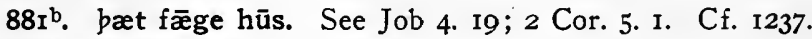

$883^{\mathrm{a}}$. legere fæst. So $723^{\mathrm{a}}$.

$884^{\text {b}}-90^{a}$. The Latin has: 'Imposita autem tertia, cruce Dominica, super mortuum, statim surrexit qui mortuus fuerat juvenis.'

$890^{\mathrm{b}}-3^{\mathrm{a}}$. Latin: 'Omnes qui aderant glorificabant Dominum.'

895. Before this line the MS. lacks XI.

$895^{\text {a }}$. wæs. Has the plural wundor as predicate nominative; cf. I ff.

903. manna might possibly be nom. sg.; cf. Ps. 143. 4 .

909. Cf. Acts 2. 24 ; Ps. I8. 4 ; II6. 3.

$9 \mathrm{II}^{\mathrm{b}}$. fǣger is used in a familiar modern sense.

$916^{\mathrm{b}}-7^{\mathrm{a}}$. 'I can not now succeed with respect to any right (of my rights).' Cf. $910^{b}$.

919 $9^{\mathrm{b}}-2 \mathrm{O}^{\mathrm{a}}$. In Gen. 72, the devils in hell ne porftan hlüde hlihhan, and in By. 47 the defeated foes hlihhan ne borftan (Klaeber, Herrig's Archiv II3. 148). Holt (following Grein) translates:- 'I dare not despise this cross with scoffing laugh'; and Simons (Cynewulfs Wortschutz, p. 79) renders hleahtre by 'Hohngelächter,' and suggests (p. 78) that herigean may = herwan, 'mock'; but cf. Klaeber, loc. cit.

$92 \mathrm{I}^{\mathrm{a}}$. Cf. Jul. $323^{\mathrm{a}}$, of bām engan hām. 
92 $\mathrm{I}^{\mathrm{b}}$. oft. The devils were continually escaping from hell, and needing to be returned thither; cf. Jul. 32I ff.

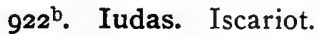

926. wiðercyr. Cf. wið̋erlēan, wið̋ertrod, and Ger. Wiederkehr.sidðan. Against Brown's emendation is the wið $\partial \bar{e}$ of the next line.

928. Julian the Apostate (33I-363). 'Though there was no direct persecution, he exerted much more than a moral pressure to restore the power and prestige of the old faith' (Encyc. Brit. 15. 548).

$93^{\mathrm{b}}$. He himself being regarded as the prophet.

940-52. See Abbetmeyer, pp. 9, I7.

94 $\mathrm{I}^{\mathrm{a}}$. sār niwigan. No doubt from Virgil (Aen. 2. 3): renovare dolorem.

$959^{\mathrm{b}}$. weres snyttro. Cf. $938^{\mathrm{b}}$.

$962^{\text {b}}-3$. Cf. Beow. 625-6: 'Gode bancode wīsæst wordum, bæs be hire [Wealhtheow] se willa gelamp.'

967. wuldor-. To be pronounced as a monosyllable $\left(\mathrm{H}^{2}{ }^{2}\right)$.

968. Before this line the MS. lacks XII.

968-ror7. There is no direct Latin source for this part.

972 ${ }^{\mathrm{b}}$. Cf. Beow. 93, swā weter bebūgeð, and $A n$. 333, swā wìde swā weter bebūgeð.

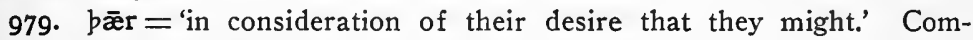
menting on the parallel line, Jul. 570, "bǣr hē hit for worulde wendan meahte,' Strunk remarks : "pǣr is to be translated by "if," i. e., "if only!" "would that!"' See my note on Chr. I3I2; Soul I4I ; and cf. Angl. 29. 27r. 993. him. Constantine.

$1004^{\mathrm{b}}$. The metrical scheme is $\mathrm{xx}-\mid u^{\prime} \mathrm{x}$, if brim be counted long, as in $A n .442^{\mathrm{b}}, 504^{\mathrm{b}}, 5 \mathrm{I} 3^{\mathrm{b}}, 1543^{\mathrm{a}}, \mathrm{I} 574^{\mathrm{b}}$, etc. Cf. $P B B$. 10. 252.

roo5. Cf. $997^{\mathrm{a}}, 998^{\mathrm{b}}$.

$1023^{\mathrm{b}}-7^{\mathrm{a}}$. The Latin has: 'Cum magno autem studio collocans pretiosam crucem, auro et lapidibus pretiosis faciens loculum argenteum, in ipso collocavit crucem Christi.'

I037 . frōfre Gāst. John I4. 26.

I05I-63 $3^{2}$. The Latin has: 'Beata autem Helena accersivit episcopum Eusebium urbis Romæ, et ordinavit Iudam episcopum in Ierosolyma ecclesiæ Christi ; mutavit autem nomen ejus, et vocatus est Cyriacus.'

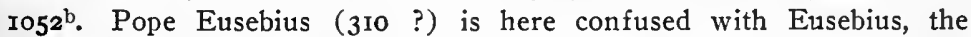
Arian bishop of Nicomedia, who baptized Constantine (Holder, Inventio Sancte Crucis, p. 10).

I059. Cyriācus. Properly, Quiriacus. He was the 15th Bishop of Jerusalem († May I, I34); cf. Holder, p. I6.

1063. $\vec{æ}$ Hæ̈lendes. The name (106 $\mathrm{I}^{\mathrm{b}}$ ), Gr. Kupıaкós, is properly an adjective, 'of the Lord,' from the Greek Kúpıos, used in the Bible for God or Christ ; $\overline{\mathscr{e}}$ is not necessarily implied.

ro72 ${ }^{2}$. wuldor-. See note on 967 .

ro75. getæhtesð. Cf. note on $93^{\mathrm{b}}$. 
$1077^{\mathrm{a}}$. So $682^{\mathrm{a}}$.

1078b-85. Latin: 'De fixoriis . . . imminet tristitia [animæ meæ]. Sed non requiescet et de hoc, donec Dominus compleat desiderium meum.'

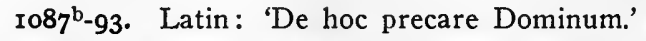

1089b. beorhtan gesceaft = 'heaven.'

II06. frōfre Gast. So I037.

I108 ${ }^{\mathrm{a}}$. So $1054^{\mathrm{a}}$.

III $4^{\text {a }}$. Latin: 'tamquam aurum.'

I12I-4 ${ }^{\mathrm{a}}$. Latin: 'Nunc cognoscimus in quem credimus' (cf. 2 Tim. I. 12).

$\mathrm{Ir}_{32} \mathbf{2}^{\mathrm{b}}$. wōpes hring. See the note in my edition on Chr. 537.

II $35^{\mathrm{b}}$. Understand was before gefylled.

${ }_{11} 6^{b}$. H. ${ }^{2}$ takes $h \bar{e} o$ as the Anglian acc. sing. fem., and so does not follow Zupitza.

II $44^{\mathrm{b}}$. bā wìc. Cf. $103^{\mathrm{a}}$, II $44^{\mathrm{a}}$.

II55a. eall æfter orde. In due succession (?). Cf. $590 ; A n .1483^{\mathrm{a}}$.

II $5^{\text {6 }}$. So Met. 27. 28; cf. pinga gehwylce, Hy. 4. 12; älces pinges, Chr. 333 , etc. Holt translates: 'in every respect.'

I $67^{\text {b. }}$ priste. Cf. 409.

$\mathrm{II}_{73^{\mathrm{a}}}$. So $1078^{\mathrm{a}}$.

$118 \mathrm{I}^{\mathrm{b}}$. sigor. An objection to this word is that it occurs again in $1183^{\mathrm{a}}$. $1182^{\mathrm{b}}-4^{\mathrm{a}}$. Latin: 'Victoria vero erit regis et pax belli.'

II92-6. Zech. 14. 20.

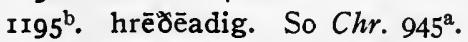

I196a. Cf. $150^{\mathrm{a}}$.

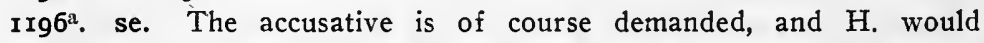
therefore read se pone $b e$. One is tempted to read be for se (cf. 4I5, 625, $966,995)$; but blunders in case are not unexampled in the poetry, as in An. $747 \mathrm{ff}$.: 'pone be . . . heofan ond eorpan . . . āmearcode mundum sīnum.'

$1206^{\mathrm{b}}-\mathbf{1}^{\mathrm{a}}$. Not in the Latin of the legend. Cf. Bede, Eccl. Hist. 4. 3, on Chad: 'Admonuit eos ut virtutem dilectionis et pacis ad invicem

servarent; instituta quoque disciplinæ regularis, quæ . . . ab ipso didicissent, et in ipso vidissent, . . . indefessa instantia sequerentur'; or, in the Old English translation: 'Monade hē hēo... . pæet hēo betwēonan him bæt mægen lufan ond sibbe . . . geornlice hēolde; ond . . . bā gesetenesse . . . be hȳ from him geleornodon ond on him gesēgon . . . bæt hēo bā . . . lēesten.' It looks as though Cynewulf had here been indebted to Bede.

I209. Cf. $P h \cdot 77^{\mathrm{b}}$.

1213 $3^{\mathrm{b}}-8^{\mathrm{a}}$. Latin: 'ut . . omnes hominum sanaret infirmitates.' 1219'. sīòes fūs. So $P h .208^{\mathrm{a}}$.

1226. āwēoxe. For the singular with pāra be, see Wülfing, Die Syntax in den Werken Alfreds des Grossen 1. 416; Grimm, Andreas und Elene, p. 94 ; cf. El. 976 , but also 1288 . 
I227 $7^{\text {-8 }}$. Summer began on May 9, so that six days earlier would be May 3, the date of the Invention of the Cross. The Latin of the legend has: 'quinto nonarum Maiarum.'

I229 $^{\mathrm{a}}$. Grein has shown (Germania I0. 424) that this means the month of May, referring to Menologium $83 \mathrm{ff}$. The following passage (Men. $75^{\mathrm{b}}-79,83^{-93^{\mathrm{a}}}$ ) is noteworthy on other accounts as well.

$1229^{\mathrm{b}}-36$. The Latin has: 'Quicumque vero memoriam faciunt sanctæ crucis accipiant partem cum . . . Maria et cum Domino nostro Jesu Christo.' At this point the Latin legend ends.

$1237 \mathrm{ff}$. Rhyme or assonance binds many of these hemistichs together. In certain cases the rhyme would be more perfect if the forms appeared in the Anglian dialect; for Holthausen's attempts at restoration see the variants.

$1237^{\mathrm{b}}$. 'Through the mortality of my earthly tabernacle.'-fǣge. So $88 \mathrm{I}^{\mathrm{b}}$; cf. Beow. 1568, I755;Gu. 1004; An. I085. Fä̋ne would make no sense.

1239. hreodode. See hridrude (hrydrode), Lk. 22. 31 (cf. Otfrid 4. 13. 16, 'redan iu thaz muat') ; Eng. riddle, 'sieve.'

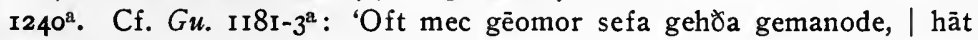
æt heortan hyge gnornende nihtes nearwe'; also Seafarer 7: 'nearo nihtwaco.' H. ${ }^{2}$ calls nihtes an adverb.

I24I $\mathrm{I}^{\mathrm{a}}$. Cf. 60I.

I242 ${ }^{\mathrm{a}}$. Cf. $597^{\mathrm{a}} ; 295^{\mathrm{b}}, 727^{\mathrm{b}}$.

$\mathbf{I 2 4 2}^{\mathbf{b}}$. peaht. It seems rather inartistic to repeat this syllable from the preceding line.

1243 ${ }^{\mathrm{a}}$. Wisdōm $=$ Christ. See I Cor. 1. 24; The Christ of Cynewulf, ed. Cook, note on 239.

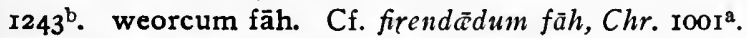

$1245^{\mathrm{a}}$. So Harr. Hell $65^{\mathrm{a}}$.

$1246^{\mathrm{a}}$. onlāg $=$ onlāh, from onlēon; the subject from $1248^{\mathrm{a}}$.

1246b. Cf. Rieger, Zs. f. D. Phil. I. 319; Wülker, Angl. r. 504; Klaeber, Mod. Lang. Notes 15. 493 ; Brown, Engl. Stud. 38. 219.

$1247^{\mathrm{b}}$. So $120 \mathrm{I}^{\mathrm{b}}$.

I248 ${ }^{\text {b }}$ begēat. $\mathrm{H}^{2}$ would read begat, for begeat (cf. II52); but see Tobit 3. 22 Vulg., 'exultationem infundis.'

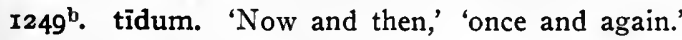

$1253^{\mathrm{a}}$. So Chr. $1194^{\mathrm{a}}$.

$1257^{\mathrm{b}}-7 \mathrm{I}^{\mathrm{a}}$. Holt translates: 'Ever until that time was the man buffeted in the surge of sorrow, was he a weakly flaring torch (C), although he had received treasures and appled gold in the mead-hall; wroth ( $Y$ ) in heart he mourned; a companion to need $(\mathrm{N})$, he suffered crushing grief and anxious care, although before him his horse (E) measured the miles and proudly ran, decked with gold. Hope (W) is waned, and joy through the course of years; youth is fled, and the pride of old. Once (U) was the splendor of youth (?); now after that allotted time are 
the days departed, are the pleasures of life dwindled away, as water (L) glideth, or the rushing floods. Wealth $(F)$ is but a loan to each beneath the heavens.'

Garnett's rendering is :

\section{Ay till then was the man}

With care-waves oppressed, a flickering pine-torch (C),

Though he in the mead-hall treasures received,

Apples of gold. Mourned for his bow (Y)

The comrade of sorrow $(\mathrm{N})$, suffered distress,

His secret constrained, where before him the horse (E)

Measured the mile-paths, with spirit ran

Proud of his ornaments. Hope (W) is decreased,

Joy, after years, youth is departed,

The ancient pride. The bison (U) was once

The gladness of youth. Now are the old days

In course of time gone for ever,

Life-joy departed, as ocean (L) flows by,

Waves hurried along. To each one is wealth (F)

Fleeting 'neath heaven.

In both of these, 'hope' (wēn, for wyn) is of course wrong.

Carleton F. Brown (Eng. Stud. 38. 207, 212) thus translates $1257^{\mathrm{b}}-64^{\mathrm{a}}$ : 'Always was there strife [retaining MS. sacc] until then (i. e., the Redemption of the Cross) - the hero overwhelmed with care-waves, dying, though [reading $b \bar{c} a h$ ] in the mead-hall he shared treasures of appled gold. The need-journeyer (i. e. one obliged to die) lamented evil (or misery), endured grievous sorrow, the anxious secret, though for him the horsc coursed, measured the mile-paths, proudly ran, adorned with wires.' $\mathrm{He}$ adds (p. 218): 'The lines in Elene are capable of an intelligible and consistent explanation, without reading personal allusions into them. The attempt to interpret them autobiographically, on the other hand, involves perplexities.'

For other renderings, see the Bibliography.

1258-70. For a discussion of Cynewulf's various runic passages, see my edition of the Christ, pp. 15I ff. (cf. Audreas, ed. Krapp, pp. $167 \mathrm{ff}$.; Brown, Eng. Stud. 38. I98-219; Tupper, Mod. Lang. Notes 27. 131-7). These runes, taken in order, spell the name CyNewulf, and each letter, if rightly interpreted, would, in general, represent a noun, or the first element of a compound noun. Each rune has a name, the name always beginning with the letter which the rune represents, and it is this name which should designate the appropriate object which the line demands. Unfortunately, though there is a late Old English poem (the Runic Poem) which presents these equivalences, we cannot always be sure that every rune represented the same object throughout the Old English period, nor in precisely what sense the object is to be regarded. The names and meanings are as follows (cf. Wyatt's convenient table in his Old English Riddles, p. xxxix): 


\begin{tabular}{|c|c|c|}
\hline Rune & Name & Meaning \\
\hline h & cēn & torch, pine (-splinter) \\
\hline m & $\bar{y} r$ & \\
\hline+ & nied & need \\
\hline M & eh, eoh & horse \\
\hline$\Delta$ & wynn & joy \\
\hline n & $\bar{u} \mathrm{r}$ & bison, wild ox \\
\hline$r$ & lagu & ocean, water \\
\hline $\boldsymbol{p}$ & feoh & money, wealth \\
\hline
\end{tabular}

Perhaps $\bar{u} r$ and $\bar{y} r$ occasion the greatest difficulty. Among the meanings proposed for ür are 'of old' (Kemble, Grein), 'money' (Leo), 'ours' (Gollancz); for $\bar{y} r$, 'misery' (Kemble), 'the bow' (Grimm, Grein), 'evil' (Gollancz). Cèn has been read as cēne, 'bold' (Kemble, Gollancz). 1257 . secg. Cynewulf.

126o. æpplede gold. Cf. $J u l .686^{\mathrm{b}}-8^{\mathrm{a}}$ : "bæt hȳ in winsele | ofer bēorsetle bēagas bēgon, | xpplede gold'; $P h \cdot 505^{\mathrm{b}}-7^{\mathrm{a}}$ : 'lig eal pigeđ | eorðan ǣhtgestrēon, æpplede gold I gifre forgripeð.' From the passages in Elene and Juliana it is clear that the 'appled gold,' or golden apples, were among the gifts received in the banqueting-hall (medoheall, winsele), and this forbids us to think of the imperial orb, which was occasionally called an apple of gold in Middle English. Thus we are told of the bronze equestrian statue of Justinian, erected in 543 by his order in Constantinople, that it held in its left hand a globe ( $\pi$ ónos) surmounted by a cross (Procopius, De Aedificiis I. 2). Godfrey of Viterbo (quoted by Du Cange, Gloss. Med. et Infim. Lat., s. v. Palla) says:

\section{Aureus ille globus pomum vel palla.}

Of Justinian's orb William of Boldensele ( 1332 ) says: 'Manu sinistra pomum, quod orbem repræsentat.' The Pseudo-Mandeville, referring to the same orb (ed. Warner, Roxburghe Club, p. 4): 'The ymage was wont to hold in his hand a rounde appel of gold'; where the French reads : 'Et soleit tenir un pomme rounde dooree en sa mayn.' So, too, in Johann Schiltberger's Bondage and Travels (Hakluyt Society, r879, p. 79), we have: 'At one time the statue had a golden apple in the hand.' It is not, however, of imperial orbs that there can be question in the Elene.

Such being the case, the poet might have had in mind the 'apples of gold' of Prov. 25. Ir, except that he seems to have referred, not to a historical text so much as to objects with which he was personally acquainted. There remains only, then, so far as I can see, to think of early examples of the pomander-case, or something like it, brought from the Orient through the agency of the Byzantines, perhaps originally by a Theodore of Tarsus, or by Syrian traders (cf. Gregory of Tours, Hist. Franc. 8. I). The pom- of pomander of course represents 'apple' (pomander = pomme d'ambrc), and a pomander itself was 'a ball made of perfumes, such as ambergris (whence the name), musk, civet, \&c., and formerly worn or carried in a case, also known by the same name, 
as a protection against infection in times of pestilence, or merely as a useful article to modify bad smells. The globular cases . . . were hung from a neck-chain or attached to the girdle, and were usually perforated, and made of gold or silver' (Encyc. Brit., IIth ed., 22. 46). How early these pomanders were known in the West I can not pretend to say; but it is certain that the Old Man of the Mountain sent to St. Louis, between May I250 and March I25I, apples of various sorts of crystal, on which 'amber' was fastened by means of gold clasps (Joinville, ed. Natalis de Wailly, p. 250). In the Roman de la Rose (ca. 1280) 'pomme d'ambre' is used as a standard of fragrance (2I,008). Another name for it was musk-ball, for which see New Eng. Dict. (= pomme de musk, Wylie, Hist. of England under Henry IV 4. I95; Anc. Kal. and Inv., ed. Palgrave, 3. 34I). See also Douet d'Arcq, Choix de Pièces (Paris, I863) 2. 306, 34I, 347, 508; Bibl. de l'École des Chartes (6. I). 354, 356; Heyd, Gesch. des Levantehandels 2. 566. Sometimes they were attached to each corner of a pillow-case (Paulin Paris, Romans de la Table Ronde [Lancelot du Lac] 4. 367-8, cf. 304). The apple of gold in the Mabinogion (Temple Classics, p. I69) was probably not a pomander: 'And the huge red youth dismounted before Arthur, and he drew a golden chain out of the pack, and a carpet of diapered satin. And he spread the carpet before Arthur, and there was an apple of ruddy gold at each corner thereof.' Quite different must have been the apple of gold on a standard in a Servian ballad (Heroic Ballads of Servia, tr. Noyes and Bacon, p. 6r).

- The pomander must have been used at a much earlier date in the Orient, from which, through Byzantium, supplies might have been distributed to the West (compare, too, such embassies, bearing presents, as those of Haroun-al-Rashid to Charlemagne, A. D. 797 and 801 ).

There is the difficulty in $J u l$. $687-8$ (quoted above) that applede gold seems to be equated with beagas; or is this not so?

$1267^{\mathrm{b}}$. So $G u$. $1107^{\mathrm{b}}$.

$1272^{\mathrm{b}}-7^{\mathrm{a}}$. Apparently imitated from Virgil, Aen. I. 50-63, the account of Aeolus and his winds. Cf. Riddle 4. For the influence of the Aeneid on Beowulf, see Klaeber, in Herrig's Archiv I26. 40-48, 339-359.

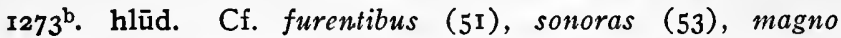
murmure (55), fremunt (56).

1276'. nēdcleofan. Cf. antro (52), claustra (56), speluncis (60).

I277 ${ }^{\mathrm{a}}$. So Gu. II7I ; cf. Jul. 520 .

I277 ${ }^{\mathrm{b}}-\mathrm{I} 32 \mathrm{r}$. For other descriptions of the Judgment, see Deering, The Anglo-Saxon Poets on the Judgment Day (Halle, I89o) ; Grau, Quellen und Verwandtschaften.

I277 ${ }^{\mathrm{b}}$-9. Cf. 2 Pet. 3. 10-12.

I280-6. Cf. Matt. I6. 27 ; 12. 36.

1286b ff. Cf. Ambrose, Comm. on Ps. 36 (Migne, Patr. Lat. I4. 980-I), as quoted by $\mathrm{H}^{2}$ (p. 98) from Brown, in Pub. Mod. Lang. Assoc. 18. 313: 
'Ergo omnes igne examinabimur. . . Ecce venit Dominus, . . . et sedebit conflans et purgans sicut aurum. . . . Sed hi etsi per ignem examinabuntur, dicant tamen: Transivimus per ignem et aquam. Alii in igne remanebunt: illis rorabit ignis, ut Hebræis pueris, qui incendio fornacis ardentis objecti sunt; ministros autem impietatis ultor ignis exuret. . . . Præcipitabuntur sacrilegi in lacum ignis ardentis.' Add from Migne 14. 950 (Brown, p. 3I8; $\mathrm{H}^{2}$, p. 98): 'Unde videntur qui bene crediderunt, et fidem suam etiam operibus executi sunt, . . . surgere in consilio justorum; peccatores autem . . . surgent in judicio. Habes duos ordines. Tertius superest impiorum, qui . . . non surgunt in judicio, sed ad pœnam.'

Brown remarks (p. 329): 'In the Elene . . . the Judgment precedes the purgatorial fire. After the three groups enter the fire, they are not again assembled for a final separation into two congregations. The wicked are precipitated thence into the abyss, while the other two groups pass directly from the fire to paradise. Nor is the order of events in the Elene to be explained as merely an instance of confusion or inaccuracy on the part of the poet. For in the earlier Fathers also the Judgment arraignment precedes the purging fire.'

1286. The subject of $d \bar{c} \bar{l} l e \partial$ is $h \bar{e}$ understood.

1294a. So Chr. 1005; cf. ēledlẽoma, Beow. 3125.

$1297^{\mathrm{b}}$. in hătum wylme. The dat. (or inst.) is evidently required. One might think of hătan wylme (inst.), for which compare Beoze. I423; An. 1277, 1542; Exod. 122; Ruin 40.

1302 ${ }^{\mathrm{b}}-3$. From Cæsarius of Arles, Sermo 251 (Patr. Lat. 39. 2210), as $I$ pointed out in my note on $C h r$. $1537^{b}-8^{\mathrm{a}}$ : 'Non venient unquam in memoriam apud Deum.'

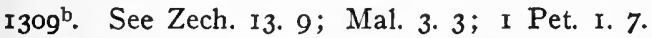

I3I $7^{\mathrm{a}}$. So Ps. 66. I; II8. 88 ; I 44.9.

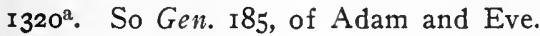




\section{NOTES ON PHOENIX}

Iff. Similar to the beginning of Lactantius' poem are Ad Flavium Felicem 193 (Cyprian, Opera, ed. Hartel, 3. 316); Dracontius, Carmen de Deo I. I78; Avitus, De Origine Mundi 193-5. Cf. Manitius, Gesch. der Christlich-Lateinischen Poesie, p. 347, note I.

For a translation of Lactantius' poem, see pp. 124-8.

$\mathbf{I}^{\mathrm{a}}$. The epic formula with which the poem opens is illustrated by Krapp on $A n$. I.-hæbbe. So $569 ; E l .808$ has $h a f u$.

$\mathbf{2}^{\mathrm{a}}$. For the postpositive on, see $97 ;$ Beow. 2357; Gen. ro52; Exod. $67 ; P n$. I0.

$\mathbf{2}^{\mathbf{b}}$. For the conception of Paradise in general, see Introduction, pp. lii-lvi. Manitius (p. 46 , note 2) is not willing to identify Lactantius' paradise of the Phœnix with that of Genesis.

3-4. nis . . mongum. Is to no one.

$4^{\mathrm{a}}$. Probably to be taken as modifying folcāgendra.

5. Sweet's emendation to foldagendra is unnecessary, and is unsupported by any other instance of the word, whereas folcägende occurs $J u l$. I86; Beow. 3II3 (where it by no means designates kings); cf. folc āhte, Beow. 522.

6. meaht. So always in $P h$. (but see 496), except in el-, foremihtig; El. always miht $(-)$.- mānfremmendum. An exclusively Cynewulfian word: El. 907 ; Jul. I37; Chr. I437.

$7^{\mathrm{a}}$. For the form of the sentence see $9,33^{\mathrm{a}}, 319^{\mathrm{a}}$.

8. stencum. Odors are rife in this poem. Cf. Gu. 1247-50.

9. iglond. Cf. 287. Krapp, commenting on $A n$. I5, says: 'The word in the above passages [including $A n .28$ ] is evidently not to be understood in the specific sense of "island," but rather in the literal sense of "waterland," "land that is reached by water." To the insular Anglo-Saxon all foreign lands must have been "water-lands"; perhaps in this poetical sense the word also carries with it the connotation of remoteness; in both the Phonix and the Andreas it is used for the Orient. Cf. also Sal. and Sat. I ff.:

\section{Hwæt! ic iglanda eallra hæbbe}

bōca onbyrged.

The elaboration of this passage makes iglanda refer to Lybia [Libya?], Greece, and India, none of them islands.' So, too, Osgood, on Pearl 693: "M. E. yle more often means "island," yet the meaning "remote province or land" is common: in Destr. Troy IOI Thessaly is an yle (translating regnum); in Alex. 1039, Italy; ib. 2116, Phrygia; at 2800 the provinces of India are thus designated, as are those of Italy and Egypt at 5IIo; "in O. T., after the equivalent Hebrew, applied to lands beyond the sea" (N. E. D. s. v. isle, I. b.).' But cf. $103^{\mathrm{a}}$. 
Ioa. Cf. Gu. 667: mōdig Mundbora, meahtum spēdig.

rob. moldan. Not the inhabited globe, as usually in Old English, but a specific region; cf. 66 .

II. open. Lactantius' line is indebted to that of Ennius which he quotes in Div. Inst. I. I8. II : Mi soli cali maxima porta patet. Virgil knows the gate of heaven (Georg. 3. 26I), Ennius (quoted in Cicero, De Republica) has it, and in Homer the Hours are warders of the gates of heaven (Il. 5. 749; 8. 393). Jacob exclaims after his vision (Gen. 28. 17): 'This is the gate of heaven,' and the heavens are conceived as opened in Ezek. I. I; Matt. 3. I6 (Mk. I. Io; Lk. 3. 21); Acts 7. 56; I0. II ; Rev. 4. I ; I9. II.

$12^{\mathrm{a}}$. For this music, see $615-654$.

$13^{\mathrm{a}}$. wong. A favorite word in the $P h$. For its application to Paradise, cf. neorxnawong, 397.

$\mathrm{I}^{\mathrm{b}}$. Adam and Eve wander into pone grēnan weald, Gen. 84I. See also 24-5, 53-5; Chr. 59I-6; El. II4-5, I237-46, I248-5I ; Rid. 294-6.

I4-2I. Kölbing (Eng. Stud. I. I69) compares the Middle English Orison of Our Lady 37-8:

per blowe

$14^{\mathrm{b}}-19^{\mathrm{a}}$. Considerably expanded from Lactantius' 1. 3, and somewhat anticipatory of $57 \mathrm{ff}$. (Lact. 2I-4); cf. Chr. I66I-2: 'nē sunnan bryne, nè cyle.' Winter appears agaim in $248-250$, summer in $209 \mathrm{ff}$. The general conception is familiar enough in the classics. Thus Homer, Od. 4. $563 \mathrm{ff}$.: 'No snow is there, nor yet great storm, nor any rain.'

I5 ${ }^{\text {a }}$ fnǣst seems more appropriate in the only other instance of its occurrence, Jul. 588: fỹres fnēst.

For other passages with correlative $n \bar{e}$, see $5 \mathrm{I}$ ff., $134 \mathrm{ff} ., 612 \mathrm{ff}$.

15 ${ }^{\mathrm{b}}$. Though there is no fỹres bläst here, it will be observed that the Phœnix receives new life purh ligges blēst, $434^{\mathrm{a}}$.

16. There is a similar rhymed passage, describing the joys of Paradise by negatives, in $G u$. 799-802, $80 \mathrm{I}-2^{\mathrm{b}}$ being:

nē lïfes lyre, nē lïces hryre,

nē drēames dryre.

$19^{\mathrm{a}}$. See $18 \mathrm{I}^{\mathrm{a}}$.

$20^{\mathrm{b}}-\mathrm{I}^{\mathrm{a}}$. An anticipation of $43^{\mathrm{b}}-7$ : observe éadig, onsund, apele $(-a)$, geblöwan. With $20^{\mathrm{b}}-\mathrm{I}^{\mathrm{a}} \mathrm{cf}$. $26^{\mathrm{b}}-7$. The author seems to miss Lactantius' point in great measure. Not only does he make no explicit mention of spring, but he does not see that Lactantius is emphasizing the notion of 'east,' already found in line I; in his Div. Inst. 2. 9. 9, he attributes 'ver scilicet orienti, æstatem meridianæ plagæ; occidentis autumnus est, septentrionis hibernum.'

$2 \mathrm{I}^{\mathrm{b}}-6^{\mathrm{a}}$. That is, above the surface of the plateau; the plateau itself is higher than the top of any earthly mountain (28-32).

25. hlǣwas. Originally hlēer meant a cairn or tumulus; thus Beow. 
2802, 3r58.-hlincas. Golf-players will recognize this word, though it has changed its meaning.

$25^{\text {b }}$ hleonad. Sievers renders by 'gedeiht' = 'thrives,' and is followed by Schlotterose. This is clearly against the sense in Beow. 14I5, for instance, where trees lean over a rock (see the minare, imminere of Aen. I62 ff.), and can not be reconciled with Mod. Eng. lean (cf. Gu. 44). The poet is describing a perfectly level, smooth plain, admitting nothing rugged (unsmēðes), neither crag (stānclifu), nor cave (dünscrafu). Schlotterose understands by unsmëðes rough vegetation, weeds, presumably having briers and brambles in mind.

28. twelfum. Bis sex. One hardly knows whether this is classical or Biblical; cf. Virgil, Aen. II. 9; Ovid. Met. 6. 72, etc., with I Kings 7. I5; Jer. 52. 2I ; Ezek. 43. I6. It will be remembered that six cubits made a reed, as used for measuring: Ezek. 40. $5 ; 4$ I. 8. Others speak of twenty cubits; see Raleigh, Hist. World I. 3; McClintock and Strong, Encyclopadia 7. 657.

$29^{\mathrm{b}}-30$. Cf. $313^{\mathrm{b}}, 424^{\mathrm{b}}-5,655^{\mathrm{b}}$.

31. hēr. In this world (so 23 ); see Introduction, p. lv.

$32^{\mathrm{a}}$. So $23^{\mathrm{a}}$; cf. $12 \mathrm{I}^{\mathrm{a}}$.

$33^{\mathrm{a}}$. sigewong. A curious reminiscence of the heroic poetry; cf. the same word, Jud. 295 .

$33^{\mathrm{b}}$. sunbearo. Solis nemus.

34. wuduholt. There is considerable pleonasm in the compounds with wudu. Thus not only do we have holt and wudu, but wuduholt, as here (and 362), and holtreudu (I7I). So not only bearu (67, etc.), but reudubearu (152, 169). This practice is continued into Middle English: holte wodez, Pearl 75 (see Osgood's note); Gaw. 742; Dest. Troy 1350.

$3^{\mathrm{a}}$. So $78^{\mathrm{b}}$.

37-8. Kölbing (see note on 14-21) compares Orison of Our Lady 39:

per ne mei non valuwen, vor ber is eche sumer,

Per ham never ne mei snou ne vorst ivreden,

and hence concludes-a rather daring assumption-that the Middle English author must have been acquainted with our poem. A closer parallel is Odyssey 7. II7-8 (tr. Cotterill):

Here doth the fruit of the trees ne'er perish or fail in its bearing, Winter and summer alike perpetual.

$37^{\mathrm{a}}$. A mere form of expression, since the cold of winter and the heat of summer were alike wanting.

$39^{\mathrm{b}}-40^{\mathrm{a}}$. Lact. II-I2.

40-1 $\mathrm{I}^{\mathrm{a}}$. Cf. $83-4^{\mathrm{a}} \cdot 40^{\mathrm{a}}=562^{\mathrm{a}}$.

4I $\mathbf{r}^{\mathrm{b}}$-6. Lact. I3-I4. Ovid has an account of the deluge in Book I of the. Metamorphoses; but Lactantius no doubt had the Biblical account 
in mind (see Introduction, pp. liv-lv). Only one peak of Parnassus stood out above the deluge in Lucan, Phars. 5.75 ff.; cf. Ovid, Met. I. 318-9.

$4 \mathrm{I}^{\mathrm{b}}$. Swā. When. Cf. 322.

$43^{\mathrm{b}}$. See $26^{\mathrm{b}}$.

$47^{\mathrm{b}}$. See 2 Pet. 3. 7 , and cf. $490^{\mathrm{a}}, 50 \mathrm{I}^{\mathrm{b}}$ ff., $52 \mathrm{I}^{\mathrm{b}} \mathrm{ff}$.

50-6. Cf. Lact. 15-20, which is influenced by Virgil, Aen. 6. $273 \mathrm{ff}$. See also $P h$. 6II ff.; $C h r$. $1660^{\mathrm{b}}-2^{\mathrm{a}}$.

50-2. Kölbing compares with Orison of our Lady 36 :

Per te nevre dea $\delta$ ne com, ne herm ne sorinesse.

See also Hampole's Pricke of Conscience 78I4-7, and the other quotations in The Christ of Cynezoulf, pp. $222 \mathrm{ff}$., where the ultimate source is indicated as Homily 15 of (Pseudo?) Boniface, which in turn reposes upon Augustine or Cæsarius of Arles.

\section{$5^{\mathrm{a}}$. See $614^{\mathrm{a}}$.}

$53^{\text {a }}$. So $G u$. $801^{\text {a }}$.

$54 \mathrm{ff}$. Note the rhymes.-nē synn nē sacu. Cf. Beow. 2472.

55. For the justification of onsȳn as 'lack, want,' see my note on 480 in The Christ of Cynezulf. It was Thorpe who first suggested the meaning 'desire.'

56. Cf. Chr. $166 \mathrm{I}^{\mathrm{a}}$.

56. Against Hart's emendation, ne sorgende slēep, I have adduced the following arguments (Mod. Lang. Notes 14. 225-6): (1) sorgian, in the poetry, is always used of persons; (2) sorgende släp is not a translation of curce insomnes; (3) the reading of the MS. is supported by various parallels. The deprecation of sleep may be illustrated by Rev. 2r. 23-25; 22. 5 ; and $I$ adduced certain passages from early Christian writers to the same general effect. Cf. Chr. 166I; Sal. 3II ; Wand. 39-40; Wulfstan I39. 28.

57 ff. Lact. 2 I-4.

$59^{\mathrm{a}}$. So $A n$. $1260^{\mathrm{a}}$.

$6 \mathrm{I}^{\mathrm{a}}$. windig wolcen. This seems to require a different verb from feallep. Cf. Schlotterose's note, and Tupper, Pub. Mod. Lang. Assoc. 25. 173 .

$62^{b}-70$. Lact. 25-8. Lactantius is no doubt thinking of Gen. 2, 6, and connecting it with Gen. 2. Io ff. These are, in the Vulgate: 'Sed fons ascendebat e terra, irrigans universam superficiem terræ. . . . Et fluvius egrediebatur de loco voluptatis ad irrigandum paradisum, qui inde dividitur in quatuor capita.' He conceives the fountain as giving birth to the river, or being itself the river, as do other early Christian Latin poets. Thus Pseudo-Cyprian, De Laude Mart. 2I (Cyprian, ed. Hartel, Vol. 3, App., p. 44): 'Ubi fons scaturiens medius sinu alvei prorumpentis emergit, et rauco per intervalla circuito sinuosis flexibus labitur'; Ad Flavium Felicem 238-9 (op. cit., App., p. 318) :

Fons illic placido perfundit agmine campos, Quattuor inde rigant partitam flumina terram. 
Avitus 1. 252, 259, 260 :

Hic fons perspicuo resplendens gurgite surgit. . . .

Eductum leni fontis de vertice flumen,

Quattuor in largos confestim scinditur amnes.

Isidore of Seville, Etymol. 14. 33: ' $E$ cujus medio fons prorumpens-totum nemus irrigat, dividiturque in quattuor nascentia flumina.'

Other Biblical passages are related to Gen. 2. 6, ro, and must have been in Lactantius' mind at the same time. Such are Ezek. 47. 7, 9, 12; Rev. 22. I ff. (7. 17; 21. 6; 22. 17); cf. John 4. 10, 14; Ps. 36. 9; Jer. 2. 13; 17. 13. See also Ovid, F. 2. 250.

63. wyllan. The identification of the fountain with the one river, which afterwards becomes four, is no doubt responsible for this plural; cf. the lagustréamas of 62 , and the plurals of $65^{\mathrm{a}}$. On the other hand, 104 .

64. flodwylmum. An. 516 has flodwylm, whereas there is no foldwylm in the poetry. Moreover, the flod- repeats the idea of lagu- $(62,70)$. Cf. El. 215 .

66а. Cf. Ezek. 47. 12; Rev. 22. 2.

$66^{\mathrm{b}}$. Cf. $349^{\mathrm{a}}$.

67. brimcald. Cf. IIo.

$68^{\mathrm{b}}$. See $36^{\mathrm{b}}$.

76. For metrical reasons, as Sievers observes ( $P B B$. 10. 490 ), the first syllable of treowum is short.

77. For the accusative with in, cf. 509, 517, El. I209.

79. Cf. Chr. $330^{\mathrm{b}}$.

$85^{\mathrm{b}}$. So $232^{\mathrm{b}}, 307^{\mathrm{b}}$.

$86^{\mathrm{a}}$. Cf. $266^{\mathrm{a}}, 347^{\mathrm{a}}$.

$86^{\mathrm{b}}$. Fenix. The first syllable is short, for metrical reasons (Sievers $P B B$. 10. 499). In Elfric's Grammar, ed. Zupitza, p. 70, we have, as an illustration of nouns ending in long -ix: hic Fenix, with this explanation: 'Swā hātte ān fugel on Arabiscre đēode, se leofađ̀ fīf hund gēara, and æfter dēað̀e eft ārīst geedcucod; and se fugel getācnað̆ ūrne æ̈rist on ðām endenēxtan dæge.'

87. Lactantius is probably here dependent on Ovid, Am. 2. 6. 54:

Et vivax Phœnix, unica semper avis.

88 -9 . See I79-18r.

91. condelle. Similarly 108, 187; also tapur, II4. One must think of the mild, serene light of the wax candle, associated, as it would be in the minds of the Anglo-Saxon, with the altar, the music, and the services of the church. Shakespeare designates the stars as candles, as in 'Night's candles are burnt out,' and 'Those gold candles fixed in heaven's air.' Milton designates the sun by the word $\operatorname{lamp}(P$. L. 7 370):

First in his east the glorious lamp was seen, Regent of day.

Cf. P. L. 3. 22. 
92. glædum. For metrical reasons, gled is always long in this text. Perhaps we should here read glādum; cf. 303; Gram. 50, 294.

gimme. Applied to the sun, literally or figuratively, also in II7, I83, 208, 289, 516.

93-4. See $102-3,114^{\mathrm{b}}-5$.

$93^{\mathrm{b}}$. æebelast tungla. So Chr. $607^{\mathrm{a}}$.

$94^{\mathrm{b}}$. See $102^{\mathrm{b}}, 290^{\mathrm{b}}$.

$95^{\mathrm{b}}$. In $\mathrm{Chr}$. 507, the disciples see two angels, and, in Chr. 522, Christ himself, fratwum blican. So in Jul. 564, an angel comes frcetwum blican.

96. tācen Godes. It is not clear whether Godes is an objective or a subjective genitive, that is, whether the sign signifies God, or belongs to God. In favor of the former is the interpretation of $254^{\mathrm{b}}$ given below.

97. wabeman. Not to be confounded with the word in 99 .

$99^{\mathrm{b}}$. So $16 \mathrm{I}^{\mathrm{b}}$.

$100^{a}$. Cf. $86^{a}$.

Ioo. firgenstream. A Beowulfian word; there='mountain-stream.' Here it seems to be 'ocean,' as in An. 300 (firigend-). The Goth. fairguni means 'mountain.'

105. wunad. Construction as in 172.

I06. tweif sioum. So 69,146 . The number is apparently due to a misunderstanding of Lactantius' ter quater, or else to an effort to extend the notion of (28), 69, I46, to this case. Ter quater is used in Latin for an indefinite number, like our 'repeatedly': see, for example, Virgil, Aen. 12. 155; Ovid, Met. 4. 733; Horace, Od. I. 31. 13; Tibullus 3. 3. 26. On the other hand, by the time of Alcuin $(\dagger 804)$, ter quater seems to mean twelve; cf. his verses in Epist. 28 (Mon. Alc., p. 208), where he refers to the twelve bishops of Britain:

\section{Urbs æterna Dei, terræ sal, lumina mundi, Bis sex signa poli, menses et ter quater anni, Atque diei horæ.}

The eagle is said to renew his youth by plunging three times into a fountain (Hopkins, 'The Fountain of Youth' Jour. Amer. Or. Soc. 26 (1905). 38-4I), who quotes, among other authors, Pseudo-Jerome, Epist. ad Presidium (Migne, Patr. Lat. 30. 187): 'Quæritque fontem et erigit pennas, et colligit in se calorem, et sic oculi ejus sanantur, et in fontem se ter mergit, et ita ad juventutem redit.' There are points of contact between the mythical eagle and the Phœnix, as Professor Hopkins points out, but the precise historical relation between them is difficult to clear up. The familiar Biblical allusion, 'so that thy youth is renewed like the eagle's,' is from Ps. 103. 5.

I07 ff. The Phœnix here appears in a priestly character, as it were, such as was sustained by the Egyptian kings in their ceremonial visits to Heliopolis and similar shrines. We have the record of such a visit by 
Pankhy, or Piankhi I, whose original seat was at Napata, now Jebel Barkal, and who, being called in by the rulers of Middle and Upper Egypt to repel the invasion of Tafnekht, probably a Libyan chief, curbed the latter's power about 728 в. с. In his progress northward he visited one place after another, and among them Heliopolis. The stele on which he recorded the chief events of his reign, set up at Napata, and now in the Cairo Museum (translations in Records of the Past 2. 81 ff.; Brugsch, Hist. Egypt 2. 23I ff.; Griffith, Egypt. Lit., pp. 5275 ff.; Breasted, Anc. Records of Egypt 4. 418-444; the part relating to Heliopolis also by Wiedemann, Zs. für Aegypt. Spr. I6 (1878). 92-3), gives an account of his visit to Heliopolis. First telling of his arrival, the stele proceeds (Rec. Past 2. 97-8): 'Then the King went to the royal headquarters [a garden or park, a paradisus, with a residence] on the west of the lake of Horus, and offered his oblations. Then he purified himself in the heart of the cool lake, washing his face in the stream of the heavenly waters in which Rā laves his face [cf. Book of the Dead, chap. 145, Budge's translation, p. 244: 'I have washed myself in the water wherein the god Rā washeth himself when he leaveth the eastern part of the sky']. Then he proceeded to the sandy height in Heliopolis, making a great sacrifice on that sandy height of Heliopolis before the face of Rā at his rising, with milch-cows [Wiedemann, 'white oxen'], milk, odorous gums, frankincense, and all precious woods delightful for scent.

' $\mathrm{He}$ went in procession to the temple of Rā, the great sanctuary, with solemn adoration. Then the Chief Priest offered supplications to ward off calamity from the King, performing the rite of lustration girded with the (sacred) vestments. He then purified him with incense and sprinkling, and brought to him garlands from the temple of obelisks [probably the temple erected by Sesostris I; see above p. xlvi]. When the garlands were brought to him, he ascended the flight of steps to the great shrine, to behold Rā in the temple of obelisks.

'The King himself stood, the great one alone;' he drew the bolt, he opened the folding doors, he saw his father Rã in the temple of obelisks, (and) the bark of Rā, and the vessel of Tum. Then he closed the doors, and set sealing-clay with the King's own signet, and enjoined the priests, (saying) : "I have set my seal; let no other king whatever enter therein."

"Then he stood, while they prostrated themselves before His Majesty, saying: "All hail for ever, indestructible Horus, lover of Heliopolis! Thou who comest as one entering into the temple of Tum, ministering to the image of father Tum Chepera, great god of Heliopolis." '

107. burnan. For this, the fountain of the sun, but at the same time the Biblical fountain of life, see the Introduction, pp. xxxvi, liii.

beacnes. Perhaps in allusion to Gen. I. 14: 'let them be for signs.' Cf. $t a \overline{c e n}, 96$.

112. This station on the tree is significant; see Introduction, pp. 1-1i. $114^{\mathrm{a}}$. See $90^{\mathrm{b}}$. 
II5. holmpræce is warranted by $A n .467 ; E l .728 ; C h r .678$; while holmwrace does not occur, and would have no sense.

II6a. So $G u$. 631.

$119^{\mathrm{b}}$. Cf. $93^{\mathrm{b}}$.

120. An anticipation of Shakespeare, $M . N . D$. 3. 2. 391-3:

Even till the eastern gate, all fiery-red,

Opening on Neptune with fair blessed beams,

Turns into yellow gold his salt green streams.

121. swā. Almost = 'then.' See Pn. 7.-haswa. Cf. I53. This is a term applied to the eagle (Rid.25.4); to the dove (Gen. I45I); and to smoke (Rid. 2. 7). The appropriateness here is not evident, in view of $29 \mathrm{Iff}$; it is probably reproduced merely as a traditional epithet.

$123^{\mathrm{a}}$. feprum snell. So $163^{\mathrm{a}}, 347^{\mathrm{a}}$.

123 ${ }^{\mathrm{b}}$. So $340^{\mathrm{a}} ; A n$. $866^{\mathrm{b}}$.

$124^{\mathrm{a}}$. Cf. $140^{\mathrm{a}} ; \mathrm{Chr} .884^{\mathrm{a}}$.

125 ${ }^{\mathrm{a}}$. swā. Has no correlative, and so is apparently a mere intensive. 126а. Cf. El. $842^{\mathrm{a}}$.

126. Cf. $592^{\mathrm{b}}$.

127. wrixleð. Used again of song in Rid. 9. 2.

I28. So Chr. $5^{10^{a}}$. Appositive with wö̋crafte.

129. Hēahcyning. So 446,483 . Cf. Cäsere, 634 .

13r. swëg. For the words of the Phœnix, according to Egyptian sources, see Introduction, p. xlii. The Hebrew poet Ezekiel, ca. 200 B. c. (Eusebius, Prap. Evang. 9. 29), attributes to him 'a voice unparalleled'

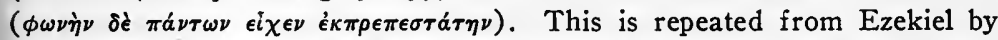
Pseudo-Eustathius, Comm. in Hexaem. (Migne, Patr. Gr. I8. 730). According to Claudian, he sings to the sun just before his death.

The singing of the Phœnix at sunrise naturally suggests that of other birds, especially of the cock. It is disputed what bird is intended in Sophocles, El. I8: 'Already the sun's bright ray is waking the songs of the birds into clearness.' Similarly, Ovid, F. 4. 165-6:

Nox ubi transierit, cælumque rubescere primo

Cœperit, et tactæ rore querentur aves.

So Virgil, Aen. 8. 456:

Et matutini volucrum sub culmine cantus.

For the cock, see Ovid, F. 2. 767 :

Jam dederat cantum lucis prænuntius ales.

Pausanias 5. 25. 9: 'The cock, they say, is sacred to the sun, and heralds his approach.' In Heliodorus I. I8 we are left undecided 'whether a natural instinct induces them to salute the returning sun.' The cock eventually became a Christian symbol. Thus in the Ambrosian hymn, 'Aeterne rerum Conditor': 
Præco diei iam sonat

Noctis profundæ pervigil,

Nocturna lux viantibus

A nocte noctem segregans.

And thus in Prudentius' morning-hymn (Cath. I. I-2, 13-16, 29-32):

Ales diei nuntius

Lucem propinquam cecinit.

Vox ista qua strepunt aves

Stantes sub ipso culmine

Paulo ante quam lux emicet,

Nostri figura est judicis.

Sed vox ab alto culmine

Christi docentis præmonet, Adesse jam lucem prope,

$\mathrm{Ne}$ mens sopori serviat.

Cf. Ambrose, Hexaem. 5. 24, and see the notes to Cath. I in the Temple Classics translation. At a much later time, Alfonso Vigliegas, translated in Alexander, Libro d'Oro, p. 448, compares the angels at the birth of Christ with the birds of dawn: 'When the sun rises in the morning, the birds sing sweetly as if saluting him and rejoicing at his coming; so when the Sun of Righteousness was born into the world, it was the duty of the birds of heaven, who are the angels, to make music, singing melodiously.' For the matin-hymn of the catreus, see note on 260 .

134 ff. Cf. Tennyson, The Holy Grail I13-5. For Old English musical instruments, see Padelford, Old English Musical Terms, Bonn, 1899.

x34. magon. 'May be compared.' Cosijn ${ }^{1}$ suggests the insertion of be before bam, comparing Oros. 2. 6. 5 ; Beow. 1284 .

$136^{\mathrm{b}}-7^{\mathrm{a}}$. I interpret: 'the strain of the organ's melody.'

137 ${ }^{\mathrm{a}}$. swe ghlēopres is confirmed by $P n .42 ; \mathrm{cf}$. $P h$. 13 $\mathrm{I}^{\mathrm{b}}$. Grein's rendering of swe gle (o) əer (in his variants) as 'sound-leather,' 'bagpipe,' may be noted as a curiosity. In his Sprachschatz he renders by clangoris sonitus, though he still questions whether swegleðer may not be the word.

$137^{\text {b. }}$ swanes feore. The belief that the music of the swan was produced in this way is illustrated by Rid. 8, which may be found in modern English in Cook and Tinker's Select Translations from Old English Poetry, p. 72.

$\mathrm{r} 39^{\mathrm{b}}$. It is difficult to account for the accusative, since woruld here does not primarily mean 'age, period' (cf. 517).

143. gefēhơ. There is an Anglian form gefēo (Gram. 374, note 2; cf. 373), but the $h$ is indicated by the onfēh $\delta$ of 159,533 .

144. briwa. Lact. ter. Perhaps the Latin is here indefinite; see note on 106.

$\mathrm{I} 44^{\mathrm{b}}-5^{\mathrm{a}}$. āscæceð fepre flyhthwate. Lact. alarum repetito verbere 
plaudit. The flapping of its wings (beating of its breast) is generally associated with the lighting of its pyre, as a fanning process; thus in Epiphanius, Ancoratus 84 (Migne, Patr. Gr. 43. 174); Isidore of Seville, Etymol. 12. 7. 22 (Migne, Patr. Lat. 82. 462), from whom Rabanus Maurus, De Universo 8. 6 (Migne, Patr. Lat. I I. 246) ; Pseudo-Jerome, Epist. ad Prasidium (Migne, Patr. Lat. 30. 187). A better illustration of the present lines is Ovid, Met. 8. 238-9. Here the partridge

Et plausit pennis, testataque gaudia cantu est.

Again (Met. 14. 576-7), of the heron:

Congerie e media tunc primum cognita præpes

Subvolat, et cineres plausis everberat alis.

The Middle English Pearl has (93-4) :

For quen bose bryddez her wyngez bete,

pay songen wyth a swete asent.

The Pearl knows the 'Fenyx of Arraby' (430), it may be observed in passing.

146. See note on 106.

146 b tida. Thus the cock, according to Alain de Lille (De Planctu Natura), in a passage used by Chaucer (Nun's Priest's Tale 33-4), marks the hours: 'Illic gallus, tamquam vulgaris astrologus, suæ vocis horologio horarum loquebatur discrimina.' With Lactantius' discriminat compare Alain's discrimina.

148. bigengan. The dative seems to be required, as in Dan. 245; Chr. 803, etc.

I50. Cf. $508^{\text {b. }}$.

I5I. büsend. Authorities differ greatly as to the number:

1000. Martial, Ausonius, Claudian (Ph.), Ambrose (Fid. Res.), Nonnus, Gregory Nazianzen, and various Rabbis.

500. Herodotus, Ovid, Tacitus (one account), Aelian, Seneca,

Epiphanius, Pseudo-Epiphanius, Aurelius Victor, Philostratus, Ambrose (Hexaemeron), Greek Physiologus, Clement of Rome, Pseudo-Eustathius, Pseudo-Jerome, Apostolical Constitutions, Æ1fric.

540. Pliny (10. 2), Solinus.

580. Horapollo.

500 and more. Isidore of Seville, Rabanus Maurus.

654. Suidas.

1469. Tacitus (one account).

Other estimates may be found in Hesiod, Ausonius, and Claudian.

152. wudubearwes. Cf. Wulf. 221. 17; 262. 6.

I54 ${ }^{\mathrm{a}}$. gēarum frōd. Cf. $219^{\mathrm{a}}$.

I54 . Cf. $13,36,78$. 
I55. wyn. Cf. $12^{\mathrm{a}}, 70^{\mathrm{b}}, 290^{\mathrm{a}}, 348^{\mathrm{b}}$.

156. In other words, he reaches this world.

$157^{\mathrm{b}}-8^{\mathrm{a}}$. A wilderness (cf. $\mathrm{I}^{6} \mathrm{I}^{\mathrm{a}}$ ), inhabited by no man, mors $u b i$ regna tenet.

I $5^{\mathrm{b}} \mathrm{ff}$. An anticipation of $335^{\mathrm{b}} \mathrm{ff}$. There seems no reason why he should pass with a retinue to the place of his burning, and our author has no authority for his statement.

I58. ealdordōm. Cf. cyning, 344 .

159. fugla cynn. So 335 .

16o. präge. Accusative of extent of time.

I64 ${ }^{\mathrm{a}}$. Cf. 339 .

166 . According to many of the authorities, the Phœnix goes to Egypt. Others make him build his nest in the country where he has passed his life, or leave the matter undecided.

I67 ${ }^{\mathrm{a}}$. So El. 274 ; cf. hēapum, 336.

$167^{\mathrm{b}}-8^{\mathrm{a}}$. Possibly, as I have translated elsewhere: "Here the pure one thrusts them abruptly away.'

r68. oðscūfeð. Cf. oðffēogeð, 347.-in sceade. Cf. on sceade, 234; in bām lēafsceade, 205; ofer sceadu, 2 10.

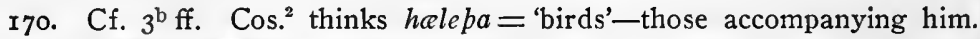
I7I $I^{\mathrm{a}}$. hēanne bëam. So $112^{\mathrm{b}}, 202^{\mathrm{a}}$.

I73 $^{\mathrm{a}}$. hē. The gender follows béama, not treowe.

174. fenix. Lact. palmam. According to Ovid, too, it is a palm (Met. I5. 396) :

Ilicet [var. ilicis] in ramis tremulæque cacumine palmæ.

Isidore of Seville (Etymol. I7. 7. I) in like manner: 'Hanc [palmam] Græci phænicem dicunt, quod diu duret, ex nomine avis illius Arabiæ, quæ multis annis vivere perhibetur.' Philip the Presbyter ( $\dagger 456$ A. D.), Comm. on Job 29. I8, says: 'Palma autem arbor secundum Græcos $\phi \circ \hat{\imath} \nu$ เ dicitur. Avis quoque illa, quam multi facile vivere autumant, $\phi \circ i \nu \iota \xi$ eodem nihilo minus vocabulo nuncupatur.' Cf. Pliny I3. 9. I3. The Coptic name for Phœnix and palm-tree is said to be the same (Seyffarth, p. 63). When, according to the Hebrew poet Ezekiel, the Phœnix is discovered, it is at the point of his story represented by Exod. I5. 27 (cf. Num. 33. 9): 'And they came to Elim, where were twelve wells of water, and three score and ten palm trees; and they encamped there by the waters.' On the confusion between the Phœnix and the palm, see note on $552-69$.

175. So $C h r$. I $165^{\mathrm{a}}$.

177. hē. The manuscript-reading can hardly be retained, in view of the weight of evidence in favor of $h \bar{e}:$ Dan. 477; Sat. 261, 584; Beow. I714, 2658; Gu. 72, 129, 421; An. 1007; Jul. 562, etc. se pe . . . äna, Ps. 7I. I9; Gn. Ex. I73, does not militate against this reading; neither does nymöe se äna God, Rid. 4I. 21 ; nor, when closely considered, does Rid. 4I. 90: Waldend üser, se mec āna mag . . gepēon. Hē here follows the gender of beama. 
$\mathbf{I} 79^{\mathrm{b}}-8 \mathrm{o}^{\mathrm{a}}$. Tupper translates (see on $6 \mathrm{I}^{\mathrm{a}}$ ): 'nor does aught that is grievous hurt him with evils.'

I89 . So $43^{\mathrm{b}}$; cf. Chr. $245^{\mathrm{b}} ; A n$. $15^{\mathrm{b}} ;$ Fates of Men 84 (without following clause). For the punctuation, see the first three passages referred to above.

I9I' ${ }^{\text {a. }}$ burh gewittes wylm. Either 'through perturbation of spirit' or 'through excitement of mind' (culminating in resolve). He can not summon up resolution enough to endure the flame, nor can he actually endure it, without a struggle. For a somewhat similar phrase, cf. Beow. 2882, wēoll of gewitie, and see the compounds brēost-, cear-, sār-, sorgwylm, in Beowulf, Elene, and Guthlac, and dēað̌es wylm, Beow. 2269. Cosijn ( $P B B$. 23. 123) adduces Cura Past. 162. 24: se wielm ठैas mōdes (frixura mentis). Cf. Tupper (as on 6 $\mathrm{I}^{\mathrm{a}}$ ). Trautmann's gewyrtes wylm is unsupported by any other example of gewyrt, as is Schlotterose's gewices.

192 ${ }^{\mathrm{a}}$. Cf. $433^{\mathrm{a}}, 266^{\mathrm{b}}-7^{\mathrm{a}}, 223^{\mathrm{b}}, 55^{\mathrm{b}}$.

192 $2^{\mathrm{b}}$. feor and nēah. Cf. $467^{\mathrm{b}}$ : sìde and wide.

194. wyrta. It is often difficult to distinguish the various senses of wyrt in the poem. Here the meaning seems to be 'plant'; but in 196 , where the adjective is the same, the sense is as plainly 'spice,' or rather 'spicy odor,' unless we make wyrta there depend upon abelstenca, which would involve a departure from customary usage.

196 $6^{\mathrm{b}}$. Wuldorcyning. So $420^{\mathrm{b}}, 537^{\mathrm{b}}$. Cf. Ps. 24. $7 \mathrm{ff}$.

I97 ${ }^{\text {a. See frympa Scyppend, } 630 .}$

198. indryhtum. Grein gives nobilitas as the meaning of indryhto (also Seaf. 89), and nobilissimus as that of indryhten (Wand. I2; Rid. 44. I ; 89. I).

199. swētest. Agrees with gehwone, 195; cf. $193^{\mathrm{a}}$.

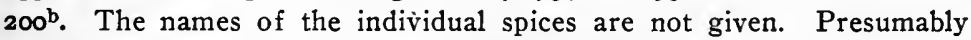
but few of them were known in England at this time.

20I. se wilda fugel. So 466,529 ; cf. ānhaga, $87,346$.

202 $2^{\mathrm{a}}$. See Introduction, pp. 1-li.

202b. hūs. So $212,217,228$. Cf. nest, $189,215$.

209. hātost. Cf. Gn. C. 7: 'swegel bið̀ hātost'; Sax. Leechd. 3. 2: 'wið hātre sunnan.'

2ro. drēogeò. Namely, the Phœnix, not the sun (as Grein, Spr., s. v. gesceap). Cf. gesceap drēoged, Hy. II. 9.

212. hādor. $E l$. has a different vowel (748).

2r3. willsele. Cf. wil(l)-, 89, I09, I49.

214a. Cf. Pn. 46; swecca swètast, Gu. I247.

221. flǣsc and bān. Epiphanius, whom our author could not have known, has the same expression: 'and this consumes itself, flesh and bone.' 230. æples gelicnes. Apparently original with our poet.

232. wyrm. Some authorities say nothing of the worm; such are Ovid, Tacitus, Dionysius (Pseudo-?) Oppian, Pseudo-Epiphanius, Isidore of Seville. The first author who mentions the worm is Pliny, or rather 
his authority, Manilius: 'From its bones and marrow there springs at first a sort of small worm, which in time changes into a little bird.'

$\mathbf{2 3 3}^{\mathrm{a}}$. æge. Herodotus seems to be the only author besides Lactantius to use the simile of an egg, but of the sepulchre of the parent: 'First he molds an egg of myrrh as large as he is able to carry; then he tries to carry it, and, when he has made the experiment, he hollows out the egg and puts his parent into it,' etc.

$233^{\mathrm{b}}$. àlæde. There is no occasion to emend, if we regard the verb as intransitive; cf. 25I. In I78, $\bar{u}$ plëedendra is also intransitive. Cf. Rood 5 .

234. on sceade. See note on 168 . Can this be an allusion to the night, during which the sun is recreated, to Christ's descent into Hades, or to the night of death which every soul must pass through? Cf. PseudoCyprian, Ad Flavium Felicem I30-134 (Cyprian, ed. Hartel, Vol. 3, App., p. 3I3):

Solque cadit supero splendorifer lumine claro,

Lux perit umbrato venienti vespere mundo,

Et remeat toto renovatque gaudia sæclo;

Sic cremata suo vivit de funere Fœnix,

Extemploque suo volucris resurgit e busto.

Add Zeno, De Res. 8 (Migne, Patr. Lat. II. 380): 'Sol quotidie nascitur, eademque die qua nascitur moritur; nec tamen instantis finis sorte terretur, suos ut repigret cursus, ut horas ac momenta producat, ut saltem paulo diutius diei sui demoretur in vita; sed fidelis semper, semper intrepidus, ad sepulcrum noctis cognatæ contendit, scius in ipso se habere quod vivit; denique adimitur ei ortus si ei auferatur occasus.'

235. earnes. Herodotus was the first to compare the Phœnix to an eagle: 'In outline and size he is very like an eagle.' Then Pliny: 'We are told that the bird is of the size of an eagle.' So also Philostratus. To Ezekiel he is about twice as large as an eagle, and to Pseudo-Eustathius of the size of a peacock.-brid. Cf. 372 .

236 ${ }^{\mathrm{a}}$. fugeltimber. Timber has, in Old English, the sense of material or substance of which a thing is made. The author has here coined a compound which the Germans might represent by Vogelstoff, and which aptly expresses the half-formed condition of the incipient bird. Against Trautmann's emendation, fugelumber, is to be urged that umbor is not found as the last element in compounds.

$23^{\mathrm{b}}$. furoror gēn. Several Christian authors represent the time required as three days. Thus Epiphanius: 'The remnants of its flesh, after about a day, produce a worm. The worm grows feathers, and is. transformed into a young bird. The third day it arrives at maturity.' Pseudo-Epiphanius: 'The next day he [the priest] finds it winged. At the end of the third day, it salutes the priest with its wings.' PseudoJerome: 'Crastino die de cinere gignitur vermis, secundo plumas effert, 
tertio ad antiquam redit naturam.' Greek Physiologus: 'The next day the priest, upon examining the altar, finds a worm in the ashes. The second day it puts forth wings, and the third it is restored to its former state.' These three days of course correspond to the three which intervened between Christ's death and resurrection. In the Old English we have three stages: (I) brid, fugeltimber; (2) gelic ealdum earne; (3) swylc he at frymoe zeas.

$239^{\text {b. }}$ Cf. $280^{\text {b. }}$

240. brǣd. Perhaps related to gebrēdad, 372; gebrēdade, 592.

$\mathbf{2 4 2}^{\mathrm{a}}$. The appropriateness of this is not evident; cf. àsundrod fram synnum, El. I309.

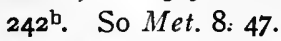

243. swā. The image drawn from the transformation of a butterfly, which Basil the Great had adopted (Hex. 8. 8; cf. Zöckler, Gesch. der Beziehungen zwischen Theologie und Naturwissenschaft, pp. 195, 292), ignoring or repudiating that of the Phœnix, is here replaced by that of seed, already found in the New Testament: Jn. I2. 24; I Cor. 15. 35-8. It is thus developed by Pseudo-Cyprian, Ad Flavium Felicem 121-5:

Semina sic versis creduntur arida terris,

Et penitus fixis putrescunt mortua sulcis,

Onde reparatis animatur culmus aristis,

Et iterum vivis flavescunt fortia granis,

Consurguntque novæ vario cum fænore messes.

Others who employ this figure are Clemens Romanus, Ep. I ad Cor. 24 ; Origen, Contra Celsum 5. $8 \mathrm{ff}$; Theophilus, Ad Autol. I. 13; Cyril of Jerusalem, Cat. 18. 6; Tertullian, Apol. 48; De Resur. 12; Minucius Felix, Oct. 34; Dracontius I. 621 ff. Cf. Sayce, Rel. Anc. Egypt and $B a b .$, p. 167 .

mon. So always in $P h . ; E i$. always $\operatorname{man}(-)$.

246. hì. So always (with $h \bar{y}$ ) in $P h$., while El. has hìe, hīo, hèo.

247 . Cf. El. $84^{\text {b. }}$-hì. Men.

251. ãlædan. Cf. note on $233^{\text {b. }}$.

252 $2^{\mathrm{a}}$. Grein (Dichtungen), 'durch des Kornes Keimkraft.'

252 $2^{\text {b }}$ clæne. One might think of I Cor. I5. 37 ; Grein (Dicht.) translates as 'klein,' but this can hardly be right.

$254^{\mathrm{b}}$. Thorpe translates $253^{\mathrm{b}}-5^{\mathrm{a}}$ : 'Then the sun's gleam in spring wakens the sign of life, the world's production'; and Grein translates (Dicht.): 'Wenn der Sonne Lichtglanz in des Lenzes Zeit des Lebens Zeichen erweckt und Weltreichtum.' So, too, Grein (Spr.) makes tācen acc. (plur.). It is better, however, to equate lifes tācen with sunnan glèm. Surely the sun, or sunshine, is a symbol of life, if anything is. Cf. note on $96^{\mathrm{a}}$.

258. geong. El. always has ging.

$259^{2}$. So $535^{\mathrm{a}}$. 
$259^{\text {b }}$. Ovid says: 'It lives not on corn or grass, but on drops of frankincense and the juices of the amomum.' Pliny: 'No one has seen it eat.' Claudian, translated by Henry Vaughan:

His appetite he never doth assuage

With common food, nor doth he use to drink,

When thirsty, on some river's muddy brink;

- A purer, vital heat, shot from the sun,

Doth nourish him, and airy sweets, that come

From Tethys' lap, he tasteth at his need;

On such abstracted diet doth he feed.

Pseudo-Epiphanius: 'It passes its life without food or drink, . . . subsisting on air.' Cf. also Lactantius.

260. meledēawes. Pliny says of honey-dew (N.H. I1. 12. 12): 'This substance is engendered from the air, mostly at the rising of the constellations. . . Hence it is that at early dawn the leaves of the trees are found covered with a kind of honey-like dew. . . . Whether it is that the liquid is the sweat of the heavens, or whether a saliva emanating from the stars, or a juice exuding from the air while purifying itself, would that it had been, when it comes to us, pure, limpid, and genuine, as when first it took its downward descent.' Seneca (Epist. 84) tells of a honey found in India in the leaves of reeds, and questions whether it may be dew from the Indian sky. The ordinary food of the Nabathæans, according to Diodorus Siculus (19. 94) is a wild honey which flows in great abundance from certain trees, and which they mix with water; cf. Strabo 12. 3. I8; 2. I. I4. But the most interesting parallel is found in Nonnus (26. $183-2 \times 4$ ). In Arizantia, according to him, there are trees which, being impregnated in the early morning by an aerial dew, distil honey, which drips from the leaves, and itself resembles dew. Attracted by its sweetness, birds come swiftly flying in flocks, and hover over the branches; dragons drink of it, and their bitter venom is converted into honey itself. On these boughs sits the horion, and by his side the catreus, brilliant of plumage and melodious of voice. Of these, the catreus, sitting on a branch of a lofty tree, 'all resplendent with its purple wings, pours forth his song; at this matin-hymn of the catreus, one would take him for a nightingale, with joyous carol saluting the dawn.'

264. Cf. 275, and El. 598-9.

$267^{\text {b }}$. Barnouw would omit his for metrical reasons; but cf. $262^{\text {b }}$.

269. swoles lāfe. Cf. $272^{\mathrm{a}}, 276^{\mathrm{b}}$.

277. clām. See Gram..$^{3}$ I2, note I ; 259, note.

278 $8^{\text {. }}$ sunbeorht gesetu. This is properly Heliopolis in Egypt, as Gryphiander's ( 1618 ) emendation (urbem for ortus) would suggest (see Introduction, p. xxxix). The Old English poet is likely, however, to have read ortus, which would carry him back to line I of the Latin; accordingly, he seems to have no suspicion that Egypt (see Lact. I5I) 
is an intermediate stopping-place, but identifies sunbeorht gesetu with $c \bar{y} p b u\left(277^{\mathrm{b}}\right)$ and $\bar{e}$ adig épellond $\left(279^{\mathrm{a}}\right)$. See note on $33 \mathrm{Iff}$.

28I-2 ${ }^{\mathrm{a}}$. Cf. $395 \mathrm{ff}$.

284. beorhstede. Cf. El. 578.-forbylmde. So only Jud. $118 ; E l .767$. 286. This statement is an invention of the Old English poet, who apparently sees no connection between the Latin here and at $33 \mathrm{I}$ ff. $\mathrm{He}$ could not well introduce an allusion to a heathen altar, and any reference to a Christian altar would of course be meaningless. Achilles Tatius is the only other author who states that the remains were buried.

287. ealonde. The $\bar{g}$ glond of 9 , as the $b \bar{a} m$ seems to indicate.

288a. Thorpe translates: 'the sign of sun'; Grein (Dicht.): 'der Leuchtglanz der Sonne'; Go.: 'the sign of the sun'; Bright says: 'sunnan segn, "the sign of the sun" = "the sun," just as the sun is also called täcen (1. 96) and beacen (1.107); the same figure is merely varied in expression to suit the alliteration.' Against this is to be said: (I) the MS. has pegn; (2) this term sufficiently corresponds to satelles, Lact. 33, and lines $90-147^{b}$ of the Old English; (3) segn is used in the poetry only in the sense of 'ensign,' 'standard,' literally or figuratively, if we except Gen. 2370, when it is used of circumcision as a sign of God's covenant; Sal. 236, where it is used of the cross; and Beow. 1204, where it is employed to mean 'cognizance.' Now päre sunnan segn could not mean 'standard of the sun'; the Phœnix is nowhere treated in the poem as a sign of the sun, that is, as standing for or designating him, though there is reason enough for $u s$ so to conceive him (see Introduction, pp. xxxviii ff.); the explanation of be acen and tācen suggested in the note on Io 7 would not apply here. There is, accordingly, no ground for departing from the MS. reading.

$288^{\mathrm{b}}$-9o. Cf. $92-94$, 102-3. One is reminded of Tennyson, Lucretius 133-4:

King of the East altho' he seem, and girt

With song and flame and fragrance.

289. glādost. Silver is called glēe, Gen. 2719, and gold is so referred to in Sal. 488 ; Rid. 64.3.

29I ff. In reading any description of the Phœnix, we must remember how hard it is to picture the sun in his thousand liveries at his rising and his setting. The earliest non-Egyptian account is that by Herodotus: 'The plumage of his wings is partly golden-colored and partly red; in outline and size he is very like an eagle.' Ezekiel, the Hebrew poet: 'In size he was about twice as large as an eagle, with wings of many colors. His legs were red, and his neck adorned with yellow feathers. His head resembled that of the domestic cock, and the pupil of his eyes was of a quince yellow, and round like a seed.' Pliny (similarly Solinus): 'The bird is of the size of an eagle, and has a brilliant golden plumage about the neck, while the rest of the body is of a purple [crimson] color, except 
the tail, which is azure, with long feathers intermingled of a roseate hue; the throat is adorned with a crest, and the head with a tuft of feathers.' Achilles Tatius: ' $\mathrm{He}$ is about the size of a peacock, but superior to him in beauty; his plumage is bedripped with gold and purple, and he boasts of being descended from the sun-a claim which is. borne out by the appearance of his head, which is crowned by a splendid circle, the very image of that orb. The hues are mingled rose and azure, and the disposition of the feathers represents the rays.' Pseudo-Epiphanius: 'The Phœnix is more beautiful than the peacock. The peacock has its wings overspread with gold and silver, but the Phœnix with sapphire, emerald, and other precious stones. It has a diadem on its head.' PseudoEustathius: 'The Phœnix is of the size of a peacock, but differs from it in color and beauty. Its wings are of crimson and gold, and its head is distinguished by a goodly diadem of circular form. The circle is of darkblue, and resembles a rose. Beautiful to look upon, and with a crest of rays, it is like the sun on high.' Philostratus: 'It emits rays, and blazes with gold, having the size and shape of an eagle.' Isidore of Seville: 'So-called, because he has the Phœnician [Tyrian] color.' Tacitus: 'Differs from all other birds in its beak and the tints of its plumage.' Ausonius (Ep. 20): 'Next in beauty to the peacock.' Claudian (tr. Vaughan):

A secret light there streams from both his eyes;

A fiery hue about his cheeks doth rise;

His crest grows up into a glorious star,

Given to adorn his head, and shines so far

That, piercing through the bosom of the night,

It rends the darkness with a gladsome light.

His thighs like Tyrian scarlet, and his wings-

More swift than winds are-have sky-colored rings

Flowery and rich, and, round about enrolled,

Their utmost borders glister all with gold.

294. wrixled. Thorpe's emendation, wrixled (adopted by Gollancz), is attractive, but cf. lix $x$ ¿ठ, 299.

301. eaggebyrd. For gebyrd in the sense of 'nature,' see 360 . For Trautmann's -gebyrgd, see Schlotterose's note.

302. stāne. The jacinth (so Lactantius), which may mean the sapphire.

3II. fötas. For fët (Jul. 472; El. 1066). Tupper says, with reference to the bearing of this form upon Cynewulfian authorship (Pub. Mod. Lang. Assoc. 26. 268) : 'What then shall we say to the use of both fótas and $f \bar{e} t$ in the Metrical Psalter; and to the appearance of fote and fét (dat.) in two riddles [ 32 and 33] certainly from the same hand?'

312. pēan. The poet makes no mention of Lactantius' pheasant.

3r7. Like the sun.

322 $^{\mathrm{a}}$. Swā. When. Cf. 4I, and also I2I. 
$324^{\mathrm{b}}-5^{\mathrm{a}}$. So Chr. $884^{\mathrm{b}}-5^{\mathrm{a}}$.

33I ff. This is referred by Lactantius to Egypt.

$337^{\text {a }}$. of. So El. 282 ; Gu. 859. Cf. PBB. Io. 280 (18. c).

$340^{\mathrm{a}}$. So $123^{\mathrm{b}}, A n .868^{\mathrm{b}}$. The passage relating the flight of the eagles, An. 865 ff., may be compared with $335^{\mathrm{b}} \mathrm{ff}$.

342. wilgedryht. So An. 9I4; cf. wilgesiððas, Beow. 23.

344. cyning. The poet Ezekiel says (cf. note on 174): 'He seemed the king of all birds, for all the winged things together hastened after him in fear.' For the retinues, compare the accounts of Tacitus, Achilles Tatius, Statius (Silv. 2. 4. 16-7), Claudian (Ph. 76-80; De Cons. Stil.).

$349^{\mathrm{a}}$. Cf. $66^{\mathrm{b}}$.

$355^{\mathrm{a}}$. So $647^{\mathrm{a}}$; Beow. I $3^{\mathrm{a}}$; cf. Chr. $20 \mathrm{I}^{\mathrm{a}}$.

364. Cosijn's emendation, aurnen for urnen, is recommended by Gen. 1626: 'oðłæat his dōgora wæs rìm ăurnen'; $E d g$. I6: 'swā nēah wæs pūsend [wintra] āurnen.'

$372^{\mathrm{a}}$. Cf. $639^{\mathrm{a}}$.

$373^{\mathrm{b}}$. Cf. $435^{\mathrm{a}}$ - -weseb. Of forms from this stem in the ind. pres., $\mathrm{Cos}^{2}$ knows only $\mathrm{Bl}$. Hom. I53. II : "ponne wesap pine handa sōna geednēowede.' Cf. Gram. ${ }^{3} 427$, note Io.

383. deorcne dēar. See $499^{\mathrm{a}}$.

385-6. Cf. Gu. 811-2.

386a. So Chr. 347; Rood 143; cf. Dan. 367; Rood 135.

$386^{\mathrm{b}}$. So $475^{\mathrm{b}}$.

$390^{\mathrm{a}}$. So $646^{\mathrm{a}}$.

$390^{\mathrm{b}}$. Cf. $450^{\mathrm{b}}, 509^{\mathrm{b}}, 517^{\mathrm{a}}$.

$393^{\mathrm{a}}$. Cf. $\mathrm{I}^{\mathrm{a}}$.

393-423. Abbetmeyer (p. 28) thinks this is derived from a common source with Gu. 79I-850, 947-8, 953-969; Chr. I379-I413; Sat. 410-42I, 478-488; Jul. 494-505. The resemblance is especially striking with the first of these passages.

395-6a. Cf. Chr. 1389-90; Gu. $804^{\mathrm{b}}-5^{\mathrm{a}}$.

397-8 . Cf. Gu. $799-800^{\mathrm{a}}$.

$39^{\mathrm{b}}-9$. Cf. $G u .8 \mathrm{1} 4$.

$400^{\mathrm{a}}$. Cf. $G u \cdot 805^{\mathrm{a}}$.

$402^{\mathrm{b}}-4^{\mathrm{a}}$. Cf. $G u .8 \mathrm{1} 9^{\mathrm{b}}-820$.

$405^{\mathrm{b}}$. Cf. Gu. $827^{\mathrm{a}}$.

$407^{\mathrm{b}}$. Seems hopelessly corrupt.

408 a āgeald. Construction not apparent.

408 $8^{\mathrm{b}}$ Cf. Beow. $7 \mathrm{II}^{\mathrm{b}}$.

409. Cf. $G u .958$.

4I I $\mathrm{I}^{\mathrm{b}}-2$. Cf. Chr. I405-6.

$413^{\mathrm{a}}$. So Sat. $4 \mathrm{r} 2^{\mathrm{a}}$.

415 $5^{\mathrm{b}}-6$. Cf. Chr. 1408 ${ }^{\mathrm{b}}-9$ : 'ond pā bidrifen wurde on pās pēostran woruld'; similarly $G u .827^{\mathrm{b}}-9^{\mathrm{a}}$. The Paradise from which they were banished was not on this earth (see Introduction, pp. liv-lv). Cf. 
Sulpicius Severus, Eccl. Hist., Bk. I, beginning: 'They were banished as exiles into our earth.'

4I7. sēlle. But betere, El. 1046.

$4^{20^{\mathrm{b}}}$. An object is required for ontȳnde, 423.

$42 \mathrm{I}^{\mathrm{a}}$. So Chr. $587^{\mathrm{a}}$.

$42 \mathrm{I}^{\mathrm{b}}$. Cf. $\mathrm{II}^{\mathrm{b}}$.

$423^{\mathrm{a}}$. So $P n \cdot 73^{\mathrm{a}}$.

$424^{\mathrm{b}}-5$. Cf. $P n$. $13^{\mathrm{b}}-\mathrm{I} 4$.

$425^{\mathrm{b}}$. So $33^{\mathrm{b}}$; cf. $30^{\mathrm{b}}, 655^{\mathrm{b}} ; E l .827^{\mathrm{b}}, 1256^{\mathrm{b}}$.

$426^{\text {b. Cf. }}$ I $53 \mathrm{ff}$.

$428^{\mathrm{b}}$. So $162^{\mathrm{b}}$.

432 ff. See 189 ff., and cf. Chr. $245 ; A n$. I58.

432. micel. El. prefers myc- (except 876).

433. feorh geong. . onfōn. Cf. $192^{\mathrm{a}}$.

435. ealdcȳðbu. See $35 \mathrm{I}, \mathrm{Chr} .738$.

436. Cf. 278.

$437^{\mathrm{b}}$ ff. Cf. $4 \mathrm{II}^{\mathrm{b}} \mathrm{ff}$.

$43^{\mathrm{b}} \mathrm{ff}$. Cf. $J u l .502^{\mathrm{b}} \mathrm{ff}$.

440. longne sīo. So 555 .

44I. lond. This conjecture of Grundtvig's is sufficiently supported by Gen. 737, pỹstre land, but in favor of the MS. reading may be adduced An. 216-7, feorh beran in gramra gripe; An. 950-I, genēðan in gramra gripe; Dan. 307, on haft heorugrimra.

$450^{\mathrm{a}}$. Cf. Chr. I565, fācentācen.

$450^{\mathrm{b}}$. So $390^{\mathrm{b}}$.

45 I ff. Cf. I $88 \mathrm{ff}$.

454 . Cf. Chr. I508b.

46I. gieltas. For normal gyltas.

$463^{\text {b. }}$ See Gen. I5. I; Ps. 3. 3 ; 28. 7 , etc.

465 ff. See 2 Cor. 2. I5; Eph. 5. 2; Phil. 4. I8; Rev. 5. 8; Ambrose, Hexaemeron 23. 80 (Migne, Patr. Lat. I4. 238); Rabanus Maurus, De Universo 8. 6. Also $P$ n. $64^{\mathrm{b}} \mathrm{ff}$., and notes.

469. Cf. 45 I.

$475^{\mathrm{b}}$. So $386^{\mathrm{a}}$.

$48 I^{b}$. longe. See $489^{b}$.

49I-588. Cf. 48, and see the references to other poems in The Christ of Cynewulf, note on $1660^{\mathrm{b}}-2^{\mathrm{a}}$.

49I. Cf. Chr. 795.

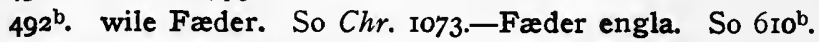

$497^{\mathrm{a}}$. Brego engla. So $568^{\mathrm{b}}$.

502. Cf. Jul. 445.-scome. Cf. the form sceame, El. 470. $504^{\mathrm{b}} \mathrm{ff}$. Cf. $219^{\mathrm{b}} \mathrm{ff}$.

506 . So Jul. $688^{\mathrm{a}} ; E l .1260^{\mathrm{a}}$.

508-45. Cf. Brown, Pub. M. L. A. I8. 308-334, especially 33I-3.

509 . Cf. Chr. $1570^{\mathrm{b}}$. 
510a. So Gu. $797^{\mathrm{a}}$.

5I1. Anwalda. Anwald means 'power' (cf. 663), which does not fit the context, while anw(e)alda (onwealda), as found in Beow. 1272, Rood 153, Rid. 4I. 4, Sat. 642, and Gu. 610, offers just the sense required. In the second hemistich, eal now bears the alliteration, as in $E l$. 803, instead of up; cf. Beow. $835^{\mathrm{a}} ; C h r .1183^{\mathrm{a}}, 1378^{\mathrm{b}} ; A n .1485^{\mathrm{a}} ; \operatorname{Dan} .275^{\mathrm{b}}$.

513. So Gu. 810; cf. Gu. II49; Chr. $777^{\text {a. }}$-gǣest. So always in $P h$., but $g \bar{a} s t$ in $E l . ;$ cf. gāest-, Pn. 21; gāst, W. 29.

514 $4^{\mathrm{b}}-5$. Cf. Chr. 1009 .

5 56 $^{\mathrm{b}}-7$. Cf. Chr. I079 $-80,1333$.

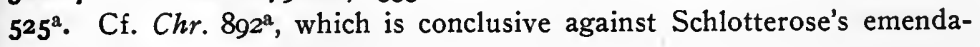
tion.

$5^{2} 5^{\mathrm{b}}$. Cf. Chr. $8 \mathrm{II}$.

526 ff. Cf. I 88 ff., 451 ff.

538. geweorbed. Note the different form in El. II92, 1275; cf. also Ph. 80, etc., with $E l$. 575 .

539 ff. Cf. 337 ff.

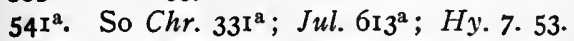

549b. Cf. purh Gēstes gi(e)fe, Chr. 649, $710 ; G u . '$ I088; El. I99, I058, II57. Job was inspired by the Holy Ghost; therefore receive his testimony. 550 ${ }^{\mathrm{a}}$. So $E l$. $1095^{\mathrm{a}} ; A n$. $1120^{\mathrm{a}}$; cf. Jul. $535^{\mathrm{a}} ; G u .626^{\mathrm{a}}$.

552-69. This passage paraphrases Job 29. I 8 and 19. 25, 26, these latter verses having been illustrated by the Phœnix as early as Clemens Romanus († A. D. 100), First Epistle to Corinthians, chap. 26. The Vulgate of 29. I8 has palma (In nidulo meo moriar, et sicut palma multiplicabo dies), while the English renders by 'sand.' Here the Septuagint has $\dot{\omega} s \sigma \tau \hat{\lambda} \epsilon \chi o s$

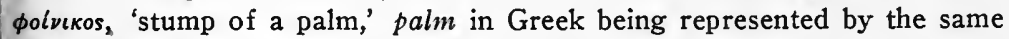

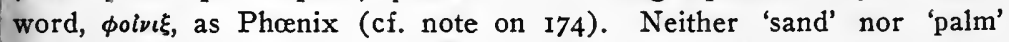
has any relation to 'nest.' Since the Hebrew words for Phanix and sand are identical- $k h \bar{o} l-i t$ is easy to see how the confusion might arise. The consensus of opinion among the best Hebrew scholars is, I believe, at present in favor of rendering this Hebrew word in Job 29. I8 by 'Phcenix,' a view which is supported by Rabbinical tradition, and is in consonance with the opinion of many scholars that the author of the book of Job had resided in Egypt, as shown by his intimate acquaintance with that country.

It remains to be seen from what Latin source the author of our poem could have gained the information which enabled him to use Job 29. I8 for his purpose, seeing that the Vulgate gave no hint of the Phœnix. This author is commonly said to be Bede (Grundtvig, Gaebler, Bright, Schlotterose, etc.), to whom the following passage has been attributed:

'Palma autem arbor secundum Græcos phoinix dicitur. Avis quoque illa, quam multi facile quidem vivere autumant, phoinix eodem nihilominus vocabulo nuncupatur. Potuit fortassis de eadem hoc loco dixisse, ut sicut illa, nidum sibi faciens, in ipso post.multa tempora a semetipsa 
dicitur concremari, et rursus de eisdem nidi cineribus fertur intra breve tempus resurgere, quæ deinceps multis vivat temporibus; fieri ergo potest ut sanctus Job in similitudine avis illius dicat se post mortem in cinere carnis velut in nido pro tempore futurum et inde resurrecturum in gloriam, atque hos esse æternos ac beatos dies, quos multiplicandos sibi fidelis Dei cultor expectet. Ita enim et superius est locutus, dicens: Et rursum circumdabor pelle mea, et in carne mea videbo Deum.'

This passage is indeed found in two uncritical editions of Bede-that of Basel, 1563 (4. 757), and that of Cologne, I612 (Vol. 4), as part of a commentary on Job; but Bede himself attributes the commentary, in his De Ratione Temporum (Chap. 4, 'De Ratione Unciarum': ed. Giles, 6. I48), to Philip the Presbyter ( $\dagger 456)$, an account of whose life is given by Gennadius, De Viris Illustribus (chap. 62). There is also said to be a Bodleian manuscript, written in Old English characters, which makes the same attribution (cf. Giles' ed. of Bede, 9. $x$-xi). The commentary has also been edited under Philip's own name (thus Basel, 1527), and sometimes with the works of Jerome, of whom Philip was a disciple (thus the Benedictines in their Vol. 5, and Vallarsi in his Vol. II).

556. gūdǣ. For $\bar{i} u d \overline{\mathscr{e}} d$.

560. scolu. El. has sceolu.

$563^{\mathrm{a}}$. lēohtes and lissa. Cf. liffes and lissa, 150; līfes ne lissa, Chr. 1366; Gu. 806 .

565. wynnum. From Job 19. 26.

566. ālyseð. This is the only word that suggests the 'redeemer' of Job 19. 25.

$575^{\mathrm{b}} \mathrm{ff}$. Cf. $267^{\mathrm{b}} \mathrm{ff}$.

58I-677. Cf. $C h r$. $1660 \mathrm{ff}$.

587. Sunne. Cf. Chr. 106, 696. For Christ as the sun, see Introduction, pp. xliv-xlv.

59 If. Cf. 337 ff., 539 ff.

$595^{\mathrm{a}}$. See $W \cdot 39^{\mathrm{a}}$.

$597^{\mathrm{a}}$. So $55^{\mathrm{a}}$.

$598^{\mathrm{b}} \mathrm{ff}$. See I Cor. 3. I3.

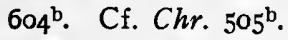

608. So Chr. I070.

6 II ff. Cf. $50 \mathrm{ff}$.

6r3. Cf. Rid. 44. 3 (Cosijn).

$6 \mathrm{r} 4^{\mathrm{a}}$. Cf. $52^{\mathrm{a}}$.

622-6a. An adaptation of Rev. 7. I2.

$624^{\mathrm{a}}$. geongra gyfena. This finds parallels in Gifts of Men 2: geongra geofona; Gu. I0I5: gingra geafena. Otherwise one might think of ginfastra gyfena, 'ample gifts,' this adjective and noun being conjoined in Beow. 1271, 2182; Gen. 2919; Jul. 168; Met. 20. 227; the metrical type, however, is rare: Beow. I1 $199^{\mathrm{a}}$, hordmāðum haleða (PBB. 10. 310). 
$626^{\mathrm{b}}-31$. A paraphrase of the Sanctus. See the note on $403-415$ in The Christ of Cynewulf. Other paraphrases are the lines just mentioned and $E l$. 750-3. The Latin is: 'Pleni sunt cæli et terra gloria tua. Osanna in excelsis.'

$63 \mathrm{r}^{\mathrm{a}}$. 'In excelsis.'

639. See El. 776 .

639 . So $G u$. $1335^{\mathrm{b}}$; El. $336^{\mathrm{a}}$.

$646^{\mathrm{a}}$. So $390^{\mathrm{a}}$.

$646^{\mathrm{b}} \mathrm{ff}$. Cf. $222^{\mathrm{b}} \mathrm{ff}$.

$647^{\mathrm{a}}$. So $355^{\mathrm{a}}$.

$65^{\mathrm{b}}$. So $\mathrm{Chr} .424^{\mathrm{b}}$.

65 ${ }^{\mathrm{b}}$. Cf. Chr. $165^{\mathrm{b}}$.

652 ff. Cf. I $88 \mathrm{ff} ., 45 \mathrm{Iff} ., 526 \mathrm{ff}$.

$68^{\mathrm{a}}$. So Chr. $58 \mathrm{0}^{\mathrm{a}}$, and note in The Christ of Cynewulf.

659. The Greek Physiologus has: 'The Phœnix resembles our Saviour, who came from heaven with his two wings full of fragrance, that is, of virtuous celestial words, in order that we with holy prayers may extend our hands, and send up spiritual fragrance by means of our good lives.'

659 . Cf. worda and weorca, Beow. 289 .

$66 \mathrm{I}^{\mathrm{b}}-3^{\mathrm{a}}$. Cf. Rev. 4. II ; I. 6; Jude 25 .

$66 \mathrm{I}^{\mathrm{b}}-2^{\mathrm{a}}$. So $C h r .777^{\mathrm{b}}-8^{\mathrm{a}}$.

665. So Chr. 557; Jul. I64.

$667 \mathrm{ff}$. For other examples of such macaronic verse in Old English, see Conybeare, Illustrations, pp. ix, $\mathrm{x}$.

$667^{\mathrm{b}}$. lucis Auctor. Cf. El. 486: ealles lēohtes Lēoht. 


\section{SUPPLEMENT TO NOTES ON PHAENIX}

\section{Translation of Lactantius, De Ave Phonice ${ }^{1}$}

In the far east there lies a blessed place, Remote from man, where open stand the gates Of the eternal heavens; no summer's heat Nor winter's cold comes ever near that land, But there an everlasting spring abides.

5 The country stretches out, a wide champaign; There yawn no hollow vales, there rise no hills, Yet higher by twelve cubits length that land Than mountains we call high. A grove is there, Sacred to Phobus, and a wood thick set

Io With trees whose leaves for evermore are green. When Phaeton's chariot set the world aflame, That place was all inviolate by fire;

And when the earth was whelmed beneath the waves Of the great flood, it lifted up itself

I5 Above Deucalion's waters. There is found No wan disease, nor suffering old age, Nor cruel death, sharp fear, nor dreadful crime, Nor maddening lust, nor wrath, nor rage that glows With love of slaughter; nor is bitter grief,

20 Or poverty in rags, or sleepless care, Or wretched famine there. There rage no storms, No winds blow there with puissance terrible, Earth is not covered there with cold, wet snow, Nor do the clouds stretch o'er the earth their fleece, Nor violent rain-storms fall. But in the midst

25 A fountain springs-living, so runs its nameClear, gently flowing, an abundant stream Of sweetest waters; ceaselessly it flows Through all the twelve months of the passing year, And keeps the woodland green. Here grows a tree That lifts its branches high, and bears a fruit

30 Mellow and fair, that never falls to earth.

Within these groves there dwells a wondrous bird, The Phœnix, solitary satellite

Of the great sun it follows and obeys; Ever it lives, by its own death restoredGreat Mother Nature gave to it this power.

${ }^{1}$ The line-numbering is that of the Latin original. 
35 When bright Aurora rising first grows red, When fly the stars before the dawn's first light, Ofttimes it plunges in the sacred flood, And of the living fount as often drinks; Then upward flies, and on the highest bough

40 Of a tall tree that overtops the grove It lights, and, turning toward the place whence comes The new-born Phœbus, waits his first bright rays, The glory of his rising. When the sun Touches the threshold of his shining gates, And the light breeze of early morn springs up,

45 Singing it pours a flood of sacred song, Invokes the new light with a wondrous voice, To which no music of the Delphic flute Nor Philomelian warblings can compare; The dying swan's last song is thought less sweet,

50 Less sweet Cyllenean lyre's sonorous strings. When, ever moving, o'er the whole round world Phobus has shed his light, and loosed his steeds In the Olympian fields, thrice does it beat Alarum with repeated stroke, and thrice

55 Is silent, worshiping the fiery one.

Priest of the light and of the sacred grove, Conscious alone of thy great mysteries, $O$ Phobus, thus it fills the flying hours Of day and night with rarest melody. But when a thousand years have passed away,

60 And the long ages weigh upon its head, It leaves its fair, accustomed resting-place Within the grove, that so it may renew Its youth. When thus, desirous of new birth, It leaves the sacred groves, it seeks the earth Where death is regnant. Into Syria

65 The aged one directs its swift-winged flight, Into the land which from itself is named Phœnicia; there it seeks through pathless tracts A secret spot, if anywhere there be Within the forest a thick place remote. It seeks a certain palm with lofty top,

70 Named by the Grecians phœnix, from the bird; Nothing can break through this to do it harm, Nor gliding serpent nor harsh bird of prey. Then Aeolus within his pendent cave Shuts up the winds, lest their harsh blasts should stir The purple air; through heaven's empty vault 
75 No cloud may move to dim the sun's bright rays,

Or shut them from the bird. There doth it build Or nest or tomb-it dies that it may live, And by itself creates itself anew.

From the rich wood it gathers here sweet balm,

80 And fragrant spices which Assyrians pluck,

Or rich Arabians, or the pigmy race,

Or Indians; such as the Sabæan land

Nourishes in its warm and fertile breast.

Cinnamon, and the rich amomum-fruit

With its far-breathing fragrance, and sweet balm

85 Hither it brings, nor are the pliant withes

Of mildest cassia, odorous acanthus,

Or fragrant incense-gum, or drops of oil

Wanting. It adds to these the tender beards

Of juicy nard; thy virtue too it brings,

All-healing myrrh. Then on the new-made nest

90 It rests, and, old and withered, seeks repose

Upon this bed of life. Then from its beak,

Dying it breathes its body's spirit forth,

Amid the mingled odors yields its life,

Nor fearing trusts itself to such repose.

95 Then by life-giving death destroyed, its form

Grows hot, the heat itself produces flame,

And from the distant sun conceives a fire;

It burns, and into ashes is dissolved.

These ashes come together in a mass,

Io0 As if compelled; the mass is like a seed.

Thence first there comes a creature without limbs,

A milk-white worm; when this has grown with time,

Into the semblance of a rounded egg

It curls itself, just as, when ugly worms

105 Hold to the rocks by slender filaments,

The worms are wont to be transformed to moths.

Thence is it framed in fashion as before,

And from the broken shell the Phœnix springs.

IIo It does not on our earth partake of food;

Of dew ambrosial from the starry skies

It drinks; on this, in midst of odorous airs,

The winged one is nourished till it grows

To full maturity. When early spring

II Begins to bloom, it takes its flight toward home,

But first, lest aught of its old form remain,

It mingles with myrrh, frankincense, and oil

The ashes, bones, or aught that still may be, 
I20 And moulds it with its beak into a ball;

The ball it in its talons takes, and flies

East to the City of the Sun, and lights

Upon an altar, leaves its burden there

Within the sacred temple's holy shrine.

Glorious is it, and wondrous to behold;

Great is the fame and beauty of the bird.

25 Its color is of Tyrian purple dyed

In grain-such color as the poppy-leaves

Show in the spring, when Flora spreads her robes

On the red earth; its wings and lovely breast

Shine with this color, and its head and neck

I30 And all its back are of this brilliant hue;

Its tail, spread out like shining gold, is flecked

With purple spots; above, between the wings,

Are the bright rainbow-colors Iris paints

I35 Upon the clouds; clear white with vivid green

Mingled, its beak is ivory, bright with gems;

You would believe its eyes twin sapphires were,

Smit with a lucent flame; a radiant crown

Surrounds its head, like the bright rays that make

I40 The glorious insignia of the sun;

Spots of bright gold cover its legs, its claws

With the fair color of the rose are dyed.

Like peacock, or like Phasis' bright-hued bird,

I45 It seems. In size ' $t$ is like the bird,

Which, huge of bulk, stalks o'er Arabia's sands,

But yet not slow, like the great-bodied fowl

Whose ponderous. weight compels a heavy flight,

But light and swift, and full of regal grace-

I50 Such has it ever looked when seen of man.

Great Egypt came to see this miracle,

And all the host, rejoicing, worshiped there

The wondrous bird. Straightway they sculptured it

In sacred marble, gave the day and year

From this another name. The race of birds

155 Gathered together, fear and prey forgot;

Supported by a thronging choir it flew ;

A joyous multitude with pious gifts

Followed its flight. But when at last it came

To the pure ether, then the throng turned back,

I60 Each seeking its own place.

O happy bird, how fortunate thy lot,

Whom God himself has caused to be new born

From thine own self! In thee there is no sex, 
Nor is there lack. O happy bird, that knows

No bond of love! Death is thy only love,

I65 Thy one delight is death! Thou long'st for death,

That thou may'st be new born. Thou art thyself

Child to thyself, thy father and thy heir,

Both thine own nurse and nursling; still thyself,

Yet not the same, thyself yet not thyself,

I70 Attaining life eterne through fecund death.

ELLA ISABEL HARRIS

\section{The Late Old English Version of the Phonix}

Two manuscripts-Vespasian D. I4 of the British Museum and 198 of Corpus Christi College, Cambridge-contain an abstract of our Phœnixstory, introduced by a brief account of the Earthly Paradise, which St. John is reported to have seen in vision. The passage in the Vespasian manuscript seems to have been first mentioned by Thomas Wright in his St. Patrick's Purgatory, I844, pp. 25-6, who translates a few lines at the beginning; from him it was taken by Soames, Anglo-Saxon Church, I856, p. 211, note 3, and Baring-Gould, Curious Myths of the Middle Ages, I869, pp. 255-6. Both manuscripts are excerpted by Kluge, Englische Studien 8 (1885). 474-9, who concludes, from the metre, that the version must be dated I050-I100.

I subjoin a somewhat emended version of MS. CCCC. I98 $\left(374^{\mathrm{b}}-7^{\mathrm{a}}\right)$, as published by Kluge, with a few notes calling attention to correspondences with the standard Old English version of the Phonix. Variants are designated by $V$. when they come from the Vespasian manuscript; otherwise they are from the Cambridge manuscript. No attempt has been made to register all the different readings of $V$., and differences of spelling are virtually disregarded.

The notes are almost exclusively devoted to pointing out correspondences with the standard version, or referring to Biblical originals.

Sanctus Johannes geseah ofer gārsecge swilce hit land wǣre. pā genam hine se engel, and gebrōhte hine to Paradisum, bæt is, neorxnawonge. Paradisum nis nāđor nē on heofonum nē on eorban Fēowærtig fæờma hēah wæs Noes flōd ofer đ̄a hēhstan dūne be on

5 worulde is-sēo dun is on Bōcleden gehăten Armenia; nū is Paradisum fēowærtig fæð̀ma hēhgra ponne Noes flōd wæs. Paradisus hangað̆ betwȳnon heofonan and eorð̌an wundorlice, swā hit se Ealwældend gescēop. Paradisus is eall efenlang and efenbrād.

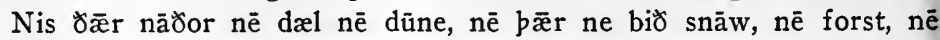
Io hagol, nē rēn; ac b̄̄r is fons vite, bæt is, lifæs wylle. Đonne

I Scs. -4 fædma. $-9 \mathrm{~V}$. denne for dæl. 
kalendas Januarii inn gāo, bonne flōwæở sēo welle swā fægere and swā smoltlice swā hunig, and nā dēopre bonne mon mæg wǣtan his finger forwyrdne. Ofer bæt land eall hīo flōweð̋ ālce mōnö̀e

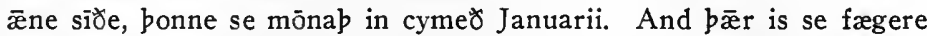

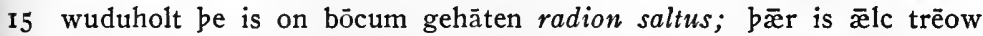
swā riht swā bolt, and swä hēah bætte nǣefre ne on eorđan nān man gesēon meahte, nē ēac hwilces cynnes hio syndon. $\mathrm{Ne}$ fealర

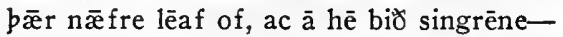

wlitig and wynsum, welena unrim.

20 Paradisus is ūprihte on eastewearde Jysse worulde. Nis $p \bar{x} r$ nē

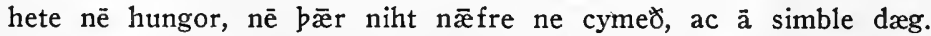

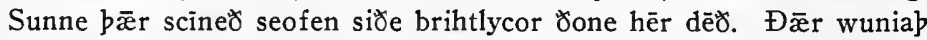
on Godes ænglas unrim, mid bām hālgum sāulum, op Dōmæsdæg.

Đ̋̄r wunað on

ān fāger fugol, Fenix hāten;

hē is mycel and mǣre, swā se Ælmihtiga hine scēop.

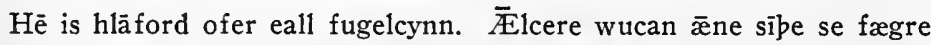
fugol hine babað in bām lïæs wylle; and bonn flēogeđ se fugel, and āsett hine on pret hēagoste trēow be is on Paradisum, ongēan

30 bā hātan sunnan. Ponne sciñæð hē swā sunnan lēoman,

and glitenað̛ swã swylce hē sio eall gylden.

His fiðera syndon ænglas feðerum gelice,

his brēost and his bile beorht syndon

fāgere and fāge - fēawe synden swylce;

35

hwæt! his ēagan æð̋ele senđon, swā clǣne swā cristal,

and swā scīre swā sunnan lēoma. His fēt syndon

blōdrēade bēgen twēgen, and se bile hwìt.

Hwaet! se fāgera fugol flēogeð of his earde, se be is fägerlīce Fenix haten.

Witodlice wuna hē on Egypta land

fïftēne wucan fæste ætgædere;

II otun gæð; $V$. inn gað. - I3 $V$. on forewarde; monað; $V$. monde. - I4 ana; $V$. ane. - I5 radian; $V$. radion. - I6 $V$. bæt nan eor 8 lic man ne geseh swa heh, ne seggen ne cann hwilces. - 2I mete; $V$. hete; $V$. by $\varnothing$ for cymeð. - 22 seofanfealdlucor and beorhtlicor; $V$. seofen siðe brihtlycor; $V$. on bissen earde for her de $\delta .-25 V$. an fugel fæger. $-26 \mathrm{~V}$. mihtige hine gescop. $-28 \mathrm{~V}$. on bære. $-29 \mathrm{~V}$. gesett uppe for asett hine on. $-3^{\mathrm{I}}$ $V$. swilc he gyldene seo. $-33^{\mathrm{b}} V$. brihte scined. $-34^{\mathrm{b}}$ æghwilces cynnes; $V$. feawe synden swylce. $-35^{\mathrm{a}} V$. eagene twa. $-35^{\mathrm{b}}$ ethelice; $V$. æðele. $-38 \mathrm{~V}$. om. twegen. $-4 \mathrm{o}^{\mathrm{a}} \mathrm{V}$. fægere. 
¿onne cumal tō him, swylce hī cyning wāere, fægniap and folgiap eall fugolcynn.

wrītigað and singað onbūtan him-

ælc on his wīsan ænne heriab.

Đonne færo bæt folc feorran swipe, wāfiap and wundriap, wellcumiað Fenix; 'Hāl wes bū, Fenix, fugela fǣgerest! feorran hider cumen!

Đū glitenast swā rēad gold, ealra fugela cyning, Fenix gehāten.'

Đonne wercað hīo of weaxe, wrïtiad Fenix,

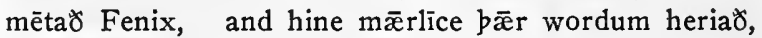
fugela fǣgerest, Fenix hāten.

Đonne fagnial b̄̄er fugelas ealle, fǣgere and fāge fela ætgedere, feallað̛ tō fōtum, Fenix grētað. His stæen is swā beorht swā bȳme, and his swēora swilce smǣte gold, and his forebrēost fāgre gehīwod, swylce marmorstān mǣ rost cynnes.

And him ān rēad hīow rudap on bām ricge; goldfylle gelic glitonap Fenix.

Hwæt! bes fugol fērde fæ̈gere tō his lande, ymbe fïftēne wucan; fugelas manige eall embūton efne fërdon, ufene and neopone and on $\bar{x}$ lce healfe ; đa hīo becōmon bǣr heora cyning sceolde, Fenix se fǣgere fugol gehāten, farab forb intō Paradisum, pæt is under heofonan hāma hēgost.

Đā wunede b̄̄r on Paradisum

Fenix se fǣgere fugel eall hālig; and bæt fugelcynn eall fērdon heom hāmweard, ǣlc tō his earde; àredon Fenix.

$43 \mathrm{~V}$. ponne cumeð him to swaswa to heora kinge (prose). $-44-5 \mathrm{~V}$. fageninde swyðe eall pæt fugelcinn $\|$ fægere gegrete $\delta$ ealle Fenix. -47 ænne; $V$. ealle hine. -5 I hider cumen; $V$. pu come. $-55-6 V$. and mete $ð$ hine fægere bær se madme stant. $-63^{\mathrm{b}} V$. mæres. $-64^{\mathrm{a}}$ ræd; $V$. read. $-64^{\mathrm{b}}$ ricge; $V$. hyrnge. $-66^{\mathrm{a}} V$. ponne fær ${ }^{\mathrm{b}}$ eft se fugel. $-66^{\mathrm{b}}$ lande; $V$. earde. -69 after this, $V$. has the following, instead of the next eight lines: otठtet heo nehiget neorxenewange. pær inn gefærð Fenix, fugele fægerest; and eall oðer fugelcinn to heora earden gewænded. 
Nū saga $̛$ hēr Sanctus Johannes sōðum wordum,

wìslìce and wærlīce swā se wertācen,

pæt six pūsend hēr on worolde Crīst forestihte.

Đone $\bar{x}$ fre embe ān būsend gēara

farađ Fenix, se fägra fugel,

wlitig and wundorlic.

pynceð him bæt hē forealdod sȳ, and gaderað bonne ofer eall Para-

85 disum tōgædere ealle bā dēorwurð̌n bōgas, and macab mycelne hēap tōgædere. And burh Godes mihte se hāte sunne scineb; and burh bāra sunnan hätnesse and hire lioman, se hēap wyröep onǣled be hē-se hālga fugol Fenix-geworht hafað̀. Hē feallađ̀ ponne onmidd bæt fȳr, and wyrờa forbærned eall tō dūste. Đonne on

90 bone briddan dæg ārīseð

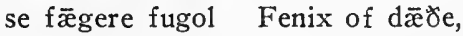

and bið edgung, and farað tō pām lifes wylle, and bapap hine bǣrinne; and him wexan onginna ở bā febera swā fægere swā hio $\bar{æ}$ fre fægereste wæ̈ron. And bus $\bar{a}$ emb būsend wintra hē hine 95 forbærneb, and eft for fæger ediung ūp ārīseb. And nafap hē nenne gemacan, nẽ nān man ne wāt hweber hit is-be carlfugol be cwēnfugol-būton Crīst sylf. Hē is-bes hālge fugel-Fenix gehāten, wlitig and wynsum, swā hine Eallwealdend gescēop; and bus drēogan sceal Drihtnes willan. $N \bar{u}$ is ùs andgyt forgyfenI00 mancenne: fugelas heriab Crīst; nū gedafena ${ }^{*}$ ùs bæt wē herian ūrne Drihten mid ælmæssan and mid hālgum bedum, and mid eallum bingum bæt wè witon bæt Gode lēof is, and gescildan ūs wip đã eahta hēahsynna, bæt wē bā ne fremman-bæt is, morbor and stala, māne āpas, and unrihtgitsunge, and unrihthæ̈medu, and gîfernesse, I05 lēasunga and āttorcræftas dyrne ligera, and twispēece, and ofermōdignæss. Beorgan wē ùs wỉ̧ ealle pās hēahsynna, and lufian ūrne Drihten mid eallum mægene and mid eallum mōde-se God be leofař and rixab,

se đe on heofonum is hēah and hālig, ealra cyninga Cyning. Crīst ūs generie, bæt wē on wynne wunian mōton,

se రe leofað and rixxað̆ sōollice mid Fæder, and Sunu, and mid bām Hālgan Gāste, ā būton ænde. Amen.

78 Scs. -79 For this line and the next $V$. has: swa se wyrhte cann. From this point on $V$. differs considerably. -95 eft for fæger; $V$. eft. 97 buton Crist sylf; $V$. but God ane; bas halgan fugeles; $V$. as in text. -98 eallwealdend; $V$. God. - 99 After willan $V$. has only: se be is on heofone heh and halig ealra kinge king. Crist us generige bæt we on wynne wunigen mote mid bam be leofeð and rixeð a bute ænde. Amen.

- IOI halgum em. from halgunge. - 102 we supplied. 
NoTES.

4. Fēowærtig fæòma. Cf. $P h .28 \mathrm{ff}, 4^{\mathrm{b}} \mathrm{ff}$.

8. efenlang and efenbrād. Cf. Rev. 2I. I6.

9. nē dūne. Cf. $P h .2 \mathrm{I}^{\mathrm{a}} \mathrm{ff} .-$ snäw, etc. Cf. $P h$. I $4^{\mathrm{b}}$ ff.--forst. Cf. Ph. 15, 58.

ro. hagol. Cf. $P h$. 16, 60.-lifæs wylle. Cf. $P h .62^{\mathrm{b}} \mathrm{ff}$.

13. Z̈lce mōnðe. Cf. Ph. 66.

15. wuduholt. Cf. $P h .34$.

17. Ne fealo. Cf. $P h .7 \mathrm{I}^{\mathrm{b}} \mathrm{ff}$.

18. singrēne. Cf. $P h .35^{\mathrm{b}}-36^{\mathrm{a}}$.

19. wlitig and wynsum. So $P h .318$; cf. $P h .7,13$.

20. èastewearde. Cf. $P h .2$.

21. hungor. So $P h$. 6r3.-niht. Cf. Rev. 21. 25.

22. seofen sì̀e. Cf. Isa. 30. 26; 60. 19, 20; Rev. 21. 23; 22. 5.

25. fäger fugol. Cf. $P h .85^{\mathrm{b}}-6^{\mathrm{a}}$.

$25^{\mathrm{b}}$. Fenix hāten. So $P h .86^{\mathrm{b}}$.

27. hlāford. Cf. $P h$. $15^{\mathrm{b}}-9$.

28. babad. Cf. Ph. 107.

29. hēagoste trēow. Cf. hēahne bēam, Ph. İI.

35. ëagan. Cf. $P h .301^{\mathrm{b}} \mathrm{ff}$.

37. fēt. Cf. $P h$. ЗI I.

39. fiēogeðे. Cf. $P h .322$.

4I. Egypta. Not in $P h$.

45 ff. Cf. $P h .335^{\mathrm{b}}$ ff.

54. Cf. $P h .33^{\mathrm{b}} \mathrm{ff}$.

6o. bȳme. Cf. $P h$. I34.

72. Cf. $P h .351$.

76. Cf. $P h .352^{\mathrm{b}} \mathrm{ff}$.

8r. pūsend. Cf. Ph. 364 .

84. gaderad. Cf. $P h .193$.

86. scineb. Cf. $P h$. 2 10.

87. onæled. Cf. $P h .216$.

90. priddan dæg. So $P h .644$.

9I. d̄̄öe. Cf. Ph. 434.

92. edgung. Cf. $P h .373,435$.

93. febera. Cf. $P h .239$.

96. carlfugol be cwēnfugol. Cf. $P h \cdot 357^{\mathrm{a}}$.

97. Crīst sylf. Cf. $V$. 'God āne'; $P h .355$, 'God āna wāt.'

98. wlitig and wynsum. So 19.

ro7. eallum mægene. Cf. Mk. 12. 30; Lk. 10. 27.

109. hēah and hälig. Only Chr. 379, 653 .

I10. ealra cyninga Cyning. So $C h r$. 136, 215; Jul. 289, etc.

III. wunian mōton. So Pr. I6. 


\section{NOTES ON PHYSIOLOGUS}

I ff. Cf. Gu. I ff.

\section{PANTHER}

I. Cf. 70 .

2. bära. The genitive is demanded, as in Chr. II84; Exod. 353, etc. $2^{\mathrm{b}}-3^{\mathrm{a}}$. Cf. Jul. $3 \mathrm{I} 4 ; A n .546$.

3. Cf. El. 635 .

$4^{\mathrm{b}}$. So $C h r .469^{\mathrm{b}}$; cf. $P n .65^{\mathrm{b}}$.

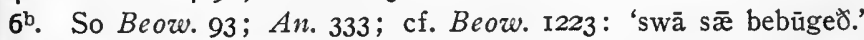

8. sealtȳða geswing. Cf. $\bar{y} ð a$ geswing, $A n .352$; Beow. 848; also sealtȳða gelāc, Seafarer 35 .

9. wrǣtlīcre. Cf. 19, 27; W. 50.-wildra. 'See Gram. 43.

ro. Cf. $P h \cdot 2^{\mathrm{a}}, 3^{\mathrm{a}}$.

roa. frēamǣrne. Subject accusative after hȳrdon.

rob. feorlondum on. The preposition follows, as in Ph. 2, 97, 362; Chr. 399; Jul. 83; Gu. ז337.

II. Cf. $A n$. I76.

$12^{\text {a. }}$ dūnscrafum. So 37 .

12 ${ }^{\mathrm{b}}$. Pandher. For Pander. Cahier's MS. B, referring to the etymology of the Greek word, thus comments: 'Panthera enim omnis fera, quasi omne animal odore capicns, interpretatur.' Rabanus Maurus (8. x) gives a somewhat different interpretation (Migne, Patr. Lat. IIr. 219): 'Panther dictus sive quod omnium animalium sit amicus, excepto dracone, sive,' etc.

I3 ${ }^{\text {a }}$. So El. 505 ; cf. El. 756; Chr. 107 r.

I4. cȳbad. So $P h .30$ (cf. Ph. 332, 425, 655; El. 827, 1256); but possibly we should read cyðdan.

15. ānstapan. Perhaps because he resorts to caves; cf. änhaga of the Phœnix, Ph. 87, 346.-Sē. For $h \vec{e}$.

16. duguða èstig. Cf. éste with the genitive, Gen. 1509-ro.

r7. in ealle tid. Accusative as in $P h .77$, etc.

18. yfla gehwylc. So $P h$. 460.- hē. The panther, who inflicts all possible injuries upon the dragon.

xg. wrätlīc. The panther is called beautiful in Pitra's Greek, Mai's Latin, Cahier's Latin MS. B, and the Ethiopic. MS. B refers the beauty to Christ, quoting Ps. 45. 2: 'Thou art fairer than the children of men.'wundrum. So $27 .-$ scȳne. Cf. 26 , and see $P h .307$.

20. hiwa. Cf. 25.-gehwylces. Dependent on scȳne; cf. $26^{\mathrm{a}}$.

$21^{a}$. So $E l .562^{a}$.

2I ${ }^{\text {b. }}$ Iōsēphes. Cf. Gen. 37. 3.

22b. A Latin manuscript of the Panther, in applying this to Christ, quotes Wisd. 7. 22, 23 (Cahier, Mélanges 3. 239-240). Other versions at 
this point refer Ps. 45. 9, 13 (in the Septuagint and Vulgate) to the Church; thus the Greek, the Armenian, and the Ethiopic. For the variety of qualities that appertain to Christ, they quote Gal. 5. 22, 23; 2 Pet. 1. 5-8 (Lauchert's Greek; cf. Pitra's Greek, the Ethiopic, the Armenian, and the Arabic).

23. beorhtra. These adjectives in -ra are comparatives.

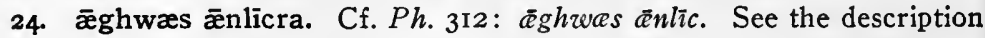
of the colors of the Phœnix, Ph. 29I-312.-lixte. Only Chr. 505; El. $23,96,105$.

26. gehwæs. See note on 20.

28. æ̈ghwylc. 'Each (color) shines more beauteous than another.'gien. Qualifies the comp.; cf. W. 50 .

29. Cf. fretzerm blīcan, Ph. 95; Chr. 507, 522; Jul. 564.-frætwum. So 48 .

3I-2. Pitra's MS. B illustrates the Lat. mansuetum by Matt. 2I. 5 (Zech. 9. 9).

$3 \mathrm{I}^{\mathrm{a}}$. Cf. Gu. I080: 'milde and gemetfæst.'

32. lufsum. Only Chr. 913 .

35. fylle fægen. Cf. Beow. 562, Ior4, I333.-fōddor p̧igeơ. So Ph. 259.

36. gereordum. Probably plur. for sing., like Lat. epula.

$37^{\text {a. }}$ So $G u$. 130 ; cf. $G u$. 186 .

$37^{\text {b }}$. under dūnscrafum. The Greek and Latin have 'in his den.'

39. swifeð. But swefed 6 times in Beow. (Gr. has swefed here in Spr.).

$40^{\mathrm{b}}, 4^{2}$ a Cf. Chr. 888-9: 'upp āstandan snēome of slǣpe'; $A n \cdot 792^{\mathrm{b}}$, $795^{\mathrm{a}}$ : 'ūp āstandan . . . snēome of slǣpe.'

$4 \mathrm{I}^{\mathrm{b}}$. Cf. $6 \mathrm{I}$.

$42^{\mathrm{a}}$. The poet adopts a ready-made formula, and misapplies it. Snēome, here translating the Latin statim of Mai and MS. B (statim emittit mugitum.magnum) should modify cymeð, rather than ästondeð (cf. Ebert, Angl. 6. 243).

42. swēghlēopor. Cf. $P h$. 137 .

43. wildres. See 9 .

$44 \mathrm{ff}$. Cf. $P h$. $192 \mathrm{ff}$.

44. stefne. In the application to Christ, the voice, according to Cahier's MS. B, is illustrated, with reference to its attractive power, by Ps. I9. 4; Matt. 28. 20; Jn. 14. 3, I8; 16. 33; 17. 12; 20. 17.-stenc. Various ancient writers -Aelian (5. 40; 8. 6), Pliny (8. 17. 23. 62), Solinus, Plutarch, Theophrastus, Horapollo, etc.- beginning with Aristotle, report that the odor of the panther attracts other animals. Aristotle's account is (Hist. An. 9. 6. 2; cf. Probl. 13. 4): 'They say that the panther is aware that its peculiar odor is grateful to other wild animals, and that it preys upon them in ambush, and, when deer approach, it catches hinds.' The tradition persists in literature into the I7th century. Thus Nash, Anat. of Absurditie, Works (ed. Grosart I. 29): 'As the Panther smelleth sweetelie 
but onely to brute beastes, which she draweth unto her to theyr destruction,' etc. Other instances may be found in Lyly, Euphues (Arber, p. 54); Euphues and his Ephoebus (Arber, p. 149); Greene, Euphues his Censure, Works (ed. Grosart) 6. 174; Mamillia (2. 44, 51, 279); S. Hawes (1503), Examp. Virt. 9. 4; Shirley, The Royal Master 3. I; Randolph, To a Deformed Gentlewoman; Jonson, Volpone 3. 6; Glapthorne, The Hollander; Rogers, Naaman, Ep. Ded. 4; Dryden, Hind and Panther 2. 228. Cf. Lauchert, Eng. Stud. 14. 196-7.

$45^{\text {a }}$. of bām wongstede. Ebert (Angl. 6. 243) conceives of this as explaining, in the poet's intention, the fragrance; but is it not rather a reminiscence of $\mathrm{El}$. 794, where the smoke does actually rise from the plain? $45^{\text {b. }}$ Cf. 65 , and $W .54$ : 'wynsum stenc.'

46. swæcca. Cf. swaccum, Ph. 214; swecca, Gu. 1247; swicce, Pn. 66. 47. Cf. $P h$. 194 .

$49 \mathrm{ff}$. Cf. $P h .324 \mathrm{ff}$.

50. beornoreat. Ebert calls attention to this anticipation of the exegesis-the introduction of men here.

51. farad foldwegum. The notion of distance is ultimately derived from Eph. 2. 17 (see p. 1xiii, above), where Jews and Gentiles are no doubt implied (cf. Ps. 148. 14).-farad. The subject is quasi-collective.

52-3. Cf. El. $36^{\mathrm{a}}, 37^{\mathrm{a}}$ : ēoredcestum, deareðlācende.-dareð̋läcende. The word only besides in $\mathrm{El}$. 651 .

53. efne swā some is not found elsewhere, and swā some regularly follows a word that receives a principal stress: El. 653, 1066, 1207, 1278, 1284, etc. In Met. 20. 124, 'and efne swā same,' efne takes the stress.

54. æefter. Grein (Spr., s. v., 6) understands as 'following after' (and so Dichtungen I. 219, 'dem Gesange folgend') ; but cf. $44^{\mathrm{a}}$.

55. drēama. Grein interprets this in one place as earthly joys ( $S p r$., s. v.), and in another (Dicht.) as 'Hochjubel,' which would seem rather to refer to heavenly joys.

58. se ealda fēond. Only El. 207. See I Pet. 5. 8; Rev. I2. 9.

58-6r. Christ is represented as binding Satan during his Descent into Hell, between the Crucifixion and the Ascension. Cf. El. 18I ff., Chr. $558 \mathrm{ff}$., the Latin hymn on the Ascension quoted on p. 117 of my edition of the Christ, 11. 87-8, and Abbetmeyer, p. $3 \mathrm{I}$.

$59 \mathrm{ff}$. Cf. Sat. $444 \mathrm{ff}$.

59-60. Cf. Chr. 732 ff.; $A n$. 1378-9.

$59^{\mathrm{a}}$. ges $\bar{\not} l d e$. Based on Rev. 12. 9; 20. 2, 3; cf. Gen. (B) 371-385.

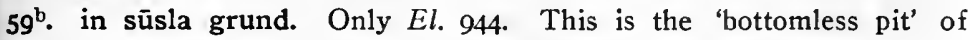
Rev. 20. 3.-grund. Syntax requires grunde, but the expression is probably a reminiscence of the phrase in El. 944 ; cf. El. 1305.

6ra. Cf. El. $884^{\mathrm{a}}$.

63. prēo niht. Cf. 38 .

$64^{\mathrm{a}}$. sigora Sellend. So Jul. 668, 705.

64 . swēte stenc. Cf. Eph. 5. 2 (so Dietrich). The poet seems to 
mean that the conquest of hell and the victory over death are the sweet odor, while in $74^{\mathrm{b}}$ it is rather the gifts imparted to men. Both are covered by Eph. 4.8 ; cf. note on $64^{\mathrm{b}}$, and Chr. $662 \mathrm{ff}$.

65 ff. Cahier's MS. B refers to Eph. 4.8 ff. (Ps. 68. 18).

65. So $P h$. $318^{\mathrm{a}}$.

67. Almost identical with $P h$. 336.- on healfa gehwone. Cf. Chr. 61, 928; Ph. 206; El. 548.

68. Cf. $P h .42^{\mathrm{a}}, 43^{\mathrm{a}}$.

69. Sanctus Paulus. Only El. 504.

71. ungnȳð̀. Cf. tō gnēað̆ gifa, Beoz. 1930.

72. tō feorhnere. So Chr. 6Io; El. 898; cf. Chr. $604 \mathrm{ff}$. See Ps. 65. 9 ff.; Acts I4. I7.

$73^{\mathrm{a}}$. So $P h \cdot 4^{23^{\mathrm{a}} \text {. }}$

$74^{\mathrm{a}}$. nipre. Only Chr. 1466.

$74^{\mathrm{b}}$. Cf. I $9^{\mathrm{a}} ;$ Beow. II, etc.-æbele stenc. Cf. aðclum stencum, Ph. $586^{\mathrm{b}}$.

\section{WHALE (ASP-TURTLE)}

I. gēn. Referring to the Panther, it would seem.--fisca. Contrasting with wildra, $P$ n. 9; dēor, $P n .12$.

$2^{\mathrm{a}}$. wöðcræfte. Only $P h .127^{\mathrm{a}}, 54^{\mathrm{a}}$.

$3^{\mathrm{a}}$. So $\mathrm{El} \cdot 3^{8 \mathrm{I}^{\mathrm{a}}}$.

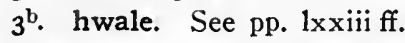

4. gemēted. Cf. Ph. 23r.

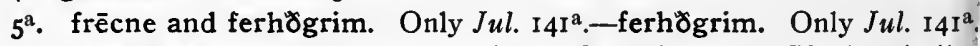

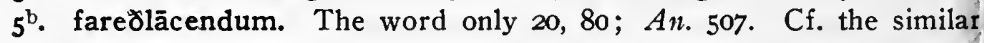
formation, $P n .53$.

6а. Cf. nippa gehwān, El. 465--nippa. So Pn. 13.

6. Cf. was him noma cenned, Jul. 24 ; see also El. $586^{\mathrm{b}}-7^{\mathrm{a}}$.

$7^{\text {a }}$. fyrgenstrēama. This word means 'ocean' in $P h$. 100; $A n .390$. Fyrnstréama is without parallel, and fyrn- always designates antiquity and is never compounded with words signifying inanimate natural objects

$7^{\mathrm{b}}$. Fastitocalon. Grein $(S p r$. $)$ was the first to see that this stood for $\dot{\alpha} \sigma \pi \iota \delta 0 \chi \epsilon \lambda \dot{\omega} \nu \eta$ (cf. above, pp. 1xxxi ff.). He quotes from Tychsen's ed. o the Syrian Physiologus (p. I63) a sentence of Eustathius' Hexaemeron 'Balæna, quam Aspidochelonem dicunt,' etc. Dietrich had suggestec (Commentatio, p. I0, note 18 ) that perhaps the first element was arov and the second $\tau \dot{0} \kappa \alpha \lambda^{\prime} \nu$ 'the beautiful city'!

8a. pæs. For his; cf. Gen. 2108.

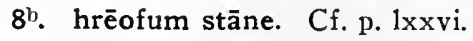

9. wörie. The general appearance of the sea-beast is as if great reeds surrounded by sand-dunes, were waving on the seashore; cf. 1xxi-lxxii.

ro. -rȳrica. Cf. Ger. Röhricht (for Rö $(h)$ ric), 'canebrake, reed-bank Lat. (h) arundinetum.

12. ēalond. Cf. Matthew Arnold's 'matted rushy isles' (Sohrab an Rustum, near end). See the different form, I6. 
I3 ff. For the anchoring of ships, see Beow. 226, 30I-3; El. $246 \mathrm{ff}$; Chr. 862-3.

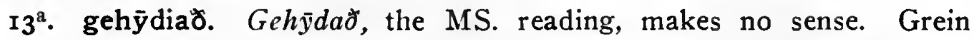
(Dicht.) translates by 'behüten'; in the Spr. he brings the word under gehédan (cf. Eng. 'heed'), and renders by 'in Sicherheit bringen.' Thorpe, properly enough, translates by 'fasten,' to which, indeed, the context virtually forces him. But the dictionaries tell us nothing of a gehydan with this meaning. Thorpe conjectures gehÿðað, and is followed by Klipstein and Ettmüller. This, presumably, he meant as a derivative of $h \dot{y} \bar{y}$, 'haven' (the verb $h \bar{y} \partial a n$, from $h \bar{u} \delta$, 'booty' means 'devastate'); but this would hardly yield the sense required. The difficulty is solved if we remember that the cordage of a ship (including no doubt cables and hawsers) in King Alfred's time was (at least sometimes) made of walrus-hide or seal-hide, as in Homer's of twisted oxhide (Od. 2. 426; 15. 29I), which may also have been employed in England, though such use is apparently not recorded. Ohthere (Alfred's Orosius, ed. Sweet, p. I8) knows of such ship-ropes (scipräpas) sixty ells long, which indicates that they must have been spliced or otherwise pieced. If the anchor-cables were thus made of hide, one could as naturally speak of vessels being 'hided' to the island as we might of their being 'roped.' The word in question, then, I take to be from an otherwise unknown gehydian, formed from the noun $h \bar{y} d$ in this specific sense. 'Hide,' in the sense of 'flog with a whip of hide,' is still in use.

13 ${ }^{\text {b }}$ hēahstefn. Only $A n .266$.

14 ${ }^{\mathrm{a}}$. unlonde. 'Land which is no land.' Not found elsewhere.

$14^{\text {b }}$. oncyrräpum. Synonyms are found in Beow. I918, 'oncerbendum fæst,' and Beow. 302, 'seomode on sāle' (cf. Ger. Seil). Other terms are streng and ancerstreng, found in Alfred's version of Augustine's Soliloquies (ed. Hargrove, p. 22). Here we have some interesting details: one end of the streng is fast on the earth, the other in the ship (cf. p. 28); in another place the ancerstreng is stretched taut from ship to ocean (mere).

15. Cf. Beow. $223^{\mathrm{b}}-4^{\mathrm{a}} ;$ El. $228 ; C h r .862$.

I5 ${ }^{\text {a }}$ - sǣlap. For MS. setla $p$, which Thorpe translates 'settle,' Grein (Dicht.) 'machen sitzfest,' (Spr.) 'collocare.' Old English has no other instance of setlan, whereas sēlan (from sāl; see note on $14^{b}$ ) is found Beow. 226, 1917; Chr. 862; El. 228, etc. If the emendation is accepted, setlan should disappear from the Old English dictionaries.

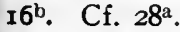

20. frëcnes. Cf. $5^{\mathrm{a}}$.

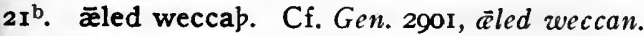

22. hēah fỹ $\bar{x}$ la $\bar{a} l e d: \bar{a} l a \partial$ is of course infelicitous.

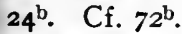

25. fērend. Only Jul. 60.-fæste. So $36,4 \mathrm{I}, 77$.

26. wic weardiað. So $P h .448$; cf. Jul. 92. 
27. sealtne wāg. So Dan. 323 ; cf. Dan. 384 .

28. nōbe. Only Jul. 343. Thorpe suggests ON. gnō̇, and translates 'bark,' as do Ettmüller and Grein (Dicht.), though in Spr. Grein hesitatingly renders by 'prey.'

29. Cf. Chr. 973--gæst. Barnouw (Textkritische Untersuchungen, p. 204) prints as $g \overline{\mathscr{C}} s t$. Grein (Spr. and Dicht.) understands the word as gast, and so Thorpe. The asp-tortoise can hardly be the spirit of the sea.

30. dēaðsele. Anticipatory of helle, 45.-drence. The word only El. 136.

$3^{1}{ }^{\mathrm{a}}$. Cf. $A n$. 512.-scipu. Cf. $3^{\mathrm{b}}$.

31'. Cf. Gu. 390,$538 ; A n$. 177, etc.

34. Cf. Sol. 493.

38. cwicsūsle. Only Chr. 561.

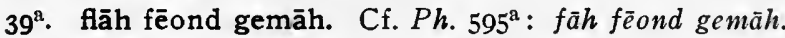

44. mid bām. Like Ger. in dem. He becomes their slayer by, etc.

45. healoð̆helme. Cf. Gen. 444.-helle sēceð. Cf. Jul. 682.

46. gōda gēasne. So El. 924 ; cf. Jul. 216, 381.-grundlēasne. See p. lxxv.-wylm. Cf. El. 1297, hātne wylm.

49. ÿömearas. Only Chr. 863 .

5o. wæterbisa. Only $G u$. 1303.-gien. Cf. $P n .28^{\mathrm{b}}$.

53. ontȳneð̃. Cf. 68.

55. pone. For hine.

59. wida. Suggests the whale; cf. $54^{\mathrm{a}}$.-ceaf. Applied to hell in An. 1705 .

6r. hlemmeð. Cf. $76^{\text {b }}$.

63. unwærlice. Cf. $59^{\mathrm{a}}$.

64. on bās lǣnan tīd. Only $C h r .1558,1585$; cf. $W .87$.

66. leahtrum fāh. Only $C h r$. 829, 1538.-fāh. Construed with leahtrum, but also with the following, in a very peculiar manner; therefore = 'guilty,' but also 'hostile.'

67. wio Wuldorcyning. Cf. Beow. 811; An. I188; Sat. 97.-Wuldorcyning. So 85 .

69. leaslice lices wynne. So El. 1297.-wynne. Plural.

$70^{\text {a }}$. ferhögereaht. Klaeber's ingenious emendation has much in its favor, but involves a considerable change-ferht gereaht to ferhte riht (not reht, as he writes), while Thorpe's emendation requires only the substitution of a single letter. The verb gereccan is frequently used in the sense of 'guide,' 'direct,' so gereaht, if a noun, might mean 'guidance' (in the right way, as frequently implied in the case of the verb). Ofer ferhogereaht would then signify 'contrary to the wise guidance of the soul.'

$70^{\mathrm{b}}$. fremedon. Klaeber is right in defending this MS: reading.

$7 \mathrm{I}^{\mathrm{b}}$. One would rather expect in pat fasten; but see similar instances of dat. for acc. in Grein (Spr. 2. 137-8), and with on (2. 331).

73. ādwylme. One might think of egereylme, supported by egerylmum, 
Ps. 104. 26, but Grein's emendation requires less change, and $\bar{a} d$ is used for the fire of hell, El. 95I (cf. Gu. 884).

$75^{\mathrm{a}}$. Cf. Chr. 1224, on hyra lifdagum.

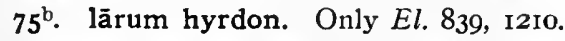

76. grimman gōman. Cf. $62^{\mathrm{a}}$.- bihlemmeơ. Only Chr. 869; cf. W. $6 \mathbf{1}$.

77. feorhcwale. Only Jul. 573.-tōgædre. So 61.

78. hlinduru. The word only $A n$. 993--nāgon hwyrft. Cf. Exod. 210, nāhton māran hwyrft; more remote Rid. 3(4). 6.

8o. bon mā be. 'Any more than.'

82. Forpon. As in Chr. 756, 766, 815, 1578 , etc.

$82^{\mathrm{b}}-\mathbf{3}$. Ettmüller's emendation, and the adaptation by Grein, can not be right, for (I) wiðsace requires a singular subject; (2) Wuldorcyninge would hardly be used so frequently; cf. $67^{\mathrm{a}}, 85^{\mathrm{b}}$, the latter only two lines away. Besides, the phrase for $82^{b}$ is not introduced in the usual way; one might think rather of $\overline{\bar{e}}$ ghwylcum men (cf. Hy. 7. I6; Met. 27. 22; Run. 23; and especially Sol. 404).

$85^{\mathrm{b}}-6^{\mathrm{a}}$. Wuldorcyning gesēon mōton. Cf. El. $1307^{\mathrm{b}}-8^{\mathrm{a}}$, mōton engla Frēan gesēon; also Chr. 501-2 ${ }^{\mathrm{a}}$.

$86^{\mathrm{b}}$. sibbe. Cf. Chr. 1338; An. 810.

$87^{\mathrm{a}}$. Cf. $64^{\mathrm{a}}$.

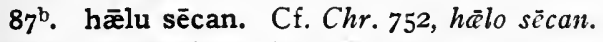

88a. swā lēofne. So Chr. 501 .

89. Cf. Chr. 1343; $A n$. 8I I; also $A n$. 106; $G u$. 1345-7.

\section{PARTRIDGE}

r. Cf. $P$ n. $8^{\mathrm{b}}-9 .-\mathrm{gen}$. A link with the Whalc $(W$. I).

4. wuldres Ealdor. Cf. $W .67^{\mathrm{a}}, 85^{\mathrm{b}}$.

5-II. Cf. 2 Cor. 6. I7, I8.

5-9. Cf. Isa. 55. 7 .

5. hwylce. The acc. after in (on), as frequently with tìd.

8. mid siblufan. So Chr. 635 .

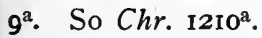

II. Cf. Heb. 2. I0, II.

II $^{2}$. gebrōpor. Cf. Matt. I2. 50; 25. 40; 28. 10; Jn. 20. I7; Rom.

8. 29 ; Heb. 2. II.

12. Uton. So $W .86$.

$14^{\mathrm{a}}$. tō. From.

$14^{\text {b. }}$ benden ùs dæg scine. Cf. $C h r .597,77^{\mathrm{b}}-2,817,1325,1579$, but especially $1593^{\mathrm{b}}-4$.

16. Cf. Sat. 233; Chr. 347; Ph. 609.

16 ${ }^{\mathrm{a}}$. So Jul. $3 \mathrm{II}$.

16b. Cf. Chr. 818, 1464 . 



\section{BIBLIOGRAPHY}

(In general, see Karl Jansen, Die Cynewulf-Forschung von ihren Anfängen bis zur Gegenwart, Bonn, I908.)

\section{ELENE}

\section{FACSIMILES OF THE MANUSCRIPT}

I894. Codex Vercellensis, ed. Wülker. Leipzig. (The first manuscriptpage of the Elene is reproduced in Holthausen's edition.)

1913. Il Codice Vercellese, ed. Förster. Rome.

\section{(a) Complete:}

\section{EDITIONS}

1836. Benjamin Thorpe, Appendix $B$ to Mr. Cooper's Report on Rymer's Fodera. London. Based on a copy made by Dr. Maier.

1840. Јаков Grim м, Andreas und Elene. Cassel. Based on Thorpe.

I856. John M. Kemble, The Poetry of the Codex Vercellensis, Part II. London. Based on Thorpe.

i858. Christian W. M. Grein, Bibliothek der Angelsächsischen Poesie, Vol. 2. Göttingen and Cassel. Based on Thorpe.

I877. Julius Zupitza, Cynezulf's Elene. Berlin. 2d ed., 1883; 3d ed., I888; 4 th ed., I 899 .

I888. RichaRD P. WülKer, Bibliothek der Angelsächsischen Poesie, Vol. 2. Lejpzig. A re-edition of Grein's Bibliothek. Based on the MS.

I889. Charles W. Kent, Cynewulf's Elene. Boston. Based on Zupitza and Wülker.

1905. Ferdinand Holthausen, Cynezulf's Elene. Heidelberg. 2d ed., I9I0. Based on the MS.

(b) Partial:

1840. John M. Kemble, Archaologia 28. 360-I. (L1. 1257 ${ }^{\mathrm{b}}-72^{\mathrm{a}}$.)

1842. Thomas Wright, Biographia Britannica Literaria: Anglo-Saxon Period, pp. 502-3. (Ll. $1257^{\mathrm{b}}-72^{\mathrm{a}}$.)

1847. Friedrich W. Emeling, Angelsachsisches Lesebuch. Leipzig. (L1. I-98.) Based on Grimm.

1850. Ludwig Ettmüller, Engla and Seaxna Scopas and Boceras. Quedlinburg and Leipzig. (L1. I-I93, I237-I321.) Based on Grimm. 1857. Heinrich Leo, Que de se ipso Cynevulfus . . . tradiderit. Halle program. (L1. I237-1321.) Based on Grimm.

I880. KARL KöRNER, Einleitung in das Studium des Angelsächsischen. Heilbronn. (L1. I-275.) Reprints Grein.

1885. William Clarke Robinson, Introduction to Our Early English Literature. London. (L1. 79-116.) 
(a). Complete:

\section{TRANSLATIONS}

English :

1856. Kemble, as above, p. I4I.

1888. Richard F. Weymouth, A Literal Translation of Cynewulf's Elene. London.

I889. James M. Garnett, Elene, Judith, etc. Boston. 2d ed., I90I.

1895. Jane Menzies, Cynewulf's Elene, a Metrical Translation from Zupit aa's Edition. Edinburgh and London.

1904. Lucius H. Holt, The Elene of Cynewulf. New York.

igio. Charles W. Kennedy, The Poems of Cynereulf. London and New York.

\section{German :}

i859. Christian W. M. Grein, Dichtungen der Angelsachsen, Vol. 2. Göttingen.

I898. H. Steineck, Altenglische Dichtungen in Wortgetreuer Übersetzung. Leipzig.

(b) Partial:

Danish :

1873. Frederik Hammerich, De Episk-Kristelige Oldquad. Copenhagen. (L1. 225-242.)

English :

1840. Kemble, as above, p. I4I. (Ll. $1257^{\mathrm{b}}-72^{\mathrm{a}}$.)

I842. Wright, as above, p. I4I. (L1. I257 $-72^{\mathrm{a}}$.)

I885. Robinson, as above, p. I4I. (L1. 79-II6.)

1900. Albert S. Cook, The Christ of Cynerulf, pp. 1xvi-lxviii. (Ll. 1237-77.)

1902. Albert S. Cook and Chauncey B. Tinker, Select Translations from Old English Poetry. Boston. (L1. $109^{\mathrm{b}}-\mathrm{I} 42^{\mathrm{a}}$, by Charlton M. Lewis ; 237-255, 1237-77, by Albert S. Cook.)

1904. William Strunk, Juliana, pp. xvi-xvii. Boston. (L1. I237-77.)

\section{German :}

1857. LEo, as above, p. I4I. (L1. I237-I321.)

1874. Hammerich-Michelsen (see under Danish, 1873), Die Älteste Christliche Epik der Angelsachsen, Deutschen, und Nordländer. Gütersloh. (L1. 225-242.)

I880. Körner, as above, p. I4I. (L1. I-275.)

Italian :

19I5. Federico Olivero, Traduzioni dalla Poesia Anglo-Sassone, con Introduzione e Note. Bari. (L1. 99-147, 21 $9^{\mathrm{b}}-260,726-802,1257^{\mathrm{b}}-77$.) 


\section{CRITICISM}

1840. J. M. Kemble, 'On Anglo-Saxon Runes,'Archaologia 28. $360 \mathrm{ff}$. I842. WRIGHT, as above, p. I4I.

I857. LEo, as above, p. I4I.

1859. F. E. C. Dietrich, Commentatio de Kynerulfi Poete Aetate. Marburg.

1865. J. Earle, Two of the Saxon Chronicles Parallel, pp. XXI-XXII. 1865. C. W. M. GreIN, 'Zur Textkritik der Angelsächsischen Dichter,' Germania 10. 42I-5.

1869. M. Rieger, 'Über Cynewulf,' Zeitschr. für Deutsche Philologie

I. 215-226, 313-334.

1877. B. TEN BRINK, Geschichte der Englischen Literatur, Vol. I. Berlin. 2d ed., I899. English translation, New York, 1883.

1878. E. Sievers, Anglia I. 573.

I879. K. KöRNER, Engl. Stud. 2. $257 \mathrm{ff}$.

I88I. P. J. CosiJn, 'Anglo-Saxonica,' Tijdschrift voor Nederlandske Taal- en Letterkunde I. I43-I59.

I882. E. SIEvERS, Göttingische Gelehrte Anzeigen, pp. 993-1001.

I883. G. JANSEN, Beiträge zur Synonymik und Poetik der

Dichtungen Cynewulfs. Münster dissertation.

I884 J. Schürmanv, Darstellung der Syntax in Cynewulfs Elene. Münster dissertation.

I884. F. KLUGE, Literaturblatt, pp. I38-9.

1885. O. GLÖDE, Untersuchung über die Quelle von Cynezulfs Elene (also Angl. 9. 271-318). Rostock dissertation.

1885. R. P. WüLKER, Grundriss zur Geschichte der Angelsächsischen Literatur. Leipzig.

1885. R. Rössger, 'Uber den Syntaktischen Gebrauch des Genitivs in Cynewulf's Elene, Crist und Juliana,' Anglia 8. 338-370.

1885, I887. E. Sievers, 'Zur Rhythmik des Altgermanischen Alliterationsverses,' Paul and Braune's Beiträge Io. 209-314, 45I-545; 12. 454-482. 1887. H. F. P. FRUcht, Metrisches und Sprachliches zu Cynerulfs Elene, Juliana und Crist. Greifswald dissertation.

1887. A. EBERT, Allgemeine Geschichte der Literatur des Mittelalters im Abendlande, Vol. 3. Leipzig.

1887. C. W. KeNt, Teutonic Antiquities in Andreas and Elene. Halle dissertation.

I887. G. KöRTing, Grundriss zur Geschichte der Englischen Literatur. Münster.

I887 (printed 1888). H. LeIding, Die Sprache der Cynezulfschen Dichtungen. Göttingen dissertation.

I888. M. Cremer, Metrische und Sprachliche Untersuchung der Altenglischen Gedichte Andreas, etc. Bonn dissertation.

1888. H. MORLEY, English Writers, Vol. 2. London. 
1888. M. Prollius, Über den Syntactischen Gebrauch des Conjunktivs in den Cynewulfschen Dichtungen. Marburg dissertation.

I889. O. BRENNER, Engl. Stud. I3. 480-2.

1889. E. LöSEth, Le Moyen Age 2. 186-7.

I889. R. P. WüLKER, Anglia 12. $629 \mathrm{ff}$.

I890. E. KoEPPEL, Literaturblatt, cols. 60-I.

1890. P. J. Cosijn, Cynewulf's Runenverzen. Amsterdam.

1891. F. Holthausen, Anglia 13. 358. (On El. 1277.)

1891. E. Sievers, 'Zu Cynewulf,' Anglia I3. I-25.

I892. F. J. Mather, 'The Cynewulf Question from a Metrical Point of View,' Mod. Lang. Notes 7. 97-107.

I892. P. J. Cosij N, Aanteekeningen op den Beowulf, p. 32. Leiden.

1892. W. M. Tweedie, Mod. Lang. Notes 7. 123-4. (On El. 348-9.)

1892. S. A. BROOKE, History of Early English Literature. London.

1893. G. WACK, 'Artikel und Demonstrativpronomen in Andreas und Elene,' Anglia 15. 209-220.

1893. A. S. Соок, 'The Date of the Old English Elene,' Anglia 15. 9-20. 1895. A. E. H. Swaen, 'Notes on Cynewulf's Elene,' Anglia 17. 123-4. (On El. 65-71, 105-6, I40.)

I896. M. B. PrICE, Teutonic Antiquities in the . . Cynewulfian Poetry. Leipzig dissertation.

1898. S. A. BRooKe, English Literature from the Beginning to the Norman Conquest. London.

1898. M. Trautmann, Kynezulf, der Bischof und Dichter. Bonn.

1899. M. Trautmann, 'Zu Cynewulfs Runenstellen,' Bonner Beiträge 2. I20. (On El. 1262-4.)

1899. O. F. Emerson, Mod. Lang. Notes 14. I66. (On El. 788.)

I899. R. Simons, Cynezulfs Wortschatz. Bonn.

I900. A. S. Соок, The Christ of Cynewulf. Boston.

1900. M. Trautmann, Anglia Beiblatt II. 322-9.

1901. F. Holthausen, Anglia 23. 516. (On El. 377, 534.)

1902. A. J. BARNouw, Textkritische Untersuchungen nach dem Gebrauch des Bestimmten Artikels und des Schwachen Adjektivs in der Altenglischen Poesic. Leiden dissertation.

1902. F. Holthausen, Anglia 25. 386. (On El. 31.)

1902. W. Strunk, 'Notes on Cynewulf,' Mod. Lang. Notes I7. $37 \mathrm{Iff}$. (On El. 581.)

1903. ABBETMEYer, as below, p. I48.

I903. C. F. Brown, 'Cynewulf and Alcuin,' Pub. Mod. Lang. Assoc. I8. 308-334.

I904. F. KlaEber, 'Zu Altenglischen Dichtungen,' Herrig's Archiv I13. 147-9. (On El. 140, 919-20.)

1904. F. Holthausen, Anglia Beiblatt 15. 73.4. (On El. I40.)

1905. F. Holthausen, 'Zur Quelle von Cynewulfs Elene,' Zeitschrift für Deutsche Philogie 37. I-19. 
1906. F. Holthausen, Anglia Beiblatt 17. 176-8.

1906. F. Klaeber, 'Notizen zu Cynewulfs Elene,' Anglia 29. 271-2. (On El. 2I-2, 3II, 629 ff., 646, 657, 979.)

1906. F. Klaeber, 'Cynewulf's Elene 1262 f.,' Jour. Eng. and Germ. Phil. 6. 197.

I907. M. Trautmann, 'Berichtigungen, Erklärungen, und Vermutungen zu Cynewulfs Werken,' Bonner Beiträge 23. 85-I46.

1907. C. F. Brown, 'The Autobiographical Element in the Cynewulfian Rune Passages,' Engl. Stud. 38. I96-233.

1907. F. Holthausen, Anglia Beiblatt i8. 77-8. (On El. 531-5.)

1908. J. J. VON DER WARTH, Metrisch-Sprachliches und Textkritisches zu Cynewulfs Werken. Bonn dissertation.

1908. A. Brand, Geschichte der Altenglischen Literatur. Strassburg.

1908. G. GRAU, Quellen und Verwandtschaften der Älteren Germanischen Darstellungen des Jüngsten Gerichtes. Halle.

1908. K. Jansen, Die Cynezulf-Forschung, pp. 91-2. Bonn.

I909. C. F. Brown, 'Irish-Latin Influence in Cynewulfian Texts,' Engl. Stud. 40. I-29.

I9I0. C. RichteR, Chronologische Studien zur Angelsächsischen Literatur. Halle.

I912. F. Tupper, 'The Cynewulfian Runes of the Religious Poems,' Mod. Lang. Notes 27. I3I-7.

\section{PHENIX}

(a) Complete:

\section{EDITIONS}

1840. N. F. S. Grundtvig, Phenix-Fuglen, et Angelsachsisk Kvad. Copenhagen. Based on the MS. With the Latin of Lactantius.

1842. Benjamin Thorpe, Codex Exoniensis. London. Based on the MS. With the Latin of Lactantius.

i849. Louis F. Klipstein, Analecta Anglo-Saxonica, Vol. 2. New York and London. Based on Thorpe, with some changes. With the Latin of Lactantius.

1850. Ludwig EtTmüller, Engla and Seaxna Scopas and Boceras. Quedlinburg and Leipzig. Based on Thorpe. With the Latin of Lactantius. 1857. Christian W. M. Grein, Bibliothek der Angelsächsischen Poesie, Vol. I. Göttingen. Based on Thorpe.

I8gi. James W. Bright, Anglo-Saxon Reader. New York. Based on Grein. With the Latin of Lactantius.

1895. Israel Gollancz, The Exeter Book. London. E. E. T. S. I04. Based on the MS.

I897. RIChaRD P. WüLKER, Bibliothek der Angelsächsischen Poesie, Vol. 3. Leipzig. A re-edition of Grein's Bibliothek. Based on the MS. 1908. Otтo Schlotterose, Die Altenglische Dichtung 'Phœnix.' Bonn. Based on the MS. With the Latin of Lactantius. 
(b) Partial:

1705. Humphrey Wanley, Catalogus, in Hickes, Thesaurus.

(Ll. 667-677.) Based on the MS.

I8I4. John J. Conybeare, in Archaologia i7. 196. (L1. I-27, 81 $\mathrm{I}^{\mathrm{b}}$-4.) Based on the MS. Reprinted, with slight changes of spelling, in

1826. John J. Conybeare, Illustrations of Anglo-Saxon Poetry. London. (Also reprints (pp. viii-ix) Wanley's transcription of 11. 667-677.)

1844. Thomas Wright, St. Patrick's Purgatory. London. (Ll. I-84.) Reprints Thorpe.

1876. Henry Sweet, Anglo-Saxon Reader. Oxford. 7th ed., I894. (L1. I-84.) Reprints Grein. Based on the MS.

1879. Stephen H. Carpenter, Anglo-Saxon Grammar and Reader. Boston. (L1. I-84.)

I880. KörNER, as above, p. I4I. (L1. I-84.)

1885. Kobinson, as above, p. 14I. (Ll. I-84.) Reprints Grein.

1897. ZuPITZA-ScHIPPER, Alt- und Mittelenglisches Übungsbuch, 5th ed. Vienna and Leipzig. 6th ed., 1902; 8th ed., I908; IIth ed., 1915. (L1. I-27, 78-89, I 82-264, 320-380, 583-677.)

1903. Carleton F. Brown, 'Cynewulf and Alcuin,' Pub. Mod. Lang Assoc., Vol. 18. (L1. 508-545.)

19r3. Frederick KLAEBER, The Later Genesis. Heidelberg. (L1. 393-423, 437-442.)

(a) Complete:

\section{TRANSLATIONS}

Danish :

1840. Grundtvig, as above, p. I45. Paraphrastic; I52 stanzas of 9 short lines each.

English :

1842. ThORPE, as above, p. 145.

1844. George Stephens, in Archaologia, Vol. 30. From Grundtvig's text. Also published separately as: The King of Birds, or the Lay of the Phonix. London, 1844 .

1895. Gollancz, as above, p. I45.

Ig02. John Lesslie Hall, in Judith, Phonix, and other Anglo-Saxon Poems. Boston.

1903. Albert S. Cook, in Cook and Tinker's Select Translations from Old English Poetry. Boston.

1910. KenNEDY, as above, p. 142.

German :

1854. Christian W. M. Grein, Der Vogel Phanix. Rinteln. With the Latin of Lactantius.

1857. Christian W. M. Grein, in Dichtungen der Angelsachsen, Vol. I. Göttingen.

I908. SCHLOTterose, as above, p. 145 . 
(b) Partial:

Danish :

I873. Frederik Hammerich, as above, p. I42. (L1. I-84.)

English :

1814 and 1826. Conybeare, as above, p. I46. (L1. I-27.)

1849. Klipstein, as above, p. 145. (Ll. 33-68a.)

1885. Robinson, as above, p. 141. (Ll. I-84.)

1890. Anna R. Brown, in Poet-Lore, Vol. 2. (L1. I-84.)

1892. William R. Sims, in Modern Language Notes, Vol. 7. (L1. I-84.)

1892. BROOKE, as above, p. 144. (L1. I-27, 33-41 ${ }^{\mathrm{a}}, 50-84,90-145,182-6 \ddot{\text {. }}$ )

1898. BROOKE, as above, p. I44. (L1. II $-17^{\mathrm{a}}, 33-39^{\mathrm{a}}, 62^{\mathrm{b}}-69$, 90-145.)

1902. Sidney Lanier, Shakspere and his Predecessors, Vol. 1. New

York. Partly verse, partly prose, and with occasional condensation. Ll. I-149 (verse), I5I-I73 (prose), I82-24I (prose, condensed), 259-264 (prose), 265-287 (prose, cond.), 335-349, 387-392, 437-442 (all prose, cond.), 424-457 (prose, much cond.), 465-475, 491-520, 539-549 (all prose, cond.).

1907. Clara M. Parker, in University of Texas Magazine, Vol. 22. (Ll. I-264, versified from the translation under 1903.)

German :

1874. Ham Merich-Michelsen, as above, p. I42. (L1. I-84.)

I880. Körner, as above, p. I4I. (L1. I-84.)

Italian :

I915. Olivero, as above, p. I42. (L1. 85-I52, I82-263, 29I-3I9.)

Latin :

I8I4 and I826. Conybeare, as above, p. I46. (Ll. I-27, 8I $\mathrm{I}_{-}^{\mathrm{b}-84}$.)

\section{CRITICISM}

1706. P. Texelius, Phanix Visus et Auditus. Amsterdam.

1825, 1827. R. F. F. Henrichsen, De Phanicis Fabula apud Gracos, Romanos, et Populos Orientales. Copenhagen.

1847. K. W. F. PIPER, Mythologie der Christlichen Kunst, Vol. I,

Part 1. Weimar.

I850. J. G. T. GRÄSSE, Beiträge zur Literatur und Sage des Mittelalters.

Dresden.

185I. C. Cahier and A. Martin, Mélanges d'Archéologie, Vol. 2.

1859. Dietrich, as above, p. 143.

1865. GREIN, as above, p. I43.

1874. J. Schipper, 'Zum Codex Exoniensis,' Germania 19. 327-338.

I877. E. Kölbing, 'Zu "On God Oreison of Ure Lefdi," v. 37,' Engl. Stud. I. I69-170.

I880. H. GaEBler, 'Ueber die Autorschaft des Angelsächsischen Gedichtes vom Phoenix,' Anglia 3. 488-526. Leipzig dissertation. 
1884. F. Holtbuer, Der Syntaktische Gebrauch des Genitives in Andreas, Guð̋lac, Phönix, dem Heiligen Kreuz und der Höllenfahrt. (Also 1885, in Anglia 8. I ff.) Leipzig dissertation.

1885. F. Kluge, 'Zum Phönix,' Engl. Stud. 8. 474-9.

I885. Sievers, as above, p. I43.

1885. WÜLKER, as above, p. I43.

1886. A. Salzer, Die Sinnbilder und Beiworte Mariens. Linz.

I887. EBERT, as above (and Vol. I, I874), p. I43.

I887. Körting, as above, p. I43.

I888. CREMER, as above, p. I43.

1890. H. BAUER, Ueber die Sprache und Mundart der Altenglischen Dichtungen Andreas, Guðlac, Phönix, Hl. Kreuz und Höllenfahrt Christi. Marburg dissertation.

I89o. F. SchöLl, Vom Vogel Phanix. Heidelberg.

I89I. M. Manitius, Geschichte der Christlich-Lateinischen Poesie. Stuttgart.

I892. J. Planer, Untersuchungen über den Syntaktischen Gebrauch des Verbums in dem Angelsächsischen Gedicht vom. Phoenix. Leipzig dissertation.

I892. Mather, as above, p. I44.

I894. M. Trautmann, 'Zur Kenntnis des Altgermanischen Verses,' Anglia Beiblatt 5. 87-96.

I894. M. Kaluza, Studien zum Germanischen Alliterationsvers, Vol. I (pp. 18-r9). Berlin.

I894. Margaret Bradshaw, 'The Versification of the Old English Poem Phoenix,' Amer. Jour. Phil. 15. 454-468.

I895. F. A. Blackburn, 'Note on the Phoenix, verse 15I,' Mod. Lang. Notes 10. I 30 .

I8g6. P. J. Cosijn, 'Anglosaxonica III,' Paul und Braune's Beiträge 21. 25-6. (On $P h$. 134 a )

1896. E. Fulton, 'On the Authorship of the Anglo-Saxon Poem Phœnix,' Mod. Lang. Notes II. 73-85.

i898. Trautmann, as above, p. I44.

I898. P. J. Cosijn, 'Anglosaxonica IV' Paul und Braune's Beiträge 23. I2I-3.

1899. J. M. HaRT, 'Phoenix 56,' Mod. Lang. Notes I4. I59.

I899. A. S. Соок, 'Phoenix 56,' Mod. Lang. Notes 14. 225-6.

1899. F. Holthausen, Anglia Beiblatt 9. 356.

I900. Cook, as above (pp. lxii-lxv), p. I44.

igoi. W. Spiegelberg, Der Name des Phanix. Strassburg.

I902. BarNouw, as above, p. I44.

1903. M. Kaluza, Anglia Beiblatt 14. 162-3. (On Ph. 324, 643, 668.)

1903. C. Aвветмeyer, Old English Poetical Motives derived from the Doctrine of Sin. Baltimore. 
1904. J. Ahrens, Darstellung der Syntax im Angelsächsischen Gedicht 'Phönix.' Rostock dissertation.

I904. F. Holthausen, 'Zum Schluss des Altengl. "Phönix," Herrig's Archiv I12. 132-3. (On $P h .668^{\mathrm{b}}$.)

1904-5. F. Klaeber, 'Emendations in Old English Poems,' Mod. Phil.

2. 141. (On $P h$. 624.)

1905. F. Schwarz, Cynewulfs Anteil am Christ: eine Metrische Untersuchung. Königsberg dissertation.

1906. F. Klaeber, 'Phenix 386'' Jour. Eng. and Germ. Phil. 6. 198.

1907. H. G. Shearin, 'The Phœnix and the Guthlac,' Mod. Lang. Notes 22. 263.

1908. Brandi, as above, p. 145 .

1908. K. JaNSEN, Die Cynewulf-Forschung, pp. 105-8.

1908. GraU, as above, p. 145 .

1910. Richter, as above, p. I45.

1910. F. Tupper, 'Textual Criticism as a Pseudo-Science,' Pub. Mod. Lang. Assoc. 25. $169 \mathrm{ff}$.

19r3. F. Klaeber, 'Notes on Old English Poems,' Jour. Eng. and Germ. Phil. 12. 258. (On Ph. 407-8.)

\section{PHYSIOLOGUS}

(For a copious bibliography of the Physiologus in general, see Mann, in Anglia Beiblatt 10. 274-87; 12. 13-23; 13. 18-21, 236-9; cf. Jellinek, ib. 13. 236-9.)

\section{(a) Complete:}

\section{EDITIONS}

1842. THorpe, as above, p. 145. London. Based on the MS. 1857. Grein, as above, p. 145. Göttingen. Based on Thorpe. 1888. Richard P. WüLKER, as above, p. I45.

(b) Partial:

1849. Klipstein, as above, p. 145 (Whale).

1850. Eтtмüller, as above, p. I45 (Whale).

1885. RoBinson, as above, p. 14I. (Panther I-I8; Whale 1-3I ; Partridge I-2, 12-16.)

\section{(a) Complete:}

\section{TRANSLATIONS}

English :

1842. ThORPE, as above.

German (Panther and Whale) :

1857. GREIN, as above, p. 146. 


\section{(b) Partial:}

\section{English :}

I885. RoBinson, as above, p. I49.

1888. Henry Morley, English Writers, Vol. 2. (Panther $6 \mathrm{I}^{\mathrm{b}}, 64^{\mathrm{b}}-74$; Whale $6 \mathrm{I}^{\mathrm{b}}-65,78-8 \mathrm{I}$.)

I892. Brooke, as above, p. I44. (Whale 7-I5, I $7^{\mathrm{b}}-\mathrm{I} 8$.)

I898. Brooke, as above, p. I44. (Whale 7-I5, I $7^{\mathrm{b}}-\mathrm{I} 8$.)

\section{CRITICISM}

1840. Kemble, as above, p. I43.

I851. Cahier and Martin, as above, p. r47.

i859. Dietrich, as above, p. I43.

1865. GREIN, as above, p. I43.

1874. SCHIPPER, as above, p. I47.

1883. EBERT, 'Der Angelsächsische Physiologus,' Anglia 6. 24I-7.

1885. WÜLKER, as above, p. I43.

1887. EBERT, as above, p. 143.

I887. Körting, as above, p. I43.

1890. F. Lauchert, Geschichte des Physiologus. Strassburg.

1894. A. S. Cook, 'The Old English Whale,' Mod. Lang. Notes 9. 65-8. 1897. E. Sokoll, Zum Angelsächsischen Physiologus. Marburg.

1898. Trautmann, as above, p. I44.

I898. CosiJn, as above, p. 148.

I900. M. F. Mann, Anglia Beiblatt II. 332-6.

1902. J. Runeberg, 'Le Conte de l'Ile-Poisson,' Mém. de la Soc. NéoPhilologique à Helsingfors 3. 343-395.

I902. BarNouw, as above, p. 144.

I903. V. Chauvin, Bibliographie des Ouvrages Arabes 7. 8-9, 16. Liége.

1903. E. MahN, Darstellung der Syntax in dem Sogenannten Angelsächsischen Physiologus. Rostock dissertation. Second part. Neubrandenburg program.

I904. F. Klaeber, Mod. Phil. 2. I42. (On W. 69.)

1905. ScHWARZ, as above, p. I49.

1908. K. JANSEN, Die Cynezulf-Forschung, pp. II5-6.

1908. BrandL, as above, p. I45.

I9II. R. J. Peebles, 'The Anglo-Saxon Physiologus,' Mod. Phil. 8. $57 \mathrm{I}-9$.

1912. F. TuPper, 'The Physiologus of the Exeter Book,' Jour. Eng. and Germ. Phil. 11. 89-91. 


\section{GLOSSARY}

[The order of words is strictly alphabetical, $a$ coming between ad and af, but initial $\delta$ following $t$. Roman numerals indicate the class of ablautverbs; WI, etc., that of the weak verbs; rd., the reduplicating; prp. the preteritive present; anv., the anomalous. The double dagger, $\neq$, is used to designate words not elsewhere found in the poetry, according to Grein. Where the designations of mood and tense are omitted, ind. pres.' is to be understood, unless some other designation has just preceded; when of mood only, supply 'ind.' if no other has preceded, otherwise the latter.]

\section{A.}

$\overline{\mathbf{a}}$, adv., ever, always: El. 744, 802, 894,896 , 1029, 1082, 1257; $\mathrm{Ph}$. 35, I80, 385, 596; W. 84, 86. See āwa, ō.

ābannan, rd., summton, convoke: inf. El. 34 .

àbēodan, II, command, order: pret. 3 sg. ābēad, El. 87 ; wish, offer: inf. El. I004.

ābrēotan, II, kill, slay: inf. El. 5 Io. † ābȳwan, Wr., purge, purify: pp. npm. ābȳwde, Ph. 545.

ac, conj., but: El. 222, 355, 450, 469, 493, 569, 863, 1304; Ph. 5, I9, 26, 35, 62, 75, I80, 317, 596, 609.

àcęnnan, WI., bear, bring forth, produce: pp. ācenned, El. 5, I78, 339, 639, 776, 816; Ph. 24I ; npm. ācende, Ph. 256.

ācigan, Wr., call: pret. 3 sg. ācigde, El. 603.

āclian, see geāclian.

àcōlian, W2., grow chill: pp. àcölad, Ph. 228.

ācweðan, V, speak, utter: pret.

3 sg. ācwæð̀, El. I072.

àcyrran, Wr., turn away: pp. ācyrred, El. IIzo.

ād, m., fire: ds. āde, El. 95I, I 290 ; is. āde, Ph. 503; pyre: ns. Ph. 365 ; gs. ādes, El. 585 ; Ph. 272 ; ds. āde, Ph. 230.

$\ddagger \bar{a} d l e \bar{g}$, m., flame of the pyre: ns. $\mathrm{Ph} .222$.

ādrēogan, II, endure: inf. El. 705, I29r.

$\ddagger \overline{a d w y l m}$, m., lake of fire: ds. àdwylme, W. 73.

æe, f., law: as. El. I98, 281, 283, 315, 397, 97I; Ph. 457; Scripture: as. El. 393 ; faith, religion: ns. El. I063; as. El. 1042.

ǣbylgð, n., offense, sin, transgression: as. El. 401, 513.

ǣcræft, m., religion: ns. El. 435. æfen, n., evening: as. El. I39.

æfest, n., malice, hatred: ns. $\mathrm{Ph}$. $40 \mathrm{I}$; as. æfst, El. 308, 524; dp. æfstum, El. 496; ip. æfstum, El. 207.

æffre, adv., ever: E1. 349, 361, 403, $448,507,524,572$; Ph. 40, 83, 128, 562, 608, 637; W. 79; always: E1. 96 I.

æfter, prep., w. dat., after (in time) : El. 430, 490, I034, 1265, 1268; Ph. III, 223, 225, 270, 350, 370, 37 I, 382, 384, 405, 434, 437, 527, $533,542,557,559,566,577,583$, 645 ; Pn. $36,44,54$; W. 68,77 ; 
after (in space): El. 233; Ph. 343; from: El. II55; according to: $\mathrm{Ph} .258,408$ (after?); among: El. 135, 972; Pn. I2; in the course of: E1. 363 ; concerning: E1. 675; in search of: E1. 828 .

æfter ठon, adv., afterwards: æfter bon, $\mathrm{Ph} .238$.

$\overline{\text { æg }}$, n., egg: ds. ǣge, Ph. 233.

¿ghwā, pron., every one: ds. ǣghwām, El. I270; Pn. 15.

äghwæs, adv., in every respect, entirely: Ph. 44, 312; Pn. 24.

æghwylc, pron., each, every one: nsm. El. I281; Ph. I64; Pn. 28.

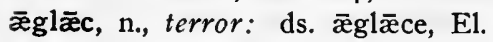
1188.

æglǣca, see āglǣca.

æglēaw, adj., skilled in the law: nsm. El. 806; npm. El. ǣglēawe, E1. 321.

æht, f., council: as. E1. 473.

ǣht, f., possession: dp. ̄̄htum, El.

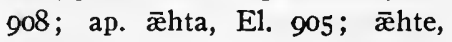
E1. 916 .

ב̌htgestrēon, n., riches, possessions: ap. $\mathrm{Ph} .506$.

ælärend, m., teacher of the law: gp. $\bar{x} l \bar{x}$ rendra, El. 506.

ælan, W I., consume: 3 sg. ǣleð, Ph. 222, 526; kindle: 3 pl.

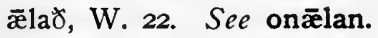
ælc, pron., each one: ns. El. 13i2. alde, mpl., men: g. ælda, Ph. I98, 546; elda, El. 476; ilda, El. 521 ; ylda, El. 792 ; d. ældum, Ph. 509. ǣled, m., fire: ns. Ph. 522; gs. হ̄ldes, El. 1294 ; as. Pn. 21. $\div \bar{\not}$ ledfȳr, n., conflagration: as. $\mathrm{Ph}$. 366.

æelfylce, n., foreign land: ds. El. 36 ælmesse, f., alms: as. ælmessan, Ph. 453.

almihtig, adj., almighty: nsm. El. I45, 800, 866, I084, I09I, I I 46,
II52; Ph. 356, 473, 630; Pn. 72 ; nsm. wk. ælmihtiga, Ph. 393; vsm. Ph. 627 .

ǣne, adv., once: El. 1253.

ǣnig, pron., any: ns. El. I59; $\mathrm{Ph}$.

3I, I38, 357, 546, 58I ; gsm. ǣnges, Ph. 136; dsm. ǣngum, Pn. 33; asm. ǣnigne, Ph. 59; adj. any: gsm. ǣniges, El. 660 ; asm. ǣnigne, El. 538; asf. ǣnige, El. I66, 567 ; isn. ǣnige, E1. 916. ǣnlic, adj., beautiful: nsm. Ph.

312, 536; nsn. El. 259; gpm. ænlicra, El. 74; comp. nsm. ǣnlicra, Pn. 24, 28; peerless (?), nsn. Ph. 9.

æppel, m., apple: gs. æples, $\mathrm{Ph}$. 230 ; as. $\mathrm{Ph} .403$.

æpplede, adj., apple-shaped: asn. El. 1260 ; Ph. 506.

$\bar{x} r$, adv., before, formerly, sooner:

El. 74, I01, 240, 459, 478, 561, 572, 602, 664, 707, 717, 909, 922, 934, 975, 987, I044, I I 8 , I I 22, I I42, I285; Ph. 252, 268, 283; Pn. 34; W. 74. See ærest.

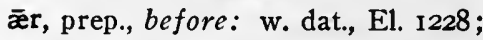
$\mathrm{Ph}$. 107, 245.

$\overline{\text { ær}, ~ c o n j ., ~ b e f o r e: ~ E l . ~ 447, ~ 676, ~ I 24 I, ~}$ 1246, 1254 .

ǣrdæg, m., dazn: ds. ǣrdæge, El. I05; former day: dp. ǣrdagum, Ph. 414.

ǣrest, adv., at first, first: El. I16; Ph. 235, 28I. See ǣr, adv.

æ̈rgewyrht, n., former deed: as. El. 1301.

† æ̈riht, n., law: as. El. 375, 590.

ǣrist, f., resurrection: ds. ǣriśte, Ph. 559 ; as. ǣriste, Ph. 495, 572. ærn, see moldærn, carcern.

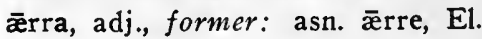
305.

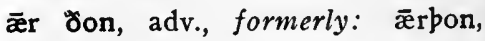
Ph. 379. 
ǣrðon, conj., before: "̄rrban, El. I084; until: æ̈rpon, Ph. 40, 83 . See æ̈r.

æscrof, adj., brave with the spear, warlike: nsm. El. 202; npm. æscrōfe, El. 275.

‡æscwiga, m., spear-fighter: np. xscwigan, El. 259.

äspring, n., spring, fountain: ds. $\bar{x}$ springe, $\mathrm{Ph}$. I04.

æt, prep., w. dat., at: El. I37, I46, 231, 25I, 399, 628, 965; Ph. I10, 239, 262, 477; W. 15 ; in: El. II 78 , I182, I 183 , I184, II89; $\mathrm{Ph}$. 280, 328, 538; near: Ph. 104; from: El. I9I, 994, 1217; to: W. 73 ; with: W. 37 .

æt, m. f., repast: ds. ǣte, Ph. 405 ; food: gs. æxtes, W. 52; as. Ph. 401.

æöelcyning, m., noble king: gs. æðelcyninges, El. 219.

æठ̀ele, adj., noble, excellent: $\mathrm{nsm}$. æbele, Ph. 9, 460; nsm. wk. æbela, Ph. 26, 43, 104, 614; nsf. El. 647,662 , II 31 ; nsn. wk. æbele, Ph. 20; gsn. æðeles, El. 591; dsf. wk. æð̌eian, El. 545; asm. æðelne, El. I 146 ; æbelne, Ph. 164, 346; Pr. 15; asm. wk.

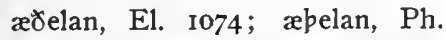
28I ; asf. wk. æठ̌̉elan, El. 275; asn. E1. 300 ; sup. nsn. æpelast, Ph. 2, 93; đsm. æðelestan, El. II74; dsn. æðelestan, El. 733; asn. æðelust, E1. 476; npm. æठ̀lestan, El. I107; ipf. æbelestum, $\mathrm{Ph} .207,43 \mathrm{I}$; righteous: npm. æele, Ph. 500; sweet: nsm. xpele, Pn. 74; npf. wk. æbelan, Ph. 528; ipm. æbelum, $\mathrm{Ph}$. 586; glorious: asf. wk. æठ̀elan, El. 787; precious: sup. dpm. æðelestum, E1. I025.

æðelic. adj., excellent: comp. nsm. æelicra, Pn. 48. æòling, m., nobleman, prince, chief: ns. El. 202; xpeling, Ph. 319, 354; gs. æð̀elinges, El. I2, 886, 1003, I198; as. El. 66; np. æðelingas, E1. 846; gp. æðelinga, El. 99, 393 .

$\ddagger$ æठ̀lstęnc, m., sweet odor: gp. æbelstenca, Ph. 195.

æòltungol, m., noble star: gp. æbeltungla, Ph. 290.

æolelu, npl., noble qualities: i. æXelum, El. 315, 1029; race: n. El. 433; nature: a. æbelu, Pn. 2.

ætsomne, adv., together: El. 834 ; Ph. 272.

ætȳwan, Wi., show, reveal: pp. ætȳwed, E1. 69.

$\ddagger$ æwita, m., one versed in the law: ds. 文witan, El. 455.

āfǣran, Wı., terrify: pp. āfǣred, $\mathrm{Ph} .525$.

āfēdan, W I., support, sustain: $3 \mathrm{sg}$. āfēdeð, Ph. 263; bring up, rear: pp. āfēded, El. 914.

āflēon, II, flee from: 3 sg. āflȳh Ph. I55.

āfyrhtan, WI., frighten: pp. āfyrhted, E1. 56 .

āfyrran, Wi., remove: pp. āfyrred, $\mathrm{Ph} .5$.

āfȳsan, Wr., impel: pp. āfȳsed, eager: nsm. Ph. 274; ready: nsm. Ph. 654 ; intent: nsm. Ph. 657.

āgalan, VI, sing: pret. 3 sg. āgōl, El. 27, 342.

āgan, prp., have, possess: 2 sg. āhst, El. 726; 3 sg. āh, El. I182; opt. 3 sg. āge, El. I124; inf. Ph. 559, 673. Negative: 3 pl. nāgon, W. 78 ; pret. 3 pl. nāhton, El. 356 . āgān, anv., go, pass: pp. El. 1227. āgangan, rd., go, pass: pp. āgangen, El. I.

āgen, adj., ozen: nsn. El. 179, 422, 
1077; asm. āgenne, El. 599; Ph. 264, 275; asf. āgne, $\mathrm{Ph} .256$; ipm. āgnum, Ph. 536; ipf. āgnum, Ph. 528.

āgend, see burg-, folcāgend.

àgifan, $\mathrm{V}$, give: pret. 3 sg. āgeaf, El. 455, 462, 619, 662; 3 pl. āgēfon, El. 587 ; inf. El. I67, 545.

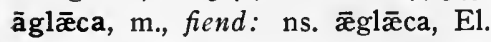
902; np. āglǣcan, Ph. 442; monster: as. āglǣean, W. 52. See ǣglǣ.

āgyldan, III, punish: pret. 3 sg. āgeald, Ph. 408. (?)

āhębban, VI, lift up, raise: $3 \mathrm{pl}$. āhebbað', Ph. 540 ; pret. 3 sg. āhōf, El. I7, 29, I12, 724, 844, 879; 3 pl. āhōfun, El. 838; āhōfon, El. 868; pp. āhafen, El. $862,885,976$; āhæfen, El. Io ; lift down: pp. āhæfen, El. 482; rear: pret. I sg. āhōf, El. 353 . āhōn, rd., crucify: pret. $3 \mathrm{pl}$. āhēngon, El. 2ro (opt.?) ; opt. pret. 3 pl. āhēngon, El. 475; pp. ăhangen, El. I80, 205, 445, 67I, 718,852 , 1076; asm. wk. āhangnan, E1. 453, 687, 798, 934.

āhȳdan, Wı., eclipse: pp. āhȳded, $\mathrm{Ph} .96$.

āhȳðan, Wr., plunder: inf. El. 4I. ald, see eald.

aldor, see ealdor.

aldordōm, see ealdordōm.

ālǣdan, Wr., emerge, spring: opt. pret. 3 sg. ālæde, Ph. 233; inf.

Ph. 25I.

älesan, V, choose, select: pp. ālesen, E1. 286 ; gp. ālesenra, E1. 380. all, see eall.

alleluia, interj. (Lat.), alleluia: $\mathrm{Ph}$. 677.

almus, adj. (Lat.), genial: gsf. alme, $\mathrm{Ph} .673$.

altus, adj. (Lat.), high: abl. pf. altis, Ph. 67I. ālȳfan, Wr., grant, vouchsafe: pp. àlȳfed, Ph. 667 .

ālȳsan, Wı., loose, release: pret. 3 sg. ālȳsde, El. I8I ; ransom, redeem: 3 sg. ālȳseð, $\mathrm{Ph} .566$.

amen, interj., amen: E1. г321. āmęrian, Wi., purge, purify: pp.

āmered, El. 1312; npm. āmerede, Ph. 544, 633.

āmetan, V, measure out: pret. $2 \mathrm{sg}$. āmǣte, El. $730 ; 3$ sg. āmæt, El. 1248.

ān, num., one: nsm. El. 4I7; asm. ænne, El. 585, 599; dsm. ānum, Pn. I6, 57; alone: nsm. wk. āna, Ph. I77, 355, 358; dsm. ānum, $\mathrm{Ph} .636$. See also ānra gehwā, ānra gehwylc.

ānboren, adj., only-begotten: nsm. E1. 392.

and, see ond.

anda, m., vexation: ds. andan, El. 970.

andleofen, f., food, sustenance: ds. andleofne, $\mathrm{Ph} .243$.

andsæc, n., opposition, resistance: as. El. 472 .

andswaru, f., answer: as. andsware, El. $166,318,375,455,462,567$, 662, I002; is. andsware, El. 642. andswerian, W2., answer: pret. 3 pl. andsweredon, El. 396.

andweard, adj., present: asn. wk. andwearde, El. 630.

andweardlice, adv., at present, now: El. II4I.

andwlita, m., face: as. andwlitan, E1. 298.

$\ddagger$ andwrāo, adj., at enmity: Pn. 17. andwyrde, n., answer: as. El. 545, 619.

ānforlǣtan, rd., give up, renounce: pret. 2 sg. ānforlēte, El. 947 ; 3 pl. ānforlēton, Ph. 438; opt. pret. 3 sg. ānforlëte, El. 630 . 
ānga, wk. adj., only, sole: nsm. Ph. 423; Pn. 73.

ānhaga, m., solitary one: ns. $\mathrm{Ph}$. 87 ; ānhoga, Ph. 346; ds. ānhagan, E1. 604.

anhȳdig, adj., mindful: nsm. El. 829 ; determined: npm. anhȳdige, El. 848 .

ānmōd, adj., with one mind, unanimous: npm. ānmōde, El. 396, III 8 .

ānra gehwā, pron., each one: gs. ānra gehwæs, $\mathrm{Ph} .487,598$.

ānra gehwylc, pron., each one: nsm. Ph. 503, 522, 534.

ānra gehwylc, adj., every: asn. El. 1287.

$\ddagger$ ānstapa, m., solitary rover: $d s$. ānstapan, Pn. I5.

anwealda, m., ruler: ns. anwalda, $\mathrm{Ph}$. 5II. See also onweald.

ār, m., messenger: vs. El. 1088; np. āras, El. 996; ap. āras, El. 981, 1007; angel: ns. E1. 76, 87, 95; ap. ăras, El. 738 .

ār, f., honor: ns. Ph. 663; dp. ārum, El. 714; goodzuill: ds. āre, El. 308.

ārǣran, WI., raise, rear, erect: inf. El. I29; pp. āräred, El. 804, 887.

äręccan, Wr., declare: inf. El. 635; Pn. 3.

ārfæst, adj., gracious: nsm. El. 12; merciful: nsm. El. 512.

ārisan, I, arise, rise: pret. 3 sg. ārās, El. 187, 486, 803, 888; Pn. 62.

ārlēas, adj., impious, wicked, godless: gpm. ārlēasra, El. 836, 130r. ärwyrôe, adj., worthy of honor, excellent: dsf. ārwyrờn, El. I 29.

àsǣlan, Wi., fetter: pp. āsǣled, El. 1244 .

asce, f., ashes: ds. ascan, Ph. 23I, 373,648 ; as. ascan, $\mathrm{Ph} .285,576$. āsceacan, VI, clap: 3 sg. āscæced, $\mathrm{Ph}$. 144.

āscēadan, rd., hold aloof: pret. I sg. āscēd, El. 470; purify: pp. āscēaden, El. I3I3.

āscian, see geāscian.

äscyrian, Wr., separate: pp. āscyred, El. I3I3.

āsēcan, Wr., seek out: imp. pl. āsēcab, El. 407; inf. āsēcean, El. Iorg.

āsęcgendlic, see unāsęcgendlīc.

āsēoðan, II, purify: pp. npm. āsodene, E1. I 308.

āsęttan, Wr., lay, set, place: pret. 3 pl. āsetton, El. 847; inf. El. 863,877 ; make: pp. āseted, El. 998.

āspyrigean, Wr., search out: inf. E1. 467.

āstęllan, Wr., raise $u p: 3$ sg. āstelleđ, Ph. 5 Ir.

āstigan, I, ascend: pret. $3 \mathrm{sg}$. āstāh, El. 188,900 ; inf. El. 795 ; start up: 3 sg. āstīgeð, El. 1273.

āstọndan, VI, rise: $3 \mathrm{sg}$. āstondeð, Pn. 40.

äsundrian, W2., separate, free: pp. npm. àsundrod, El. I309; àsundrad, $\mathrm{Ph} .242$.

āswębban, Wr., still, calm: pp. àswefed, $\mathrm{Ph}$. 186 .

àơrēotan, VI, weary, irk: pret. 3 sg. āprēat, El. 368.

āttor, n., poison, venom: gs. āttres, Pn. 58; is. ātre, Ph. 449.

āttorsceaða, m., venomous foe: ds. àttorsceapan, Pn. 33.

$\ddagger \bar{a}$ ȳdran, Wi., produce: pp. npm. ātȳdrede, El. 1279.

auctor, m. (Lat.), author: ns. Ph. 667.

āwa, adv., for ever: El. 951. See $\overline{\mathbf{a}}, \bar{o}$.

āweaxan, VI, growe: opt. pret. $3 \mathrm{sg}$. 
āwēoxe, E1. I226; pp. āweaxen, Ph. 265.

āwęccan, WI., awake, arouse: $3 \mathrm{sg}$. āweceð, Ph. 567 ; pret. 3 sg. āwehte, El. 304, 946; opt. pret. 2 sg. āweahte, El. 782; pp. āweaht, Ph. 367 ; incite: I sg. āwecce, El. 927.

āwęndan, WI., turn: pp. āwended, E1. 58I.

āweorpan, III, cast, hurl: pret. 2 sg. āwurpe, El. 763 ; contradict, gainsay: inf. El. 771.

āwer, adv., anywhere: El. 33. [āhwær.]

āwrītan, I, inscribe: pp. āwriten, El. 9I.

āwyrdan, Wi., destroy, spoil: opt. 3 sg. ãwyrde, $\mathrm{Ph} .247$.

āwyrged, adj., accursed: nsm. wk. āwyrgda, W. 87 ; npm. āwyrgede, E1. 1299.

āyrnan, III, run out, elapse: pp. āurnen, Ph. 364 .

\section{B.}

bæc, n., back: as. $\mathrm{Ph} .309$.

bǣl, n., fire: 'gs. bǣles, Ph. 47; flame: ns. El. 578 ; is. bǣle, $\mathrm{Ph}$. 227, 284; pyre: ns. Ph. 216.

‡bælöracu, f., rush of flame, violence of fire: ds. bǣlpræce,

Ph. 270.

bǣm, see bēgen.

bǣ, f., bier: ds. bǣre, E1. 873. -bǣru, see gebǣru.

bæठ, n., bath: as. E1. 490, I034; gp.

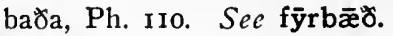

bæơweg, m., sea: as. El. 244. bald, adj., bold: nsm. El. 593; nsf. (= boldly) El. 4r2, 1073.

baldor, m., prince: ns. El. 344 . bān, n., bone: as. (ap.?) Ph. 221 ; gp. bāna, Ph. 575; ap. Ph. 270, 27I; 283, 286, 512; El. 788. bāncofa, m., body: as. bāncofan, E1. 1250.

bānfæt, n., body: ns. Ph. 229; ap. bānfatu, Ph. 520.

bann, see gebann.

bannan, rd., call: inf. El. 45. See ābannan.

basu, adj., crimson: nsm. Ph. 296. bađian, see bibaðian.

be, prep., by: w. dat., E1. 78, 505, 756 ; bi, Pn. I3; W. 9, I8; among: w. dat., E1. 1274; concerning, in regard to: w. dat., E1. I68, 337, 342, 350, 420, 444, $562,601,665,706,861,867$, го68, I 189, I24I, I257; bi, Ph. 388; Pn. 8, I5, W. 3, Pr. I ; upon, by means of: $\mathrm{w}$. inst., $\mathrm{bi}, \mathrm{Ph}$. 262.

be-, see also bi-.

bēacen, n., sign: ns. El. I62, I194; gs. bēacnes, $\mathrm{Ph}$. I07; as. El. I00, I09, 784, 842; is. bēacne, El. 92. See sige-, sigorbēacen.

bēacnian, W2., betoken, signify, typify: 3 sg. bēacnay, $\mathrm{Ph} .389$, 575,646 .

beadu, f., battle: ds. beadwe, El. 34,45 .

beaducræftig, adj., valiant, warlike: nsm. Ph. 286.

beadurōf, adj., stout in battle, brave: nsm. El. 152; dsf. beadurōfre, El. I004; npm. beadurofe, E1. I 185 .

beadư̆rēat, m., army: gp. beadubrēata, El. 31.

bēag, m., crown: ns. Ph. 602; collar: gp. bēaga, Ph. 306 .

bēaggifa, m., lord: ns. El. 100 ; gs. bēaggifan, El. II99.

beald, adj., steadfast: nsm. Ph. $458 ;$ bold $(l y)$ : nsm. Ph. 550 .

bealu, n., evil, wrong, iniquity: gs. bealwes, W. 72. See Jēodenbealu. 
bealucī̄, f., evil deed, sin: gp. bezlud̄̄da, El. 515 .

bealusorg, f., baleful sorrow, anguish: as. bealosorge, $\mathrm{Ph} .409$. beam, m., tree (in the Elene always = cross): ns. El. 91, 217, 624, 887 ; Ph. 447; gs. bēames, $\mathrm{Ph}$. 402 ; ds. bēame, Ph. I22; as. El. 424, 1074, I255; Ph. II2, I7I, 202 ; np. bēamas, $\mathrm{Ph} .35$; gp. bēama, El. 85r, Iог 3, I225; $\mathrm{Ph}$. I77; ap. bēamas, El. 865. See sige-, wudu-, wynbēam.

bearhtm, see breahtm.

bearn, n., child, son: ns. El. I79, 39I, 422, 446, 783, 851, 1077; ds. bearne, El. 525, 562, 837; as. El. 814, 964, II27; np. Ph. 396; Pn. I3; gp. bearna, El. 476; Pr. II ; dp. bearnum, Pn. 25 ; ap. El. I8r, 354. See frēo-, God-, sigebearn. bearo, m., forest, grove: gs. bearwes, $\mathrm{Ph}$. 122, 148 ; ds. bearwe, Ph. 432 ; as. Ph. 67 ; np. bearwas, Ph. 7I ; gp. bearwa, Ph. 80. Sce sun-, wudubearo.

bebēodan, II, bid, command: pret. 3 sg. bebēad, E1. 378, 710, 715, 980, 1018, II31, I220; bibēad, $\mathrm{Ph}$. 36 ; pp. beboden, El. 224, 412.

bebod, n., command: as. El. II70. bebūgan, II, avoid: inf. El. 609; encircle: 3 sg. bibūgeð, Pn. 6.

bebyrgan, WI., bury: 3 sg. bebyrgeð, $\mathrm{Ph} .286$.

† beclingan, III, bind: pp. beclungen, El. 696 .

becuman, IV, reach: pret. 3 sg. becwōm, El. I42.

będ, see nēobęd.

-bed, see gebed.

bedelfan, III, bury: pp. bedolfen, El. I08I.

bedyrnan, Wr., hide, secrete: inf. El. 584 ; pp. bedyrned, E1. 602.

befæstan, Wr., make fast, make securc: 3 sg. bifæsted, W. 30 ; pp. befæsted, EI. I 300 ; establish: pp. befæsted, E1. І2 3 .

befēolan, IV, grant: pp. befolen, E1. 196, 937.

befōn, rd., seize: pret. 3 sg. befēng, E1. 843; invest, encompass, clothe: pp. bifongen, $\mathrm{Ph} .259$, $380,527,535$.

beforan, adv., beforehand: El. II42, II 54 .

beforan, prep., before: w. dat., El. 108.

begangan, rd., fulfil: opt. 2 sg. begange, El. II 7 I.

bēgen, num., both: n. bū, El. 614, 889; Ph. 402; g. bēga, El. 618, 964; bēgra, El. ı009; d. bǣm, El. 805 .

begēotan, II, pour out: pret. 3 sg. begēat, El. I248.

begietan, V, get, obtain, attain:

pret. $3 \mathrm{sg}$. begeat, El: II52; inf. Ph. 669 .

begrafan, VI, bury, hide: pp. begræfen, El. 974; apf. begravene, El. 835 .

behealdan, rd., behold: pret. 3 sg. behēold, El. III, 243; inf. bihealdan, $\mathrm{Ph}$. II4; observe: inf. bihealdan, $\mathrm{Ph} .90$; inhabit: $3 \mathrm{sg}$. bihealdeb, $\mathrm{Ph} .87$; pret. 3 sg. behēold, El. II 44 .

behęlian, Wr., bury, hide: pp. beheled, E1. 429; apf. behelede, E1. 831.

behlidan, I, close, shut: pp. behliden, E1. I230.

behȳdan, Wr., conceal: pp. behȳded, E1. 793, 988, 1082; bihȳded, Ph. 4I8; asf. bihȳdde, Ph. I7o.

belïôa, I, deprive, rob: pp. gsm. belidenes, El. 878 .

belūcan, II, lock $u p$ : inf. El. 1027. 
bemïon, I, hide, keep secret: inf. E1. 583 .

bēn, f., prayer, petition: as. bēne, E1. I089.

beneah, see benugan.

benugan, prp., to have at disposal

(w. gen.): $3 \mathrm{sg}$. beneah, El. 6I8. bēodan, II, proclaim: 3 sg. bēode',

Ph. 497 ; opt. pret. 3 sg. bude,

E1. I212; inf. E1. 80; pp. boden,

E1. 972; offer: pp. boden, E1.

18. See ā-, be-, for-, gebēodan. beofian, W2., tremble: $3 \mathrm{sg}$. beofab,

E1. 759 .

bēon, see wesan.

beorg, m., hill, mountain: ds.

beorge, El. 510, 578 ; np. beorgas,

$\mathrm{Ph} .2 \mathrm{I}$; gp. beorga, $\mathrm{Ph}$. 3r. See sondbeorg.

beorgan, III, save (w. dat.): pret.

3 pl. burgon, El. 134 .

‡ beorgan, III, taste: $3 \mathrm{sg}$. beorger,

$\mathrm{Ph}$. IIo.

beorhhlio, n., mountain-slope: ds.

beorhhlide, E1. 788, roog.

$\ddagger$ beorhstęde, m., eminence, funeral-

pile: ds. Ph. 284.

beorht, adj., bright, radiant, gleam-

ing, shining, beaming: nsm. El.

88, 489; Ph. I22, 240 ; nsm. wk. beorhta, Ph. 602; dsf. wk. beorhtan, E1. 822; asm. wk. beorhtan, Pn. 7 ; asf. beorhtan, E1. I089; npf. beorhte, Ph. 35; gpn. beorhtra, Pn. 26; comp. nsm. beorhtra, El. IIIo; Pn. 23; sup. nsm. beorhtast, Ph. 80, 306; nsn. beorhtast, Ph. 227; asn. beorhtost, E1. 948; excellent, glorious, illustrious: asm. wk. beorhtan, El. I255; asn. beorhte, E1. 790 ; npm. beorhte, Pr. II ; pure (?), glorious (?): asm. beorhtne, Ph. 389; clear: isf. wk. beorhtan, Ph. I28. See hiw-, sunbeorht. beorhte, adv., brightly: E1. 92; Ph. 3I, 545, 599; super. beorhtast, $\mathrm{Ph}$. 179; splendidly, $\mathrm{Ph}$. 5ì2. beorhtm, see breahtm. beorn, m., man, hero: gs. beornes,

E1. 710, 805, 1062; gp. beorna,

E1. $100,114,186,253,873$, I187, I I99.

$\ddagger$ beornðrēat, m., troop of men: ns. beornbrēat, Pn. 50.

berǣdan, WI., rob: pret. 3 pl. berǣddon, El. 498.

beran, IV, carry, bear, convey:

3 sg. byreð, El. ıा96; biereð, $\mathrm{Ph}$.

I99; 3 pl. bera 8, El. I I87; inf. El.

45, 109. See reordberend.

berēafian, W2., rob: pp. berēafod, E1. 9 Io.

berstan, see forberstan.

bescūfan, II, push, hurl: $3 \mathrm{sg}$. bescūfeð, El. 943.

besēon, V, look: inf. sg. beseoh, E1. 83.

besęttan, Wr., surround: $3 \mathrm{sg}$. biseted, Ph. 530; set: pp. biseted, Ph. 304; adorn, bejewel: inf. E1. I026; cover: pp. beseted, Ph. 297.

besittan, V, hold: pret. 3 pl. bisǣton, El. 473.

beswican, I, beguile, deceive: $3 \mathrm{pl}$. beswicað, W. 33 ; pret. 3 sg. biswāc, Ph. 4I3; inf. W. 65; pp. beswicen, W. 56 .

besylcan, Wi., weaken: pp. besylced, E1. 697.

betǣcan, Wr., deliver: pret. 3 pl. betæhton, El. 585 .

beteldan, see biteldan.

bętera, see gōd.

beðęccan, WI., cover: pret. 3 sg. bepeahte, El. 1236; bepehte, E1. I 298 ; 3 pl. bepeahton, El. 836 ; pp. bebeaht, El. 76, 884 ; bibeaht, W. 45 ; npm. bipeahte, Ph. 490 , 
605 ; load: pret. 3 sg. bibeahte, Pn. 6I.

Bethlem, pr. n., Bethlehem: $\mathrm{d}$. Bethleme, El. 39r.

beơringan, III, burden, oppress: pp. beprungen, El. 950, I245; encircle: pp. biprungen, Ph. $34 \mathrm{I}$. beðurfan, prp., need: 3 sg. beðearf, El. 543 .

betwēonum, prep. w. gen., among: El. 1207.

beweorcean, WI., adorn: inf. El. 1024.

beweotigan, see bewitigan.

bewindan, III, invest, clothe, wrap: pp. biwunden, Ph. 666; npm. bewundene, El. 734; encompass: pp. biwunden, W. I8.

bewitigan, W2., do, perform (attend to ): 3 pl. beweotigap, El. 745 ; watch: inf. Ph. 92.

bewrecan, V, lash, beat: pp. apm. bewrecene, El. $25 \mathrm{I}$.

bi(-), see also be(-).

bibadian, W2., bathe: 3 sg. bibabad, Ph. I07.

biclyppan, Wr., seize: 3 sg. biclyppe $ð, \mathrm{Ph} .277$.

bìd, n., expectation: ds. bìde, El. 885.

bìdan, I, abide, remain: 3 sg. bided, E1. I093; $\mathrm{Ph} .47$; pret. 3 sg. bād, El. 329; ptc. bīdende, El. 484. See gebidan.

biddan, V, ask, beg: pret. 3 sg. bæd, E1. 494, 600, 1069, I101 ; imp. sg. bide, El. I090; inf. El. 790, 8r4. bidēglian, W2., conceal: pp. bidegglad, $\mathrm{Ph} .98$.

bīgan, WI., bow, bend: 3 sg. bige $\gamma$, Ph. 459.

bigang, m., course: ns. El. II 24. bigęnga, m., inhabitant: ds. $\mathrm{Ph}$ 。 bïgengan, 148.

bihelan, IV, sequester: pp. asf. biholene, $\mathrm{Ph} . \mathrm{IzO}$. bihlęmman, Wr., snap: $3 \mathrm{sg}$. bihlemme 8 , W. 76.

bill, n., sword: ns. El. 25\%; ap. bil, El. 122.

bindan, see ge-, onbindan.

biniman, IV, bereave, deprive:

pp. apm. binumene, $\mathrm{Ph} .488$.

biscēawian, W2., take heed to:

3 sg. biscēawad, W. 64 .

bisceop, m., bishop: ns. El. 1095, I 27; ds. bisceope, El. I057, I073, I2I 7 ; as. El. I052.

bisceophād, m., episcopal rank: ns. E1. I2I2.

bisęncan, WI., sink: 3 sg. bisence $\gamma$, W. 48 .

bisgu, see bysgu.

bisorgian, W2., dread, fear: $3 \mathrm{sg}$. bisorgad, Ph. 368.

biteldan, III, cover: 3 sg. bitelde $\nsim$, Ph. 273; pp. bitolden, Ph. 555; surround: $3 \mathrm{pl}$. beteldar; $\mathrm{Ph}$. 339; array: pp. bitolden, $\mathrm{Ph}$. 609.

bitre, adv., bitterly: E1. I245.

bitter, adj., bitter, grievous: nsf. Ph. 404; asf. bittre, $\mathrm{Ph} .409$; harmful, noxious: gsn. bitres, Ph. I79.

bitȳnan, Wr., close, lock: pp. bitȳned, Ph. 4I9.

biweaxan, rd., overgrow: pp. biweaxen, $\mathrm{Ph}$. 3 I0.

blāc, adj., bright, shining, shining white: nsm. wk. blāca, El. 9I ; ipn. blācum, Ph. 296.

blǣ, adj., brilliant: nsn. Pn. 26.

blæd, m., fulness: ns. Ph. 662; glory: gs. blæ̈des, El. I62; ds. blǣde, El. 489; as. El. 354; bliss: as. El. 826; Ph. 39I ; inspiration: as. $\mathrm{Ph} .549$.

blæddæg, m. day of bliss: gp. blǣddaga, Ph. 674 .

blæst, m., blaze, flame: ns. Ph. I5; as. $\mathrm{Ph} .434$. 
blanca, m., white horse: ds. blancan, El. 1185.

blandus, adj. (Lat.), mild: asm. blandum, Ph. 674 .

blēd, f., fruit: as. blēde, Ph. 402 ; np. blëde, Ph. 35; ip. blēdum, Ph. 38, 7I, 207; branch: np. blēde, $\mathrm{Ph} .466$. See wudublēd.

blēo, n., form, shape: as. II06; ip. blēom, El. 759 ; color: ip. blēom, Pn. 23.

blēobrigd, n.(?), variety of colors, play of colors: ip. blēobrygdum, Ph. 292.

blētsian, W2., bless, adore: 3 pl. blētsiađ, $\mathrm{Ph} .620$.

blican, I, shine: 3 sg. blīeè, $\mathrm{Ph}$. I86, 599; Pn. 29; opt. 3 sg. blice, $\mathrm{Ph} .115$; inf. Ph. 95.

blind, adj., blind: npm. blinde, El. I215. See mödblind.

blindnes, f., blindness: gs. blindnesse, El. 389; ds. blindnesse, El. 299.

blinn, n., end, ceasing: ds. blinne, E1. 826 .

bliss, f., bliss, joy: ip. blissum, El. II38; $\mathrm{Ph}$. I26.

blissian, see geblissian.

blïðe, adj., joyous, glad: nsm. El. I317; dsm. wk. blipan, Ph. 599; npm. El. 246; blipe, Ph. 620; comp. bliơra: nsm. El. 96.

blond, see geblond.

blondan, see geblọndan.

blōstma, m., blossom, flower: np. blōstman, Ph. 74; dp. blōstmum, Pn. 47 ; ip. blōstmum, Ph. 21. blōwan, see geblōwan.

bōc, f., book: gp. bōca, E1. I212; dp. bōcum, El. 204, 290, 826, I 255 ; ap. bēc, El. 364, 670, 853 .

bōcstæf, m., letter: dp. bōcstafum, El. 9 I.

bod, see be-, gebod.

boda, m., messenger, ambassador: ns. E1. 77 ; np. bodan, E1. 262, 55I. See spelboda.

bodian, W2., announce: pp. bodod, El. II 1 I.

bona, see feorgbona.

bora, see hornbora.

bord, n., shield: as. El. II87; gp. borda, El. II4; dp. bordum, El. 24, 235 ; ship: ns. El. 238. See orȳöbord.

$¥$ bordhaga, m., protection of the shield: ds. bordhagan, El. 652 .

bordhrēota, m., shield: ap. bordhrēoð̄an, El. I22.

boren, see ānboren.

bōsm, m., bosom (poet. for earth) : as. Pn. 7.

bōt, f., cure, healing, reparation, atonement: as. bōte, E1. 299, 389, I217; repentance: ds. bōte, El. I039, II26; as. bōte, El. 515.

brād, adj., broad: nsn. brād, El. 9 I7.

brǣce, see unbrǣce.

brǣ, f.(?), flesh: ns. Ph. 240.

breahtm, m., sound, music: ds. breahtme, $\mathrm{Ph}$. I34; noise: is. breahtme, El. 39; beorhtme, El. 205 ; bearhtme, E1. 865 .

brec, see gebrec.

brecan, IV, burst forth, break forth: 3 pl. brecad, Ph. 67; rend asunder: 3 sg. brice $\delta, \mathrm{Ph}$. 504 ; pret. 3 pl. brācon, El. I22; rush, dash: inf. El. 244. See gebrecan.

brēdian, see gebrēdian.

bregd, see gebregd; brigd.

bregdan, III, plait, weave: pp.

brogden, El. 257; Ph. 306; set, inlay: pp. brogden, Ph. 602; vary, shift: ptc. bregdende, Pn. 23. See onbregdan; brogdenmæl.

brego, m., lord, prince: ns. Ph. 
497 ; as. $\mathrm{Ph} .568$; bregu, $\mathrm{Ph}$. 620.

brēost, n., breast: ap. Ph. 292 ; mind, heart: dp. brēostum, El. 595, 967, 1038, 1095; Ph. 458, 568 ; ip. brēostum, Ph. 550.

brēostloca, m., bosom's recess, soul: as. brēostlocan, El. I250.

brēostsefa, m., heart: ns. El. 805 , 842, 1046; Ph. 126.

brēotan, see ābrēotan. brid, m., young bird, nestling: ns.

Ph. 235 ; gs. briddes, Ph. 372. bridels, m., bridle: gs. El. II99; as. E1. I I 75, I I85.

bridelshring, m., bridle-ring: dp. brīdelshringum, E1. I I94.

† brigd, n.(?), variety: gp. brigda, Pn. 26. See blēobrigd; bregd. brim, n., sea: ns. Pn. 7 ; as. El. I004; ds. brime, El. 253; np. brimo, E1. 972.

brimcald, adj., cold as the sea: asn.

Ph. IIo; npn. Ph. 67.

brimoisa, m., ship: ap. brimpissan, E1. 238.

brimwudu, m., ship: as. El. 244. bringan, W ., bring: 3 pl. bringa Ph. 660; pret. 3 sg. brōhte, El. ı130; 3 pl. brōhton, El. 873, 996, ıог6; pp. brungen, El. I 38 . See gebringan.

brōga, see witebrōga.

brogdenm文, n., damasccned sword: ns. El. 759.

brond, m., fire: ns. Ph. 216; gs. brondes, Ph. 283 .

bront, adj., steep, high: apm. bronte, El. 238.

brosnian, W2., wither: 3 pl. brosniad, $\mathrm{Ph}$. 38. See gebrosnian.

bröðor, m., brother: ns. El. 489, 822 ; as. El. 5 10. See gebrōor. brūcan, II, use, enjoy (w. gen.): 3 pl. brūcab, El. 1320; pret. I sg. brēac, El. 1251; inf. E1. 1315; Ph. I48, 674 .

brūn, adj., dusky: nsm. Ph. 296.

bryce, see unbryce.

bryne, m., flame: ns. Ph. 229, 520;

burning: as. $\mathrm{Ph} .545,575$. See ligbryne.

bryrdan, see onbryrdan.

brytta, m., dispenser: ns. E1. I62,

I94; originator: as. bryttan, El. 958.

bryttian, W2., destroy: $3 \mathrm{sg}$. bryttað, E1. 579.

bū, see bēgen.

būend, see foldbūend.

bügan, II, occupy, inhabit: 3 pl. būgað, Ph. I57. See bebūgan.

burg, f., city: gs. byrig, El. 864 ; ds. byrig, El. 822, I006, I054. I204; Ph. 475, 588, 633, 666; gp. burga, E1. I52; dp. burgum, E1. 412, 972, 992, 1057, 1062; Ph. 380 .

burgāgend, m., holder of the city: gp. burgāgendra, El. II75.

burgloca, m., fortified position: as. burglocan, El. $3 \mathbf{I}$.

burgsæl, n., castle-hall: dp. burgsalum, Pn. 50. .

burgsittend, m., citizen: dp. burgsittendum, E1. 276.

burna, m., fountain: ds. burnan, Ph. 107.

būtan, prep., without: w. dat., El. 802, 81 I, 826, 894, 953, 1292; Ph. $637,65 \mathrm{I}$; save, except: w. acc., E1. 539; w. dat., El. 1228; Pn. I6, 33, 57 .

bütan, conj., unless: El. 689; exccpt: El. 66I; Ph. 358.

byldan, Wı., incite: pret. $3 \mathrm{sg}$. bylde, E1. I039.

-bylgð, see ǣbylgð.

bȳme, f., trumpet: gs. bȳman, $\mathrm{Ph}$.

497 ; np. bȳman, El. 109; Ph. I34. -byrd, see gebyrd. 
-byrde, see gebyrde.

byre, m., child, offspring: ns. $\mathrm{Ph}$.

r28; np. Ph. 409.

byrga, see gebyrga.

byrgan, Wr., taste, eat: pret. 3 pl. byrgdon, $\mathrm{Ph}$. 404. Sec gebyrgan.

byrgan (bury), see bebyrgan.

byrgen, f., grave, tomb: ds. byrgenne, El. I86, 484; gp. byrgenna, E1. 652 ; dp. byrgennum, Ph. 512.

byrnan, III, burn: 3 sg. byrneð,

$\mathrm{Ph} .214,218,502,531$.

byrne, f., corslet: ns. El. 257.

byrnwigend, m., corsleted warrior:

gp. byrnwigendra, El. 34 ; byrn-

wiggendra, El. 224; dp. byrn-

wigendum, E1. 235.

byro, see beran.

bysgian, W2., torment: $3 \mathrm{sg}$.

bysgad, W. 51. See gebysgian. bysgu, f., trouble: ip. bisgum, El.

1245.

bȳwan, see ābȳwan.

\section{c.}

cāf, adj., bold, brave: npm. cāfe, El. 56.

cald, adj., chill, cold: ipm. cāldum,

Ph. 59. See brimcald.

caldu, see sincaldu.

Calvarie, pr. n., Calvary: n. El. 676; d. El. 672, I0II ; Calvarię, El. 1098 .

campwudu, m., shicld: ns. El. 51. carcern, n., prison: ds. carcerne, E1. 715 .

cāserđōm, m., reign: gs. cāserdōmes, El. 8.

cāsere, m., emperor: ns. El. 42, 999; gs. cāseres, El. 262, 330, 55I, 669;

Ph. 634; ds. El. 70, 175, 212, 416. ceafl, m., mouth: ns. W. 59.

cearwylm, m., wave of sorrow: dp.

cearwelmum, E1. I258. cēas, f., strife, battle: ds. cēase, El. 56.

ceaster, f., city: gs, ceastre, El. 384 ; as. ceastre, E1. 274, 846, 1205; gp. ceastra, El. 973; dp. ceastrum, Pn. 49.

ceasterware, mpl., citizens: $\mathrm{dp}$. ceasterwarum, El. 42.

celum, n. (Lat.), heaven: abl. s. celo, $\mathrm{Ph} .669$.

cęmpa, m., soldier, champion: ns. $\mathrm{Ph} .452$; np. cempan, Ph. $47 \mathrm{I}$.

cęnnan, Wr., bear, beget: pret. I sg. cende, $354 ; 3$ pl. cendan, E1. 508; pp. cenned, El. 336, 392 ; $\mathrm{Ph}$. 639; devise: pp. cenned, El. 587 ; W. 6. See ācęnnan.

cēol, m., ship: np. cēolas, W. I7; ap. cēolas, El. 250.

cēosan, II, choose: 3 pl. cēosað, $\mathrm{Ph}$. 479; opt. I sg. cēose, Ph. 553. See gecēosan.

ceruphin, npl., cherubim: n. El. 750.

ciest, see ēoredciest.

cïgan, see ā-, gecīgan.

cild, n., child: gs. cildes, El. 336, 776 ; Ph. 639.

cildhād, m., childhood: ds. cildhâde, El. 915 .

cirice, f., church: as. cirican, El. 1008.

clā, f., talon: ip. cläm, Ph. 277.

clǣne, adj., pure: nsm. Ph. I67; nsn. Ph. 252; npm. Ph. 518, 54I ; gpm. clǣnra, El. 96; dpf. clǣnum, El. 750 ; ipn. clǣnum, Ph. 459. $S e c$ unclǣne.

clǣne, adv., entirely, wholly: $\mathrm{Ph}$. 226.

clǣnsian, see geclǣnsian.

cleofa, see nȳdcleofa.

$\ddagger$ cleofian, W3., cleave, adhere: 3 pl. cleofiad, W. 73 .

cleopian, W2., call, cry: pret. 3 sg. cleopode, El. I $100 ; 3$ pl. cleop- 
odon, El. 1319; inf. cleopigan, E1. 696 .

clēowen, n., ball: ds. clēowenne, $\mathrm{Ph} .226$.

clif, see stānclif.

clingan, see be-, geclingan.

clom, m., fetter: dp. clommum, E1. 696.

clynnan, Wi., resound: pret. $3 \mathrm{sg}$. clynede, El. 5 I.

clyppan, see biclyppan.

-cnǣwe, see orcnǣwe.

cnāwan, see ge-, oncnāwan.

cnēo, n., knee: ds. El. 848; cnēow, El. II36; as. $\mathrm{Ph}$. 459, 514.

cnēomǣg, m., kinsman: dp. cnēomāgum, El. 587, 688.

cniht, m., child: ns. El. 339.

†cnihtgeong, adj., youthful: nsm. E1. 640.

cnyssan, WI., beat, strike, smite:

3 sg. cnysed, $\mathrm{Ph}$. 59; pp. cnyssed, E1. 1258.

cofa, see bān-, heolstor-, Jēostorcofa.

cōlian, W2., to be cold: pret. 3 pl. cōlodon, El. 883. See ācōlian.

collenferhð, adj., elated: npm. collenferhðe, El. 247, 849; troubled: npm. collenferhðe, El. 378; bold: npm. collenferhbe, W. I7.

condel, f., candle: ds. condelle, $\mathrm{Ph}$. 91. See swegl-, wedercondel.

Constantinus, pr. n., Constantine: n. El. 103, 1008; g. Constantines, El. 8; d. Constantīno, E1. I45; v. El. 79 .

corn, n., individual grain: gs. cornes, Ph. 252.

corøor, n., band, multitude: ds. cororre, El. 70, 543, 69I ; corpre, El. 304; gp. corðra, El. 274; Ph. I67.

cost, see gecost.

cræft, m., ability, knowledge, power, skill: gs. cræftes, El. 558; as. cræft, El. I54, 374, 595, I172; dp. cræftum, El. I018, I059; ip. cræftum, Ph. 344. See $\bar{\circledR}-$, leornung-, lēođ̌-, mōd-, searu-, snyttru-, sọng-, word-, wō̄cræft.

cræftig, adj., skilful, expert: nsm. El. 419; W. 24, 72. See beadu-, leoðucræftig.

Crēcas, pr. n., Greeks: g. Crēca, E1. 250, 262, 999.

$\ddagger$ cring, f. 'n., slaughter: ns. El. II 5.

cringan, III, fall, perish: pret. 3 pl. crungon, E1. 126.

Crīst, pr. n., Christ: n. El. 460; Ph. 590; g. Crīstes, El. 103, 212, 499, 973; Ph. 388, 5I4; d. Criste, E1. 678, то1 I, I035, I050, II20; a. E1. 798 .

Crīsten, adj., Christian: gp. Crīstenra, E1. 980, 1069; dp. Crīstenum, El. 989 , I211.

cuman, IV, come: 3 sg. cymed, $\mathrm{Ph}$. 484, 508; Pn. 42, 44; W. 54; 3 pl. cumað, El. I303; pret. I sg. cwōm, El. 908; 3 sg. cwōm, El. 549, 871, IIIo; cōm, El. I50; 3 pl. cwōmon, El. 274, I214; opt. 3 sg. cyme, Ph. 93, I02; inf. El. 279, I205; Ph. 9I ; pp. cymen, E1. I I23; go: 3 pl. cumad, W. 79; return: 3 sg. cymed, $\mathrm{Ph} .222$, 366. See à-, becuman.

cumbul, see eofor-, heorucumbul. -cund, see godcund.

cunnan, prp., know: I sg. can, El. $635,640,683,925$; cann, El. 684; I pl. cunnon, El. 399 ; 2 pl. cunnon, El. 535, 648; 3 pl. cunnon, El. 317 ; pret. 3 sg. cūðe, El. 1163; 3 pl. cūđon, El. I67, 28r, $284,328,393,398$, 1020; opt. 2 sg. cunne, El. $857 ; 3$ pl. cunnen, El. 374,376 . 
cunnian, W2., think out, decide: imp. pl. cunniad, E1. 53I. cūð, adj., known, familiar: nsm. E1. 42 ; nsn. cūb, El. I I92. See uncūò.

cwacian, W2., quiver: 3 sg. cwacap, E1. 758 .

cwalu, f., torture: ds. cwale, El. 499. See dēad-, feorh-, lig-, swyltcwalu.

cwānig, adj., sad, sorrowful: npm. cwănige, El. 377.

cwealm, m., agonizing death: ns. El. 676; agony: as. Ph. 642.

$\ddagger$ cwealmgeniolla, m., deadly enmity: as. cwealmgenï̋lan, El. 6 Io.

-cwēme, see gecwēme.

cwēn, f., queen: ns. E1. 247, 378, 384, 4I I , 4I 6, 533, 55 I, 558, 605, 662, 7 I 5, 849, 980, IOI8, 1069, II52, I205; gs. cwēne, El. I136; ds. cwēne, El. 324, 587, 6ro, Ir 30 ; as. E1. 275 ; vs. El. II70. See gūò-, sige-, ठēodcwēn.

cweðan, V, say, speak: 3 pl. cweðab, El. 749; pret. 3 sg. cwæठ, El. 667 ; 3 pl. cwædon, El. I69, 57I, I 20 . See $\overline{\mathbf{a}}-$, ge-, oncweðan.

cwic, adj., living: asm. cwicne, El. 691. See healfcwic.

cwicsūsl, n., hell-torment: ds. cwicsūsle, W. 38.

cwide, m., speech: dp. cwidum, El. 547. See geagn-, hlēoðor-, hosp-, sōorcwide.

cwylman, Wr., kill: pp. cwylmed, El. 688.

cylegicel, n., icicle: ip. cylegicelum,

Ph. 59.

cyme, m., coming: ns. El. 4I ; Ph.

53; ds. E1. 1228; Ph. 107, 245 ;

as. Ph. 47,490 ; appearance: as.

E1. I086. See hidercyme.

-cynd, see gecynd. cynegold, n., diadem: ns. Ph. 605 . cynestōl, m., throne: ds. cynestōle, E1. 330; royal dwelling: dp. cynestōlum, Pn. 49.

cyneðrym, m., royal majesty: as. cynebrym, Ph. 634.

cyning, m., king: ns. El. I3, 32, 5I, $56,62,79,96,104,129,145,152$, I $58,195,342,392,460,866,942$, 1042, 109I ; $\mathrm{Ph} .175,356,496$, 514, 614, 664; cining, El. 49, 800, II52; gs. cyninges, El. 610, 672, I192; Ph. 54I ; cininges, El. I075, II70; dis. cininge, El. 989 ; as. E1. 453 , 928, 934 ; Ph. 344 ; gp. cyninga, El. 5, I78, 816. See æర̈̀l-, eor'-, hēah-, heofon-, mægen-, rodor-, sōö-, orym-, wuldorcyning.

cynn, n., kind, race, lineage, species: ns. El. 837 ; gs. cynnes, El. I88, 305, 521, 591, I204; Ph. 358, 492, 535, 546; W. 40 ; ds. cynne, E1. 898 ; $\mathrm{Ph} . \mathrm{I} 98$; as. W. I ; cyn, El. 209; Ph. 330; np. Pn. 2 ; W. 56; nation: ns. $\mathrm{Ph} .335$; as. $\mathrm{Ph}$. I59. See ęngel-, gim-, man-, sigorcynn.

cyr, see wiöercyr.

Cyriācus, pr. n., Cyriacus (the changed name of Judas): $\mathrm{n}$. El. I059, т098, I2I I ; Ciriācus, El. II30; a. El. I069.

cyrran, Wi., turn: 2 sg. cyrrest, El. 666 ; pret. 3 sg. cirde, El. 915; return: 3 pl. cyrrað, Ph. 352 . See ā-, ge-, oncyrran.

cyst, m., choicest, most excellent: as. Pr. I5. Sec uncyst.

cȳðan, Wr., make known, proclaim, reveal: I sg. cȳðe, El. 702; 3 pl. cȳpad, Ph. 30, 332, 344, 425, 634; Pn. I4; imp. sg. cȳ゙, El. 607 ; inf. El. 16I, 175, I99, etc. (12 times) ; pp. cȳðed, E1. 827 ; tell, 
relate: inf. cȳpan, W. 2 . See gecȳòn.

cȳðig, see on-, uncȳðig

cȳððu, f., home: as cȳpbu, $\mathrm{Ph}$.

277. See ealdcȳðซu.

\section{D.}

dǣ, f., deed, act: as. E1. 386; gp. d̄̄da, El. 1283; Ph. 463 ; W. 34 ; ip. d̄̄dum, Ph. 445, 452, 528. See bealu-, gōd-, gū-, mān-, wēa-, weld̄̄d.

dǣdhwæt, adj., powerful: npm. dǣdhwæte, El. 292.

dæg, m., day: ns. Ph. 334; Pr. 14; gs. dæges El. I40, 198; $\mathrm{Ph}$. I47, 478 ; as. El. 312, 697, 1223; Pn. $4 \mathrm{I}$; is. El. 485 ; dæge, El. I85; Ph. 644; Pn. 6r ; gp. daga, El. 358; dagana, El. 193. See ǣr-, blǣd-, fyrn-, gewin-, lif-, sīodæg; gēardagas.

dægred, n., dawn: as. Ph. 98. dægweorc, m., day's work: ds. dægweorce, El. 146.

dægweoroung, f., festival: gs. dægweorðunga, El. I234.

dæl, n., dale: np. dalu, Ph. 24.

dǣl, m., part, portion: ns. El. 1.232, 1298; as. Ph. 26I ; dp. dǣlum, El. І 306. See èast-, westdǣl.

dǣlan, Wı., divide: 3 sg, d̄̄leð, El. 1286; distribute, bestow: $3 \mathrm{sg}$. dǣleð, Ph. 453; Pn. 7I. See gedǣlan.

dafenlīc, see gedafenlīc.

dagas, see gēardagas.

dāl, see gedāl.

Dānūbie, pr. n., Danube: g. El. 37 ;

a. E1. 136 .

$\ddagger$ dareð̋lācende, mpl., lancers: $\mathrm{n}$.

Pn. 53; deareðlācende, El. 37;

g. daređlācendra, El. 65I.

daroð, m., spear: np. daroðas, El. 140.

Dāvid, pr. n., David: n. El. 342. dēad, adj., dead: nsn. El. 882 ; gpm. dēadra, El. 65I, 945. deal, adj., proud: nsm. Ph. 266. deareठ̀-, see dareð. dearninga, see undearninga. dēad, m., death: ns. El. 606; $\mathrm{Ph}$. 52, 485, 499; dēap, Ph. 88; gs. dēađes, El. 584 ; dēapes, Ph. 642 ; ds. dēað̌e, El. I87, 303, 780; $\mathrm{Ph}$. 583; dēape, El. 302, 500; $\mathrm{Ph}$. 434, 557; as. El. 477 ; Ph. 368 , 383 ; Pn. 62.

dēadcwalu, f., death-throe: ap. dēaðcwale, El. 766.

dēad̈dęnu, f., valley of death: as. dēaơdene, Ph. 4I6.

dēarræced, n., grave, hall of death: np. $\mathrm{Ph} .48$.

dēaorsęle, m., hall of death: as.

W. 30 .

dēaw, see meledēaw.

dēglian, see bidēglian; dēogol, digol, dȳgol.

dēgol, see digol.

delfan, III, dig: inf. El. 829. See bedelfan.

dēma, m., judge: gs. dēman, El. $746,1283$.

dēman, Wr., condemn: pret. $3 \mathrm{sg}$. dēmde, El. 500; inf. El. 303; judge: inf. El. 3II ; Ph. 494. See gedēman.

dęnu, f., glen: np. dene, Ph. 24. See dēaơdęnu.

dēoful, n., devil: gs. dēofles, El. III9; gp. dēofla, El. I8I, 302; W. 32 ; dp. dēoflum, W. 84. See hęlle dēofol.

dēofulgild, n., idolatry: dp. dēofulgildum, E1. I04I.

dēogol, adj., concealed: nsm. El. 1093. See dēglian, dígol, dȳgol. dēop, adj., deep: nsm. El. IIgo; gpf. dēopra, E1. 13I4; secret: asf. wk. dēopan, El. 584 . dēope, adv., deeply: El. I08I. 
dēophycgende, adj., thoughtful: nsm. El. 882; dēophycggende, El. 352.

dëoplice, adv., thoroughly: sup. dēoplīcost, El. 280.

dēor, n., beast: ns. Pn. 12, I9; gs. dēores, Pn. 25; np. Pn. 53; gp. dēora, Pn. 5. See hildedēor; wilder.

deorc, adj., black: nsm. wk. deorca, Ph. 499; nsf. wk. deorce, Ph. 98; asm. deorcne, $\mathrm{Ph} .383$.

dēore, adj., dear: nsf. wk. dēore, Ph. 560 ; sacred: sup. gsf. wk. dēorestan, El. I234. See dȳre. dēorlīee, adv., fitly: sup. dēorlicost, El. Ir 59 .

dēormōd, adj., brave, dauntless: nsm. Ph. 88.

dierne, see dyrne.

digol, n., concealment: ds. dēgle,

El. 339; grave: ds. digle, Pn. 62.

See dēglian, dēogol, dȳgol.

disig, see dysig.

dōgorgerīm, n., number of days,

time: ip. dōgorgerīmum, El. 780. dögorrìm, n., number of days, time:

gs. dōgorrīmes, $\mathrm{Ph} .485$; ip. dōgorrìmum, El. 705.

dohtor, f., daughter: dp. dohtrum, $\mathrm{Ph} .406$.

dōm, m., judgment: gs. dōmes, El.

I3I 4 ; Ph. 48 ; as. El. 1280; Ph.

524; glory: ns. Ph. 642 ; as. El.

365, 450; will: gp. dōma, El. 726; happiness: gs. dōmes, E1. 945. See cāser-, ealdor-, seonoð-, ठ̌̄ow-, wīs-, witedom. dōmgeorn, adj., eager for glory: npm. dōmgeorne, El. I29I.

dömlic, adj., glorious: ipf. dōmlīcum, Ph. 445, 452.

† dōmweoroung, f., honor: ap. dōmweorø̀unga, E1. I46.

dōn, anv., do: imp. sg. dō, El. 54r ; placé: inf. El. II75. See gedōn; gōddōnd. draca, m., dragon: gs. dracan, El. 766 ; ds. dracan, Pn. 16, 57. drǣdan, see ondrǣdan.

drēam, m., ioy: ns. El. 1232; gs. drēames, $\mathrm{Ph} .482$; as. $\mathrm{Ph} .658$; gp. drēama, Ph.658; Pn. 55; ap. drēamas, $\mathrm{Ph} .560$; harmony: gp. drēama, $\mathrm{Ph} .138$. See sindrēam. †ręnc, m., drowning: ns. El. 136 ;

is. drence, W. 30 .

drëogan, II, bear, suffer: $3 \mathrm{pl}$. drēogap, El. 766 ; pret. 3 sg. drēah, El. I26I ; inf. El. 2Ir, 952; fulfil: 3 sg. drēogeđ, $\mathrm{Ph} .210$.

See ādrēogan.

drēorig, see heorodrēorig. drēosan, II, fall: 3 sg. drēoseð, $\mathrm{Ph}$. 26r ; 3 pl. drēosad, Ph. 34 . drīfan, I, drive: 3 sg. drīfeð, El. 358. See Ourhdrïan. drohtao, m., abode: as. Ph. 4I6. drohtian, W2., dwell, live: 3 sg. drohtao, Ph. 88; ptc. npm. drohtiende, W. 32.

drūsan, Wr., droop: ptc. drūsende, Ph. 368 ; smoulder: ptc. drūsende, E1. 1258.

drȳge, adj., dry: asm. drȳgne, El. 693.

dryht, f., multitude: dp. dryhtum, Ph. 334; men: gp. dryhta, Pn. 25. See gedryht.

dryhten, m., lord: ns. El. 8r, r87, 365, 500, 717, 897, 1280; Ph. I38, 445, 454, 494; Pn. 55 ; gs. dryhtnes, El. 198, 280, 352, 49I, 948, 971, го1о, I160, I168, I206; Ph. 48, $383,452,499,557,583,597,600$; ds. dryhtne, E1. I93, 292, II 40 ; Ph. 658 ; W. 84 ; Pr. 14 ; as. El. $346,37 \mathrm{r}$; Ph. 478,560 ; vs. El. 726, 760; gp. dryhtna, El. 37r ; W. 84 .

dryhtlēoờ, n., national song: as. El. 342. -dryhto, see indryhto. 
dryhtscipe, m., power: ns. El. 45I. drȳman, WI., rejoice: ptc. gpm. drȳmendra, Ph. 348.

dryre, m., fall: ns. $\mathrm{Ph}$. I6.

düfan, II, thrust: pret. 3 pl. dufan, El. 122.

duguo, f., host, throng: ns. El. I29I; gp. duguð̃, El. 8I ; Ph. 348, 494; men: gp. dugữa, Pn. 57 ; dp. duguð̌um, El. 450, I093; dugoðum, El. II60; ap. duguðe, W. 33; provision: gp. duguða, El. 693; dugeba, Ph. 454; salvation: gs. dugưde, $\operatorname{Pr}$. I4; kindncss: gp. duguða, Pn. I6. dūn, f., hill: as. dūne, El. 717.

dūnscræf, n., ravine: np. dūnscrafu, $\mathrm{Ph} .24$; dp. dūnscrafum, $\mathrm{Pn}$. I2, 37.

duru, f., door: ns. El. I230; Ph. I2. See hlinduru.

dwāscan, Wr., blot out, extinguish: 3 sg. dw̄̄sceb, Ph. 456.

dwola, see gedwola.

dȳgol, adj., concealed: asf. dȳgle, El. 54I; Pn. 37. See dēglian, dēogol, digol.

dynnan, Wr., make a noise: pret.

3 sg. dynede, El. 50.

dȳre, adj., dear: npm. El. 292. See dēore.

dyrnan, Wr., keep secret: pret. 2 pl. dyrndun, El. 626; inf. El. 971. See bedyrnan.

dyrne, adj., hidden, secret: nsf. El. 723 ; nsn. El. I093; asf. W. 33; npm. dierne, El. I081.

dysig, n., folly: ds. dysige, El. 707. dysig, adj., foolish: npm. disige, El. 477.

dyslīc, adj., foolish: asf. dyslīce, El. 386.

E.

ac, adv., also: E1. 3, 742, 1007, 1278; Ph. 375. ēacnian, see geēacnian.

ēad, n., bliss, happiness: gs. èades, Ph. 398,638 ; as. Ph. 319.

ēadhrēöig, adj., blessed: nsf. wk. ēadhrēđige, El. 266.

ēadig, adj., blessed: nsm. El. 806; nsf. ēadige, El. 619; asf. ēadge, Ph. 473; asn. Ph. 279; npm. eadge, Ph. 62I, 677; gpm. èadigra, El. I290; Ph. 38r, 603; dpm. èadgum, Ph. II, 500; happy: nsm. wk. ēadga, Ph. 36r ; righteous (?): nsm. Ph. 482; npm. wk. èadgan, Ph. 526; unscathed: nsm. Ph. 20, 46. See hrēờ-, tīrēadig.

ēadwela, m., blessedness: gs. ëadwelan, El. I316; riches: ns. $\mathrm{Ph}$. 25I ; dp. èadwelum, Ph. 586.

eafera, m., child, son: ds. eaferan, E1. 439 ; dp. eaferum, Ph. 405; ap. eaforan, El. 353.

ēage, n., eye: gp. ēagena, El. 298; ip. èagum, W. I2.

èaggebyrd, f., eye: ns. Ph. 301 .

eald, adj., old: nsm. ald, E1. 1266; nsm. wk. ealda, El. 207 ; Pn. 58 ; dsm. ealdum, El. 455; $\mathrm{Ph} .238$; asm. ealdne, El. 905; apn. ald, El. 252 ; comp. nsm. yldra, El. I59, 436, 462; ancient: gsi. ealdre, $\mathrm{Ph} .376$; asm. ealdne, Ph. 32I.

ealdcÿðठu, f., old home, former abode: as. ealdcȳðbe, Ph. 35I; ealdcỹðbu, $\mathrm{Ph} .435$.

ealdfēond, m., old enemy, devil: gs. ealdfēondes, Ph. 40I ; gp. ealdfëonda, Ph. 449; dp. ealdfēondum, E1. 493.

† ealdgewin, n., ancient battle: ns. El. 647 . ealdian, see geealdian.

ealdor, m., life: ds. ealdre, $\mathrm{Ph} .40$, $83,562,594$; aldre, El. 349, 57 I, 
I2I8; as. Ph. 487 ; ap. aldor, El.

132. Tó ealdre, for ever.

ealdor, m., prince, king: ns. aldor, El. 97,157 ; Pr. 4.

ealdordōm, m., sovereignty, dominion: ds. aldordōme, El. 768 ; as. $\mathrm{Ph} .158$.

eall, adj., all, the whole of: nsm. El. II55; Ph. 7 ; nsf. El. I277; nsn. El. 753, Ph. 279 (or adv.); gsf. ealre, El. 772 ; eallre, El. 446 ; gsn. ealles, El. 486, 512, 1236; asm. ealne, El. 73I; Ph. 42, 67; Pn. 68; asf. ealle, El. 293, 729; Ph. 77; Pn. 17 (in ealle tìd, always), 65; asn. E1. I197; npm. ealle, El. II 8 ; $\mathrm{Ph}$. 495; gpm. ealra, El. I87; Ph. 177, 628; Pn. 73; allra, El. 816; eallra, E1. 370, 475, 483, 519, 649; gpf. eallra, E1. 422, 894, 1285; gpn. ealra, El. 769; alra, El. 645; dpm. eallum, El. 1220; Ph. I32; dpf. eallum, Pn. 48, 56; dpn. eallum, El. I088, I10I; apm. ealle, E1. 385 ; apf. ealle, $\mathrm{Ph}$. 576 ; apn. (asn. ?) eal (or adv.) 285,5 I I.

eall, adv., wholly, entirely: eal, El. 856; Ph. 24I, 285 (or adj.), 505, 5 II (or adj.) ; eall, El. II3I, I293, I3II; Ph.'279 (or adj.).

ealles, adv., altogether, wholly: $\mathrm{Ph}$. $58 \mathrm{r}$.

eallinga, adv., by all means: W. 82 . ēalọnd, m., island, isle: ds. ēalonde,

Ph. 287; W. 21 ; as. W. 12.

$S e \mathcal{e}$ ëglond, iglond.

earc, f., arc: ds. earce, El. 399.

eard, m., home, dwelling: gs. eardes,

Ph. 36I ; ds. earde, Ph. 346, 354 ;

as. E1. 599,$622 ; \mathrm{Ph} .87,158$, 264, 275, 321, 427; Pn. II.

earding, f., abode: ap. eardinga, $\mathrm{Ph}$. 673. eardstęde, m., dwelling-place: ds. $\mathrm{Ph} .195$.

eardwic, n., dwelling: as. Ph. 43I ; gp. eardwīca, Pr. I5.

earfeðe, n., distress, hardship, torture: dp. earfeðum, El. 700 , 1292.

earhfaru, f., arrow-flight: as. earhfære, E1. 44, I 6.

earhgeblond, n., sea: as. El. 239.

earm, m., arm: is. earme, E1. I236. earm, adj., wretched, poor: npm. earme, $\mathrm{Ph} .442$; dpm. earmum, Ph. 453.

earn, m., eagle: ns. El. 29, III ; gs. earnes, $\mathrm{Ph} .235$; ds. earne, $\mathrm{Ph}$. 238.

earnian, W2., earn, win, deserve (w. gen.) : 3 sg. earnað, Ph. 484 ; inf. Pr. 13. See geearnian.

èastan, adv., from the east: Ph. 94, I02, 290, 325.

ēastdǣl, m., eastern part: dp. ēastdælum, Ph. 2.

ēastweg, m., eastern road, eastern way: dp. eastwegum, Ph. II3; ap. ēastwegas, El. 255, 996.

ēaðe, adv., easily: El. 1292; super. ȳpast, Ph. II3. See ëde.

èaðmēde, adj., benignant: nsm. Pn. 56.

ēaðmēdu, f., reverence: dp. ēaðmēdum, El. I088, I гог.

eatol, adj., dreadful: nsm. El. 902. ēawan, see ge-, odēawan; æt-, geờywan.

eaxlgestealla, m., trusted compan ion: gp. eaxlgestealna, El. 64.

Ebrēas, pr. n., Hebrews: g. Ebrēa E1. 287,448 .

Ebreisc, pr. n., the Hebrew tongue a. Ebrisc, El. 725 .

Ebreisc, adj., Hebrew: asf Ebreisce, El. 397 ; apm. Ebresce E1. 559.

èce, adj., eternal, everlasting: nsm 
El. 800, 1042; Ph. 319, 473, 608; nsf. (nsm. ?) Ph. 636; nsn. El. 526; gsm. èces, E1. 746, I316; Ph. 398, 4I I, 600; gsm. wk. ècan, Ph. 482; asn. Ph. 38I, 572; gpn. ēcra, El. 802.

ēce, adv., for ever: E1. I218, I23I ; Ph. 594.

ęcg, see heardęcg.

edgeong, adj., become young again, rejuvenated: nsm. $\mathrm{Ph} .435,536$, 608 ; edgiong, $\mathrm{Ph} .58 \mathrm{I}$.

edniowunga, see edniwunga.

edniwe, adj., renewed, restored: nsm. Ph. 287; nsf. Ph. 24I; nsn. Pn. 223 (m. ?); asn. Ph. 370, 558 ; isn. Ph. 77, 258 (or adv.). edniwe, adv., again, anew: Ph. 258 (or adj.).

edniwinga, adv., anew, once more:

Ph. 534; edniowunga, El. 300. ēdre, adv., immediately: E1. 649, 1002.

edwęnden, f., change: ns. Ph. 40. efenhlēoðor, m., concord of voices: is. efenhlēopre, $\mathrm{Ph}$. 62I.

ęfnan, Wi., do, carry out: pret. 3 pl. efnedon, El. 7r3. See geęfnan.

ęft, adv., again: El. 255, 350, 382, 516, 903, 924, I000, I275; Ph. 24I, $25 \mathrm{I}, 256,264,275,366,373,379$, 533, 645, 648; once more: $\mathrm{Ph}$. 423, 433; once: $\mathrm{Ph} .224$; afterwards: El. 500, 5I4, II55; Ph. 231, 272, 354; back: E1. I43, I48, 1220 ; in due season: $\mathrm{Ph} .222$, $277,35 \mathrm{I}, 376$.

६gesa, m., fear, terror: ds. egsan, Ph. 46I ; is. egesan, El. 82, $32 \mathrm{I}$, II29; egsan, El. 57. See hildęgesa.

:geslic, adj., dreadful, terrible: nsm. Ph. 522.

glond, n., island: as. W. I6. See ealọnd, iglọnd. ēgstrēam, m., river: ds. ēgstrēame, El. 66; sea: ds. ègstrēame, El. $24 \mathrm{I}$.

èhtan, WI., pursue: pret. 3 pl. ēhton, El. I39; persecute: $3 \mathrm{sg}$. ēhteð, El. 928.

elde, see alde.

èled, m., fire: gs. èldes, El. I294.

Elene, pr. n., Helen: n. El. 219, 266, 332, 404, 573, 604, 620, 642, 685,953 , I05I, II 88, I218; g. Elenan, El. 848, 1063; a. Elenan, El. 1003 .

ellen, n., strength, courage, zeal:

gs. elnes, El. 725, 829; ds. elne, Ph. 484.

ęllenrōf, adj., vigorous: nsm. Pn. 40.

ęlð̄èd, f., enemy: ap. elbēoda, El. I 39.

ęlð̄ēodig, adj., hostile: nsm. elbēodig, El. 908; npm. elpēodige, El. $57,82$.

ęnde, m., end: ns. $\mathrm{Ph} .365,484$;

ds. El. 59, I37, 802, 8I I, 894, 953 ;

Ph. 637, 65I; as. El. 590; Ph.

562 ; shore: ds. W. 15.

ęndelif, n., end of life: gs. ende-

līfes, El. 585.

ęndian, W2., end, bring to an end:

opt. 3 sg. endige, Ph. 83 . See geęndian.

ęnge, adj., narrow: dsm. wk. engan, E1. 921 ; dsn. wk. engan, El. 712 ; asf. El. 1262; cruel: nsm. wk. enga, $\mathrm{Ph} .52$.

ęngel, m., angel: gp. engla, E1. 79, $476,487,773,777,784,858$, I IоI, I23I, I28I, I307, I316; Ph. 492, 497, 568, 6ro; Pn. 63; dp. englum, E1. 622, I320; Ph. 621, 629, 677. See hëahęngel.

ęngelcynn, n., race of angels: ds. engelcynne, El. 733.

ēode, see gān. 
$\ddagger$ eoforcumbul, n., boar-helmet: ns.

El. 259; ds. eofurcumble, El. 76. eofot, n., sin: gp. eofota, El. 423. $\ddagger$ eofulsæc, n., blasphemy: as. El. 524.

eorcnanstān, m., precious stone: dp. eorcnanstānum, El. 1025; ip. eorcnanstānum, $\mathrm{Ph} .603$.

ēoredciest, f., crowd, company; troop of cavalry: dp. eoredcestum, E1. 36; ēoredciestum, $\mathrm{Ph}$. 325 ; ip. ẽoredcystum, Pn. 52. eorl, m., man, warrior: ns. $\mathrm{Ph} .482$; ds. eorle, El. 256, 787 ; np. eorlas, E1. 66, 275, 321, 848; gp. eorla, El. 225, 435, 1074; Ph. 25I ; dp. eorlum, El. I2, 332, 404, 417, 620, I198; ap. eorlas, W. 49. eorlmægen, n., multitude of men: as. El. 981 .

eorre, sec yrre.

eorocyning, m., king of earth: gp. eorodcyninga, El. II74.

eorठe, f., earth: ns. El. 753; gs. eorðan, Ph. 243, 506; eorpan, Ph. $43,207,349,487$; Pn. 48,68 ; ds. eorðan, El. 591, 622, 878, I ro9, 1226 ; Ph. 629; eorban, Ph. 136, 460,638 ; as. eorðan, E1. 728, 829, 836; Ph. I54; eorban, Ph. I3I, 249, 33I.

eorðweg, m., earth: ds. eorðwege, El. I015; $\mathrm{Ph}$. I78; dp. eorowegum, El. 736 .

ēower, pron., your: asf. ēowre, El. 315; gsn. ēowres, El. 305 ; asn.

E1. 375,579 .

ermðu, see yrmðu.

Essāias, pr. n., Isaiah: n. El. 350.

ēst, f., grace: as. El. 986; Ph. 46; will: as. $\mathrm{Ph} .403$.

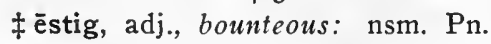
I6.

et, conj. (Lat.), and: Ph. 672, 674 . ède, adj., easy, agreeable: super. nsn. ëðost, El. I294. Sce ēað̌e. ēđel, m., home: gs. ēðles, Ph. 4II ; ds. èđle, El. 1220; Ph. 392; as. èbel, $\mathrm{Ph} .158$; native country: as. ëpel, Ph. 349, 427 ; domain: gs. èđles, Pn. Ir.

ëdellọnd, n., fatherland: as. èbellond, $\mathrm{Ph} .279$.

èdelturf, f., country: ds. èbeltyrf, Ph. 32r.

ëơgesȳne, adj., conspicuous, easily seen: nsf. E1. 256.

èdigean, Wr., rise, show oneself: inf. El. r107.

-ettan, see onettan.

Eusēbius, pr. n., Eusebius: a. Eusēbium, E1. 105 I.

F.

fācen, n., evil, guile: gs. fācnes, $\mathrm{Ph}$. 450; W. 24 ; is. fācne, Ph. 595.

fæc, n., interval, while: ds. fæce, E1. 960 ; as. E1. 272,383 ; Pn. 38.

fǣcne, adj., crafty, guileful: nsm. wk. fǣena, W. 7I ; asm. (asn.) Ph. 415 ; isn. El. 577.

fæder, m., father: ns. El. 343,436 , 463, 517, 528, 1084; Ph. 197, 375, 455, 492, 630; Pn. 72; gs. Ph. 95, 390, 646; ds. fædere, El. 438, 454 ; fæder, Ph. 610; as. El. 89r ; vs. E1. I84, I106, II5I; Ph. 627 ; np. fæderas, El. 398, 425, 458; gp. fædera, E1. 388.

fæderlic, adj., paternal: asf. wk. fæderlican, El. 431.

fǣge, adj., doomed to die: gsm. fǣges, Ph. 22I ; asn. wk. El. II7, 88I, I 237.

fægen, adj., glad: nsm. Pn. 35. Set wilfægen.

fæ̈ger, adj., fair, beautiful, winning. nsm. El. 911; Ph. 85, 232, $29 \mathrm{r}$ nsmn. El. 891 ; nsf. Ph. I25, 307 nsn. Ph. 182, 236, 360, 510; gsf 
fǣgre, Ph. 352; asm. wk. fǣgran, El. 949 ; asf. fǣgre, Ph. 328 ; wk. fæ̈geran, El. 98; ipm. fǣgrum, Ph. 64 (ipf. ?), 654; ipf. fæ̈grum, Ph. 6ro; comp. nsm. fǣgerra, Pn. 29; asn. fǣgerre, El. 242; apf. fǣgerran, Ph. 330; sweet: super. ipm. fǣgrestum, Ph. 8; delightful: nsn. Pr. 3.

fāgre, adv., beautifully, splendidly, richly: El. 743; Ph. 274, 295; 585; admirably: fägere, E1. 1213; gloriously: Ph. 627.

fǣle, adj., lovely: nsm. E1. 88. fær, n., war: ds. fære, El. 93. See gefær.

fāran, see āfēran.

fāringa, adv., suddenly: Ph. 53I; W. 44,60 .

fæst, adj., fast, firm, secure: nsm. E1. 771, 1037; nsf. E1. 723; nsn. E1. 883; asm. fæstne, E1. 909; Ph. 172; npm. fæste, El. 570; W. I8; apm. fæste, El. 252; proof: nsm. $\mathrm{Ph}$. 468. See ār-, gryre-, -met-, sigor-, sōo-, tìr-, wis-, wlitig-, wuldorfast.

fæstan, see be-, odfæstan.

fæste, adv., fast, firmly: El. 933, 937, 1208; Ph. 419, 569; W. 25, 4I, 77; permanently: W. 36.

fæsten, n., fastness: ds. fæstenne, W. 7I; as. El. I34. See lagufæsten.

fæstlice, adv., fast, firmly: El. 427; comp. fæstlicor, E1. 797.

-fæstnes, see soðfæstnes.

fæstnian, see gefæstnian.

fat, n., casket: as. E1. I026. See bān-, goldfæet.

¡ðठ m, expanse: as. El. 729; embrace: ds. fæờme, El. 766 , 88I ; lap, bosom: as. Ph. 487, 556. fæòmian, WI., encircle, surround: 3 pl. fæð mað, El. 972.

fæömrīm, n., cubit: gs. fæð̀mrīmes, $\mathrm{Ph}$. 29.

fāh, adj., spotted: nsm. El. I243; variegated: nsm. fằg, $\mathrm{Ph} .292$. fāh, adj., hostile: nsm. Ph. 595; W. 66 ; abhorred: nsm. El. 769, 925.

fămig, adj., foamy: apm. fămige, E1. 237.

faran, VI, journey, go: $3 \mathrm{sg}$. færed, El. 1274; 3 pl. farad, Ph. 326; fly: 3 sg. fare $\nsim, \mathrm{Ph} .123 ; 3 \mathrm{pl}$. farad, El. 734; Pn. 5I, 54; W. 58 ; advance: pret. 3 sg. för, El. $27,35,5$ I ; 3 pl. fōron, El. 2I, 26 I. See ge-, geondfaran. faraठ̀-, fareठ-, see faroð-. faroð, see sāfearoò.

faroðhęngest, m., ship: np. fearoðhengestas, E1. 226.

faroðlācende, adj., sea-faring: npm.

W. 20; dpm. fareð̋lācendum,

W. 5 ; swimming in the sea: npm. farađ̆lācende, W. 80.

faru, see earh-, ÿðfaru.

$\ddagger$ Fastitocalon, pr. n., asp-turtle: ns. W. 7 .

fēa, adj., fez: npm. El. 174; dpm. fēam, El. 818.

-fēa, see gefēa.

feala, indec. n., much, many: El. $362,636,778,912,945,987$, 1044; fela, Ph. 387,580 .

-feald, see manigfeald.

-fēalìc, see gefēalìc.

feallan, rd., fall: 3 sg. fealleb, $\mathrm{Ph}$. 6r; 3 pl. feallad, $\mathrm{Ph} .74$; pret. 3 pl. fēollon, El. 127, I134. See gefeallan.

fealu, adj., yellow: nsm. fealo, $\mathrm{Ph}$. 2I8; tawny: npm. fealwe, Ph. 3II ; gay: npm. fealwe, Ph. 74. -fearoot-, see -faroot-.

fēdan, see āfēdan. 
fēgan, see gefēgan.

fel, see wælfel.

fela, see feala.

fēlan, see gefēlan.

feld, m., field: ns. Ph. 26. See hęrefeld.

fęng, m., grasp, grip: ds. fenge, W. $8 \mathrm{I}$; as. E1. 1287 ; Ph. 215.

Fenix, m., Phanix: ns. Ph. 86, 218, $340,558,597,646$; as. Ph. I74.

fēogan, W3., hate: 3 pl. fēogað, El. 360 ; pret. 3 pl. fēodon, El. 356 ; inf. Pr. 13.

feohgestrēon, n., riches: gp. feohgestrēona, El. gir.

feoht, see gefeoht.

fēolan, see befēolan.

fēon, see gefēon.

fēond, m., enemy, fiend, devil: ns.

E1. 207, 900, 954; Ph. 595; Pn. 58; W. 39; gs. fēondes, El. 72I-2; Ph. 4I9; gp. fēonda, El. 68, 108, 1179; dp. fēondum, W. 36 ; ap. El. 93. See ealdfēond.

fēondscipe, m., enmity: as. El. 356, 498.

feor, adv., far: Ph. 1, 192, 4I5; deep: El. 83I ; in the far past: El. II42; comp. fyr, El. 646.

feorgbona, m., destroyer of life: ns. W. $4 \mathrm{I}$.

feorh, n., life: ns. Ph. 223, 266, 280;

gs. feores, El. 680; ds. feore, El. 498 ; as. Ph. 192, 263, 371, 433, 558; ap. feore, El. 134; time: ds. feore, El. I288; tō wīdan feore, for ever: El. 2II, I32I ; W. 89.

feorhcwalu, f., death: ds. feorhcwale, W. 77.

feorhhord, n., soul, spirit: ns. Ph. 221.

feorhlęgu, f., murder: ds. feorhlege, E1. 458.

feorhnęru, f., salvation: ds. feorhnere, El. 898; Pn. 72. ¥feorlond, m., distant land: $\mathrm{dp}$. feorlondum, Pn. Io.

feormian, W2., consume: 3 sg. feormað, Ph. 218.

feorran, adv., from afar: E1. 993, I213; Ph. 326.

fēower, adj., four: El. 744.

-fēra, see gefēra.

fēran, Wr., go: inf. El. 215. See gefēran.

-fēre, see gefēre.

fërend, m., sailor: np. W. 25.

ferho, m. n., mind, soul, heart: ns. El. 174, 991 ; ds. ferhpe, Ph. 504; ferhðe, El. 1037, I.164; fyrhðe, El. $196,463,570,641$; as. El. 427 , 797,801 (see wīdan ferh $\%$ ); Ph. 4I5; fyrhð, El. 76I (see widan ferhð). See collen-, stærced-, wērigferhð.

ferhờgereaht, n., wise guidance of the soul: as. W. 70 .

ferhöglēaw, adj., wise : nsm. fyrhðglēaw, El. 88I ; gpm. ferhðglēawra, El. 327.

ferhögrim, adj., cruel-hearted: nsm. W. 5 .

ferhðsefa, m., mind, heart: ds, ferhðsefan, El. 316, 850, 895: firhðsefan, El. 213; fyrhðsefan El. 98, 1079; as. fyrhðsefan, El 534.

ferhठ̋wērig, adj., sad: apm. fyrhð̋. wērige, El. 560.

fęrian, WI., carry: inf. El. I08.

fēora, m., band of foot-soldiers: ap fēòn, El. 35.

fēòtegęst, m., stranger: np. fēđe gestas, El. 845 .

feöer, f., feather: ip. feðrum, $\mathrm{Ph}$ 306; februm, $\mathrm{Ph}$. 380; wing pinion: np. feðre, $\mathrm{Ph}$. I37; af fepre, $\mathrm{Ph}$. I45; ip. feprum, $\mathrm{Pl}$ 86, 100, 123, 163, 347; plumage ap. fepre, Ph. 205; ip. feprun $\mathrm{Ph} .239,266$. See also fiore. 
-feðtere, sce haswig-, ūrigfeðere.

feðerhoma, m., plumage: ns. feperhoma, Ph. 280.

fętian, see gefętian.

fetrian, see gefetrian.

-fic, see gefic.

fif, indecl. adj., five: El. 379.

fiffelwǣg, m., sea: as. El. 237.

findan, III, find: 2 sg. findest, El.

84 ; 3 pl. findap, E1. 1032 ; pret.

I sg. fand, El. I255; 3 sg. fand,

E1. 202; 3 pl. fundon, El. 327,

379, I217; opt. pret. 2 sg. funde,

E1. I080; 3 sg. funde, El. 831 ; imp. pl. findap, E1. 373; inf. El. $632,64 \mathrm{I}, 925$; pp. funden, El. $974,987$.

finger, $\mathrm{m}$., finger: gp. fingra, El. I20.

finire, vb. (Lat.), end: $3 \mathrm{sg}$. finit, E1. 1236; Pr. 16.

finis, m. f. (Lat.), end: abl. s. fine, $\mathrm{Ph} .675$.

finta, m., tail: ns. Ph. 295.

firas, mpl., men, human beings: $\mathrm{g}$. fīra, El. 898, 1078, 1173; Ph. 396, 535; W. 39; fȳra, Ph. 492 ; d. fírum, Ph. 3 ; Pn. Io.

firen, f., $\sin$ : as. firene, $\operatorname{Pr}$. I 3 ; gp. firena, El. I314; ip. firenum, W. 44 ; pain, pang: dp. firenum, El. so9. See hęllfiren.

firgenstrēam, m., ocean: as. $\mathrm{Ph}$. 100.

firh丈-, see ferhð-.

fisc, m., fish: np. fiscas, W. 80 ; gp. fisca, W. I. See sǣfisc.

fit, f., song, poem: is. fitte, W. I.

fiöre, n., wing: np. fipru, $\mathrm{Ph} .297$; dp. fïrum, El. 743; ap. fipru, Ph. 652; ip. fiprum, Ph. 316. See also feðer, -feðere.

Hēsc, n., flesh: as. $\mathrm{Ph} .22 \mathrm{I}$; is. flēsce, Ph. 259, 535.

Gāh, adj., crafty: nsm. W. 39 . Iān, m. f., arrow: gp. flāna, El. II7. flēogan, II, fly: 3 sg. flēogè, $\mathrm{Ph}$. 322 ; pret. 3 pl. flugon, E1. I40; inf. Ph. I63. Sec oðflēogan.

flēon, II, flee: 3 sg. flỳh\%, $\mathrm{Ph} .460$; pret. 3 pl. flugon, El. 127, I34. Sce àfēon.

fliht, sce flyht.

-flit, see geflit.

-fita, see geflita.

flōd, m., current: np. flōdas, El. 1270. See lagu-, męrefiōd.

flödweg, m., ocean-road: is. flōdwege, El. 215.

flōdwylm, m. f., flood: ip. flōdwylmum, Ph. 64 .

flot, n., voyage: ds. flote, El. 226.

flota, see ge-, wǣgflota.

flyht, m., flight: ds. flihte, El. 744; is. flyhte, Ph. I23, 340.

flyhthwæt, adj., strong in fight, swift-flying: $\mathrm{gsm}$. flyhthwates, Ph. 335 ; apf. flyhthwate, Ph. 145. fnǣst, m., breath: ns. Ph. 15 .

fōddor, n., food, fodder: as. Ph. 259; Pn. 35 ; fōdder, El. 360.

fōdoröęgu, $\mathrm{f} .$, sustenance: $\mathrm{gs.}$ fōdorpege, $\mathrm{Ph} .248$.

fōg, see gefōg.

folc, n., folk, people, crowd: ns. El. 362,872 ; gs. folces, E1. I 57,499 , I095; ds. folce, El. 415, 895, 989, 1056; as. E1. I17, 1287; is. folce, El. 89I ; gp. folca, El. 27, 215, 502; Pn. 51; Ph. 326; dp. folcum, El. II 43 ; Ph. 322.

folcāgend, m., ruler of a nation: gp. folcāgendra, $\mathrm{Ph} .5$.

folcscearu, f., nation: ds. folcscere, E1. 402 ; folcsceare, El. 968.

foldbūend, m., inhabitant: np. foldbūende, El. ror4.

folde, f., earth: gs. foldan, $\mathrm{Ph} .3$, 8, 257, 396; ds. foldan, El. 721-2, 974, 987, 1080; $\mathrm{Ph} .60,174$; as. foldan, $\mathrm{Ph} .74, \mathrm{I} 97$; land: ns. Ph. 29; as. foldan, Ph. 352; 
region: as. foldan, $\mathrm{Ph} . \mathrm{I} 55$; soil: as. foldan, Ph. 64; mold: is. foldan, $\mathrm{Ph} .490$.

foldgræf, n., grave: ds. foldgræfe, E1. 845 .

$\ddagger$ foldhrērende, adj., walking on the earth: gpn. foldhrērendra, Pn. 5.

foldwæstm, m., fruit of the earth: ip. foldwæstmum, $\mathrm{Ph} .654$.

foldweg, m., way, road: ip. foldwegum, Pn. 5r.

folgad, m., following: as. folgab, E1. 904 .

folgian, W2., follow: 3 pl. folgiad, Ph. 59I; be subject to: $3 \mathrm{sg}$. folgab, E1. 930.

folm, f., hand: ap. folme, E1. I066; dp. folmum, E1. 1076.

fōn, see be-, ge-, on-, ymbfōn.

for, prep. w. dat., before, in the presence of: E1. I10, I24, I70, I75, I $80,332,351,362,404,406$, $417,587,596,620,688,782,867$, I 198 , I273; on account of, because of: E1. $63,49 \mathrm{I}, 496,52 \mathrm{I}$, 564, 657, 677, 703, I134; Ph. 46г ; in: E1. 4, 979; on: El. 59I ; in regard to: $\mathrm{El}$. $\mathrm{I} 065$; $\mathrm{w}$. acc., instead of: E1. 3I8; before: El. 546; for, as: Ph. 344.

foran, adv., before, in front: $\mathrm{El}$. II84; Ph. 292. See beforan.

forbēodan, II, forbid: ' pp. apn. forbodene, Ph. 404.

forberstan, III, fail, be wanting:

3 sg. forbirsted, Ph. 568.

fore, adv., aforetime: El. 1262.

fore, prep., w. dat., before: El. 577, 637, 746, 848; Ph. 600; for: Pn. 62 ; of: Pn. 34 ; w. acc., before: Ph. 5I4.

foregęnga, m., forefather: np. foregęngan, Ph. 437.

foremihtig, adj., eminent in power, prepotent: nsm. Ph. I59. forescēawian, W2., foresee: pret. I sg. forescēawode, El. 345.

foredanc, m., forethought: ap. forebancas, El. 356 .

forgifan, V, give, grant, bestow: $3 \mathrm{sg}$. forgifeð, $\mathrm{Ph}$. 6r5; pret. I sg. forgeaf, El. 354 ; pret. $3 \mathrm{sg}$. forgeaf, El. 144, 164, 1218; $\mathrm{Ph}$. 377 ; pp. forgiefen, $\mathrm{Ph} . \mathrm{I75}$.

forgildan, see forgyldan.

forgrindan, III, demolish, destroy: pp. forgrunden, $\mathrm{Ph} .227$.

forgripan, I, seize: $3 \mathrm{sg}$., forgripeð, Ph. 507.

forgyldan, Wr., recompense, requite: inf. forgildan, $\mathrm{Ph} .473$.

forht, adj., fearful: nsm. Ph. 504, 525.

forhycgan, W3., scorn, despise: I sg. forhycge, Ph. $55^{2}$.

forlāran, WI., seduce: pret. $3 \mathrm{sg}$. forlǣrde, El. 208.

forlǣtan, rd., let, allow: pret. $3 \mathrm{sg}$. forlēt, El. 598 ; opt. 2 pl. forlǣten, E1. 700 ; pret. 3 sg. forlēte, E1. 712; imp. sg. forlæ̈, E1. 793 ; abandon: $3 \mathrm{sg}$. forlæ̈teð, El. 929 ; opt. 2 sg. forlæte, El. 689 ; pret. I pl. forlēten, El. 432. See ānforlætan.

forniman, IV, snatch away, destroy: 3 sg. fornimeð, El. 578; pret. 3 sg. fornam, El. I3I, 136; fornōm, Ph. 268.

forsēcan, WI., visit: pp. forsōht, E1. 933.

forsēon, V, abhor, scorn: pret. 2 pl. forsēgon, El. 389; 3 pl. forsāwon, E1. 1318.

forst, m., frost: ns. Ph. 58, 248; gs. forstes, $\mathrm{Ph} .15$.

forswēlan, Wi., burn, shrivel: $3 \mathrm{sg}$. forswēleđ, Ph. 532.

ford, adv., forth: E1. 120, I39, 318, 590, 636, 784, 1062, I 105, 1 268; forward: Ph. 455; thenceforth: 
E1. 213; Ph. 579; always: El. I92; Ph. 637.

forठan, conj., therefore, hence, wherefore: El. 309 (adv.?), 517, 522, I319; forpon, Ph. 368, 4II ; W. 82.

forठ̀gewitan, I, depart, pass away: pp. gpm. forögewitenra, E1. 636. forðryccan, WI., crush, oppress: pp. forprycced, El. I277.

forðsnottor, adj., very wise: asm. forösnotterne, E1. I053, I I6I ; gpm. forbsnotterra, El. 379.

forठ̋weard, adj., abiding, lasting: asm. forठweardne, Ph. 569.

fordylman, Wr., envelop, wrap: pret. 3 sg. forbylmde, Ph. 284; pp. forbylmed, El. 767 .

¥ fortyhtan, Wr., lead astray: pret. $3 \mathrm{sg}$. fortyhte, El. 208.

forweard, adj., in front, forward: nsm. $\mathrm{Ph} .29 \mathrm{I}$.

forwyrd, f., destruction: as. El. 765 . fōt, m., foot: np. fōtas, Ph. 3II; dp. fōtum, Ph. 578; ap. fēt, El. I066; ip. fôtum, Ph. 276.

fōtmǣl, n., foot-measure, foot: $\mathrm{dp}$. fōtmǣlum, El. 831.

-frǣge, sec gefrǣge.

frætwe, fpl. adornments: n. El. I27I ; Ph. 73, 257; g. frætwa, Ph. I50; d. frætwum, El. 88; Pn. 29,48 ; a. Ph. 508 ; i. frætwum, Ph. 610; attraction, perfection: a. Ph. 330, 335; i. frætwum (exquisitely), Ph. 309; splendor: i. frætwum (splendidly), Ph. 95 ; treasure: a. Ph. 200. frætw(i)an, W2., embellish, deck, adorn: inf. frætwan, El. II99; pp. gefrætwad, Ph. II6, 239; gefrætwed, Ph. 274; garnish: pp. gefrætwed, $\mathrm{Ph}$. 585. See gefrætwian.

iram, prep., from, out of: w. dat., E1. I40, I90, 296, 299, 30I, 4II,
701, 7I2, II20, II42, I309; from, E1. 590 ; Ph. 353, 524.

Francan, pr. n., Franks: n. E1. 2I. frèa, m., lord: ns. El. 488, I068;

gs. frēan, $\mathrm{Ph} .578$; as. frēan, El. 1307 ; Ph. 675 ; vs. El. 680. See mānfrēa.

$\ddagger$ frēamǣre, adj., well known: asm. frēamǣrne, Pn. Io.

-freca, see gūofreca.

frēcen, n., danger: gs. frēcnes, W. 20.

frēcne, adj., terrible, dangerous, perilous: nsm. W. 5; dsn. wk. frēcnan, El. 93; asf. wk. frëcnan, Ph. $390,450$.

frēfrend, m., comforter: ns. Ph. 422.

-frēge, see gefrēge.

fręmman, WI., accomplish, do, pcrform: 3 pl. fremmad, $\mathrm{Ph} .470$; W. 44 ; pret. 3 pl. fremedon, El. 646; offer: pret. I sg. fremede, E1. 472 ; 3 pl. fremedon, E1. 569; utter: opt. 2 sg. fremme, El. 524; promo:e: pret. 3 pl. fremedon, W. 70. See gefręmman; heaסัo-, mān-, rihtfręmmende.

frēobearn, n., noble child: ns. El. 672.

frēond, m., friend: ns. El. 954; Pn. I5; ap. frȳnd, El. 360.

frēondlēas, adj., friendless: nsm. E1. 925.

frēondrǣen, f., friendship: as. frēondrǣdenne, El. I208.

frēotrēo, n., noble tree: as. El. 534. freoðian, W2., protect: pret. $3 \mathrm{sg}$. freoðode, E1. II47. See gefreodian.

freodu, f., peace: ds. freobu, $\mathrm{Ph}$. 597. See also friò.

fricca, m., herald: np. friccan, El. 54,550 .

fricgan, V, ask, inquire: inf. fricggan, El. I57, 560; ptc. gpm. 
fricgendra, E1. 99I. See gefricgan.

-frige, see gefrige.

frignan, III, ask, inquire: $2 \mathrm{sg}$. frignest, El. 589; 3 sg. frigneb, El. 534 ; inf. El. $443,570,850$, I068, I 64 ; pp. frugnen, El. 542. See gefrignan.

frīgu, f., love: as. frīge, El. 34I. frið, m. n., deliverance, rescue: gs. fribes, Pr. I3; as. El. II84. See also freoou.

friòelēas, adj., savage, barbarous: npm. friðelēase, El. I27.

friơowęba, m., peace-weaver, angel: ns. El. 88.

frōd, adj., old: nsm. El. I237; Ph.

I54, 219, 426; npn. E1. 431 ; wise, experienced: nsm. El. 343, 438, 463,531 ; Ph. 570; asm. frōdne, El. II64; vsm. El. 542; apm. frōde, El. 443; gpm. frōdra, El. 637 ; masterly: asn. Ph. 84.

frōfor, f., consolation, joy, support: gs. frōfre, El. I037, I I06; ds. fröfre, El. 502, II 43 ; W. 36; gp. frōfra, El. I96, 993. See hygefrōfor.

from, prep., see fram.

from, adj., bold: npm. frome, El. 261 .

fromlice, adv., boldly: E1. 454; speedily: $\mathrm{Ph}$. 37I.

fruma, m., beginning: gs. fruman, El. II42; ds. fruman, $\mathrm{Ph} .328$; author, creator: ns. El. 772 ; as. fruman, E1. 839; vs. E1. 793; prince, lord: ns. Ph. 377 ; as. fruman, El. 210. See hild-, lēod-, lif-, ordfruma.

frymo, f., beginning: ns. $\mathrm{Ph} .637$; ds. frymðe, $\mathrm{Ph} .239$; frymbe, $\mathrm{Ph}$. 84,280 ; creature, creation: gp. frymða, El. 502; Ph. I97; frymba, El. 345; Ph. 630.

fugel, m., bird: ns. Ph. 86, 100, 104,
I2I, 20I, 2I 5, 257, 266, 29I, 3II, $322,466,529,558,574,578,597$, 652 ; fugol, $\mathrm{Ph} .145$; gs. fugles, Ph. I25, I74, 309, 360, 387, 426, 5 Io; ds. fugle, $\mathrm{Ph} .328,585$; Pr. I; np. fuglas, Ph. I63, 315, 352, 59I ; gp. fugla, Ph. I55, I59, 330, 335; Pn. 5.

fugeltimber, n., young bird: ns. Ph. 236.

fūl, n., foulness, impurity: gp. fūla, El. 769 .

ful, adj., full: nsm. El. 752, 769; nsn. Ph. 267; asn. E1. 939. See gelēaf-, hyht-, scyld-, syn-, womful.

ful, adv., full, fully: E1. I67, 860.

fullæstan, see gefull:̄stan.

fultum, m., aid, help: as. E1. I053; $\mathrm{Ph}$. 390, 455, 646.

fulwian, see gefulwian.

fulwiht, f. n., baptism: gs. fulwihtes, El. 490, I034; as. fulwihte, El. 172, 192.

furoror, adv. further, more: furbor, $\mathrm{Ph} .236$; furøur, El. 388.

furðum, adv., even, just: syððan furbum (just as soon as), El. 914.

furður, see furðor.

fūs, adj., ready: Ph. 208; nsf. El. I219; about to die: nsm. El. I237.

-fylce, see ælfylce.

fylgan, Wi., follow: pret. 2 pl. fylgdon, El. 371. See gefylgan. fyll, m., dissolution: ds. fylle, $\mathrm{Ph}$. $37 \mathrm{I}$.

fyllan, Wi., overthrow: pret. $3 \mathrm{sg}$, fylde, El. I04I.

fyllan (fill), see gefyllan. fyllo, f., feast: gs. fylle, Pn. 35 . fȳr, n., fire: ns. Ph. 219, 380, 504 525 ; gs. fȳres, El. I106, I 287 $\mathrm{Ph} .15,215,276,490,545$; as El. I3II, I314; W. 22; is. fȳre 
Ph. 531. See ǣled-, bǣlfȳr. fȳrbæơ, n., bath of flame: ds. fỹrbaðe, Ph. 437; hell-fire: ds. fȳrbæöe, E1. 949.

fyrd, m., army: gp. fyrda, El. 35. fyrdhwæt, adj., brave: npm. fyrdhwate, E1. 2I, II79.

fyrdlēod, n., war-song: as. El. 27. fyrdrinc, m., warrior: np. fyrdrincas, E1. 26r.

fȳren, adj., fiery: ipf. fȳrnum, Pn. 60.

fyrgenstrēam, m., ocean-stream: gp. fyrgenstrēama, W. 7 .

fȳrhät, adj., ardent: nsf. El. 937. fyrhtan, see āfyrhtan.

fyrhठ(-), see ferhð(-).

fyrmest, adv., first: El. 68; especially: E1. 316.

fyrn, adv., long ago: E1. 632, 64I, 974.

fyrndæg, m., ancient day, day of yore: dp. fyrndagum, El. 398 , 425,528 ; Ph. 570.

fyrngēar, npl., past years: i. fyrngēarum, Ph. 2 I9.

fyrngefiit, n., old strife: as. E1. 904. ¥ fyrngeflita, m., ancient enemy: as. fyrngeflitan, Pn. 34.

fyrngemynd, n., history: as. El. 327.

fyrngesceap, n., ancient decrec: ns. Ph. 360 .

yrngeset, n., ancient habitation: ap. fyrngesetu, $\mathrm{Ph} .263$.

yrngeweorc, n., ancient work: ns. Ph. 95 ; as. Ph. 84 .

yrngewrit, n., ancient scripture: np. fyrngewritu, El. 43I; ap. fyrngewritu, El. 373, 560 ; fyrngewrito, El. 155.

yrngidd, n., ancient learning: gp. fyrngidda, E1. 542 .

yrnwita, m., prophet: ns. fyrnweota, El. 343; fyrnwiota, El. 438 ; as. fyrnwitan, E1. II 54 . fyrran, see āfyrran.

fyrst, m., interval, space of time: ds. fyrste, El. 490 ; as. El. 67 , 694.

fyrstmearc, f., appointed time, proper interval: ds. fyrstmearce, E1. I034, I268; $\mathrm{Ph} .223$.

fyrwet, n., curiosity: ns. El. I079.

fȳsan, Wi., prepare one's self: inf. El. 226, 981. See à-, gefȳsan.

G.

gād, n., lack: ns. El. 992.

-gædre, sce tōgædre.

gædrian, W2., gather: 3 sg. gædrað, $\mathrm{Ph}$. 193. See gegædrian.

gǣlan, Wı., delay: pret. 3 pl. gǣldon, El. 692, 1001.

gæ̈lsa, see hygegǣlsa.

gæst, m., guest: ns. W. 29. See fēògęst.

gǣst, see gāst.

galan, VI, scream: pret. 3 sg. gōl, E1. 52; sing: pp. galen, E1. I24. Sce āgalan.

galdor, m., word: dp. galdrum, El. I61.

galga, m., cross: ds. galgan, El. I79, $480,719$.

gam-, see gom-.

gān, anv., go: pret. 3 sg. ēode, El. I096; 3 pl. ēodan, El. 320, 377 ; èodon, E1. 4II, 557, 846. See āgān; gangan.

gang, m., course: dp. gangum, El. 633, I256; gongum, El. 648; expanse: as. gong, $\mathrm{Ph}$. II 8. See bigang.

gangan, rd., go: imp. pl. ganga $\delta$, El. 406; gangab, El. 313, 372; gongad, Ph. 519. See à-, begangan; gān.

gār, m., spear: np. gāras, E1. 23, I25; ap. găras, El. I18.

gārsecg, m., ocean: gs. gārsecges,

W. 29; as. $\mathrm{Ph} .289$. 
gārơracu, f., battle: ds. gārbræce, El. 1186.

‡gārörīst, adj., bold with the spear: nsm. gārprist, El. 204. gāst, m., spirit, soul; ghost: ns.

El. 936, 1037, I145; gs. gāstes, E1. 199, 1058, 1070, I100, II 57 ; gāstes, Ph. 549; ds. gāste, El. 47I, 889; as. El. 352, 480; ḡ̄st, Ph. 5I3; vs. El. I I06; np. gāstas, Ph. 5I9, 539, 544, 593; gp. gāsta, E1. I76, 682, 790, I022, I077; ḡ̄sta, Ph. 6I5; dp. gāstum, El. 302 ; ap. gāstas, El. I82.

gāstgerȳne, n., spiritual mystery: dp. gāstgerȳnum, E1. I89, II48.

gāsthālig, adj., holy: npm. gāsthālige, El. 562; gǣsthālge, Pn. 21 . gāstlēas, adj., dead: asm. gāstlēasne, El. 875.

gāstsunu, m., spiritual son: ns. El. 673.

gaudium, n. (Lat.), joy: ap. gaudia, Ph. 669.

ge, conj., or, and: Ph. 523; Pn. 74; ge. . . . ge, both . . . and:

El. 965,966 ; ge . . . ond, whether . . . or: E1. 629, 630 . gē, pron., see òu.

geāclian, W2., disquiet, excite: pp.

geāclad, El. 57 ; geāclod, El. II 29. geador, adv., together: El. 26, 889;

Ph. 285.

geæfnan, see geęfnan.

geaflas, mpl., jaws: n. Ph. 300.

geagncwide, m., contradiction: as.

E1. 525; answer: ap. gēncwidas,

E1. 594 .

geagninga, adv., completely: E1. 673.

-gēan, see ongēan.

gēar, n., ycar: ns. El. 7 ; gp. gēara,

E1. I, 648; dp. gēarum, El. 1265;

$\mathrm{Ph} .258$; ip. gēarum, $\mathrm{Ph} .154$.

See fyrngēar. gēara, adv., formerly, of yore: El. 1266.

geard, m., home: dp. geardum, $\mathrm{Ph}$. 355, 647; court: dp. geardum, $\mathrm{Ph}$. 578. See middangeard.

gēardagas, mpl., life: n. El. 1267; past days, days on earth: d. gēardagum, $\mathrm{Ph} .384$; i. gēardagum, El. 290, 835 .

geare, adv., readily: E1. I67, 399; exactly: E1. 648, 719, 860; gearwe, El. 1240; super. gearwast, El. 328; well: E1. 419; completely: E1. 531; clearly: comp. gearwior, El. 946.

gearolice, adv., completely: El. 288. gearu, adj., ready: nsm. El. 85, I045; nsf. El. 222, 1029; npm. gearwe, El. 23, 227, 555; npn. E1. 605 .

gearusnottor, adj., very wise: nsm. gearosnotor, El. 4I8; asm. gearusnottorne, El. 586.

gearwian, W2., make ready, prepare: inf. El. I000; $\mathrm{Ph} .189$. See gegearwian.

geāscian, W2., learn: pp. geāscad, Ph. 393.

gēasne, adj., destitute: nsm. El. 924 ; asf. W. 46.

geatolic, adj., stately: nsf. El. 33I ; splendid: nsn. El. 258.

gebǣru, f., behavior, bearing: ns. Ph. I25; as. (ap. ?) El. 659; gebǣro, El. 7 Io.

gebann, n., behest: as. E1. 557 .

gebed, n., prayer: ap. gebedu, $\mathrm{Ph}$. 458.

gebēodan, II, bid, command: inf. El. 276, 1007; offer: pret. 3 sg. gebēad, Ph. 401.

gebidan, I, expect, await: inf. Ph. 562 ; wait: inf. El. 865 ; reach attain: 3 sg. gebidee, $\mathrm{Ph}$. ${ }^{5}{ }^{2}$. gebindan, III, bind: pp. gebunden El. 772, 1245. 
geblissian, W2., gladden, cheer, transport: pp. geblissod, El. 840, 876, 990, II26; geblissad, Ph. 7, I40.

geblond, see earhgeblond.

geblondan, rd., blend: pp. geblonden, Ph. 294.

geblōwan, rd., bloom, flower, blow: pp. geblōwen, $\mathrm{Ph} .21,27,47$, I79, 240 ; asf. geblowene, $\mathrm{Ph}$. 155.

gebod, n., behest, bidding: ns. $\mathrm{Ph}$. 68.

gebrec, n., crash, noise: ns. El. II4. gebrecan, IV, break: pp. gebrocen, $\mathrm{Ph} .80,229$.

gebrēdian, W2., restore, regenerate: pp. gebrëdad, $\mathrm{Ph}$. 372; npm. gebrēdade, $\mathrm{Ph} .592$.

gebregd, n., vicissitude: ns. $\mathrm{Ph} .57$. gebringan, Wr., bring, gather: $3 \mathrm{sg}$. gebringe $\delta$, Ph. 27I, 283; pp. gebrōht, W. 72.

gebrosnian, Wz., decay: pp. gebrosnad, $\mathrm{Ph} .270$.

gebrōoror, mpl. brothers: n., gebrōpor, Pr. II.

gebyrd, f., nature: as. $\mathrm{Ph} .360$. See èaggebyrd.

gebyrde, adj., innate, natural: nsn. El. 593.

gebyrga, see lēodgebyrga.

gebyrgan, Wr., taste: opt. 3 sg. gebyrge, $\mathrm{Ph}$. 26r.

gebysgian, W2., trouble, afflict: pp. gebysgad, $\mathrm{Ph} .62, \mathrm{I} 62,428$; overcome: pp. gebiesgad, Pn. 39 .

gecēosan, II, choose, select, elect: 3 sg. gecēoseð̋, $\mathrm{Ph} .382 ; 3$ pl. gecěosað, W. 37; pret. 3 sg. gecēas, El. I039, I166; ger. gecēosanne, El. 607; pp. asm. gecorenne, El. I059; npm. gecorene, Ph. 54I, 593; dpm. gecorenum, Ph. 388.

gecigan, WI., invoke: 3 sg. gecȳgð, Ph. 454. geclǣnsian, W2., cleanse: inf. E1. 678; pp. geclǣnsod, El. 1035, I3II.

geclingan, III, contract: pp. npf. geclungne, Ph. 226.

gecnāwan, rd., recognize, perceive:

3 sg. gecnāweð, W. 38; pret.

3 sg. gecnēow, El. II40; opt. pret. I sg. gecnēowe, El. 708; pp. gecnāwen, E1. 808.

gecost, adj., proved, tried: nsn. El.

257; ism. gecoste, El. 269; npm. gecoste, El. I 86 .

gecwēme, adj., dear: nsm. El. I050. gecweð̌an, V., speak: pret. 3 sg. gecwæช, El. 338, 440, 939, II9I ; Ph. 55I ; Pn. 69; Pr. 4; gecwæp, E1. 344 .

gecȳgan, see gecīgan.

gecynd, f., nature, kind, species: ns. El. 735 ; Ph. 387 ; ds. gecynde, Pn. 9 ; as. $\mathrm{Ph} .329$; germinal vigor: as. $\mathrm{Ph} .252,256$; sex: ns. Ph. 356 ; trait: as. W. 49 . See sundorgecynd.

gecyrran, Wi., change: pp. gecyrred, E1. I06I; pass: pp. gecyrred, El. 1265; turn: I sg. gecyrre, Pr. 8.

gecÿðan, Wi., announce, make known: 3 sg. gecȳðеঠ, El. 595; opt. 2 sg. gecȳðe, El. 690; 3 sg. gecy̆ð̌e, El. ıogı; 3 pl. gecy̆ðan, El. 409 ; pret. 3 sg. gecȳðde, El. 866; imp. sg. gecÿð, El. 446; inf. E1. 588; gecȳban, $86 \mathrm{I}$; ger. gecȳðanne, El. 533; pp. gecȳðed, El. 816, 1050 .

gedæ̋lan, WI., diversify: pp. gedǣled, Ph. 295.

gedafenlic, adj., becoming, proper: nsn. El. I 68 .

gedāl, n., death, dissolution: as. $\mathrm{Ph}$. 65I. See woruldgedāl.

gedēman, WI., ordain: pp. gedēmed, Ph. I47. 
gedōn, anv., apply: inf., El. II59; show forth: imp. sg. gedo, El. 784 .

gedryht, f., flock: ns. Ph. 348; host, multitude: ns. El. 27, 1290; Ph. 615, 635; as. El. 737. See sib-, wilgedryht.

gedwola, m., error, heresy: ds. gedwolan, El. IIr9; as. gedwolan, El. 371, 104I ; is. gedwolan, El. 3 II.

geēacnian, W2., impregnate: pp. geēacnod, El. 34I.

geealdian, W2., grow old: pp. geealdad, $\mathrm{Ph} .427$.

geearnian, W2., earn, deserve:

2 sg. geearnast, El. 526.

geēawan, Wr., manifest, reveal:

opt. 3 sg. geēawe, $\mathrm{Ph} .334$.

geęfnan, Wr., do, execute: pret.

3 sg. geefnde, El. Ior5; inf.

geæfnan, Pn. 18, 33.

geęndian, W2., end: pp. geendad,

Ph. 500.

gefær, n., expedition, journey: ns.

Ph. 426 ; as. El. 68.

gefæstnian, W2., fasten: pp. gefæstnod, El. 1068.

gefaran, VI, die: pp. asm. gefærenne, El. 872.

gefēa, m., delight, happiness, joy:

ns. El. 195; Ph. 422, 607;'ds.

gefēan, Ph. 400 ; as. gefēan, El.

$870,949,980$; Ph. 248, 389, 569. gefēalic, adj., agreeable, joyous: nsn. Ph. 5 Io.

gefeallan, rd., fall: pp. gefeallen, El. 651 .

gefēgan, Wi., fit together: pp. gefēged, Ph. 309; fix: W. 4I. gefēlan, Wı., feel: 3 sg. gefēleð,

W. 24.

gefeoht, n., battle: ds. gefeohte, El.

II 84 ; as. El. 646.

gefēon, V, be glad, rejoice: pret.

3 sg. gefeah, El. I I0, 247, 849;
3 pl. gefǣgon, El. III6; ptc. gefēonde, El. I74, 991.

gefēra, m., companion, fellow: ns.

E1. 1261 .

gefēran, Wr., come, go: inf. El. 736.

† gefēre, ađj., accessible: nsm. Ph. 4.

gefęrian, W2., bring: pp. gp. geferedra, El. 993.

gefętian, W2., bring, fetch: inf. El. 1053; gefetigean, El. II6I.

gefetrian, W2., shackle: pret. $3 \mathrm{sg}$. gefetrade, Pn. 60.

gefic, n., deceit, fraud: is. gefice, El. 577 .

geflit, n., strife: ap. geflitu, E1. 443, 954. See fyrngeflit.

geflita, see fyrngeflita.

geflota, m., swimmer: ds. geflotan, W. 7 .

gefōg, see stāngefōg.

gefōn, rd., seize, take: 3 sg. gefēhð,

Ph. I43 (hlyst gefēh $\delta$, listens). gefrǣge, $\mathrm{n}$., report, hearsay: is. $\mathrm{Ph}$. 176.

gefrǣge, adj., known, famous: nsn.

Ph. 3; gef rēge, El. 968.

gefrætw(i)an, W2., adorn, embel-

lish, deck: pp. gefrætwed, $\mathrm{Ph}$.

274, 585; gefrætwad, $\mathrm{Ph}$. I16,

239 ; npm. gefrætwade, El. 743. gefrēge, see gefrǣge, adj.

gefręmman, WI., do, commit, accomplish: I pl. gefremmap, El. 515; 3 pl. gefremmab, $\mathrm{Ph}_{2} 495$; pret. I sg. gefremede, El. 363, 818; 3 sg. gefremede, El. 299, 9I2; I pl. gefremedon, El. 402; 2 pl. gefremedon, El. 386; opt.

3 sg. gefremme, $\mathrm{Ph} .463$; pret.

3 sg. gefremede, El. 779; pp. gefremed, El. 415; grant: pret. 3 sg. gefremede, El. 50r; gain: pret. $3 \mathrm{sg}$. gefremede, $\mathrm{Ph}$. 650 . gefreodiain, W2., defend, protect: 
imp. sg. gefreopa, Ph. 630 .

gefricgan, V, learn: pp. gefrigen, E1. 155 .

gefrige, n., information, result of inquiry: ip. gefreogum, Ph. 29. gefrignan, III, hear, learn: pret. 3 pl. gefrugnon, El. 172; opt. pret. 3 pl. gefrugnen, El. IOI4; pp. gefrugnen, $\mathrm{Ph}$. I.

gefullæstan, Wr., help: pret. 3 sg. gefullæ̈ste, El. II5I.

gefulwian, W2., baptize: pp. gefulwad, El. I044.

gefylgan, W3., persist in: 2 pl. gefylgad, El. 576; follow: inf. Ph. 347.

gefyllan, Wr., fill: 3 sg. gefylleð, Ph. 653 ; opt. 3 sg. gefylle, El. 680; pp. gefylled, El. 452, II 43 ; Ph. 627; fulfil: opt. 3 sg. gefylle, El. I084; pret. 3 sg. gefylde, El. I07I; pp. gefylled, El. II3I, II35; W. 60.

gefȳsan, Wr., set in motion: pp. npm. gefȳsde, El. 260, r27o; Pn. 52.

gegædrian, W2., gather: 3 sg. gegædrað, Ph. 269; pp. gegædrad, Ph. 512.

gegearwian, W2., equip, supply: pp. gegearwod, El. 47; 889.

geglęngan, WI., adorn: pp. geglenged, El. 90.

gehæftan, Wi., torture: pp. gehæfted, El. 6I3.

gehealdan, rd., hold, keep, observe: pret. 3 sg. gehēold, El. I92; 3 pl. gehēoldan, Ph. 476; shield: pp. gehealden, $\mathrm{Ph} .45$.

geheaðrian, W2., confine: pp. geheadrod, El. I276.

gehęfgian, W2., depress, burden: pp. gehefgad, Ph. I53.

gehēgan, WI., hold: inf. Ph. 493. gehigd, see gehygd.

gehladan, VI, load: pret. 3 pl. gehlōdon, El. 234; pp. npm. gehladene, Ph. 76 .

gehlēô, m., comrade: ns. El. II3. gehōn, rd., hang with, load with: pp. gehongen, Ph. 38; npm. gehongene, $\mathrm{Ph} .7 \mathrm{r}$.

gehrēodan, II, adorn, deck: pp. gehroden, Ph. 79; load: pp. npm. gehrodene, W. 74.

gehou, f., care, grief: ds. E1. 667 ; as. El. 609 ; dp. gehðum, E1. $3^{22}$. gehwā, pron., each, every, all: gsf. gehwæs, Ph. I97; gsn. gehwæs, El. 569; Pn. 26; dsm. gehwām, El. 358, 465, I187, 1229; Ph. 66, 45I, 469, 603 (mf.); W. 62;

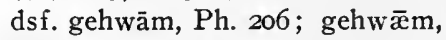
El. 973; asm. gehwone, $\mathrm{Ph}$. 195 , 606; gehwane, Ph. 464; asf. gehwæne, El. 548; gehwone, Ph. 336; Pn. 67. See also änra gehwā.

gehwǣr, adv., everywhere: El II 83 .

gehwæòt, pron., both, either: nsm. Ph. 374; gsn. gehwæores, El. 628,964 .

gehweorfan, III, turn: pret. 3 sg. gehwearf, El. II26.

gehwylc, pron., each, all, every: nsm. El. I287, I317; Ph. I85, 38I, 503, 522, 534; Pn. 23; W. 39; gsm. gehwylces, Pn. 22 ; gsn. gehwylces, E1. 319, 423, 910, 1030, I156, 1310; Ph. 624; Pn. 20; dsm. gehwylcum, El. 278; Pn. 46; W. 6; dsf. gehwylcre, El. I313; Pn. 57 ; dsn. gehwylcum, $\mathrm{Ph}$. IIo; asm. gehwylcne, El 598, I179; asn. El. 409, 645; Ph. 460, 615 ; Pn. 18; gpf. gehwylcra, E1. 1283; dpm. gehwylcum, Ph. 133. See also ānra gehwylc.

gehȳdan, Wr., hide, conceal: pp. nsn. gehȳded, El. I092; apf. gehȳdde, El. 832. 
gehȳdian, W2., make fast: 3 pl. gehÿdiað, W. 13.

gehygd, n., thought, meditation: dp. gehygdum, Ph. 459; gehigdum, El. 1224.

gehȳnan, Wi., weaken: pp. gehȳned, E1. 720; 923.

gehȳran, Wr., hear, learn: pret. 2 sg. gehÿrdest, El. 785; 3 sg. gehȳrde, El. 709, 953, 957 ; 1 pl. gehȳrdon, El. 364, 660; 3 pl. gehȳrdon, El. 1002; opt. 2 sg. gehȳre, El. 442 ; imp. pl. gehȳrađ, El. 333 ; Ph. 548; inf. El. 5II, I282; nearken unto, obey: pret. 3 pl. gehȳrdun, Ph. 444.

gehyrstan, WI., adorn: pp. gehyrsted, El. 33I.

gehyrwan, Wr., neglect: inf. E1. 221.

\section{geīewan, see geȳwan.}

gelǣca, see güơgelǣca.

gelǣdan, Wi., lead, bring: 3 sg. gelǣ deð, Ph. 244; pret. 3 pl. gelæ̈ddon, El. 7I4.

gelǣstan, Wr., do, carry out: opt. 3 sg. gelæ̈ste, El. I I97; ger. gelǣstenne, El. I 66 ; practise: opt. pret. 3 pl. gelǣston, El. I208. gelēafa, m., belief, faith: ns. E1. Iо36; gs. gelēafan, E1. 966; as. gelēafan, El. 49I ; is. gelēafan, E1. II37; Ph. 479.

gelēaffull, adj., faithful: nsm. El. I048; gelēafful, El. 960 .

gelēodan, rd., grow: pp. geloden, El. 1227.

gelęttan, W I., hinder: 2 sg. geletest, El. 94 .

gelic, adj., like, sinilar: nsm. $\mathrm{Ph}$. 237 ; nsn. W. 8; gsn. gelīces, Ph. 387 ; npm. gelice, El. I320; super. nsf. gelicast, Ph. 302; nsn. gelīcast, $\mathrm{Ph} .424$.

gelice, adv., like, alike: $\mathrm{Ph} .37,60 \mathrm{I}$; super. gelicost, El. 1272; gelicast, $\mathrm{Ph}$. 585. See ungelice.

gelicnes, f., likeness: ns. Ph. 230. gelimpan, III, happen: pret. 3 sg. gelamp, El. 27I, II55; opt. 3 sg. gelimpe, El. 44I ; succeed: pret. 3 sg. gelamp, E1. 963 .

gelīðan, I, attain: pp. geliden, El. 249; pass away: pp. geliden, El. 1269 .

gelȳfan, Wr., believe: I sg. gelȳfe, El. 796 ; pret. 3 pl. gelȳfdon, El. 518.

gelysted, pp., eager: npn. gelyste, W. 23. Sce lystan.

‡gemāh, adj., malicious: nsm. $\mathrm{Ph}$. 595 ; W. 39.

gemang, n., host, number: ds. gemonge, $\mathrm{Ph} .265$; as. El. 96, 108, I 8 . In gemonge, prep., w. dat., in the midst of.

gemearc, see oinggemearc.

gemearcian, W2., mark: 3 sg. gemearcad, Ph. I46; pp. gemearcad, Ph. 3 I8.

gemęngan, Wr., pollute: pp. npm. gemengde, E1. 1296.

gemētan, WI., find, mect with: 3 sg. gemēteð, Ph. 429; pp. gemēted, El. 871, I0I3, I225; $\mathrm{Ph}$. $23 \mathrm{I}$; W. 4.

gemetfæst, adj., even-tempered: asn. Pn. 3I.

gemetgian, W2., grow mild: $3 \mathrm{sg}$. gemetgap, El. 1293.

gemong, see gemang.

gemöt, n., assembly: as. El. 279; Ph. 49I.

gemyltan, Wr., melt: pp. gemylted, E1. I312.

gemynd, n. f., memory, mind: ds. E1. 644 ; as. El. I233, I248, I303. See fyrn-, in-, mōdgemynd.

gemynde, adj., mindful: nsf. El. I064. See ingemynde.

gemyndig, adj., mindful, heedful: 
nsm. El. 213, 819, 902, 940; nsf. E1. 266.

gēn, adv., still: El. 1080, 1092 ; gin, $\mathrm{Ph} .236$; gien, $\mathrm{Pn} .28$; W. 50; next: El. 1063, I078; again: El. 373, 925; moreover, also: El. 1218; Pr. I. See also gina. geneahhe, adv., very: El. 1065, I 58 .

genēgan, WI., address: inf. E1. 385.

genęmnan, Wr., name: pp. genemned, El. 74I.

genēosian, W2., visit: 3 sg. genèosad, $\mathrm{Ph}$. 35I.

genęrian, Wr., save: pret. 3 sg. generede, El. I63; 3 pl. generedon, E1. I32; deliver: pret. 3 sg. generede, El. 301 .

-gēnes, see tōgēnes.

-gęnga, see bi-, foregęnga.

geniman, IV., take: pret. $3 \mathrm{sg}$. genam, El. 599.

genïla, m., enmity, hostility: ds. genïllan, El. 70I ; as. geniollan, El. 6ı. See cwealm-, 1ăò-, sweord-, torngenïlla.

geniwian, W2., renew, restore: pp. genīwad, $\mathrm{Ph}$. 279, 580 .

gēoc, f., help, consolation: ds. gēoce, El. II39, I247.

gēocend, m., helper: ns. El. 682, 1077.

geof-, see gif-.

geofon, n., sea, ocean: gs. geofones,

Ph. II8; geofenes, El. 227, I201. geogod, f., youth: ns. El. I265; ds. geogoðe, El. 638 .

geogoðhād, m., youth: gs. geogoðhādes, El. I267.

geolorand, m., shield: as. E1. 118. gēomor, adj., sad, sorrowful, woful: nsm. El. 627; Ph. 556; dsm. gēomrum, El. 922; asf. wk. geoomran, $\mathrm{Ph}$. I39, 517; npm. gēomre, E1. 322; apm. gēomre, El. I82. See hygegẽomor.

gēomormōd, adj., sad, sorrowful:

npm. gēomormōde, El. 4I3, 555;

Ph. 353, 412.

geond, prep. among, through, throughout, in: w. acc., El. 16, 278, 734, 969, II77; Ph. 82, II9, 323; Pn. I, 4, 65, 68, 70.

geondfaran, VI, traverse: 3 pl. geondfarad, $\mathrm{Ph} .67$.

geondlācan, rd., flow through: opt. 3 sg. geondlāce, $\mathrm{Ph} .70$.

geondwlitan, I, survey: $3 \mathrm{sg}$. geondwlīteđ, $\mathrm{Ph}$. 2 I I.

geong, adj., young: nsm. Ph. 258,

647 ; giong, Ph. 355 ; comp. nsm. gingra, El. 159; rejuvenated: nsn. Ph. 267; asn. Ph. 192, 433; fresh: gpf. geongra, Ph. 624 .

See cniht-, edgeong; ging.

geopenian, W2., open: pp. geopenad, El. I23I ; reveal: opt. 2 sg. geopenie, El. 792; inf. geopenigean, El. I I02.

georn, adj., zealous: nsf. El. 268.

See dömgeorn.

georne, adv., earnestly, zealously:

E1. 199, 216, 322, 413, 471, 600,

II57, II7I ; comp. geornor, $\mathrm{Pr}$. 12; eagerly: $\mathrm{Ph} .92$, IOI ; accurately: E1. II63; surely, well: comp. geornor, $\mathrm{Ph}$. 573; gladly: W. 74 .

geornlīee, adv., zealously: E1. 1097, I 48.

gēotan, II, pour: pp. goten, El.

II33. See be-, Jurhgēotan.

gerǣde, n., means: ip. gerǣdum,

E1. $1054,1108$.

gere, adv., see geare.

gereaht, see ferhð̈gereaht.

geręccan, Wi., report: inf. El. 649 . gereord, n., meal: dp. gereordum,

Pn. 36 . 
geręstan, Wr., rest: 3 sg. geresteð, El. 1083 .

gerìm, see dōgor-, wintergerìm.

gerūma, m., room: as. gerūman,

E1. 320 (on gerūman, away, apart).

gerȳman, WI., extend: pret. 3 sg. gerȳmde, El. I249.

gerȳne, n., secret: as. El. 566; ap. gerȳno, E1. 280, 589, 813. See gāst-, wordgerȳne.

gesǣlan, Wr., bind: pret. 3 sg. gesǣlde, Pn. 59.

gesǣlig, adj., blessed: nsm. E1. 956; nsm. wk. ges $\bar{x}$ liga, Ph. 350. gesamnian, W2., assemble: pp. gesamnod, El. 26, 282.

gescēadan, rd., decide: pp. gescēaden, E1. I49.

gesceaft, f., creature: gp. gesceafta, El. 894 ; Pn. 73 ; dp. gesceaftum, Pn. 56 ; creation: as. El. 729; heaven: as. El. I089; existence: as. $\mathrm{Ph} .660$; object: as. $\mathrm{El} . \mathrm{I} 83$, 1032.

gesceap, n., destiny, fate: ap. gesceapu, Ph. 210; object: as. E1. 790. See fyrngesceap. gescęððan, VI, harm, molest, plague: pret. 3 sg. gescōd, $\mathrm{Ph}$. $400 ; 3$ pl. gescōdan, Ph. 442. gescinan, I, illumine: 3 sg. gescineb, $\mathrm{Ph}$. II 8 .

gescrīfan, I, decree, ordain: pret.

3 sg. gescrāf, El. 1047. gescyldan, WI., defend, protect:

pp. gescylded, $\mathrm{Ph}$. 180 . gescyppan, VI, create, fashion: pret. 3 sg. gescōp, $\mathrm{Ph} .84, \mathrm{r} 38$, I97.

gescyrdan, Wi., cut to pieces: pp. gescyrded, E1. I4I.

gesēcan, Wr., seek, visit: 3 sg. gesēceð, El. I280; Ph. I56, 264; W. 29 ; pret. 3 sg. gesōhte, E1.
230, 255, 270; gain, reach: 3 sg. gesēceð, $\mathrm{Ph}$. 166.

gesęcgan, WI., speak: inf. gesecggan, El. I68; proclaim: inf. El. 985 .

gesēfte, adj., pleasant: super. nsm. gesēftost, El. r295.

gesęllan, Wr., pay: inf. gesyllan, El. 1284 .

gesēon, V, behold, see: I pl. gesēoð, E1. II2I ; pret. 3 sg. geseah, El. 88, I00; geseh, El. $842 ; 3$ pl. gesǣgon, E1. 68; gesāwon, E1. I III ; opt. pret. 3 sg. gesēge, El. 75 ; inf. El. I308; Ph. 675; W.

86 ; gesion, El. 243 ; pp. gesegen, El. 7 I.

geset, n., abode, dwelling, haunt, seat: ap. gesetu, $\mathrm{Ph} .278,417$, 436. See fyrngeset.

gesēđan, WI., prove, verify: inf. El. 582 .

gesęttan, Wr., place, establish: pret. 3 sg. gesette, $\mathrm{Ph}$. ro, 395; opt. pret. 3 sg. gesette, El. I055; destine: 2 sg. gesettest, E1. 739. gesih', see gesyh'\%.

gesittan, V, sit, sit down: pret. 3 pl. gesǣton, El. 868; inf. $\mathrm{Ph}$. $67 \mathrm{I}$.

gesomnian, W2., gather: 3 sg. gesomnat, Ph. 576.

gespon, n., twist: as. gespon, El. II35 (wira gespon, nails).

gesprecan, V, speak: opt. pret. 3 sg. gesprāce, El. 667 ; pp. gpf. gesprecenra, El. I285. gespring, see wyllegespring. gęst, see gæst.

gestadelian, W2., establish, ordain: pp. gestapelad, Ph. 474.

gesteald, n., mansion: gp. gestealda, E1. 802.

gestealla, see eaxlgestealla. gestrēon, see æht-, feoh-, woruldgestrēon. 
gestrȳnan, Wr., gain, secure: 3 pl. gestrȳnab, Ph. 392.

gesund, adj., prosperous: asm. gesundne, El. 997, 1005.

gesweorcan, III, grow dark: pret. 3 sg. geswearc, El. 856.

geswęrian, VI, swear: I sg. geswerige, El. 686.

geswican, I, cease from: I pl. geswīcab, El. 516; 2 pl. geswicað, Pr. 7.

geswigian, W3., bring to silence: pp. geswiged, $\mathrm{Ph}$. 145 .

geswin, n., strain: ns. Ph. I37.

geswing, n., tossing, welter: ns. Pn.

8. See handgeswing.

geswiörian, W2., lessen, weaken: pp. geswiorod, E1. 698, 918; geswiörad, El. I264.

gesyhð, f., vision, sight: ds. gesyhðe, El. I84, 346, 847, 965; gesihote, El. 614; as. El. 98.

gesyllan, see gesęllan.

gesȳne, adj., plain: nsn. El. I44; visible: nsn. El. 264. See ēögesȳne.

getācnian, W2., show: pp. getācnod, El. 754 .

getǣcan, WI., reveal: pret. 2 sg. getǣhtesঠ, El. I075; opt. pret. 3 sg. getǣhte, El. 6or.

getęllan, WI., count: pp. geteled, E1. 2, 634 .

getęngan, WI., dedicate, devote: pret. 3 sg. getengde, El. 200.

getęnge, adj., resting on: npm. El. 228; apm. El. III4.

gedanc, mn., thought: ds. gebance, El. 267,807 ; as. gebanc, El. 1239; gp. geponca, El. I286; dp. gepancum, El. 312 ; ip. geponcum, $\mathrm{Ph}$. 552. See in-, mōdgeð̆anc. geठ̌eaht, f., counsel: as. gebeaht, El. I060; device, plot: ap. gepeahte, El. 468; knowledge: as. gepeaht, El. I24I. See rǣdgeð̌eaht.

geð̋ęncan, Wr., think: imper. pl. gepencab, E1. 3ㄱ․

geð̌̃on, III, exalt, advance: pp. gebungen, $\mathrm{Ph} .160$; perfect: pp. gepungen, $\mathrm{Ph} .649$.

geơinge, n., fate: gs. gepinges, El. 253.

geðōht, m., thought: ns. gebōht, El. 426.

geơolian, W2., endure, suffer: inf. gepolian, E1. 1292.

geơrēan, W2., torment: pp. npm. geprēade, El. 321.

geðrēatian, W2., persecute: pp. geprēatod, El. 695.

geðrec, n., rush: ns. geprec, El. II4. geơringan, III, overcome: inf. gepringan, El. 40.

geơrōwian, W2., suffer: pret. 3 sg. gebrōwade, El. 519; gebrōwode, El. $859 ; 3$ pl. gebrōwedon, El. 855 ; opt. (?) pret. 3 sg. gebrōwade, E1. 563 .

geörȳðan, Wr., arm, embattle: pp. geprȳped, $\mathrm{Ph} .486$.

getimbran, Wr., build, erect, construct: 3 sg. getimbreð, Ph. 202, 430 ; opt. pret. 3 sg. getimbrede, El. roro.

getrȳwe, adj., true, faithful: nsm. E1. 1035.

getȳn, Wr., train: pp. apm. getȳde (skilled), El. Ior8.

getȳnan, Wr., shut in: pret. 3 sg. getȳnde, E1. 921 ; bury: pp. getȳned, El. 721-2.

gewadan, VI, penetrate: pret. $3 \mathrm{sg}$. gewōd, El. Irgo.

gewǣde, see wintergewǣe.

gewālan, Wr., pain, torture: pp. gew $\bar{x}$ led, El. I244.

geweald, n., might, power: as. El. 120, 726; dp. gewealdum, El. 6 ro. 
geweaxan, rd., grow up: pp. geweaxen, Ph. 3I3.

$\ddagger$ gewelgian, W2., endow: pp. gewelgad, Pn. 4I.

gewęndan, Wi., turn: opt. 3 sg. gewende, El. 6i7 ; pp. gewended, E1. 1047.

geweorc, see fyrngeweorc. geweorp, see wintergeweorp. geweorðan, III, be: 3 pl. geweorðað, El. 6I4; pret. $3 \mathrm{pl}$. gewurdon, El. I288; become: 3 sg. geweorped, $\mathrm{Ph}$. 538; gewyrðeð, E1. II92, I275; pret. I sg. gewearð, El. 923; come: opt. 3 sg. geweorðe, Ph. 4I ; pp. geworden, El. 994; happen: pret. 3 sg. geweard, El. 632, 64I ; inf. E1. 456, 6II ; pp. geworden, El. 643.

geweorðian, W2., distinguish, honor: 3 sg. gewyrðeð, E1. II92; pp. geweorðad, El. I77; Ph. 551 ; geweorðod, E1. I50, 823 .

gewęrian, Wi., clothe: pp. npm.

gewerede, E1. 263.

gewician, W2., dwell, abide, take up one's abode: 3 sg. gewicað, Ph. 203; 3 pl. gewiciað, W. I9. gewin, n., struggle: ns. $\mathrm{Ph}$. 55. See ealdgewin.

gewindæg, m., day of toil, time of tribulation: np. gewindagas, $\mathrm{Ph}$. 612.

gewitan, I, go: 3 sg. gewited, W. 28; 3 pl. gewitad, W. ı6; pret. 3 sg. gewāt, El. I48; vanish, pass away, depart: 3 sg. gewited, El. I277; Ph. 99, I62, 320, 428; 3 pl. gewitap, El. I272 ; pret. 3 sg. gewāt, E1. 94; opt. I sg. gewite, Ph. 554; pp. gewiten, Ph. 97; npm. gewitene, El. 1268; fly: 3 sg. gewited, $\mathrm{Ph}$. I22; come: 3 sg. gewited, W. 58. See fordgewitan. gewitt, n., mind, understanding: ns.

El. 938, II9I ; gs. gewittes, Ph. I9I ; as. El. 357, 459.

gewlęncan, Wi., adorn, bedeck: pp. gewlenced, E1. I264.

gewlitigian, W2., beautify, embellish: pp. gewlitegad, Ph. II7.

gewrit, n., record: ap. gewritu, El. 654,658 ; scripture: np. gewritu, El. 674; ap. gewritu, E1. 387 ; writing, book: np. gewritu, Ph. 313, 655; dp. gewritum, El. 827 , 1256; Ph. 30; Pn. 14; ip. gewritum, $\mathrm{Ph}$. 332, 425. See fyrngewrit.

gewunian, W2., dwell in, sojourn in, inhabit: pret. 3 sg. gewunode, E1. ıо38; opt. 3 pl. gewunien, Ph. 48r.

gewyrcan, WI., make, build, construct: 3 sg. gewyrceð, Ph. 469; inf. El. I04; commit: opt. I pl. gewyrcen, E1. 513; bring to pass: 3 sg. gewyrce $ో, \mathrm{Ph} .537$; create: pret. 2 sg. geworhtest, El. 727, 738 .

gewyrd, f., event, occurrence: ns. El. 647. See sundorgewyrd.

gewyrdan, Wi., inflict damage, do harm: inf. Ph. I9. See ungewyrded.

gewyrht, see ǣrgewyrht.

$\ddagger$ gewyrtian, W2., perfume: pp. gewyrtad, Ph. 543.

geȳwan, Wr., show: pret. 2 sg. geỷwdest, El. 787 ; 3 sg. geȳwde, El. 488; pp. geȳwed, El. 74, I83; geīewed, E1. 102.

gicel, see cylegicel.

gidd, n., speech: gp. gidda, El. 4I8; dp. giddum, El. 586 ; ip. giddum, E1. 53I. See fyrngidd.

gieddian, W2., sing: pret. 3 sg. gieddade, $\mathrm{Ph}$. $57 \mathrm{I}$.

giedding, f., utterance: ap. gieddinga, Ph. 549. 
gief-, see gif-.

gien, see gēn.

gielt, see gylt.

gietan, see be-, ongietan.

gif, conj., if: El. 435, 44I, 459, 5I4,

$533,542,576,621,773,777,782$, $789,857,1004$.

gifa, see beag-, hyht-, wil-, wuldorgifa.

gifan, V, give: 3 pl. gifa $\varnothing$, El. 360 ; grant: 3 sg. gifeঠ, $\mathrm{Ph} .3 \mathrm{rg}$; pret. 3 sg. geaf, El. 365 . See ā-, for-, ofgifan.

gifre, adj., greedy, rapacious: nsm. $\mathrm{Ph}$. 507. See wælgifre.

gifu, f., gift, grace: ns. El. 265; ds. gife, El. I 144 ; giefe, Ph. 658;

Pn. 71 ; as. gife, E1. 176, I82, I99, 596, 967, I033, I058, II57, I20I ; giefe, Ph. 327, 557; gp. gyfena, $\mathrm{Ph}$. 624; geofona, Ph. 384; ap. gife, El. 1247; endowment: gp. geofona, $\mathrm{Ph}$. 267. See wuldorgifu.

gild, see dēofulgild.

gildan, III, return, repay: pret. 3 sg. geald, E1. 493. See forgildan.

gim, m., gem, jewel: ns. Ph..I17, $183,208,300,516$; ds. gimme, $\mathrm{Ph}$. 92, 303; np. gimmas, El. 90 ; gp: gimma, $\mathrm{Ph} .289$. See gold-, sincgim.

gīm-, see gȳm-.

gimcynn, n., precious stone: $\mathrm{dp}$. gimcynnum, E1. I024.

gin, see ongin.

gin, see gēn.

gina, adv., still, yet: El. Iozo.

ging, adj., young: asm. gingne, El.

875 ; vsm. wk. ginga, El. 464; apm. ginge, E1. 353. See also

\section{geong.}

ginnan, see onginnan.

gio, adv., once: E1. 436. See also gūdǣd, iū. girwan, Wr., build, erect: inf. El. 1022.

gìsel, m., hostage: ds. gīsle, El. 600. glæ̈, adj., glad, joyous: dsm. wk. glādan, Ph. 593; comp. nsm. glæ̈dra, El. 956; brilliant, sparkling: dsm. glædum, Ph. 92; glādum, $\mathrm{Ph} .303$; super. nsm. glādost, Ph. 289.

glæ̈dmōd, adj., glad-hearted: nsm. El. 1096 ; Ph. 462 ; npm. glæ̈mōde, $\mathrm{Ph}$. 5 I9.

glēm, m., ray, radiance: ns. $\mathrm{Ph}$.

253 ; splendor: ns. E1. I267.

glæs, n., glass: ns. Ph. 300 .

glēaw, adj., sage, wise: nsm. El.

$807, \mathrm{I} 2 \mathrm{I} 2$; $\mathrm{Ph}$. I44; asf. glēawe,

El. II63; npm. glēawe, El. 314;

Ph. 29; gpm. glēawra, El. 638; apm. glēawe, El. 594; super. npm. glēawestan, El. 536. See $\overline{\mathbf{x}}$-, ferh"ठ-, hygeglēaw.

glēawhȳdig, adj., wise: nsm. El. 935.

glēawlīce, adv., wisely, prudently: E1. 189.

glēawmōd, adj., discerning, prudent, sagacious: nsm. Ph. $57 \mathrm{I}$.

glēawnes, f., wisdom: is. glēawnesse, El. 962.

glēd, f., fire, flame: gp. glēda, El. I 302.

glęngan, WI., adorn, grace: $3 \mathrm{sg}$. glengeð, $\mathrm{Ph} .606$. See geglęngan.

glīdan, I, glide: inf. Ph. I02. See tōglìdan.

gliw, n., cheer, joy: ds. gliwe, $\mathrm{Ph}$. I39.

glōm, see mistglōm.

gnornian, W2., bemoan: pret. $3 \mathrm{sg}$. gnornode, El. I260.

gnornsorg, f., sorrow: as. gnornsorge, El. 655; gp. gnornsorga, E1. 977.

gnyrn, f., blemish: gp. gnyrna, El. 
422 ; sadness: gp. gnyrna, El. II39.

gnyrnwrǣc, f., revenge for wrong:

dp. gnyrnwrǣcum, El. 359.

gnȳò, see ungnȳde.

God, m., God: n. El. 4, 14, I6r, etc. (ro times) ; Ph. 36, 281, 355, 565 ;

Pn. 55; g. Godes, E1. 109, 179, 20r, etc. (23 times) ; Ph. 46, 9r, $96,403,408,46 \mathrm{I}, 57 \mathrm{I}, 6 \mathrm{I} 9$; d. Gode, E1. 962, 1048, I 100, I I17, I139; Ph. 517, 657; Pr. I2; a. E1. 209, 345, 687, etc. (8 times) ; v. El. 760, 786, 810, 819; Ph. 622. gōd, n., bounty, good: np. Pn. 7I ; gp. gōda, El. 924; Ph. 615, 624; W. 46.

gōd, adj., good: gpm. gōdra, El. 637 ; gpf. gōdra, Ph. 462 ; comp. nsm. betera, El. 506; nsn. sēlle, Ph. 4I7; asm. beteran, El. 6I8; asn. betere, E1. 1039, 1046, 1062 ; super. nsm. sēlest, El. ro28; nsn. sēlest, El. 975; sēlust, E1. 527; asm. wk. sēlestan, Ph. 395, 620; vsm. wk. sëlesta, El. ıo88; vsf. wk. sëleste, E1. II70; apm. sēleste, E1. I202; apm. wk. sēlestan, El. rorg.

Godbearn, n., Son of God: ns. El. 719; gs. Godbearnes, Ph. 647. godcund, adj., divine, God-given: asf. godcunde, E1. Io33.

gōddǣd, f., good deed: ip. gōddǣium, Ph. 669.

gōddōnd, m., benefactor: ap. göddēnd, El. 359.

godspel, n., gospel: gs. godspelles, E1. 176.

gold, n., gold: ns. El. I309; ds. golde, E1. 90, 331 ; as. El. I260; Ph. 506; is. golde, E1. 1024. See cynegold.

goldfæt, n., gold-setting: ds. goldfate, $\mathrm{Ph} .303$.

goldgim, m., golden jewel: ap. goldgimmas, El. I I I4. goldhoma, m., garment ornamented with gold: ap. goldhoman, El. 992.

goldhord, n., treasure: as. E1. 791. goldwine, m., king: ns. E1. 20 r.

gōma, m., jaw: ap. gōman, W. 62, 76.

gomen, n., pleasure: ns. E1. I265.

gemol, adj., old: nsm. Ph. I54;

gomel, Ph. 258; dsm. gamelum, E1. 1247.

gong(-), see gang(-).

Gotan, see Hrēogotan.

grǣdig, adj., greedy: nsm. Ph. 507. græf, see fold-, moldgræf.

græswong, m., grassy plain: ds. græswonge, $\mathrm{Ph} .78$.

grafan, see begrafan.

gram, adj., hostile: gpm. gramra,

E1. I 8; dpm. gramum, El. 43.

grāp, f., grip, grasp: dp. grāpum, E1. 760 .

grēne, adj., green: nsm. Ph. 298; nsn. Ph. 293 ; asf. Ph. I54; npm.

Ph. 13, 36, 78 .

grēot, m., earth, dust: gs. grēotes,

Ph. 556; ds. grēote, $\mathrm{Ph} .267$; is. grēote, El. 835 .

grim, adj., angry, fierce, grim: asm.

grimne, El. 525; apm. grimme, Ph. 46r; W. 62; apm. wk. grimman, W. 76. See ferh'-, heorugrim.

grima, m., helmet: ns. E1. 125.

grīmhelm, m., helmet: ns. E1. 258. grindan, see forgrindan.

grīpan, see forgripan.

gripe, m., grip: ds. El. I302. See stāngripe.

grund, m., ground: ds. grunde, E1.

III4; bottom: as. El. I299; W.

29 ; earth, world: as. El. I289;

Ph. I18, 498; abyss: as. E1. 944;

Pn. 59. See hęllegrund.

grundlēas, adj., bottomless: asm.

grundlēasne, W. 46 . 
grymetan, WI., roar: ptc. asn. grymetende, Pn. 7.

$\ddagger$ gryrefæst, adj., terribly firm: nsn. El. 760 .

gūdæd, f., formor deed: gp. güd̄̄da, Ph. 556. See also gīo, iū.

guma, m., human being, man: ns.

El. 531 ; Ph. 570 ; vs. El. 464 ; np. guman, El. 562, II86; Pn. 21 ; gp. gumena, El. 14, 201, 254, 278, 638, 1096, 1203; W. 62; dp. gumum, $\mathrm{Ph}$. 139 .

gumrice, n., kingdom of men: ds. E1. I221.

gūò, f., battle, combat: ds. gūðe, E1. 23.

$\ddagger$ gūơcwēn, f., queen: ns. El. 254, 331.

güơfreca, m., valiant chief: ds. gūofrecan, $\mathrm{Ph} .353$.

$\ddagger$ gūolgelǣca, m., warrior: ap. güðgelǣcan, E1. 43 .

† gūơheard, adj., brave: nsm. El. 204.

gūorōf, adj., strong in battle: npm. güờōfe, El. 273.

† gūơscrūd, n., armor: ns. El. 258. güoweard, m., battle-prince: - ns.

El. 14.

gyf-, see gif-.

gyfl, n., food: as. Ph. 4Io.

gyldan, sce $\bar{a}-$, for-, ongyldan.

gylden, adj., golden: nsm. El. I25. gylt, m., sin: ds. gylte, $\mathrm{Ph} .408$;

gp. gylta, El. 8I7; ap. gieltas,

Ph. 46I ; ip. gyltum, W. 74.

gȳman, Wi., notice, heed: opt.

3 sg. gime, El. 616.

gyrn, m. n., sorrow: is. gyrne, $\mathrm{Ph}$. 410.

gyrnan, WI., long, yearn: 3 sg. gyrneð, Ph. 462.
H.

habban, W3., have, hold, possess:

I sg. hafu, El. 808; hæbbe, Ph. I, 569; 3 sg. hafad, El. 825, 910; Ph. I75, 667; Pn. 30; W. 49, 72; I pl. habbal, Ph. 393; pret. I sg. hæfde, El. I253, I254; 3 sg. hæfde, E1. 63, 224, 412, 1130; 2 pl. hæfdon, El. 369; 3 pl. hæfdon, El. 49, 155, 249, 381, 415, 870,998 ; Ph. 408; opt. I sg. hæbbe, E1. 288 ; 3 sg. hæbbe, El. 594; 3 pl. hæbben, E1. 316, 408; inf. El. 621 .

hād, m., class: ds. hāde, El. 740; form, shape, nature: ds. hāde, E1. 72 ; as. E1. 336,776 ; Ph. 372 , 639; inanner: as. E1. 1246. See bisceop-, cild-, geogoờ-, sācerd-, wifhād.

hādor, adj., radiant: asn. Ph. 2 I2.

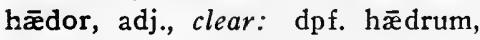
E1. 748 .

hǣdre, adv., brightly: Ph. II5; clearly: Ph. 6I9.

hæft, m., bondage, imprisonment: ns. El. 703.

hæftan, see gehæftan.

hæftnȳd, d., bondage, thraldom: ds. hæf tnēde, El. 297.

hægl, m., hail: ns. $\mathrm{Ph} .60$; gs. hægles, Ph. 16.

hǣl, f., hail, greeting: as. El. I003. hǣlan, WI., save, redeem: ptc. nsm. hæ̈lende, $\mathrm{Ph} .590$.

hæle, m., man: ns. $\mathrm{Ph} .554$.

Hælend, m., Saviour: ns. El. 809, 862 , 912, 920; Ph. 650; gs. Hǣlendes, El. I063; as. Ph. 616; God: vs. El. 726 .

hæled, m., man, warrior: ns. El. 640,936 ; as. El. 538 ; vs. E1. 5II; np. El. 1006, I297; Pn. 20 ; 
hæleb, El. 273; W. 22; gp. hæleða, E1. 73, I 56, I88, 852, 1054, I108, 1204; hælepa, Ph. 49, I35, I70; W. 40; dp. hæleठum, El. 66I, 671, 679, 709, го12, г273.

hælo, f., cure, healing: as. El. I216; hǣlu, W. 87.

hærfest, m., harvest: ds. hærfeste, Ph. 244.

hǣs, f., behest: as. E1. 86.

hætan, see onhæitan.

hæठ̀en, adj., heathen: npm. hæ̋ene,

El. I26; dpf. hǣ ðenum, El. 1076. hætu, f., heat: ns. Ph. 17.

haga, see ān-, bord-, turfhaga. hāl, see wānhāl.

hālig, adj., holy: nsm. El. 218, 679, 740, 75I, 936, ı087, I 145; Ph. I83; nsm. wk. hālga, E1. 75I, I094; Ph. 8I, 4I8; nsf. El. 625, 885 ; Ph. 626, 641 ; nsf. wk. hālige, E1. 720, IOI2, I224; nsn. El. 976, I 95 ; nsn. wk. hālige, El. 429; gsm. hāliges, Ph. 79; hālges, Ph. 399; gsm. wk. hālgan, El. 86; dsf. wk. hālgan, El. I006, I054, I204; asm. wk. hālgan, El. 457, 785; Ph. 339; asf. hālge, Ph. 476; hālige, El. 355; asf. wk. hālgan, El. I032; asn. El. 758,843 ; asn. wk. hālige, E1. I07, I28, 442, 70I, 84I ; hālge, $\mathrm{Ph}$. 6I9; npm. hālge, $\mathrm{Ph}$. 447, 539 ; npf. hālge, Ph. 73 (inviolable?); gpm. hāligra, E1. 821; Ph. 656; dpm. hālgum, E1. 988; Ph. 42I, 5I5; apf. hālige, El. 333, 364, 670, 853, II69; ipm. hālgum, Ph. 206, 444. See gāsthālig.

hals, m., neck: ns. Ph. 298.

hām, m., home: gs. hāmes, $\mathrm{Ph} .483$; ds. Ph. 593, 599; as. El. I43, I48, 921; Ph. 244.

hand, f., hand: dp. handum, El. 805,843 ; ap. handa, E1. 457. $\ddagger$ handgeswing, n., combat: ns. El. I 5 .

hasu, adj., gray: nsm. wk. haswa, Ph. I2I.

haswigfeòere, adj., gray-plumed: nsm. wk. haswigfeora, Ph. I53.

hāt, adj., hot: nsm. El. II33; Ph. 521 ; nsn. El. 628; dsm. hātum, E1. 1297 ; super. nsf. hātost, $\mathrm{Ph}$. 209 ; asn. hātost, El. 579; consuming: nsm. wk. hāta, Ph. 613. See fȳrhāt.

hata, see lēodhata.

hātan, rd., call, name: 3 sg. hāteð, E1. 756; 3 pl. hātađ, Ph. I73; pp. hāten, El. 439, 505; Ph. 86; Pn. I3; bid, command: pret. 3 sg. heht, El. 42, 79, 99, I05, I29, I 53, 276, 691, 863, 877, 999, 1003, 1007, 1023, I05I, I 161, I I98, I202; hēt, El. 2I4; opt. pret. 3 sg. hehte, E1. 509; imper. sg. hāt, E1. I I73.

hāte, adv., fervently: $\mathrm{Ph} .477$.

hē, pron., he: nsm. El. 9, I3, I5, etc. (64 times); Ph. 5, I42, I46, etc. (39 times); Pn. I7, I8, 30, 3I, 59, 62; W. 4I, 44, 49, 66, 76; nsf. hēo, El. 254, 570, 957, I023, I 36 , I I43, I 202 ; hīo, El. 268, $325,384,420,568,598, \cdot 7$ I0, 966, 1008, I015, I 140, I158, I219; $\mathrm{Ph}$. 4I3; nsn. hit, E1. I70, 27I, 789, 882, II55; Ph. 53I ; gsmn. his, E1. I47, 162, I93, etc. (I4 times); Ph. 2II, 262, 267, etc. (20 times) ; Pn. 34; W. 40, 43, 55, 63, 74; gsf. hiere, El. 222; hire, El. I200; dsmn. him, El. I8, 72, 76, etc. (40 times); Ph. 88, I67, I79, etc. (2I times); W. $25,4 \mathrm{I}, 67$, 73, 86; dsf. hire, E1. 223, 567, 609 , etc. (I3 times); asm. hine, El. I4, 200, 440, etc. (I3 times); Ph. I06, II I, 28I, 365, 380, 420; W. 5I, 65; asf. hie, El. 677, I I46; 
asn. hit, E1. 350, 702, 979; $\mathrm{Ph}$. 84 ; np. hīe, El. 48,68 , etc. ( 35 times); hīo, El. 166, 324, 326, 569, 571, 835; hēo, El. I16, 382, 555, 565; hì, Ph. 247, 327, 389, 402, 4IO, 4II , 4I5, 476, 489, 658; W. 32, 58; hȳ, Ph. 48ז, 609; W. 12, 35, 36; gp. hira, E1. 174, 359, 45I, III2, I209, I232; W. 75; hiera, El. 360; hyra, Ph. 405, 543; dp. him, El. 182, 319, 325, etc. (I9 times) ; $\mathrm{Ph} .36,39, \mathrm{I} 60$, etc. (I8 times); ap. hie, E1. 208, I 36 ; hì, Ph. 246, 395.

heafela, m., head: np. (as sing.) hea felan, $\mathrm{Ph} .604$.

hēafod, n., head: ns. Ph. 293; ds. hēafde, $\mathrm{Ph} .604$; is. hēafde, $\mathrm{Ph}$. I 43.

$\ddagger$ hèafodwylm, n., tears: ns. El. I 133 .

hēah, adj., high, lofty: nsm. Ph. 590 ; nsm. wk. hēa, Ph. 447 ; nsf. Ph. 626; asm. hẻanne, E1. 424, 983; Ph. II2, I7I, 202; asn. Ph. 429; W. 22; comp. nsn. hērre, Ph. 28; super. nsf. hīhst, E1. I97; exalted: asm. hēanne, Ph. 39I.

hēah, adv., high: Ph. 23, 521, 64I ; hëa, Ph. 32, 121.

hẽahcyning, m., king in the highest: ns. $\mathrm{Ph} .129,446$; as. $\mathrm{Ph}$. 483.

hēahęngel, m., archangel: gp. hēahengla, El. 75I.

hēahmægen, m., mighty power: ns. E1. 753 ; as. El. 464 .

hēahmōd, adj., mettlesome, proud: nsm. Ph. II 2 .

hēahseld, n., throne: as. Ph. 6rg. hēahsetl, n., throne: ds. hēahsetle, Ph. 5I5.

hēahstefn, adj., high-prowed: apn. W. I3.

heal, see medoheal. healdan, rd., hold: pret. 3 sg. hēold, E1. 824; inf. El. 449, 758; keep, observe: 3 sg. healdeð, $\mathrm{Ph} .457$; 3 pl. healdap, Ph. 391 ; pret. 3 pl. hēoldon, El. I56; opt. 2 sg. healde, El. II69; inf. Ph. 399. See be-, gehealdan.

healf, f., side: gp. healfa, E1. 548;

Ph. 206, 336; Pn. 67; ap. halfa, E1. 955; healfe, E1. I180.

\pm healfcwic, adj., half-dead: npm. healfcwice, El. I33.

healsian, W2., adjure: I sg. healsie, E1. 699.

healt, adj., halt: npm. healte, El. I 2 I 5 .

hēan, adj., humiliated, abject: nsm. Ph. 554; asm. hēanne, E1. 70I ; poor: npm. hēane, El. 1216; lowly: dpm. hēanum, W. 43.

hēannes, f., height: ds. hëannesse, El. I125; Ph. 63I (in, on hēannesse, in the highest).

hēap, m., host, multitude, troop, throng: ns. El. 14I, 549; as. El. 1206 ; is. hēape, El. 269; ip. hēapum, Ph. 336; Pn. 67.

heard, adj., hard: dsm. heardum, El. 809; comp. npm. heardran, E1. 565 ; cruel: nsm. E1. 704 ; isf. heardre, E1. 83; grievous: nsn. El. I 5 ; dpn. heardum, E1. I80; stern: asn. El. 557 ; severe: nsm. wk. hearda, Ph. 58, 613. See gū̃-, nīð-, бræc-, ठrohtheard.

hearde, adv., very: E1. 400.

heardęcg, adj., with hard edge: nsn. El. 758.

hearding, m., hero: npm. heardingas, E1. 25, I30.

hearm, m., injury: gp. hearma, E1. 912.

hearm, adj., malicious, fiendish: gpm. hearmra, Ph. 44I. 
hearmloca, m., prison: ds. hearmlocan, E1. 695.

hearpe, f., harp: gs. hearpan, $\mathrm{Ph}$. I35.

¥ heað̌ofręmmende, adj., fighting: nsm. El. 130.

heaðorōf, adj., brave, valiant: gsm. heaporōfes, Ph. 228.

hearowylm, m., fierce flame: gp. heaðowelma, El. 579; ds. heaðuwylme, E1. I305.

headrian, see geheadrian.

hębban, VI, lift, raise, rear: $3 \mathrm{sg}$. hefeð, Ph. II2; pret. 3 pl. hōfon, El. 25: inf. El. 107; pp. hafen, E1. 123, 890. See āhębban.

hęfgian, see gehęfgian.

hēgan, see gehēgan; með̌elhēgende.

helan, IV, hide, conceal: inf. El. 703, 706. See bihelan.

hęlian, see behęlian.

hęll, f., hell: gs. helle, El. I230;

W. 78 ; as. helle, W. $45,68$.

hęlledēofol, m., devil: ns. El. gor. hęllegrund, m., abyss of hell: as.

E1. 1305 .

hęllesceaða, m., dcvil: as. hellesceapan, E1. 957.

$\ddagger$ hęllfiren, f., hellish sin: gp. hellfirena, Pr. 6.

helm, m., defender, protector: ns.

E1. I48, I76, 223; as. E1. 475.

See grim-, heoloo-, nihthelm.

help, f., help, succor: ds. helpe, El.

679, Iо12; as. helpe, El. Iо32;

Ph. 650.

hęngest, see faroð̀-, wāghęngest. hēo, see hiw.

heofon, m., heaven: ns. heofun, El.

753 ; gs. heofones, El. I230; Ph.

I83; as. El. 728; Ph. I3I ; np. heofonas, $\mathrm{Ph} .626$; gp. heofona, El. 699; Ph. 446, 483; heofuna, Ph. 63I; dp. heofonum, El. IOI, I 88,527 ; Ph. 58, 73, I29, 39I,
444, 52I, 64I, 656; heofenum, El. $83,801,976$.

heofoncyning, m., king of heaven: gs. heofoncyninges, El. I70; $\mathrm{Ph}$. 6I6; heofoncininges, E1. 748; ds. heofoncyninge, El. 367.

heofonhrōf, m., cope of hcaven, vault of heaven: ds. heofunhrōfe, $\mathrm{Ph}$. I73.

heofonlī, ađj., heavenly: nsm. El. 740, I 145.

heofonrice, n., kingdom of heaven: gs. heofonrices, El. 197, 445, 629, 718, II25; Ph. I2; ds. E1. 62 I.

heofonsteorra, m., star: np. heofonsteorran, El. III3.

heofontungol, n., star of heaven: dp. heofontunglum, $\mathrm{Ph} .32$.

$\$$ heolorhelm, m., helmet of invisibility: is. heolophelme, W. 45. heolstor, n., darkness, obscurity: ds. heolstre, El. III3; is. heolstre, El. $1082 ; \mathrm{Ph} .418$.

heolstorcofa, m., dark abode, tomb: np. heolstorcofan, $\mathrm{Ph} .49$.

$\$$ heolstorhof, n., abode of darkncss: ap. heolstorhofu, El. 764 . heonan, adv., hence: $\mathrm{Ph}$. I.

heorte, f., heart: gs. heortan, El. I224; Ph. 552; ds. heortan, El. 628 ; Ph. 477.

† heorucumbul, n., ensign: as. El. I07; heorucumbol, El. 25.

heorudrēorig, adj., wounded: npm. heorudrēorige, El. I215; disconsolate, disheartened: $\mathrm{gsm}$. heorodrēorges, $\mathrm{Ph} .217$.

heorugrim, adj., dire, fierce: $\mathrm{npm}$. heorugrimme, El. IIg.

hēr, adv., here: El. 66I ; Ph. 23, $3 \mathrm{I}, 536,638,668$; W. 43 .

hęre, m., army, multitude, troops:

ns. E1. 65 ; gs. herges, El. I43; heriges, El. 205; ds. herge, El. 52 ; as. El. 58 ; gp. heria, El. I01; herga, El. I15, 210; heriga, 
E1. I48; dp. hergum, El. 32, 4I, I IO, I80; herigum, El. 406.

hęrefeld, m., battle-field: ds. herefelda, El. I26; ap. herefeldas, El. 269.

¥ hęrehūð, f., prey: as. herehūbe, W. 61 .

hęremægen, n., multitude, assembled people: ds. heremægene, E1. 170 .

† hęremeðel, m., assembly: ds. heremeðle, El. 550.

hęreræswa, m., leader of the army: np. hererǣswan, El. 995.

hęresī', m., warlike expedition: ds. heresiöe, El. I33.

hęretēma, m., leader of the army:

ds. heretēman, El. Io.

hęreðrēat, m., army: ds. here-

prēate, El. 265.

hęreweorc, n., battle, war: gs.

hereweorces, E1. 656.

hęrian, WI., adore, praise, worship, magnify: 3 pl. heriab, El. 453; herga $\delta$, Ph. 54I, 616; pret. 3 pl. heredon, E1. 893; inf. herigean, El. 920 ; pp. gpm. hergendra, El. I097; dpm. hergendum, El. I22I. hērre, see hēah.

herwan, see hyrwan.

hęte, m., hate: as. El. 424.

hęttend, m., enemy, hater: np. El. II9; hettende, Ph. 44I; dp. hettendum, El. I8.

hidercyme, m., advent: as. $\mathrm{Ph} .42 \mathrm{I}$. hīehðu, f., height: ds. hiehða, El. I087.

Hierusalēm, pr. n., Jerusalem: d.

Ierusalēm, E1. I056; a. E1. 273. hige(-), see hyge(-).

hild, f., war: ns. El. I8; ds. hilde, E1. 32 ; battle: ns. E1. I49; ds. hilde, El. $49,52,65$; is. hilde, El. 83.

hildedēor, adj., bold, brave: nsm. E1. 936. ¥hildęgesa, m., terror of battle: ns. El. II 3 .

hildenǣdre, f., battle-adder, spear: np. hildenǣdran, El. I4I ; ap. hildenǣdran, El. II9.

hilderinc, m., warrior: np. hilderincas, E1. 263.

$\ddagger$ hildesęrce, f., coat of mail: dp. hildesercum, El. 234.

hildfruma, m., commander: ns. El. IO, IOI.

hindan, adv., behind: Ph. 293.

$\ddagger$ hindanweard, adj., behind: npn. Ph. 298.

¥ hinderweard, adj., backward: nsm. Ph. 3I4.

hinsī̄, m., death: ds. hinsīpe, W. 68.

hīw, n., color, hue: ns. Pn. 25; gp. hiwa, Pn. 20; appearance: ns. W. 8 ; ds. hiwe, Ph. $3 \mathrm{II}$; is. hīwe, Ph. 291 (color?), 302; beauty: ds. hiwe, $\mathrm{Ph} .8 \mathrm{r}$; form: as. hēo, El. 6.

hīwbeorht, adj., radiant: nsm. El. 73.

hladan, see gehladan.

hlæ̈fdige, f., lady: vs. E1. $400,656$. hl̄̄w, m. n., mound: np. hlǣwas, Ph. 25.

hlāf, m., bread: ns. E1. 6r3; gs. hlāfes, E1̣. 6 I6.

hlāford, m., lord: gs. hlāfordes, El. 265 ; as. E1. $475,983$.

hleahtor, m., jubilation: is. hleahtre, E1. 920.

hlēapan, rd., run: pret. 3 pl. hlēopon, E1. 54.

$\ddagger$ hlęmman, Wr., snap: 3 sg. hlemmeð, W. 6r. See bihlęmman.

hlęnce, see wælhlęnce.

hlēo, m. n., protection: ns. El. 99, 150 ; as. E1. 507, 616; Ph. 374, 429 ; vs. El. 1074.

hleonian, W2., overhang, impend:

3 sg. hleonad, $\mathrm{Ph} .25$. 
hlēor, n., face: as. El. I099, II33.

hlēoð̀or, n., melody, lay: gs.

hlēoðres, Ph. I3I; gp. hlēopra,

Ph. I2; utterance: np. hlēopor,

$\mathrm{Ph}$. 656. See efen-, swēghlēoðor.

hlēoðorcwide, m., commandment, decree: as. hlēoporcwide, $\mathrm{Ph}$. 399.

hlēoơrian, W2., chant: 3 pl. hlēopriað, Ph. 539; speak: inf. El. 901.

hlëđa, see gehlēða.

hlïdan, see be-, onhlidan.

hlifian, W2., tower, rise: 3 sg. hlifad, $\mathrm{Ph} .604 ; 3$ pl. hlïfiad, $\mathrm{Ph}$. 23, 32. See oferhlifian.

hlihhan, VI, rejoice: ptc. nsm. hlihhende, El. 995.

hlinc, m., bank, ledge: np. hlincas, $\mathrm{Ph} .25$.

hlinduru, f., gate: ap. W. 78 .

hlì, see beorh-, stānhliò.

hlūd, adj., loud: nsm. El. I273.

hlūde, adv., loudly: El. I Io, 406.

hlūttor, adj., bright, clear: nsm. Ph. 183 .

hlyn, m., sound, tone: ns. $\mathrm{Ph} . \mathrm{I} 35$. hlyst, f., attention, listening: as. $\mathrm{Ph}$. I 43 .

hlȳt, m., number, throng: ds. hlȳte, El. 821 .

hnāg, adj., deplorable, lamentable: gsf. hnāgre, El. 668.

hnęsce, adj., soft: nsn. El. 615.

hof, n., court: ds. hofe, El. 557; cell: ds. hofe, El. 712; prison: ds. hofe, El. 834. See heolstor-, morðor-, y'ohof.

\section{hoga, see ānhoga.}

hold, adj., gracious: nsm. Ph. 446. holm, m., sea: ds. holme, W. 5I ; as. EI. 983 .

holmoracu, f., turmoil of the sea: as. holmpræce, El. 728; Ph. II 5. holt, n., forest, grove, wood: ns.
Ph. 8I ; gs. holtes, El. II3; Ph. 73, 429. See wuduholt.

holtwudu, m., forest, wood: ds. holtwuda, Ph. I7I.

họma, see feð̌er-, gold-, lïchọma. hōn, rd., hang, crucify: pret. 3 pl.

hēngon, El. 424. See ā-, gehōn. hond, f., hand: as. $\mathrm{Ph}$. 44I.

hord, n., treasure: as. El. I092.

See feorh-, goldhord.

$\ddagger$ horh, m. n., defilement, filth: is. horu, El. 297.

horn, m., horn: np. hornas, Ph. $\mathrm{r} 34$. hornbora, m., trumpeter: np. hornboran, El. 54.

¥ hospcwide, m., blasphemy, reviling word: as. El. 523.

hrā, n., body: as. E1. 579; corpse: ns. E1. 885; Ph. 228.

hrædlice, adv., quickly: El. 1087.

hraobe, adv., quickly: El. 76, 406; immediately: $\mathrm{El} .669,7 \mathrm{I0}$; rabe, El. 372.

¥ hrāwērig, adj., weary in body, weary of life: nsm. Ph. 554.

hrefen, m., raven: ns. El. 52; hrefn, El. I Io.

hrēmig, adj., rejoicing, exultant: nsm. El. I49; Ph. I26; nsf. El. II38; npm. hrēmige, $\mathrm{Ph} .592$.

hrēodan, see gehrēodan.

hreodian, W2., sift: pret. I sg. hreodode, El. I239.

hrēof, adj., leprous: npm. hrēofe, El. 1215; rough: dsm. hrēofum, W. 8.

hrēoh, adj., rough, angry: gpm. hrēora, $\mathrm{Ph} .45$; fierce: nsm. $\mathrm{Ph}$. 217 ; nsn. Ph. 58.

hrēosan, II, fall, descend: 3 sg. hrēoseð, Ph. 60 ; inf. El. 764 . hrēoð̀a, see bordhrēoða.

hrēow, see wælhrēow.

hrērend, see foldhrērend.

Hrēðas, pr. n., Goths: g. Hrēða, El. 58. 
hrēōēadig, adj., glorious: nsm. El. I 195.

hreð̈er, m. n., heart, soul: as. El. II 45 .

hreôerloca, m., bosom, breast: as. hređerlocan, El. 86.

Hrēögotan, pr. n., Goths: n. El. 20. hrēöig, see ēad-, wilhrēōig.

hrim, m., hoar-frost: ns. Ph. 6o; gs. hrimes, $\mathrm{Ph}$. 16.

hring, m., sound: ns. El. II32.

hring, m., orb: ns. Ph. 305; ring, circle: is. hringe, $\mathrm{Ph} .339$; domain, province: ds. hringe, W. 40. See brïdelshring.

hringedstefna, m., ship: np. hringedstefnan, El. 248.

hrōf, m., roof, height: as. El. 89; ap. hrōfas, Ph. 590. See heofonhrōf.

hrōpan, rd., make proclamation: pret. 3 pl. hrēopan, El. 54; hrēopon, El. 550.

hrōr, adj., brave, valorous: gpm. hrōrra, El. 65 .

hrōðer, m., comfort, help: ds. El. I6, II60.

hrūse, f., earth: ds. hrūsan, El. 218, $625,843,1092$.

hryre, m., downpour: ns. Ph. I6; destruction: ds. $\mathrm{Ph} .645$.

hū, adv., how: El. 176, 179, 185, $335,367,456,474,512,56 \mathrm{I}, 6 \mathrm{II}$, $632,643,954,960,997$; Ph. 342, $356,359,389$.

Hūgas, pr. n., Hugs: n. El. 21. Hūnas, pr. n., Huns: g. Hūna, El. 20, 32, 4I, 49, 58, 128, 143 .

hund, indecl. n., hundred: El. 2, 379,634 .

hungor, m., hunger: ns. $\mathrm{Ph} .6 \mathrm{r} 3$; W. $5 \mathrm{I}$; gs. hungres, El. 6I6, 70I ; ds. hungre, El. 703 ; is. hungre, El. $613,687,695,720$.

hūru, adv., in truth, verily: El. I047, II 50. hūs, n., abode, house: ns. Ph. 212, 228 ; as. $\mathrm{Ph} .202$, 217; body: as. El. $88 \mathrm{I}, 1237$.

hūơ, f., booty, plunder: ds. hūðe, E1. 149. See hęrehūơ.

hwā, pron., who: nsn. hwæt, El. I6I, 4I4, 532, 649, 903, II60; asn. hwæt, El. 400, 1165; isn. hwan, E1. II58 (tō hwan, why). See ǣg-, gehwā.

hwæl, m., whale: ns. W. 47 ; gs. hwæles, W. 8I ; ds. hwale, W. 3 . hwǣr, adv., where: E1. 205, 217, $429,563,624,675,720$, I103. See gehw̄̄r; āwer.

hwæs, see ǣghwæs.

hwæt, adj., active, brave: npm. hwate, El. 22. See dæd-, flyht-, fyrd-, lof-, sundhwæt.

hwæt, intj., lo: El. 293, 334, 364, $397,670,853,920$.

hwæס̄er, see gehwæסेer.

hwæסेre, adv., yet, still, nevertheless: El. 719; hwæbre, Ph. 222, $366,443,640$.

hwætmōd, adj., brave, courageous: npm. hwætmöde, El. 1006.

hweorfan, III, be active: 3 pl. hweorfad, Ph. 500; pass: 3 pl. hweorfad, Ph. 519; turn: 2 pl. hweorfad, Pr. 6; escape: inf. W. 8I. See gehweorfan.

hwil, f., time, while: as. hwile, El. $479, \quad 582,625$. See swylt-, wræchwil.

hwilen, adj., transitory: asf. wk. hwilnan, W. 87. See unhwilen. hwit, adj., white: nsm. El. 73; npn. Ph. 298.

hwōn, see lȳthwōn.

hwonne, adv., until: E1. $254 ; \mathrm{Ph}$. 93, 102; when: $\mathrm{Ph} .114,334$.

hwōpan, rd., threaten, menace: opt. 3 pl. hwōpan, El. 82; inf. Ph. 582.

hwylc, pron., which, what: dsm. 
hwylcum, El. 85I ; dsf. hwylcre, El. 858; asm. hwylcne, El. 862; asf. hwylce (swā hwylce, whatsoever), Pr. 5, asn. E1. 608. See ǣ-, ge-, nāthwylc.

hwyrft, m., course: dp. hwyrftum, E1. I ; relief: as. W. 78. See ymbhwyrft.

hycgan, see for-, wiðhycgan; dēop-, stī̄o-, wið̋erhycgende.

hȳdan, Wr., hide, conceal: pp. hȳded, E1. 218; npm. hȳdde, El. I 108 . See à-, be-, gehȳdan.

hyder, adv., this way: El. 548.

hȳdian, see gehȳdian.

hȳdig, see ān-, glēaw-, stīò-, wọnhȳdig.

hygd, see gehygd.

hyge, m., heart, soul, mind: ns. hige, El. 84I, 995, 1082; ds. El. II69; Pr. 6; hige, El. 809; as. E1. 685, 1094; is. hige, $\mathrm{Ph} .477$.

hygefrōfor, f., consolation: as. higefrōfre, El. 355.

† hygegǣlsa, adj., sluggish, lazy: nsm. Ph. 314 .

hygegēomor, adj., sad, sorrowful: npm. hygegēomre, El. 1216; higegēomre, El. I297.

hygeglēaw, adj., prudent: vpm. higeglēawe, E1. 333 .

hygerūn, f., heart's secret: as. hygerūne, El. rog9.

hygeðanc, m., thought: dp. higebancum, E1. 156 .

hyht, m., hope: ns. Ph. 423, 480; Pn. 73 ; as. El. 798 ; joy: as. El. 629 ; gp. hyhta, El. 197.

hyhtful, adj., joyful: nsm. El. 923. hyhtgifa, m., giver of joy: ns. El. 852.

$\ddagger$ hyhtlīce, adv., gaily: $\mathrm{Ph} .79$.

hyldan, see onhyldan.

hȳnan, see gehȳnan.

hȳnơu, f., affliction, misery: dp. hȳnðum, El. 210. hȳran, Wr., hear: pret. I sg. hÿrde, E1. 240 ; Pr. I; 3 sg. hỹrde, Ph. 129; I pl. hỹrdon, El. 538, 670, 853 ; Pn. 8 ; 3 pl. hȳrdon, El. 572 ; obey, hearken to: pret. 2 sg. hȳrdest, El. 934; 3 pl. hȳrdon, W. 75 ; opt. pret. 3 pl. hȳrdon, E1. 839, I210; inf. E1. 367. See gehȳran.

hyrdan, see onhyrdan.

hyrde, m., ruler, prince: ns. El. 348,859 .

hyrst, f., armor: ip. hyrstum, El. 263.

hyrstan, see gehyrstan.

hyrwan, Wr., despise: pret. 3 pl. hyrwdon, El. 355 ; neglect, disregard: pret. 3 pl. herwdon, El. 387. See gehyrwan.

hyse, m., son, youth: vs. El. 523 . hȳð, f., harbor: ds. hȳðe, El. 248. hȳòan, see āhȳoan.

\section{I.}

ic, pron., $I$ : ns. El. 240, 288, 319, etc. (49 times); Ph. I, 547, 552, 553, 561, 568; Pn. 34; W. I; Pr. I, 7 ; gs. min, El. 347 ; ds. mē, El. I63, I64, 317, etc. (I6 times); Ph. 567; Pr. 5, 9; as. mec, E1. 469, 528, 819, 910, 1078; mē, El. 355, 361, 577, 700, 920 ; np. wē, El. 364, 397, 399, etc. (I5 times); Ph. 393, 573, 668, 670; Pn. 2, 8; W. 85, 88; Pr. I2; dp. ūs, El. 400; Ph. 23, 29, 3I, 424, 650, 655, 667; Pn. 62, 7I; Pr. I4; ap. ūsic, El. 533, Pl. $630 ;$ ūs, El. 637.

ican, Wr., increase: 3 sg. iceð, El. 905.

ides, f., lady, queen: ns. E1. 405; gs. idese, El. 229; as. idese, El. 241.

idge, Ph. 407. (?) 
ier-, see yr-.

iewan, see geiewan.

iglond, n., island: ns. Ph. 9. See èalond, èglond.

ilca, pron., the same: nsn. ilce, $\mathrm{Ph}$. 379 ; asf. ilcan, El. I83; asn. ilce, El. $43^{6}$.

ilde, see alde.

in, adv., in: El. 122, 846; W. 58, 79. in, prep. w. dat., in, on, upon: El. 177, 196, 210, etc. (56 times); Ph. 107, 168, 20r, etc. (38 times) ; W. 30, 71, 75, 88; Pr. I6; w. acc., in, into, to: El. 6, 9, 201, 274, $305,336,452,693,765,775,776$, 931, 943, 944, 1026, 1089, I 123, I 205, I 287, 1290, I 299, I303, I 305 ; Ph. 139, 200, 416, 44I, 487, 509, $517,520,556,567,568,572,597$, 640, 649, 658, 660, 661 ; Pn. I7, 59; W. I6; Pr. 5; throughout: El. 1209; Ph. 77, 509, 517.

in, prep. (Lat.), in: w. abl., Ph. 669. inbryrdan, see onbryrdan.

indryhto, f., blessing: dp. indryhtum, Ph. 198.

ingemynd, f. n., regard: as. El. I253.

¥ ingemynde, adj., impressed: asn. E1. 896 .

ingeơanc, m., inward desire, earnest purpose: as. ingepanc, El. 680.

innan, adv., within: El. I057; $\mathrm{Ph}$. 200, 301; Pn. 4 (geond innan, throughout).

innod, m., breast: as. E1. II46; inwards: ds. innope, W. 55.

instapes, adv., immediately: El. I 27.

inwit, n., iniquity, malice: as. E1. 207.

inwitðanc, m., wicked thought: ip. inwitbancum, E1. 308.

Iōb, m., Job: g. Iōbes, Ph. 549.

Iōsēph, pr. n., Joseph: g. Iōsēphes, 788 ; Pn. 2 I. ir-, see yr-.

Israhelas, pr. n., Israelites: $\mathrm{g}$. Israhela, El. 338, 36r, 433, 800 .

iū, adv., formerly, long ago, once: Ph. 4I. See also gīo, gūdǣd.

Iūdas, pr. n., Judas: Iscariot, a. El. 922; Bishop Cyriacus, n. El. $418,586,609,627,655,667,682$, $807,860,875,935,1033$; a. El. $600,922,1056$.

Iūdēas, pr. n., Jews: g. Iūdēa, El. 209, 268, 837 ; d. Iūdēum, El. 216, $328,977,1203$; a. Iūdēas, El. 278.

K.

kalend, m., month: a. E1. I229.

\section{L.}

lā, intj., lo, behold: El. 903.

lāc, n., gift, present: as. E1. II37; ds. lāce, El. 1200.

lācan, rd., flicker, flare: ptc. nsm. lācende, El. 580, I I I ; flap : $3 \mathrm{pl}$. lācað, Ph. 316; fly: ptc. nsm. lācende, El. 900. See geondlācan; dareð-, faroð-, lyftlācende.

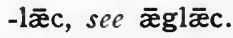

-lǣca, see āg-, gelæ̈ca.

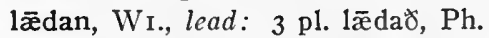

345 ; inf. El. 24I, 69I ; pp. læeded, Ph. 49I; carry: 3 sg. læ̈deb, Ph. 577; spread: pp. 1æded, El. 969; hold: 3 sg. 1ǣdeð, El. II84. See ā-, gelædan; ūplǣende.

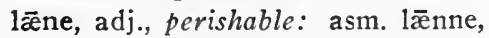
Ph. 220; apm. Ph. 489, 505; fleeting, transitory: nsn. El. I27I; gsn. wk. lǣnan, Ph. 456; asf. wk. lǣnan, W. 64 ; asn. wk. Ph. 48I.

læ̈ran, WI., teach, instruct: pret. 3 sg. lärde, El. 529; pp. npm. 
læ̈rde, El. I73, I9I; advise, admonish: I sg. Ī̄re, E1. 522; inf. El. I206. See forlǣran; ælǣrend.

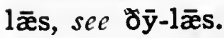

lǣssa, adj. comp., less: asn. 1̄̄sse, E1. 48 .

lǣstan, Wr., carry out, follow: inf. E1. 368. See gefullǣstan; gelæstan.

1̄̄tan, rd., let, allow: 3 sg. 1æteð, W. 65 ; pret. 3 pl. lëton, E1. 237 , 250; imper. sg. 1æt, El. 819; cause: pret. 3 sg. leort, El. I 105. See forlǣtan.

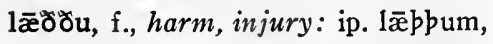
Ph. 582 .

lāf, f., rcmains: gs. lāfe, Ph. 376; as. lāfe, Ph. 575 ; leavings, relics: as. läfe, Ph. 269, 272, 276.

lagu, m., flood, water: as. $\mathrm{Ph}$. гог. lagufæsten, n., sea: as. E1. IоI7; lago fæsten, El. 249.

laguflōd, m., flood, river: gp. laguflōda, Ph. 70.

lagustrēam, m., river: ds. lagostrēame, El. I37; np. lagustrēamas, $\mathrm{Ph} .62$.

lām, m., clay, dust: is. lāme, $\mathrm{Ph}$. 555.

lama, m., a lame person: np. laman, EI. I2I4.

land, see lond.

lang(e), see long(e).

lār, f., instruction, doctrine, lore: ds. lāre, El. 286; as. lāre, El. $335,368,388,432,929$, І I66, І 246 ; Ph. 476; dp. lārum, El. 839, г210; W. 75; instigation: ip. lārum, El. 497.

lārēow, m., scholar: np. lārēowas, Ph. 424.

lārsmio, m., scholar: ap. lārsmið̀as, E1. 203.

lāst, m., course, trace, track: ds. lāste, El. 30; Ph. 440 (on lāste, behind).

late, adv., late: El. 708; slowly: Ph. 3i6.

lāo, n., harm, injury, misfortune: gs. lāpes, Ph. 53; Pn. 32.

lāo, adj., detested, hated: asn. El. 94 ; gpm. Iāơra, El. I42; dpm. lāoum, El. 30 ; super. nsf. lāđost, E1. 978 .

lāogenïola, m., enemy, persecutor: ns. Ph. 50.

laðian, W2., invite, summon: $3 \mathrm{sg}$. lapap, El. 55I ; pp. laðod, El. 556 ; npm. laðode, El. 383.

lāolīc, adj., loathsome, hateful: asn. E1. 520.

lāttēow, m., leader: ns. lāttiow, El. 520, 899; gs. lāttēowes, E1. 1210. laus, f. (Lat.), praise: abl. s. laude, $\mathrm{Ph} .676$.

lēaf, n., leaf: np. Ph. 39; dp. lëafum, El. 1227.

-lēafa, see gelēafa.

lēaffull, see gelēaffull.

lēafscead, n. f., leafy shade: ds. leafsceade, Ph. 205.

leahtor, m., iniquity, sin, transgression: gp. leahtra, E1. 839; $\mathrm{Ph}$. 5I8; ap. leahtras, Ph. 456 ; ip. leahtrum, W. 66.

leahtorlēas, adj., sinless: npm. leahtorlēase, El. I209.

lēan, n., recompense, reward: ds. lēane, Ph. 386,475 ; as. El. 825 . See sige-, sigorlëan.

lēas, n., falsehood: ds. lēase, El. 576 . lēas, adj., deprived of: nsm. El. 693; asm. lēasne, El. 945; dp. lēasum, $\mathrm{Ph}$. 454; free from: nsm. El. 422, 778; asm. lēasne, E1. 497. See ār-, frið̀e-, gāst-, grund-, leahtor-, męte-, sāwl-, sorglēas. 
lēas, adj., false: npm. lēase, El. I300; deceptive: asm. lēasne, W. 66.

lēaslic, adj., deceitful: apf. lēaslīce, W. 69.

lēasung, f., lie: ns. El. 580; dp. lēasingum, E1. 1123; ap. lēasunga, El. 689.

lęccan, Wi., irrigate, water: $3 \mathrm{pl}$. leccap, Ph. 64.

lēf, adj., weak: npm. lēfe, El. I2I4. lēg, see àd-, tēonlëg; lig.

¥lēgen, adj., fiery, flaming: isn. lēgene, El. 757.

leger, n., bed, couch: ds. legere, El. $602,723,883$; disease: ns. Ph. 56.

lęgu, see feorhlęgu.

lęncten, m., spring: ns. El. I227;

ds. lenctenne, $\mathrm{Ph} .254$.

lẹng, see lọnge.

lēodan, see gelēodan.

lēode, mpl. men, people: n. E1. 20, I28, IIII, III6; g. lēoda, El. I8I, 285, I127; d. lēodum, El. 666, 723; a. E1. 163, 208.

lēodfruma, m., prince: ns. El. I9I ; as. lēodfruman, $\mathrm{Ph} .345$.

lēodgebyrga, m., protector of the people: ns. El. II, 203; np. lēodgebyrgean, E1. 556.

lēodhata, m., hater of men: np. lēodhatan, El. I300.

lēodmǣg, m., countryman: gp. lēodmǣga, El. 380 .

lēodmægen, n., multitude of men: ns. El. 272.

lēodscipe, m., land: ds. Ph. 582. lēof, adj., dear, beloved: nsm. El. I036, I048; nsm. wk. lēofa, El. 5 II ; asm. lēofne, Ph. 345, 479, $56 \mathrm{r} ;$ W. 88; gpm. lēofra, El. I206; super. vsm. lēofesta, El. 523 ; comp. nsn. lēofre (preferable), E1. 606.

-leofen, see andleofen. lēoflīc, adj., lovely: nsn. El. 286; asn. Ph. 440.

lēofspel, n., glad news, message of love: ds. lëofspelle, El. 518; ap. lēofspell, El. IoI7.

lëoftāl, adj., gracious: nsm. Pn. 32. lēoht, n., light: ns. El. 7, 94, 486; gs. lēohtes, El. 486; Ph. I16, 563 ; as. El. 298, 307, I1 23; Ph. 508; is. lēohte, El. 734; $\mathrm{Ph}$. 596, 607; gp. lēohta, El. 948; luminary: ns. Ph. 288.

leoht, adj., cheerful: nsm. El. I73; light, agile: $\mathrm{Ph} .317$.

lēoht, adj., bright, radiant, glorious: nsm. El. I045; nsn. El. 163; asf. wk. lēohtan, El. 737 ; asn. wk. lēohte, Ph. 66I; joyous: ism. lēohte, EI. II37; enlightening: asm. lēohtne, El. 49I, 1246; fair, clear: ism. lēohte, $\mathrm{Ph} .479$.

lēohte, adv., clearly, brightly: El. 92, 966 , III 6 .

lēoma, m., light: ns. Ph. I03; blaze, effulgence: ns. El. 1294; Ph. II6.

lēon, see onlēon.

leornian, W2., learn: pret. I p1. leornedon, El. 397.

leornungcræft, m., learning: as. El. 380 .

lēod, n., song: as. Ph. 547. See dryht-, fyrd-, sigelēor.

lēoðेcræft, m., art of poetry: as. E1. $125 \mathrm{I}$.

$\ddagger$ lëoðrūn, f., counsel in song, secret counsel: as. lēoðrrūne, El. 522.

leoðucræftig, adj., active, nimble: asn. leopucræftig, Ph. 268.

lesan, V., collect, gather: pret. I sg. læs, El. I238. See ālesan.

lēst, see weorudlēst.

letitia, f. (Lat.), gladness: gs. letitie, $\mathrm{Ph} .673$.

lęttan, see gelęttan.

lic, n., body: ns. El. 883, 890; Ph. 
563 ; gs. lices, $\mathrm{Ph} .645,65 \mathrm{I}$; W. 69; ds. lice, Ph. 523, 584; as. El. 878 ; Ph. 205, 268, 513 . -lic(e), see ge-, onlic(e). licgan, $\mathrm{V}$, be at rest: 3 sg. ligeð, $\mathrm{Ph}$. 182.

lichoma, m., body: ds. līchoman, E1. 737 ; as. lichoman, Ph. 220 ; np. lichoman, $\mathrm{Ph}$. 518; ap. lichoman, Ph. 489.

lician, W2., be pleasing: inf. $\mathrm{Ph}$. 5 I7.

licnes, see gelicnes.

lif, n., life: ns. E1. 526, 606; $\mathrm{Ph}$. 220, 4I7; gs. lifes, El. I37, 520, 664, etc. (9 times); Ph. 53, I50, I5I, etc. ( 8 times); ds. life, El. 575, 878; Ph. I9I, 367,607 ; as. E1. 305, 622, 1046; Ph. 370, 38I, 434, etc. (Io times); W. 64. See ęndelif.

lifdæg, m., day of life: dp. lifdagum, El. 44I ; W. 75.

liffruma, m., author of life: ns. E1. 335 .

lifgan, W3., live: 3 sg. leofap, Pn. I7; 3 pl. lifgar, Ph. 596; pret. 2 pl. lifdon, El. 3 I I ; ptc. lifgende, El. 486; abide: 3 sg. leofaor, E1. 540. See unlifgende.

lifweard, m., guardian of life: ds. lifwearde, El. го36.

lifwyn, f., joy in life: ds. lifwynne, E1. 1269.

lig, m., fire, flame: ns. El. 580, IIII; Ph. 39, 218, 268, 505; gs. liges, $\mathrm{Ph} .434$; ds. lige, $\mathrm{Ph} .533$; is. lige, El. I300. See lēg.

ligbryne, m., burning, fire: ds. $\mathrm{Ph}$. 577.

$\ddagger$ ligcwalu, f., fiery torment: ds. ligcwale, E1. 296.

lige, m., lie: ns. El. 575 ; ds. El. 666 ; as. El. 307.

ligesearu, n., deception: dp. ligesearwum, E1. 208. ligesynnig, adj., lying: nsm. El. 899.

ligeword, n., falsehood, lying word: ip. lygewordum, $\mathrm{Ph}$. 547. ligöracu, f., fire's violence, flame's rage: ds. ligpræce, $\mathrm{Ph} .225,370$. lïhtan, W I., shine, give light: $3 \mathrm{sg}$. lïhteð, $\mathrm{Ph} .587 ; 1$ lyhted, $\mathrm{Ph}$. I87. lim, n., limb: np. leomu, E1. 883; ap. leomu, Ph. 513; ip. leomum, Ph. 649.

limpan, see gelimpan.

limsēoc, adj., lame: npm. limsēoce, E1. I2I4.

$\ddagger$ lindweorud, n., troop armed with shields: lindwered, ns. E1. I42. lindwigend, m., fighting-man, warrior: gp. lindwigendra, El. 270. liss, f., joy, ecstasy: ds. lisse Ph. 672 ; gp. lissa, $\mathrm{Ph} .150,563$.

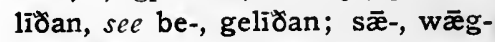
lï̌nend.

lixan, Wr., gleam, shine, glisten: 3 sg. lixed, Ph. 33, 290, 299; Pn. 27; 3 pl. lixað, $\mathrm{Ph} .604$; pret. 3 sg. lixte, Pn. 24; 3 pl. lixtan, E1. 23, 90, 125; lixton, E1. III6; inf. $\mathrm{Ph} .94$.

loc, n., clasp: ip. locum, E1. I027. loca, m., stronghold, prison: ds. locan, El. I8I. See brēost-, hearm-, hreðer-, ðēostorloca. lōcian, W2., look: 3 sg. lōcað̆, Ph. IOI ; pret. 3 sg. lōcade, El. 87.

lof, n., praise: ns. E1. 212, $890 ; \mathrm{Ph}$. $66 \mathrm{I}$; ds. lofe, W. 88 ; as. E1. 748; Ph. 617, 634, 676.

lofhwat, adj., keen for praise: nsm. wk. lofhwata, El. II.

lofian, W2., praise: 3 pl. lofiar, E1. 453; Ph. 337, 56I.

-loga, see wæ̈rloga.

lọd, n., land: ns. Ph. 20, 28; gs. landes, El. I27I; ds. londe, $\mathrm{Ph}$. 50 ; as. $\mathrm{Ph} .70$, I66; land, El. 250, 262, 270, 999; np. Ph. Iт6; 
gp. londa, Ph. 2; earth: gs. londes, Ph. I50, 508. See ēa-, èg-, èđel-, feor-, ig-, mōr-, un-, wynlond.

londwela, m., riches of the world: ap. londwelan, Ph. 505.

long, adj., long: nsn. lang, El. 432 ; asm. longne, $\mathrm{Ph} .440,555$; enduring, lasting: nsm. wk. longa, $\mathrm{Ph} .607$. See nihtlong.

longe, adv., long: Ph. 48r, 489; lange, E1. 602, 723, 793, III9; comp. leng, El. 576, 702, 706, 907.

lūcan, II, knit together, unite: inf. $\mathrm{Ph} .225$; enclose, set: pp. locen, El. 264. $S e c$ be-, onlūcan.

lufe, f., love: ds. lufan, El. 49I, 564; as. lufan, El. 948, 1206. See siblufe; lufu.

lufian, W2., love: 3 sg. lufap, El. $597 ; 3$ pl. lufiad, Ph. 478.

lufsum, adj., pleasant: nsm. Pn. 32.

lufu, f., love: ns. El. 937. See lufe. lungre, adv., forthwith, immediately: E1. 30, 368 .

lust, m., pleasure, joy: ds. luste, El. 138, 26r ; W. 26; ip. lustum, El. $702,125 \mathrm{I}$.

lux, f. (Lat.), light: gs. lucis, $\mathrm{Ph}$. 667,672 .

lȳfan, see à-, gelȳfan.

lyft, m. f., air: ds. lyfte, Ph. I23, 340 ; as. El. 734, 900; Ph. 316; wind: is. lyfte, Ph. 62; sky, heaven: ds. lyfte, El. I27I ; Ph. 39 ; as. $\mathrm{Ph}$. IOI.

lyftlācende, adj., floating in the air: nsm. El. 796.

lygeword, see ligeword.

lȳhtan, see lìhtan.

lyre, m., loss: ns. Ph. 53.

lȳsan, Wr., loose, release: inf. El. 296. See ālȳsan. lystan, WI., desire: 3 sg. lysteঠ, W. 52. See gelysted.

lȳt, n., few: as. E1. 63 .

lȳtel, adj., little: dsn. lȳtlum, El. 960 ; asn. El. 272, 383. See unlȳtel.

lȳthwōn, n., few: ns. El. I42.

lȳtle, adv., a short time, a little while: El. 664 .

\section{M.}

mā, n., more: ns. El. 634 .

mă, adv., longer, more: El. 434, $8 \mathrm{I} 7 ;$ W. 80.

mæcg, see wræcmæcg.

$\mathrm{m} \overline{\mathrm{g}}$, f., kinswoman, relative: ns. E1. 330, 669. See cnēo-, lēod-, winemǣ.

mægen, n., strength, power, might: ns. El. 698; gs. mægnes, $\mathrm{Ph}$. 625 ; as. mægn, E1. 408; is. mægene, El. I223; mægne, $\mathrm{Ph}$. 471 ; gp. mægena, El. 347, 810; host, troop: ns. El. 55, 138, 233 , 283, 1293; as. E1. 6r, 242. See eorl-, hēah-, hęre-, lëod-, ofermægen.

mægencyning, m., lord of hosts: ns. El. 1248 .

mægenðrym, m., great glory: is. mægenprymme, El. 735 ; heavenly host: gs. mægenprymmes, $\mathrm{Ph}$. 665.

mǣl, n., time: gp. mǣla, El. 987. See brogden-, fōtmǣl.

mǣlan, W I., say, speak: pret. $3 \mathrm{sg}$. mǣlde, El. 35r ; 3 pl. mǣldon, E1. 537.

mǣran, W I., celebrate, glorify, extol: 3 pl. mǣrad, Ph. 338, 344. mære, adj., glorious: nsm. El. 340; nsn. El. 970; gsf. wk. mnǣran, E1. 864; dsm. mǣrum, Ph. I65; dsf. wk. mǣran, Ph. 633; asm. mǣrne, El. 629; wk. mǣran, El. 
I223; asf. wk. mǣran, El. I064, I242; $\mathrm{Ph}$. 660; asn. wk. E1. 2I4; apn. wk. mǣran, El. 990 ; super. nsm. mǣrost, El. IOI3, I225; nsmn. mǣ rost, $\mathrm{Ph}$. II9; known: nsn. El. II77. See frēamǣre.

mærsian, W2., celebrate: $3 \mathrm{pl}$. mǣrsiað, Ph. 6r7.

mærðu, f., glory, renown: gp. mærða, Ph. 472; ip. mærðum, E1. I5; miraculous deed: El. $87 \mathrm{I}$.

mǣst, adj., see micel.

mæite, sce unmǣe.

mæðel, see meðel.

magan, prp., can, be able: I sg. mæg, E1. 632, 635, 702, 705; Ph. 561; 2 sg. meaht, El. 5 II ; 3 sg. mæg, El. 448, 466, 588, 6I I, 735, 770; $\mathrm{Ph}$. I4, II3, I79, 347, 448, 58I, 594; Pn. 18; I pl. magon, Pn. 2; 2 pl. magon, El. 582,$583 ; 3$ pl. magon, El. I291; Ph. I34; pret. 3 sg. meahte, El. 33, I60, 243, 609,860 ; 3 pl. meahton, El. I66, 477 ; opt. I sg. mæge, E1. 677; 3 sg. mæge, El. I 78 ; pret. 3 sg. meahte, El. II59; opt. pret. I pl. meahten, Ph. 573; 3 pl. meahton, El. 324, 979.

-māh, sce gemāh.

Maius, pr. n., May: ap. Maias, El. I 229.

mān, n., evil, guilt, sin: gs. mānes, Ph. 633; as. El. 626; is. māne, E1. I296; gp. māna, E1. I3I7.

man, pron., one, any one: ns. El. 358, 7 I 1, 755.

man, m., man, person: ns. El. 467 ; mon, Ph. 243; gs. mannes, El. 660; monnes, Ph. I28; as. man, El. 872 ; np. men, Ph. I57, I73, 496; Pn. 66; gp. manna, E1. 326, 735, 903, 1229, 1312; monna, Ph. 323, 358, 544; dp. mannum, E1. I6, 626 .

mancynn, n., mankind: gs. moncynnes, $\mathrm{Ph}$. I76; monncynnes, Ph. 377, 422.

māndǣd, f., evil deed: ap. māndǣde, Ph. 457.

mānfrēa, m., wicked lord, devil: vs. E1. 942.

mānfręmmende, adj., sinful, wicked, evil-doing: npf. El. 907 ; dpm. mānfremmendum, Ph. 6. -mang, see gemang.

manig, adj., many: nsm. El. 23I, 258; monig, Pn. 50; asn. El. I0I7; npm. monge, Ph. 443, 49I; npn. monge, Pn. I ; dpm. manigum, E1. 970, 1176; manegum, E1. I5; monegum, Ph. 170, $52 \mathrm{I}$; mongum, Ph. 4, 323; dpn. manegum, El. 50I ; apm. monige, E1. 499.

manigfeald, adj., manifold: npn. monigfealde, $\mathrm{Pn}$. 70; apn. monigfeald, El. 644 .

manrim, n., number of men: ds. manrīme, E1. 650 .

$\ddagger$ mānðēaw, m., evil custom: dp. mānpēawum, El. 930.

manðwǣre, adj., kind: nsm. monpwāre, Pn. 3I.

$\ddagger$ mānweorc, adj., sinful, wicked: dsm. mānweorcum, El. 8r2.

Māria, pr. n., Mary: d. Mārian, E1. 1233; a. Mārian, E1. 775.

marmstān, m., marble: ds. marmstāne, $\mathrm{Ph}$. 333 .

mað̌lian, W2., speak, address, harangue: pret. $3 \mathrm{sg}$. maðelode, El. 685; mapelode, E1. 332, 604, 807 ; maðelade, El. 404, 627, 642, 655 ; mabelade, El. 573.

māoum, m., trcasure: ap. māðmas, El. 1259.

maximus, adj. (Lat.), greatest, 
mightiest: apn. maxima, Ph. †męreweard, m., warder of the 670. sca: ns. W. 53 .

meagol, adj. powerful: ip. meaglum, Ph. 338.

meaht(-), see miht(-).

mearc, see fyrst-, gemearc.

mearcian, W2., designate, indicate: 3 pl. mearciad, Ph. 333. See gemearcian.

mearcpæס, n., road through a province: ap. mearcpadu, El. 233.

mearh, m., horse: ns. El. 55, II93; ds. meare, E1. Iı76. See sæ--, ÿomearh.

mēde, see ēaơmēde.

mēdla, see onmēdla.

medoheal, f., mead-hall: ds. medohealle, E1. I259.

-mēdu, see èaðmēdu.

melda, m., betrayer, informer: npm. meldan, El. 428.

meledēaw, m., honey-dew: gs. meledẽawes, $\mathrm{Ph} .260$.

męngan, Wi., confound, confuse: inf. El. 306. See gemengan.

męngu, f., company, crowd, multitudc: ns. El. 225; menigo, El. $87 \mathrm{I}$; ds. mengo, El. 377, 596; as. Ph. 420.

męnnisc, adj., human: asn. E1. 6.

meord, f., guerdon: as. meorde, Ph. 472.

Meotud, m., Creator, Lord, God: ns. El. 1043; $\mathrm{Ph} .176,358$; Meotod, El. 366; gs. Meotudes, E1. 46I, 474, 564; Ph. 6, 457, 47I, 524; Meotodes, E1. 686, 986; Metudes, E1. I3I8; ds. Meotude, Ph. 443, 660; Metude, Ph. 6r7; vs. Metud, El. 8Ig. nęre, see y̆omęre.

nęreflōd, m., flood: ns. Ph. 42. nęrestræt, f., sea-path, sea: ds. merestrǣe, El. 242.

męrian, see āmęrian.

meritare, vb. (Lat.), merit: inf. Ph. 668.

metan, V, mcasure, traverse: pret.

3 sg. mat, El. 1263. See āmetan. mētan, Wr., meet, find: 3 pl. mētað, Ph. 247; pret. 3 sg. mētte, El. 833; 3 pl. mētton, El. I 6 ; pp. mēted, E1. 986. See gemētan.

męte, m., food: as. Ph. 260.

mętelēas, adj., without food: nsm. E1. 612, 698.

-metfæst, see gemetfæst.

metgian, see gemetgian.

mēðe, adj., exhausted, miserable, disconsolate:' nsm. E1. 612, 698; dsm. mēoum, E1. 812; gpm. mēpra, Ph. 422.

medel, n., council, asscmbly: ds. meðle, El. 593; meble, E1. 546; judgment: mæole, Ph. 538; prayer: ds. meðle, El. 786. See hęremeðel.

meöelhēgende, adj., counseling, dcliberating: apm. E1. 279.

meðelstęde, m., assembly-room, council-chamber: ds: E1. 554.

Metud, see Meotud.

micel, adj., much, great: nsm. wk. micla, W. 47 ; nsf. Ph. 189, 432; mycel, El. 426; dsm. wk. miclan; W. 3; asf. wk. myclan, E1. 597 ; ism. mycle, E1. 735; isn. mycle, El. 646; ipf. myclum, E1. 44, I02, I000; super. nsm. mǣst, El. 3I ; nsf. mǣst, E1. 35, 196, 977, 993 ; nsn. mǣst, E1. 984; W. Io; asf. mǣeste, E1. $38 \mathrm{r}, 408$; isn. mǣste, El. 274; Ph. I67; numerous: super. asf. mæst, Ph. 462; grand: nsf. Ph. 625 ; super. ism. mǣste, Ph. 618. 
miclum, adv., greatly: E1. 876; myclum, E1. 840.

mid, adv., also, besides: Ph. 532.

mid, prep., w. dat. or inst., with, by:

E1. 92, 297, 577, 707, 714, 742, $805,843,86 j, 891$, 1025, I067, II23, II78; Ph. 8, 249, 529; $\mathrm{Pr}$. 5, 8; at: E1. I05; with, among: E1. 328, 377, 622, 821, 844, 854, I203, I233; Ph. 23, 3I, I49, I60, 345, 494; with, together with: $\mathrm{Ph} .215,523,543,584,610,62$, 629, 677; W. 3I, 44; w. acc., with, together with: E1. 275, 407, 737 (to?), 998; Ph. 483, 560 ; W. $28,88$.

midd, adj., middle, midst of: dsf. middre, Ph. 262; dpm. middum, Ph. 340.

middangeard, m., earth, world: gs. middangeardes, El. 810; $\mathrm{Ph}$. I57, 665; as. El. 6, I6, 434, 775, 9I8, II77; Ph. 4, 42, II9, 323, 640; Pn. I, 70.

middel, m., middle: ds. midle, El. I296; Ph. 65; as. El. 864.

mìdl, n., bit (on a bridle): dp. mìlum, El. II76, II93.

miht, f., might, power: as. E1. 295, 3I0, 558, 597, 727, II63, I242; Ph. 583; meaht, Ph. 6, 647; W. 33; gp. mihta, El. 337, 366, 786, 819, I043; meahta, Ph. 640; ap. mihte, El. 584; meahte, $\mathrm{Ph}$. 6I7; ip. mihtum, El. I5, 340, I070, I100; meahtum, Ph. Io, 79, 499.

mihtig, adj., mighty: nsm. E1. 680, I068; meahtig, Ph. 538; nsm. wk. mihtiga, El. 942; Ph. 496; meahtiga, Ph. 377. See æl-, fore-, tîrmihtig.

milde, adj., mild, gracious, merciful: nsm. E1. 1043, I317; Ph. 538; dsm. wk. mildan, Ph. 657 ; asn. Pn. 3I ; Pr. 9.

milpæঠ, m., mile-path: ap. milpađas, E1. 1263.

milts, f., mercy: as. miltse, El. $50 \mathrm{r}$. min, pron., my, mine: nsm. El. $436,462,5 \mathrm{I} 7,528,822,918,1082$; nsn. Ph. 563; dsm. minum, El. 438, 454, 47I; dsn. minum, $\mathrm{Ph}$. 553; asm. minne, El. 535, 68I, 903, 1085; asf. mine, El. 349; isn. mine, Ph. I76; vsm. El. 447, 5II ; vsf. E1. 656; gpm. minra, El. 8I7; dpm. minum, E1. 930; dpf. minum, El. 907 ; apm. mine, El. I63; apf. mine, E1. 916.

mirce, adj., dark, gloomy: apf. Ph. 457.

† mistglōm, m.(?), misty' gloom: ds. mistglōme, W. 47.

mïdan, I, conceal, kecp secret: pret. 3 sg. māol, El. 28, 1099. See bemiððan.

mitis, adj. (Lat.), mild, gentle: asm. mitem, Ph. 674.

mōd, n., mind, heart, spirit: ns. El. 597, 990, 1064; Ph. 657; gs. mōdes, E1. 554, I242; ds. mōde, E1. 268; Ph. 446; as. Pr. 9; is. mōde, El. 377, I223; $\mathrm{Ph}$. 47I. See ān-, dēor-, gēomor-, glǣd-, glēaw-, hēah-, hwæt-, rēonig-, wērigmōd.

mōdblind, adj., blind in heart: npm. mōdblinde, El. 306.

mōdcræft, m., power of mind: as. El. 408.

mōdgemynd, n., memory: as. El. $38 \mathrm{I}$; heart: ns. E1. 840; intelligence, wit: as. W. 3 .

mōdgeðanc, m., inmost thought: as. mōdgebanc, E1. 535 .

mōdig, adj., valiant, brave: gpm. mōdigra, El. I38; dpn. mōdegum, El. II93; spirited, highhearted: nsm. El. 1263; Ph. 10 ; 
noble: nsm. wk. mōdga, $\mathrm{Ph}$. 262; asm. mōdigne, Ph. 338; gpm. mōdigra, El. 1293.

mödor, f., mother: ns. El. 340; as. E1. 214.

mōdsefa, m., heart, mind: ds. mōdsefan, E1. 876 .

mōdsorg, f., grief, sorrow: as. mōdsorge, El. 6I.

moldærn, n., grave, earthy dwelling: ds. moldærne, Ph. 564 .

molde, f., earth: gs. moldan, $\mathrm{Ph}$. 66; ds. moldan, $\mathrm{Ph} .260,496$; as. moldan, El. 55; land: as. moldan, $\mathrm{Ph}$. 10 .

moldgræf, n., grave: dp. moldgrafum, $\mathrm{Ph}$. 524.

moldweg, m., earth: ds. moldwege, El. 467.

molsnian, W2., decay: pp. molsnad, $\mathrm{Ph} .564$.

mon (-), see man(-).

mōnað̃, m., month: gp. mōnja,

$\mathrm{Ph} .66$.

monig, see manig.

monరwǣre, see manðwǣre.

morgenspel, n., morning nezes:

ns. El. 970.

f mōrlọnd, n., moorland: as. mōrland, El. 612.

morðor, n., murder: gs. morðres, El. 428, 626; sin: gs. mororres, E1. 942.

mordorhof, n., place of punishment: ds. morðorhofe, El. 1303. norठorsleht, m., slaughter: gs. morðorslehtes, El. 650 .

nōt, see gemōt.

nōtan, anv., may: 3 sg. mōt, El. 916; Ph. I48, 36I, 383, 516; I pl. mōtun, Ph. 668, 670; 3 pl. mōton, El. 906, I307, I3I5; mōtan, W. 8I ; pret. 3 pl. mōston, El. I75; opt. 3 sg. mōte, $\mathrm{Ph}$. I90, 433, 436, 559; I pl. mōtan, Pr. I6; 3 pl. mōten, El.
433 ; mōtan, W. 88; mōton, W. 86 ; pret. 3 pl. mōsten, El. 1005. Moyses, pr. n., Moses: n. El. 337 ; g. El. 283 ; d. Moyse, El. 366; a. E1. 786 .

mund, f., hand: ip. mundum, El. 730; Ph. 333.

munt, m., monntain: np. muntas, Ph. 21 .

mūo, m., mouth: as. El. 660,1283 ;

Pn. 43; W. 53 .

myltan, see gemyltan.

mynd, see ge-, weorömynd.

mynde, see gemynde.

myndgian, W2., remember: $1 \mathrm{pl}$.

myndgiap, E1. 657.

myndig, see gemyndig.

myngian, W2., remind: $3 \mathrm{sg}$. myngap, El. 1079.

\section{N.}

nædre, f., serpent: gs. nǣdran, $\mathrm{Ph}$. 4I3. See hildenǣdre.

næfre, adv., never: El. 388, 468, $538,659,778$; Ph. $38,88,567$.

nægel, m., nail: np. næglas, El. I 109, III5; gp. nægla, El. 1078, 1086, I103; dp. næglum, 1065, II28; ap. næglas, El. II 58, II73. nǣnig, pron., no one, none: nsm.

El. 505 ; gsm. nǣnges, Ph. 397. nǣre, see wesan.

næs, m., cliff: ds. næsse, El. 832. næs, see wesan.

nāhton, see āgan.

nales, adv., not at all, by no means:

E1. 359, 470, I253; nalles, El.

8I8, II 34 .

nama, m., name: ns. El. 418, 437, 530, 586, 750, 1061 ; noma, W. 6 ; ds. naman, El. 78, 505, 756; noman, $\mathrm{Ph} .174$; as. naman, El. 465,503 ; is. noman, Pn. I3.

nān, pron., no one, none: nsm. $\mathrm{Ph}$.

449 ; nsn. Ph. 5 I. nāt, see witan. 
nāthwylc, pron., some one: nsm. El. 73.

Nazareð, pr. n., Nazareth: d. El. 9I3.

ne, adv., not: El. 28, 62, 8r, etc.

(43 times); $\mathrm{Ph} .14,22,25$, etc.

(21 times); Pn. 2, 3; W. 20.

nē, conj., neither, nor: El. 167, 221, 240 , etc. (II times); Ph. I4, I5 (2), etc. (49 times); W. 78. nēah, adv., near: El. 66; Ph. 192. neahhe, see geneahhe.

nēan, adv., from near: $\mathrm{Ph} .326$;

sufficiently: E1. 657.

nearo-, see nearu-.

nearu, f., uneasiness: is. nearwe,

E1. 1240; narrow cell: ds. nearwe, El. 7II; perplexity, embarrassment: ds. nearwe, El. IIO3; concealment, obscurity: ds. nearwe, E1. III5.

nearulic, adj., oppressive: gpm. nearolicra, El. 9I3.

nearusearu, f., device, plot: as. nearusearwe, El. I Iog.

nearusorg, f., distress, crushing sorrow: as. nearusorge, E1. I26I. nearwe, adv., narrowly, exactly:

E1. I158; tightly: El. 1276; grievously: $\mathrm{Ph} .4 \mathrm{I} 3$.

nēat, n., cattle: np. E1. 357.

nëawest, f., neighborhood, vicinity:

ds. nēaweste, El. 67, 874 .

nębb, n., beak, bill: ns. Ph. 299. nèd, $s e c$ nȳd.

nēgan, Wr., address, speak to: inf. E1. 287, 559. See genēgan. nellan, see willan. nęmnan, Wi., name, call by name: 3 pl. nemnay, $\mathrm{Ph}$. 397; pret. 3 sg. nemde, E1. 78, 1060; pp. nemned, El. Ir95. See genęmnan.

nemne, conj., except that, save that: Ph. 260. nēobęd, n., deathbed: as. Ph. 553 nēod, f., desire: ns. $\mathrm{Ph} .189,432$. nēol, adj., steep, deep: $\mathrm{dsm}$. nēolum, E1. 832.

nēolnes, f., depth, abyss: as. nēolnesse, El. 943.

neorxnawong, m., paradise: as. Ph. 397 ; neorxnawang, El. 756. nēosan, Wr., go to, visit: inf. El. I52. See genēosian.

nēotan, II, enjoy: inf. Ph. I49, 36I, 384; Pn. II; W. 89.

neoðan, adv., beneath: El. III5; neopan, $\mathrm{Ph} .307$.

nēowe, see niwe.

Nęrgend, m., Saviour, Deliverer:

ns. El. 46r, 503, 799, 1086; $\mathrm{Ph}$.

498; Nerigend, El. I078, I I73; gs. Nergendes, E1. 465, 1065. nęrian, see genęrian. nęru, see feorhnęru. nesan, V, survive: inf. El. I004. nest, n., nest: ds. neste, $\mathrm{Ph}$. 215, 553 ; as. $\mathrm{Ph} .189,432,45 \mathrm{I}, 469$, 530 ; gp. nesta, Ph. 227.

nigoða, adj., ninth: nsf. nigoðe, El. 874 ; asf. nigoðan, E1. 870. niht, f., night: ns. $\mathrm{Ph} .98$; ds. $\mathrm{Ph}$. 262; gp. nihta, E1. 694; dp. nihtum, El. I228; ap. El. 483 ; Pn. 63. See orēoniht. nihtes, adv., by night: El. I98, I240; Ph. I47, 478.

nihthelm, m., darkness: ns. El. 78. nihtlong, adj., night-long, lasting the night: asm. nihtlangne, El 67.

niman, IV, take, snatch away seize: 3 sg. nimeð, El. 578, 1279 Ph. 485 ; opt. 3 sg. nime, El $447,615,676$, 1233; Ph. 380 See bi-, for-, geniman. nioðoweard, adj., below: nsm niopoweard, $\mathrm{Ph} .299$. 
nið, m., man, person: gp. niðða, El. 465, 503, 1086; nippa, Pn. I3; W. 6.

nïð, m., hatred, enmity, malice: ns. nīp, Ph. 400 ; as. El. 838; nìp, Ph. 4I3; gp. nïða, El. 913; attack: gp. nība, Ph. 45I, 469; feud: as. E1. 905.

niठter, adv., down, below: El. 832; niber, W. 28 ; nyorer, El. 943.

niobheard, adj., brave in fight, stern in fight: $\mathrm{nsm}$. El. $\mathrm{x} 95$.

-nïlla, see genïlla.

niठre, adv., below: nipre, Pn. 74. niwe, adj., new: nsm. El. 195; Ph. 266 (n.?) ; dsm. wk. nīwan, $\mathrm{Ph}$. 400 ; dsf. wk. nīwan, El. I103; asm. nēowne, El. 87o; asn. nīwe, $\mathrm{Ph} .43 \mathrm{I}$; isf. wk. nīwan, El. 106I, I128 (niwan stefne, anerv). See edniwe.

niwigan, W2., renew: inf. El. 94I. See geniwian.

niwinga, see edniwinga.

nō, adv., never, not at all, by no means: El. $780,838,1083,1302$; Ph. 80, r 57, 259.

toma, sce nama.

cordan, adv., from the north: norban, $\mathrm{Ph} .324$.

10̄ँ, f., prey (?): as. nōpe, W. 28. rū, adv., now: El. 313, 372, 406, etc. (28 times); Ph. 447, 470, 583; W. I; then (?): E1. 388.

ıu, conj., now that, since: El. 534, $635,702,815,1171$.

zugan, see benugan.

เüða, adv., now: E1. 539, 66I.

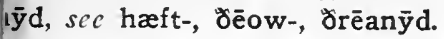

nȳdcleofa, m., prison, dungeon: ds. nȳdcleofan, El. 7II ; as. nēdcleofan, El. 1276.

$\bar{y}$ dðearf, f., need, necessity: ds. nȳdpearfe, El. 657. ysse, nyste, nyton, see witan. yð̌er, see niðer. o.

o, adv., ever, always: Ph. 72; oo, $\mathrm{Ph}$. 25. See ā, āwa.

of, prep., of, out of, from: w. dat., El. 75, 181, 186, 187, 282, 295, 297, 303,440,482, 700, 7 II (2), $715,736,762,780,794,803,845$, 915, 927, 1023, 1087, III3, III5, I 226, I303, I305; $\mathrm{Ph} .65,66,109$, I22, $174,230,232,233,234,250$, $267,321,337,349,373,474,5 \mathrm{I} 5$, 648 ; Pn. 42, 45, 49, 50, 62; W. $38,55,8$ I.

ofen, m., furnace: gs. ofnes, El. I3II.

ōfer, m., edge, shore: ds. ōfre, W. 9.

ofer, prep., w. dat., above, over: El. 733 ; $\mathrm{Ph} .588,604,64 \mathrm{I}$; w. acc., over: El. 118, 233, 237, 244, 249, 255, 269, 385, 881, 918, 983, 996, 997, 1017, I133, II 35 , I20I ; Ph. IOI, I03, II5, I59, 202, 210, 289, 309, 590; W. 70; over, upon: El. 89, 239, 434, 1289; against: E1. 31, 372; Ph. 403, 4II ; throughout: El. $158,98 \mathrm{I}$; Ph. 4, 197, 33I, 498; after: El. 432, 448; across: Ph. II8; beyond, surpassing: Ph. 330, 480. oferhlifian, W2., rise above: $3 \mathrm{sg}$. oferhlifad, $\mathrm{Ph}$. I2I.

ofermægen, n., superior power, excecding might: ds. ofermægene, El. 64; Ph. 249.

oferswið̄an, WI., overcome: $2 \mathrm{sg}$. oferswiotesঠ, E1. 93; inf. E1. I 78 ; pp. asm. of erswīodne, El. 958. See unoferswìbed. oferðearf, f., great need: ds. oferpearfe, El. 521.

Oferwealdend, m., Sovereign, Lord:

ns. E1. 1236.

ofest, f., haste: ip. ofstum, El. 
44, 102, 1000; ofestum, Ph. 190;

Pn. 52.

ofet, n., fruit: is. ofete, Ph. 77. ofgifan, $\mathrm{V}$, forsake, relinquish:

3 sg. ofgiefed, Ph. 426; inf. ofgiefan, Ph. 4r2.

ofstlice, adv., hastily: El. 225, 713, I 197.

oft, adv., often: E1. 238, 30r, 386, 47I, 513, 92I, II4I, I213, I253; Ph. II, I08, 26I, 442; W. 4; sup. oftost, W. 63 .

ōliccan, Wr., please: inf. Pr. I'2. on, prep., w. dat., in, on, upon: E1. 28, 30, 36, etc. (I46 times); Ph. 2, 30, 50, etc. (44 times); Pn. I0, I4, 39; W. 21, 22, 25, 26, 40, 5I, 73; Pr. 6; among: $\mathrm{Ph}$. I60, 23I, 237, 278; at: Ph. 244, 246; by, with: Ph. 484, 578; w. acc., in, into, on, upon, to: E1. 84, 96, ro8, etc. (39 times); Ph. 74, 97, 98, etc. (I7 times); Pn. 41, 54, 67; W. 12, 27, 34, 35, 64, 70, 87; Pr. II.

onălan, Wr., kindle, inflame: pp. onǣled, E1. 95I ; Ph. 216, 503.

onbindan, III, unbind, loose: pret.

$3 \mathrm{sg}$. onband, El. I250.

$\ddagger$ onbregdan, III, start $u p$ : pret.

3 sg. onbrægd, E1. 75 ; lift, movc (intr.): 3 sg. onbrygded, $\mathrm{Ph}$.

I 43.

onbryrdan, Wi., elate, inspire: pp. onbryrded, El. I095; Ph. 126, 550 ; inbryrded, E1. 842, I046.

oncnāwan, rd., acknowledge, recognize: inf. El. 362, 395; understand, perccive: pret. $3 \mathrm{sg}$. oncnēow, El. 966.

oncor, m., anchor: ip. oncrum, El. 252.

$\ddagger$ oncorrāp, m., hazeser, cable: ip. oncyrrāpum, W. I4.

oncweðan, V, answer: pret. $3 \mathrm{sg}$. oncwæช̀, El. 573, 669, 682, 935, I 67 ; inf. El. 324.

oncyrran, Wr., change: pret. $3 \mathrm{sg}$. oncyrde, E1. 503; avert, turn aside: inf. El. $6 \mathrm{ro.}$

† oncỹdig, adj., devoid: nsm. El. 725 ; ignorant: nsm. El. 961.

ond, conj., and: El. 93r, 977, 984, I210; otherwise the word occurs in the manuscripts always as 7 ; E1., I86 times; Ph., 99 times; Pn., I3 times; W., I I times; Pr., twice. Because ond thus occurs in the Elene, the abbreviation is uniformly so printed in that text, but in the others as and. The prefix and-, however, which also usually occurs as 7 , is found in andsware, El. 567 and 1002 (cf. 970) and is uniformly so printed.

ondrǣdan, V, fear: imp. sg. ondrǣd, El. 8I.

önettan, Wi., hasten: $3 \mathrm{sg}$., ōnetteð, Ph. 2r7, 455.

onfōn, rd., take, receive: $3 \mathrm{sg}$. onfēhð, Ph. 533; pret. $3 \mathrm{sg}$. onfēng, El. I92, 238, 490, г033: I 28 ; 2 pl. onfëngon, El. 335 gain: 3 sg. onfēhð, $\mathrm{Ph} . \mathrm{r} 59$ pret. 3 sg. onfēng, Ph. 645 ; inf Ph. I92, 433.

ongēan, prep., w. dat., against: El 43 ; towards: $\mathrm{Ph} .9 \mathrm{I}$; ongēn with: E1. 609, 667; before W. 67.

ongietan, see ongitan.

ongin, n., beginning: ns. ongyn $\mathrm{Ph} .638$.

onginnan, III, begin: $3 \mathrm{sg}$. on ginned, $\mathrm{Ph}$. I88; 3 pl. onginnat Ph. 224; pret. 3 sg. ongan, E I 57, I98, 225, 286, 384, 468, 55ई $570,696,828,850,901$, I06? I094, I I48, I I 56, I I64, I 205 ; 2 p ongunnon, E1. 303, 306, 3II. 
ongitan, V, learn, discover: pp. ongiten, El. 288; know, recognize: 3 pl. ongitap, El. 359; understand: imp. sg. ongit, El. 464 ; inf. Ph. 573.

ongyldan, III, pay the penalty, requite: pret. 3 pl. onguldon, $\mathrm{Ph}$. 410.

ongyn, see ongin.

onhǣtan, Wr., ignite: pp. onhäted, Ph. 212.

onhlidan, I, open: pp. onhliden, Ph. I2, 49.

onhyldan, Wi., bow: pret. 3 sg. onhylde, El. I099.

onhyrdan, WI., strengthen, encourage: pp. onhyrded, El. 84I. onlēon, I, grant, bestow: pret. 3 sg. onlāg, El. 1246.

onlic, adj., like: super. nsm. onlicost, Ph. 312.

onlice, adv., similarly, in like manner: El. 99; $\mathrm{Ph} .242$.

onlūcan, II, unlock, open: pret. 3 sg. onlēac, El. I25I.

onmēdla, m., pride: ns. El. 1266. onsāwan, rd., sow: pp. onsāwen, Ph. 253.

onscunian, W2., shun, despise: pret. 2 pl. onscunedon, El. 370. onsęndan, Wr., send: pret. 3 pl. onsendan, E1. $\mathrm{1} 20$; yield $u p$ : pret. 3 sg. onsende, El. 480 ; offer: imp. sg. onsend, El. 1089. onsion, sec onsȳn.

onspannan, rd., open: pret. $3 \mathrm{sg}$. onspēon, El. 86.

onspringan, III, spring up: $3 \mathrm{pl}$. onspringað, Ph. 63.

onsund, adj., flourishing: nsm. Ph. 20 ; unscathed: nsm. Ph. 44. onsȳn, f., face: ds. onsȳne, El. 746; Ph. 600; as. onsion, El. 349.

orsȳyn, f., lack, want: ns. Ph. 55, 398. ontȳnan, Wi., open, reveal: 3 sg. ontȳneð, W. 53, 68; pret. 3 sg. ontȳnde, El. 1249; Ph. 423; pp. ontȳned, El. I230.

onwæcnan, Wr., rise again, revive:

3 sg. onwæcneð, Ph. 648.

onweald, m., power: ns. onwald, $\mathrm{Ph}$. 663. See also anwalda.

onwęndan, Wr., change: pp. onwended, Ph. 82.

onwindan, III, unlock: pret. 3 sg. onwand, El. I250.

onwrēon, I, declare, disclose, reveal: pret. 2 sg. onwrige, El. 813; 3 sg. onwräh, El. I243; opt. pret. 3 sg. onwrige, El. I072; inf. El. 589, 674; pp. onwrigen, El. I124, 1254 .

oo. Sec ò.

open, adj., open: nsf. Ph. II ; allrevealing: asf. wk. openan, $\mathrm{Ph}$. 509; far-famed, well-known: nsn. El. 647.

cpenian, see geopenian.

oncnǣwe, adj., evident, plain: nsm. El. 229.

ord, m., spear: as. El. $\mathrm{II}_{87}$; ip. ordum, E1. 235 ; beginning: ds. orde, El. 140, 590, II55; chief: ns. El. 393.

ordfruma, m., author: ds. ordfruman, Pn. 58.

organa, f., organ: gs, organan, $\mathrm{Ph}$. I36.

orscylde, adj., guiltless: asm. orscyldne, El. 423.

ordanc, m., art: ip. orponcum, $\mathrm{Ph}$. 304.

oठ, prep., till, until: w. acc., El. I39, 312, 590, 870, I257; Ph. 47, 490.

oðēawan, Wr., appear, be manifest: pp. oð̌ēawed, Ph. 322. See a!so oðȳwan.

öorer, pron., other: nsm. El. 506; dsm. ōorum, Ph. 343; dsn. 
ōðrum, E1. 233; asm. ōðerne, E1. 540, 928; asf. ōpre, W. 49; npn. ōpre, W. 55 ; dpm. ōprum, Pn. 24, 28; dpf. ōprum, Pn. 56. oðfæstan, Wi., inflict: inf. E1. 477. ‡оðflēogan, II, fly away: $3 \mathrm{sg}$. oðflēogeð, Ph. 347.

‡ờscūfan, II, hasten azway

(from): 3 sg. oðscūfeð, Ph. I68. odరret, conj., until: El. 866, 886;

opbæt, Ph. I4I, I66, 263, 346, 363, 420, 484; W. 36, 59; oðbæt, $\mathrm{Ph}$. $15 \mathrm{I}$.

oðठе, conj., or: E1. 74, I59, 634, 975, IiI4; opbe, Ph. 300; and: E1. 508 .

oðȳwan, Wr., display, show: pret.

3 sg. oðȳwde, El. I63. See also oð̄eawan.

owiht, pron., anything: asn. El. $57 \mathrm{I}$.

\section{P.}

pæठ, see mearc-, milpæס.

† panठ̈er, m., panther: ns. pandher, Pn. I2.

Paulus, pr. n., Paul: n. El. 504; Pn. 69.

pax, f. (Lat.), peace: gs. pacis, Ph. 672.

pēa, m., peacock: ds. pēan, Ph. 312. perennis, adj. (Lat.), unceasing:

ab1. sf. perenne, Ph. 676 .

plega, see sundplega.

plegean, W2., move, plunge: inf. El.

245 ; clap: pret. 3 sg. plegade, E1. 806 .

\section{R.}

rād, f., expedition, journey: ds. rāde, El. 982 . See swonrād. rador(-), see rodor(-). ræced, see dēaòræced.

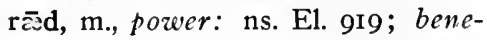
fit, weal: dp. rǣdum, El. I009; counsel: ap. rǣdas, E1. 156; discernment, foresight, wisdom: gs. rǣ des, El. 553. See unrǣd. ræ̈dan, rd., advise, counsel, exhort: pret. 3 sg. reord, El. I023. See berǣdan.

-rǣde, see gerǣde.

-rǣden, see frēondrǣen.

ræ̈dend, m., giver: ns. Pn. 55 .

ræ̈dgeðeaht, f., counsel, wisdom:

as. rǣdgebeaht, El. I162; coun-

cil: as. rādgepeaht, El. I052.

rǣôeahtende, adj., taking thought, being wise, wise: npm. rādpeahtende, El. 449, 869 .

ræfnan, WI., suffer: inf. Ph. 643. ræ̈ran, Wi., raise, stir up: pret.

3 pl. rǣrdon, El. 954; inf. El. 443, 941. See āræ̈ran.

ræst, f., rest: gs. ræste, W. 23; place for rest: as. ræste, Pn. 36. See wælręst; ręstan.

rǣswa, see hęrerǣswa.

rand, m., shield: ns. El. 50. See geolorand.

rāp, see oncorrāp.

rade, see hrä̀.

rēaf, see wælrēaf.

rēafian, see berēafian.

-reaht, see gereaht.

rëc, m., smoke: ns. El. 804; as. El. 795.

ręccan, Wr., explain, expound:

opt. 3 pl. reccen, El. 553; inf. E1. 281, 284. See ā-, geręccan. -red, see dægred.

regnum, n. (Lat.), kingdom: ap. regna, $\mathrm{Ph} .670$.

rēn, m., rain: ns. $\mathrm{Ph}$. I4; gs. rēnes, Ph. 246.

rēonig, adj., sad: nsm. El. I083; dsn. wk. rēonigan, E1. 834 .

rẽonigmöd, adj., sad, sorrowful, dozencast: npm. rēonigmōde, El. 320 ; W. 23.

reord, f., melody: is. reorde, $\mathrm{Ph}$. 
128; ip. reordum, $\mathrm{Ph} .338$. See gereord.

reordberend, adj., endowed with speech (man): gpm. reordberendra, El. I282.

reordian, W2., cry: 3 pl. reordiad, Ph. 632; discourse, speak, say: pret. 3 sg. reordode, El. 405, 417, 463, 1073; reordade, $\mathrm{Ph}$. 550.

rēotan, II, weep, mourn: 3 sg. rēoteð, El. 1083. See wið̀rēotan. ręst, see ræst.

ręstan, see geręstan.

rīce, n., power: ns. El. 13 ; royalty: as. El. 9 ; empire: gs. rīces, El. 59 ; as. El. 40 ; sway, dominion: as. E1. 147, 449; victory: gs. rīces, El. 62; kingdom: ns. El. 917, I231 ; gs. rīces, El. 820; ds. $\mathrm{Ph} .664$; as. El. 63I ; realm, region: as. Ph. I56. See gum-, heofon-, woruldrīce.

rīce, adj., mighty, powerful: nsf. wk. rīce, El. 4II ; super. nsm. wk. rīcesta, E1. 1235 .

ricene, adv., instantly, at once: El. $607,623,982$, II 62 .

ricsian, W2., be mighty, rule: 'opt. 3 sg. rīcsie, El. 774; inf. El. 434.

rïdan, I, ride: pret. 3 pl. ridon, $\mathrm{El}$. 50.

riht, n., right: gs. rihtes, El. 880; ds. rihte, El. 390, 663; ryhte, E1. 369 ; is. rihte, El. 917; gp. rihta, El. 910; law: as. E1. 372; ryht, $\mathrm{Ph} .664$; truth: as. El. 60I, 124I ; doom: as. El. I282; equity, justice: is. ryhte, $\mathrm{Ph}$. 494. See $\overline{\mathbf{x}}-$, unriht.

riht, adj., right, true: nsm. El. 13; asf. rihte, El. 28I. See ǣ-, unriht.

rihte, adv., rightly, exactly, truth- fully: El. 553, 566; ryhte, El. I075; Pn. 3.

rihtfręmmende, adj., righteous: npm. ryhtfremmende, $\mathrm{Ph} .632$. rīm, n., number: gs. rimes, El. 2; ds. rīme, El. 284, 634; as. El. 635 ; Pn. 3. See dōgor-, fæòm-, ge-, manrìm.

riman, WI., account, esteem as: pp. npm. rìmde, Pr. 10.

rïme, see unrīme.

rīmtalu, f., number: as. rīmtale, E1. 820.

rinc, m., warrior, hero: ap. rincas, El. 46. See fyrd-, hilderinc. rīsan, see ārīsan. -rist, see ǣrist.

rōd, f., cross, rood: ns. El. 219, $624,720,887,973$, I012, I224; gs. rōde, El. I03, 147, 206, 856, I 235 ; Ph. 643; ds. röde, El. 482, 601, 774, 1067, 1241; as. rōde, El. 631, 919, 1023; gp. rōda, El. 834, 880; ap. rōda, El. 869.

rodor, m., heaven, sky: ns. El. 856; gs. radores, El. 795; gp. rodora, El. 206; rodera, El. 482, 1067 , I075; $\mathrm{Ph} .664$; dp. roderum, E1. 13, 46, 147, 460, 631, 919, 1023, II5I, I235; Ph. I4; radorum, E1. 762, 804. See sūờ-, ūprodor.

rodorcyning, m., king of heaven: gs. rodorcyninges, El. 887 ; radorcyninges, El. 624 .

rōf, adj., valiant, gallant: asm. rōfne, E1. 50. See æsc-, beadu-, ęllen-, gūò-, heað̋o-, sigerōf.

Rōm, pr. n., Rome: g. Rōme, El. I052.

Rōmware, pr. n., Romans: n. El. 46; g. Rōmwara, El. 9, 40, 59, 62, I29; Rōmwarena, El. 982. rūm, adj., spacious, extensive, widestretching: npm. rŭme, $\mathrm{Ph}$. 14 ; 
full: comp. asf. rūmran, El. I24I. See gerūma.

rūn, f., mystery, secret: as. rūne, E1. I262; ap. rüne, E1. 333, I169; secret council, private council: ds. rūne, E1. 4II, II62. See hyge-, lẽoð-, wælrūn.

ryht(-), see riht(-).

rȳman, sce gerȳman.

ryne, m., expanse: ds. E1. 795.

-rȳne, see gerȳne.

ryp, m., reaping, ingathering: gs.

rypes, Ph. 246.

rȳric, see sǣrȳric.

\section{S.}

sacan, see for-, wiosacan.

sācerdhād, m., priesthood: as. E1. I055.

Sachius, pr. n., Zacchaus: n. E1. 437.

sacu, f., strife: ns. El. 906; Ph.

54 ; as. sæce, E1. 94I ; affliction:

ds. sæce, El. ro3I. See also sæcc.

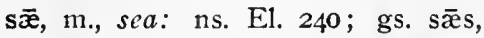

El. 729 ; as. Ph. 103. See Wendelsā.

sæcc, f., fight, battle: ds. sæcce,

El. II78, II83. See and-, eoful-, widersæc; sacu.

sæad, n., seed: ns. Ph. 253.

sæ̈fisc, m., sea-fish: gp. sǣfisca, W. 56 .

sæ̋gan, Wr., cause to set: pp. sǣged, Ph. I42.

sæl, see burgsæl.

s̄̄l, m. f., delight, joy, happiness:

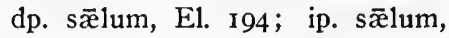
Ph. I40.

sǣlan, Wr., tie, make fast with ropes: 3 pl. sælab, W. 15; pp. npm. sǣlde, El. 228. See à-, ges̄̄lan.

sælig, see ge-, wansǣlig.

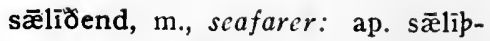
ende, W. 48.

sæ̈mearh, m., ocean-steed, ship: as. E1. 245 ; np. sǣmearas, El. 228 ; ap. s̄̄mearas, W. I 5 .

sǣne, adj., backward, slack, negligent: nsf. E1. 220.

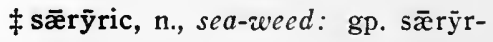
ica, W. Io.

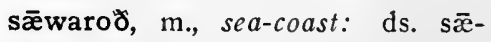
waroðe, El. $25 \mathrm{I}$.

Salomōn, pr. n., Solomon: g. Salomōnes, E1. 343.

salor, n., palace: ds. salore, El. 382, 552.

same, adv., similarly: El. 1207, I284; some, E1. 653, го66, 1278; Pn. 53. Swä some, also, as well. samnian, see somnian.

samod, adv., together: El. 6I4, 729, 889; somod, Ph. 5I3, 584; also: somod, Ph. 629; somed, E1. 95 .

sanctus, adj. (Lat.), holy, saint: nsm. El. 504; Pn. 69.

sang, see song.

sār, n., pain, pang: ip. sārum, E1. 479, 697, 933; mischicf, trouble: as. El. $94 \mathrm{I}$.

sār, adj., dire, grievous: asf. sāre, Ph. 369.

sārlīc, adj., grievous: nsn. Ph. 406. sãrwracu, f., misery, tribulation: ns. Ph. 54; ds. sārwræce, $\mathrm{Ph}$. 382 .

Saulus, pr. n., Saul: g. Saules, El. 497.

sāwan, see onsāwan.

sãwol, f., soul: ns. sāwol, El. 890; sāwel, Ph. 523; gs. sāwle, El. II72; as. sāwle, Ph. 566; np. sāwla, Ph. 540, 584; gp. sāwla, El. 46I, 564, 799, 906; Ph. 498; dp. sāwlum, Ph. 488, 589 . 
sāwollēas, adj., lifeless: asm. sāwollēasne, El. 877.

scanca, m., leg: np. scancan, $\mathrm{Ph}$. 310.

sceacan, IV, go, pass by: pp. sceacen, El. 633. See äsceacan. scead, n.f., shadow: ds. sceade, $\mathrm{Ph}$. I68, 234; ap. sceadu, Ph. 2 Io. See lēafscead.

scēadan, rd., command, marshal: pret. $3 \mathrm{sg}$. scēad, El. 709. See ā-, gescēadan.

-sceaft, see gesceaft.

scealc, m., retainer: np. scealcas,

E1. 692; man: dp. scealcum,

W. 3 I.

sceamu, f., shame: as. sceame, El. 470. See also scomu.

-sceap, see gesceap.

scearplice, adv., abruptly: Ph. I68. scearu, see folcscearu.

scēat, m., region: ns. Ph. 3; gp. scēata, Ph. 396; Pn. 68; lurking-place: dp. scēatum, El. 583 . sceaða, m., cnemy, foe: ap. sceaðan, E1. 762. See āttor-, hęlle-, womsceaða.

scēawian, W2., see, behold: 3 pl. scēawiap, Ph. 327 ; pret. 3 sg. scēawede, El. 58. See bi-, forescēawian.

sceolu, f., host, throng: ns. E1. 763; scolu, Ph. 560; multitude: ns. E1. 836; horde: ns. El. I30I.

-sceop, see wīdsceop.

scęðठan, VI, harm, injure: $3 \mathrm{sg}$. sceped, $\mathrm{Ph} .39,88$; inf. Ph. I80; sceppan, Ph. 449, 595; weigh upon, oppress: 3 sg. sceðped, El. 310. See gescęððan.

scinan, I, shine: 3 sg. scineo, $\mathrm{Ph}$. I83, 210, 5I5, 589; 3 pl. scinab, E1. 743, I319; opt. 3 sg. scine, Pr. I4; ptc. scinende, El. III5. See gescinan. scinna, m., demon: gp. scinnena, IV. 3 I.

scip, n., ship: ap. scipu, W. I3, 3r. -scipe, see dryht-, fëond-, lēod-, Jēodscipe.

scīr, adj., bright, glorious: nsm. Ph. 234; asm. wk. sciran, El. 370 ; asf. wk. scīran, El. 310; gorgeous: nsf. Ph. 308.

scīran, Wr., determine, appoint:

pp. scīred, El. I232.

scolu, see sceolu.

scomu, f., dishonor, shame: ds. scome, Ph. 502. See also sceamu.

scræf, see dünscræf. scrifan, see gescrïfan.

scrīoan, I, move, sail: inf. El. 237. scrūd, see gūòsscrūd.

scūfan, II, cast, thrust: inf. El. 692. See be-, odscūfan.

sculan, anv., should, ought, shall, will, be necessary: 2 sg. scealt, E1. 673, 687, 95I; 3 sg. sceal, E1. 545, 580, 756, 768, I I92; Ph. 250 ; sceall, El. I 76 , I28I ; 3 pl. sculon, El. 210; pret. $3 \mathrm{sg}$. sceolde, E1. 764, I049; Ph. 378, 643 ; 2 pl. sceoldon, El. 367; 3 pl. sceoldon, El. 838, 982; Ph. 4I2; opt. 3 sg. scyle, El. 896 ; Ph. 563; be said: 3 sg. sceal, Ph. 90 .

scunian, see onscunian.

scūr, m., shower, storm: ns. Ph. 246; ap. scūras, El. II7. See winterscūr.

scyld, m., shield: ns. Ph. 308, 463. scyld, f., fault, iniquity, sin: gp. scylda, E1. 470, r313; ip. scyldum, Ph. I8o.

scyldan, see gescyldan.

scyldful, adj., guilty, sinful: dpm. scyldfullum, El. 3 Io.

scyldig, adj., guilty: asm. scyldigne, El. 692. See unscyldig. 
scyldwyrcende, adj., sinful, guilty: nsf. Ph. 502; apm. El. 762.

scyll, f., shell: ds. scylle, Ph. 234; scale: ip. scyllum, $\mathrm{Ph} .310$.

scyndan, Wi., hurry, hasten: pret.

3 sg. scynde, E1. 30.

scynde, see unscynde.

scȳne, adj., brilliant, resplendent, beautiful: nsf. $\mathrm{Ph} .308$; nsn.

Pn. 19; npm. Ph. 300, 591; gpn. scȳnra, Pn. 26. See wlitescȳne. scyppan, see gescyppan.

Scyppend, m., Creator: gs. Scyppendes, Ph. 327 ; as. Scippend, E1. 370 ; vs. E1. 791 ; Ph. 630.

scyrdan, see gescyrdan.

scyrian, see āscyrian.

se, sē, adj., pron., that, the, he, who, which: nsm. El. II, 42, 76, etc. (35 times); Ph. 3, 7, 9, etc. (55 times); Pn. 15, 38, 58, 69, 73; W. $4,47,53,57,59,67,71$; nsf. sēo, El. 266, 309, 580, 619, 624, $662,675,7$ I5, I0I8, I I 31 , I I52, I205; Ph. 98, I20, I4I, 30I, 307, 334, 342, 560, 587; sīo, El. 254, 378, 384, 4I I, 4I4, 4I6, 558, 709, $720,763,884,980$, I 012 , 1 224 ; nsn. 广æt, El. 59, 272, 91 I, 985; Pn. 19; bæt, E1. 94, I01, 426, etc. (2I times); Ph. 9, I3, 20, etc. (I4 times); Pn. I2, 58, 64, 74; W. I6, 38; Pr. 4; gsmn. ðæs, E1. 221, 428, 752, 966, I065; bæs, E1. $39,60,86$, etc. (38 times); $\mathrm{Ph} .65$, 107, 122, etc. (I 4 times); Pn. 25, 43; W. 8, 8I ; see also ठæa; gsf. pǣre, El. 293, 610, 864, 1234; Ph. 66, 90, 288; dsmn. đām, El. 342, 418, 420, etc. ( 8 times); pām, El. 70, 93, r33, etc. (20 times); $\mathrm{Ph} .50,78,89$, etc. (28 times); Pn. 15, 17, 33, 45,66 ; W. 3, 6, 14, 21, 37, 7I,

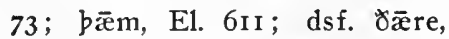
E1. 545, 601, 803, I24I; bǣre,
E1. $324,587,716$, etc. (I0 times) ; Ph. 23I, 633, 666; Pn. 44, 54; asm. бone, El. 243; bone, El. $302,370,423$, etc. (22 times); Ph. 85, I73, 28I, 305, 339, 396, 439; Pn. 4I, 54, 59; W. 52, 55 ; pane, El. 294; asf. ðā, El. 63I, 783, ı089, เ242; bā, El. 98, ı83, 274, etc. (3I times); W. 28, 6I ; asn. ðæt, El. 40I, 432 ; bæt, $\mathrm{Ph}$. $69,200,268$, etc. (I2 times); ismn. bon, $\mathrm{Ph} .238,262,424$; W. 8o; see also tō dan; ซỹ, E1. ז85; bỹ, E1. 96, 797, 891; Ph. 573, 644; Pn. 61 ; Pr. 12; bē, El. 97, 796, 946, 956; see also

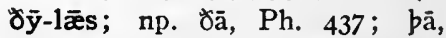
E1. I69, I72 (2), etc. (I I times); Ph. 35, 66, 7I, etc. (I5 times); W. 25, 80; gp. bāra, El. 450, 470, 5I5, etc. (I3 times); $\mathrm{Ph}$. 3I, I38; Pn. 2, 23; pæ̈ra, El. 285, 608, 1078; dp. đām, E1. 927 ; pām, El. 277, 354, 750, etc. (9 times); Ph. 8, 76, I09, etc. (12 times); Pn. 36; W. 44; ap. đā, El. 582 ; bā, El. 1 53, 323, 468, etc. (I6 times); $\mathrm{Ph} .193,283$, 292 ; W. 76 . See se ठe.

sealt, adj., salt: asm. sealtne, W. 27 ; apm. sealte, Ph. 120.

$\ddagger$ sealtȳy, f., salt wave: gp. sealtyेpa, Pn. 8.

searo-, see searu-.

searu, n., plot, deceit, wile, craft: as. El. 72I-2; searo, W. 42 ; ap. searo, Ph. 4I9; care: ip. searwum, Ph. 269. See lige-, nearusearu.

searucræft, m., skill, workmanship: ip. searocræftum, E1. I026.

searulice, adv., cunningly, artistically: searolice, Ph. 297.

searudanc, m., shrewd thought, wise thought: ip. searubancum, El. II90; searopancum, El. 4I4. 
sēað, m., well, cistern, pit: as. El. 693.

sēcan, WI., seek, visit, repair to: 3 sg. sēceð, Ph. 278, 349, 458, 524; Pn. 36; W. 45 ; opt. 3 pl. sẽcen, W. 35 ; inf. El. 598 ; Ph. 275, 320, 67I ; W. 87; seek, search for: pret. 3 pl. sōhton, El. 322, 474; Ph. 4I6; inf. El. I5I, 2I6; sēcean, El. I149; ask, inquire, question: I sg. sēce, El. 3I9, 4IO; pret. 3 sg. sōhte, El. 325, 568; 3 pl. sōhton, El. 4I4; inf. E1. 420, II57; report to: inf. sēcean, El. 983; favor, approve: inf. El. 469; rush to: 3 pl. sēcab, El. I 80 . See ā-, for-, gesēcan.

sęcg, m., man, warrior: ns. El. I257 ; np. secgas, El. 47, 998, IOOI ; secggas, El. 260; gp. secga, El. 97, 271 ; vp. secgas, El. 552.

sęcgan, W3., tell, say, declare: $3 \mathrm{pl}$. secgap, El. 674; secgad, Ph. 313, 425, 655; Pn. 20; pret. I sg. sægde, Pn. 34; 2 sg. sægdest, El. 665 ; 3 sg. sægde, El. 437 ; 3 pl. sægdon, El. 588; imper. sg. saga, El. 623,857 ; inf. El. 317 , 376, 567, 574; Pn. 9; Pr. I ; secggan, El. I60; speak: pret. 3 pl. sægdon, El. I9o; teach, instruct: pret. 3 sg. sægde, El. 366; ascribe: pret. 3 pl. sægdon, El. III7. See gesęcgan; unāsęcgendlīc.

sedes, f. (Lat.), seat: abl. p. sedibus, Ph. $67 \mathrm{I}$.

sefa, m., mind, heart: ns. El. I73, 627, 956, I I90; as. sefan, El. 376 ; ds. sefan, El. 382, 474, 532, I I 49, I 65. See brēost-, ferh'̈-, mōdsefa.

sēfte, see gesēfte.

segn, m., ensign, standard: ns. El. I24. sēl, adv., comp., better: El. 796; super. sēlest, El. 374, 532 ; sēlost, E1. I I 58,1 I65.

seld, see hēahseld.

sęle, see dēað-, wilsęle.

sēlest, see gōd.

se(o)lf, sce sylf.

sēlle, sce gōd.

sęllan, Wı., give, grant: pret. $3 \mathrm{sg}$. sealde, El. I82, II7I ; pp. seald, El. 527. See ge-, ymbsęllan.

sęllend, m., giver: ns. Pn. 64 . sellic, adj., rare, wonderful: nsn. $\mathrm{Ph}$. 606; comp. nsm. sellicra, Pn. 30; peculiar: asf. sellicran, Ph. 329.

sęmninga, adv., immediately, forthwith: El. II10, 1275; W. 27.

sęncan, see bisęncan.

sęndan, WI., send: 3 sg. sendeð, El. 931; Ph. 488; pret. 3 sg. sende, El. I200; lay: opt. pret. 3 pl. El. 457. See onsęndan. sēoc, see limsēoc.

seofeða, adj., seventh: asm. seofeðan, El. 697.

seofon, num., seven: El. 694. seolfren, adj., silver: asn. El. 1026. seomian, W2., abide, remain: $3 \mathrm{sg}$. seomad, $\mathrm{Ph}$. 19.

sēon, V, see: pret. 3 pl. sǣgon, El. I 105. See be-, for-, gesēon.

seonoo, m., council: ds. sionoðe, El. I54; as. seonob, Ph. 493.

seonoðdōm, m., assembly's decision: ap. seonoðdōmas, El. 552. sēoðan, see āsēoð̆an.

seppan, Wr., tcach, instruct: pret.

3 sg. septe, El. 530.

sēraphīn, mpl., seraphim: a. El.

755.

sęrce, see hildesęrce.

set, see geset.

sēoan, see gesēðan.

se $\delta \mathrm{e}$, rel. pron., who, that: nsm. E1. 303, 774, 913, 945, 1044, I 126, 
II 84 ; se be, Ph. 3I9, 536; W. 48,63 ; gsm. (see خæs ठ̀) ; dsm. pām be, Ph. 516; asm. bone pe, El. I162; np. pā ঠe, El. 280, 283, 315, 380; pā be, El. 154, 327, 373, I020; Ph. 316, 443; W. 79; gp. bāra be, El. 508, 818, 97I, 975, I014, I226; dp. pām be, W. 69; ap. bā be, E1. 897; W. 73. setl, n., seat: as. Ph. 439. See hëahsetl.

sęttan, WI., set, place: pret. 3 sg. sette, El. I136; Ph. 282; count, reckon: opt. pret. 3 sg. sette, El. 495 ; rccord: pret. I pl. setton, El. $658 ; 2$ pi. setton, E1. 654 ; torture, persccute: inf. El. 479; ordain: pret. 3 sg. sette, Ph. 328 . Sce à-, be-, ge-, ymbsęttan.

sib, f., peacc: ns. Ph. 622; gs. sybbe, E1. 446; ds. sybbe, E1. 598, I I 83 ; as. sybbe, E1. I 207, I315; bliss: ds. sibbe, Ph. 60I; grace: as. sibbe, W. 86; kinship, friendship (or kin, kinsfolk): ns. syb, El. 26.

sibgedryht, f., kinsfolk: ns. Ph. 618.

siblufe, f., lovc: ds. siblufan, Pr. 8. sĩd, adj., broad, wide: asm. sidne, E1. 729, I289; Ph. I03, 498; spacious: asn. sïde, Ph. I56; vast: asn. El. I58; grcat, deep: asm. sĩdne, El. 376 .

sīde, adv., far, wide: E1. 277; Ph. 467.

sīdweg, m., distant part, great distance: dp. sidwegum, E1. 282; Ph. 337.

sigan, I, fyy in, press in: 3 pl. sigad, $\mathrm{Ph} .337$.

sige, m., victory: as. El. 144 .

$\ddagger$ sigebēacen. n., sign of victory, victorious standard: ns. El. 888; ds. sigebēacne, E1. I68, 1257; gp. sigebēacna, El. 975. sigebēam, m., tree of victory, cross: gs. sigebeames, El. 965; ds. sigebèame, El. 420, 444, 665, 86I ; gp. sigebēama, E1. I028; ap. sigebēamas, El. 847 .

sigebearn, f., victorious son: ns. E1. 48I, 863, I147.

$\ddagger$ sigecwēn, f., victorious queen: as. E1. $260,998$.

sigelēan, n., reward of victory: gp. sigelēana, El. 527.

sigelēoð, n., song of victory: ns. E1. I24.

sigerōf, adj., bent on victory, victorious: nsm. El. 158, 437; dsm. sigerōfum, El. 7I, I90; npm. sigerōfe, El. 47, 868.

sigespēd, f., succcss, victory: as. E1. II72.

sigewong, m., field of victory: ns. Ph. 33 .

sigor, m., victory: gs. sigores, El. 85, I84, II21; as. El. II83; gp. sigora, El. 346, 488, 732, I140, I 308; Ph. 329, 464, 493, 675; Pn. 64.

†. sigorbēacen, n., emblem of victory, victorious standard: ns. E1. 985 .

$\doteqdot$ sigorcynn, n., conquering race: ns. El. 755 .

sigorfæst, adj., victorious, triumphant: nsm. Ph. 282.

sigorlēan, n., reward of victory: as. E1. 623.

Silvester, pr. n., Silvester: d. Silvestre, El. Igo.

sinc, n., trcasurc: gs. sinces, El. I 94.

sincaldu, f., ever-during cold: ns. Ph. I7.

sincgim, m., jewel: ns. El. 264. sincweoroung, f., costly gift: ap. sincweorठunga, El. 1219.

sindrēam, m., evcrlasting joy, per- 
petual bliss: ds. sindrẽame, El. 74I; dp. sindreamum, Ph. 385 . sine, prep. (Lat.), without: w. abl., Ph. 675 .

singal, adj., constant, continual: nsf. El. 906.

singallīce, adv., perpetually, ceaselessly: El. 747.

singan, III, sing, chant, hymn:

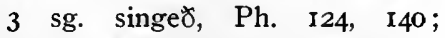
3 pl. singab, El. 747; singa 8 , Ph. 617, 635; pret. 3 sg. sang, E1. 337, II89; 3 pl. sungon, El. $56 \mathrm{I}$; inf. $\mathrm{Ph} .676$; pp. sungen, E1. II54; ring out: pret. 3 pl. sungon, E1. 109.

siomian, W2s, abide, remain: pret.

3 sg. siomode, El. 694.

sionod, see seonod.

sioðtan, see siððan.

sīo, m., journey, march: gs. sið es,

El. 247, 260, 1219; ds. sỉðe, El. I00I ; as. El. III, 243, 997, 1005; Ph. 440, 555; time: gp. sīpa, Ph. 464; ip. sīðum, El. 818; sibum, Ph. 69, 106, 146; proceeding, 'deal': ns. El. 9II ; advance: as. $\mathrm{Ph}$. 90, II4; $d c$ parture: gs. sīpes, Ph. 208; ds. siððe, Ph. 220 (bēon on sið̀e, escape). See hęre-, hin-, ūt-, wilsī̄o.

sīo, adv., later: El. 74, 240, 572, 975.

$\ddagger$ sīðdæg, m., later day: dp. sīðdagum, E1. 639.

siơfæt, m., departure: ns. El. 229; voyage: gs. sioffates, El. 220.

sīoian, W2., depart, vanish: pret.

3 sg. sïðode, El. 95; journey:

3 pl. sïpiap, $\mathrm{Ph} .584$.

siðran, adv., later, afterwards: $\mathrm{El}$.

27I, 48I, 483; sibpan, Ph. 385, 409, 577, 579; siðpan, El. 1315; syðban, El. 518; syððan, El. 502, 504, 639, 677, 1060; since then, thenceforth, thereafter: El. 926, 1028; sippan, W. 42; Pr. 9; siðban, El. 636; syððan, El. 950, I302; syðban, El. 507; sioððan, E1. I147; then: sibpan, Ph. III ; Pn. 66.

siðరan, conj., after, when: El. 57, 230, 1016, 1037, 105I; syððan, El. 17,842 ; as soon as, when: syððan, El. 116, 248, 914, 1002; sibpan, Ph. 117, 224; since: sippan, Ph. 129.

sittan, V, sit: 2 sg. sitest, El. 732 ; 3 sg. siteð, $\mathrm{Ph} .208$. See be-, gesittan; burgsittend; Orym-, ymbsittende.

slǣp, m., sleep: ns. Ph. 56; ds. slǣpe, El. 69, 75; Pn. 42; is. slǣpe, Pn. 39. slāw, see unslāw. sleht, see morðorsleht. slïoe, adj., awful, dreadful: asf. slïðan, El. 857.

slïðen, adj., fell, walign: asn. slïpen, W. 42.

smǣte, adj., purc, fine: nsn. E1. I309.

smēagan, W2., consider, reflect: pret. 3 pl. smēadon, El. 413. smēðe, see unsmëðe. smið, m., goldsmith: gp. smipa, Ph. 304. See lārsmiơ.

smylte, adj., screne: nsm. Ph. 33 . snāw, m., snow: ns. Ph. 14, 248. snel, adj., swift, speedy: nsm. $\mathrm{Ph}$. I63, 347; snell, $\mathrm{Ph}$. 23 ; nimble: nsm. Ph. 3r7.

snēome, adv., straightway: Pn. 42. snottor, adj., wise: nsm. El. I Iço; nsm. wk. snottra, Pn. 69; super. dpm. snoterestum, E1. 277. See forð-, gearusnottor.

snūde, adv., quickly, spcedily, straightway: E1. 154, 313, 446; Ph. 488. 
snyrgan, Wr., sail, scud: inf. El. 244.

snyttro, f., prudence, sagacity, wisdom: gs. El. 154, 293, 374, 544, 554, 1060, I172; as. El. 382, $407,938,959$; is. El. 313. See unsnyttro.

snyttrocræft, m., prudence, sagacity, wisdom: ns. snyttrucræft, Ph. 622.

sōfte, see unsōfte.

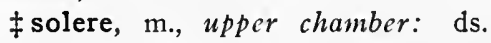

Ph. 204. [Lat. solarium.]

some, see same.

somed, see samod.

-somne, see æt-, tōsomne, somnian, W2., gather, collect: $3 \mathrm{sg}$. somnað, $\mathrm{Ph}$. I93, 269, 467; pret. 3 sg. samnode, El. 60; 3 pl. samnodan, E1. 19; assemble: 3 pl. somniað, $\mathrm{Ph} .324$; pret. 3 sg. samnode, El. 55 ; compose: opt. I sg. somnige, $\mathrm{Ph}$. 547. See gesomnian.

somod, see samod.

sōna, adv., soon, quickly, speedily:

El. 47, 85, 222, 514, 713, 888, I031; Ph. I20; Pr. 8 . Sōna swā, as soon as, the moment that.

sondbeorg, m., sand-hill, sanddune: ip. sondbeorgum, W. Io. song, m., song: as. Ph. 540; sang, El. 29, II 2, 868; is. songe, $\mathrm{Ph}$. 337.

sọngcræft, m., musical creation: dp. songcræf tum, $\mathrm{Ph}$. I32.

sorg, f., sorrow, care, anxiety: ns. Ph. 56; ds. sorge, E1. 922, I03I ; Ph. 6II; dp. sorgum, El. 694; ip. sorgum, El. 1244. See bealu-, gnorn-, mōd-, nearusorg. sorgful, adj., sorrozeful: comp. apn. sorgfulran, $\mathrm{Ph}$. $4 \mathrm{I} 7$. sorgian, W2., sorrow, grieve: 3 sg. sorgad, E1. 1082. See bisorgian. sorglēas, adj., free from sorrow: comp. nsm. sorglēasra, E1. 97. sōo, n., truth: ds. sōðe, El. I60, $307,390,574,663$; as. E1. 395 , 588, 690, 708, 808, I I 40 .

sōð, adj., true: nsm. El. 46r, 488, 564 ; nsn. El. 888; asm. wk. sōðan, El. 892; vsm. Ph. 622; gpn. sōðra, El. 778 .

sōocwide, m., word of truth: ip. sōđcwidum, El. 530.

sōðcyning, m., true king: ns. El. 444; Ph. 329, 493.

sōðfæst, adj., faithful, believing, righteous: nsm. $\mathrm{Ph} .523$; nsf. wk. sōpfæste, Ph. 587; npm. sōðfæste, El. 1289; Pn. 66; npf. sōof fste, Ph. 540; gpm. sōðfæstra, El. 7; Ph. 635; dpf. sōðfæstum, Ph. 589; blessed: gpm. sōðfæstra, Ph. 606.

sōðfæstnes, f., faith, piety: is. sōof fæstnesse, El. II 49.

sōolīce, adv. truly: El. 200, 317, 517, 665, 799.

sōowwundor, n., true miracle: as.

E1. I 122.

spāld, n., spittle: as. El. 300.

spannan, see onspannan.

spēd, f., success, victory: as. El. I182; fulness, abundance: ns. Ph. 640 ; as. El. 366 ; Ph. 394. See sige-, wigspēd.

spēdig, adj., abounding, rich: nsm. Ph. Io.

spel, see god-, lēof-, morgen-, wilspel.

spelboda, m., prophet: ns. Ph. $57 \mathrm{I}$. spēowan, Wr., spit: pret. 2 pl.

spēowdon, E1. 297.

spild, n., seduction, temptation: as. El. III9.

splott, n., splotch, spot: ip. splottum, $\mathrm{Ph} .296$. spon, see gespon. 
spōwan, rd., avail, succeed: inf. E1. 9 I7.

sprecan, V, speak: pret. $3 \mathrm{sg}$. sprac, El. 332, 404, 725. See gesprecan.

spring, see $\bar{æ}-$, gesprlng. springan, see onspringan. spyrigean, sce āspyrigean. stæf, see bōc-, wrōhtstæf. stāl, m., stead: as. Pr. I I. stæpes, see instæpes.

stæppan, VI, stride on, advance: pret. 3 pl. stōpon, E1. I2I, 7 I6. stærcedferhठ, adj., courageous, brave: npm. stærcedfyrhðe, El. 38.

stæठ, n., bank, shore: ds. stæðe, El. 38, 232; stape, W. I8; as. E1. 60, 227.

stān, m., stone: ns. El. 6r 3 ; ds. stāne, El. 565; Ph. 302 ; W. 8; as. El. $6 \mathrm{I}_{5}$; ip. stānum, El. 492 , 509. See eorcnan-, marmstān. stānclif, n., cliff, crag: np. stānclifu, Ph. 22 ; dp. stānclifum, El. I35.

standan, see stọndan.

stāngefōg, n., mason's art: ip. stāngefōgum, El. I02I.

stāngripe, m., handful of stones: dp. stāngreopum, El. 824 .

stānhlì̀, n., cairn: dp. stānhleoðum,

E1. 653 .

stapa, see ănstapa.

staðelian, W2., fix, set, establish:

I sg. staðelige, El. 797 ; pret.

3 sg. stapelode, Ph. I30; opt.

I pl. staðelien, El. 427 ; strengthen: inf. staðolian, El. rog4. See gestaðelian.

-steald, see gesteald.

-stealla, see gestealla.

stēam, m., smoke, vapor: ns. El.

803; Pn. 45. See also stȳman. stēap, adj., steep: npm. stēape, $\mathrm{Ph}$.

22. stearc, adj., hard: nsn. El. 6r5; obstinate, obdurate: $\mathrm{npm}$. stearce, El. 565; piercing: nsf. Ph. 302.

stęde, m., place, stand: as. El. I35. See beorh-, eard-, meðel-, wọngstęde.

stędewọng, m., place, locality: ds. stedewange, El. 675, IO2I.

stefn, f., voice: ns. Ph. I35, 542;

ds. stefne, $\mathrm{Ph}$. 542; Pn. 44, 54;

ip. stefnum, El. 748,750 ; sound:

is. stefne, Ph. 497.

stefn, m., time: is. stefne, El. I06I, I 128.

stefn (prow), see hēahstefn.

stefna, see hringedstefna.

stęllan, see àstęllan.

stęnc, m., odor, fragrance: ns. $\mathrm{Ph}$.

81; Pn. 44, 64, 74; W. 54, 57; as. $\mathrm{Ph} .659$; ip. stencum, Ph. 8; Pn. 54; W. 65; spice: ip. stencum, Ph. 206, 586. See æठ̀elstęnc.

steorra, see heofonsteorra.

Stēphānus, pr. n., Stephen: n. El. 492, 824; a. E1. 509.

stigan, I, mount, rise: $3 \mathrm{sg}$. stīge $\delta$, Ph. 520; 3 pl: stigad, Ph. 542. See āstigan.

stille, adv., still: $\mathrm{Ph} .185$.

stīohīdig, see stīòhȳdig.

stīohycgende, adj., determined, steadfast: nsm. El. 683; npm. E1. 7 I6.

stīohȳdig, adj., stout-hearted, courageous: npm. stīohīdige, E1. I2I.

stōl, see cynestōl.

stondan, VI, stand: $3 \mathrm{sg}$. stondep, Ph. 78; 3 pl. stondad, Ph. 22, 36, 78, I85; standap, E1. 577 ; pret. 3 sg. stōd, Ph. 45; 3 pl. stōdon, El. 232; ride (of ships) : 3 pl. stondad, W. I7; pret. 3 pl. stōdon, El. 227; be 
rife: pret. 3 sg. stōd, E1. II3; endure: 3 sg. stondeð, $\mathrm{Ph} .89$, I8I. See āstondan.

storm, m., storm: gp. storma, Ph. I85.

stōw, f., place, spot: ns. E1. 675; ds. stōwe, El. 7 r6, 803 ; as. stōwe, E1. 683; Ph. I69; Pn. 37; ap. stōwe, E1. 653. See wicstōw. strǣt, see merestrǣt.

\section{strang, see strong.}

strēam, m., flood, stream: as. El.

I20I; is. strēame, W. I8; ap. strëamas, $\mathrm{Ph}$. I20. See ēg-, firgen-, lagu-, wyllestrēam.

stręngơ, f., might, power: ns. $\mathrm{Ph}$. 625 .

strēon, see gestrēon.

strong, adj., strong: nsm. Ph. 86, 99, I6I ; hard, severe: nsm. strang, E1. 703.

strūdan, II, plunder, rob: $3 \mathrm{sg}$. strūdeð̀, El. go5.

strȳnan, see gestrȳnan. stund, f., time: ip. stundum, E1. I2I, 232. See woruldstund. stunde, adv., straightway: E1. 724. stȳman, Wi., fume, reek: $3 \mathrm{sg}$. stȳmeð, Ph. 2r3. See also stēam. sum, pron., some, certain: asn. E1. 403; W. I2; npm. sume, E1. I32, 133, 548 (2); Ph. 315; apm. sume, E1. I3I, I36; ip. sumum, Pn. 8;.Pr. I ; $a$ : asf. sume, El. 479; part $(l y)$ : nsm. Ph. 296 (3). See also sumes. -sum, see luf-, wynsum. sumes, adv., somezhat: $\mathrm{Ph} .242$. sumor, m., summer: gs. sumeres, E1. I228; Ph. 37, 209.

sunbearo, m., sumny grove: ns. Ph. 33.

sunbeorht, adj., sun-bright: apn. Ph. 278, 436.

sund, n., sea, ocean: gs. sundes,
W. 15 ; ds. sunde, E1. 228; is. sunde, El. 251.

-sund, see ge-, onsund.

¥sundhwæt, adj., with swift motions: npm. sundhwate, W.

57.

sundor, adv., in different directions, far and wide: El. 407, IoI9, apart, aside: E1. 603.

¥ sundorgecynd, f., remarkable character: as. Pn. 30.

$\ddagger$ sundorwis, adj., wondrous wise: asm. sundorwīsne, El. 588 .

sundplega, m., bath: ds. sundplegan, Ph. III.

sundrian, see āsundrian.

sunne, f., sun: ns. Ph. I20, I4I, 209, 587; gs. sunnan, $\mathrm{Ph}$. 17 , $90,253,288,305$; ds. sunnan, E1. IIIo; Ph. 532, 579, 601.

sunu, m., son: ns. E1. 46I, 564, 592, 778; Ph. 375; gs. suna, E1. 222 ; ds. suna, E1. 1200, I3I8; as. El. $474,686,892$; vs. El. 447 ; dp. sunum, $\mathrm{Ph}$. 406. See gāstsunu.

sūsl, n., torment, torture: is. sūsle,

E1. 772; gp. sūsla, El. 944; Pn.

59 ; ip. sūslum, El. 950. See cwicsūsl.

sūoan, adv., from the south: sūpan, Ph. $186,324$.

sūorodor, m., southern sky: as.

Ph. I4I.

swā, adv., thus, so: E1. I63, 27I, 306, etc. (29 times); Ph. 47, I04, I40, etc. (I I times); Pn. 25, 55, 69; W. I I, 31, 62, 88; Pr. 15 ; in like manner: Ph. $38 \mathrm{I}$, $437,534,583,646,650$; even: E1. 691; also: Ph. 405; then: Ph. I2I ; Pr. 7.

swā, conj., as, even as, just as: El. 87 , 100, 190, 223, 325, 378, 4II, $436,478,54 \mathrm{I}, 589,597,606,674$, $715,835,838,896$, I022, I I3I, 
I I55, I 255, I269; Ph. 23, 29, 36, 4I, 108, 120, 243, 280, 328, 496, 558, 597, 652, 655; Pn. 20; W. 47 ; Pr. 5 ; like: El. I309; $\mathrm{Ph}$. 300, 315; as soon as: El. 128 ; as far as: El. 972; Pn. 6; as, since, because: El. 207, 340, 498, 1291, 1294; when: Ph. 4I (?), 322; swā . . . swā, as . . . so: E1. 785,789 ; as well

as: El. 325, 606; such

as: E1. 644, 645; swā hwylc, see hwylc; swā some, see same. swæcc, m., odor: gp. swæcca, Pn. 46; ip. swæccum, Ph. 214. See swicc.

swǣs, adj., dear, beloved: nsm. El.

517; dsm. swǣsum, El. 439; vsm. E1. 447 ; own: nsm. $\mathrm{Ph}$.

375 .

swan, m., swan: gs. swanes, $\mathrm{Ph}$. 137.

swār, adj., heavy: nsm. Ph. 315; sore: nsn. $\mathrm{Ph} .56$.

swaru, see andswaru.

swā-ðēah, adv., nevertheless, yet: swā-pēah, El. 500; Ph. 565.

sweart, adj., black, dark: super. apm. wk. sweartestan, El. 93I ; abominable: gpf. sweartra, Pr. 7. swębban, see āswębban.

swefan, V, sleep: 3 sg. swifeð, $\mathrm{Pn}$.

39 ; pret. 3 sg. swæf, El. 70.

swefn, n., vision, dream: gs.

swefnes, El. 7 I.

swēg, m., melody, music: ns. $\mathrm{Ph}$.

I3I ; gp. swēga, Ph. 6r8.

†े swēghlēoðor, m., melody: ns. swëghlēopor, Pn. 42; gs. swēghlëopres, Ph. I37.

swegl, n., heaven, sky: gs. swegles, E1. 507; Ph. 103, I14, 208, 288, 374; ds. swegle, El. 75, 623, 755 ; Ph. I86, I99, 467, 635; sun: ds. swegle, $\mathrm{Ph}$. I24; as. $\mathrm{Ph} .212$. sweglcọdel, f., heaven's candle, sun: gs. sweglcondelle, Ph. I08. swēlan, see forswēlan.

swelgan, III, swallow: $3 \mathrm{sg}$. swelged, $\mathrm{Ph}$. 507.

‡swelling, f., swelling sail: dp. swellingum, E1. 245.

swęng, m., blow, buffet: ap. swengas, El. 239.

sweofot, m., sleep, slumber: ds. sweofote, Pn. 39.

swēora, m., neck: as. swēoran, Ph. 305.

sweorcan, see gesweorcan.

sweord, n., sword: is. sweorde, El. 757.

sweordgeniola, m., foe, enemy:

ap. sweordgeniolan, El. I181.

swēot, n., rank, troop: dp. swēotum, E1. 124.

sweotole, adv., openly: E1. 26; with authority, with certainty: E1. I68, 86I.

sweotollice, adv., clearly, plainly: E1. 690 .

swerian, scc and-, geswęrian.

swēte, adj., sweet: nsm. Pn. 64; nsm. wk. swēta, W. 57; asm. swētne, W. 65; ipm. swētum, Ph. 214; ipf. swètum, Ph. 652; comp. nsm. swētra, Ph. I32; swèttra, Pn. 46; sup. swētest, Ph. I99; apf. swētestan, Ph. I93. sweðrian, W2., diminish: $3 \mathrm{sg}$. swebrað, Ph. 608; go out, die down: 3 sg. sweprat, Ph. 229.

swican, see be-, geswican.

¥ swicc, m., fragrance, perfume:

ds. swicce, Pn. 66. See swæcc. swice, m., escape: as. W. 78 . swift, adj., swift: nsm. Ph. 317. swīge, adj., still, quiet: nsm. El. 1275 .

swigian, W3., be silent, quiet down: 3 sg. swiad, Ph. I42. $\mathrm{Sec}$ geswigian. 
swilt, see swylt.

swimman, III, swim: 3 pl. swimmað, W. 57.

swin, see geswin.

swing, see geswing.

swinsian, W2., sing, make melody:

3 sg. swinsað, Ph. 124, I40, 618; roar, resound: pret. $3 \mathrm{sg}$.

swinsade, El. 240.

swīo, adj., right: comp. asf. swīoran, El. 347 ; strong: comp. nsm. swipra, Pn. 46.

swïoan, see oferswïdan.

swìde, adv., much, strongly: El. 663; super. swiðost, E1. 668; eagerly: El. 940; exactly: super. swiðost, El. II03; very: swipe, Ph. 3 I7.

swiðrian, see geswiðrian.

swol, n., heat: ds. swole, Ph. 2I4;

flame: gs. swoles, Ph. 269.

swongor, adj., sluggish: nsm. $\mathrm{Ph}$.

$3 I 5$.

swonrād, f., sea: as. swonrāde, E1. 997.

swylc, pron., such as: nsm. $\mathrm{Ph}$.

239; gsn. swylces, El. 571 ; apm.

swylce, El. 32.

swylce, adv., also, moreover: El.

I033.

swylce, adv., conj., as if: Ph. 233,

W. 9; like, as: E1. III3; Ph.

235, 305; likewise: E1. 3.

swylt, m., death: ns. El. 447 ; swilt,

E1. 677 .

swyltcwalu, f., agony of death: as.

swyltcwale, Ph. 369.

swylthwil, f., hour of death: ds.

swylthwile, Ph. 350, 566.

syb, see sib.

-syhd, see gesyho.

sylcan, see besylcan.

sylf, pron., self, own: nsm. E1.

$303,466,732,855$, I280; $\mathrm{Ph}$.

I99, 204, 382; self, Ph. 374;

seolf, El. 708, 808; nsm. wk. sylfa, Ph. 532; gsm. sylfes, $\mathrm{Ph}$. 282, 530; gsf. sylfre, El. 222 ; selfre, El. I200; dsm. sylfum, El. 69, I84; seolfum, El. 985 ; asm. sylfne, E1. 200, 209; Ph. III ; seolfne, El. 488, 603 ; npm. seolfe, El. II2I; gpm. sylfra, El. I207; dpm. sylfum, El. I295; apm. sylfe, El. I00I.

symbel, n., banquet, feast: ns. $\mathrm{Ph}$. 406.

symle, adv., always, ever, for ever:

E1. 469, 915, 1216; $\mathrm{Ph} .76$, 108, 146, 369, 375, 601, 661; Pn. 30, 35 ; Pr. 7.

Sȳmon, pr. n., Simon: n. El. 439, 530.

syn, f., sin: ns. El. 4I4; gs. synne, El. 772; gp. synna, El. 497, 5I4, 778, 940, 958, I318; dp. synnum, E1. 677, I309; ip. synnum, E1. 1244; Ph. 242; feud, hostility: ns. synn, Ph. 54 .

-sȳn, see onsȳn.

-sȳne, see gesȳne.

synful, adj., sinful, guilty: npm. synfulle, El. I295.

synnig, adj., sinful, sinning: nsm. El. 956; Ph. 523. See ligesynnig.

synwyrcende, adj., wicked, guilty: vsm. E1. 944 ; npm. El. 395.

Syrware, pr. n., Syrians: g. Syrwara, Ph. I66.

syðరan, see siððan.

syx, num., six: n. El. 74I, 1228; d. syxum, El. 742 .

syxta, adj., sixth: nsn. syxte, El. 7 .

$\mathbf{T}$.

tācen, n., emblem, sign, token: ns.

E1. I7I ; Ph. 96, 254; ds. tācne, E1. I84; as. E1. 85, I04, I105, II2I ; is. tācne, Ph. 450; gp. tācna, E1. I64; question: gp. tācna, El. 319; proof: ip. tācnum, 
El. 854; heroic deed: gp. tãcna, El. 645 ; interpretation: ns. $\mathrm{Ph}$. 510; scnse: as. $\mathrm{Ph} .574$ See wēatācen.

tācnian, see getācnian.

tæcan, WI., point out: opt. pret. 3 sg. tāhte, El. 631. See be-,

\section{getǣcan.}

tǣl, see lēoftāl.

talian, Wi., reckon: pp. npm. talade, Pr. Io.

talu, see rimtalu.

tān, m., twìg: ip. tānum, Ph. 430.

tapur, m., taper: ns. $\mathrm{Ph}$. II 4 .

tēag, f., chain: ip. tēagum, Pn. 60.

tēar, m., tear: np. tēaras, E1. II34. teldan, see biteldan.

tęlg, m., dye: gp. telga, Pn. 22.

telga, m., bough, branch: np. telgan, Ph. 76; dp. telgum, $\mathrm{Ph}$. I88.

tęllan, Wr., consider: pret. I sg. talde, El. 909. See getęllan.

tēma, see hęretēma.

tempel, m., temple: ds. temple, El.

I058; as. El. 1010, 1022.

tęngan, see getęngan.

-tęnge, see getęnge.

tēon, 1I, make, take: pret.' 3 pl.

tugon, $\mathrm{Ph} .440$.

tēona, m., grief, sorrow: ds.

tēonan, E1. 988.

tēonlēg, m., devouring flame: ns.

E1. 1279.

tēonlice, adv., grievously, with sorrow(?): $\mathrm{Ph} .407$.

teosu, f., destruction: as. W. 34 .

tid, f., time: as. E1. 787 ; $\mathrm{Ph} .77$,

209, 390, 450, 509, 517, 857, 1209;

Pn. I7; W. 64,87 ; tiid, Ph. 5;

gp. tīda, El. I044; ip. tîdum,

El. 1249; period: as. El. 193;

hour: ns. El. 874 ; Ph. 334 ; as.

El. 870; ap. tỉda, Ph. I46.

tiht, see tyht, til, adj., good: gsn. tiles, El. 325 ; gpf. tilra, W. 34 .

tilgan, W2., strive for: 3 pl. tilgar, Ph. 472.

tīma, m., time: ds. tīman, Ph. 246. timber, see fugeltimber.

timbran, Wr., build: inf. Ph. 188. $\mathrm{See}$ getimbran.

tìr, m., renown, honor: as. El. I64; glory: is. tire, El. 754.

tïrēadig, adj., renowned, famous: nsm. El. I04; nsf. El. 605; glorious: nsm. wk. tīrēadga, $\mathrm{Ph}$. ıо6; npm. tīrēadge, Pr. Io; blessed: nsm. El. 955.

tïrfst, adj., glorious: asn. $\mathrm{Ph}$. 574; wk. tīrfæste, Ph. 69.

tīrmihtig, adj., almighty: nsm. tirmeahtig, $\mathrm{Ph}$. I75.

tō, adv., too: El. $63,663,708$; on: E1. 1105.

tō, prep., w. dat., to: El. 10, 23, 32, etc. (53 times); Ph. 60, I9I, 226, etc. (I4 times); Pn. 66; W. 14 ; Pr. 5,7 ; from: El. 319, 325, 410, 568; W. 36, 86; Pr. I4; for, as: El. 16, I7, I84, 574, $600,898,982,988$, I001, 101 2 , I057, I058, I1 39 , II 43, II 58, I160, II62, I176, I 200, I247; $\mathrm{Ph}$. $40,83,139,198,243,386,475$, 562, 594, 61 I, 658; Pr. 71, 72; W. 89; at: Ph. 195; during, over: El. 21 I, 349, I218, 1321 ; w. gen. (see tō ठæs); w. ins. (see tō ठan); w. inf., Ph. 275; w. gerund, E1. 533, 607, 1166 .

tōēacan, adv., besides, likewise: Ph. 285.

tōgædere, adv., together: Ph. 225; tōgædre, W. 6I, 77.

tōgēanes, prep., w. dat., to: $\mathrm{Ph}$. 421; toward: Ph. 124, 579; before: Ph. II.

tōgēnes, adv., in return, in reply: El. 167,536 . 
tōglīdan, I, depart, vanish: $3 \mathrm{sg}$. tōglīder, El. I269; pret. 3 sg. tōglād, El. 78.

tohte, f., battle, strife: as. tohtan, E1. I 80 .

‡torht, n., clear light: as. E1. I249. torht, adj., bright, refulgent, glorious: nsn. Ph. 96; nsn. wk. torhte, $\mathrm{Ph} .28$; npm. torhte, Pr. Io; apf. torhte, Ph. 200; super. nsn. torhtost, El. I64; famous(?): nsm. wk. torhta, Ph. 574.

torn, n., grief, sorrow: ds. torne, El. II34.

torngenïla, m., bitter foe, bitter enemy: np. torngeniolan, E1. 568,1306 .

tōsomne, adv., together: El. I202. tōo, m., tooth: np. tōpas, Ph. 407. tō Oræs, adv., so: El. 704 (2).

tō Xan, adv., so: El. 703.

tōwegan, $\mathrm{V}$, disperse: pp. tōwegen, Ph. I 84 .

tōweorpan, III, destroy, abolish:

pp. tōworpen, El. 430.

tōwrecan, V, drive apart, scatter:

pp. npm. tōwrecene, E1. I3I.

træf, see wearhtræf,

‡trāg, f., evil: gs. trāge, El. 668.

trāg, adj., bad, evil: nsm. E1. 955;

gsn. trāges, El. 325.

trāglìce, see untrāglīce.

tredan, V, tread, traverse: $3 \mathrm{sg}$. trydeð, El. 612; paw(?): pret.

3 sg. træd, El. 55.

trēo (treow), n., tree, wood: ds.

treowe, $\mathrm{Ph}$. 175, 643; as. treow,

Ph. 200; dp. treowum, $\mathrm{Ph} .76$;

tree, cross: ns. El. I027; trīo,

El. 429; gs. treowes, E1. I252;

ds. El. $206,706,828,867$; as. El.

107, I28, I47, I65, 214, 442, 70I,

757,841 ; treow, El. 664.

trēow, f., faith: is. trēowe, $\mathrm{Pr} .5$
Trōiānas, pr. n., Trojans: n. El. 645 .

trymman, WI., strengthen: pret.

3 sg. trymede, El. 14; 3 pl. trymedon, El. 35 .

trȳwe, see getrȳwe.

tū, sec twēgen.

$\ddagger$ tunece, f., coat: ns. Pn. 22.

tungol, m. n., star: np. Ph. 96; gp. tungla, Ph. 93, IIg. See æðel-, heofontungol.

turf, f., turf, sod, sward: ds. tyrf,

Ph. 66; soil: Ph. 349. See èdelturf.

‡turfhaga, m., sod, turf: ds. turfhagan, El. 830 .

twēgen, num., two: nm. El. 854; nf. twā, El. 880; nn. tũ, El. 2, $605,634,754$; dm. twām, El. I306; af. twā, El. 955, II80; an. tī, $\mathrm{Ph} .652$.

twęlf, num., twelve: im. $\mathrm{Ph} .69$, I06, I46; in. twelfum, Ph. 28. twēntig, num., twenty: dn. twēntigum, El. 830 .

twēo, m., doubt: ns. El. I7I; ds. twēon, El. 668.

twēonde, see untwēonde.

-twēonum, see betwēonum.

tȳdran, see ātȳdran.

tyht, m., march, motion: ds. tyhte, El. 53; tihte, Ph. 525 (on tihte, astir).

tyhtan, Wi., incite, spur on: $3 \mathrm{pl}$. tyhtap, W. 34. See fortyhtan. tȳn, see getȳn.

tȳnan, see bi-, ge-, ontȳnan.

$Ð$.

రō, adv., then: El. I38, I57, I94, etc. (I6 times) ; bā, El. I, 7, 25, etc. (76 times) ; Ph. 43, 395, 4I3. 'yā, conj., when: El. 389, III3; pā, El. 294, 556, 709, 786, 1219, I220; Ph. 28I. 
J̄̄er, adv., there: El. 256, 833, 875, III3, I28I; Ph. II ; IV. 36; bǣr, El. 4I, 84, II4, etc. (24 times) ; Ph. I4, 21, 25, etc. (33 times); W. 58, 79; thither: pǣr, El. 735 .

ठळ̄̄r, conj., where: Pn. 38; pǣr, E1. 70, 329, 693, 822, I0I2, I105, I107, 118I ; Ph. 8I, 106, 157, 397, $44 \mathrm{I}, 448,468,489,560,579,58 \mathrm{r}$, $587,607,658$; to the place where: b̄̄r, Ph. 327, 429; IV.

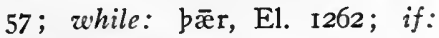
bǣr, El. 839, 979.

dæs, adv., conj., as: Ph. 313; so:

Pn. 4 ; because: E1. 823. Sec also tō ơs.

ðæs ðe, conj., because: bæs ðе, E1. 1317; bæs be, El. 957; Ph. 476; as: bæs be, Ph. 424; Pn. 13; from the time that: bas be, E1. 4, 68; that: bæs be, E1. II40; after: pres be, Pn. 62 .

Oæt, conj., that, in order that. so that: El. 59, I75; bæt, El. 9, I5, 36, etc. (66 times); Ph. I48, I68, I77, etc. (I9 times); W. II, I2, 25, 32, 35, 66, 85, 88; Pr. 15. See odræt.

dætte, conj., that: pætte, Ph. I, 69; Pn. 21, 27; W. 39, 55.

Jafian, W2., accept, agree to: inf. bafian, E1. 608 .

Janc, m., thanks, gratitude: ns. banc, El. 8I I, 893 ; ponc, Ph. 623 ; thought: gs. ponces, $\mathrm{Ph}$. 144. See fore-, ge-, hyge-, inwit-, or-, searuðanc.

Jancian, W2., thank: pret. $3 \mathrm{sg}$. bancode, El. 962, I I39.

Janon, adv., thence: panon, El. I43, I48, 348; ponan, Ph. 4I5, 554.

danon, conj., whence: bonan, $\mathrm{Ph}$. I 3 .

ye, indecl. pron., who, which, that:
E1. 453, 717, 726, 1080; be, El. I60, I62, I63, etc. (31 times); Ph. 31, 138, 196, 252, 516; Pn. I8, 34, 7I; W. 43; Pr. 4; be him (= whose), $\mathrm{Ph} .656$. See se 'de; dæs ठe.

Je, conj., where: El. 7I7; or: be, Ph. 357; because: Ph. 568; be, Ph. 369; that: Ph. 410; than: be, W. 8 o.

céah, conj., although, though: El.

82 ; bēah, E1. 48, I74, 362, etc.

( 12 times); Ph. 380; 563, 638,

642. See swā-ðēah.

Deaht, f., thought: as. peaht, El. I242. See gereaht.

Jeahtian, W2., consider, deliberate: pret. 3 pl. beahtedon, El. 547. See rǣdoahtende.

dearf, f., need: ns. bearf, E1. 426, 553. See nȳd-, oferdearf.

dearl, adj., grievous: nsf. bearl, E1. 704.

Jearlic, adj., terrible: asn. bearlic, Ph. 644 .

¿ēaw, m., custom, rite, practice:

ns. bēaw, W. 3I; dp. bēawum,

El. I2I I ; ip. ঠēawum, Ph. 444. See mānđ̄eaw.

Jęccan, Wr., enfold, invest: $3 \mathrm{sg}$. beceð, $\mathrm{Ph} .216,365$; overspread: pret. 3 sg. beahte, Ph. 42 ; deck: 3 pl. peccad, Ph. 249. See beJęccan.

degn, m., follower, minister, attendant: ns. begn, Ph. I65, 288; dp. pegnum, El. 487; man: as. pegn, El. 540; gp. pegna, El. I5I, 549; disciple: dp. begnum, $\mathrm{Ph}$. 388.

Jegnung, f., service, worship: ds. begnunge, El. 739 ; as. begnunge, E1. 745 .

đęgu, see fōdorðęgu.

Jęncan, WI., intend, purpose: pret. 3 sg. bōhte, E1. 206; think, re- 
flect: pret. 3 pl. bōhton, El. 549. See geð̨̋ncan.

Jęnden, conj., while, so long as: penden, Ph. 89, I8I, 398; Pr. I4. Jēod, f., nation, people: ns. pēod,

El. 448, 468; ds. pēode, El. 539 ;

Ph. 160; np. pēoda, Ph. 34I ;

gp. bēoda, El. I85, 421, 659, 78r.

See ęl-, werðēod.

Gēodcwēn, f., queen of the people: ns. bēodcwēn, El. I 56 .

Jēoden, m., prince, king: ns. El. 487 ; bēoden, El. $563,777,858$; Pn. 63; gs. peoodnes, E1. 267; chief: ds. pēodne, $\mathrm{Ph}$. $\mathrm{I} 65$; lord: gs. peodnes, $\mathrm{Ph} .68$; Jēodnes, Ph. 605.

Jēodenbealu, n., great evil: gp. pēodenbealwa, El. 403.

ðēodig, see ęlð̄ēodig.

Jēodscipe, m., discipline: as. pēodscipe, E1. I 67.

$\ddagger$ סẽodwiga, m., champion of his people: ns. pēodwiga, Pn. 38 .

Oèon, see geð̌̀on.

ठ̀èostorcofa, m., dark chamber: ds. pēostorcofan, El. 833 .

Jēostorloca, m., tomib, grave: ds. bēosterlocan, El. 485 .

Jēostre, adj., darkened, benighted: dp. pēostrum, El. 3 I2.

Jēostru, f., darkness: dp. pēostrum, E1. 767 ; bȳstrum, E1. 307.

dēow, m., servant: ns. pēow, $\mathrm{Ph}$. 165. Sce lāttēow.

Jēowdōm, m., service: as. bēowdōm, El. 20r.

бēownȳd, f., bondage, thraldom: as. pēownèd, El. 770 .

Oerscan, III, beat: pirsceð, El. 358. Oes, pron., this: nsm. bes, E1. 703, 704; nsf. Jēos, El. 533; pēos, El. 468, 551, 647, I277; Ph. 50r ; nsn. Jis, El. 435 ; pis, El. I62, 903, 906, II 87 ; Ph. 465; gsmn. pisses, $\mathrm{Ph}$. I5I, 387, 426, 509; gsf. pisse, Ph. 349 ; dsf. pysse, E1. 402, 539, 643; pisse, Ph. 321 ; dsn. bissum, El. 518, 576; asm. pisne, Pn. 7; pysne, El. 312 ; asf. pās, Ph. I39, 390, 416, 450; W. 64,87 ; asn. pis, E1. 630,659 ; Ph. 48I ; isn. bȳs, El. 92; gpf. pyssa, E1. 858; dpn. Jyssum, El. 700; apm. ðās, El. I173; apn. păs, El. 749.

Jicgan, V, receive: opt. pret. $3 \mathrm{sg}$. pēge, El. I259; seize upon: $3 \mathrm{sg}$. piged, Ph. 219; taste: 3 sg. piged, Ph. 259; devour: 3 sg. piged, Ph. 505 ; Pn. 35 ; partake of: pret. 3 pl. bēgun, Ph. 402 , 4 IO.

Oin, pron., thy, thine: nsm. pin, E1. $489,773,777,789$; nsn. bin, E1. 597,782 ; gsn. pines, E1. 727 , 820 ; Ph. 628; dsm. pinum, El. 767 ; dsf. binre, El. 739; asm. binne, El. 510 ; asf. pine, El. 929, 1089; asn. pin, E1. 770, 784, 813; dpm. binum, E1. 666; ipf. pinum, El. $73^{\circ}$.

Jincan, see Jyncan.

Oing, n., thing, matter: gp. pinga, E1. 409, 608; オinga, E1. I156.

oinge, see geơinge.

dinggemearc, n., measure of history, time: gs. pinggemearces, El. 3 .

Oingian, W2., spcak, make address: pret. 3 sg. pingode, E1. 77, 609, 667 ; intercede: pret. 3 sg. pingode, E1. 494. ठisa, see brim-, wæterðisa. Oōht, see geð̄ōht.

Oolian, W2., suffer, endure: pret. 3 sg. polade, Pn. 63; inf. polian, E1. 770. 'See geŏolian. ठon, see æfter ठon, ǣrరon; se. Jònan, see Janon. Jonc, see Janc.

Sonne, adv., then: Ph. 125, I53, 
I88, 236, 274, 33I, 335, 589; W. 19, 27, 53; - bonne, El. 50, 446, $489,526,931$, I286, I315; $\mathrm{Ph}$. 99, I 42, 156, etc. (27 times); Pn. 49 ; W. $13,16,30,60,76$.

Oonne, conj., when, if: E1. I280; Ph. 182; ponne, E1. 473, 618, II78, II79, I185, I273; Ph. 48, 208, 219, etc. (22 times); Pn. 35,$40 ;$ W. 24, 38, 51, 7I; than: E1. 49, 74, 388, 647; Ph. 3I, I28. Oracu, f., conflict, battle: ds. præce, E1. 45, I85. See bǣl-, gār-, holm-, līg-, wǣpen-, wīgðracu. $\ddagger$ Oræcheard, adj., brave in battle, valiant in fight: npm. bræchearde, E1. I23.

Jrǣgan, WI., run: pret. 3 sg. †rǣgde, El. I263.

orāg, f., time, season: as. prāge, Ph. I60; ip. prāgum, E1. I239; $\mathrm{Ph} .68$.

Orēa, m. f., woe: ip. prēam, El. 1277.

Orëagan, W3., punish: pp. npm. prēad, El. 1296.

ờēalīe, adj., terrible, horrible: nsm. prēalíc, El. 426.

orēan, see geơrēan.

Orēanȳd, f., dire constraint." ns. brēanȳd, El. 704; ip. brēanēdum, E1. 884; prēanȳdum, Pn. 6I.

Orēat, m., troop, band, throng: ds. prēate, E1. 326, 329, 537; as. brēat, El. 546 ; is. brēate, El. $5 \mathrm{I}$, I5I, 215, 217, 254, 27I, 873, 1096 ; ip. prēatum, $\mathrm{Ph}$. 34I, 50I. See beadu-, beorn-, hęreðrēat.

orēatian, see geörēatian.

Orec, see geðrec.

Örēo, num., three: nn. brēo, El. 2, 285 ; gf. brēora, El. 858; am. brīe, El. 847 ; af. brēo, El. 483 , 833,$869 ;$ Pn. 63 ; an. prēo, El. I 286.

Oreodian, see yrydian.
Orēoniht, fpl., three nights: $\mathrm{g}$. prēonihta, Pn. 38.

Orēotan, see āörēotan.

Oridda, adj., third: nsm. bridda, El. 855, I 298 ; nsf. pridde, El. 884 ; asm. priddan, Pn. $4 \mathrm{I}$; ism. priddan, El. I85, 485; Ph. 644; Pn. 6I.

Oringan, III, crowd, throng, press on, hasten: 3 pl. bringad, $\mathrm{Ph}$. I63, 336, 50I ; pret. 3 pl. prungon, El. 123, 329; Pn. 67. See be-, geðringan.

Orist(e), adj., bold, brave, daring: nsf. prīste, El. 267 ; gpm. brīstra, El. 1286. See gärörīst.

Orīste, adv., confidently, surely: briste, El. 409, 1167.

Oritig, adj., thirty: E1. 3.

Oriwa, adv., thrice: briwa, $\mathrm{Ph}$. I44 (2).

† Oroht, m., pain, suffering: ns. broht,' E1. 704.

Orohtheard, adj., patient: nsm. prohtheard, El. 494.

orosm, m., smoke: is. prosme, El. 1298.

Orōwian, W2., suffer, endure: pret. 3 sg. prōwode, El: 42I ; inf. prōwian, El. 769. See geơrōwian.

Oryccan, see fororyccan.

Orydian, W2., weigh, ponder: pret. I sg. preodude, El. 1239; 3 pl. prydedon, El. 549.

Orym, m., glory, majesty: ns. prym, El. $483,8 \mathrm{I} 6$; gs. brymmes, El. 348, 859; ds. brymme, El. I77, 329 ; as. prym, El. I0go; Ph. $54 \mathrm{I}$; is. prymme, El. 745; $\mathrm{Pn}$. 4I ; gp. prymma, E1. 483, 519; splendor: is. prymme, Ph. 605; onset: ns. prym, Ph. $4 \mathrm{I}$; lord: vs. prym, Ph. 628; gp. prymma, Ph. 628. See cyne-, mægenð̆rym. 
Orymcyning, m., king of glory: as. prymcyning, E1. 494.

Orymlīe, adv., gloriously: prymlīce, E1. 78I ; Ph. 68, 514.

orymsittende, adj., throned in majesty: dsm. prymsittendum, E1. 8II; Ph. 623.

orȳnes, f., trinity: gs. prȳnesse, E1. 177.

orȳ̇d, f., raging: np. prȳbe, $\mathrm{Ph}$. I84; host: ip. prȳbum, Ph. 326 ; Pn. 5I.

Әrȳ̄on, see geðัrȳðan.

† Orȳðbold, n., mighty dwelling: as. brÿðbold, El. I5I.

Oū, pron., thou: ns. El. 84, 92, 400, etc. (3I times); pū, El. 8I, 83, 446, etc. ( 13 times); Ph. 630 ; gs. pin, El. 928; ds. $\delta \bar{e}$, El. 8I, 810, 927 ; bē, El. 79, 82, 44I, etc. (14 times); Ph. 622, 623; as. pec, El. 403, 447, 539, 676, 823, 931, 942; np. gē, El. 290, 293, 294, etc. (29 times); Pr. 5, 6, 9 ; dp. ēow, El. 298, 309, 339, etc. (I0 times); Pr. 7; ap. ēowic, El. 318; ēow, El. 295, 368, 551, 578, 699 .

¿ūf, m., banner, standard: ns. būf, El. 123 .

Jurfan, prp., need: 2 sg. pearft, El. 940 ; can: I sg. bearf, E1. 919; pret. 3 sg. porfte, El. I 104. See beðurfan.

durh, prep., w. acc., through, in, by, with: burh, El. 6, 183, 295, etc. (29 times); Ph. 316, 366, 372, 639, 662; Pn. 43; W. 3 ; by means of, by reason of, on account of: Jurh, El. II06; burg, E1. 289,790 ; burh, El. 86,98 , I20, etc. (37 times); Ph. 6, 30, 46 , etc. (23 times); Pn. I8; W. 33, 42, 55, 65; Pr. 9.

Jurhdrifan, I, possess, imbue: pp. purhdrifen, El. 707.
Ourhgēotan, II, fill, endue: pp. purhgoten, El. 962.

Jurhwadan, VI, bore, pierce: pret. 3 pl. purhwōdon, El. Io66.

Ourst, m., thirst: ns. purst, $\mathrm{Ph} .6 \mathrm{I} 3$. Jus, adv., thus, so: E1. I89, 400, 528 ; Ph. 570, 632; bus, El. I120, I237; $\mathrm{Ph} .482,62 \mathrm{I}$.

Jūsend, n., thousand: ns. pūsend, Ph. 364; as. pūsend, $\mathrm{Ph}$. I5I ; np. būsendu, El. 285 ; ap. būsend, E1. 326 .

రwǣre, see manðwǣre.

¿y, see sē.

Oyder, adv., that way, thither: byder, El. 548.

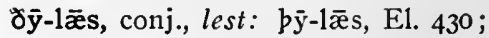
$\mathrm{Ph} .246$.

dylman, see fordylman.

Jyncan, WI., seem, appear: pret.

3 sg. bühte, El. 72, II65; opt. 3 sg. pince, El. 532; bynce, El. 541 .

Oyslic, adj., such: asm. byslīcne, E1. 546; asn. byslic, El. 540. Oȳstru, see ठēostru.

\section{U.}

ufan, adv., above: Ph. 308 .

ufeweard, adj., on the upper side: nsm. Ph. 299.

ūhta, m., morning twilight, dawn: ds. ūhtan, E1. 105.

unāsęcgendlīc, adj., indescribable: nsm. El. 466.

unbrǣe, adj., imperishable, immortal: nsn. El. I029.

unbryce, adj., imperishable: nsm. $\mathrm{Ph} .642$.

unclǣne, adj., unclean, vile: dpm. unclǣnum, El. 30 I.

uncūo, adj., unknown: asf. uncūore, E1. 1102.

uncyst, f., iniquity: ap. uncyste, Ph. 526. 
undearninga, adv., openly, frankly: E1. 405; undearnunga, El. 620. under, prep., w. dat., under, beneath: El. I3, 46, 75, etc. (20 times); Ph. 14, 27, 32, etc. (15 times); deep in: El. 218, 485, $625,653,695,832,843, \quad 1092$; w. acc., under, beneath: El. 44, 764, 992 ; Ph. 97, 101, 374; amid: Pn. 37; W. 47.

ungelice, adv., otherwise, differently: E1. 1307 .

ungewyrded, adj., scathless, uninjured: nsm. Ph. I8I.

‡ungnȳòe, adj., unstinted: npn. Pn. 71.

unhwīlen, adj., everlasting, eternal: nsm. E1. 1232.

unlifgende, adj., dead, lifeless: gsm. unlifgendes, E1. 879.

† unlond, n., what one mistakenly takes for land: ds. unlonde, W. 14 .

unlȳtel, adj., large, great: nsn. E1. 283,872 .

unmǣte, adj., infinite: nsf. Ph. 625.

unoferswiöed, adj., unconquered, invincible: nsn. El. 1188.

unræd, m., evil counsel: ip. 'unrǣdum, Ph. 403; sin, folly: as. W. 70 .

unriht, n., wrong, sin: gs. unrihtes, El. 472,516 ; as. El. 582 .

unriht, adj., false: asf. unrihte, El. 1042.

unrime, adj., numberless, unnumbered: nsn. El. 6I ; npn. unrìmu, Pn. 2.

unscyldig, adj., guiltless, innocent: asm. unscyldigne, El. 496.

unscynde, adj., unblemished, glorious: asm. unscyndne, E1. 365; asf. El. 120I ; apf. El. I247.

unslāw, adj., active, diligent: nsm. E1. 202. unsmēð̀e, adj., rough, rugged: gsn. unsmēðes, Ph. 26.

unsnyttro, f., folly: gp. unsnyttra, E1. I285; ip. unsnyttrum, E1. 947.

unsōfte, ađv., hardly, scarcely, with difficulty: El. I 32.

untrāglīce, adv., without delay: E1. 4I0.

untwëonde, adj., undoubting, unwavering: asm. untwēondne, El. 798.

†uwær, adj., unwary: isn. unware, W. 59.

$\ddagger$ unwærlice, adv., unwarily: W.

63.

unweaxen, adj., immature, young: asm. unweaxenne, El. 529.

unwęmme, adj., inviolate: $\mathrm{nsm}$. $\mathrm{Ph} .46$.

unwillum, adv., unwillingly: W. 4. unwislice, adv., foolishly: El. 293. ūp, adv., up, upwards: El. 87, 95, 353, 700, 712, 714, 717, 736, 794, 803, 879, I 107, I226; Ph. 93, 102, 289, 5II ; Pn. 40; W. I6.

üplæ̈dende, adj., lofty, tall: gpm. ūplædendra, $\mathrm{Ph}$. I78.

üplīc, adj., celestial, heavenly: dsm. wk. ūplican, Ph. 392; dsn. wk. üplican, $\mathrm{Ph} .663$.

uppan, prep., over, upon: w. dat. E1. 886.

uppe, adv., above, on high: E1. 52 ;

Ph. 629; Pn. 74.

ūprador, $s e c$ üprodor.

üprodor, m., heaven, firmament: as. ūprador, El. 73r.

üpweard, adv., upward, toward heaven: El. 806.

ürigfeð̌ere, adj., dewy-zinged. nsm. wk. El. 29; ūrigfeðra, El. III.

ūser, pron., our: npm. ūsse, E1. 425, 458; Ph. 438; apm. ùsse, Ph. 4I4. 
ūt, adv., out: El. 45; Ph. 233; Pn 44 ; W. 58.

ūtan, adv., around, about: Ph. I64, 530 ; without: Ph. 301.

uton, interj., let us: W. 86 ; Pr. 12. ūtsīo, m., departure: as. ìtsīî, W. 79.

ūoweota, m., wise man, scribe: npm. üơweotan, El. 473.

\section{W.}

wā, adv., woe: E1. 628.

wadan, VI, speed, press on: inf.

El. 246. See ge-, Jurhwadan.

wæcnan, see onwæcnan.

wæd, n., sea: gs. wædes, W. 9 .

-wǣde, see gewæ̈de.

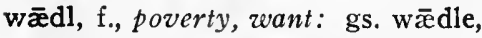

Ph. 55 ; ds. w $\bar{x} d l e$, El. 617.

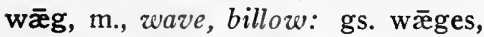

E1. 230 ; as. W. 27 ; gp. wāga,

Ph. 45. See fifelw⿳亠口冋.

wāgflota, m., ship: ap. wæ̈gflotan, E1. 246.

wæ̈ghęngest, m., wave-stallion, ship: ap. wǣghengestas, El. 236. wäglï̀nd, m., seafarer: np. w $\bar{x}$ glïpende, W. II.

wǣlan, sce gewǣlan.

wælfe1, adj., fierce against corpses:

nsm. El. 53 .

wælgifre, adj., murderous: nsm.

Ph. 486.

wælhlęnce, f., coat of mail: np.

wælhlencan, El. 24.

wælhrēow, adj., cruel, implacable:

gpm. wælhrēowra, El. II2.

wælrēaf, n., spoil of death: as. $\mathrm{Ph}$.

273.

wælręst, f., grave: ds. wælreste,

E1. 724 .

walrūn, f., secret hope of carnage:

as. wæl rūne, El. 28.

wǣpen, n., weapon, arm: ns. E1.
II89; as. El. I7; ip. wǣpnum, E1. 48 ; Ph. 486.

wǣpenठracu, f., conflict, battle: as. wæ̈penpræce, El. I06.

wær, see unwær.

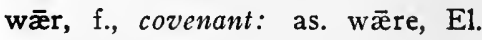
80,823 .

wærlic, adj., wary, prudent: gpn. wærlicra, E1. 544.

wærlīce, see unwærlice.

wǣrloga, m., perfidious one: ds. w̄̄rlogan, W. 37.

wæstm, m. f. n., fruit: np. wæstmas, $\mathrm{Ph} .34,255$; gp. wæstma, $\mathrm{Ph} .466$; dp. wæstmum, $\mathrm{Ph}$. 250; ap. wæstmas, Ph. 243 ; ip. wæstmum, Ph. 72; form: ap. wæstma, Ph. 332 ; proportion: ip. wæstmum, $\mathrm{Ph} .237,580$; increase, ip. wæstmum, El. 34I. See foldwæstm.

wæter, n., water: ns. Ph. 6r ; Pn. 6 ; gs. wæteres, El. 39, 60; wætres, Ph. 4I; np. Ph. 65; gp. wætra, $\mathrm{Ph}$. $\mathrm{I} 84$.

wæterठisa, m., mighty swimmer: ns. wæterpisa, W. 50.

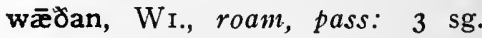
wǣðеð, El. I274.

wāfian, W2., gaze at: 3 pl. wāfiað, $\mathrm{Ph} .342$ (wundrum wāfiaơ, wonder).

wald-, see weald-.

wan, adj., dark, black: nsm. El. 53 ; nsf. won, Ph. 99.

wang(-), see wong(-).

wanhāl, adj., sick, weak: $\mathrm{dpm}$. wannhālum, El. I030.

wanian, W2., fade: 3 pl. waniad, Ph. 72.

wansǣlig, adj., unhappy, miserable: npm. wons $\bar{x}$ lige, El. 478; dpm. wansæaligum, El. 978.

ware, see ceaster-, Rōm-, Syrware. wão, f., flight: ip. wābum, Ph. 99, I6I. 
waðema, m., wave: ap. wabeman, Ph. 97.

wēad̄̄d, f., evil deed, sin: as. El. 495.

weald, m., wood, forest: ds. wealde, El. 28 ; np. wealdas, $\mathrm{Ph}$. I3.

-weald, see ge-, onweald.

-wealda, see anwealda.

wealdan, rd., hold sway, rule: 2 sg. wealdest, E1. 76r ; opt. $3 \mathrm{sg}$. walde, E1. 8or ; inf. El. 450.

Wealdend, m., Ruler, Lord: ns. E1. 4, 80, 337, 347, 482, 512, 752, 1043, 1067, 1085; Waldend, El. 206, 42I ; Ph. 464; gs. Wealdendes, El. 391, 85I, 892 ; vs. El. 773, 78r ; Waldend, E1. 732; $\mathrm{Ph}$. 631. See Oferwealdend.

weallende, adj., surging, beating, glowing: nsn. El. 938; ism. $\mathrm{Ph}$. 477.

weard, m., guardian, protector: ns. E1. 153, 197, 338, 445, 718, 1022, I316; Ph. I52; as. El. 84, IIOI ; np. weardas, El. 384. See gūò-, lif-, męre-, yrfeweard.

-weard, see and-, for-, foro-, hindan-, hinder-, nioðo-, ufe-, üpweard.

weardian, W2., hold possession of, inhabit, occupy: 3 sg. weardad, Ph. 161, I68, I72; weardap, $\mathrm{Ph}$. 85 ; 3 pl. weardiað, Ph. 448; W. 26 ; pret. 3 sg. weardode, El. Ir $45 ; 3$ pl. weardedon, El. I35; inf. Pn. II.

weardlīe, see andweardlice. ‡wearhtræf, n., abode of felons:

dp. wearhtreafum (hell), El. 927. wearm, adj., warm, hot: nsf. Ph.

I87; nsn. Ph. I8.

wearmian, W2., become hot, glow:

3 pl. wearmiad, $\mathrm{Ph} .2 \mathrm{I} 3$.

wearoð, see sǣwearoð. wēatācen, n., sign of woe: ns. Ph.

$5 \mathrm{I}$.

weaxan, VI, grow, increase: 3 sg. weaxeঠ, Ph. 232, 234 ; pret. $3 \mathrm{sg}$. wēox, El. I2, 914; 3 pl. wēoxan, E1. 547. See à-, bi-, geweaxan. weaxen, see unweaxen. wębba, see friðowębba. wębbian, W2., weave, devise: pret. 2 pl. webbedan, El. 309.

węccan, Wr., waken: 3 sg. węceð,

Ph. 255; kindle: 3 pl. weccar,

W. 2r. See āwęccan.

węd, n., penalty: as. El. I284.

wēdan, Wi., rage: ptc. wēdende, El. 1274 .

weder, n., weather: ns. $\mathrm{Ph} . \mathrm{I} 8, \mathrm{r} 82$; gs. wedres, W. 26; gp. wedra, Ph. 57.

wedercondel, f., candle of the sky, sun: ns. $\mathrm{Ph}$. 187 .

wefan, $\mathrm{V}$, weave: pret. I sg. wæf, E1. 1238.

weg, m., way: as. El. II50. See bæơ-, east-, eorס-, fold-, mold-, sīôweg.

wegan, V, endure, experience: pret. 3 sg. wæg, E1. 61, 655. See tōwegan.

wel, adv., well, rightly: Ph. 443, 5 I6.

wela, m., riches, wealth: gs. welan, Ph. 55, I49. See ēad-, lọnd-, woruldwela.

weldæd, f., good deed: dp. weldǣdum, Ph. 543.

weleras, mpl., lips: a. W. 54 .

welgian, see gewelgian. welm, see wylm.

wëman, Wi., persuade: 3 pl. wēmað, W. 35.

wēmend, m., revealer, discloser:

ns. E1. 880 .

węmme, see unwęmme.

wēn, f., hope: ns. Ph. 567. 
wēna, m., cxpectation: ds. wēnan, El. 584 .

wēnan, Wi., expect: pret. 3 sg. wënde, El. 668; inf. El. I I04; hope: pret. 3 sg. wēnde, El. 62 ; imagine: pret. 3 pl. wēndon, El. 478; opt. 3 sg. wēne, $\mathrm{Ph} .546$; think: 3 pl. wēnað, W. 20; wēnap, W. II.

węndan, Wr., turn: I sg. wende, El. 348; depart: pret. 3 sg. wende, El. 440 ; change: inf. El. 979. See à-, ge-, onwęndan.

Wendels $\bar{x}$, pr. n., Mediterranean

Sea: d. E1. 23 I.

-węnden, see edwęnden.

weorc, n., deed, act, work: ns. $\mathrm{Ph}$.

598; gs.'weorces, El. IIO, 849;

gp. weorca, Ph. 386, 475, 659;

ap. E1. 1318; ip. weorcum, El.

1243; Ph. 527; W. 85. See dæg-, ge-, hęre-, mānweorc.

weorcean, see beweorcean.

-weorp, see geweorp.

weorpan, III, cast, throw: pp. npm.

worpene, El. I304. See ă-, tō-, wiơweorpan.

weorठan, III, be, become: 3 sg. weorठeð, Ph. 2II, 372; weorbeð, Ph. 80, 142, 240, 257, 304, 364, 503; W. 42; wyrðeð, El. 575; 3 pl. weorbay, $\mathrm{Ph} .49$; weorðab, W. 56 ; pret. 3 sg. weard, El. 5 , 9, 15, etc. (I8 times); Ph. 404, 4I7, 445; 3 pl. wurdon, El. I30, 584, I278; Ph. 407; opt. I pl. weorðen, El. 428; pret. 2 sg. wurde, El. 401 ; 3 sg. wurde, El. 336, 429, 961, 976; inf. El. 220, 58I, 688, 1049, I177; weorban, $\mathrm{Ph} .378,564$. See geweorठan. weorolian, W2., honor: $3 \mathrm{pl}$. weorpiar, $\mathrm{Ph} .343$; pret. opt. 3 pl. weorðeden, El. 1222; pp. weorठod, El. I196; adore, worship: pret. 3 sg. weorðode, El.
I 37 ; 3 pl. weorðodon, El. 89I. See geweorð̋ian.

weoromynd, f. n., honor: ns. $\mathrm{Ph}$. 636.

weorơng, see dæg-, dōm-, sincweoroung.

weorud, n., host: ns. werod, El.

53 ; gs. werodes, El. 39; as. werod, El. $19,48,60,94$; is. weorude, El. I28I ; W. 59; gp. weoruda, El. 223, 68I ; Ph. 465, 565 ; weoroda, El. 752, 815, 897 ; weroda, El. 789, II50; wereda, El. 1085; dp. weoredum, $\mathrm{Ph}$. 588; people, multitude: ns. El. I117; ds. weorode, El. 844; dp. weorodum, El. 35I, 782, 867; Ph. I87; company: is. werode, El. 230 ; assembly: as. weorod, El. 158. See lindweorud.

$\ddagger$ weorudlēst, f., want of men: ds. werodlēste, El. 63 .

weota, see ūơweota. See also wita. wer, m., $\operatorname{man}$ : ns. El. 508; gs. weres, El. 34I, 959, 967, 1038; as. El. 785 ; Ph. 394 ; np. weras, E1. 22, 314, 478, 547; Ph. 33I ; Pn. I4; gp. wera, El. 537, 543, 596 ; dp. werum, El. 978, I222 ; ap. weras, El. 287, 559; ip. werum, El. 236; human being: gs. weres, El. 72 ; gp. wera, El. 304, 475; male: gs. weres, Ph. 357.

$\ddagger$ węrgan, WI., curse, revile: pret. 2 pl. wergdon, El. 294.

węrgðu, f., curse, condemnation: ns. El. 309; ds. wergðe, El. 295; as. El. 2 II, 952.

węrian, Wi., apparel, clothe: pp. npm. werede, Ph. 596. See gewęrian.

wērig, adj., miserable, wretched: nsf. wk. wërge, El. 763; vpm. wērge, El. 387 ; npn. wk. wēregan, E1. 357. See ferhö-, hräwērig. 
wērigferhð', adj., weary-hearted: npm. wërigferhðe, W. I9.

wērigmōd, adj., weary in soul: nsm. Ph. 428 .

werod, see weorud.

werōēod, f., nation, people: ds. werpēode, El. 643 ; as. werpēode, El. 969 ; dp. werpēodum, El. 17. wesan, anv., be, exist: I sg. eom, El. 923 ; 2 sg. eart, El. 809, 8I 5 ; Ph. 630 ; 3 sg. weseð, Ph. 373; is, E1. $426,465,512$, etc. (23 times); $\mathrm{Ph} . \mathrm{I}, 5,7$, etc. (26 times); Pn. 12, 15, 19, 31, 55, 58,74 ; W. $6,8,82$; biö, El. 339 , 340,432 , etc. (16 times); $\mathrm{Ph}$. II, 37, 82, etc. (34 times); W. 4, 31, 60; bip, Ph. 131, 185, 340, $463,480,516$; W. 40, 62, 66; 3 pl. sint, El. 740, 744, 826; synt, El. $605,742,1267$; sindon, El. I08I ; Ph. 71, 297, 310, 626, 655 ; Pn. I; syndon, El. 754; sind, Ph. 359, 465, 528; Pn. 4, 70; bēođ, El. 1295, 1304, I308; $\mathrm{Ph}$. I I6, I84, 255, 474, 489, 491, 526, 544; Pr. 9; bēob, Ph. 96; W. 22; bīoo, El. 1289; pret. I sg. wæs, El. 1243; 3 sg. wæs, E1. I, 7, II, etc. (89 times); $\mathrm{Ph}$. 239, 280, 379, 397; Pn. 64; 2 pl. wǣron, El. 29I; 3 pl. wæ̈ron, E1. 22, 25, 46, etc. (15 times); Ph. 443 ; opt. 2 sg. sie, El. 542, 817; 3 sg. sie, El. 675, 773, 789, 799, 810, 893, 1229; Ph. 623; sì, Ph. 622; sỳ, Ph. 66ı ; 3 pl. sien, El. 430 ; pret. I sg. wǣre, E1. 707; 3 sg. wæ̈re, El. I59, I6I, I7I, etc. (I4 times); $\mathrm{Ph}$. 639 ; Pn. 22; inf. Ph. I65, 435. Negative: 3 sg. nis, El. 9II ; Ph. 3, 50, 3I4; pret. 3 sg. næs, El. 99I ; Ph. 637 ; opt. pret. 3 sg. nǣre, El. 17I, 777.

-west, see nēawest. west, adv., westward: Ph. I62.

westan, adv., from the west: $\mathrm{El}$. IoI6; Ph. 325.

westdǣl, m., western part: ap. westdǣlas, Ph. 97.

wēste, adj., deserted, secluded: asf. $\mathrm{Ph} .169$.

wēsten, n., waste, desert, wilderness: ds. wēstenne, El. 611, Ph. $20 \mathrm{I}$; as. Ph. I6I.

-wet, see fyrwet.

wēòel, f., poverty: ns. wēpel, $\mathrm{Ph}$. 612.

wic, mfn., abode, dwelling, mansion: as. E1. I038, II 44 ; $\mathrm{Ph}$. 448; W. 26, 37 ; np. Ph. 474; dp. wicum, Ph. 470, 6ri. See eardwic.

wicg, n., horse: as. El. 1196.

wician, W2., encamp: pret. 3 sg. wicode, El. $65 ; 3$ pl. wicedon, El. 38. See gewician.

wicstōw, f., druelling-place: ds. wicstōwe, Ph. 468.

wìd, adj., great, extended: nsm. wk. wìde, W. 59; dsm. wk. wìdan, W. 89 ; dsn. wk. widan, E1. 2II, I288, I32I; npm. wide, Pn. 4 ; apm. wide, W. 54. See widan ferhø.

widan ferho, fyrho, adv., for ever: E1. 76I, 80I.

wide, adv., widely, far: El. 13I, 277, 969; Ph. 467.

$\ddagger$ widsceop, adj., numerous: npm. widsceope, Pn. 6.

wif, n., woman: ns. E1. 223, 286, 508; gs. wîfes, El. I132; as. Ph. 394; dp. wifum, El. I222; ip. wi fum, E1. 236.

wîfhād, m., female sex: gs. wîfhädes, Ph. 357.

wig, n., war, battle: ns. El. 13I ; gs. wïges, El. I9; wigges, El. 825 ; ds. wigge, El. 48, I182, 
II 89 ; as. E1. II2; is. wigge, E1. 150, II96.

wiga, m., warrior: ns. Ph. 486;

gs. wigan, El. 938; np. wigan,

El. 246 ; gp. wigena, El. 63 , I50,

153, 217, I090; wigona, El. 344.

See æsc-, ðēodwiga.

wigend, m., warrior: ds. wiggende,

E1. 984 ; ap. E1. 106 . See byrn-, lindwigend.

wigspēd, f., victory: as. E1. I65.

$\doteqdot$ wigðracu, f., contest, strife: ds.

wigpræce, E1. 430 ; as. wiggbræce,

E1. 658 .

wiht, f., anything, aught: ns. Ph.

26, I79, 6II; as. El. 684; Pn.

32 ; is. wihte, $\mathrm{Ph} .19,448$. See owiht.

wilde, adj., wild: nsm. wk. wilda,

Ph. 201, 466, 529; asm. wildne,

$\mathrm{Ph} .343$.

wilder, n., beast, wild beast: gs. wildres, Pn. 43; gp. wildra, Pn.

9. [wild(d)ēor.]

wilfægen, adj., glad, rejoiced: nsm. E1. 828 .

wilgedryht, f., devoted retinue: ns. Ph. 342 .

wilgifa, m., ruler, king, lord: ns. wilgiefa, Ph. 465 ; gs. wilgifan, E1. 22I ; ds. willgifan, E1. III2; vs. willgifa, El. 815.

wilhrēoig, adj., gladdened, exultant: nsn. willhrēoig, El. III7. will-, see wil-.

willa, m., will, desire: ns. E1. 773, 789, 963, II36, II60; gs. willan, El. 267 ; ds. willan, El. 193, 678, IOII; as. willan, E1. 68I, I07I, 1085, I132, II 53 ; Ph. 470; W. 35, 43; dp. willum, $\mathrm{Ph}$. I49; choice: ' ip. willum, $\mathrm{Ph} .537$; joy, delight: ds. willan, Ph. 565 ; ip. willum, El. 452, 1252; attraction: gs. willan, W. 66.

willan, anv., will, wish: I sg. wille,
E1. 574, 790, 814; W. 2 ; 3 sg. wille, Ph. I64; wile, Ph. 472, 492 ; pret. I sg. wolde, El. 469, 1080; 3 sg. wolde, El. 219, 456; 2 pl. woldon, El. $394 ; 3$ pl. woldon, E1. 40, 361, $97 \mathrm{I}$; woldan, Ph. 399; opt. 2 sg. wille, El. 608, 621; 3 sg. wile, El. 420. Negative: 3 sg. nele, Pn. 32 ; pret. 3 pl. noldon, E1. 566 .

willum, see unwillum.

wilsęle, m., pleasant hall: ns. willsele, $\mathrm{Ph}$. 213.

wilsīo, m., glad pilgrimage: as. willsit, El. 223.

wilspel, n., glad news: ds. willspelle, El. 994; gp. wilspella, E1. 984 .

wilsum, adj., delicious: dpmn. wilsuman, $\mathrm{Ph}$. Io9.

wilwọng, m., delightful plain: ds. willwonge, Ph. 89.

-win, see gewin.

wind, m., rvind: ns. $\mathrm{Ph} .182$; ds. winde, E1. I272.

windan, see be-, onwindan.

windig, adj., wind-driven: nsn. $\mathrm{Ph}$. $6 \mathrm{I}$.

wine, see goldwine.

winemǣ, m., dear kinsman: np. winemāgas, E1. Ior6.

winter, m., winter: gs. wintres,

Ph. 37, 245; year: gp. wintra, El. 4, 633; Ph. 152, 363, 420, 580 ; ip. wintrum, Ph. I62, 428. wintergerim, n., date: ap. El. 654 . wintergewæde, n., winter garment: ip. wintergew $\overline{\mathrm{d}} \mathrm{dum}, \mathrm{Ph} .250$.

wintergeweorp, n., winter storm: ns. Ph. 57.

winterscūr, m., winter shower: ns. $\mathrm{Ph}$. I8.

wìr, m., wire: gp. wìra, El. II35; ip. wirum, E1. 1264.

wis, adj., wise, prudent: nsm. El. 592 ; super. npm. wk. wisestan, 
El. 169, 323; apm. wīsestan, El. I53. See sundorwis.

wīsdōm, m., wisdon: gs. wīsdōmes, El. 357, 543, 596, 939, II44, II9I ; as. El. 334, 674, I243 ; Ph. 30 .

wise, f., fact: as. wīsan, El. 684; np. wīsan, Ph. 359; custom, manner: ns. W. 32.

wisfæst, adj., wise, learned: npm. wisfæste, El. 3I4; Pn. I4.

wislice, see unwīslīce.

wist, f., food, nourishment: as. wiste, E1. 6I7; ap. wiste, Ph. 245.

wita, m., wise man: 'gs. witan, El. 544. See $\overline{\mathbf{x}}-$, fyrnwita; also weota.

wit, see inwit, gewitt.

witan, prp., know: I sg. wāt, El. 4I9, 815; 3 sg. wāt, Ph. 355,357 , 369 ; 2 pl. witon, El. 644 ; pret. 3 sg. wiste, El. 860, 1203; 3 pl. wiston, El. 459 ; imper. sg. wite, E1. 946; inf. Pn. 3. Negative: I sg. nāt, El. 640; I pl. nyton, El. 401 ; pret. I sg. nysse, $\cdot \mathrm{El}$. I $240 ; 3$ sg. nyste, El. 7 I9.

witan, WI., upbraid with, reproach for: opt. pret. 3 sg. wite, El. 416.

witan, see gewitan.

wite, n., torture, torment: as. El. 520 ; Ph. 644; gp. wita, El. 765; dp. wìtum, El. 77I ; ip. wìtum, El. 180 ; suffering: gp. wita, El. Io3o.

witebrōga, m., horrible punishment: ap. wittebrōgan, E1. 932.

witedōm, m., prophecy: ns. El. II53; as. Ph. 548.

witga, m., prophet, sage: ns. El. 35I, I189; gs. witgan, El. 592, 938; np. wītgan, El. 561; Ph. 30; gp. witgena, E1. 289, 334, 394. wid, prep., w. dat., against: E1. I8, 64, I65, 185, 416, 525, 837, 927, II 82, II 88; Ph. 44, 45I, 469; to: El. 77 ; with: El. 307 (2), 308; w. gen., against: El. 616; w. acc., against: El. 403, 513; W. 67 ; with: El. 823 .

wiðercyr, m., return, way of escape: as. El. 926.

wiðerhycgende, adj., hostile, malevolent: nsm. El. 952.

widersæc, n., opposition, contradiction: as. El. 569 .

wiohycgan, Wr., scorn, loathe: opt. 3 sg. wiohyccge, El. 618.

‡ wiörēotan, II, contend against, resist: pp. wiðroten, El. 369 .

wiolsacan, VI, gainsay, withstand, deny: 2 sg. wiðsæcest, El. 663, 933; pret. I pl. wið̋sōcun, El. II 22; 2 pl. wiơsōcon, El. 390 ; reject, forsake: pret. $3 \mathrm{sg}$. wiosōc, El. 1040; opt. 3 sg. wiðsæce, El. 617; defy: pret. 3 sg. wiơsōc, El. 767 ; resist: opt. 3 sg. wirsace, W. 84.

wiơweorpan, III, reject: pret. 2 pl. wiotwurpon, El. 294.

witigan, see bewitigan.

wlanc, see wlonc.

wlęncan, see gewlęncan. wlita, see andwlita.

wlītan, I., look, glance, gaze: $3 \mathrm{pl}$. wlitad, Ph. 34I; pret. 3 sg. wlāt, El. 385 ; opt. 3 pl. wliten, W. I2. See geondwlitan.

wlite, m., beauty, brightness: ns. Ph. 75; ds. El. 1319; Ph. 609; Pr. I6; as. $\mathrm{Ph} .332$.

wlitescȳne, adj., beauteous of aspect, beautiful: nsm. El. 72.

wlitig, adj., beautiful, fair, lovely, delightful: nsm. El. 77; Ph. 7, 318, 516; Pn. 65; nsf. Ph. 588; dsf. wk. wlitigan, Ph. 666; asm. wk. wlitigan, Ph. 439; asn. El. 
89; Ph. 203; asn. wk. wlitige, El. 165 ; npm. wlitige, Ph. 598 ; ipmfn. wlitigum, Ph. 72; comp. nsm. wlitigra, Ph. 132; super. asf. wlitegaste, El. 749 .

wlitigan, see gewlitigan. wlitige, adv., brightly: $\mathrm{Ph} .543$. wlitigfæst, adj., changeless in beauty: nsm. Ph. 105.

wlonc, adj., proud, stately: nsm. Ph. 100; W. 50; wlanc, El. 23I ; dpm. wloncum, W. 43.

wolcen, n., cloud: ns. Ph. 6r ; np.

Ph. 184 ; gp. wolcna, El. 89; dp. wolcntm, E1. 1272, 1274; Ph. $27,247$.

wọm, m., blemish, sin: gp. womma, El. 583, 1310.

wōma, m., terror, tumult: ns. E1.

19; illusion: ns. El. 71 .

womb, f., body, belly: ns. Ph. 307. womful, adj., sinful, guilty: apm.

womfulle, El. 76r.

wọmsceaðेa, m., sinner: np. womsceaðan, E1. 1299.

wọn, sce wan.

wọng, m., field, plain: ns. Ph. 7, I3, I9, 43, 4I8; gs. wonges, $\mathrm{Ph}$. I49; wanges, El. 684; ds. wonge, Ph. 363 ; as. Ph. 281, 439; ap. wongas, $\mathrm{Ph} .320$. See græs-, neorxna-, sige-, stęde-, wilwong.

wọngstęde, m., place: ds. Pn. 45 ; wangstede, El. 794, IIO4.

wọnȳdig, adj., foolish: apm. wonhȳdige, El. 763 .

wōp, m., weeping, lamentation:

ns. Ph. 5I; gs. wōpes, El. II 32 . word, n., word: ns. Pr. 4 ; as. El. 338, 344, 440, 939, 1072, II 191 ; Ph. $398,4 \mathrm{II}, 55 \mathrm{I}$; is. worde, El. 946; np. El. 547; Ph. 655; gp. worda, El. 544, 569, I284; Ph. 659; ap. El. 334, 394, 582, 749, 990, 1003, 1168; ip. wordum, El.
169, 287, 351, 385, 529, 537, 559, 589, 893; Ph. 425; W. 2, 85; shout: ip. wordum, El. 24; speech: gs. wordes, El. 3r4, 419; behest: as. El. 221, 77I; voice: as. El. 724 ; prayer: ip. wordum, El. I319. See ligeword.

$\ddagger$ wordcræft, m., speech: gs. wordcræftes, El. 592; poetic art: is. wordcræfte, El. 1238.

wordgerȳne, n., mysterious saying: ap. wordgerȳno, El. 289, 323.

wōrian, Wr., toss, heave: opt. 3 sg. wōrie, W. 9.

worn, m., multitude, number, throng: ns. El. 633; Ph. 343; as. El, 304 ; np. wornas, Pn. 6. worpian, W2., stone: pp. worpod, El. $492,825$.

woruld, f., world: ns. El. 1277; $\mathrm{Ph} .89$, II7, I8r, 501; gs. worulde, $\mathrm{Ph} .4 \mathrm{I}$; El. II42; ds. worulde, El. 4, 440, 361, 979, 994, II 53, I252; as. El. 508; Ph. 130, 139, 211; Pn. 4, 65; age: as. El. 452 ; Ph. 662 ; gp. worulda, El. 452; Ph. 662 (in, purh woruld worulda, world without end).

woruldgedāl, n., death, destruction: ds. woruldgedāle, E1. 58r.

woruldgestrēon, n., treasure of the world: ap. $\mathrm{Ph} .255$.

woruldrice, n., world, kingdom of this world: ds. El. 456, 779, I049.

woruldstund, f., day on earth: dp woruldstundum, El. 363 .

woruldwela, m., worldly posses: sion: ap. woruldwelan, $\mathrm{Ph} .480$ wōð, f., sound, strain: gp. wōða, El 749; wōba, Pn. 43.

wöठcræft, m., poetic skill: is. wōð cræfte, Ph. 548; W. 2; song is. wōðcræfte, $\mathrm{Ph}, 127$. 
wracu, f., vengeance: ds. wræce, El. I7, 495; misery: ns. Ph. $5 \mathrm{I}$. See sārwracu.

wrǣe, see gnyrnwrǣ.

wrachwil, f., period of exile: ds. wræchwile, Ph. 527.

wræcmæcg, m., miserable man: vp. wræcmæcggas, El. 387.

wrǣtlic, adj., marvelous, wondrous: dsn. wrǣetlīcum, Pn. 9; comp. asf. wrǣtlicran, W. 50; beauteous: nsf. Ph. 307; nsn. Pn. I9; npm. wrætlice, Ph. 63; comp. nsm. wrǣtlicra, Pn. 27.

wrǣtlice, adv., strangely: Ph. 367, 378; splendidly: $\mathrm{Ph} .75$; curiously: Ph. 294; artistically: super. wrǣtlicost, El. I020.

wräठ, adj., perverted, perverse: asn. El. 459; hostile: nsm. El. I 82 ; dpm. wrāđum, El. I65, II82. See andwrāo.

wrāơe, adv., perversely: El. 294. wradu, f., support, help: ns. El. I030; as. wraðt, El. 84; Ph. 247 ; wrabe, W. 35.

wrecan, V, press forward, advance: pret. 3 pl. wrǣcon, El. I2I, 232. See be-, tōwrecan.

wręccan, Wr., awake, arouse: inf. E1. 106.

wręnc, m., composition:

gp.

wrenca, Ph. I33.

wrēon, I, cover, conceal: pret. 2 pl. wrigon, E1. 583. See onwrēon.

wridian, W2., thrive, flourish: 3 sg. wridad, Ph. 27, 237.

writ, see gewrit.

wrïtan, I., write: opt. I sg. wrīte, Ph. 548. See āwritan.

wrïðan, I, twist, weave: pp. npf. wriðene, El. 24.

wrixlan, Wr., trill, warble, carol:

3 sg. wrixled, Ph. I27; change:

3 sg. wrixled, El. 759 ; variegate:
3 sg. wrixley, $\mathrm{Ph}$. 294. [Cf.

Ger. wechseln.]

wrōht, m. f., misfortune: ns. $\mathrm{Ph}$. 6r2; sin, evil: as. El. 309.

wrōhtstaf, m., crime, treachery: ap. wrōhtstafas, El. 926.

wudu, m., forest, wood: ns. Ph. 37 ; gs. wuda, $\mathrm{Ph} .65$; as. $\mathrm{Ph} .85$. See brim-, camp-, holtwudu.

wudubēam, m., tree: gp. wudubēama, Ph. 75 .

wudubearo, m., grove: gs. wudubearwes, Ph. I52; ds. wudubearwe, $\mathrm{Ph}$. 169 .

wudublëd, f., forest fruit: dp. wudublēdum, Pn. 47 ; ap. wudublēda, $\mathrm{Ph}$. 194.

wuduholt, n., forest, wood: ns. Ph. 34 ; dp. wuduholtum, Ph. 362.

wuldor, n., glory: ns. El. 5, I78, I86, 893; gs. wuldres, El. 77, $84,89,217,295,727,738,752$, $80 \mathrm{I}, 828,844,867$, 1040, го90, 1252; Ph. I17, 130, 439, 475, 516, 588, 628, 662; W. 89; Pr. 4, I6; ds. wuldre, El. 747, 782, 823, 1047, I I 50; Ph. 386, 542, 598; as. El. 813, III7, I 124; Ph. 567 ; is. wuldre, El. II35; $\mathrm{Ph}$. $3 \mathrm{I} 8$, 55I, 609, 666 (wuldre, gloriously).

wuldorcyning, m., king of glory: ns. Ph. I96, 420, 537 ; gs. wuldorcyninges, El. I32I ; ds. wuldorcyninge, El. 291, 963, I304; as. W. 67,85 .

wuldorfast, adj., glorious: asf. wuldorfæste, El. 967.

wuldorgifa, m., giver of glory: ns. wuldorgeofa, El. 68I.

wuldorgifu, f., glorious gift, grace:

ip. wuldorgifum, El. ro72.

wulf, m., wolf: ns. E1. 28, I12.

wund, f., wound: ap. wunde, El.

5 I 4.

wundor, n., wonder, miracle, 
marvel: ns. El. 897 ; as. El. 867 , III2, I254; np. El. 827; gp. wundra, El. 363, 779; ip. wundrum, El. 1238; $\mathrm{Ph} .63,85,232$, 307, 342, 367, 468, 602 ; Pn. 19, 27 ; wondrous power: gp. wundra, Ph. 394. Wundrum, wondrously, strangely. See sōöwundor.

wundorlic, adj., wondrous: asm. wundorlicne, Pr. 2 ; npf. wundorlice, $\mathrm{Ph} .359$.

wundorlice, adv., wonderfully: comp. wundorlicor, $\mathrm{Ph}$. I27.

wundorwyrd, f., wonderful event: as. El. I07I.

wundrian, W2., marvel, wonder:

3 pl. wundriad, Ph. 33I; pret. 3 sg. wundrade, El. 959.

wunian, W2., dwell, live, be: $3 \mathrm{sg}$. wuna $\%$, Ph. $580 ; 3$ pl. wunia $ð$, Ph. 609; wuniap, W. 25; pret. $2 \mathrm{sg}$. wunodest, El. 950; 3 sg. wunode, El. 1028; opt. 3 sg. wunige, El. 624 ; pret. 3 sg. wunode, El. 724; inf. Ph. 363, 386; wunigan, El. 821, 908; haunt: 3 sg. wunar, $\mathrm{Ph}$. 105; inhabit: $\mathrm{Ph} .172$; Pr. 16; remain: 3 sg. wunad, Ph. I8I ; wunab, $\mathrm{Ph} .82$; pret. 3 sg. wunade, Ph.64I. See gewunian. wurma, m., crimson: is. wurman, Ph. 294.

wylla, m., well: np. wyllan, Ph. 63 . wyllegespring, $\mathrm{n}$., well-spring: dp. wyllegespryngum, $\mathrm{Ph}$. Iog.

wyllestrēam, m., welling stream: gp. wyllestreama, Ph. 362 ; ap. wyllestrēamas, $\mathrm{Ph}$. 105.

wylm, m., swell, surge: ns. Ph. 283; gs. wylmes, E1. I299; ds. wylme, El. 765, 1297, I310; welm, El. 230 ; stream: as. El. 39 ; activity: as. $\mathrm{Ph} . \mathrm{I} 9 \mathrm{I}$; lake: as. W. 46. See àd-, cear-, flōd-, hēafod-, heaðowylm. wyn, f., delight, joy, bliss, pleasure: ns. El. 789; Ph. 12, 290, 348; wynn, $\mathrm{Ph}$. 7o, 155; gs. wynne, Ph. 480 ; as. El. I09o; Ph. 4II; wynne, E1. I040; W. 69; dp. wynnum, $\mathrm{Ph}$. 237, 278,345 ; W. 22; ip. wynnum, $\mathrm{Ph} .7,27,3$ r 3. See lifwyn. wynbēam, m., tree of delight: as. El. 844 .

wynlic, adj., fair: nsm. Ph. 34 . wynlond, n., blissful land: as. $\mathrm{Ph}$. 82.

wynsum, adj., pleasant, charming, ravishing, delightsome: $\mathrm{nsm}$. Ph. 13, 318; Pn. 65; W. 54; asm. wynsumne, El. 794; $\mathrm{Ph}$. 659 ; asn. Ph. 203; npf. wynsume, $\mathrm{Ph} .529$; npn. wynsumu, $\mathrm{Ph}$. 65; gpf. wynsumra, Ph. I96; apf. wynsume, $\mathrm{Ph}$. 194, 245 ; ipf. wynsumum, $\mathrm{Ph} .653$; comp. nsm. wynsumra, $\mathrm{Ph}$. 133 ; Pn. 45 ; sup. nsm. wynsumast, Pn. 43.

wyrcan, Wr., do, work: pret. I sg. worhte, El. 470; 3 sg. worhte, El. 827,897 ; inf. El. 1020; make, create: 3 sg. wyrced, Ph. 45I; pret. 3 sg. worhte, Ph. 394. See gewyrcan; scyld-, synwyrcende. wyrd, f., fate: ns. El. I047; destiny: gp. wyrda, El. 80, 589, 978 ; event: as. E1. 54I, 583, I064; gp. wyrda, El. 813, I124, 1256; fact: as. E1. I102. See for-, ge-, wundorwyrd.

wyrdan, Wr., destroy: 3 sg. wyrded, El. 904. See ā-, gewyrdan; ungewyrded.

-wyrde, see andwyrde.

wyrged, see āwyrged.

-wyrht, see gewyrht.

wyrhta, m., creator, maker: ns. Ph. 9, 130. 
wyrm, m., worm: ns. $\mathrm{Ph} .232$; dp. wyrmum, Ph. 565.

wyrresta, adj., worst: apm. wyrrestan, El. 932.

wyrsa, adj., worse: dsn. wyrsan, El. 1040.

wyrt, f., plant: np. wyrta, Ph. 465, 529; gp. wyrta, Pn. 47; dp. wyrtum, Ph. 474; ap. wyrta, Ph. 194; ip. wyrtum, Ph. 273, 430 ; root: ip. wyrtum, $\mathrm{Ph} .172$; spice: np. wyrta, Ph. 213; gp. wyrta, Ph. I96; dp. wyrtum, $\mathrm{Ph}$. 265 ; ip. wyrtum, Ph. 653.

wyrðe, adj., dear, precious: npm. wyrðe, El. 291. See ärwyrde. wyrtian, see gewyrtian.

\section{Y.}

yfel, n., evil: as. E1. 493; is. yfele, El. 493; yfle, $\mathrm{Ph} .594$; gp. yfela, El. 902 ; yfla, Ph. 460 ; Pn. 18. yfemest, adv., uppermost: El. 1290. ylde, see alde.

yldra, m., forefather: np. yldran, $\mathrm{Ph} .438$; ap. yldran, Ph. $4 \mathrm{r} 4$. yldu, f., old age: ns. Ph. 52 ; yldo, $\mathrm{Ph} .6 \mathrm{I} 4$; as. $\mathrm{Ph} .190$.

ymb, prep., w. acc., beside, about, around: El. 39, 50, 60, 66, 136, 227, 260, 869; Ph. 292, 305, 619; W. 61; ymbe, Ph. 164; after: E1. 272,383 ; on account of, concerning, with reference to: El. 214, 442, 534, 541, 560, 664, 959, 1064, 107r, I18r, 1255; $\mathrm{Ph}$. $360,572$. ymbfōn, rd., grasp: 3 sg. ymbfēhð, Ph. 276 .

ymbhwyrft, m., surface: as. $\mathrm{Ph}$. 43 ; Pn. 68; surface of the carth: as. E1. 73r.

ymbsęllan, Wr., compass, surround: pp. ymbseald, W. I0; npm. ymbsealde, E1. 742.

ymbsęttan, Wr., encompass, surround: ymbseteð, $\mathrm{Ph} .204$.

ymbsittend, m., neighbor: gpm. ymbsittendra, E1. 33.

yppe, adj., known: nsn. El. 435. yrfe, n., inheritance, heritage: gs. yrfes, El. I320.

yrfeweard, m., heir: ns. Ph. 376. yrmou, f., misery, sorrow, woe: ns. Ph. 52; -yrmpu, Ph. 405, 614 ; as. El. 953 ; dp. ermðum, E1. 768 .

yrnan, see āyrnan.

yrre, n., anger, wrath: as. Ph. 408 . yrre, adj., angry: asm. eorne, El. 685; nsf. El. 573; eorre, El. 401.

ỳsle, f., ash, cinder: np. yslan, $\mathrm{Ph}$. 224; ap. ysslan, Ph. 2ji, 286, 576.

$\bar{y} \delta$, f., wave: gp. $\bar{y} \Varangle a$, El. 239. See sealtȳö.

ÿofaru, f., flood, rush of billows: ds. $\bar{y} \delta$ fare, Ph. 44 .

ÿohof, n., wave-dwelling, ship: ap. $\bar{y}$ ○hofu, El. 252.

ÿzmearh, m., ocean-steed, ship: ap. ẏmearas, W. 49.

ÿðmęre, m., billowy ocean: as. $\mathrm{Ph}$. 94.

ȳwan, see æt-, ge-, oðȳwan. 



\section{ERRATA}

B. xxxiv, 1. 5: for nineteenth read ninth or tenth. - P. 46, end of second paragraph: for On read On'.-P. 1, fourth paragraph: delete Europe. - P. lix, second quotation: for Job. I2 read Job 12.

\section{ELENE}

25, here-; 74, ǣnlicra; 107, h[ere ]-; 107, variant, MS., Edd. heoru-; 173, lêoht; 213, hē; 279, -h[ēegende; 313, ge[cēos]ab; 313, variant, before Wa., Ten Brink (Zs. f. D. Alt., Anz. 5. 60), geceosa $\delta$ ? alesað?; 509, 824, Stēphānus; 581, -gedāle; 639, sìð-; 788, Iōsēphes; 829, 848, an-; 909, variant, talade?; 956, glǣdra; 96i, variant, on- for onc-; 1049, wor $[u] 1 \mathrm{~d}-$; 1083, geresteð.

\section{PHENIX}

317, lēoht; 352, fug [l] as; 352, variant, $M S$., Edd. fugelas.

6, wid-.

\section{PANTHER}

P. 89 , next to last line, $232^{\text {b }}$. - P. 94 , fourth 1. f. b.: Wortschatz. - P. 96 , under I $132^{\mathrm{b}}$ : See the note on $A n$. 1278 in Krapp's edition. - P. 99, fifth line below runes: secg. - P. 102, title: PHCENIX. - P. I21, under $550^{\mathrm{a}}: A n$.

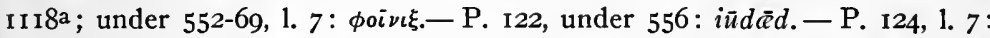
cubits'.-P. 133, under I5:Hē.-P. I38, under 69: lēaslīce līces wynne. So. Chr. 1296. - P. 134, last line: Absurditie (Works, ed. Grosart, I. 29). - P. 147, under I825, I827: R. J. F. - 159, under biscēawian: biscēawa $\delta$. - P. I61, under brēost: El. I095 should be ip. - P. 163, under corðor: El. 69I should be is.; under cræft: dp. should be ip.; under cræftig, after 72 : npm. -e, El. 315; under cumbul: see eofor-, hęrecumbul. - P. 165, under dægweoroung: ap. for gs. - P. 167, under ēadwela, following 1316: as. ēadwelan, Ph. 386 (and delete the last entry). - P. 169, under ęløēodig: E1. 57 should be apm. - P. 173, under firgenstrēam, add: See also fyrgenstrēam. - P. 176, under fruma: El. 839 should be gs.; under ful: El. 939 should be nsm. - P. 177, under galdor: ip. for dp. - P. 178, under gāstgerȳne: ip. for dp.-P. 179, under gebrosnian: crumble; under gecynd: f. n. for f. - P. I83, under gēn: before Pr. I insert W. I. - P. I87, under glēaw: El. 3is is apm. - P. 189, under grymetan: nsn. for asn. - P. I9I, under heard: ipn. for dpn. - P. 192, for heorucumbul read hęrecumbul, and so for El. 25. - P. 196, under hygeðanc: ip. for dp. - P. 200, under lifwyn: np. for ds.; under ligesearu: ip. for dp. P. 20I, under lyftlācende: asm. for nsm.-P. 218, under snyttro: El. 293 should be as. - P. 223, under tō, prep.: insert 922 in 1. 7. - 230, under wǣgflota: as. for ap. - 232, under wer: El. 314 should be ap. -234, under wilgifa: as. for ds. - 235, under wisfæst: El. 314 should be apm. -235, under witan: I for Wr. 


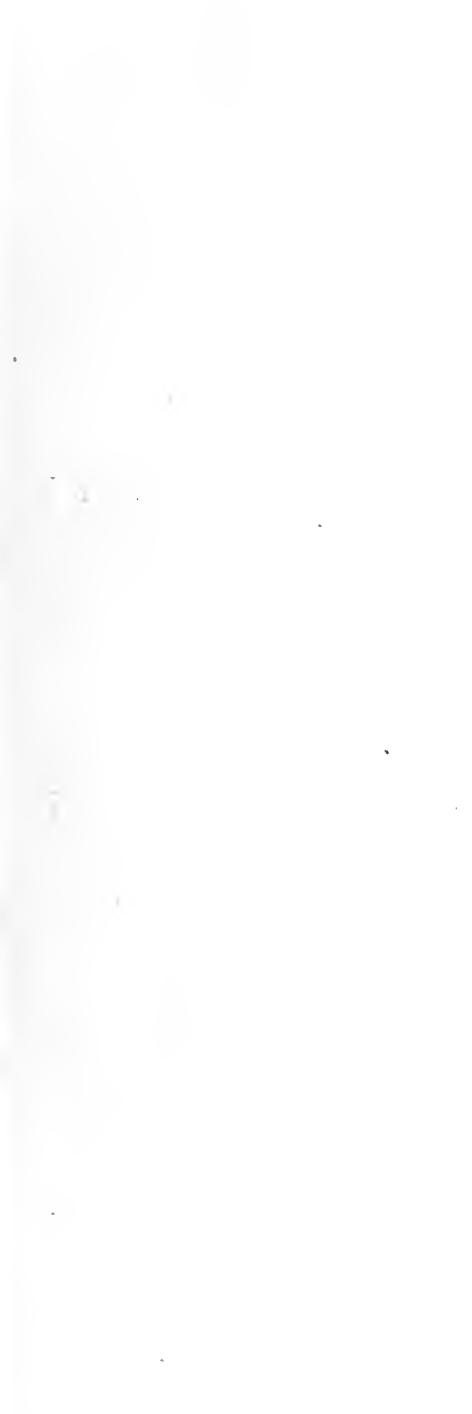




- 



\section{PLEASE DO NOT REMOVE CARDS OR SLIPS FROM THIS POCKET}

\section{UNIVERSITY OF TORONTO LIBRARY}

PR

1505

C6

cop. 2
Cook, Albert Stanburrough

The old English Elene 
